\title{
Masonería y sociedades secretas en México
}

José Luis SOBERANES FERNÁNDEZ Carlos Francisco MARTíNEZ MORENO coordinadores

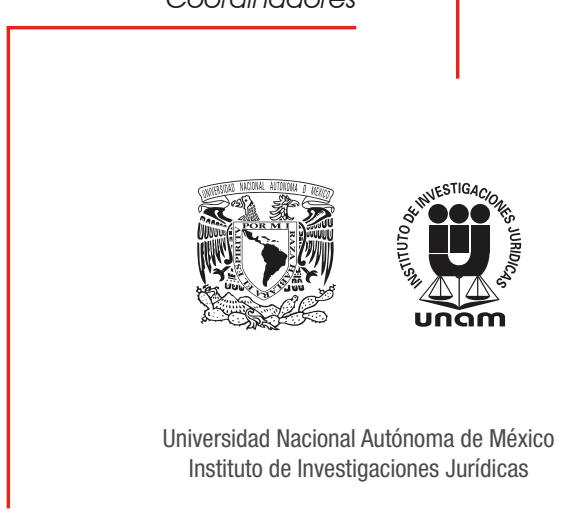


MASONERÍA Y SOGIEDADES SECRETAS

EN MÉXICO 


\title{
INSTITUTO DE INVESTIGACIONES JURÍDICAS
}

Serie DOGTRINA JuRÍDiCA, núm. 837

\author{
COORDINACIÓN EDITORIAL \\ Lic. Raúl Márquez Romero \\ Secretario Técnico \\ Lic. Wendy Vanesa Rocha Cacho \\ Jefa del Departamento de Publicaciones
}

Amaranta Luna Castillejos

Cuidado de la edición

Álvaro Luna Castillejos

Formación en computadora

Óscar Martínez González

Apoyo editorial

Mauricio Ortega Garduño

Elaboración de portada 


\title{
MASONERÍA Y SOCIEDADES SEGRETAS EN MÉXICO
}

\author{
JOSÉ LUIS SOBERANES FERNÁNDEZ \\ Carlos Francisco Martínez Moreno \\ Coordinadores
}
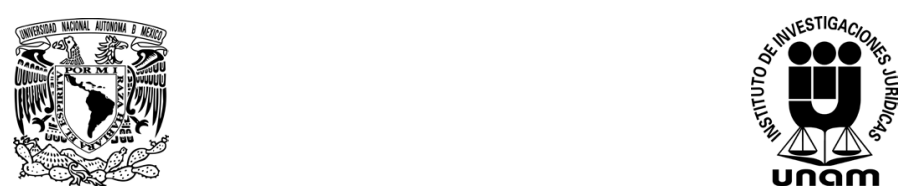

UNIVERSIDAD NACIONAL AUTÓNOMA DE MÉXICO INSTITUTO DE INVESTIGACIONES JURÍDICAS MÉXICO, 2018 
Primera edición: 4 de octubre de 2018

DR (C) 2018. Universidad Nacional Autónoma de México

\section{INSTITUTO DE INVESTIGACIONES JURÍDICAS}

Circuito Maestro Mario de la Cueva s/n Ciudad de la Investigación en Humanidades Ciudad Universitaria, 04510 Ciudad de México

Impreso y hecho en México

ISBN: 978-607-30-0755-9 


\section{CONTENIDO}

Presentación ............................. XI

José Luis SOberanes FernándeZ Carlos Francisco MaRTínez MOREnO

Luces y sombras de la masonería: las incongruencias

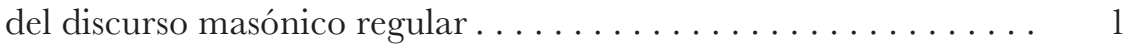
Javier Alvarado Planas

Las logias lautaro, los caballeros racionales y el movimiento independentista americano........... 41

José Antonio FERRER BenIMELI

Prohibiciones masónicas papales, reales y la Constitución de Cádiz . . . . . . . . . . . . . . . . 71

José Antonio Ferrer Benimeli

Las sociedades secretas de Los Guadalupes y de Jalapa, y la independencia de México. . . . . . . . . . . . . . .

VIRGinia Guedea RinCÓN-GALLARDO

La imperial Orden de Guadalupe, precedente de las primeras corporaciones masónicas del México nacional ............. 109

María Gristina TORALES PACHEGO

Iglesia católica y masonería. Las condenas pontificias . . . . . . . . 127

EMILIO MARTínez AlBESA

La mirada de la Santa Sede sobre la masonería mexicana . . . . . . . 219

PAOLO VALVO

El liberal moderantismo durante el gobierno de Ignacio Comonfort. . . . . . . . . . . . . . . . . . . . . 243 Silvestre Villegas Revueltas 
La lucha entre masones y católicos en el Porfiriato. La creación de la Gran Dieta Simbólica de México en 1890 . . . . . . . . . . 271 SALVADOR GÁRDENAS GUTIÉRREZ

Masones: iideólogos y fundadores de la Constitución mexicana de 1917 ? . . . . . . . . . . . . . . . . . . 313 Carlos Francisco Martínez Moreno

Masonería y anticlericalismo en la década de 1920 . . . . . . . . . 351 JEAN MEYER

Juristas masones del exilio republicano español en México . . . . . . . 365 Eva Elizabeth MARTínez CHÁvez

La educación después de las reformas de $1833 \ldots \ldots \ldots \ldots \ldots \ldots$ ANNE STAPLES 


\section{PRESENTACIÓN}

El año de 2017 ha sido rico en conmemoraciones - no siempre celebraciones- y nos ha permitido recordar acontecimientos del pasado que, de una $u$ otra forma, han colaborado en la conformación de nuestra sociedad contemporánea.

Dichas conmemoraciones son una forma de asumir nuestro pasado y todo lo que éste representa en la construcción de nuestro presente; es una manera de no mostrarnos ingratos, pues, para bien o para mal, ese pasado ya forma parte de nuestro ser.

Quinientos años de la Reforma protestante, trescientos de la masonería, ciento cincuenta del triunfo de la República (varias instituciones lo hicieron, incluidas facultades, institutos y dependencias de la UNAM), cien de la Constitución mexicana, cien de la Revolución Rusa, etcétera.

Cuando se llevan a cabo este tipo de conmemoraciones, siempre traen consigo la oportunidad de reflexionar respecto al significado y la trascendencia del hecho o acontecimiento cuyo aniversario estamos evocando.

La masonería es una institución fundamental en la historia moderna y contemporánea del mundo occidental, así como en la formación del Estado liberal y democrático de derecho, y, por ende, en la configuración de nuestro país como una nación libre y soberana en los siglos XIX y XX.

Por supuesto, la masonería ha generado muchas pasiones, alabanzas y críticas feroces, pero no es una institución que pase desapercibida ante cualquier persona que observe nuestra realidad política, presente y pretérita.

¿En el siglo XXI ya existe la serenidad suficiente para contemplar de manera objetiva a dicha institución fundamental de nuestra histórica patria? Pensamos que sí, por ello nos hemos animado a organizar este volumen colectivo, aprovechando el tricentenario de la creación de la Gran Logia de Londres, el 24 de junio de 1717, primera obediencia masónica aceptada especulativa, madre de todo el movimiento masónico mundial, así como al bicentenario de las primeras logias masónicas regulares en la Nueva España.

Para colaborar en este volumen hemos invitado a muy distinguidos especialistas de México y el extranjero, con lo que hemos conseguido -modestia 
Esta obra forma parte del acervo de la Biblioteca Jurídica Virtual del Instituto de Investigaciones Jurídicas de la UNAM

aparte- ${ }^{-}$un libro bastante bien logrado; vaya, pues, nuestro agradecimiento a todos ellos por su muy valiosa colaboración.

Queremos agradecer al Instituto de Investigaciones Jurídicas de la Universidad Nacional Autónoma de México, y a su director, el doctor Pedro Salazar Ugarte, por haber patrocinado este proyecto académico.

José Luis SOBERANES FERNÁNDEZ Carlos Francisco MarTínez Moreno 


\title{
LUCES Y SOMBRAS DE LA MASONERÍA: LAS INGONGRUENCIAS DEL DISGURSO MASÓNICO REGULAR
}

\author{
Javier Alvarado Planas*
}

SUMARIO: I. Introducción. II. Acusaciones infundadas contra la masonería. III. Acusaciones fundamentadas contra la masonería. IV. Reflexión final.

\section{INTRODUCCIÓN}

Fue y sigue siendo un notable hallazgo el que una asociación civil asumiera como finalidad la mera reunión fraternal de personas de cualquier religión, raza, clase social e ideología política, y que, convencidos de la existencia de Dios y de la inmortalidad del alma, acordaran respetar unas reglas ceremoniales o un orden más o menos cerrado para debatir sobre todo tipo de asuntos relacionados con el mundo del pensamiento, el arte, la filosofía... en fin, la cultura, con prohibición expresa de tratar asuntos políticos o religiosos.

Como es sabido, la masonería medieval se transformó en el siglo XVIII al calor de las modas novatoras e ilustradas de dicho siglo, las cuales practicaban una socialibilidad culta más abierta y flexible que la de las academias, pero alejada de la frivolidad imperante en las tertulias, cafés y cenáculos de la época. En efecto, mientras las academias eran corporaciones especializadas por razón de la materia y en las que imperaba una incómoda censura, en las logias se podía discurrir sobre diversas materias de filosofía, moral, arte, historia, ciencia y, además, hacerlo sin más censura que la obligada por la cortesía y educación.

Aunque lamentablemente no disponemos todavía de un estudio de conjunto sobre el exacto papel desempeñado por las logias masónicas en el

* Catedrático de Historia del Derecho y de las Instituciones, Universidad Nacional de Educación a Distancia (España). 
desarrollo de la Ilustración y del pensamiento liberal, la mayoría de los historiadores coinciden en que tuvo una influencia decisiva. ${ }^{1}$

Por citar algunos ejemplos de logias señeras, cabría mencionar a la parisina Las Nueve Hermanas, fundada en $1765,{ }^{2}$ verdadero motor cultural de la época, que fue frecuentada por el filósofo Helvetius; el astrónomo Lalande; Benjamin Franklin (1779-1781) - embajador en París de Estados de Unidos-; Adrien-Nicolas, marqués de la Salle; Emmanuel de Pastoret, criminalista; el historiador Antoine Court de Gébelin; Jacques Montgolfier; Emmanuel-Joseph Sièyes, etcétera.

En Alemania, uno de los núcleos de la Ilustración fue la logia Amalia de las Tres Rosas de Weimar, de la que fueron miembros el príncipe soberano Carlos Augusto de Weimar y sus consejeros y principales protagonistas del renacimiento cultural del ducado: Goethe, Herder, Wieland, Schiller, etcétera. Gracias a la labor de esta logia, la corte de Weimar se convirtió en uno de los principales y más celebrados centros culturales de Europa.

En Viena, una de las más famosas fue la logia La Verdadera Concordia (Zur wahren Eintracht), que se inspiraba en los principios de la cultura ilustrada y regalista. ${ }^{3}$ Entre sus miembros y visitantes encontramos a mecenas, escritores, filósofos, artistas, científicos e intelectuales, como el médico de la corte Ignaz Fischer; Ignaz von Born, geólogo y consejero áulico de José II; el barón Joseph Sonnenfels, del Consejo secreto de la emperatriz María Teresa y autor de un tratado en defensa de la abolición de la tortura; el conde Joseph Emmanuel Malabayla del Canal, eminente botánico; el barón Carlo Antonio Martini, profesor de derecho romano en la Universidad desde 1754 e iniciador de la escuela alemana de derecho natural. Entre los músicos, destacaron Joseph Haydn y Johann Holzer. Wolfgang Amadeus Mozart visitó esta logia en varias ocasiones. Lo cierto es que ésta fue el auténtico centro de la vida intelectual en Viena, ${ }^{4}$ al actuar como una especie de academia literaria, artística y científica, como contrapunto a las conservadoras academias oficiales. Por iniciativa de Born, la logia decidió difundir aquellas planchas o trabajos accesibles al mundo

1 Sobre este asunto, véase mi trabajo Monarcas masones y otros príncipes de la Acacia, Madrid, Dykinson, 2017, 2 vols.

2 Con el nombre inicial de Logia de las Ciencias, por el filósofo Claude-Adrien Helvetius (1715-1771) y su amigo Joseph-Jérôme Lalande. Muerto aquél, Lalande cambió el nombre de la logia en 1776 por el de Las Nueve Hermanas (Les Neuf Soeurs). Véase Amiable, Louis, Une loge maçonnique d'avant 1789, la loge des Neuf Sceurs, París, Edimaf, 1989.

3 Rosenstrauch-Königsberg, Edith, Freimaurerei im Fosephinischen Wien, Viena, Salier 1975, p. 50. Weisberger, William R., Speculative Freemansonry and the Enlightenment. A Study of the Craft in London, Paris, Prague and Vienna, Nueva York, McFarland \& Co. Inc., 1993, pp. 167 y 168; Irmen, Hans-Josef, Die Protokolle der Wiener Freimaulerlogier "Zur Wahren Eintracht”, 1781-1785, Frankfurt am Main, s.e., 1994.

4 Rosenstrauch-Königsberg, Edith, op. cit., pp. 50-55. 
profano y editó una revista: Physikalische Arbeiten der Freunde Einträchtigen in Wien, dirigida por el propio Born, que llegó a publicar siete números entre 1783 y 1788. Estas logias serían un antecedente de lo que luego fueron las llamadas logias de investigación. El método seguido para ello era el tradicional de la masonería; los miembros de la logia presentaban periódicamente sus planchas para ser comentadas en el taller y contribuir al recíproco enriquecimiento de todos sus integrantes (recordemos que el ágape masónico formaba parte de las tenidas).

Décadas más tarde, en parecida línea, una logia de Bruselas, Les Amis Philanthropes, presidida por Pierre Théodore Verhaegen (1796-1862), propiciaría la creación de la Universidad Libre de Bruselas, cuyo primer rector fue el propio Verhaegen.

Por su parte, en la España del Trienio Liberal (1820-1823), una de las logias más influyentes fue La Templanza ${ }^{5}$ de Madrid, la cual, salvando su carácter más que irregular, agrupó a políticos como Agustín Argüelles, uno de los principales autores de las Constitución de Cádiz de 1812, el conde de Toreno; los futuros ministros Alcalá Galiano y Juan Álvarez de Mendizábal, o José María Calatrava, ministro de Justicia y autor del primer Código Penal liberal español de 1822, además de hermano de Ramón Calatrava, futuro gran maestro de la masonería española.

Los ejemplos podrían multiplicarse fácilmente. En suma, es innegable el papel cultural y benéfico-asistencial desempeñado por la masonería mediante la erección de orfanatos, hospitales, universidades, bibliotecas, laboratorios de ideas, bajo su dependencia. Sin embargo, pese a esta importante labor filantrópica y cultural, la masonería no ha gozado de un unánime reconocimiento. Esta hostilidad es más llamativa si tenemos en cuenta que la masonería llamada regular estableció, desde 1723, la obligación de no debatir ni inmiscuirse en cuestiones políticas y religiosas. En todos los países democráticos la masonería se encuentra legalmente reconocida y trabaja en favor de ciertos principios filantrópicos y humanitarios, entonces, ¿por qué fue y sigue siendo condenada o malquista por confesiones religiosas como la cristiana, ${ }^{6}$ la musulmana o la

5 Alvarado, Javier, Masones en la nobleza de España, una Hermandad de Iluminados, Madrid, La Esfera de los libros, 2016, pp. 151 y ss.

6 Según Jean-François Var, diácono de la Iglesia ortodoxa de Francia, "cada una de las dieciséis Iglesias autocéfalas que constituyen la Iglesia ortodoxa es libre de legislar para sí misma y promulgar una ordenanza sobre cuestiones de fe o disciplina. Ninguna lo ha hecho a propósito de la masonería, a excepción de la Iglesia de Grecia. Empero su decisión, únicamente tiene validez para ella, sin vincular a las demás Iglesias. En efecto, el 12 de octubre de 1933, la asamblea episcopal de Grecia presidida por el arzobispo de Atenas Crisóstomo, promulgó una condena de la masonería prohibiendo a todo clérigo afiliarse a la misma so pena de degradación e instando a los fieles ya descarriados a romper sus relaciones con las logias". Véase Var, Jean-François, "La Iglesia ortodoxa y la masonería", en Ferrer Benimeli, José Antonio (dir.), Masonería y religión: convergencias, oposición, incompatibilidad?, Madrid, Pontífica Universidad Javeriana, 1996, pp. 125-148. 
judía? ¿Acaso no fue y es la masonería un leal complemento a la formación moral y espiritual del ser humano?

Ello nos lleva a analizar las acusaciones que, desde sus orígenes, se han vertido sobre la masonería regular, entendiendo por tal aquella que, al menos, prohíbe a sus logias todo debate sobre materias políticas o religiosas. A estos efectos, vamos a tratar este asunto desde el punto de vista de la coherencia interna del discurso masónico. Más preferentemente, vamos a estudiar si la propia masonería, en sus enseñanzas y ritos, cumple y se atiene a la regularidad u ortodoxia masónica que ella misma defiende.

Las acusaciones o motivos de descrédito que pesan sobre la masonería pueden clasificarse en débiles y fuertes. Entre los primeros o infundados hay que citar las acusaciones de:

1. Ser una sociedad secreta.

2. Adorar al Gran Arquitecto del Universo como un dios masónico.

3. Conspirar contra la Iglesia católica.

4. Alentar un contubernio judeo-satánico-comunista.

5. Fomentar el relativismo, indiferentismo y sincretismo religiosos.

6. Practicar el deísmo y una religión natural.

Entre las causas que, en nuestra opinión, constituyen razones fuertes o fundamentadas que prueban las contradicciones del discurso masónico estudiaremos:

1. Los términos atroces del juramento masónico.

2. Ciertos temas de los altos grados como la venganza hiramita y templaria.

3. El tema de la cruzada contra el islam, desarrollado en ciertos altos grados.

4. El contenido deísta de algunos altos grados.

5. El contenido gnóstico de varios temas descritos en los altos grados.

6. El contenido político de algunos altos grados.

Pasemos a estudiarlos. 


\section{ACUSACIONES INFUNDADAS CONTRA LA MASONERÍA}

\section{1. ¿Sociedad secreta o sociedad con secretos?}

Ya en los primeros años de existencia de la masonería, diversos Estados -seguidos al poco por la Iglesia católica- la prohibieron porque celebraba asambleas sin la debida autorización del gobierno. Por su parte, la primera bula condenatoria de la masonería, promulgada en 1738, consideraba sospechosos tanto el juramento de secreto como la misma fórmula del juramento: "se ligan el uno con el otro con un pacto tan estrecho como impenetrable según las leyes y los estatutos que ellos mismos han formado y se obligan por medio de juramento prestado sobre la Biblia y bajo graves penas a ocultar con un silencio inviolable, todo lo que hacen en la oscuridad del secreto". ${ }^{7}$ Es verdad que, tras la llegada de los regímenes liberales o constitucionales, no habría ya nada de censurable en la existencia de un juramento de secreto. Además, nótese que, en su condición de asociación civil legalmente establecida en la mayor parte de los países democráticos del mundo, la masonería no constituye en puridad una sociedad secreta sino, más bien, una sociedad con secretos, por ejemplo, sus rituales. Tales secretos han de ser respetados, de igual modo que también existe un deber y derecho de secreto o confidencialidad que afecta a otras personas o instituciones por mor del derecho establecido, ya sean instituciones públicas (por ejemplo, el secreto del sumario en el procedimiento judicial, el secreto de las deliberaciones en el consejo de ministros...), empresas privadas (derechos de propiedad intelectual y patentes) o colectivos profesionales (el secreto profesional de los abogados, los médicos y los periodistas). La propia religión católica contempla determinados secretos, como el de confesión o el de la elección pontificia. Estas premisas nos llevan a una conclusión: la existencia de un juramento de secreto no presupone, por sí solo, ningún ilícito. Ahora bien, cosa distinta y censurable es que la fórmula del juramento contuviera $-\mathrm{y}$ todavía mantenga- ciertas expresiones criminales y contrarias al espíritu fraternal y humanitario de la masonería que luego analizaremos.

\section{Adorar al Gran Arquitecto del Universo como un dios masónico}

Igualmente, pese al landmark masónico que exige a los masones creer en Dios, se ha acusado a la masonería de adorar a un dios propio (el Gran Arquitecto del Universo). Sin embargo, ello ha sido reiteradamente desmentido

7 Clemente XII, Constitución Apostólica In eminenti (Abril, 1738), en Ferrer Benimeli, José Antonio, La masonería actual, Barcelon, AHR, 1977, p. 184. 
por las propias autoridades masónicas. Por citar alguna de las últimas resoluciones oficiales de la masonería regular, en octubre de 1950, septiembre de 1962, diciembre de 1981 y junio de 1985, la Gran Logia Unida de Inglaterra ha reafirmado "la creencia en un Ser Supremo", del cual, sin embargo, no ofrece "una propia doctrina de fe". En este sentido, se aclaró: "no existe un Dios masónico. El Dios del masón es el propio Dios de la religión por él mismo profesada. Los masones tienen un respeto mutuo por el Ser Supremo en cuanto Él sigue siendo Supremo en sus religiones respectivas [...] que tiene que ser el de una religión monoteísta". ${ }^{8}$

\section{Conspirar contra la Iglesia católica}

Por su parte, sobre la acusación de maquinar contra la Iglesia católica, conviene recordar que tal argumentario fue consecuencia de las guerras por la unidad de Italia que implicaron la desaparición de los Estados pontificios (cuya superficie era un tercio de la península itálica). Pío IX y León XIII responsabilizaban, en buena medida, a las sociedades secretas de la pérdida de los Estados Pontificios, entre ellas a la masonería, identificada con la carbonería, de modo que interpretaron como conspiración contra la Iglesia lo que en realidad era una lucha por la unidad de Italia. Aunque la acusación de conspirar contra la Iglesia quedó recogida en el canon 2335 del Código de Derecho Canónico de 1917, en el canon 1374 del vigente Código de Derecho Canónico (1983) se suprimió la referencia a la masonería, de modo que su enunciado quedó mucho más matizado: "quien da su nombre a una asociación que maquina contra la Iglesia debe ser castigado con una pena justa”. Con ello se reconocía que las obediencias masónicas no necesariamente maquinaban contra la Iglesia.

\section{Alentar un contubernio judeo-satánico-comunista}

Otro de los tópicos del antimasonismo decimonónico, todavía vigente, sigue vinculando el origen de la masonería con un contubernio judeo-masónico internacional que en el siglo XVIII pretendió acabar con el orden tradi-

8 Publicados por Ferrer Benimeli, José Antonio, "El Gran Arquitecto del Universo", en Ferrer Benimeli, José Antonio (dir.), op. cit., pp. 49-55. Sobre esto también véase Álvarez Lázaro, Pedro, "Algunas reflexiones sobre las relaciones Iglesia/Masonería hoy", en Álvarez Lázaro, Pedro (coord.), Maçonaria, egreja e liberalismo. Masonería, Iglesia y Liberalismo, Actas da Semana da Faculdade de Teologia, Porto-Madrid, s.e., 1996, pp. 140-142. 
cional representado por el trono y el altar. Para reforzar esa línea argumental, se ha llegado a afirmar que la masonería fue un arma de la subversión radical whig inglesa, cuando lo cierto es que, desde 1721 hasta hoy, la Gran Logia de Inglaterra, así como la de Escocia y la de Irlanda, siempre han tenido como dirigentes a miembros de la nobleza titulada, en su mayoría adscrita al sector tory (algunos de ellos de confesión católica).

También, siguiendo las tesis del jesuita Augustín Barruel, publicadas en sus conocidas Mémoires pour servir á l'histoire du jacobinisme (Londres, 1797-1798), se ha afirmado que la Revolución francesa fue ejecutada meticulosamente por la masonería con el fin de acabar con el trono y el altar, y que las logias francesas se concertaron para socavar el poder de los Borbones. Sin embargo, el propio Barruel exceptuaba de la conspiración a los masones ingleses, a quienes muestra una alta consideración (había sido iniciado en Londres y elevado al grado de maestro masón). En todo caso, la historiografía moderna hace tiempo que desautorizó la tesis de la influencia masónica en la Revolución francesa. Repárese en que las dos principales autoridades del Gran Oriente de Francia eran dos conspicuos aristócratas a los que la Revolución se llevó por delante; el duque Felipe de Orléans (gran maestro, que acabó en la guillotina), y el duque de Montmorency (gran administrador del Gran Oriente, quien acabó sus días exiliado en Lisboa). Es más cierto que la masonería fue una institución especialmente damnificada durante la época del Terror, pues mientras en 1789 había en Francia cerca de quinientas logias, en 1796 apenas habían sobrevivido unas veinte. En pocos años, la masonería francesa prácticamente había dejado de existir porque los revolucionarios consideraban que las logias eran centros reaccionarios y elitistas en los que maquinaban aristócratas y burgueses contrarrevolucionarios. ${ }^{9}$

Otro de estos lugares comunes del antimasonismo les atribuye la expulsión de los jesuitas de Portugal y España, pese a que investigadores como los jesuitas Ferrer Benimeli o Pinedo han demostrado que la masonería no tuvo responsabilidad alguna en ello. ${ }^{10}$ Por el contrario, las razones de tales medidas se encontraban en el enfrentamiento entre los defensores de las competencias del Estado, contrarios a las intromisiones de la Iglesia en lo temporal (regalistas), frente a los ultramontanos, defensores de las prerrogativas de

9 Reinalter, Helmut, "La Masonería y la Revolución Francesa”, en Ferrer Benimeli, José Antonio (coord.), Masonería, Revolución y Reacción. Actas del IV Symposium de Metodología aplicada a la Historia de la Masonería Española, Alicante, Alianza, 1990, vol. I., pp. 29-37.

10 Pinedo, Isidoro (S. J.), voces "Aranda, conde de" y "Expulsión de los Jesuitas", en O'neill, Charles E. y Domínguez, Joaquim M $\mathrm{M}^{\mathrm{a}}$ (dirs.), Diccionario histórico de la Compañia de Jesús, Roma-Madrid, Universidad Pontífica Comillas, 2001, vol. I, pp. 212 y 213 y vol. II, pp. 1347-1353; Ferrer Benimeli, José Antonio voz "Masonería”, op. cit., vol II, pp. 2557-2563. 
Esta obra forma parte del acervo de la Biblioteca Jurídica Virtual del Instituto de Investigaciones Jurídicas de la UNAM www.juridicas.unam.mx

la Iglesia, entre los que se encontraban los jesuitas; la disputa se saldó con la supresión de la Compañía de Jesús decretada por el papa Clemente XIV en 1773. $\mathrm{Al}$ respecto, cabe señalar que nadie ha tachado de masón a dicho papa por disolver la Compañía de Jesús.

Por su parte, el tópico de la consideración de la masonería como un instrumento del judaísmo internacional arranca y se basa en los Protocolos de los Sabios de Sión, un texto que supuestamente revelaba la existencia de una conspiración internacional del judaísmo y la masonería para hacerse con el gobierno del mundo. No obstante, desde 1921 se sabe que los Protocolos no son más que una falsificación ideada por la policía política rusa. Concretamente se trataba del plagio de una obra del abogado parisino Maurice Joly (1829-1878), titulada Diálogo de los infiernos entre Maquiavelo y Montesquieu, o la política de Maquiavelo en el siglo XIX, publicada en 1864, en Bruselas, en la que se criticaba la política de Napoleón III. Dicha obra fue plagiada y publicada en 1905 por Sergei Aleksandrovick Nilus, un oficial de la policía política del zar, con el objetivo de advertir acerca de "una conjuración judeo-masónica mundial que debe conducir a nuestro corrompido mundo a su inevitable ruina". Para ello retituló el texto como Protocolos de los Sabios de Sión y sustituyó el binomio maléfico Maquiavelo-Napoleón III por masonería-judaismo. ${ }^{11}$ En 1919, un capitán alemán llamado Müller von Hausen, bajo el seudónimo de Gottfried zur Beck, volvía a publicar los Protocolos con el patrocinio de la nobleza germánica para provocar una cruzada antisemita en Alemania. A partir de ese momento, la difusión de tal mito se propagó como si fuera una verdad histórica que fue hábilmente manipulada con fines políticos (fue el argumento central del Mein Kampf de Hitler). Todavía hoy se siguen invocando los Protocolos como prueba indubitada de una supuesta conspiración mundial que, en rigor, surgió como crítica a Napoleón III.

La cruzada antimasónica alcanzó el límite del ridículo con motivo del fraude perpetrado por Léo Taxil y su invención del satanismo masónico. Léo Taxil fue el seudónimo que utilizó el periodista y falsario Marie Joseph Jogand-Pagès (1854-1907) para publicar, a partir de 1885, diversos libros en los que denunciaba la existencia de una masonería satánica que practicaba todo tipo de ritos orgiásticos y blasfemos. Sin embargo, algunos obispos y conocedores de los entresijos del asunto avisaron infructuosamente que Léo Taxil era un impostor que sólo buscaba la fama y el dinero que le proporcionaban sus conferencias y publicaciones (una de ellas alcanzó la tirada de 100000 ejemplares). En vano advirtieron que Jogand-Pagès había sido condenado años atrás a ocho

11 Me baso en el documentado trabajo de Ferrer Benimeli, José Antonio, El contubernio judeomasónico-comunista, Madrid, Itsmo, 1982, pp. 135-190. 
Esta obra forma parte del acervo de la Biblioteca Jurídica Virtual del Instituto de Investigaciones Jurídicas de la UNAM www.juridicas.unam.mx https://biblio.juridicas.unam.mx/bjv

años de cárcel por inventarse falsas noticias (una de ellas, la existencia de una ciudad romana bajo las aguas del lago Leman, llegó a ser creída por ciertas sociedades arqueológicas). También se sabía que, favorecido por una amnistía, había probado fortuna publicando libros anticlericales como Pio IX ante la Historia, su vida política y pontifical; sus vicios, sus idolos, sus crimenes. Finalmente, en 1897, cuando Taxil vio que su negocio editorial ya no daba para más, convocó una conferencia en la Sociedad Geográfica de París para presumir de haber engañado a la Iglesia católica durante doce años con la invención de una masonería satánica. ${ }^{12}$ Pero el mito del satanismo masónico ya se había instalado en el imaginario colectivo de muchas personas, quienes creyeron que las logias eran conventículos de enmascarados hombres de negro que se reunían en sótanos lúgubres para tramar venganzas sangrientas y se dedicaban a practicar misas negras, ritos satánicos, profanar hostias y crucifijos.

Años más tarde, al mito judeo-masónico-satánico se añadió otro elemento más: el comunismo. Algunos autores afirman que la masonería sirvió de puente entre la era protestante y la del comunismo soviético, y vinculan la masonería con el comunismo como si uno hubiera originado o apadrinado el nacimiento del otro. Lo cierto es que la masonería no sólo no tuvo nada que ver con el surgimiento del comunismo, sino que, por el contrario, fue especialmente maltratada por dicha ideología. Los Congresos de la Internacional Comunista celebrados en Moscú en 1921 y 1922 reiteraron la decisión de expulsar del partido a los masones por considerar que la masonería era una organización elitista y burguesa contraria a los intereses del proletariado.

Pese a todo lo anterior, todavía persiste cierta historiografia que mantiene el mito del contubernio judeo-masónico-satánico-comunista, pues, aunque ello no se encuentre respaldado por los hechos históricos, ha sido hábilmente utilizado por diversos líderes políticos para canalizar la frustración y resentimiento de sus seguidores, para cohesionarlos frente a un enemigo común o para satisfacer las mentes perezosas que se contentan con explicaciones simples. Es verdad que conviene no confundir una parte con el todo y no distinguir entre masonería regular y masonerías irregulares; por ejemplo, calificar de politizada o de anticlerical a toda la masonería supone una generalización tan errónea como afirmar que el futbol se juega con los pies (no en el rugby), que el cristianismo acepta la poligamia (sólo la practican algunos mormones) o que todas las aves vuelan (el avestruz, el pingüino o el kiwi no lo hacen). En suma, ya no cabe hablar de masonería, sino de masonerías, en plural, sobre todo a partir del siglo XIX, cuando algunos Grandes Orientes abandonaron los tradicionales landmarks de 1723 y permitieron en sus talleres los deba-

12 Ibidem, p. 31. 
tes políticos y sociales. Frente a la masonería llamada regular, se alzaron en el continente europeo otras masonerías rivales, denominadas irregulares, de tendencia adogmática y progresista.

\section{Fomentar el relativismo, indiferentismo y sincretismo religiosos}

Igualmente, diversas autoridades religiosas han acusado a la masonería de practicar el relativismo, el indiferentismo y el sincretismo religiosos. En la medida en que la masonería negaba la existencia de una verdad objetiva o la posibilidad de un conocimiento objetivo de la verdad, el relativismo colisionaba con los dogmas de las religiones reveladas. Por su parte, el indiferentismo afirmaba que todas las religiones eran diversos caminos que expresaban la única verdad. ${ }^{13}$ Pero estas acusaciones, que podrían estar justificadas en la actitud de ciertas masonerías latinas de los siglos XIX y XX, no lo estaban respecto a otras, como, por ejemplo, las anglosajonas y escandinavas. Éstas no negaban verdad objetiva alguna ni rechazaban dogmas religiosos, por la sencilla razón de que ellas mismas tenían sus dogmas o landmarks, uno de los cuales exigía a sus miembros (pues ello se consideraba una verdad objetiva) la creencia en Dios y en la inmortalidad del alma. Lo que sucedía es que tales masonerías regulares respetaban la forma o credo religioso practicado por cada uno de sus integrantes. Podría traerse aquí a colación la siguiente declaración de un masón procesado por la Inquisición de Madrid, en 1757, el cual afirmó: "no es cierto que los francmasones profesemos la indiferencia, lo que sucede es que para ser francmasón es indiferente que uno sea católico o no lo sea". ${ }^{14}$ Nótese, por tanto, que, en rigor, la masonería regular no amparaba el indiferentismo religioso, sino la libertad de cultos.

Respecto al cargo de indiferentismo, debe convenirse que en ningún texto fundacional de la masonería regular se encontraba la afirmación de que todas las religiones expresaran una única verdad. Lo más parecido a esta idea estaba publicado en las constituciones masónicas, que afirmaban la existencia de una religión universal identificada con los preceptos de Noé. Sin embargo, es verdad que algunos rituales de la segunda mitad del siglo XVIII abrazaron ciertas formas de gnosticismo (de esto se hablará más adelante).

La Gran Logia Unida de Inglaterra ha aclarado en varias ocasiones que "la Masonería no es una religión, ni un sustitutivo de la religión", y que "no es

13 "Declaración de la Conferencia Episcopal alemana de 28 de abril de 1980", Sillar. Revista Católica de Cultura, Huesca, núm. 2, abril-junio de 1981, p. 76.

14 Proceso reproducido por Llorente, Juan Antonio, Historia crítica de la Inquisición en España, Madrid, Hiperión, 1980, p. 69. 
misión de la masonería tratar de unir credos religiosos diferentes", ni propiciar un "sincretismo". ${ }^{15}$ Es más, aunque al aceptar la libertad de culto y de conciencia, la masonería - respetando las creencias de sus miembros- no adoptó institucionalmente una postura sobre el concepto de Dios, los textos oficiales de la masonería regular - en especial los anglosajones, siempre explícitamente teístas-, exigieron la creencia en el Dios revelado por las religiones monoteístas. Incluso, resulta paradójico que se acusara a la masonería inglesa de relativista y deísta, cuando ella misma - traicionando en cierta manera su neutralidad religiosa- hacía pública profesión de todo lo contrario, es decir, de teísmo.

Asimismo, respecto a la acusación de fomentar en las logias el relativismo religioso mediante la cofraternización entre cristianos, católicos y protestantes, así como judíos, musulmanes, hindúes, ya incluso el Concilio Vaticano II manifestó que era necesario que los católicos reconocieran los tesoros espirituales y morales existentes en otras religiones: "La Iglesia católica no rechaza nada de lo que en las religiones no cristianas hay de santo y verdadero [porque] reflejan un destello de aquella Verdad que ilumina a todos los hombres". ${ }^{16}$

Con todo, algunos rituales masónicos contienen temas y escenas poco afortunadas. Un exponente de los efectos contraproducentes de la equivocidad de ciertos símbolos masónicos fue señalado a mediados de siglo XX a propósito de la publicación de un libro escrito por un exmasón y pastor anglicano, Walton Hannah, luego convertido al catolicismo, ${ }^{17}$ quien tachó de blasfemos los rituales de la masonería inglesa. Ello llevó a muchos masones a presentar su baja y, además, inició una serie de desencuentros entre la Gran Logia Unida de Inglaterra y un amplio sector de la Iglesia anglicana, sector que juzgaba incompatible ser a la vez masón y cristiano. En su libro, Walton Hannah consideraba blasfemo el término Kahbalón, acrónimo empleado en el rito del Arco Real para referirse a Dios. ${ }^{18}$ Dicha palabra procedería de la unión de tres sílabas que significan Dios en sus idiomas respectivos: Yah (Yahveh, que significa El Ser o Yo soy en hebreo), Baal (que significa también Dios o señor en el idioma caldeo) y On (literalmente Ser, referido al dios Osiris)..$^{19}$ No obstante, en otros textos masónicos se le da a esta palabra un sentido diferente; por ejemplo, en el rito escocés de 33 grados,

15 Publicados por Ferrer Benimeli, José Antonio, "El Gran Arquitecto del Universo", en Ferrer Benimeli, José Antonio (dir.), Masonería y religión..., cit., pp. 49-55.

16 Juan Pablo II, Audiencia. Miércoles 9 de septiembre de 1998, Vaticano, Libreria Editrice Vaticana, https://w2.vatican.va/content/john-paul-ii/es/audiences/1998/documents/hf_jp-ii_aud_09091998.html.

17 Hannah, Walton, Darkness Visible: a Revolution and Interpretation of Freemasonry, Londres, s.e., 1952.

18 Hannah, Walton, op. cit., pp. 26, 34 y 35. Como respuesta a las críticas recibidas por este libro, publicó Christian by Degrees, Londres, 1954, en donde además editó algunos altos grados del escocismo.

19 Hatman, Alexis, Diccionario Masónico, Barcelona, Asociación Cultural Meru, 2007, p. 20. 
el grado 18 menciona tal palabra sin atribuirle esa etimología y la traduce como "el señor es nuestra ayuda".

En todo caso, repárese en que tales palabras no representaban necesariamente a divinidades concretas, sino que eran nombres que significaban literalmente "Dios" en sus respectivos idiomas. Y debido a que el tema que inspiraba el grado del Arco Real era la búsqueda de la palabra perdida (el sagrado Nombre de Dios), la leyenda de dicho grado ofrecía varias palabras sustitutas, una de las cuales (Yahbalón), al estar formada por los nombres que significan Dios en varias religiones antiguas, pretendía representar el sentimiento religioso que había animado al hombre a lo largo de la historia y, a la vez, un reconocimiento de (y citamos el Concilio Vaticano II) "todo lo santo y verdadero que pueda haber en las religiones no cristianas". Según nuestra interpretación, el acrónimo Yahbalón no implicaba necesariamente ningún indiferentismo, sincretismo o eclecticismo religioso; tampoco suponía situar en el mismo o distinto nivel unas religiones sobre otras, ni equivalía a situarlas a todas como iguales. Podía simbolizar el reconocimiento de la omnipresencia de Dios a lo largo de la historia y de lo universal de la espiritualidad humana. En suma, la desafortunada elección del acrónimo Tahbalón revelaba la ingenuidad o el mal gusto de ciertos masones, pero no nos parece técnicamente blasfema. De cualquier modo, la presión mediática creada por el libro de Walton Hannah obligó a la Gran Logia Unida de Inglaterra a retirar de sus rituales el equívoco nombre como sustituto de la palabra perdida y a afrontar la crisis originada por una oleada de peticiones de baja.

\section{Practicar el deísmo y una religión natural}

Respecto a la acusación hecha a la masonería regular de practicar el deísmo o una religión natural, cabe decir que es incierta. Ya desde sus primeros tiempos, se acusó a la masonería especulativa de alejarse del teísmo tradicional para abrazar un deísmo que negaba tanto la intervención de Dios en el mundo, como la eficacia y valor de la liturgia. El deísmo del siglo XVIII, aunque aceptaba la existencia de Dios como creador del universo, rechazaba la posibilidad de que pudiera revelar sus designios directamente o a través de profetas e intermediarios, así como de que su influencia pudiera ser invocada en cualquier forma de rito o liturgia. $\mathrm{Al}$ no aceptar las supuestas intervenciones de Dios en el mundo, negaba la existencia de la Providencia Divina, de los profetas o mensajeros, las apariciones, los milagros y la revelación de la Palabra de Dios mediante libros sagrados, como la Biblia o el Corán. La divinidad era, según esta corriente, una realidad manifestada por medio de leyes naturales, las cuales sólo eran accesi- 
bles por el conocimiento científico: únicamente la razón podía descubrir tales leyes y articular sobre ellas una religión natural y una ética positiva.

No obstante, lo cierto es que acusar a toda la masonería de practicar el deísmo era, cuando menos, inexacto. En efecto, en las constituciones masónicas, publicadas por la Gran Logia de Londres, en 1723, se aludía a Cristo como Gran Arquitecto de la Iglesia (recordemos que la expresión Gran Arquitecto se reserva a la Divinidad), lo que suponía un reconocimiento implícito del carácter divino de Jesucristo y de su papel providencial y salvífico. También se preceptuaba la obligación de efectuar los juramentos masónicos sobre la Biblia, lo que implicaba reconocer su valor como texto sagrado, en el cual se había revelado la Palabra de Dios. El landmark de respetar las fiestas masónicas de san Juan Bautista y de san Juan Evangelista o de los cuatro santos coronados constituía también una aceptación del carácter mediador de los santos, amén del reconocimiento de un culto organizado conforme a cierta liturgia. Como puede verse, todo ello era contrario al deísmo y estaba en perfecta línea con el teísmo. Los mismos compiladores de dichas constituciones - el reverendo James Anderson, pastor de la Iglesia presbiteriana escocesa, y Jean-Theophile Desaguliers, ministro de la Iglesia anglicana- eran convencidos teístas, y no deístas. También lo eran los católicos irlandeses que fundaron la Gran Logia de los Antiguos, rival de la de Anderson, incluido su gran secretario, Laurence Dermott, redactor de las constituciones de los antiguos, publicadas en 1756 con el subtítulo de Ahiman Rezon. En dicho texto se afirma:

Todo masón está obligado a creer firmemente y adorar fielmente a Dios eterno al igual que las enseñanzas sagradas que los dignatarios y Padres de la Iglesia han redactado y publicado para el uso de los hombres sabios; de tal suerte que ninguno de los que comprenden bien el Arte pueda marchar sobre el sendero irreligioso del desgraciado libertino o ser introducido a seguir a los arrogantes profesores del ateísmo o del deísmo. ${ }^{20}$

Es decir, no sólo se reconocía de forma expresa la creencia en un Dios personal que mostraba sus enseñanzas por medio de la revelación y de los Padres de la Iglesia, sino que se condenaba explícitamente el deísmo. Ello evidencia que la masonería originaria era inequívocamente teísta, y no deísta.

De igual manera, el antimasonismo clerical acusó pronto a la masonería de propugnar una religión natural, pero lo cierto es que los textos masónicos fundacionales no mencionan tal concepto, sino que sólo se refieren a la "religión universal". Recordemos, por otra parte, que la propia palabra católico procede del

20 Ahiman Rezon or a Help to a Brother, Londres, s.e., 1756, p. 105. 
griego kath'holon y significa "universal". Además, la religión universal propugnada por la masonería de los modernos no encajaba exactamente en un planteamiento naturalista, sino que casaba más bien con la tradicional concepción del derecho natural, concebido como conjunto de normas éticas y morales impresas por Dios en el alma del hombre.

En efecto, las constituciones de Anderson identificaban las artes, en general, y la geometría, en particular, con un conocimiento universal revelado por Dios e innato en todos los hombres. En dicho contexto, se invocaba una frase del apóstol san Pablo: "la obra de la ley escrita en sus corazones" (Hechos 2, 15), al tiempo que se afirmaba que Adán, "creado a imagen de Dios, tenía las ciencias[...] inscritas en su corazón". Con todo, tales remisiones a una religión universal constituían una estrategia para evitar las disputas religiosas entre católicos y protestantes, que estaban socavando los cimientos de la fraternidad masónica, así como un medio de facilitar también el acceso a judíos y musulmanes. ${ }^{21}$

Así, la religión universal que Dios había impreso en los corazones de todos los hombres quedaba identificada con la religión prediluvial de Noé22 y, por tanto, era anterior al islam, al cristianismo y a la fundación del judaísmo de Abraham (Génesis 11, 25-27). De esta manera, el noaquismo masónico fue una forma de conciliar las tres religiones del libro: la judía, la cristiana y la musulmana.

Se podría objetar que el universalismo interreligioso preconizado por las constituciones de Anderson podía resultar sospechoso de herejía para los teólogos católicos de la época, pero cualquier duda a este respecto quedaba aclarada desde el momento en que la religión universal del texto de 1723 era identificada, en la versión de 1738, con los preceptos de la ley de Noé. De hecho, ni el texto de 1723 ni el de 1738 fueron incluidos en el Index romano de libros prohibidos. Por tanto, la invocación a una doctrina revelada por Dios a Noé y consignada en un texto sagrado alejaba absolutamente las constituciones masónicas del deísmo y del naturalismo. En definitiva, la masonería regular no fue deísta ni defensora de una religión natural.

21 Pese a ello, han sobrevivido diversos textos de esos primeros años que pueden consultarse en Carr, Harry (ed.), The Early Masonic Catechisms, Londres, Manchester University Press, 1963; la cual fue reeditada por la Kessinger Publishing Company, Kila MT, s.d. Han sido editados y comentados por Négrier, Patrick, Textes fondateurs de la Tradition maçonnique 1390-1760, París, Grasset, 1995 y por Langlet, Philippe (recop.), Les textes fondateurs de la franc-maçonnerie, París, Dervy, 2006.

22 E incluso anterior a Noé. Sobre el tema masónico de la translatio scientia desde el Paraiso terrenal hasta los tiempos actuales, pasando por Caldea, Egipto, Israel, Grecia, Roma, Francia e Inglaterra, véase Alvarado Planas, Javier, "Saberes traslaticios: la leyenda de las dos columnas prediluviales", Glossae. European Fournal of Legal History, Valencia, núm. 10, 2013, pp. 48-69. 
Esta obra forma parte del acervo de la Biblioteca Jurídica Virtual del Instituto de Investigaciones Jurídicas de la UNAM www.juridicas.unam.mx https://biblio.juridicas.unam.mx/bjv

\section{ACUSACIONES FUNDAMENTADAS CONTRA LA MASONERÍA}

Las contradicciones del discurso masónico radicaban más probablemente en ciertas escenas y temas contenidos en los rituales de los altos grados redactados a mediados del siglo XVIII. Así, por ejemplo, loar el deseo de venganza (hiramita o templaria), frente al mensaje del perdón mostrado por Jesucristo, ofendía al verdadero cristiano. Se zahería a judíos y musulmanes desde el momento en que se les exigía que asumieran la idea de la cruzada a Tierra Santa o que portaran la cruz de san Andrés. Se negaba la autoridad de los profetas o ministros de la Iglesia. Se abrazaban abiertamente formas de gnosticismo que defendían que la masonería era heredera de un conocimiento esotérico por encima de las religiones, transmitido por iniciados desde la más remota antigüedad. Se soslayaba la enseñanza de los fundadores de las religiones reveladas y se cuestionaba, en fin, la divinidad de Jesucristo. Ello sin contar con que ejecutar a un acusado sin antes haberle escuchado o deponer un juramento bajo coacción eran costumbres totalmente contrarias a las leyes civiles y penales de cualquier país civilizado. Comentemos con más detalle estos aspectos del discurso masónico.

\section{El inhumano juramento masónico}

La primera condena pontificia de la masonería fue decretada el 28 de abril de 1738 mediante la bula In Eminenti, del papa Clemente XII. ${ }^{23}$ Ésta denunciaba los términos atroces e inhumanos en los que estaba redactado el juramento masónico. Concretamente, al mencionar que los masones juraban sobre la Biblia mantener su secreto bajo amenaza de graves castigos (iureiurando ad Sacra Biblia interposito, tum gravium poenarum exaggeratione inviolabili silentio obtegere adstringuntur), el papa parecía darse por enterado de que dicho juramento castigaba con la muerte al masón perjuro, lo cual, además de sobrepasar lo moralmente aceptable e incurrir en grave conducta delictiva, constituía una herejía. La segunda condena de la masonería, llevada a cabo mediante la bula Providas de Benedicto XIV, fechada el 18 de mayo de 1751, insistía en censurar los términos del juramento masónico.

¿Cuáles eran lo términos de este acto sacrílego? Un texto masónico de 1727, titulado La confesión de un masón, desvelaba los términos del juramento depuesto ante Dios y sobre la Biblia exigido a los que ingresaban en la masonería:

23 Bula In Eminenti de Clemente XII contra los masones, 2 de abril de 1738, Archivio Segreto Vaticano, Bandi sciolti, serie I, 35. 
Yo guardaré y esconderé, o no divulgaré ni daré a conocer los secretos de la palabra del masón, bajo pena de serme arrancada la lengua de debajo de mis mandíbulas y mi corazón arrancado de debajo de mi axila izquierda, y mi cuerpo sepultado bajo el límite de los altos mares, allí donde la marea desciende y sube dos veces en veinticuatro horas. ${ }^{24}$

Ya en su momento, algunos masones consideraron crueles y excesivos los términos de un juramento como éste, que llevaba aparejados -en caso de incumplimiento- atroces castigos impropios de una corporación que se postulaba como adalid de la fraternidad. Pero, sorprendentemente, tal fórmula no fue mitigada, sino que se propagó por todas las logias del continente europeo y americano. $\mathrm{Al}$ poco tiempo, la versión más extendida de la fórmula de juramento del aprendiz masón añadía el consentimiento explícito del deponente a ser ejecutado en caso de perjurio:

Juro y prometo, sobre los Estatutos generales de la Orden, y sobre esta espada símbolo del honor, ante el Gran Arquitecto del Universo, guardar inviolablemente todos los secretos que me serán confiados por esta Respetable Logia, así como todo lo que habré visto hacer o escuchado decir; nunca escribirlos, grabarlos, ni burilarlos, si no he recibido el permiso expreso, y de la manera que podrá serme indicada. Prometo amar a mis hermanos, socorrerles según mis facultades; prometo además atenerme conforme a los estatutos y Reglamentos de esta Respetable Logia. Consiento, si fuera perjuro, a tener la garganta cortada, el corazón y las entrañas arrancadas, el cuerpo quemado y reducido a cenizas, y mis cenizas lanzadas al viento y que mi memoria sea en execración a todos los Masones. ¡Que el G. :A. :D. :U. $:$ me ayude!.25

Sabido es que tales castigos físicos eran herencia del derecho penal medieval inglés y, concretamente, de la pena aplicada a los reos de alta traición

24 Una edición bilingue inglés-francés, con un breve estudio, de éste y otros textos masónicos fue publicada por Langlet, Philippe, op. cit., pp. 409-443. Asimismo, entre 1730 y 1755, varias revistas británicas, como The Daily fournal y The Scots Magazine, publicaron partes de los rituales de la masonería. Lo mismo sucedió en otros países.

25 Semejante fórmula era utilizada por las logias españolas, pues se habían servido de los rituales franceses y belgas; Frau Abrines, Lorenzo y Arús, Rosendo, Diccionario Enciclopédico de la Masonería, op. cit., vol. V, p. 581; Ruiz, César, Rito Escocés Antiguo y Aceptado. Ritual del Aprendiz masón precedido por un breve estudio del Grado, Madrid, s.e., s.f., pp. 56-57; Caballero de Puga, Eduardo, Ritual del aprendiz masón según documentos auténticos y originales ajustados en sus definiciones a los últimos adelantos de las ciencias filosóficas y naturales, Madrid, Arranz y Compañía, 1883, p. 46. Un estudio comparativo de las diversas fórmulas del juramento del aprendiz puede consultarse en Désaguliers, René, "Notes sur le serment maçonnique du premier grade", Reinassance Traditionelle, París, núm. 1, 1970, pp. 3-20. 
o atentado al rey (laesa maiestatis), que consistía en colgar, abrir el vientre y eviscerar al condenado mientras seguía vivo. No obstante, aunque fuera una fórmula de origen medieval, la mera antigüedad no podía constituir razón suficiente para su conservación, pues, en otro caso, se llegarían a legitimar otras instituciones medievales como la esclavitud o el derecho de pernada.

Atendiendo a una valoración exclusivamente jurídica de la fórmula del juramento masónico, cabe señalar que contiene varios ilícitos incompatibles con el Derecho Natural elaborado desde la escolástica medieval, y, sobre todo, con la legislación liberal surgida tras la Declaración de los derechos del hombre y del ciudadano, aprobada por la Asamblea Nacional Constituyente francesa en 1789.

Existe un primer ilícito, en la medida en la que el deponente acepta que, si incumple sus obligaciones, se le haga sufrir un daño que podría llegar a costarle la vida. Podría considerarse que tal fórmula viola el concepto de dignidad humana y además los derechos a la integridad física y a la vida.

El segundo ilícito derivaría de la intervención de un tercero, el cual es autorizado a ejecutar al que incumple su juramento. Ninguna legislación civilizada actual contempla que un particular habilite a otro para que, en determinado caso, le quite la vida. Véase, como botón de muestra, la penalización de la asistencia al suicidio. Por tanto, la fórmula del juramento vulneraría varios preceptos de la legislación penal de la mayoría de los países civilizados, por cuanto encierra la propuesta de comisión del delito de coacciones graves, lesiones, inducción o asistencia al suicidio, homicidio, e, incluso, de asesinato.

El tercer ilícito del juramento masónico deriva de la calidad de la pena establecida: la muerte. En la introducción del Convenio Europeo de Derechos Humanos se afirma que el derecho de toda persona a la vida "es un valor fundamental en una sociedad democrática" y que la abolición de la pena de muerte "es esencial para la protección de este derecho y el pleno reconocimiento de la dignidad inherente a todo ser humano". Resulta paradójico que las Grandes Logias que mantienen este tipo de penalidades en sus juramentos sean, a la vez, decididas defensoras de la abolición de la pena de muerte. Igualmente paradójico es el hecho de que este juramento, cuyo quebrantamiento lleva aparejada la pena de muerte, atente contra las propias constituciones nacionales e internacionales de la masonería, las cuales obligan a los masones a acatar las leyes de sus respectivos países, incluidas aquellas que han suprimido la propia pena de muerte ¿Cómo puede explicarse que la masonería lleve a gala combatir la pena de muerte y acatar las leyes abolicionistas, y, a la vez, mantenga dicha pena capital, aunque sea simbólica, dentro de su organización?

La fórmula del juramento también podría traspasar los límites del derecho de asociación reconocido en la legislación de los países democráticos, que declara ilegales aquellas asociaciones que utilicen medios tipificados como delito. Y 
es claro que la formula masónica utiliza "medios tipificados como delito", pues el juramento -imprescindible para entrar en la asociación- exige que el candidato ponga su vida como garantía del cumplimiento de su compromiso y, además, autorice a otro a llevar a cabo la ejecución de la pena en caso de incumplimiento. Puesto que tales compromisos exigidos al candidato están tipificados como delitos, la fórmula de este juramento podría determinar la ilegalidad de la asociación y su consiguiente disolución por sentencia judicial.

Recapitulando: la fórmula del juramento masónico, entendida de forma literal, atenta claramente contra la dignidad humana, el derecho a la vida y a la integridad fisica; restaura la pena de muerte abolida en la mayor parte de las legislaciones europeas; contiene conductas tipificadas como delito (proposición para delinquir, coacción grave, homicidio, asesinato, inducción o asistencia al suicidio), y vulnera los límites del derecho de asociación al utilizar medios tipificados como delito.

Los masones interpelados por este asunto ${ }^{26}$ suelen aducir que se trata de fórmulas antiguas e intrascendentes que ningún masón toma en serio. Aducen que los términos del juramento son puramente simbólicos. Lo cierto es que, aunque se trate de un hecho simbólico e histórico y que la pena de muerte nunca haya llegado a producirse, no nos hallamos ante una mera manifestación realizada en un contexto informal, sino, al contrario, ante una fórmula juramental que implica la asunción de unos deberes de confidencialidad. Como cualquier otro juramento de confidencialidad, el acto implica una obligación. El que la acepta queda jurídicamente vinculado a cumplirla; y a quien la recibe, le asiste de manera correlativa el derecho a reclamar su posible incumplimiento, incluso por vía judicial. Las obligaciones derivadas de un juramento son materia tan seria que la mayor parte de las legislaciones del mundo regulan tal institución y castigan su violación. De igual manera, la mayoría de los países desarrollados del mundo protegen los secretos industriales, la propiedad intelectual y los contratos de confidencialidad, y castigan su violación con sanciones económicas o penas de cárcel. Por poner un ejemplo extremo, jurar o testificar falsamente en un juicio está castigado con penas de hasta tres años de cárcel en España, cinco en Estados Unidos y ocho en Uruguay.

26 A esta cuestión dedica un capítulo de su obra Hannah, Walton, op. cit., pp. 20-24, recogiendo las opiniones de algunos masones ingleses sobre estos inocentes juramentos. Uno de esos masones y también pastor anglicano, incomprensiblemente calificó la fórmula del juramento como menudencia (cowboys and indians). Debido a la división de pareceres, en 1986 la Gran Logia Unida de Inglaterra cerró en falso el debate a pesar de la opinión de su gran maestro, el duque de Kent, favorable a suprimir todas las penalidades del juramento por considerarlas un "moscardón en el sombrero". 
Cerremos esta reflexión sobre el juramento masónico recordando la hipótesis de que una de las razones que motivó la bula pontificia de 1738 fue que, gracias a las pesquisas inquisitoriales previas a dicha bula, la Iglesia había podido averiguar los términos vehementemente sospechosos del juramento masónico efectuado sobre la Biblia y bajo amenaza de padecer graves castigos, en caso de perjurio. En la encíclica Providas, de mayo de 1751, Benedicto XIV insistió en los anteriores motivos de la bula de 1738. La encíclica Ecclesiam de Pío VII de septiembre de 1821 denunciaba los términos de un "juramento tan severo". ${ }^{27}$ Más explícitamente, en la constitución apostólica Quo Graviora, fechada en marzo de 1826, León XII sostenía:

Nosotros condenamos singularmente y declaramos nulos los juramentos impíos y culpables por los cuales aquéllos que ingresando en esas sociedades, se obligan a no revelar a ninguna persona lo que ellos tratan en las sectas y a condenar a muerte los miembros de la sociedad que llegan a revelarlo a los superiores eclesiásticos o laicos ¿Acaso no es, en efecto, un crimen el tener como un lazo obligatorio un juramento, es decir un acto debido en estricta justicia, que lleva a cometer un asesinato, y a despreciar la autoridad de aquellos que, teniéndo la carga del poder eclesiástico o civil, deben conocer todo lo que importa a la religión o a la sociedad, y aquello que puede significar un atentado a la tranquilidad?

Y, en efecto, dado que la fórmula juramental utilizada en los rituales masónicos amenazaba con la pena de muerte al masón perjuro, ya únicamente por esta circunstancia, la condena pontificia de la masonería no sólo se ajustaba al derecho canónico, sino que también era coherente con las leyes nacionales e internacionales del mundo contemporáneo.

\section{La venganza hiramita y templaria}

Otra de las contradicciones del discurso masónico regular se encuentra en ciertos altos grados cuya creación se remonta a la segunda mitad del siglo XVIII. Lo más curioso es que tales incoherencias ya fueron puestas de manifiesto por algunos masones de la época.

La principal y más sólida de las críticas a los altos grados procede de un príncipe experto en la materia, Federico de Orange, hijo del rey Guillermo I de los Países Bajos, y hermano del también masón Guillermo II. El príncipe

27 Se trata, en este caso, más bien, de un documento contra la carbonería y no contra masonería. 
Federico era gran maestro de la Gran Logia Nacional de los Países Bajos y del Gran Capítulo de los Grados Superiores desde 1816, ${ }^{28}$ y, en calidad de tal, había sido recibido en diversos sistemas y grados masónicos, como el rito escocés rectificado, el escocés antiguo y aceptado, y el sueco. Profundo conocedor del simbolismo de los sistemas de altos grados, se mostró muy crítico con esta parte de la masonería, hasta el punto de que, en 1819, redactó y difundió una Memoria $^{29}$ en la que calificaba tales grados de antimasónicos y anticristianos. Un año después, coherente con su escrito, dimitió como gran maestro del Gran Capítulo de los Grados Superiores. En su Memoria, el príncipe de Orange explicaba las razones por las que, en su opinión, ciertos grados incorporados a varios ritos masónicos (entre ellos, el rito francés, el escocés rectificado, el escocés antiguo y aceptado y el de Memphis-Mizraim) eran contrarios al universalismo preconizado por la masonería y, además, contenían enseñanzas abiertamente opuestas a las predicadas por Jesucristo. El príncipe Federico no era el primero ni sería el último en criticar esta deriva de la masonería. Antes que él, algunos masones ya habían denunciado los calamitosos efectos de la indiscriminada obsesión de algunos hermanos por las cintas, colores, mandiles y títulos pomposos. Pero, en este caso, se trataba de un problema de mayor sustancia.

Recordemos que la eclosión de los altos grados se produjo en Francia en la década de $1740 .{ }^{30}$ De entre los diversos temas desarrollados en ellos, destacaron

28 Vanpeype, Dirkc J., "Prince Frederik (Grand Master 1816-1881) and the Higher Degrees in the Netherlands", Ars Quatuor Coronatorum, Boston, 1997, pp. 92 y 110.

29 Fue publicada en Annales maçonniques, littéraires et historiques de la maçonnerie des Pays-Bass, Bruselas, 1825, t. IV, p. 76.

30 Para el análisis de los diversos altos grados de la masonería nos hemos basado en la siguiente bibliografia. Los 25 grados del rito de Perfección, que luego dieron origen a otros sistemas rituales como los 33 grados del rito Escocés Antiguo y Aceptado, los 7 del rito francés, y los 99 grados del rito Memphis-Mizrain, han sido estudiados por Guérillot, Claude, La Rose Maçonnique, París, Véga, 1995, 2 t. De este mismo autor: Le rite de Perfection. Restitution des rituals traduit en anglais et copiés en 1783 par Henry Andrew Francken, París, Guy Trédaniel, 2007. Por su parte, el barón Tschudy publicó en 1787 unos Recueil Précieus de la Franc-maçonnerie Adonhiramite con los cuadernos de los 13 grados de dicho sistema.

Respecto a los 33 grados del escocismo, la Biblioteca Nacional de Madrid conserva el manuscrito 7834, de época napoleónica, escrito en francés con el rito completo y lamínas en color para ilustrar la decoración del templo y la indumentaria de cada grado. También Stanislas de L'Aulnaye, François-Henri, Thuileur des trente-trois degrés de l'ecossisme de rit ancien dit accepté, Paris, Delannay, 1813. Igualmente fue publicado por Cassard, Andrés, Manual de la masonería, o sea, el tejador de los ritos antiguo escocés, francésy de adopción, Nueva York, Windham Press, 1861 y por Folger, Robert B., The Ancient and Accepted Scottish Rite, in Thirty-Three degres, Nueva York, The Author, 1862. Otra versión publicada en 1888 puede consultarse en Blanchard, Jonathan, Scotch Rite Masonry Illustrated: the Complete Ritual of the Ancient and Accepted Scottish Rite Profusely Illustrated, Chicago, s.e., 1905, 2 vols., que publica unos interesantes comentarios al final de cada grado, aunque en algunas partes peca de subjetivismo al 
cinco. Los dos primeros argumentos eran esencialmente masónicos: en primer lugar, la reconstrucción del Templo de Jerusalén, y, en segundo, la búsqueda de la palabra perdida, es decir, el sagrado nombre de Dios ( $(\mathrm{ha}-\mathrm{Sem})$. Los otros tres temas, ajenos a la tradición masónica, surgirían más o menos al hilo de las modas culturales del siglo. El tercero era la venganza hiramita; el cuarto, las cruzadas para reconquistar Tierra Santa, y el quinto, la venganza templaria. Los hechos demostraron que la filosofía y esencia de estos tres últimos temas tuvieron un dificil encaje en la masonería porque defendían enseñanzas incongruentes con los principios consignados en las propias constituciones fundacionales de los masones antiguos y modernos.

dejarse llevar por su condición de antimasón, anticatólico y antimonárquico (por ejemplo, véase t. I, p. 484). Fueron asimismo publicados por Picart, Bernard, Cérémonies et coutumes religieuses de tous les peuples du monde... París, s.e., 1809, vol. 10, pp. 427-436.

En la Biblioteca del Palacio Real de Madrid se conserva un manuscrito datable en torno al año 1823, que reúne algunos grados del rito de perfección, y que fue indebidamente titulado "Papeles de Mr. Thebet, Reglamentos de varios grados masónicos, y otros papeles que aunque no son de mucho interés conviene en mi concepto que se custodien entre los Manuscritos de la Real Biblioteca de la Reyna", Archivo General de Palacio, Madrid, sección: Reinados, Papeles reservados de Fernando VII, caja 28, exp. 33, núm. 1 a 5; igualmente, véase: Thompson McGlenachan, Charles, The Book of the Ancient and Accepted Scottish Rite of Freemasonry: Containing Instructions in all the Degrees from the Third to the Thirty-Third, and Last Degree of the Rite: Together with Ceremonies of Inauguration..., Nueva York, Macoy Pub. \& Masonic Supply Co., 1914. Por su parte, Frau Abrines, Lorenzo y Arús, Rosendo, op. cit., (utilizamos la edición de México, 1989), dedicaron el quinto volumen a publicar la mayor parte de los rituales de los diferentes sistemas; los del régimen escocés antiguo y aceptado los tradujeron de Laffont-Ladebat, Charles, Ancient and Accepted Scoth Rite; Eighteenth Deegre, Nueva Orleans, Stone Guild, 1856, que completaron con los practicados en Bélgica y Francia.

El rito francés puede seguirse también en Vuillaume, Claude-André, Manuel maçonnique, o tuileur des divers rites de maçonnerie practiqués en France, París, Dervy, 1830 (reeditado en 1975); Manuel général de maçonnerie contenant les sept grades du rite français, les trente-trois degrés du rite ecossais et les trois grades de la maçonnerie d'adoption, París, s.e., 1883.

Hay versiones en idioma español, del siglo XIX, de todos estos ritos: Ragón, Jean-Marie, Ritual del grado de R. conteniendo el análisis de los 14 grados que le preceden en el Rito escocés, Barcelona, 1875. Grande Oriente Español, Francmasonería: ritual escocés y francés seguido en España y sus provincias de Ultramar: cartillas de los $G G .1^{\circ}$ al $18^{\circ}$ del rito escocés y $1^{\circ}$ al $7^{\circ}$ y último del francés, Nueva York, 1879; Caballero de Puga, Eduardo, Francmasonería: ritual escocés de los grados capitulares del cuarto al décimo octavo, Madrid, 1889. Grande Oriente Español, Francmasonería: ritual escocés y francés seguido en España y sus provincias de Ultramar: cartillas de los G.G. $19^{\circ}$ al $33^{\circ}$ del rito escocés. Sexta clase. Orden filosófico, Nueva York, 1890; Caballero de Puga, Eduardo, Francmasonería: Ritual escocés y francés seguido en España, sus posesiones y dependencias, Madrid, 1894 (es una síntesis sin apenas referencias a las leyendas e instrucción de los grados).

Del siglo XX son las versiones de Gloton, Edmon, Memento des grades philosophiques (du $19^{\circ}$ au $30^{\circ}$ degré), París, Sagrée Réservée, 1929; Berteaux, Raoul, Le rite ecossais ancien et accepte. Sa symbolique, ses

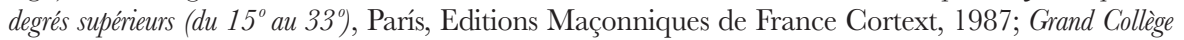
des rites. Suprême conseil pour la France et les territoires hors metropole, Cahiers des grades philosophiques (du $19^{\circ}$ au $30^{\circ}$ degré), París, Dervy, 1969. Además de otros que citaremos oportunamente.

DR @ 2018. 
Explicaremos ahora, si bien sucintamente, las contradicciones relativas a la venganza hiramita (en referencia a la venganza por el asesinato de Hiram Abí, uno de los maestros artesanos del templo de Jerusalén) y a la venganza templaria.

Aclaremos al lector que el acceso al tercer grado -aquel que confiere la maestría masónica-, ${ }^{31}$ se efectuaba mediante una ceremonia en la que el candidato escenificaba la muerte y resurrección del maestro de obras del templo de Salomón, Hiram Abí, mencionado en la Biblia (libro de los Reyes 7, 13-48). Cuenta el apólogo de este tercer grado que Hiram Abí dividió a los constructores en tres categorías (aprendices, compañeros y maestros) y asignó a cada grupo una palabra secreta que les servía para reconocerse entre ellos. Fue entonces cuando tres compañeros se conjuraron para acceder ilegítimamente a los secretos del grado de maestro y trataron de arrebatar a Hiram Abí la palabra secreta de la maestría. Emboscados cada uno de ellos en las puertas del sur, de occidente y de oriente del templo, le propinaron respectivamente tres golpes sucesivos que le provocaron la muerte. Sin embargo, no lograron arrancarle la palabra secreta.

La mayor parte de los altos grados surgidos en Francia o Alemania a mediados del XVIII, concibieron el progreso masónico a partir de este tercer grado, al cual se añadió un cuarto basado en la captura y ejecución de los tres asesinos del maestro Hiram Abí; de ahí que se definan como "venganza hiramita".

En efecto, en la década de 1740, se redactó el grado de Maestro Elegido de los Nueve ${ }^{32}\left(9^{\circ}\right.$ grado del antiguo rito de perfección y del rito escocés antiguo y aceptado, y $4^{\circ}$ grado del rito francés), que iniciaba la serie de los llamados grados de venganza. Según la leyenda del grado, el rey Salomón había publicado un edicto para recompensar a quien descubriera el paradero de los asesinos del maestro Hiram Abí. Un pastor acudió ante el rey Salomón para denunciar que

31 Debido a que los rituales masónicos son el principal secreto de la masonería, sorprende que los propios masones no se hayan recatado en publicarlos. Por limitarnos sólo a las ediciones en español y relativas a los tres primeros grados del rito escocés antiguo y aceptado, además de las arriba citadas, hay que mencionar: Orestes, Manual del Past'Master, Madrid, s.e., 1871; Ruiz, C., Rito Escocés Antiguo y Aceptado. Ritual del Aprendiz masón precedido por un breve estudio del Grado, Madrid, Moreno y Rojas, s.f.; Del Pino, Francisco, Manual del Grado de Compañero Masón, Madrid, Moreno y Rojas, s.f.; J. Ruiz "Alvar Fáñez", Ritual del Compañero Masón. Rito Escocés Antiguo y Aceptado, Madrid, s.f.; Caballero de Puga, Eduardo, Ritual del aprendiz masón según documentos auténticos y originales... cit.; Ragón, J. M., Ritual del Grado de maestro, Barcelona, Salvador Manero, 1873; Utor, J. y del Pino, F., Manual del maestro masón. Redactado en presencia de los mejores autores antiguos y modernos. Con autorización de la Sapientísima Gran Logia Simbólica del Gran Oriente de España, Madrid, Imprenta del Gran Oriente de España, 1883; J. Ruiz "Alvar Fáñez” y C. Ruiz "Algebra”, Ritual del maestro masón, Madrid, s.e., s.f.

32 Guérillot, Claude, Le rite de Perfection. Restitution des rituals traduit en anglais et copiés en 1783 par Henry Andrew Francken, París, Tredaniel, pp. 97 y 98. También fue publicado en Recueil precieux de la maçonnerie Adonhiramite, Filadelfia, s.l.i., 1787, p. 19. 
uno de los asesinos estaba escondido en una gruta. El rey envió a nueve maestros masones (en otras versiones era el propio pastor) para que lo capturaran. El rito del grado escenificaba cómo uno de esos nueve maestros elegidos entró en la cueva, donde halló al asesino desarmado, sumido en una profunda desesperación, mientras pedía clemencia; "besándole las manos para enternecerlo, le suplicó que socorriese el hambre que le devoraba en aquel momento" y que "no hallaba ningún asilo que le pusiere a cubierto de los terribles remordimientos que le devoraban". ${ }^{33}$ Pese a ello, el maestro elegido, llamado Joabert (en otras versiones es Perignan, nombre derivado del latín peregrinus), le dio muerte con una daga. ${ }^{34}$ Así, "le traspasó el pecho con su puñal, diciendo Sterkim, que significa venganza", 35 en resarcimiento de la muerte de Hiram. Acto seguido, el asesino fue decapitado. Se llevó entonces su cabeza al rey Salomón, quien la expuso en el extremo de una pica para escarmiento de los traidores. Según explicaban las enseñanzas del grado, se exigía al candidato el juramento de "sacrificar a los Manes de Adonhirám" y de no revelar los secretos, so pena - citamos textualmente - de "que la muerte más horrenda sea la expiación de mi perjurio, y luego que mis ojos sean privados de la luz, por el yerro ardiente, que mi cuerpo sea presa de las fieras, y que mi memoria sea en execración a todos los Masones de la tierra". Tras esta terrible promesa, se encadenaban otras, a cuál más cruel e intimidatoria; una se deponía bajo la amenaza de "consentir que me sea cortada la lengua"; 36 otra implicaba aceptar "todas las penas corporales que me sean impuestas, que me abran las venas de la garganta [...] que mi sangre salga lentamente de mis venas" hasta la muerte; 37 y otra, que "sufra la cautividad más dura, que mis cadenas no puedan ser cortadas jamás, que mi cuerpo sea expuesto a merced de las fieras más feroces". ${ }^{38}$

Volvamos a las censuras vertidas contra este rito de la venganza hiramita por el príncipe de Orange. En su refutación, éste se basó en las más avanzadas doctrinas penales de la época, recogidas en el Código penal napoleónico de 1810, redactado por una comisión integrada por nobles masones. ${ }^{39}$ Según el

33 Papeles de Mr. Thebet, op. cit., expte. 33, núms. 1-5.

34 Guérillot, Claude, op. cit., pp. 97 y 98. Igualmente en los Papeles de Mr. Thebet, op. cit, expte. 33, núms. 1-5., y en Cassard, Andrés, op. cit., pp. 222 y 224.

35 Papeles de Mr. Thebet, op. cit.

36 Grado de segundo elegido o de Perignan, Recueil precieux de la maçonnerie... op. cit., p. 25.

37 Grado de maestro escocés, Recueil precieux de la maçonnerie..., op. cit., p. 81.

38 Grado de caballero de la espada, ibidem, p. 108.

39 Alvarado, Javier, "Masones en los orígenes de la ciencia penal europea", en Delgado, J. M. y Morales, A. (coords.), Gibraltar, Cádiz, América y la masonería. Constitucionalismo y libertad de prensa, 1812-2012. XIII Symposium Internacional de Historia de la masonería española, Zaragoza, s.e., 2014, pp. 775-809. 
príncipe Federico, primeramente, se había condenado a una persona sin respetar su presunción de inocencia, pues no se la había escuchado, ni se habían aportado pruebas de su culpabilidad. Por tanto, era injusto que "Salomón y su consejo como jueces hubieran pronunciado una sentencia de muerte basada en la mera declaración de un ciudadano que afirm[aba], sin pruebas, que el hombre que estaba escondido era un asesino". El relato masónico, además de injusto, era ahistórico, porque reflejaba una imagen distorsionada de la sabiduría del rey Salomón: “¿cómo el más sabio de los reyes y el más justo de los hombres puede condenar a muerte a un desconocido escondido en una gruta por un crimen del que no hay ninguna prueba más que el testimonio de un desconocido?". ${ }^{40}$

Por otra parte, las enseñanzas morales contenidas en este grado eran incongruentes: no había ninguna enseñanza moral en el hecho de que el asesino de Hiram fuera decapitado y el asesino de un asesino fuese recompensado con la elevación de grado. Ningún código moral podía justificar que se ordenase a un desconocido que matara un hombre indefenso: "no se nos puede hacer creer que eso sea más perfecto por el hecho de matar a un hombre desarmado y desesperado". ${ }^{41}$ Además, el vengador no era un verdugo autorizado, sino un asesino que creía matar a otro criminal. Ninguna enseñanza moral, incluida la masónica, podía basarse en la idea de la venganza. Finalmente, el príncipe argumentaba que era contrario a las enseñanzas de Jesucristo el no dar a un acusado desesperado la posibilidad de arrepentirse, pues, si él perdonó a quienes le crucificaban diciendo "Padre, perdónales porque no saben lo que hacen", ¿cómo aceptar que este grado masónico preconizara la venganza? Este cúmulo de despropósitos venía, además, agravado por la misma ubicación del grado, habida cuenta de que, al estar situado al comienzo del sistema, contaminaba el resto de los grados superiores e impedía el acceso a aquellos masones que rechazaran este grado por motivos de conciencia.

La Memoria del príncipe de Orange tuvo eco inmediato en otras obediencias europeas, las cuales procedieron casi inmediatamente a suavizar los términos más severos del rito. Algunos masones optaron por considerarlo contrario a las enseñanzas de la masonería y ajeno a la iniciación, e incluso hubo logias que prohibieron la entrada a hermanos visitantes que estuvieran en posesión del grado de Maestro Elegido de los Nueve. ${ }^{42}$ Modernamente,

40 Memoria del príncipe Federico de Orange, en Annales maçonniques, littéraires et historiques de la maçonnerie des Pays-Bass, Bruselas, 1825, t. IV, pp. 121 y 122.

41 Ibidem, pp. 76 y 123.

42 Véase Vassal, Pierre Gérard, Cours complet de Maçonnerie, París, Slatkine Reprints, 1827, pp. 305-313. 
historiadores masones como Guérillot consideran los grados de venganza como una "recopilación de elementos disparatados e inaceptables cuyo significado iniciático es difícil de aceptar". ${ }^{43}$

En todo caso, la concepción de la venganza como restauración de la justicia, aunque pudiera resultar aceptable para la cultura judía o para la mentalidad europea de mediados del XVIII, sería considerada como una idea totalmente desafortunada en el contexto iniciático de los siglos XIX y XX, momento que señala el auge y expansión del liberalismo y de la doctrina de los derechos humanos. De hecho, como ya se ha mencionado, poco después, algunos rituales maquillaron el argumento para suavizar la idea de la venganza. Así, en el libro titulado Instrucciones para los grados altos según el rito moderno, publicado en 1822, el asesino de Hiram ya no era ejecutado, sino que, tras ser descubierto en la cueva, "se quit[aba] la vida clavándose un puñal en el corazón". ${ }^{44}$ Esta tesis del suicidio del asesino de Hiram encuentra acomodo en otras versiones posteriores. En éstas, además, se describe al rey Salomón como un monarca preocupado por aplicar la justicia y evitar la venganza, pues el masón "no debe olvidar nunca que todo brazo armado que no corresponda a un poder legítimo sólo puede ser criminal". ${ }^{45}$

En las versiones de idioma español practicadas a fines del XIX encontramos ambas soluciones. En una de ellas, el perseguidor "sorprende dormido al asesino, que tenía un puñal a sus pies, y no pudiendo contener su impaciente celo, toma el arma y le hiere, primero en la cabeza y después en el corazón y expira inmediatamente; entonces separó del tronco la cabeza del traidor". ${ }^{46}$ En otra interpretación se mataba al asesino en defensa propia, dado que, tras ser descubierto, había atacado a sus perseguidores, los cuales no tuvieron otra opción que darle muerte. ${ }^{47}$ Asimismo, Eduardo Caballero de Puga, grado $33^{\circ}$, aclaraba: "antiguamente se llevaba al candidato a una habitación en forma de caverna donde había un maniquí que figuraba estar echado sobre un lecho de hierba seca al cual debía dar una puñalada en la cabeza y otra en el corazón, y como la cabeza estaba separada del tronco, volvía con ella cogida por los cabellos en muestra de triunfo". ${ }^{48}$ No obstante, matizaba Caballero de Puga, lo que en los tiempos modernos representaba la caverna no era sino la

43 Guérillot, Claude, op. cit., p. 116. También en Blanchard, Jonathan, op. cit., t. II, p. 373.

44 Instrucciones para los grados altos según el rito moderno, Burdeos, s.e., 1822, p. 27.

45 Así en Cassard, Andrés, op. cit., p. 536.

46 Frau Abrines, Lorenzo y Arús, Rosendo, op. cit., vol. V, p. 741, quienes publicaron los ritos en 1883 traduciendo la versión de Laffont-Ladebat, Charles, Ancient and Accepted, op. cit.

47 Caballero de Puga, Eduardo, op. cit., p. 193.

48 Ibidem, p. 192. 
ignorancia; del mismo modo que "la decapitación del traidor con la espada de la verdad" significaba que la ignorancia debía morir. ${ }^{49}$

Ejecutado uno de los tres asesinos del maestro Hiram, los grados de vengan$z a$ proseguían con la persecución y castigo de los otros dos masones traidores. Para ello, también a finales de la década de 1740, se elaboró otro grado, Ilustre de los Quince, que pasó a ser el grado $10^{\circ}$ del rito de perfección y de otros sistemas rituales, como el francés o el escocés. Según la fábula de este grado, tras la ejecución de uno de los asesinos del maestro Hiram Abí, Salomón envió a quince maestros a que capturasen a los otros dos malvados. Una vez llevados los dos asesinos a su presencia, el rey ordenó que fueran "ejecutados con los más atroces tormentos a fin de que sus muertes estuvieran a la altura de la abominación de sus crímenes": 50

[...] fueron atados a unos potros por los pies, los brazos y el cuello, y se les abrió el cuerpo hasta sus partes deshonestas, principiando desde el pecho, permanecieron ocho horas expuestos al sol, devorados por las moscas y otros insectos. Sus lamentables gritos conmovieron á sus verdugos, quienes le cortaron la cabeza, y sus cuerpos fueron echados fuera de la ciudad para que sirviesen de pasto a los cuervos". ${ }^{51}$

$\mathrm{Al}$ igual que el anterior grado de venganza, este relato generó multitud de críticas, a las que se añadió la reprobación de la práctica de una pena atroz, evidentemente contraria a los fines ilustrados y humanitarios de la propia masonería. Recordemos que, por esas fechas, eran bien conocidas las censuras de los Ilustrados al derecho penal de la época y, concretamente, a su sistema de castigos, tan cruel como desproporcionado. Por ello, algunos masones de finales del XVIII intentaron justificar la venganza frente a los asesinos de Hiram mediante una extravagante interpretación en clave astronómica. Dando al mito un significado zodiacal, se quiso ver a los nueve y quince maestros elegidos como otros tantos signos del zodiaco y constelaciones, cuyas posiciones cortaban en aspa la Eclíptica y el Ecuador en el solsticio de verano y el equinoccio de primavera. ${ }^{52}$ En cualquier caso, estos remiendos resultaron tan bienintencionados como infructuosos, pues no consiguieron sanar el vicio de origen que aquejaba a la parábola hiramita: se hacía evidente que ¡el tema de la venganza

49 Ibidem, p. 201. También Frau Abrines, Lorenzo y Arús, Rosendo, op. cit., vol. V, pp. 746-748.

50 Guérillot, Claude, op. cit., p. 112.

51 Papeles de Mr. Thebet, op. cit., núms. 1-5. La misma atroz descripción en Cassard, Andrés, op. cit., p. 229, en Caballero de Puga, Eduardo, op. cit., pp. 227-231, o en Frau Abrines, Lorenzo y Arús, Rosendo, op. cit., vol. V, p. 749.

52 Caballero de Puga, Eduardo, op. cit., pp. 227-231. 
no podía constituir el eje vertebral de un ritual autorizado por una organización iniciática supuestamente basada en la fraternidad!

Así las cosas, a mediados del XVIII, algunos masones, deseosos de diseñar nuevos altos grados, desempolvaron la leyenda templaria y tuvieron la ocurrencia de considerarse legítimos sucesores de éstos. Por tal motivo, a los grados de la venganza hiramita le siguieron los grados de la venganza templaria. Si tres eran los malos compañeros que asesinaron al maestro Hiram Abí, semejantemente, la ruina de los templarios y vivicombustión de su gran maestre Jacques de Molay habría sido tramada por tres instancias: el rey de Francia, el papa y la Orden de san Juan del Hospital de Jerusalén (luego llamada Orden de Malta). En estos grados había de jurarse el odio a la Orden de Malta, aunque -como es sabido- dicha orden nada tuvo que ver con la disolución de los templarios y, además, de los cientos de testimonios presentados contra el Temple, no había ningun caballero hospitalario. Sin embargo, en estos grados, volvieron a repetirse escenas que conculcaban los más elementales principios masónicos de respeto y neutralidad política y religiosa. Pero pese a las llamadas de advertencia de muchos masones preocupados por tales derivas, la leyenda de los templarios fugitivos acogidos en Escocia por los masones acabó triunfando.

\section{Las cruzadas masónicas contra el Islam}

Otro de los extravagantes temas desarrollados en los altos grados masónicos fue el de las cruzadas contra el Islam para liberar Jerusalén y reedificar el templo de Salomón. Ya en 1737, el caballero Ramsay defendió, en un discurso pronunciado en su logia de París, que la masonería tenía su origen en las cruzadas: "Nuestros ancestros, los cruzados, procedentes de todos los lugares de la cristiandad y reunidos en Tierra Santa, quisieron de esta forma agrupar a los súbditos de todas las naciones en una sola cofraternidad". 53

El texto originario de algunos rituales mencionaba también a un supuesto rey Federico III de Prusia, en referencia a un rey mesías que, cual nuevo Noé, dirigiría la última cruzada para recuperar definitivamente Jerusalén. ${ }^{54}$ Llevados de su entusiasmo, algunos masones abrigaron por aquel entonces la esperanza de que la providencia divina acabaría convirtiendo a Federico II de Prusia, en ese mítico y ansiado rey Federico III de Jerusalén. Inspirado igualmente en las cruzadas medievales y también relacionado con el imaginario Federico III de Prusia, se creó, antes de 1762, el grado de Caballero Kadosh o Caballero del Águila

\footnotetext{
53 Négrier, P., op. cit., pp. 305-335.

54 Así opina Guérillot, Claude, op. cit., p. 328.
} 
Blanca y Negra. ${ }^{55}$ Pocos años después se creaba otro nuevo grado para explicar que Federico III había convocado a todos los caballeros masones a una última cruzada que seguiría la ruta de Nápoles, Rodas, Chipre, Malta, Jafa y Jerusalén. En las postrimerías del siglo XVIII, se elaboraron otros grados caballerescos que exigían a sus miembros llevar "al lado izquierdo del pecho, bordada la cruz blanca de san Andrés" 56 y "derramar hasta la última gota de sangre" en combatir "el islamismo y la barbarie". También el grado $32^{\circ}$ del rito escocés prolongó el tema de la convocatoria de una última cruzada que liberaría Jerusalén. ${ }^{57} \mathrm{~A}$ consecuencia de ello, el rey Federico II de Prusia se había dispuesto a convocar una cruzada para liberar Tierra Santa, con el fin de "arrojar de allí a los infieles", proyecto -al parecer- truncado por la muerte del monarca. Buena parte del grado describe el campamento y tiendas de los caballeros masones convocados a esta última cruzada. El ritual obligaba al aspirante a escenificar cinco campañas militares, "fortalecido con la armadura de la doctrina del gran maestro de Nazaret, que es la doctrina de la masonería".

Pues bien, el tema de la participación de los masones en las cruzadas constituyó otro de los motivos de crítica a los altos grados. El príncipe Federico de Orange consideraba que su leyenda inspiradora, el ritual y las enseñanzas morales que lo acompañaban, eran absolutamente contrarias al universalismo que debía predicar la masonería. Desde el punto de vista de la lógica, ni un judío ni un musulmán aprobarían de buen grado que se les hiciera tomar parte en las cruzadas de Tierra Santa ${ }^{58}$ cuya finalidad era precisamente combatir al islam y convertir el templo de Jerusalén en una catedral cristiana. Tampoco le pareció adecuado que el supuesto candidato masónico fuera - por mor de esta fábulaproclamado caballero de San Andrés e investido con la capa de cruzado: "¡no se puede imaginar - exclamó- algo más absurdo que un judío decorado con la cruz de san Andrés, mártir cristiano, dispuesto a participar en la cruzada para conquistar Jerusalén!". ${ }^{59}$ A lo que se sumaba una conclusión ineludible: estos grados, por su temática, vedaban el progreso masónico tanto a judíos como a

55 Ibidem, pp. 373-375. Versiones de este grado pueden seguirse en G.J.G.E. ou chevalier Kados, connu aussi sous les titres de chevalier Elu, de chevalier de l'aigle-noir, París, s.e., 1781; Ragon, J. M., Nouveau rituel de kadosch. Parfait initié. Grade philosophique, $5^{\circ}$ et dernier grade du rite français, París, Collignon, 1829; "Grade du chevalier kadosh (1775)", Latomia, Bibliothèque du Gran Orient des Pays-Bas, núms. 34-3, 1982, pp. 159-168.

56 Cassard, Andrés, op. cit., p. 395.

57 Ibidem, p. 416.

58 Memoria del príncipe Federico de Orange, op. cit., IV, p. 80.

59 Ibidem, p. 125. 
musulmanes, los cuales difícilmente consentirían reconocer como patrón a un mártir cristiano como san Andrés. ${ }^{60}$

Con una argumentación similar, señalando su frivolidad y su carácter pueril, otros autores también criticaron esta leyenda masónica. ${ }^{61}$ Insistieron en que conculcaba los principios masónicos de universalidad (un masón judío o uno musulmán, como acabamos de decir, rechazarían la obligación de devolver Jerusalén a la cristiandad); de fraternidad (poco había de fraternal en que el candidato escenificara una guerra santa contra el islam), y de neutralidad política y religiosa (la cruzada contra el islam era, por definición, un asunto político y religioso). En suma, el tema de la cruzada contra el islam, aceptable para la mentalidad de algunos masones del XVIII, seducidos por la leyenda templaria, era incompatible con el universalismo y la pax masonica defendida por una organización que aspiraba a crear espacios de entendimiento entre todos los hombres con independencia de sus ideas y creencias. No era lógico defender la tolerancia y fraternidad entre cristianos y musulmanes, mientras se acusaba a los antepasados de éstos de ser infieles, torturadores y ocupantes ilícitos de Jerusalén.

Tratando de soslayar estas críticas, algunas obediencias masónicas intentaron suavizar el discurso belicista. En este sentido, se advirtió al candidato que combatía con "los principios de la equidad y la justicia y no sobre los de la venganza y represalia sobre los enemigos". Surgieron singulares sofismas, como aclarar al iniciado que las cruzadas emprendidas por la masonería eran eminentemente pacíficas y tenían por objeto combatir la intolerancia y el fanatismo. Las versiones más racionalistas del grado insistían en el simbolismo moral de la cruzada y de la guerra contra el fanatismo, la ignorancia, la superstición y la tiranía: "organizado el ejército de masones de quince grandes cuerpos, acampa por toda la superficie de la tierra esperando la señal para el ataque definitivo". ${ }^{62}$

Estas matizaciones no sanaron, sin embargo, el vicio de origen. La apología de la cruzada o guerra santa, por muy atenuada que se presentara, era difícilmente compatible con los principios defendidos, en teoría, por la masonería. ¿Acaso estos mismos masones de finales del XVIII o del XIX habrían tolerado un grado masónico que ensalzara el yihad (guerra santa) contra los cristianos, aunque fuera en clave metafórica? Además, no todos los masones interpretaban simbólicamente la idea de cruzada contra el infiel; por el contrario, algunos se la tomaban al pie de la letra. Así, en el convento de Wilhelmsbad, que reunió en 1782 a toda la masonería rectificada de la Estricta Observancia Templaria, uno de los miembros allí presentes propuso

60 Ibidem, p. 88.

61 Blanchard, Jonathan, op. cit., t. II, p. 102. Sobre esto véase Guérillot, Claude, op. cit., p. 243.

62 Frau Abrines, Lorenzo y Arús, Rosendo, op. cit., vol. V, p. 867. 
Esta obra forma parte del acervo de la Biblioteca Jurídica Virtual del Instituto de Investigaciones Jurídicas de la UNAM www.juridicas.unam.mx

el reclutamiento de un ejército de 20000 soldados ipara expulsar a los turcos de Lampedusa y Linosa!

\section{De nuevo la acusación de deísmo}

La evolución de los altos grados tuvo otro febril episodio en ciertas versiones de los grados $13^{\circ}, 29^{\circ}$ y $33^{\circ}$ del rito escocés antiguo y aceptado, practicado en la mayoría de las obediencias regulares europeas y americanas. En ellos se abandonó el teísmo establecido en las constituciones fundacionales de la masonería especulativa para abrazar el deísmo. Más concretamente, se rechazó la idea de un Dios personal, se negó la existencia de una doctrina o mensaje revelado por Dios y, en consecuencia, se desautorizó el valor y función de los profetas y sacerdotes.

Así, por ejemplo, en los grados $13^{\circ}$ y $29^{\circ}$, se afirmaba que la francmasonería no podía "fundamentar la existencia de Dios en el concepto admitido al efecto por las religiones positivas, porque en ese caso tendría que mostrarse partidaria de una u otra creencia religiosa, lo que se opondría al principio de máxima libertad consignado en los Estatutos". ${ }^{63}$ De esta manera, el concepto de Dios había de basarse en la razón. Este argumento, sin embargo, descansaba en un sofisma dado que implicaba el rechazo de la premisa de que todas las religiones positivas coinciden, al menos, en fundamentar la existencia de Dios en la revelación y no sólo en la razón. Negar toda idea de revelación condujo a una postura radical, contradictoria con la misma tradición masónica regular recogida en las constituciones andersonianas de los modernos de 1723, así como en las de los antiguos de 1756.

Como ya se ha mencionado, frente a la religión revelada, recibida o comunicada "desde fuera" por Dios, a través de su palabra, y plasmada en los textos sagrados o en las enseñanzas de los profetas, el deísmo y la religión de la razón se apoyaban en la capacidad intelectual del hombre para deducir principios inmutables en los que todos los creyentes estuvieran de acuerdo, a saber: la creencia en un Ser Supremo, y el perfeccionamiento del hombre mediante la práctica de las virtudes.

Así, en una de las versiones del grado $33^{\circ}$ apareció la siguiente afirmación de sesgo deísta, en clara desautorización al papel de los profetas, sacerdotes, pastores, rabinos, imanes y demás ministros de las religiones reveladas: "Dios no ha dado a ningún hombre la autoridad para reemplazarle y representarle en la tierra y todos aquellos que pretenden ser sus ministros y representantes,

\footnotetext{
63 Ibidem, p. 762.
} 
no deben ser creídos". ${ }^{64}$ Resulta sorprendente la profesión de fe deísta consignada en la redacción de este grado masónico, pero no porque el deísmo fuera incongruente con la masonería. Ciertamente -ya lo hemos aclarado- tanto las constituciones masónicas de los modernos como las de los antiguos eran claramente teístas. En este sentido, afirmaban la creencia en un Dios personal, que se revelaba por medio del libro sagrado, de la enseñanza de los profetas, y cuya influencia benéfica podía ser invocada a través de la liturgia o de ciertas festividades religiosas. Pero ello no impedía a los deístas el acceso a la logia: el deísmo era, pues, una de tantas opciones válidas. Lo sorprendente es que un ritual masónico aprobado por una obediencia regular consignara el deísmo como única opción lógica y que, además, lo hiciera en unos términos tan desconsiderados y descalificadores hacia las religiones reveladas que se había comprometido a respetar. En suma, la filosofía que sustentaba estas versiones de los altos grados masónicos se situaba claramente en el campo del deísmo y del naturalismo y, por tanto, era contraria al teísmo masónico tradicional defendido por las constituciones fundacionales y practicado por la mayoría de los masones regulares.

Especialmente incongruente con las constituciones fundacionales de la masonería fueron algunas versiones del grado $18^{\circ}$ del rito escocista, las cuales arremetían contra las religiones "[que] encierran a los hombres, los dividen y se oponen al progreso, mientras que la masonería trabaja en unirlos para hacer de ellos una sola familia de hermanos y amigos". ${ }^{65}$ Y, más adelante, se afirmaba: "Los sacerdotes han desvirtuado el sentido humanitario de la palabra caridad haciéndola sinónima de limosna". ${ }^{66}$

Anotemos que el diseño de este grado $18^{\circ}$ fue objeto de las críticas más severas. El ya citado gran maestro masón, Federico de Orange, lo calificó de desafortunado y blasfemo. En primer lugar, porque la vida y enseñanzas de Cristo ya estaban perfectamente explicadas en el Nuevo Testamento y no había ninguna necesidad de incluirlas en un grado masónico. En segundo, porque convertir la vida de Jesucristo en una leyenda o emblema y situarla al mismo nivel de las leyendas de Zorobabel, Hiram y demás personajes, ofendía los sentimientos de un verdadero cristiano. ${ }^{67}$ En tercer lugar, porque ciertas partes del rito eran indignas, contrarias al cristianismo e, incluso, rayanas en lo delictivo, por ejemplo, la escenificación del juramento que debía deponer el candidato en el momento mismo en que un hacha se levantaba sobre

\footnotetext{
64 Blanchard, Jonathan, op. cit., t. II, p. 477.

65 Ragón, Jean-Marie, op. cit., p. 103.

66 Ibidem, p. 112.

67 Ibidem, p. 90.
} 
su cabeza (también en el grado 28을 escocés de san Andrés). “Ciómo se puede aceptar [razonaba el príncipe Federico] un juramento forzado, pronunciado mientras que el símbolo de la fuerza está suspendido sobre nuestra cabeza? No solo un verdadero cristiano, sino todo el que haya comprendido el Nuevo Testamento, debe estar indignado ante este acto despreciable". ${ }^{88} \mathrm{Y}$, en cuarto y último lugar, porque la imposición de la figura de Jesús, según las enseñanzas del Nuevo Testamento, probablemente atentaría contra las creencias religiosas de los masones judíos y musulmanes que no reconocían la divinidad de Cristo. La argumentación del príncipe Federico no está exenta de lógica. En efecto, si la presencia de Jesús en este grado trataba de mostrar los valores universales de todas las religiones - en este caso, los del cristianismo-', extraña que la masonería no dedicara también algún grado o siquiera alguna escena de sus múltiples grados a las enseñanzas de Mahoma. En el mismo sentido eran cuestionables, por antiuniversalistas, las referencias que hacía este grado a los masones convertidos en cruzados durante la Edad Media, para combatir "el fanatismo destructor de los hijos de la media-Luna". ${ }^{69}$ ¿A qué obedecía esta descalificación del islam? ¿Acaso no era uno de los mandatos masónicos evitar las disputas religiosas?

En cualquier caso, la enseñanza leída al candidato venía a dar una explicación que trataba de aclarar el sentido final de la filosofia del grado rosacruz: "dado el carácter de universalidad que la Masonería tiene, no nos es permitido ensalzar ni combatir a ninguna religión; de todas admitimos lo bueno que en ellas puede existir, y sólo la Verdad enseñamos y propagamos, sin preocuparnos si pertenece a una religión o no pertenece a ninguna". ${ }^{70}$ Como se desprende de este texto, cierta masonería de altos grados pretendía ser una sintesis de ciertos valores de todas las religiones, lo que implícitamente parecía indicar que el masón no debía seguir una en concreto. Reparemos, no obstante, llegados a este punto, en que una cosa es seguir una religión, al tiempo que se aceptan ciertos valores de otras religiones, y cosa muy distinta constituye la práctica del eclecticismo religioso. Si ésta era la esencia del grado, o de la masonería, hay que concluir que resultaba contraria a los principios establecidos en las propias constituciones de Anderson rectoras de la masonería regular, las cuales imponían la neutralidad religiosa.

68 Ibidem, p. 90 y 130. También quien accedía al grado 9o del sistema escocés antiguo y aceptado aceptaba "que la espada de la justicia descargue sobre mi cabeza"; en Frau Abrines, Lorenzo y Arús, Rosendo, op. cit., vol. V, p. 741.

69 Cassard, Andrés, op. cit., p. 329.

70 Frau Abrines, Lorenzo y Arús, Rosendo, op. cit., vol. V, p. 795. 
Por otra parte, la defensa a ultranza de un universalismo masónico llevó también a redacciones desafortunadas y poco respetuosas con las creencias religiosas del masón cristiano. Una de las versiones del grado afirmaba que "la divinidad atribuida a Jesús de Nazareth" no era "para nada tomada en cuenta en este grado", ni la masonería se ocupaba "en atribuirle ni negarle tal o cual carácter". Cristo era, según este discurso, "el símbolo del maestro, la alegoría que representa el poder del amor y de la virtud". ${ }^{71}$ Así, convertido en un mero símbolo, se sometió al Jesús de los cristianos a un minoramiento gratuito. En rigor, esto contrariaba los más elementales deberes masónicos, dado que la masonería no debía entrar a especular sobre la divinidad de Cristo. Como cualquier debate religioso estaba proscrito en sede masónica, tal cuestión no debía ni siquiera plantearse.

Además, esta forma de eclecticismo o sincretismo religioso no explicaba claramente quién determinaba la selección de "lo bueno de cada religión", y lo que constituía la auténtica "Verdad": ¿era, acaso, la conciencia?, ¿la revelación?, ¿la razón humana? El ritual del grado practicado en varias obediencias regulares se decantaba por esta última opción, es decir, por la razón, lo cual implicaba la adopción de la causa deísta. Se explicaba, en efecto, que ya no eran la $f e$, la esperanza y la caridad los caminos para encontrar la palabra perdida. En su lugar, se levantaban la tolerancia y la caridad como únicos medios para "realizar la obra masónica". Ante lo cual, cabría preguntarse: ¿acaso con esa deliberada omisión a la virtud de la fe no se daba a entender que las religiones reveladas carecían de valor? Así parecían entenderlo los redactores de este grado cuando afirmaban que Jesús era, para los masones, "un símbolo de abnegación, un emblema de la Sabiduría, extirpando el error con la Razón". Elidida, pues, su condición divina y misión salvífica, el Jesucristo "rosacruz" quedaba reducido a la condición de mero maestro, de un sabio que -como tantos otros- había combatido la ignorancia sólo con la razón, es decir, valiéndose de facultades humanas y no sobrenaturales o espirituales.

En su descalificación de las religiones reveladas, el deísmo de estos masones dejó expedito el paso al culto a la diosa razón. Con ello no sólo se abandonó el teísmo de la masonería regular, sino que, además, se rechazó toda interpretación mística, espiritual o mistérica de los rituales masónicos, los cuales quedaron convertidos en meras formalidades profanas. Significativamente, en ciertas versiones del grado $19^{\circ}$, se prolongaría la filosofía del grado $18^{\circ}$, al exigir al iniciado que se comprometiera a "no reconocer más guía que la Razón", para hacerse digno del título de "gran pontífice del Templo de la Razón". ${ }^{72}$

\footnotetext{
71 Idem.

72 Ibidem, p. 801.
} 


\section{El gnosticismo masónico}

No podemos entrar a enumerar las variadas formas de gnosticismo que se desarrollaron en el siglo XVIII. Baste indicar que, paralelamente al movimiento de la Ilustración, y a veces integrados en él, circularon movimientos o corrientes de pensamiento que se consideraban depositarios de un saber universal e inmutable. Según estas teorías, la gnosis -literalmente, conocimiento, iluminación-, custodiada por una élite de iniciados o adeptos, podía ser transmitida por la razón o la iluminación a quienes tuvieran la debida cualificación. Ello debía llevarse a cabo conforme a un método o procedimiento específico que, en buena medida, descansaba en la firme convicción del poder mágico y taumatúrgico de los gestos, sonidos, palabras y, en suma, en la eficacia de los rituales para transformar al hombre. Muchos consideraron que esta gnosis estaba situada, incluso, por encima o fuera de los dogmas y enseñanzas religiosas, porque ella misma constituía la única religión universal o sophia perennis, en la cual bebían las religiones históricas. Por eso, en todas estas religiones se podían encontrar vestigios de tal Verdad Eterna, ya fuera la mesopotámica, la egipcia, la judía, la brahmánica, la cristiana o la musulmana. Como prueba de esta identidad entre las distintas religiones, algunos rituales masónicos equipararon el asesinato y resurrección de Hiram Abí con los de Osiris, vengado por su hijo Horus, ${ }^{73}$ y otros dioses asesinados y luego resucitados; o, incluso, con el propio Jesús.

En este contexto, se habló de un gnosticismo cristiano o de un cristianismo esotérico, entendido como el conjunto de enseñanzas teóricas y prácticas supuestamente transmitidas por Jesucristo y sus apóstoles a un grupo elegido de discípulos especialmente aptos. Todo ello suponía, a la postre, poner en tela de juicio la originalidad y exclusividad del mensaje salvífico cristiano. ${ }^{74}$ Así las cosas, no puede sorprender que las autoridades católicas vieran en todos estos argumentos, tanto una negación del valor de la revelación, ${ }^{75}$ como un intento de suplantar el papel de la religión y de sus sacramentos, sobre todo en lo atinente a ciertos ritos masónicos, con palabras sagradas, gestos, signos y toques, a los que se atribuía cierta eficacia o capacidad para transformar objetivamente al hombre. ${ }^{76}$

73 Stanislas L'Aulnaye, François-Henri, op. cit., p. 58.

74 Blanchard, Jonathan, op. cit., t. II, p. 373.

75 Así lo afirmó la Declaración de la Conferencia Episcopal alemana de 28 de abril de 1980, Sillar, Revista católica de cultura, vol. 2, abril-junio, 1981, p. 77.

76 En "las acciones rituales manifiestan, en las palabras y símbolos, un carácter semejante al de los sacramentos", op. cit., p. 76. 
Tal fue el caso, por ejemplo, del grado 23 del rito de perfección, redactado en torno a 1748, el cual otorgaba a su poseedor el título de Caballero del Sol o del Águila, y que luego se incluiría en el rito escocés antiguo y aceptado. Según explicaba el texto del ritual, el grado tenía como objetivo "limpiarse del pecado original". Sobra decir que ello suponía una negación del valor del sacramento del bautismo cristiano, así como una ostensible injerencia en las competencias de una religión revelada. El ritual se proponía la revelación de "la Pura y Santa Verdad sin velos ni disimulos", ${ }^{77}$ lo cual implicaba la posesión exclusiva de un conocimiento o gnosis auténtica frente a la enseñanza falsa, incompleta o velada transmitida por profetas o mesías. Saliendo al paso de este tipo de afirmaciones contenidas en los rituales, las autoridades de la Iglesia católica volvieron a recordar la incompatibilidad del catolicismo con todo método masónico que se presentara "capaz por sí solo de lograr el perfeccionamiento del hombre", sin que quedara "espacio para la gracia del Espíritu Santo y la misión de la Iglesia". ${ }^{78}$

Como esta gnosis estaba fuera, más allá y por encima de las religiones, ${ }^{79}$ para acceder a tal conocimiento esotérico, el ritual masónico aconsejaba al candidato lo siguiente: "romper el yugo de los prejuicios infantiles que rodean los misterios de la Religión reinante [...] bajo el aspecto de una serpiente que debéis vencer, porque es un ídolo adorado solo por los ignorantes y el vulgo bajo el nombre de Religión". ${ }^{00}$ Seguidamente, se recreaba el viaje espiritual del aspirante, a quien acompañaban siete querubines, pasando por el primer Cielo, el de las delicias corporales de esta vida, hasta su llegada al tercer Cielo, donde residía la Pura Verdad.

Si hemos de valorar la coherencia de tales afirmaciones en un contexto masónico, sin entrar a prejuzgar la validez de esta forma de gnosticismo (pues cada cual era libre de creer lo que considerase más oportuno), tales enseñanzas contrariaban nuevamente los landmarks o deberes masónicos que obligaban a no debatir cuestiones de fe. No era coherente predicar, por un lado, el respeto a todas las religiones reveladas, mientras que, por otro, se calificaban tales religiones como supersticiones vulgares e infantiles. Era incongruente obligar al masón a seguir los mandamientos de la religión por él profesada, para,

77 Claude Guérillot, op. cit., p. 377.

78 Así, la "Declaración de la Conferencia Episcopal alemana de 28 de abril de 1980", op. cit., p. 78.

79 La enseñanza del grado acusa una fuerte impronta deísta según Guérillot, Claude, op. cit., p. 361. En nuestra opinión, más que deista, era gnóstico.

80 Ibidem, p. 342. 
más tarde, indicarle que había de abandonar tales espejismos para seguir un supuesto conocimiento por encima de toda religión.

Así, podemos concluir que la masonería no fue una institución gnóstica, aunque algunos de sus rituales sí que acusaron la influencia del gnosticismo. En este punto, cabría preguntarse hasta qué punto una obediencia regular transgredía su deber de neutralidad religiosa cuando autorizaba oficialmente grados o rituales que invadían funciones religiosas o eran irrespetuosas con los dogmas de las religiones reveladas. ¿Incumplía acaso una Gran Logia Nacional regular su deber de neutralidad religiosa al establecer relaciones de amistad y reconocimiento con otras obediencias o Soberanos Consejos que practicaban ritos abiertamente políticos u hostiles al catolicismo? Creemos que sí.

\section{La politización de los altos grados}

En el transcurso del siglo XIX y comienzos del XX, diversas obediencias masónicas regulares prefirieron sustituir las interpretaciones astrológicas o alquímicas de los rituales masónicos por otras más modernas, de perfil social y político. Así, en virtud de dichas exégesis de nuevo cuño, las enseñanzas de algunos altos grados se convirtieron en una reivindicación del derecho de asilo y del deber de todo Estado a no "permitir la extradición de los perseguidos por causas religiosas o políticas". ${ }^{81}$ Algo parecido se haría con otros grados, hasta el extremo de que, en su versión más liberal, el rito escocés de 33 grados sustituyó su contenido bíblico por unas elementales y pintorescas reflexiones sobre los derechos del ciudadano. Así, en el grado 9o, el pastor que conduce a la caverna representaba "a la Prensa, gracias a la cual la libertad y la ciencia persiguen a la ignorancia hasta sus más ocultas guaridas"; ${ }^{82}$ el grado $10^{\circ}$ explicaba el derecho y deber de extradición, ${ }^{83}$ y el grado $11^{\circ}$ mostraba el derecho de sufragio universal, aunque con la siguiente matización que todavía practican algunas obediencias: "el débil, así como el ignorante, no pueden cargarse de una responsabilidad que no les es dado sobrellevar ni comprender; por eso, ni las mujeres ni los adolescentes eligen ni son elegidos para los empleos, aunque ninguno les niegue la ciudadanía". ${ }^{84}$ Asimismo, tal grado $11^{\circ}$ proporcionaba, según la interpre-

\footnotetext{
81 Caballero de Puga, Eduardo, op. cit., p. 224.

82 Ibidem, p. 186.

83 Frau Abrines, Lorenzo y Arús, Rosendo, op. cit., vol. V, p. 750.

84 Ibidem, p. 755.
} 
tación que estamos comentando, unas rudimentarias afirmaciones sobre las formas de gobierno y la organización territorial en forma de municipios, consejos y diputaciones provinciales. El grado $12^{\circ}$, por su parte, explicaba al candidato la teoría de los impuestos directos e indirectos. El grado $13^{\circ}$ se refería al "derecho inalienable e imprescriptible de rendir culto a Dios de la manera que juzgue conveniente con arreglo a su razón". Los grados sucesivos obligaban al candidato a jurar defender diversos derechos, como el de la libertad individual (grado $15^{\circ}$ ), el derecho de reunión (grado $17^{\circ}$ ), la libertad de enseñanza (grado $20^{\circ}$ ), la libertad de trabajo $\left(\operatorname{grado} 22^{\circ}\right.$ ) y el habeas corpus (grado $\left.23^{\circ}\right) .{ }^{85} \mathrm{El}$ grado $32^{\circ}$, en fin, se refería a "Nuestro Soberano Jesús de Nazaret, apóstol de los derechos y deberes del hombre". ${ }^{86}$ De esta manera, la enseñanza ocultista, rosacruz, hermética, templarista, moral o religiosa del conspicuo rito escocés antiguo y aceptado desaparecía para ceder paso a una visión juridicista, en virtud de la cual las enseñanzas iniciáticas se convertían en un mediocre manual de derecho político que, por eso mismo, incumplía estrepitosamente el landmark de no debatir cuestiones políticas en logia.

\section{REFLEXIÓN FINAL}

Por supuesto que tales incongruencias fueron siempre contestadas por muchos masones; lo cierto es que muy pocas obediencias regulares llevaron a cabo una labor profiláctica de esos altos grados. Pero, además, de nada valía que una potencia masónica aprobara unos rituales depurados de incoherencias, si luego entablaba relaciones de amistad y reconocimiento con grandes logias de otros países que practicaban el mismo rito, pero plagado de referencias políticas o antirreligiosas. Por eso, el problema ya no estaba sólo en las obediencias que autorizaban la práctica de ritos politizados o antirreligiosos, sino también en aquellas obediencias regulares que establecían relaciones de amistad o reconocimiento con otras que practicaban ritos politizados u hostiles al cristianismo ¿Cómo era posible que una Gran Logia Escandinava regular, que sólo aceptaba cristianos entre sus afiliados, reconociera como obediencias regulares a aquellas que practicaban ritos abiertamente anticristianos? Lo cierto es que ello ocurre y sigue ocurriendo. Era el caso de obediencias teóricamente neutrales en esta materia, como la Gran Logia de Escocia, que no permite la práctica de altos grados en sus talleres, o la Gran

85 Ibidem, pp. 780, 803, 811 y 813.

86 Blanchard, Jonathan, op. cit., t. II, p. 472. 
Logia Unida de Inglaterra, que no ha reconocido ningún alto grado y, por tanto, ha prohibido su práctica en los locales de su jurisdicción (a excepción del grado del Arco Real, el cual considera un grado complementario de la maestría). Pero, si bien se puede afirmar que la masonería inglesa no reconoce los altos grados, también es cierto que no prohíbe a sus miembros la práctica de cualesquiera sistemas de altos grados en otros locales ajenos a la Gran Logia, incluidos aquéllos politizados u hostiles al cristianismo. Es más, ha dado el reconocimiento de regularidad a obediencias nacionales que practican ritos que contienen pronunciamientos políticos y religiosos que vulneran los tradicionales deberes masónicos.

Hemos también mencionado las severas críticas de los propios masones a la artificiosidad y banalidad de ciertos altos grados: si con ellos se pretendía profundizar en nuevos aspectos del simbolismo, hubiera bastado con desarrollar e incorporar ciertos temas a los rituales de cualquiera de los tres primeros grados. En una carta de 1813, el masón Jean-Baptiste Willermoz sostenía:

No creemos que hayan sido necesarios una serie de 33 y mucho menos de 90 grados para llegar a conocer la esencia fundamental de la Masonería; nosotros consideramos esta multitud de grados, y aquellos otros que les puedan suceder, como adarajas de un edificio que no se elevará jamás; y no tenemos la menor duda de que han sido creados por amor a los sistemas y sus distinciones, por el orgullo de la denominación y la codicia que no ha entregado nunca gratuitamente sus juguetes. ${ }^{87}$

A finales del siglo XIX, masones como Lorenzo Frau Abrinés y Rosendo Arús sostenían que los temas de la mayoría de los altos grados estaban plagados de anacronismos y elucubraciones, los cuales sólo obedecían a la fantasía de sus creadores y cuyo sentido último era, por ende, imposible de conocer. Por eso no dudaron en calificar tales grados de "completamente inútiles". ${ }^{88}$ La deriva de los altos grados fue resumida por Le Forestier, con una certera conclusión; "la exégesis más ingeniosa no podría descubrir en la leyenda, los emblemas y la decoración de los grados de venganza, el menor simbolismo que sugiera alguna idea elevada o generosa". ${ }^{89}$

En efecto, desfilan en ciertas ceremonias y juramentos masónicos toda una panoplia de ideas de lo más pintorescas amontonadas por los masones de los siglos XVIII y XIX sin el menor rigor histórico, por lo demás, preñadas de un

87 Biblioteca Nacional de París, Loges de Lyon, Directoire Écossais, FM 2, FOS 51-60, publicada por Naudon, Paul, La franc-maçonnerie chrétienne, París, s.e., 1970, p. 113.

88 Frau Abrines, Lorenzo y Arús, Rosendo, op. cit., voz "príncipe”, vol. II, p. 1169.

89 Le Forestier, René, L'occultisme et la franc-maçonnerie Ecossaise, Milano, s.e., 1987, pp. 211-245. 
tal gnosticismo ${ }^{90} \mathrm{y}$ anticlericalismo que todavía convierten en justificadas las prevenciones de las confesiones religiosas hacia la masonería.

Se extrañan los masones de que todavía subsistan recelos o condenas por parte de las Iglesias cristianas. Algunos sacerdotes masonólogos han dado cuenta "del grave problema pastoral creado por muchos católicos pertenecientes a determinadas organizaciones masónicas (especialmente en Iberoamérica) que no se encuentran incluidos en las razones expuestas en los documentos de la Iglesia que penalizan la pertenencia a la masonería en general, pero sí afectados por las penas o prohibiciones". ${ }^{91}$ Incluso, desde hace años, existen algunos esfuerzos de insignes masones y diversas obediencias por lograr aproximaciones.

Sin embargo, resulta desalentador que la propia masonería que se proclama regular, no haya hecho prácticamente nada por evitar sus incongruencias. Por el contrario, ha mantenido una tenaz, negligente y sostenida falta de criterio a la hora de redactar o reformar sus textos rituales. Son los propios masones los que deben dar el primer paso efectuando una profilaxis de sus rituales, con el fin de eliminar tales escenas y rastros irregulares. Además deberían establecer un mayor rigor en los protocolos seguidos para conceder el reconocimiento de la regularidad a otras obediencias, de tal manera que se niegue tal reconocimiento a aquéllas que observen rituales irregulares o que mantengan relaciones con obediencias que los practiquen. Por poner un ejemplo, la Gran Logia Unida de Inglaterra, adalid de la regularidad masónica, mantiene la histórica prohibición de practicar en sus locales cualquier otro rito que no sea el inglés de emulación. Sin embargo, reconoce la regularidad masónica de numerosísimas obediencias que practican ritos abiertamente irregulares, por contener temas y escenas de crítica política y religiosa, lo cual convierte a la masonería inglesa en sospechosa de irregularidad. Y lo mismo podría decirse de cualquier otra obediencia masónica que autoriza la práctica de tales ritos irregulares u otorga el reconocimiento de regularidad a obediencias de otros países que practican ritos irregulares: ella misma queda tachada de irregularidad o, por decirlo más gráficamente, contaminada. Y conste que, más que emitir un juicio de valor, nos limitamos a señalar las palmarias contradicciones o incoherencias del propio discurso masónico.

En suma, éstas son las luces y las sombras de la masonería. Si bien es cierto que la masonería especulativa fue la primera asociación civil de la historia

90 Insistimos en que no criticamos el gnosticismo, sino la contradicción que supone el que la masonería regular lo asuma en sus rituales incumpliendo su deber de no tratar temas que impliquen una toma de postura religiosa.

91 Como informa Pedro Álvarez Lázaro, jesuita y catedrático de Historia contemporánea de la Universidad Pontificia de Comillas, en "Algunas reflexiones sobre las relaciones Iglesia/ Masonería hoy", véase Álvarez Lázaro, Pedro (coord.), Maçonaria, egreja e liberalismo. Masonería, Iglesia y Liberalismo, Actas da Semana da Faculdade de Teologia, Porto-Madrid, s.e., 1996, pp. 140-142. 
Esta obra forma parte del acervo de la Biblioteca Jurídica Virtual del Instituto de Investigaciones Jurídicas de la UNAM

de la humanidad que asumió como fin la pura práctica de la fraternidad, ¡es una lástima que la filosofía de algunos altos grados empañen ese loable propósito! En este sentido, la masonería regular fue y es un magnífico programa que ha cosechado indiscutibles éxitos, aunque continúa lastrado por sus contradiciones internas. En definitiva, un magnífico proyecto, pero negligentemente ejecutado. 


\title{
LAS LOGIAS LAUTARO, LOS CABALLEROS RACIONALES Y EL MOVIMIENTO INDEPENDENTISTA AMERICANO
}

\author{
José Antonio Ferrer Benimeli*
}

\begin{abstract}
SUMARIO: I. Introducción. II. Sociedades secretas, patrióticas y masónicas. III. La incógnita de los libertadores. IV. Las logias Lautaro. V. Miranda, ¿fundador de logias.? VI. Características internas. VII. ¿Sociedades masónicas o políticas? VIII. Conclusión. IX. Bibliografia.
\end{abstract}

\section{INTRODUCGIÓN}

La falsa identificación que cierta literatura ha hecho entre masonería y Revolución -la Revolución francesa en particular- o entre la masonería y las revoluciones hispanoamericanas de principios del siglo XIX, ha dado lugar a otra, también falsa - o al menos no necesaria-identificación entre masonería y República. Tanto más porque la masonería actual, moderna o "especulativa", continuación de la masonería operativa medieval, ${ }^{1}$ nace en Inglaterra, un país monárquico de tradición, donde sigue siendo tutelada por la familia real, ${ }^{2}$ al igual que en los países escandinavos, y como en su día lo fue en no pocas naciones europeas, entre ellas en la Italia reunificada bajo la dinastía de Víctor Manuel. ${ }^{3}$

El caso de las repúblicas hispanoamericanas exige un ejercicio de análisis desapasionado, hoy especialmente difícil debido al peso de una tradición

\footnotetext{
* Universidad de Zaragoza.

1 Sobre la masonería operativa, véase Ferrer Benimeli, José Antonio, Masonería, Iglesia e Ilustración, Madrid, Fundación Universitaria Española, 1976, vol. I, pp. 23-50.

2 Actualmente en la persona del duque de Kent que ejerce como Gran Maestre de la Gran Logia de Inglaterra.

3 Mola, Aldo A., Storia della Massoneria italiana dall'Unità alla Repubblica, Milano, Bompiani, 1994.
} 
fomentada, sobre todo, por la antimasonería más visceral, ${ }^{4}$ curiosamente compartida por aquellas masonerías latinoamericanas que, haciendo suyas las tesis de la antimasónicas, ven en la independencia de sus países la obra de la masonería, si bien lo que para unos tiene connotaciones negativas y nefastas, para otros son positivas y gloriosas.

El problema de fondo que se suele plantear, y no siempre resolver, es el relativo al auténtico papel desempeñado por la masonería en la obra de la Independencia, pues suele existir cierto confusionismo ya desde el punto de partida.

Se da como un axioma la vinculación de los criollos con los centros culturales, políticos, sociales y masónicos de la Europa de entonces, así como el papel que esos centros o sociedades desempeñaron en Hispanoamérica, facilitando la difusión de las nuevas ideas de libertad, democracia, republicanismo y emancipación o, si se prefiere, de independencia. Los criollos que pudieron venir a Europa - entre ellos Miranda, Bolívar, San Martín, Belgrano, Alvear, Mier, Nariño y tantos otros-, empapados de las corrientes político-culturales en boga en aquel entonces en Europa, regresaron a las Indias con nuevas ideas y decisiones que aceleraron el proceso emancipador.

\section{SOCIEDADES SECRETAS, PATRIÓTICAS Y MASÓNICAS.}

Hubo sociedades de pensamiento, literarias, económicas, universitarias, políticas, patrióticas, masónicas..., que, valiéndose a veces del secreto o simplemente de la clandestinidad, una vez trasplantadas en América, sirvieron para difundir ideas y fomentar ideales de libertad e independencia.

Sociedades de pensamiento como Los Amigos de las Luces y de la Libertad; literarias como Los Amantes del País o Los Amantes de la Ilustración; económicas como Las Sociedades de Amigos del País; políticas como Las Ventas de Carbonarios o Los Guadalupes; patrióticas como Los Caballeros Racionales o Logias Lautaro; masónicas como La Fraternidad Colombiana, La Protectora de las Virtudes, etcétera.

4 A título de ejemplo, véase en la colección antisectaria dirigida desde Burgos en plena guerra civil por el sacerdote catalán Juan Tusquets el libro de Ibáñez, Primitivo, La Masonería y la pérdida de las colonias, Burgos, 1938. Y en Argentina el representante más característico de la antimasonería reciente es el también sacerdote Maguirre, Patricio J., La Masonería y la Emancipación del Río de la Plata, Buenos Aires, Nueva Hispanidad, 1969, reeditada por sus seguidores en 2000 y que es una muestra más de quien dedicó muchos años de su vida a luchar de forma obsesiva contra la masonería a través de una pintoresca revista escrita y editada por él en Buenos Aires desde 1981 a 1989, que empezó titulándose "Informaciones sobre la Masonería y otras sociedades secretas" para concluir con el más sensacionalista de "Revelaciones sobre la Masonería". 
Sin embargo, el error radica en la simplificación que a veces se hace, al confundir sociedad secreta con sociedad patriótica o política, o la equiparación de ambas con la masónica. La confusión proviene fundamentalmente de elevar a categoría de esencial lo que es puro accidente y, sobre todo, de quienes olvidan finalidades y proposiciones programáticas expresadas en constituciones y reglamentos, para acogerse sólo a formalidades externas o terminológicas. Dicho de otra forma, cuando se prescinde de lo estructural ideológico, político y social, y se carga el acento en lo meramente lingüístico o semántico, o incluso en lo organizativo y ritualístico esotérico.

El hecho de no distinguir adecuadamente entre masonería, sociedades secretas y sociedades patrióticas, por una parte, y entre logias masónicas y logias Lautaro, por otra, está en la raíz de la disparidad de juicios históricos o de historiadores sobre el particular.

Un caso concreto lo encontramos a raíz de la célebre logia Lautaro, de Buenos Aires, que no era masónica, sino una sociedad secreta política establecida en 1812 llamada Sociedad de Lautaro, la cual, según Mitre, estaba en relación con la Gran Reunión Americana fundada por Miranda en Londres, y sus filiales Caballeros Racionales, de Cádiz y Madrid, que tampoco eran logias masónicas, a pesar de la tan reiterada como falsa afirmación de lo contrario. ${ }^{5}$

\section{LA INCÓGNITA DE LOS LIBERTADORES}

En esta misma línea de distinción entre logias masónicas y "mirandistas" está el esclarecedor estudio introductorio del académico Pedro Luis Barcia a la obra de Cuccoresse, San Martin y la masonería (Buenos Aires, 1993), y el no menos interesante de Pilar González Bernaldo de Quirós, Producción de una nueva legitimidad: ejército y sociedades patrióticas en Buenos Aires entre 1810 y 1813 (París, 1990), que sirve de

5 Este asunto ya lo abordaron -entre otros- en su día Mitre, Bartolomé, Emancipation of South America, Londres, Kessinger Legacy, 1893; y en Historia de San Martín y de la Emancipación Sudamericana, Buenos Aires, Congreso de la Nación, 1939; y Pacheco Quintero, Jorge, Influencia de la Masonería en la Emancipación de América (Aspecto Colombiano), Bogotá, s.e., 1943. Más recientemente Ferrer Benimeli, José Antonio, "La masonería y la independencia de América española...", cit., pp. 159-177; "Aproximación a las llamadas logias Lautaro", Hoy es Historia, Montevideo, t. IV, núm. 23, septiembre-octubre de 1987, pp. 48-58; "Cádiz y las llamadas 'Logias' Lautaro o Caballeros Racionales", De la Ilustración al Romanticismo. Ideas y Movimientos clandestinos, Cádiz, Servicio de Publicaciones Universidad, 1988, pp. 149-176; "Les Caballeros racionales, les loges lautariennes et les formes déviées de la franc-maçonnerie dans le monde hispanique", Sous le masque de la Franc-Maçonnerie, Bruselas, L'Université, 1990, pp. 11-30; París, Centre National de la Recherche Scientifique, 1991, pp. 37-53. "La masonería española ante la Independencia de América", Comunicación, Historia y Sociedad. Homenaje a Alfonso Braojos, Sevilla, Eloy Arias, 2001, pp. 87-101. 
necesario complemento a Martín V. Lazcano, Las Sociedades Secretas, Políticas y Masónicas en Buenos Aires (Buenos Aires, 1927). También Alfonso Fernández Cabrelli, en La Francmasonería en la Independencia de Hispanoamérica (Montevideo, 1988), dedica un significativo capítulo a "Francmasonería, sociedades secretas y la logia Lautaro", en el que recopila, analiza e intenta concluir una forma integradora que finalmente resulta confusa por ser excesivamente conciliadora de tesis antitéticas. Un nuevo intento de explicación es el de Alfredo Boccia Romanach, La masonería y la independencia de América. Mitos e historia de las sociedades secretas (Asunción: Servi Libro, 2003).

En la obra de Furlong y Geoghegan, Bibliografia de la revolución de mayo (1810-1828), hay hasta 24 estudios de esa "pequeña Gran Logia que independizó a Bolivia”, según Beltrán Avila, ${ }^{6}$ y cuyo papel en la revolución de octubre de 1812 y en la independencia de América estudian Juan Canter, Raúl Ruiz, Antonio Zúñiga y Martín Lezcano, entre otros. ${ }^{7}$ Sin embargo, al tratar el tema de la participación del general San Martín en las actividades de dicha logia, nos encontramos ya con las tesis de Duthu, Furlong y la obra póstuma de Cuccorese, ${ }^{8}$ quienes no sólo mantienen que el general no era masón, sino

6 Beltrán Ávila, Marcos, La pequeña Gran Logia que independizó a Bolivia 1823-1825, Cochabamba, Atlantic, 1948.

7 Avendaño, Rómulo, "La Sociedad Lautaro. Rectificaciones históricas", La Revista de Buenos Aires, Buenos Aires, núm. 19, 1869, pp. 439-445; núm. 21, 1870, pp. 129-141; Barcia, Augusto, San Martín y la Logia Lautaro, Buenos Aires, s.e., 1950; Canter, Juan, "La Logia Lautaro y la independencia de América según Antonio R. Zúñiga", Crítica Histórica, Buenos Aires, s.e., 1933, pp. 78-90; "La Logia Lautaro y la revolución de octubre de 1812", La Nación, Buenos Aires, 1934; "La Sociedad Patriótica y la Logia Lautaro" (Resumen de la Conferencia pronunciada en el Ateneo Ibero-Americano), y "La Logia Lautaro y su evolución", La Nación, Buenos Aires, 1934. "La Logia Lautaro y Mendoza", Revista de la Junta Provincial de Estudios Históricos, Santa Fe, vol. II, 1936, pp. 78-90; Eyzaguirre, Jaime, La Logia Lautarina y otros estudios sobre la Independencia, Santiago de Chile, Fco. De Aguirre, 1973; Gandía, Enrique de, "La política secreta de la Gran Logia de Londres", Boletín de la Academia Nacional de la Historia, Buenos Aires, 1976; Herrera Valdés, Willy, Las sociedades secretas y la independencia política del cono sur americano: O'Higgins, San Martín y la logia Lautaro, tesis doctoral, Universidad Complutense de Madrid, 1985; Onsari, Fabián, San Martín, la logia Lautaro y la Franc-Masonería, Buenos Aires, Avellaneda, 1951; Pacífico Otero, José, "La Logia Lautaro. Su valor y su significado histórico", La Nación, Buenos Aires, 1910; Oviedo Martínez, Benjamín, "La Logia Lautarina", Revista Chilena de Historia y Geografia, Santiago de Chile, t. LXII, 1929, pp. 105-126; Paz Soldán, Mariano, "La Logia Lautaro", Historia del Perú independiente, Lima, 1868, vol. I, pp. 228-232; Ruiz y Ruiz, Raúl A., "La logia Lautaro y la Independencia de América", Revista de la funta Provincial de Estudios Históricos, Santa Fe, t. XV, 1946, pp. 73-82 y en Revista "San Martín", del Instituto Nacional Sanmartiniano, Buenos Aires, núm. 13, 1947, pp. 117-126; Zúñiga, Antonio E., La Logia Lautaro y la independencia de América, Buenos Aires, Taller Gráfico J. Estrach, 1922; Picirelli, Ricardo, San Martíny la politica de los pueblos, Buenos Aires, Aguirre, 1957, pp. 121-181.

8 Duthu, D., "San Martín y la logia Lautaro", Revista Eclesiástica del Arzobispado de Buenos Aires, vol. V, 1905, pp. 900-902; Furlong, Guillermo, "La Logia Lautaro", Criterio, Buenos Aires, 1930, pp. 721 y 722; Cuccorese, Ignacio Juan, San Martín y la Masonería, Buenos Aires, Instituto Nacional Sanmartiniano, 1993. 
que hacen la apología de su catolicismo, como si catolicismo y masonería fueran cosas antitéticas. ${ }^{9}$

Por otro lado, Fabian Onsari y Alcibiades Lappas ${ }^{10}$ defienden la personalidad moral y masónica de San Martín, aludiendo a detalles como su iniciación -nunca probada-, su correspondencia masónica - que tampoco lo es-, e incluso su presunta actuación en la masonería en Bélgica, donde fue distinguido por la logia La Parfaite Amitié, afirmaciones que en ningún caso prueban. ${ }^{11}$

Este aspecto del papel desempeñado por los llamados libertadores o prohombres de la independencia, en cuanto miembros o no de la masonería, es una cuestión que necesita, igualmente, de clarificación, pues la misma divergencia que existe respecto al general San Martín se puede apreciar en el caso de Simón Bolívar. Nicolás Navarro dedica su libro La masonería y la independencia ${ }^{12}$ a la memoria de Bolívar, en el centenario de su decreto, condenando la masonería (8 de noviembre de 1828), con lo que pretende demostrar -sin conseguirlo- que ni Bolívar ni Miranda fueron masones. Sobre esta misma idea vuelve Alfonso Junco en su trabajo La masonería condenada por los prohombres de la independencia. Sin embargo, Pacheco Quintero y Restrepo Canal ${ }^{13}$ estudian precisamente el aspecto colombiano del influjo masónico en la obra de la independencia.

Por lo que respecta a Francisco de Miranda, todos los historiadores están de acuerdo en que el precursor de la independencia americana fue este venezolano, hijo del canario y capitán de milicias Sebastián de Miranda y Bavelo. ${ }^{14}$ Sin embargo, es más difícil encontrar un acuerdo para conocer el nombre de la logia, así como el lugar y la fecha de iniciación en la masonería del general Miranda, pues algunos historiadores dicen que se inició en una logia del estado de Virginia, otros en Filadelfia, otros en Londres, algunos aseguran que fue

9 Sobre esta cuestión Ferrer Benimeli, José Antonio, op. cit., y Massoneria e Chiesa Cattolica, 2a. ed., Roma, Paolina, 1982.

10 Onsari, Fabián, op. cit., Lappas, Alcibíades, San Martín y su ideario liberal, Buenos Aires, Símbolo, 1982; San Martín y las logias y San Martín y su formación, Buenos Aires, s.e., 1978.

11 El hecho de recibir un diploma no quiere decir que sea masón. En muchos casos se trata de una simple manifestación de agradecimiento.

12 Navarro, Nicolás E., La Masonería y la Independencia, Caracas, Sur-América, 1928; Ferrer Benimeli, José Antonio, "Bolívar y la Masonería...", cit., pp. 631-687.

13 Junco, Alfonso, "La Masonería condenada por los prohombres de la Independencia", Cuadernos Hispano-Americanos, Madrid, núm. 30, 1952, pp. 295-303; Pacheco Quintero, Jorge, op. cit., Restrepo Canal, Carlos, "Informe sobre la Masonería y la Independencia", Boletín de Historia y Antigüedades, Bogotá, vol. 46, 1959, pp. 232-237.

14 Para conocer a Francisco de Miranda (1752-1816) es indispensable adentrarse en el Archivo del General Miranda y en especial en sus 24 volúmenes de Diarios (Viajes, Revolución Francesa, Negociaciones...) publicados entre 1929 y 1938 por la Academia Nacional de Historia de Venezuela. 
en París o en Rusia, y no faltan quienes insinúan su iniciación en Gibraltar o Cádiz, durante los meses que allí residió, a comienzos de 1776, aprovechando su estancia y destino en la guarnición gaditana. ${ }^{15}$

Sin embargo, como demuestra documental, histórica y masónicamente Fréderic W. Seal-Goon - miembro de la Quatuor Coronati Lodge No 2076 de Londres, la primera logia de investigación masónica- en su trabajo The mythical Masonry of Francisco de Miranda, ninguna de estas presuntas iniciaciones fue posible, ${ }^{16}$ además de que su nombre no figura ni una sola vez en los archivos de la Gran Logia de Inglaterra, ni en ninguna masonería de la época; tampoco en ninguno de sus numerosos y prolijos diarios, ni en su abundante correspondencia encontramos el más mínimo indicio de que hubiera sido masón.

Respecto a la vinculación de Miranda con las logias Lautaro que servían de cobertura para empresas revolucionarias, la conclusión a la que llega el ya citado investigador masón Frederic Seal-Coon es que "no fue ni inventor ni miembro de ningún tipo de seudomasonería" y mucho menos de masonería, lo que reduce el interés del personaje como sujeto masónico, "mas no su importancia como héroe y patriota revolucionario". Es indudable que la opinión

15 Seal-Coon, F.W., "Spanish-American Revolutionary Masonry. The mythical Masonry of Francisco de Miranda", Ars Quatuor Coronatorum, Londres, vol. 94, noviembre de 1982, pp. 83106; Zeldis, León, "Freemasonry's Constitution to South American Independence. A factual Approach", Ars Quatuor Coronatorum, Londres, vol. 111, octubre de 1999, pp. 79-101; Rodríguez de Alonso, Josefina, Le siècle des Lumières conté par Francisco de Miranda, París, france-empire, 1974, pp. 30-33; Spencer Robertson, William Life of Miranda, Chapel Hill, University of North Carolina Press, 1929 y La vida de Miranda, Caracas, Academia Nacional de Historia, 2006.

16 El caso de Rusia puede ser sintomático. Por un lado el nombre de Miranda no aparece nunca en las páginas de Telepneff, Vernadsky, Semeka, Friedrich, Pypin, Theakston, Longionov, Sokolovskaya... por citar sólo algunas de las autoridades que han escrito sobre la masonería rusa de aquel período. Ferrer Benimeli, José Antonio y Cuartero Escobés, Susana, Bibliografia de la Masonería, Madrid, Fundación Universitaria Española, 2004, vol. II, pp. 624-628 y en particular véase Cross, A.G., "British Freemason in Russia during the Reign of Catherine the Great", Ars Quatuor Coronatorum, vol. 111, Londres, 1971, pp. 239-259, Lentin, Anthony, "A Rusian Freemasonry in the Reign of Catherine the Great: Prince M. M. Shcherbatov (1733-1790)", Ars Quatuor Coronatorum, Londres, vol. 111, octubre de 1999, pp. 156-161, y Bakounine, Tatiana, Répertoire biographique des francs-maçons russes (XVIIIe et XIXe siècles), París, Institut d'Etudes Slaves de l'Université de Paris, 1967. Según Alcibíades Lappas, el príncipe Alexander Ypsilantis, ayudante de campo del zar tuvo un encuentro con Miranda en una logia llamada La Paix. Sin embargo -como observa Seal-Coon-, esa logia no existía en Rusia, y cuando Miranda estuvo en Rusia, Ypsilantis no había nacido aún (de hecho nació en 1792 e ingresó en la masonería en 1810, cuando Miranda estaba en Londres a punto de zarpar para Venezuela). Finalmente no había zar cuando Miranda visitó Rusia, ya que entonces reinaba la emperatriz Catalina, que le concedió usar el uniforme de coronel de Rusia. Archivo del General Miranda. Viajes. Diarios 1785-1787, Caracas, Sur-America, 1929, t.II, pp. 111-470. Viajes por Grecia, Turquía y Rusia. Tampoco figura Miranda en los ricos archivos de la masonería de Gibraltar de esa época estudiados por Sheriff, Keith, The Rough Ashlar. The History of English Freemasonry in Gibraltar, 1727-2002, Gibraltar, Grand Lodge of Gibraltar, 2002. 
de que Francisco de Miranda fue masón ha estado y sigue estando sumamente difundida en gran parte del mundo de lengua española, especialmente en la parte septentrional de Sudamérica, donde la figura de Francisco de Miranda ha entrado en la leyenda y su nombre se evoca entre los más ilustres.

Añade Seal-Goon - que conoce muy bien el Archivo del General Miranda, así como el de la Gran Logia de Inglaterra- que la búsqueda de pruebas para avalar la masonería o seudomasonería de Miranda es fascinante $\mathrm{y}$, al mismo tiempo, desconcertante, dificultada por las contradicciones de no pocos historiadores latinoamericanos, pues, pese a su renombre, y principalmente a causa de su patriotismo, en ocasiones aceptan sin crítica alguna afirmaciones de sus predecesores, sin cotejar y relacionar entre sí hechos y cronologías que desmienten o contradicen escritos anteriores. ${ }^{17}$

Según William Spence Robertson -considerado el biógrafo y mejor conocedor de Miranda-, una hipótesis que no contradice las actividades políticas de Miranda durante su estancia en Londres es que allí "fundó una sociedad que se desarrolló hasta convertirse en influyente club de revolucionarios hispanoamericanos, y se llamó la Logia Lautaro", club que desplegó actividad en la América del Sur donde fomentó "la revolución en que San Martín desempeñó destacado papel". Pero añade: "el examen de sus papeles inéditos nada revela que pueda probar, sea que perteneciera a la Orden Masónica" sea que fuese el fundador de la Lautaro. En realidad, concluye, ni siquiera existen rastros indicadores de que Miranda se encontrara nunca con San Martín. ${ }^{18}$

La disparidad de los testimonios anteriores, a los que se podrían añadir otros muchos, ponen de manifiesto la complejidad de ciertos hechos históricos, sobre todo cuando las opiniones predominan sobre las pruebas. No se trata del (tan denostado por algunos) culto del fetiche documental, sino de la constatación de que en la mayor parte de los casos las conjeturas continúan en lugar de utilizar documentos. Como indica Piccirelli en su estudio sobre la logia Lautaro: ${ }^{19}$ sobran argumentos y faltan pruebas en un asunto en el que la imaginación, en muchos, ha suplido casos al documento, dando como resultado que el estudio crítico de las fuentes es el que fundamenta el concepto histórico.

Ante esta actitud, hay autores que ciertamente utilizan documentos auténticos, como Carnicelli, aunque no indica dónde se encuentran, o como Antonio de Zúñiga, quien aporta comentarios y análisis de los hechos, pero se guarda las

17 A título de ejemplo su presunta iniciación en Rusia en nota 16.

18 Robertson, Spence, op. cit., pp. 157-158, el principal indicio de la posible vinculación de Miranda con una sociedad revolucionaria, se encuentra en los recuerdos fragmentarios de O’Higgins, Bernardo, Epistolario, Santiago de Chile, Ernesto de la Cruz, 1916, t. I, p. 30.

19 Piccirelli, Ricardo, op. cit., pp. 113, 128, 129 y 143. 
constancias documentales para sí, con lo que la opción del lector es creer en su exposición o no creerse nada, y esto no satisface a la ciencia histórica. ${ }^{20}$

En algún caso, como en el de Carnicelli, afortunadamente ya vamos conociendo su fabuloso archivo documental masónico particular -hoy es en parte ya de dominio público- con lo que esperamos que su extraordinaria obra pronto alcance el valor histórico-científico que se merece.

\section{LAS LOGIAS LAUTARO}

Según Carnicelli, Miranda decidió servirse del sistema de las logias para llevar a cabo sus proyectos emancipadores, teniendo en cuenta que era el mejor medio de mantener el entusiasmo y la mística entre los afiliados a una organización de tipo revolucionario, y evitar, además, la vigilancia y persecución por parte del Gobierno español. ${ }^{21}$

Con este propósito - prosigue Carnicelli- organizó en la ciudad de Londres, en 1797, una sociedad de carácter revolucionario, de tendencia republicana, con el nombre de Gran Reunión Americana, de la que se constituyó Gran Maestro. El objetivo de esta sociedad era la emancipación de las colonias españolas de América. La primera "logia" filial de esta sociedad la fundó y organizó en la misma ciudad de Londres. Posteriormente se abrieron otras filiales de la Gran Reunión Americana en París y en Madrid, con el nombre de Juntas de las ciudades y provincias de la América Meridional, y en la ciudad de Cádiz con el nombre de Sociedad de Lautaro o de Caballeros Racionales, así como en Buenos Aires, Mendoza y Santiago de Chile, con el nombre de Logias Lautaro, y en Caracas con el de Sociedad Patriótica. ${ }^{22}$

La organización del general Miranda funcionaba en su casa, en Grafton Street 27, según el historiador Julio Mancini. Hasta 1810, en su calidad de Gran Maestro, inició en la "logia" patriótica revolucionaria a los que acabarían siendo los principales protagonistas de la independencia americana, entre ellos -según Carnicelli- los chilenos Bernardo O’Higgins, José Manuel Carrera, Juan Martínez de Rosas, Gregorio Argomedo, Juan Antonio Rojas; los argentinos José de San Martín, José María Zapiola, Carlos María de Alvear,

20 Zúñiga, Antonio E., op. cit.

21 Carnicelli, Américo, La Masonería en la Independencia de América, Bogotá, Cooperativa Nacional de Artes Gráficas, 1970, t. I, p. 73.

22 Ibidem, pp. 74 y 92. La elección del título "Lautaro" -el guerrero mapuche- es ya muy significativa, pues Lautaro, caudillo araucano, fue el que venció a Valdivia el conquistador de Chile, en Tucapel en 1554. El patriota chileno Bernardo O’Higgins relató a Miranda la heroica resistencia del Toqui-mapuche Lautaro contra los españoles de Pedro Valdivia en el siglo XVI. 
Bernardo Monteagudo y Mariano Moreno, quienes en 1811 fundarían en Buenos Aires la logia Lautaro que luego sería extendida a la ciudad de Mendoza (Argentina) y a la de Santiago (Chile); también se encontrarían entre los que ingresaron en la organización de Miranda el fraile dominico Servando Teresa de Mier, de México; Vicente Rocafuerte, Carlos de Montúfar y Juan Pío de Montúfar, del Ecuador; Pedro José Caro, de Cuba; el hondureño José Cecilio de Valle; Andrés Bello, Luis López Méndez y Simón Bolívar, de Venezuela; José María Vergara Lozano, de Santafé, etcétera. ${ }^{23}$

Sobre el carácter de esta organización Carnicelli es claro:

En este movimiento revolucionario gran parte de sus miembros tenían la doble investidura o carácter de masones de Logias regulares universales y de masones de Logias patrióticas revolucionarias americanas, y otros únicamente de esta última investidura, a los cuales es necesario diferenciar, por cuanto las Logias mirandistas tenían una finalidad exclusivamente política que las separaba de la filosofía sustentada por la auténtica masonería. ${ }^{24}$

El propio Américo Carnicelli, al reproducir la constitución y reglamento de la logia lautarina de Santiago de Chile, dice: "La siguiente es la Constitución de la logia Lautaro de Santiago de Chile, fundada en el año de 1817, tal como fue expedida por sus fundadores y cuyas normas generales conservan muy poco de la Ley Fundamental de la Masonería Universal. Fácilmente se deduce que se trata de una organización eminentemente política". ${ }^{25}$ En otro contexto, hablando tanto de la logia Gran Reunión Americana, como de las Lautaro de Buenos Aires, Mendoza y Santiago, dice que se trataba de "logias patriotas revolucionarias que de masonería sólo tenían matices litúrgicos". ${ }^{26}$

Otro tanto afirman Fernando Nadra, Guillermo Furlong, Martín V. Lazcano y José Manuel Estrada; por ejemplo, el primero afirma de forma terminante: "la logia Lautaro nada tenía de común con la francmasonería. Imitaba, en efecto, su disciplina, tenía semejanzas, nada más que semejanzas con ella, pero no pertenecía a la liga del masonismo. Era una sociedad meramente política”. ${ }^{27}$

23 Ibidem, pp. 75 y 76.

24 Ibidem, pp. 76 y 77.

25 Ibidem, p. 212.

26 Carnicelli, Américo, op. cit., 1970, t. II, p.13.

27 Nadra, Fernando, San Martín hoy, Buenos Aires, Cartago, 1974, pp. 30-32; Furlong, Guillermo, El General San Martín ¿Masón-católico-deista?, Buenos Aires, Club de Lectores, 1950, pp. 74 y 75; Lazcano, Martín V., Las sociedades secretas políticas y masónicas en Buenos Aires, Buenos Aires, El Ateneo, 1927, t. I, p. 210; Avendaño, Rómulo, op. cit., pp. 372 y ss. 
Según estos autores, Miranda y los demás líderes de la Independencia, por razones estratégicas, se aprovecharon de la masonería para impulsar su movimiento revolucionario, creando una organización paralela en su constitución externa, pero radicalmente distinta en su finalidad.

Fernando Nadra, al tratar de la logia Lautaro fundada por San Martín en Buenos Aires, en 1812, dice que su propósito fundamental "era la lucha por la independencia americana y por la instauración del régimen republicano. Estaba inspirada en los ideales de la Revolución Francesa y en todas las organizaciones revolucionarias que, por aquel tiempo, se constituyeron en los países europeos con el objeto de luchar contra la monarquía y el feudalismo, por la organización de la unidad nacional, por la democracia burguesa y el progreso económico".

$\mathrm{Y}$ entre los aspectos del programa -que coinciden exactamente con los reproducidos por Carnicelli al hablar de la logia Lautaro de Santiago de Chile de 1817-, Nadra destaca el de "trabajar con sistema y plan en la independencia de la América y su felicidad, obrando con honor y procediendo con justicia".

El propio Antonio Ignacio de Cortavarria, comisario regio de la isla de Puerto Rico, nombrado por el Consejo de Regencia, al escribir al virrey del Nuevo Reino de Granada, Portovelo -el 27 de abril de 1812-, sobre la correspondencia interceptada de Alvear, se expresa en términos en los que se limita a decir que en ciudades como Londres, Caracas, Cádiz, Filadelfia y otros puntos se habían formado "Logias o Asociaciones Secretas". A partir de aquí, el confusionismo y falsa identificación de logias con sociedad secreta o patriótica será constante hasta nuestros días.

En cualquier caso estamos ante unas instituciones, llámense Lautaro, Caballeros Racionales, Reunión de Americanos, Conjuración de Patriotas, Unión Americana, Gran Reunión Americana, Sociedad Patriótica, Supremo Consejo de América... que reciben todos estos nombres para significar lo mismo: ${ }^{28}$ sociedades que en verdad no tenían nada de masonería, aunque a veces adoptaran el nombre de logias. ${ }^{29}$

Ni siquiera hay acuerdo en la denominación de estas sociedades. Para Martínez Zaldúa, ${ }^{30}$ los Caballeros Racionales de Cádiz no eran una logia, sino los miembros integrantes de la Gran Reunión Americana de Londres.

28 Padrón, Morales, Historia de América, p. 87, en lugar de decir Caballeros Racionales, dice Caballeros Nacionales; Lappas, op. cit., pp. 16-21.

29 De la misma forma que muchas estancias del Vaticano - por poner un ejemplo- no tienen nada que ver con la masonería, aunque también se llamen logias, ya que en uno y otro caso no se trata de cuestiones lingüísticas o puramente semánticas, sino histórico-ideológicas.

30 Martínez Zaldúa, Ramón, La Masonería en Hispanoamérica, México, Costa-Amic, 1965, p. 15. 
Sin embargo, para Fernando Nadra, ${ }^{31}$ la sociedad fundada por Miranda se llamaba Lautaro o Caballeros Racionales.

\section{MIRANDA, ¿FUNDADOR DE LOGIAS?}

El masón Pedro A. Barbosa de la Torre, de Maracaibo, en su obra mecanografiada, titulada Simón Bolívar y la Francomasonería, ${ }^{32}$ también menciona estas seudologias mirandistas, las cuales - dice- eran "volantes" e itinerantes a imitación de las logias militares bonapartistas.

De igual manera, en 1813, Bartolomé Mitre, en su obra Historia de San Martín y de la Emancipación Sud-Americana ${ }^{33}$ en el capítulo primero del primer volumen, que se titula "Introducción histórica a la Emancipación Sud-Americana", se expresaba así:

El caraqueño Francisco Miranda tuvo la primera visión de los grandes destinos de la América republicana, y fue el que fundó en Londres, a fines del siglo XVIII, la primera asociación política a que se afiliaron todos ellos, con el objeto de preparar la empresa de la emancipación sobre la base del dogma republicano con la denominación de Gran Reunión Americana. En ella fueron iniciados en los misterios de la libertad futura, O'Higgins, de Chile; Nariño, de Nueva Granada; Montúfar y Rocafuerte, de Quito; Caro, de Cuba y representante de los patriotas del Perú; Alvear, argentino, y otros que debían ilustrarse más tarde confesando su credo y muriendo ante él. Ante ella prestaron juramento de hacer triunfar la causa de la emancipación de la América meridional, los dos grandes libertadores Bolívar y San Martín.

Y en el capítulo segundo, intitulado "San Martín en Europa y América", párrafo X, escribe: "Las Sociedades secretas compuestas de sud-americanos, con tendencia a la emancipación de la América del Sur sobre la base del dogma republicano, se asemejaban mucho por su organización y por sus propósitos a las ventas carbonarias calcadas sobre los ritos de la masonería, de

31 Nadra, Fernando, San Martín hoy, Buenos Aires, Cartago, 1974, p. 26.

32 Barbosa de la Torre, Pedro A., Simón Bolivar y la Francmasonería, Maracaibo, s.e., 1977.

33 Mitre, Bartolomé, op. cit., Historia de San Martín y de la Emancipación Sudamericana, op. cit. Frau Abrines, Lorenzo y Arús y Arderiu, "Bartolomé Mitre Martínez (1821-1906)”, Diccionario Enciclopédico de la Masonería, México, Editorial del Valle de México, 1976, t. 2, pp. 812-814, es descrito como "estadista, militar, historiador, presidente de la República y distinguido francmasón argentino. Fue iniciado en la Logia Unión del Plata núm. 1; el 21 de julio 1860 recibía el grado 33, y el 24 de agosto 1893 fue elegido Gran Maestre de la Gran Logia Argentina”. 
las que no tenían sino sus formas y sus símbolos" ${ }^{34}$ En el mismo capítulo, párrafo XII se lee lo siguiente:

En Londres se reunió [San Martín] con sus compañeros Alvear y Zapiola, poniéndose en contacto con otros sud-americanos que a la sazón se hallaban allí [...] Todos pertenecían a la Asociación fundada en Londres por Miranda, que era matriz de la de Cádiz, como queda dicho, y en la cual Bolívar acababa de prestar juramento en manos del mismo Miranda antes de regresar a Venezuela en compañía del ilustre maestro. San Martín y sus dos compañeros fueron iniciados en el $5^{\circ}$ y último grado ${ }^{35}$.

\section{CARACTERÍSTICAS INTERNAS}

Estas mismas ideas ya las había expresado Mitre en su obra Historia de Belgrano y de la Independencia argentina; en el capítulo XXIV, del tomo segundo, bajo el epígrafe "Belgrano y San Martín", se puede leer lo siguiente: "Estos dos hombres [Alvear y San Martín] fueron los primeros que introdujeron en Buenos Aires las Sociedades secretas aplicadas a la politica".

Las sociedades secretas compuestas de americanos, que antes de estallar la revolución se habían generalizado en Europa, revestían todas las formas de las logias masónicas; pero sólo tenían de tales los signos, las fórmulas, los grados y los juramentos. Su objeto era más elevado y por su organización se asemejaban mucho a las ventas carbonarias. El primer grado de iniciación de los neófitos era el juramento de trabajar por la independencia americana; el segundo, la profesión de fe del dogma republicano. La fórmula del juramento del segundo grado era la siguiente: "Nunca reconocerás por el gobierno legítimo de tu patria sino a aquel que sea elegido por la libre y espontánea voluntad de los pueblos; y siendo el sistema republicano el más aceptable al gobierno de las Américas, propenderás por cuantos medios estén a tus alcances, a que los pueblos decidan por él". ${ }^{36}$

34 Sobre la radical diferencia entre la Masonería y la Carbonería; Ferrer Benimeli, José Antonio, La Masonería actual, Barcelona, American Historical Review, 1977, pp. 36-39.

35 Obsérvese que ni siquiera hay coincidencia con la masonería en la cuestión de los grados, pues frente a los tres tradicionales de la masonería, aquí son cinco.

36 Bartolomé Mitre, Historia de Belgrano y de la Independencia Argentina, citado en Nicolás, Navarro, La Masonería y la Independencia, pp. 29 y 30. Es una lástima que Mitre no indique sus fuentes de información, que por otro lado, el Archivo del General Miranda no corrobora. 


\section{VII. ¿SOCIEDADES MASÓNICAS O POLÍTICAS?}

Basta leer con atención estos pasajes para apreciar con qué claridad describió ya Bartolomé Mitre las asociaciones políticas secretas atribuidas a Miranda; asociaciones que eran cosa muy distinta de la masonería, e incluso de la carbonería, de las que tan sólo habían tomado una superficial apariencia de signos, fórmulas, grados y juramentos secretos. Según Navarro, la institución de Miranda fue obra pura y exclusivamente suya; fue él quien la ideó, la fundó, la dirigió e, incluso, se erigió por sí y ante sí en Gran Maestro de ella. ${ }^{37}$ Fue una sociedad secreta, sí, pero una de carácter político, para un propósito perfectamente definido que nada se relacionaba con el que pretendía la Masonería.

Comparando las constituciones, reglamentos e incluso el juramento de estas "logias" Lautaro, Caballeros Racionales, etcétera, con los de la masonería, constatamos que, tal como son descritas, ${ }^{38}$ no eran otra cosa que sociedades secretas políticas que buscaban la emancipación americana y la implantación del régimen republicano en los países de ultramar. Por poco que se conozca la historia de la masonería y su ideario de fraternidad universal, de tolerancia, de defensa de los derechos del hombre, de su alejamiento de cuestiones religiosas y políticas ${ }^{39}$, las conclusiones son claras, a pesar de que autores como Ramón Martínez Zaldúa, en su obra La Masonería en Hispanoamérica; Julio Mancini, en su Bolivary la emancipación de las Colonias españolas desde los orígenes hasta 1815, o Alcibíades Lappas, en San Martín y su ideario liberal - por poner sólo tres ejemplos suficientemente distanciados en la ideología y en el tiempo- se empeñen en mantener un confusionismo que no escapa al más elemental aprendiz de historiador.

En primer lugar, destaca el empeño de Martínez Zaldúa en afirmar no sólo que las logias lautarianas fueron instituciones de carácter masónico, sino en que quiera demostrarlo apoyándose en las palabras de Mitre, que -como acabamos de ver- afirman y dejan bien claro precisamente lo contrario. ${ }^{40}$

La obra de Mancini - una de las autoridades que más se suelen esgrimir para justificar la afiliación de Miranda y Bolívar a la masonería- no tiene más valor que el ser una mala y manipulada repetición de lo escrito por Mitre: Mancini habla de prácticas masónicas, de logias, de talleres, Grandes Maestres,

\footnotetext{
37 Nicolás, Navarro, op. cit., p. 31.

38 Pues de estas "logias" no existe documentación directa, ni en Londres, ni en Madrid, ni en Cádiz.

39 Sobre qué es y qué no es la masonería, Ferrer Benimeli, José Antonio, El contubernio judeo-masónico ..., cit., pp. 335-377, La masonería como problema político..., cit.; La Masonería ..., cit.

40 Martínez Zaldúa, Ramón, op. cit., p. 26.
} 
etcétera, cuando en realidad Bartolomé Mitre deja bien clara la diferencia entre las sociedades patrióticas mirandistas y la masonería de la época. ${ }^{41}$

Más grave es la tergiversación histórica de Alcibíades Lappas, quien reproduce como máximo argumento unas cartas, publicadas por el contraalmirante Julio Guillén, ${ }^{42}$ de Carlos de Alvear a Rafael de Mérida, donde se habla de hermanos, logias, Sociedades de Caballeros Racionales, etcétera, términos y expresiones que, a priori, identifica con la masonería, a pesar de que es de sobra conocido que la llamada "logia" Caballeros Racionales de Cádiz, ni por su finalidad, ni por los juramentos allí exigidos podía ser masónica, a pesar de que en la correspondencia citada por Guillén se utilice o no indistintamente el término de logia o el de sociedad. Para constituir una logia masónica hace falta algo más que la mera utilización del término, como hemos visto, pero la manipulación de Lappas es tal que no duda en citar una presunta "Lista de Masones Americanos participantes en la Guerra contra España", conservada en el Archivo Histórico Nacional, de Salamanca, de la cual llega a afirmar que se trata de los "participantes en la lucha por la Emancipación Americana", cuando en realidad es una lista correspondiente a la Guerra Civil de 1936-1939.43

Según el mismo historiador argentino, la logia Caballeros Racionales reunió en su seno muchas de las más brillantes personalidades de la emancipación americana. La presidieron tres argentinos: José de Moldes, hasta fines de 1808, cuando regresó a América; Carlos de Alvear, hasta septiembre de 1811, antes de partir a Londres, y el sacerdote Ramón Eduardo Anchoris. En la misma logia gaditana militaron otros eclesiásticos, entre ellos el mexicano fray Servando Teresa y Mier, así como los canónigos José Cortés Madariaga y Juan Pablo Fretes, chileno el primero y paraguayo el segundo.

En referencia a dichos canónigos, Benjamín Vicuña Mackenna informa que Bernardo de O’Higgins los encontró en 1799 en Cádiz, y con su colaboración dio "cumplimiento de la comisión revolucionaria y secreta que había recibido de Miranda". ${ }^{44}$ Con relación a fray Servando Teresa de Mier, Salvador Méndez Reyes dice que fue iniciado en una casa situada en el ba-

41 Mancini, Jules, Bolivar et l'Emancipation des Colonies Espagnoles des origines à 1815, París, Perrin, 1912.

42 Guillén, Julio, "Correo insurgente de Londres capturado por un corsario portorriqueño, 181 1", Boletín de la Academia Chilena de la Historia, Santiago de Chile, vol. XXVII, núm. 63, 1960, pp. 125 y ss. La reproducción de dicha correspondencia en Carnicelli, Américo, op. cit., t. I, pp. 92-10.

43 Lappas, Alcibíades, La masonería argentina a través de sus hombres, Buenos Aires, Belgrano, 1966, p. 65 (nota 18).

44 Ibidem, p. 20. O’Higgins permaneció en Cádiz casi 30 meses participando en las actividades del grupo Unión Americana. 
rrio de San Carlos, cerca de la muralla del puerto gaditano. Años más tarde, recordando su ceremonia de iniciación, a la pregunta respecto al estado y la tierra de la cual provenía, Mier contestó: "de Monterrey en América". El paso siguiente fue una voz desde el interior que dijo: "Cúbranle los ojos y que entre". Carlos de Alvear, criollo de Buenos Aires, presidía la ceremonia y le dijo a Mier: "Señor, esta Sociedad se llama de Caballeros Racionales ya que nada más racional que mirar por su Patria y sus paisanos. Deberá Vd. defenderla, socorrer a sus compatriotas y guardar absoluto secreto sobre todo lo que pase aquí". El candidato tuvo que dar tres pasos para cada uno de los lados de la sala, con la advertencia de que cuantos pasos diera por la América Septentrional debería darlos por la América del Sur y viceversa. Finalmente, le comunicaron el lema secreto: "Unión y Beneficencia". ${ }^{45}$

El propio Mier, en carta dirigida a José Bernardo Cantú, asegura que dicha sociedad no era de masones, si bien su fundador Alvear tal vez hubiera imitado nombres, grados y algunas fórmulas de la masonería. Incluso, cuando fray Servando arengaba a sus seguidores para ingresar, les repetía que no era una sociedad de masónica, sino de patriotismo y beneficencia. ${ }^{46}$

Por unas cartas interceptadas en enero de $1812^{47}$ del argentino Carlos de Alvear, oficial del Ejército Real de España, sabemos algunas noticias de lo ocurrido en esa ciudad antes de que Alvear saliera para Londres. Dichas cartas, fechadas en Londres el 28 de octubre de 1811 y dirigidas al patriota venezolano Rafael Mérida, ${ }^{48}$ presidente de la sociedad patriótica de Caracas, están depositadas en el Archivo Alvaro de Bazán, de la Armada Española, y

45 Méndez Reyes, Salvador, "Fray Servando Teresa de Mier y el reconocimiento de México por la Santa Sede", Del mundo hispánico a la consolidación de las naciones, 1808-1840, Tlaxcala, Gobierno del Estado de Tlaxcala, 2010, p. 439; Guzmán, José R., "Fray Servando Teresa de Mier y la Sociedad Lautaro" Anales del Instituto Nacional de Antropología e Historia, México, 7a. época, 1967-1968, pp. 257-288.

46 Madero Quiroga, Adalberto, Ensayos de David Alberto Cossío, Monterrey, Senado de la República, 2002, pp. 315-321.

47 El bergantín inglés "La Rosa", al mando del capitán John Moake, fue capturado por el corsario particular realista, Rovira, en las inmediaciones del Cabo Codeva, el día 3 de enero de 1812. Un paquete de correo enviado por Luis López Méndez fue confiado al sobrecargo del bergantín inglés señor John Grown, para ser entregado a la esposa de López Méndez en Caracas. En la carta que el caraqueño Luis López Méndez, afiliado a la logia o sociedad Mirandista de Londres, dirigía a su esposa, decía: "Se acompaña una carta para Mérida que se la manda unos que han venido aquí de Cádiz".

48 Rafael Diego Mérida, venezolano, en agosto de 1797 era escribiente de la Real Audiencia de Caracas. El general Simón Bolívar al ocupar Caracas con su ejército, el 6 de agosto de 1813, libertando a Venezuela lo distinguió con el nombramiento de secretario de Estado y del Despacho de Gracia, Justicia y Policía de su Gobierno. 
fueron dadas a conocer por el historiador contraalmirante Julio Guillén. ${ }^{49}$ En una de ellas, de carácter personal, Alvear le dice a Rafael de Mérida:

Mi estimadísimo Hermano: $\mathrm{Al}$ fin he salido del poder de los tiranos, y me hallo aquí acompañado de los hermanos que en el oficio indico.

España está dando ya las últimas boqueadas; todo sigue en el mismo desorden en que Vd. lo dejó.

Aquí [Londres] he establecido una logia para servir de comunicación con Cádiz, Filadelfia y esa [Caracas], como también para que encuentren abrigo los Hermanos que escapen de Cádiz. Nuestro Román de la L. ha salido del Castillo y tiene la ciudad por cárcel, y lo estoy esperando de un momento a otro. Murguiondo y Valbín debían salir pronto. Rada se enmendó enteramente y es uno de los Hermanos más celosos y activos; Armenteros ha estado muy tibio, al parecer por temor del Gobierno. Por la relación verá Vd. lo ocurrido con Larrea y López Conde...

Dará Vd. mil expresiones de mi parte y la de Zapiola a los Hermanos Caicedo y Toledo. ${ }^{50}$ No pillar a éste le ha sido muy sensible al déspota Gobierno español; a los quince días de haber Vds. salido lo echaron de menos, e inmediatamente dieron orden de registrar escrupulosamente los buques que fuesen a salir y a las avanzadas de la Isla y Ejército que si lo pillaban muerto o vivo serían premiados, pues era muy perjudicial su ida porque podía dar noticias de todo.

El Hermano Roche ha tenido la desgracia de perder su bergantín cerca de San Lucar pérdida que todos hemos sentido por ser un Hermano y más de la actividad, celo y demás prendas que Vd. sabe caracterizan a dicho Roche...

Esta carta iba acompañada de la siguiente lista, encabezada con el título $\mathrm{N}^{\circ}$ 1: Lista de los Hermanos que se han recibido en la Logia $\mathrm{N}^{\circ} 3$ [Cádiz], después de la partida del Hermano Mérida:

Antonio del Valle, José Sotolonga, naturales de la Habana. Miguel Santa María, Vicente Acuña, Joaquín La Carrera Ortiz, José Herrera, naturales del Reino de México.

Andrés Arango, Vicente Quesada, naturales de la Habana. Juan Vatres, José María Vergara, naturales de Santafé.

49 Guillén, Julio, op. cit., pp. 125 y ss. Posteriormente las reprodujo Carnicelli, Américo, op. cit., pp. 92-96.

50 Domingo Caicedo, diputado suplente de Santafé, y José Antonio Alvarez de Toledo, teniente de navío y diputado por Santo Domingo, salieron huyendo de la persecución que contra ellos se había desatado en Cádiz. Los diputados abandonaron España dirigiéndose uno a Santafé de Bogotá y otro a Caracas por la vía de Filadelfia. 
En otra carta, de igual fecha y escrita también en Londres, pero de carácter oficial, Alvear se expresaba así:

"Logia N. 7 [Londres]

Unión, firmeza y Valor

Salud.

Al Ve. Presidente de la Logia N. ${ }^{\circ}$ [Caracas]:

En cumplimiento de nuestra obligación, paso a dar cuenta de lo ocurrido en la Logia N. 3 [Cádiz] después de vuestra partida. Inmediatamente salisteis vos y los vos dignos hermanos que os acompañaban, estuvo a punto de cerrar sus trabajos la Logia $\mathrm{N}^{\circ} 3$ por las voces que sabéis se empezaron a divulgar por Cádiz. Para tratar lo que se debía hacer junté a los hermanos del $5^{\circ}$ grado, y después de haber acordado todo lo que la prudencia nos dictó, resolvimos seguir en nuestros trabajos a toda costa e riesgo. La Providencia, que ciega a los tiranos, nos favoreció esta vez, pues nuestros trabajos continuaron con el mejor éxito y felicidad, a pesar de las asechanzas del Gobierno. Después de vuestra partida se aumentó la sociedad con los hermanos que reza la adjunta lista $\mathrm{N}^{\circ} 3$.

De los cuales, uno ha ido ya a Méjico, y seis deben salir para diferentes puntos de América a tomar parte activa en la justa causa que defendemos.

$\mathrm{El} \mathrm{N}{ }^{\circ} 2$ es la lista de los americanos que habiéndoseles propuesto entrasen en la Sociedad se excusaron por temor al Gobierno español; os la remito para que la comuniquéis a las Logias que estén en el distrito de esa, pues para nuestra constitución quedan excluidos para siempre. Al mismo tiempo incluyo una relación de algunos incidentes ocurridos por falta de algunos Hermanos, y va con el N. ${ }^{\circ} 3 .{ }^{51}$ Habiendo llegado a esta ciudad [Londres] con los hermanos Zapiola, ${ }^{52}$ San Martín, Mier, Villa-Urrutia y Chilavert, hemos fundado por orden de la Logia $\mathrm{N}^{\circ} 3$ una con el N. ${ }^{\circ}$ 7, y hemos recibido a los Hermanos que figuran en la lista que va con el N. ${ }^{\circ}$ 4. Queda de Presidente de la Logia N. 3 el Hermano Ramón Eduardo Anchoris. Todo lo cual os lo comunico a fin de que lo hagáis presente a esa muy respetable Logia encargándoos nos déis cuenta así mismo de todo lo que os haya ocurrido en Filadelfia y en esa capital.

Las listas N. ${ }^{\circ} 2$ y N. ${ }^{\circ} 4$ a las que hace referencia la carta eran las siguientes:

51 En una posdata rectifica diciendo: "No puedo mandar el N. 3 por falta de tiempo, pues piden inmediatamente las cartas".

52 Zapiola era argentino y oficial de la Marina de Guerra Española.

DR @ 2018. 
N. ${ }^{\circ}$ 2. Lista de los americanos que por constitución no pueden ser admitidos en ninguna Sociedad de Caballeros Racionales a causa de haber rehusado entrar en la N. 3 [Logia de Cádiz] por temor a los déspotas españoles.

D. Manuel Rodrigo, natural de Buenos Aires y Diputado suplente de dicha ciudad.

El Marqués de San Felipe y Santiago, natural de La Habana y diputado suplente por Cuba.

D. Luis Velasco, natural de Buenos Aires y diputado suplente por dicha ciudad.

D. Andrés Savariego, natural de la Ciudad de Méjico y diputado suplente por dicho Reino.

D. Joaquín Obregón, natural de Méjico y director de la Lotería de dicha ciudad.

N. ${ }^{\circ}$ 4. Lista de los Hermanos admitidos en la Sociedad de Caballeros Racionales N. 7 [Londres].

Manuel Moreno, natural de Buenos Aires.

Luis López Méndez, natural de Caracas. ${ }^{53}$

Andrés Bello, natural de Caracas. ${ }^{54}$

Marqués del Apartado, Natural de Caracas.

La importancia de estas cartas era grande para el Gobierno español, sobre todo si tenemos en cuenta que el movimiento revolucionario patrocinado por Miranda había culminado con la declaración de independencia de Venezuela, firmada en Caracas el 19 de abril de $1810 .{ }^{55}$ Inmediatamente se formó un gobierno con el nombre de Junta Suprema Conservadora de los Derechos de Fernando VII. Una de sus primeras iniciativas fue nombrar Teniente Coronel de las Milicias a Simón Bolívar y enviarlo a Londres en

53 El paquete de cartas interceptado iba dirigido a su mujer. Luis López Méndez, abogado y literato nació en Caracas en 1770. Fue uno de los tres designados por la Suprema Junta de Caracas el 6 de junio de 1810 en unión de Simón Bolívar -jefe de la Delegación-y de Andrés Bello, en misión especial ante el Gobierno inglés en Londres. Al regresar Bolívar a Venezuela, quedó López Méndez en Londres como representante de la Suprema Junta de Caracas. Posteriormente fue nombrado ministro del Gobierno Republicano de Venezuela, y ministro plenipotenciario de Colombia. Cumpliendo instrucciones de Bolívar, hizo contratos de alistamiento para la organización de la Legión Británica en Londres, y envío de armas, municiones y equipo de guerra.

54 Andrés Bello, poeta, político y escritor, fue maestro de Bolívar y uno de los designados en la misión ante el Gobierno inglés. Autor de la famosa Gramática castellana, en 1829 se trasladó a Santiago de Chile, donde fundó la universidad de Chile y fue su primer rector. Autor de derechos internacionales, fue también redactor del Código Civil chileno. Nacido en Caracas el 29 de noviembre de 1781, murió en Santiago de Chile el 15 de octubre de 1865.

55 Recordemos algunas de las fechas en que se declaró, por primera vez, la Independencia de las provincias de América: Venezuela el 19 de abril de 1810; Argentina el 25 de mayo; Nueva Granada el 20 de julio; México el 16 de septiembre; Chile el 18 de septiembre de 1810. 
misión diplomática con Luis López Méndez y Andrés Bello ante el gobierno de Su Majestad Británica. ${ }^{56}$

A raíz de la acción por la que el bergantín inglés La Rosa fue apresado por un corsario de Puerto Rico, la correspondencia encontrada en él fue debidamente revisada por el Comisario Regio de Puerto Rico, nombrado por el Consejo de Regencia de la isla de León, Antonio Ignacio Cortavarría. Al leer las cartas de Carlos M. a de Alvear sobre las "logias" mirandistas de Londres y Cádiz, pasó una circular el Virrey del Nuevo Reino de Granada en Portobelo y al Gobernador Capitán General de Venezuela y demás dependencias españolas en América, para alertarlos y exigirles estricta vigilancia sobre el movimiento revolucionario de las sociedades secretas, promovido por los insurgentes americanos en los territorios bajo su mando. Dicho documento decía lo siguiente:

De cierta correspondencia aprehendida en un Buque mercante inglés que se dirijía [sic] desde Londres a Caracas, resulta que tanto en estas dos ciudades, como en Cádiz, Filadelfia y en otros puntos que se expresan, se han formado Logias o Asociaciones Secretas, algunos de cuyos individuos debían pasar a diversos parajes de la América española, con el fin, según parece, de generalizar la insurrección en ella. No parece quienes debiesen emplearse determinadamente en esta inicua empresa, ni constan todos los que componen dicha Asociación, pero se asegura en la correspondencia que están comprometidos en ella los siguientes: Don Carlos Alvear, Román de la Luz, Don Rada, Don Murguiondo, Don Valbin, Don Armenteros, Don Larrea, Don López Conde, Don Zapiola, Don Caicedo, Don Toledo y Don Roche, cuyos nombres se expresan en la correspondencia; Antonio del Valle, José Sotolongo, Andrés Arango y Vicente Quesada, naturales de la Habana: Miguel Santamaría, Vicente Acuña, Joaquín La Carrera Ortiz y José Herrera, naturales del Reino de Méjico; Juan Vatres de Guatemala; José M. ${ }^{a}$ Vergara de Santafé; Manuel Moreno de Buenos Aires; Luis López Méndez, Andrés Bello y Don Rafael de Mérida, de Caracas; Marqués del Apartado, de Méjico; Don San Martín, Don Mier, Don Villa-Urrutia, Don Chilaver y Don Ramón Eduardo Anchoris.

Aunque los papeles interceptados en los que vienen designados estos sujetos como individuos de dichas sociedades, no constituyan por sí solos y sin que precedan las comprobaciones correspondientes una prueba bastante de este hecho, ni del proyecto de fomentar dicha insurrección, que al parecer se indica en ellos, creo que el zelo de V.S. los considerará suficientes para observar si algunos de ellos arriba de ese Reino, y tomar en este caso las providencias, que le dicte su prudencia y apoderarse de sus papeles y ponerse por este y otros

56 Se embarcaron en el puerto de La Guaira el 10 de junio de 1810 en la corbeta inglesa "Wellington" y llegaron al puerto de Portsmouth, Inglaterra, el 11 de junio de 1810. 
medios que juzgue convenientes, en estado de calificar esta especie, que tan delicada y de tanta trascendencia me creo obligado a poner en noticia de V.S. con la debida reserva debiendo añadir para su gobierno que dichos papeles interceptados en el buque inglés, aunque no está comprobada la identidad ni es posible llegar a comprobarla por ahora por su naturaleza y demás circunstancias, aparecen firmados en Londres por don Carlos Alvear en 28 de octubre último [1811], y remitidos a don Rafael Mérida residente en Caracas.

Como se observará en esta circular y en las cartas interceptadas, se está jugando con un triple juego terminológico de logias, sociedades secretas y sociedades patrióticas o políticas. En el fondo subyace el tema de la masonería, por una parte, y el de las sociedades patrióticas, por otra.

Fue también en Cádiz donde San Martín tuvo noticias de lo que estaba ocurriendo en América. Unos años más tarde lo recordaba en carta dirigida al presidente del Perú, mariscal Ramón Castilla, escrita en Boulogne-sur-Mer el 11 de septiembre de 1848, en la que decía lo siguiente: "Como Vd. yo serví en el ejército español, en la Península, desde la edad de trece a treinta y cuatro años, hasta el grado de teniente coronel de caballería. En una reunión de americanos, en Cádiz, sabedores de los primeros movimientos acaecidos en Caracas, Buenos Aires, etc., resolvimos regresar cada uno al país de nuestro nacimiento, a fin de prestarle nuestros servicios en la lucha, pues calculábamos se había de entablar". 57

Efectivamente, en sus andanzas fue Cádiz la ciudad más frecuentada por San Martín, pues ésta era entonces la puerta de entrada a España y el camino hacia América. Allí prestó servicios cuando la peste de 1803; allí conoció al colombiano Juan García del Río, que habría de ser su ministro en Lima y su primer biógrafo; 58 conoció también a otro joven, Alejandro Aguado, futuro marqués de las Marismas, que sería su bienhechor en Francia; ${ }^{59}$ y ahí solicitó y obtuvo su retiro del Ejército español. ${ }^{60}$

De los Caballeros Racionales de Madrid las noticias son indirectas y se conocen gracias a Bernardo Frías y su Historia del general Güemes, donde se lee que José de Moldes y Francisco Gurruchaga, debido al estado decadente y de notoria impotencia en el que se iba hundiendo la monarquía española,

57 Biblioteca de Mayo, Buenos Aires, Edición del Senado de la Nación, 1960, t. II, 1921.

58 Gual Jaen, Ricardo, El General San Martín. Biografia, London, W. Marchant, 1823.

59 Karduner, Luis, Alejandro Aguado, Buenos Aires, Instituto Judío Argentino de Cultura e Información, 1953.

60 Piccirilli, Ricardo, ¿San Martín conoció a Guido en Londres?, Investigaciones y Ensayos núm. 3, Buenos Aires, Academia Nacional de la Historia, 1967, pp. 121 y ss. El Real Decreto que concedió el retiro de San Martín es de fecha 19 de septiembre de 1811. 
iniciaron en 1817 la formación de una sociedad secreta o conjuración de americanos para aprovechar tan interesante coyuntura y proclamar la independencia de la patria. ${ }^{61}$ Según Frías, dicha sociedad secreta estaba compuesta, además por el coronel Eustaquio de Moldes y José de Gurruchaga, por el doctor Juan Antonio de Moldes, Bernardo O'Higgins, Zapiola, Balcarce, los hermanos Lezica, Manuel Pinto, Carlos de Alvear.

Por su parte el peruano José Gálvez Barrenechea, basado en los papeles de Riva Agüero, dice que en 1807 surgió en Madrid la logia Caballeros Racionales, presidida por el argentino José Moldes. ${ }^{62}$ Coincide con Riva Agüero otro patriota peruano, el general José de Rivadeneira, quien, detenido por las autoridades virreinales, fue condenado y remitido a la prisión de Cuatro Torres del Arsenal de la Carraca, en Cádiz, donde estaba detenido también Francisco de Miranda. ${ }^{63}$ Rivadeneira ha dejado un testimonio interesante, según el cual los Caballeros Racionales de Madrid, ante el avance de las tropas francesas, se refugiaron en Sevilla, para pasar luego a Cádiz. Además, da una extensa nómina de afiliados, ${ }^{64}$ refiriéndose a su posterior encuentro con San Martín, en 1822, en el Cuartel General de Huaura, dice: "Me estrechó en sus brazos, recordó nuestra antigua amistad, nuestros trabajos en la sociedad de Cádiz para que se hiciese la América independiente. ${ }^{65}$

María Eugenia Vázquez Semadeni insiste en que los Caballeros Racionales fue una sociedad con fines estrictamente políticos: la consecución de la independencia. No fueron reconocidos por ninguna autoridad masónica "al no tener las finalidades filosóficas y filantrópicas de la masonería, ni sus contenidos esotéricos". La autora añade que la filial establecida en Jalapa, en 1812, sí tuvo relación con los grupos insurgentes de la región de Veracruz a los que enviaron pólvora, armas y caballos, así como noticias y hombres. Incluso, varios miembros de los Caballeros Racionales llegaron a integrar la Junta Gubernativa Provisional de Naolingo, vinculada con el movimiento insurgente de Morelos, pero, su protagonismo en la lucha fue breve, pues sus

61 Frías, Bernardo, Historia del general D. Martín Güemes y de la Provincia de Salta de 1810 a 1822, Salta, El Cívico, 1902, pp. 256 y 257.

62 Gálvez Barrenechea, José, Homenaje a San Martin, Lima, s.e.,1950, p. 8.

63 Tras cuatro años de prisión de Cádiz, fue trasladado a Barcelona, donde permaneció hasta 1820, cuando fue liberado a raíz de la sublevación de Riego, y pudo regresar al país de su nacimiento.

64 Entre ellos figuran Mérida, Tobar, Caicedo y Castillo, colombianos; Pérez, Toledo, Ruiz y Obregón, mejicanos; Suárez, Pinedo y Juanos, guatemaltecos...

65 San Martín, que apreciaba los servicios y sacrificios de Rivadeneira, lo nombró General de Brigada, a pesar de no haber participado en la lucha armada, y lo designó gobernador del Callao. 
actividades fueron descubiertas y detenidos muchos de sus integrantes, algunos, incluso, condenados a muerte o entregados a la Inquisición.

La información obtenida en las causas seguidas tanto por los tribunales civiles, como por la Inquisición, sirve de complemento a lo manifestado por otras vías, como correspondencias privadas. Así, se detienen en detalles de la ceremonia de iniciación en la que los candidatos debían hacer un juramento que los comprometía a defender la patria, no descubrir el secreto de la asociación y resguardar siempre la religión católica. Tenían señas y palabras de reconocimiento - similares a las masónicas- y celebraban sus reuniones en distintos lugares, desde billares hasta las casas de algunos miembros. El secreto tenía como finalidad impedir que las autoridades se enteraran de la existencia y objetivos de la sociedad. ${ }^{66}$

\section{CONCLUSIÓN}

Como se ha señalado, la disparidad de testimonios pone de manifiesto la complejidad de ciertos hechos históricos, sobre todo cuando las opiniones predominan sobre las pruebas, y el tópico, fruto de una reiterada y mecánica repetición, se convierte en dogma intocable.

No se trata del (tan denostado por algunos) culto al fetiche documental, sino de la constatación de que en la mayor parte de los casos siguen utilizándose conjeturas e hipótesis - a veces contradictorias- en lugar de auténticos argumentos convincentes. En especial, respecto a las mal llamadas logias Lautaro, sobran opiniones y faltan pruebas, en un asunto en el que la imaginación o la ignorancia muchas veces han suplido al documento, dando como resultado que el estudio crítico de las fuentes sea el que fundamenta el concepto histórico y que se acepten sin crítica algunas afirmaciones, sin

66 Vázquez Semadeni, María Eugenia, "La Masonería en México, entre las sociedades secretas y patrióticas, 1813-1830", Revista de Estudios Históricos de la Masonería Latinoamericana y Caribeña, San José de Costa Rica, vol. 2, núm. 2, diciembre de 2010-abril de 2011, pp. 20-33; Campos García, Melchor, Sociabilidades políticas en Tucatán. Un estudio sobre los espacios públicos, 1780-1834, Mérida, Universidad Autónoma de Yucatán, 2003; Guedea, Virginia, "Una nueva forma de organización política: la sociedad secreta de Jalapa 1812", Un hombre entre Europa y América. Homenaje a fuan Antonio Ortega y Medina, México, Amaya Garriz, 1993, pp. 185-208; Archivo General de la Nación [México], Indiferente de guerra, vol. 22, fols. 2730. Teresa de Mier, Fray Servando, "Declaraciones decimosexta y decimoséptima ante la Inquisición de México, noviembre 1817, documentos 959 y 960", Colección de documentos para la Guerra de independencia, en Hernández y Dávalos, en Juan E. (comp.), México, Universidad Nacional Autónoma de México, 2008. 
Esta obra forma parte del acervo de la Biblioteca Jurídica Virtual del Instituto de Investigaciones Jurídicas de la UNAM www.juridicas.unam.mx

cotejar y relacionar entre sí hechos y cronologías que desmienten o contradicen escritos anteriores.

En cualquier caso, estamos ante hechos históricos complejos y, sobre todo, polémicos, por la previa toma de posiciones ideológicas incompatibles con la búsqueda de la "verdad histórica" o al menos de su aproximación.

Debido a la abundante bibliografía existente, aquí se estudia sólo el caso de Miranda, dejando de lado el de otros libertadores, como San Martín, O’Higgins, Bolívar... sobre los que también hay numerosos trabajos con enfoques y valoraciones muy diversos.

\section{BIBLIOGRAFÍA}

Arango Jaramillo, Mario, Masonería y poder politico en Colombia. Medellín, Hombre Nuevo, 2011.

AvendaÑo, Rómulo, "La Sociedad Lautaro. Rectificaciones históricas", La Revista de Buenos Aires Buenos Aires, núm. 19, 1869, pp. 439-445; núm. 21, 1870.

BAKOUMINe, Tatiana, Répertoire biographique des francs-maçons russes (XVIIIe et XIXe siècles), París, Institut d'Etudes Slaves de l'Université de Paris, 1967.

Barbosa de la TorRe, Pedro A., Simón Bolívar y la Francmasonería, Maracaibo, s.e., 1977.

Barcia Trellez, Augusto, San Martín y la Logia Lautaro, Buenos Aires, s.e., 1950.

Beltrán ÁviLA, Marcos, La pequeña gran logia que independizó a Bolivia 18231825, Cochabamba, Atlantic, 1948.

Biblioteca de Mayo, Buenos Aires, Edición del Senado de la Nación, 1960, t. II, p. 1921.

Bocaia Romanach, Alfredo, La masonería y la independencia de América. Mitos e historia de las sociedades secretas, Asunción, Servi Libro, 2003.

Campos García, Melchor, Sociabilidades políticas en Tucatán. Un estudio sobre los espacios públicos, 1780-1834, Mérida, Universidad Autónoma de Yucatán, 2003.

CANTER, Juan, "La Logia Lautaro y la independencia de América según Antonio R. Zúñiga", Crítica Histórica, Buenos Aires, s.e., 1933, pp. 78-90.

CANTER, Juan, "La Logia Lautaro y la revolución de octubre de 1812", La Nación, Buenos Aires, 1934.

CANTER, Juan, "La Logia Lautaro y su evolución", La Nación, Buenos Aires, 1934.

CANTER, Juan, "La Logia Lautaro y Mendoza", Revista de la funta Provincial de Estudios Históricos, Santa Fe, vol. II, 1936. 
Esta obra forma parte del acervo de la Biblioteca Jurídica Virtual del Instituto de Investigaciones Jurídicas de la UNAM www.juridicas.unam.mx

Carnicelli, Américo, La Masonería en la Independencia de América, Bogotá, Cooperativa Nacional de Artes Gráficas, 1970, t. I y II.

CARniCelli, Américo, Historia de la Masonería colombiana (1833-1940), Bogotá, s.e., 1975, t. II.

Castro Olivas, Jorge Luis, Sociedades Secretas y Masonería en el proceso de emancipación peruana, tesis de maestría en Historia, Universidad nacional Mayor de San Marcos, Lima, 2009.

Catanzaro, Tomás, "Las Sociedades Patrióticas Secretas de la Emancipación”, Revista Luz, Lima, vol. 3, núm. 9, marzo 1952.

CATANZARO, Tomás, "El precursor Olavide y las organizaciones secretas", Revista del Instituto Libertador Mariscal Castilla, Lima, vol. 9, núm. 9, 1971.

Cross, A.G., "British Freemasonry in Russia during the Reign of Catherine the Great", Ars Quatuor Coronatorum, Londres, vol. 111, 1971.

Guccorese, Ignacio Juan, San Martín y la Masonería, Buenos Aires, Instituto Nacional Sanmartiniano, 1993.

Duthu, D., "San Martín y la logia Lautaro", Revista Eclesiástica del Arzobispado de Buenos Aires, Buenos Aires, vol. V, 1905.

EyZAGUIRRE, Jaime, La Logia Lautarina y otros estudios sobre la Independencia, Santiago de Chile, Francisco De Aguirre, 1973.

Fernández Cabreldi, Alfonso, La Francmasonería en la Independencia de Hispanoamérica, Montevideo, América Una, 1988.

Fernández Cabreldi, Alfonso, Masonería y Sociedades Secretas en las luchas Emancipadoras de la Patria Grande, Montevideo, América Una, 1975.

Fernández Cabreldi, Alfonso, Masonería, Morenismo, Artiguismo: prensa e influencia de la francmasonería en los movimientos independentistas del Río de la Plata, Montevideo, América Una, 1982.

Ferrer Benimeli, José Antonio, "Aproximación a las llamadas logias Lautaro”, Hoy es Historia, Montevideo, t. IV, núm. 23, septiembre-octubre 1987.

Ferrer Benimeli, José Antonio, Masonería, Iglesia e Ilustración, Madrid, Fundación Universitaria Española, 1976-77, 4 vols.

FERrer BenimeLI, José Antonio, Masonería e Inquisición en Latinoamérica durante el siglo XVIII, Caracas, Universidad Andrés Bello, 1973.

Ferrer Benimeli, José Antonio, Massoneria e Chiesa Cattolica, 2a. ed., Roma, Paolina, 1982.

Ferrer Benimeli, José Antonio, "Bolívar y la Masonería", Revista de Indias, Madrid, vol. XLIII, núm. 172, 1983. 
Esta obra forma parte del acervo de la Biblioteca Jurídica Virtual del Instituto de Investigaciones Jurídicas de la UNAM www.juridicas.unam.mx https://biblio.juridicas.unam.mx/bjv

Ferrer Benimeli, José Antonio, "Cádiz y las llamadas "Logias" lautaro o Caballeros Racionales", De la Ilustración al Romanticismo. Ideas y Movimientos clandestinos. Ideas y movimientos clandestinos, Cádiz, Servicio de Publicaciones Universidad, 1988.

FERrer Benimeli, José Antonio, El contubernio judeo-masónico-comunista, Madrid, Istmo, 1982.

Ferrer Benimeli, José Antonio, "La Franc-Maçonnerie européenne: Expansion en Amérique du sud", Revista La Pensée et les Hommes, Bruselas, vol. 19, 1922.

Ferrer Benimeli, José Antonio, La Masonería actual, Barcelona, American Historical Review, 1977.

Ferrer Benimeli, José Antonio, La masonería como problema político-religioso. Reflexiones históricas politico-religioso. Reflexiones históricas, Tlaxcala, Universidad Autónoma, 2010.

Ferrer Benimeli, José Antonio, "La masonería española ante la Independencia de América", Comunicación, Historia y Sociedad. Homenaje a Alfonso Braojos, Sevilla, Eloy Arias, 2001.

Ferrer Benimeli, José Antonio, "La masonería y la Independencia de América española (Reflexiones metodológicas)", Anuario de Estudios Americanos, Sevilla, vol. XXXV, 1978.

Ferrer Benimeli, José Antonio, "Las Cortes de Cádiz, América y la Masonería", Cortes y Constitución de Cádiz. 200 años, Madrid, Espasa, 2011, t. II.

Ferrer Benimeli, José Antonio, "Les Caballeros Racionales, les loges lotariennes et les formes déviées de la franc-maçonnerie dans le monde hispanique", Sous le masque de la Franc-Maçonnerie, Bruselas, L'Université, 1990.

Ferrer Benimeli, José Antonio y CuARTero Escobés, Susana, Bibliografia de la Masonería, Madrid, Fundación Universitaria Española, 2004, 3 vols.

FraU Abrines, Lorenzo y ARÚs, Rosendo, "Bartolomé Mitre Martínez (1821-1906)", Diccionario Enciclopédico de la Masonería, México, Valle de México, 1976, t. II.

FrÍAS, Bernardo, Historia del general D. Martín Güemes y de la Provincia de Salta de 1810 a 1822, Salta, El Cívico, 1902.

Furlong, Guillermo, "La Logia Lautaro", Criterio, Buenos Aires, vol. 10, 1930.

Gálvez Barrenechea, José, Homenaje a San Martín, Lima, s.e.,1950, p. 8.

GANDÍA, Enrique de, La política secreta de la Gran Logia de Londres, Buenos Aires, 1976. 
Esta obra forma parte del acervo de la Biblioteca Jurídica Virtual del Instituto de Investigaciones Jurídicas de la UNAM www.juridicas.unam.mx

Geoghegan, A.R., Bibliografia de la revolución de mayo (1810-1828), Buenos Aires, Biblioteca del Congreso de la Nación, 1960.

Geoghegan, A.R., El General San Martín. ¿Masón-católico-deista?, Buenos Aires, Club de Lectores, 1950.

GonzÁlez Bernaldo De QUiRós, Pilar, "Masonería y Nación: la construcción masónica de una memoria histórica nacional", Historia, Santiago de Chile, núm. 25, 1990.

GonzÁlez Bernaldo de Quirós, Pilar, "Producción de una nueva legitimidad: ejército y sociedades patrióticas en Buenos Aires entre 1810-1813", Cahiers des Amériques Latines, París, núm. 10, 1990.

González Bernaldo De Quirós, Pilar, "La Revolución Francesa y la emergencia de nuevas prácticas de la política: la irrupción de la sociabilidad en el Río de la Plata revolucionario (1810-1815)", Santiago de Chile, Universitaria, 1990.

GONZÁLEZ BERnALDO DE QUIRÓs, Pilar, "Masonería y política: el supuesto origen masónico de la organización nacional. Análisis de un Banco de datos sobre la pertenencia masónica de la clase política porteña durante la formación del Estado-Nación (1852-1862)", Masonería española y América, Zaragoza, José Antonio Ferrer Benimeli, vol. I, 1993.

GonZÁLez BERnALDO DE Quirós, Pilar, Civilité et politique aux origines de la nation argentine. Les sociabilités à Buenos Aires 1829-1862, Paris, Publication de la Sorbonne, 1999.

Gual Jaen, Ricardo, El General San Martín. Biografia, London, W. Marchant, 1823.

GuEDEA, Virginia, "Una nueva forma de organización política: la sociedad secreta de Jalapa 1812", Un hombre entre Europa y América. Homenaje a Juan Antonio Ortega y Medina, México, Amaya Garriz, 1993.

Guillén, Julio, "Correo insurgente de Londres capturado por un corsario portorriqueño, 1811", Boletín de la Academia Chilena de la Historia, vol. XXVII, núm. 63, 1960.

GuZMÁn, José R., "Fray Servando Teresa de Mier y la Sociedad Lautaro" Anales del Instituto Nacional de Antropología e Historia, México, 7a. época, 1967-1968.

HERRERA VALDÉS, Willy, Las sociedades secretas y la independencia política del cono sur americano: O'Higgins, San Martín y la logia Lautaro, tesis de doctorado en Universidad Complutense de Madrid, 1985.

IBAÑEz, Primitivo, La Masonería y la pérdida de las colonias, Burgos, s.e., 1938. 
Esta obra forma parte del acervo de la Biblioteca Jurídica Virtual del Instituto de Investigaciones Jurídicas de la UNAM www.juridicas.unam.mx

Junco, Alfonso, "La Masonería condenada por los prohombres de la Independencia”, Cuadernos Hispano-Americanos, Madrid, núm. 30, 1952.

Karduner, Luis, Alejandro Aguado, Buenos Aires, Instituto Judío Argentino de Cultura e Información, 1953.

LAPPAS, Alcibíades, San Martíny su ideario liberal, Buenos Aires, Símbolo, 1982.

LAPPAS, Alcibíades, La Masonería Argentina a través de sus hombres, Buenos Aires, Belgrano, 1966.

LAPPAS, Alcibíades, San Martín y las logias y San Martín y su formación, Buenos Aires, s.e., 1978.

Lazcano, Martín V., Las sociedades secretas politicas y masónicas en Buenos Aires, Buenos Aires, El Ateneo, 1927, t. I.

LENTIN, Anthony, "A Rusian freemason in the Reign of Catherine the Great: Prince M.M. Shcherbatov (1733-1790)", Ars Quatuor Coronatorum, Londres, vol. 111, 1998.

Leturia, Pedro, La emancipación hispanoamericana en los informes episcopales a Pio VII, Buenos Aires, Instituto Investigaciones Históricas, 1935.

López Albújar, Carlos, Masones y Masonería en el Perú, Lima, José Pardo, 1961.

Madero Quiroga, Adalberto, Ensayos de David Alberto Cossí, Monterrey, Senado de la República, 2002.

Maguirre, Patricio J., La Masonería y la Emancipación del Río de la Plata, Buenos Aires, Nueva Hispanidad, 1969.

Mancini, Jules, Bolívar et l'Emancipation des Colonies Espagnoles des origines á 1815, París, Perrin, 1912.

Martín Lazcano, V., Las Sociedades secretas politicas y masónicas en Buenos Aires, Buenos Aires, El Ateneo, 1927, 2 vols.

Martínez Zaldúa, Ramón, La Masonería en Hispanoamérica, México, CostaAmic, 1965.

MÉNDEz Reyes, Salvador, "Fray Servando Teresa de Mier y el reconocimiento de México por la Santa Sede", Del mundo hispánico a la consolidación de las naciones, 1808-1840, Tlaxcala, Gobierno del Estado de Tlaxcala, 2010.

MiTRE, Bartolomé, Emancipation of South America, Londres, Kessinger Legacy, 1893.

Mitre, Bartolomé, Historia de San Martín y de la Emancipación Sudamericana, Buenos Aires, Congreso de la Nación, 1968.

Mitre, Bartolomé, Historia de Belgrano y de la Independencia Argentina, Buenos Aires, El Ateneo, 1876, 3 vols. 
Esta obra forma parte del acervo de la Biblioteca Jurídica Virtual del Instituto de Investigaciones Jurídicas de la UNAM www.juridicas.unam.mx

Mola, Aldo A., Storia della Massoneria italiana dall'Unità alla Repubblica, Milano, Bompiani, 1994.

Morales PADrón, Francisco, Historia de América. En Manual de Historia Universal, Madrid, Espasa Calpe, 1962, vol. VI.

NadRA, Fernando, San Martín hoy, Buenos Aires, Cartago, 1974.

Navarro, Nicolás, La Masonería y la Independencia, Caracas, Sur-America, 1928.

OcAmpo, Emilio, Alvear en la Guerra con el Imperio del Brasil, Buenos Aires, Claridad, 2003.

O'Higgins, Bernardo, Epistolario, Santiago de Chile, Ernesto de la Cruz, 1916, t.l.

Onsari, Fabián, San Martín, la logia Lautaro y la Franc-Masonería, Avellaneda, 1951.

Orrego Vicuña, Eugenio, O’Higgins, Buenos Aires, Losada, 1946.

Oviedo MarTínez, Benjamín, "La Logia Lautarina", Revista Chilena de Historia y Geografia, Santiago de Chile, vol. LXLL, 1929.

Oviedo MaRTínez, Benjamín, "La Logia Lautaro. Su valor y su significado histórico", La Nación, Buenos Aires, 1910.

PAcheco QuinTERo, Jorge, Influencia de la Masonería en la Emancipación de América (Aspecto Colombiano), Bogotá, s.e., 1943.

PACífico OTERo, José, "La Logia Lautaro. Su valor y su significado histórico", La Nación, Buenos Aires, s.e., 1910.

Paz Soldan, Mariano Felipe, "La Logia Lautaro", Historia del Perú independiente, Lima, 1868, vol. I.

PICGIRILLI, Ricardo, ¿San Martín conoció a Guido en Londres?, Investigaciones y Ensayos núm. 3, Buenos Aires, Academia Nacional de la Historia, 1967.

PiCcirilli, Ricardo, San Martín y la política de los pueblos, Buenos Aires, Aguirre, 1957.

PicGIRILLI, Ricardo, "San Martín y la logia Lautaro", Museo Histórico Nacional, Buenos Aires, serie II, núm. XVI, 1958.

Pinto Lagarrigue, Fernando, La masonería y su influencia en Chile, Santiago de Chile, Orbe, 1973.

Restrepo Canal, Carlos, "Informe sobre la Masonería y la Independencia", Boletín de Historia y Antigüedades, Bogotá, vol. 46, 1959.

Reyes Heredia, Guillermo de los, Herencias secretas. Masonería, politica y sociedad en México, Puebla, Universidad Autónoma, 2009.

Rodríguez Alonso, Josefina, Le siècle des Lumières conté par Francisco de Miranda, París, france-empire, 1974. 
Esta obra forma parte del acervo de la Biblioteca Jurídica Virtual del Instituto de Investigaciones Jurídicas de la UNAM www.juridicas.unam.mx

Romero, Celestino B., Raiz histórica de la Masonería en Venezuela, Caracas, La Esfera, 1957.

Romero, Juvenal, La Revolución de Mayo y la Masonería, Buenos Aires, Hellas, 1960.

Rottjer, Anibal A., La Masonería en la Argentina y en el mundo, Buenos Aires, Nuevo Orden, 1973.

RuIZ y RuIZ, Raúl A., "La logia Lautaro y la Independencia de América", Revista de la Junta Provincial de Estudios Históricos, Santa Fe, vol. 15, 1946.

Seal-Goon, F.W., "Spanish-American Revolutionary Masonry. The mythical Masonry of Francisco de Miranda", Ars Quatuor Coronatorum, Londres, vol. 94, 1981.

Seal-Coon, F.W. "La mítica masonería de Francisco de Miranda” La Masonería española entre Europa y América, Zaragoza, José Antonio Ferrer Benimeli, 1991, vol. I.

Seal-Coon, F.W., "Simón Bolívar, freemason", Ars Quatuor Coronatorum, Londres, vol. 90, 1977.

Seal-Coon, F.W.,"More light: Simon Bolivar, freemason”, Ars Quatuor Coronatorum, Londres, vol. 92, 1979.

SEAL-CoOn, F.W., "Spanish-American Revolutionary Masonry", Ars Quatuor Coronatorum, Londres, vol. 94, 1981.

SHERIFF, Keith, The Rough Ashlar. The History of English Freemasonry in Gibraltar, 1727-2002, Gibraltar, Grand Lodge of Gibraltar, 2002.

Spencer Robertson, William, Life of Miranda, Nord Carolina, University, 1929.

Spencer Robertson, William, La vida de Miranda, Caracas, Academia Nacional de Historia, 2006.

Teresa DE Mier, Fray Servando, "Declaraciones decimosexta y decimoséptima ante la Inquisición de México, noviembre 1817, documentos 959 y 960", Colección de documentos para la Guerra de independencia, en Hernández y Dávalos, Juan E. (comp.), México, Universidad Nacional Autónoma de México, 2008.

VÁzquez Semadeni, María Eugenia, "La Masonería en México entre las sociedades secretas y patrióticas", Revista de Estudios Históricos de la Masonería Latinoamericana y Caribeña, San José de Costa Rica, vol. 2, núm. 2, diciembre 2010-abril 2011.

Vicuña Mackenna, Benjamín, Vida del Capitán General de Chile Don Bernardo O’Higgins, Santiago de Chile, Rafael Joven, 1882. 
Esta obra forma parte del acervo de la Biblioteca Jurídica Virtual del Instituto de Investigaciones Jurídicas de la UNAM

Viauña Mackenna, Benjamín, La Revolución de la Independencia del Perú, Santiago de Chile, Universidad, 1938.

Villanueva, Carlos A., Bolívar y el general San Martín, París, s.e., 1911.

Villanueva, Carlos A., La Revolución de la Independencia del Perú, Santiago de Chile, Universidad, 1938.

ZELDIS, León, "Freemasonry's Constitution to South American Independence. A factual Approach", Ars Quatuor Coronatorum, Londres, vol. 111, 1998.

ZúÑIgA, Antonio E., La Logia Lautaro y la independencia de América, Buenos Aires, Taller Gráfico J. Estrach, 1922. 


\title{
PROHIBICIONES MASÓNICAS PAPALES, REALES Y LA CONSTITUCIÓN DE GÁDIZ
}

\author{
José Antonio Ferrer Benimeli*
}

El paso de la masonería medieval de los constructores de catedrales (operativa) a la masonería moderna (especulativa) puede seguirse a través de una serie de documentos que permiten apreciar la transición. Éstos se encuentran, sobre todo, en la famosa Gran Logia de Edimburgo, que tenía sus reuniones en la St. Mary's Chapel Lodge. Precisamente es ésta la que ha conservado sus archivos completos desde 1599. De igual manera, existen los de la Logia Madre de Kilwinning. Estos archivos nos permiten constatar que, poco a poco, en el transcurso del siglo XVII, en los procesos verbales, al lado de los verdaderos operarios que trabajaban la piedra, aparecen otros personajes que ejercían una profesión totalmente diferente.

Asimismo, consta que en 1670, en la logia escocesa de Aberdeen, las tres cuartas partes de sus cuarenta afiliados eran abogados, cirujanos y mercaderes. Precisamente, ya en esta logia existía la distinción entre los constructores de edificios y los que se dedicaban a especulaciones acerca de la geometría.

Con el tiempo, los especulativos se impusieron a los operativos. De ahí que aquella organización profesional de los constructores de catedrales derivara hacia esa otra masonería, ya no operativa, sino especulativa, la cual tomó cuerpo a partir de febrero de 1717, cuando cuatro de las logias londinenses - pues no eran éstas las únicas existentes-: Goose and Gridiron, Crown Ale House, Apple Tree y The Rummer and Grapes se quejaron de la falta de iniciativa del ya anciano sir Christopher Wren, arquitecto en jefe de la St. Paul's Church, quien, estrictamente, no se puede decir que fuera el Gran Maestre, al menos en el sentido moderno, aunque, de todas formas, debido a su alta posición y méritos, gozaba de una autoridad indiscutida, especialmente desde que fue encargado de dirigir la reconstrucción de Londres a raíz del gran incendio del 2 de septiembre de 1666, el cual

\footnotetext{
* Universidad de Zaragoza.
} 
destruyó las dos terceras partes de la ciudad. ${ }^{1}$ Entonces, las citadas cuatro logias decidieron intentar una reforma de carácter legislativo dentro de la institución masónica. Reforma propia de las sociedades tradicionales en crisis que buscaban el retorno a los orígenes y la restauración de un pasado concebido como la edad de oro.

En febrero de 1717, tuvo lugar esta transformación, consistente en la fundación de una Gran Logia que en un principio recibió el nombre de Gran Logia de Londres y Westminster. ${ }^{2}$ Es decir, no se decidió la fusión de las cuatro logias en una sola, sino la creación de un organismo federal que recibió el nombre de Gran Logia, con un Gran Maestre al frente. Se acordó que seguirían reuniéndose trimestralmente las cuatro logias en asamblea, presididas por el maestre antiguo, hasta que fuera nombrado un nuevo Gran Maestre de la orden. ${ }^{3}$

La elección tuvo lugar el 24 de junio del mismo año, en la fiesta de su Patrono San Juan Bautista. Por gran mayoría de votos fue nombrado Anthony Sayer, gentleman. A partir de entonces se verificó un cambio en la orientación de la hermandad masónica pues, aunque se conservó escrupulosamente el espíritu de los masones operativos, con sus principios y usos tradicionales, se abandonó el arte de la construcción a los trabajadores de oficio, si bien se mantuvieron los términos técnicos de la arquitectura, aunque a tales expresiones se les dio un sentido simbólico. A partir de aquel periodo, la masonería se transformó en una institución, cuyo objetivo era lograr una finalidad ética, susceptible de propagarse por todos los pueblos civilizados.

Desde un punto de vista jurídico, fue el triunfo del derecho escrito sobre la costumbre, donde nació un nuevo concepto, el de obediencia o federación de logias. En adelante es aquí donde residirá la soberanía, ya que únicamente la Gran Logia tendrá autoridad para crear nuevas logias, con lo que, de hecho, surge una legitimidad masónica que hoy sus descendientes llaman masonería regular.

La redacción de las Constituciones, que en adelante serán la pauta a seguir por esta nueva masonería, corrió a cargo de dos pastores protestantes: uno de

1 Christopher Wren (1632-1723), ya muy débil, fue relevado -el 21 de abril de 1718por el rey Jorge I del cargo de Superintendente General de los Edificios. Un tanto despechado se fue a vivir a Hampton Court, donde murió a los 91 años, el 25 de febrero de 1723. Fue enterrado en el ángulo sudeste de la cripta de "su" catedral de San Pablo.

2 Después adoptó el nombre de Gran Logia de Inglaterra o de los Modernos. A ésta siguieron otras como la Gran Logia de Irlanda, en torno a 1725, la Gran Logia de Escocia hacia 1736, la Gran Logia de los "Antiguos" en 1751, y, finalmente, con la fusión de los Antiguos y Modernos, la Gran Logia Unida de Inglaterra en 1813.

3 Schuster, Georg, Die geheimen Gesellschaften, Verbindungen und Orden, Leipzig, Verlag von Theodor Leibing, 1906, t. II, p. 14. 
ellos, el doctor John Théophile Desaguliers, hijo de un pastor calvinista francés de La Rochelle, emigrado en 1685, después de la revocación del Edicto de Nantes, eminente físico y miembro de la Royal Society; el otro, el doctor en teología James Anderson, cuyo nombre figura en el frontispicio de las Constituciones, por lo que en adelante han sido conocidas con el nombre de las Constituciones de Anderson.

La primera edición apareció en $1723 .{ }^{4}$ Esta carta magna de la masonería especulativa está compuesta de tres partes: la primera es una narración seudohistórica de la Arquitectura, la cual refleja un pasado mítico que Anderson hace remontar hasta el mismo Adán. ${ }^{5}$ La segunda es un código que reglamenta la manera de fundar las logias, su funcionamiento y su derecho disciplinar, la tercera está dividida a su vez en dos partes: una deontológica, intitulada The Charges of a Free-mason (Las obligaciones de un francmasón), y la otra, administrativa, con el título de General Regulations (Reglamentos generales).

De una forma simbólica se hace constar que, en adelante, ya no será la catedral un templo de piedra a construir, sino que el edificio que habrá de levantarse en honor y gloria del Gran Arquitecto del Universo será la catedral del universo, es decir, la humanidad. El trabajo sobre la piedra bruta destinada a convertirse en cúbica, es decir, perfecta y apta a las exigencias constructivas, será el hombre, quien habrá de irse puliendo en contacto con sus semejantes, por medio de una enseñanza simbólico-ritualista.

Si comparamos lo que conocemos de los constructores de catedrales y sus tradiciones corporativas, ${ }^{6}$ con lo que las Constituciones de Anderson conservaron para unos fines nuevos, es fácil conjeturar las razones que impulsa-

\footnotetext{
4 Anderson, James, The Constitutions of the Free-Masons; containing the History, Charges, Regulations... of that most Ancient and Right Worshipful Fraternity, Londres, s.e., 1723. A esta edición de 1723 siguieron otras, y en especial la de 1738 en la que se lee en la página 24: "En el año 26 del imperio de Augusto, tras la conquista de Egipto el Verbo se hizo carne, nació el Señor Jesucristo Emmanuel, el Gran Arquitecto y Gran Maestre de la Iglesia Cristiana". Sobre las diferentes ediciones de las Constituciones de Anderson, Ferrer Benimeli, José Antonio, Bibliografia de la Masonería, Madrid, Fundación Universitaria Española, 1978, pp. 154-156.

5 "Adán, nuestro primer padre, creado a imagen de Dios, el Gran Arquitecto del Universo, debió tener las Ciencias liberales, en particular la Geometría, inscritas en el corazón". Anderson James, op. cit., p. 1. Este texto en la edición de 1738 queda transformado en: "El Todopoderoso Arquitecto y Gran Maestro del Universo habiendo creado todas las cosas muy buenas y conforme a la Geometría, en último lugar formó a Adán a su propia imagen...".

6 Se conservan más de 150 estatutos y reglamentos manuscritos (Antiguos Deberes u Old Charges); el más antiguo no es Regius inglés de 1390, sino los estatutos y reglamentos de Bolonia de 1248. La primera versión impresa son las Constituciones conocidas como de Roberts, un año anteriores a las de Anderson. Ferrer Benimeli, José Antonio, "Les Statuts et Régléments de Bologne de 1248", Travaux de la Loge nationale de recherches Villard de Honnecourt, París, 2a, serie, núm. 11, 2o. semestre de 1985, pp. 209-214.
} 
ron a Anderson, Desaguliers y sus contemporáneos para utilizar la logia, sus fórmulas y sus tradiciones. Buscaron en la masonería el lugar de encuentro de hombres de cierta cultura, con inquietudes intelectuales, interesados por el humanismo como fraternidad, por encima de las separaciones y de las oposiciones sectarias, que tantos sufrimientos habían acarreado a Europa la Reforma, por una parte, y la Contrarreforma, por otra. Los animaba el deseo de encontrarse en una atmósfera de tolerancia y fraternidad.

El nacimiento de esta nueva masonería - denominada especulativa. por oposición a la operativa medieval- supuso un cambio esencial en el concepto y en la práctica de la sociabilidad. Los masones abandonaron la forma gremial y corporativa de los constructores medievales de catedrales para constituir una nueva sociedad basada en la tolerancia (política, religiosa y social) y en el pacifismo, después de los estragos ocasionados en Europa especialmente a raíz de las guerras de religión. Buscaban una igualdad fraternal por encima de separaciones sectarias o simplemente estamentales. Deseaban constituir una reunión de hombres creyentes más allá de las divisiones políticas y religiosas del momento; querían conocerse y trabajar juntos a pesar de la diversidad de sus opiniones religiosas y su afiliación a confesiones o ideologías diferentes.

Pero así como en épocas pasadas los masones operativos estaban obligados, en cada país - al igual que los demás súbditos- a profesar la religión del príncipe, cualquiera que ésta fuera, ${ }^{7}$ en adelante -como señalan las Constituciones de 1723- sólo se pediría a los masones especulativos, respetando su religión particular, que fueran "hombres buenos y verdaderos, hombres de honor y probidad", ${ }^{8}$ cualquiera que fuera la denominación o creencias con las que pudieran ser distinguidos. Es decir, sólo se les exigiría aquella creencia o religión en la que todos los hombres estaban de acuerdo -la cual en Occidente no era otra que la cristiana, en sus diferentes versiones ${ }^{-9}$ y se dejaba a cada uno la práctica y creencias particulares de sus respectivas religiones. Por esta razón, los únicos que quedaban excluidos -según las mismas Constituciones- eran los que, con una expresión un tanto puritana de la época, son llamados "ateos estúpidos y libertinos irreligiosos". La masonería buscaba ser "un Centro de unión y un medio de conciliar una verdadera amistad entre personas que de otra forma permanecerían en una perpetua distancia", falta de unión y amistad, en gran medida, fruto de las intransigencias de recientes

7 Esta regla, conocida como cujus regio ejus religio (tal país, tal religión), fue propuesta y adoptada en la Paz de Augsburgo, sellada en septiembre de 1555 entre los católicos y protestantes de Alemania, y llegó a constituir jurisprudencia.

8 Anderson, James, The Constitutions of the Free-Masons..., op. cit.

9 Católica, protestante, calvinista, luterana, anglicana, presbiteriana... 
guerras de religión en las que se habían asesinado miles de personas en nombre de sus respectivos dioses.

Los masones rompieron la sociabilidad tradicional -y por lo tanto oficial- que establecían la parroquia, en el ámbito familiar; los gremios, en el corporativo, y los estamentos en el social. La masonería amplió el concepto de sociabilidad, incluso frente a otros intentos más locales o nacionales que tanto proliferaron en el llamado Siglo de las Luces o del Iluminismo, como los círculos, museos, ${ }^{10}$ clubes, sociedades literarias, gabinetes de lectura, sociedades económicas y de agricultura, etcétera. Asimismo, precisamente por sus características iniciales de búsqueda de paz, tolerancia y fraternidad, adoptó una dimensión más universal y cosmopolita, una pluralidad ideológica política y religiosa, y, al mismo tiempo, cierta igualdad social en una época en la que no existía ni siquiera dentro de los propios estamentos en los que estaba dividida la sociedad: clero, nobleza y tercer estado.

Pero a pesar de que en el artículo 20. de las Constituciones de Anderson se dice que "todo masón, cualquiera que sea el lugar donde trabaje o resida, debe estar sometido a la autoridad civil, y no debe jamás encontrarse en complots contra la paz y tranquilidad del reino, ni ser desobediente a los magistrados inferiores", los masones, en cuanto asociación, quedaron constituidos como una forma de sociabilidad no oficial, no estatista, es decir, privada del reconocimiento del Estado, lo que equivalía a considerarla jurídicamente ilícita y, en consecuencia, fuera de la ley, pues, según el derecho romano -en vigor en la época- estaban prohibidas las asociaciones formadas sin el consentimiento de la pública autoridad. Desde el momento en que no era una sociedad oficial y reconocida por el Estado, se convertía en secreta o al menos clandestina, aparte de que la fidelidad a la tradición del secreto y del juramento heredados de los masones operativos contribuyó a complicar más la situación.

Este juramento contenía terribles amenazas con las que se conminaba al perjuro, como las recogidas en un catecismo de la masonería de Berna, Suiza, en 1740:

Si faltare a mi promesa consiento en que me sea arrancada la lengua, cortada la garganta, atravesado el corazón de parte a parte, quemado mi cuerpo y mis cenizas arrojadas al viento para que no quede ya nada mío sobre la Tierra, y

10 Ferrer Benimeli, José Antonio, "Le Musée scientifique de Paris dans les mémoires secrets pour servir à l'histoire de la République des Lettres en France, ou Journal d'un Observateur", Miscellanea fontium historiae Europee Emiékkónyv H. Balázs Eva Történészprofesszor 80 Születésnapjára, Budapest, ELTE, 1997, pp. 201-216. 
el horror de mi crimen sirva para intimidar a los traidores que fueran tentados de imitarme. Que Dios sea en mi ayuda. ${ }^{11}$

Estas amenazas - para muchos muestra evidente de la gravedad del secreto y de los fines de la masonería- en realidad no son otra cosa que la fórmula del juramento exigido por las leyes inglesas de los siglos XVII y XVIII, en las cuales se intimida al perjuro con las penas destinadas al culpable de alta traición, es decir, arrancarle y quemarle las entrañas y arrojarlas al mar "a la distancia de un cable, allá donde el flujo y el reflujo pasan dos veces en veinticuatro horas". ${ }^{12}$

El hecho de aparecer como una sociedad no reconocida por el Estado o al margen de él supuso, en sus orígenes, un grave problema, pues pronto empezaron a ser mal vistos y prohibidos por las autoridades de casi todas las naciones de la Europa continental del siglo XVIII, desde la prohibición de 1735 en los Estados Generales de Holanda hasta la de Guillermo III de Prusia en 1798. Pocos fueron los países o soberanos que no prohibieron las reuniones de masones en sus Estados en algún momento del siglo XVIII.

Entre los que no las prohibieron cabe citar a Inglaterra, pues la Gran Logia Unida de este país se constituyó el 27 de diciembre de 1813, con la fusión de la Gran Logia de los Antiguos, bajo la presidencia del duque de Kent, y la Gran Logia de los Modernos, cuyo Gran Maestre era el duque de Sussex, ambos hijos de Jorge III. El influjo de estos dos hermanos hizo que en seis semanas se resolvieran los enfrentamientos y se acordaran los artículos de la Unión, así como la nueva Constitución de la Gran Logia Unida de Inglaterra. Parece ser que los sucesos de Francia aceleraron las cosas, pues tanto los Antiguos como los Modernos dirigieron al rey Jorge III (1738-1820) declaraciones de fidelidad y de condena de la Revolución francesa.

La presencia de la nobleza en los altos cargos de la masonería inglesa marca un antes y después en el respeto e interés público por la masonería en ese país. Se inició con el duque de Montagu, nombrado Gran Maestre en 1721, y a quien Desaguliers dedicó el libro de las Constituciones de 1723, por orden del duque de Wharton, su sucesor como Gran Maestre de los Francmasones. Y en 1737 se dio el paso definitivo cuando la Gran Logia recibió a un miembro de la familia real, el príncipe de Gales, Luis Fréderic, primogénito de Jorge II y padre de Jorge III. Aunque no accedió al trono, tres de sus hijos fueron

11 Lüthi-Tschanz, Karl J., "Die Freimaurerei im Freistaat Bern (1739-1803)”, Blätter für bernische Geschichte, núm. 14, 1918, p. 170.

12 Mounier, Jean-Joseph, De l'influence atribuée aux philosophes, aux francs-maçons et aux iluminés sur la Révolution de France, Tübingen, Cotta, 1801, p. 142; Luquet, Georges Henri, La franc-maçonnerie et l'Etat en france au XVIIIème siècle, París, Vitiano, 1963, p. 56. 
masones: el príncipe de Gales, el duque de Kent y el duque de Sussex, e inauguró la tradición de colocar la masonería bajo la protección de la familia real, que se mantiene hasta hoy con el duque de Kent como actual Gran Maestre de la Gran Logia de Inglaterra.

Las primeras autoridades europeas en prohibir las reuniones de masones fueron los magistrados de Ámsterdam y La Haya, en los Estados Generales de Holanda, en 1735. Justificaron dicha prohibición en el hecho de que los conventicula o reuniones clandestinas atentaban contra la seguridad de la ciudad de Ámsterdam y de sus habitantes y perturbaban la paz común.

Los Estados Generales de Holanda y Frisia Occidental decidieron formar una comisión para destruir esa sociedad. Se confiscaron sus cajas y arcas, dentro de las cuales fueron encontradas diferentes cosas, entre ellas el juramento de sus miembros al ser aceptados, y que era del siguiente tenor:

Yo atestiguo solemnemente y juro en presencia del todopoderoso Dios y de esta Sociedad, que nunca jamás descubriré ningún secreto, que esta tarde o en cualquier tiempo me sea dado conocer aquí; que no descubriré o grabaré, ni en papel, ni en cobre, bronce, madera o piedra, o que yo por ningún bien o mal, en modo alguno manifestaré o participaré a nadie, bajo pena del propio castigo, que mi corazón sea arrancado a través de mi pecho izquierdo y mi lengua arrancada de raíz del fondo de mi boca, que mi cuerpo sea quemado y mis cenizas esparcidas al viento, para que de este modo se extermine mi recuerdo. ${ }^{13}$

La clandestinidad y el juramento fueron considerados equivalentes a perturbación de la paz y a atentado contra la seguridad pública.

Dos años después, en 1737, los Estados Generales de Holanda dieron un nuevo decreto, en el que, aunque reconocían que no habían descubierto nada contrario al buen orden en esas reuniones, juzgaban prudente suprimirlas.

Un año antes, en 1736, los Consejos de Berna y Ginebra también habían prohibido en sus respectivos cantones de la Confederación Helvética las reuniones de masones. El hecho de que las primeras prohibiciones se hicieran en países protestantes es digno de tener en cuenta.

Los siguientes en prohibir las reuniones de masones fueron: en 1737, el Gobierno de Luis XV de Francia, por medio de su primer ministro, el cardenal Fleury, y el príncipe elector de Manheim en el Palatinado; en 1738, los magistrados de la ciudad de Hamburgo y el rey Federico I de Suecia; en 1743, la emperatriz María Teresa de Austria; en 1744, las autoridades de Avignon, París y Ginebra; en 1745, de nuevo, el Consejo del Cantón de Berna, el Consistorio de la ciudad de Hannover y el jefe de la Policía de París; en 1748, el

13 Acta Historico-Ecclesiatica, Weimar, vol. 1, 1734-36, p. 105. 
gran sultán de Constantinopla; en 1751, el rey Carlos VII de Nápoles (futuro Carlos III de España) y su hermano Fernando VI de España; en 1763, los magistrados de Danzig; en 1770, el gobernador de la isla de Madeira y el Gobierno de Berna y Ginebra; en 1784, el príncipe de Mónaco y el elector de Baviera Carlos Teodoro; en 1785, el gran duque de Baden y el emperador de Austria José II; en 1794, el emperador de Alemania Francisco II, el rey de Cerdeña Víctor Amadeo y el emperador ruso Pablo I, y en 1798, Guillermo III de Prusia, por citar sólo los más conocidos.

En este contexto, las prohibiciones y condenas de Clemente XII, en 1738, y de Benedicto XIV, en 1751, así como el decreto del cardenal Firrao para los Estados Pontificios, en 1739, no son más que otros tantos eslabones en la larga cadena de medidas adoptadas por las autoridades europeas en el transcurso del siglo XVIII. ${ }^{14}$

En todos estos casos, bien se trate de Clemente XII o Benedicto XIV, del sultán de Constantinopla, del Consejo de la República y Cantón de Ginebra, de la emperatriz María Teresa de Austria, de los magistrados de la ciudad de Hamburgo, del rey de Nápoles o del jefe de la Policía de París - por aludir sólo a algunos de los más representativos- se constata que las razones alegadas por unos y otros, que corresponden a gobiernos protestantes (Holanda, Ginebra, Hamburgo, Berna, Hannover, Suecia, Danzig y Prusia), católicos (Francia, Nápoles, España, Viena, Lovaina, Baviera, Cerdeña, Portugal, Estados Pontificios), e incluso islámicos (Turquía), coinciden con las expuestas por Clemente XII y Benedicto XIV. En definitiva, se reducen al secreto riguroso con el que los masones se envolvían, así como al juramento hecho bajo tan graves penas, y sobre todo a la jurisdicción de la época -basada en el derecho romano- por la que toda asociación o grupo no autorizado por el gobierno

14 Sobre las relaciones entre la Iglesia católica y la masonería en el siglo XVIII, véase: Ferrer Benimeli, José Antonio, Masonería, Iglesia e Ilustración. Un conflicto ideológico-político-religioso, Madrid, Fundación Universitaria Española, 1976-1977. Existe una síntesis de los cuatro volúmenes que conforman el título anterior en: Ferrer Benimeli, José Antonio, Los archivos secretos vaticanos y la masonería. Motivos politicos de una condena pontificia, Caracas, Universidad Católica Andrés Bello, 1976; Les archives secrètes du Vatican et de la franc-maçonnerie. Histoire d'une condamnation pontificale, París, Dervy, 1989; Arquivos secretos do Vaticano e a franco-maçonaria. História de uma condenação pontificia, San Pablo, Madras, 2007. Véase también, del mismo autor: La masonería española en el siglo XVIII, Madrid, Siglo XXI, 1974; La masonería como problema político religioso. Reflexiones históricas, México, Universidad Nacional Autónoma de México, 2010; "La franc-maçonnerie et l'Eglise catholique du XVIII e siècle à nos jours", Actes du colloque vers une réconciliation catholiques et francs-maçons, Toulouse, Institut Catholique, 2007, pp. 5-12; "The Catholic Church and Freemasonry: an Historical Perspective", Ars Quatuor Coronatorum, vol. 16, 2006, pp. 234-255; y en compañía de Cuartero Escobés, Susana, Bibliografia de la masonería, Madrid, Fundación Universitaria Española, 2004. 
era considerado ilícito, centro de subversión y un peligro para el buen orden y la tranquilidad de los Estados.

En esta escala de motivaciones, las bulas pontificias no fueron una excepción. Esto se deduce no sólo del análisis textual de las mismas, sino de la abundante correspondencia vaticana existente sobre la materia, e incluso de la procedente del Santo Oficio romano, en especial la de 1737. Es cierto que tanto Clemente XII como Benedicto XIV, a los motivos de seguridad del Estado - es decir, a los motivos políticos-añadieron otro de tipo religioso: las reuniones de masones eran "sospechosas de herejía", por el mero hecho de que éstos admitían en sus logias a individuos de diversas religiones, es decir, a creyentes católicos y protestantes, con tal de que pertenecieran a alguna religión monoteísta; este motivo en el siglo XVIII tenía una valoración muy distinta a la de nuestros días: en la época, las reuniones -incluso los simples contactos- entre católicos y protestantes estaban severamente prohibidas por la Iglesia católica bajo la pena de excomunión, es decir, la misma sanción que será infligida a los masones.

Resulta curioso y paradójico que la bula de Clemente XII condenara las reuniones de masones porque en ellas se admitían indistintamente a católicos y protestantes, a pesar de que la masonería -justamente en la Inglaterra antipapista y anticatólica de 1723 a 1736-, lejos de ser hostil, era una de las pocas organizaciones que acogía a los católicos, hasta el punto de nombrar a uno de ellos Gran Maestre de Inglaterra en 1929: Thomas, duque de Norfolk. Unos años después, en la festividad invernal de San Juan en 1736 (27 diciembre), también fue designado Gran Maestre en Francia el católico lord Derwentwater, que ejerció hasta 1738. Otro tanto podríamos decir de Irlanda, donde los católicos perseguidos encontraron en las logias un asilo pacífico para reunirse y, al mismo tiempo, tener un contacto más humano con los no católicos tolerantes. ${ }^{15}$

Es claro, pues, que existían razones de Estado para condenar a los masones. Al fin y al cabo, Clemente XII y Benedicto XIV no hicieron sino seguir el ejemplo de otros Estados molestos e intranquilos ante el ambiente de secreto y juramento con el que se rodeaban los masones. A los gobiernos de Europa -y en este punto estaban de acuerdo tanto los protestantes como los católicos y musulmanes- les disgustaba esa actitud clandestina de los masones, que les impedía estar al corriente de lo que pudiera tratarse en sus reuniones. A la Santa Sede le ocurría lo mismo. La prueba está en la correspondencia de la época y en el edicto que el cardenal Firrao, secretario de Estado, publicó el 14

15 Chetwode Crawley, W.J., "The Old Charges and the Papal Bulls", Ars Quatuor Coroniatoraum, vol. 24, 1911, pp. 47-65 y 107-117. 
de enero de 1739 en Roma, en el cual se dice que las reuniones masónicas no sólo eran sospechosas de herejía, sino, sobre todo, peligrosas para la tranquilidad pública y seguridad del Estado Eclesiástico, ya que, si no tuvieran materias contrarias a la fe ortodoxa y al Estado y tranquilidad de la República, no usarían tantos vínculos secretos. Por esta razón, se condenó a los masones a la pena de muerte, confiscación de bienes y demolición de las viviendas donde estuvieran reunidos, en una época en la que ni siquiera el Tribunal de la Inquisición -según su derecho penal- podía condenar a muerte por la mera sospecha de herejía, que era purgada con pena de prisión.

Con relación a la confidencialidad, llama la atención que los masones fueran condenados - entre otros motivos- por el secreto con el que se rodeaban, pero que Clemente XII concluya su bula In eminenti utilizando el mismo motivo del secreto para no hacer públicas todas las causas de la condena: "Y por otras causas justas y razonables conocidas de Nos". ${ }^{16}$

Además, en la bula Providas (1751) de Benedicto XIV se reclaman, como máximo argumento, aparte de la carta de Plinio Cecilio - por cierto, incorrectamente aplicada-, las disposiciones del derecho romano (Dig. 47, tít. 22: De Collegiis et corporibus) contra los collegia illicita, que prohibían las asociaciones formadas sin el consentimiento de la autoridad pública. Aquí cabe hacer notar que la ilicitud de tal asociación, desde el punto de vista jurídico, influyó en considerarla y tenerla como ilícita no sólo desde el aspecto jurídico-político, sino incluso desde el moral. Hubo una clara trasposición y petición de principio en esta motivación. De la misma manera, como ya expresó en 1782 el exjesuita Karl Michaeler, en su respuesta a la bula de Benedicto XIV, lo que parece ser una prueba lógica en realidad es un argumento que más bien desautoriza lo que pretende probar, pues afirma justamente todo lo contrario; hoy en día es bien conocido que la cita de Plinio sobre leyes romanas es usada por el autor precisamente contra los cristianos. Por lo tanto, y paradójicamente, los masones eran acusados del mismo delito que los paganos impugnaron a los primeros cristianos, con lo que quedaba manifiesta tanto la deficiencia de la ley romana como su aplicación.

Numerosos Estados, a raíz de las bulas pontificias, y siguiendo sus deseos manifestados a través de las nunciaturas, prohibieron la masonería bajo las más severas penas. Entonces sucedió que en las naciones confesionales los

16 Mellor, Alec, Nuestros hermanos separados los franc-masones, Barcelona, AHR, 1968, p. 175. Hay autores que insisten demasiado en esta cláusula "secreta" de la bula - como Alec Mellor - cuando más bien se trata de una fórmula cancilleresca de la época que se solía utilizar en algunos casos. El propio Carlos III, en la Pragmática Sanción de expulsión de los jesuitas de los reinos de España del año 1767, dice: "Estimulado de gravísimas causas [...] y otras urgentes, justas y necesarias, que reservo en mi Real Ánimo [...]”. 
masones fueron perseguidos por ofender a la religión católica, puesto que estaban excomulgados; el delito de masonería se fundamentaba en la lesión del orden religioso católico, y debido a que éste se tenía como base de la Constitución de los Estados católicos, el delito eclesiástico automáticamente pasaba a concebirse y castigarse como crimen político. Por este motivo, en ningún documento del siglo XVIII -y en esto no son excepcionales las bulas de Clemente XII y Benedicto XIV- se prohíbe la masonería en cuanto institución, sino la reunión de masones, la cual recibe toda clase de denominaciones en la bula In eminenti de Clemente XII: asambleas, conventículos, juntas, agregaciones, círculos, reuniones, sociedades, entre otros.

A excepción de en Roma y en los países donde estaba implantada la Inquisición, la mayor parte de estas prohibiciones apenas tuvo vigencia en el siglo XVIII, pues las bulas pontificias no recibieron el placet regio o exequatur y no tuvieron vigencia en algunos países, como Francia. ${ }^{17}$

En el siglo XIX se experimenta un cambio notable. La aparición de las sociedades patrióticas o políticas -en especial la de los carbonarios- por un lado, y el impacto de la Revolución francesa en los soberanos absolutistas de la Europa del Congreso de Viena que no se resignaban a perder su poder, por el otro, serán objeto de especial preocupación por parte de Roma.

Tras la Revolución francesa, en los países anglosajones la masonería adquirió cierto prestigio social, especialmente en Estados Unidos, Gran Bretaña y Escandinavia, donde la presencia del clero no católico siguió siendo importante e influyente dentro de la masonería; en la misma medida, los reyes de Inglaterra y Suecia controlaban la masonería en sus respectivos países, y gran parte de los presidentes de Estados Unidos militaban en sus filas. Sin embargo, en los llamados países católicos, los ideales de la masonería -confundidos e identificados en gran medida con los del liberalismo- suscitaron, por parte de la Iglesia católica y de los gobiernos absolutistas de la época, una dura reacción, derivada de la conocida unión entre el trono y el altar en defensa de sus respectivos poderes. De esta forma, durante los primeros años del siglo XIX, el enfrentamiento Iglesia católica-masonería se vio afectado por las consecuencias interpretativas de la Revolución francesa y el nacimiento del famoso mito del complot masónico-revolucionario, en cuya difusión contribuyó el abate y exjesuita Barruel. A partir de estos años, la masonería latinoeuropea tuvo una imagen menos sólida y respetable en comparación con la mantenida

17 El Parlamento de París se negó a registrar la bula In eminenti y ni siquiera fue promulgada en Francia. Por lo tanto, en todo el territorio francés, siguiendo el derecho de la época, la prohibición papal fue ignorada y legalmente considerada nula y sin efecto, según el viejo adagio jurídico lex non promulgata non obligat. Al respecto véase: Hericourt, Louise de, Les lois eclésiastiques de France, París, Denis Mariette, 1771. 
en el mundo anglosajón, y llegó a verse especialmente afectada a causa de la confusión surgida por la proliferación de las sociedades secretas, así como al identificarse erróneamente a los masones con los iluminados bávaros, los jacobinos, los carbonarios y otros por el estilo. La aparición de las llamadas sociedades patrióticas y su lucha por la unificación italiana -en especial los carbonarios, que rápidamente fueron identificados con los masones- atrajeron la atención de los papas, quienes veían amenazado su poder temporal.

Aquí enlazamos el tercer aspecto que se desarrollará: las Cortes de Cádiz. Inquisición, Iglesia y clero, por un lado, y liberalismo, masonería y revolución, por otro, son las coordenadas que, en cierto modo, van a enfrentar a historiadores masones y antimasones en torno a las Cortes de Cádiz.

Como bien dice Ramón Solís, "la afirmación, harto repetida, de que los diputados doceañistas, el Cádiz de las Cortes y, en general, todo el pensamiento liberal de esta época están dirigidos, si no gobernados, por las logias es completamente errónea". ${ }^{18}$ Sin embargo, goza de tanto crédito y prestigio, se mantiene por ciertos historiadores con tal seguridad, que, como tantas veces ocurre, una afirmación infundada ha llegado a considerarse fruto de una detenida investigación. Curiosamente, existe cierta tendencia a señalar en esta época un gran influjo y poder de la masonería entre los liberales de Cádiz, quienes defendían una causa diametralmente opuesta a la del rey intruso José Bonaparte, y que era apoyada por los afrancesados y masones.

En este sentido, una de las pruebas de esta actitud de las Cortes de Cádiz, no sólo no influidas por la masonería, sino de franca orientación antimasónica, se encuentra en la Real Cédula fechada en Cádiz el 19 de enero de 1812, en la que se confirma el Real Decreto del 2 de julio de 1751, y se vuelve a prohibir la francmasonería en los dominios de Indias e islas Filipinas.

En dicha Real Cédula, escrita en ausencia y cautividad del rey Fernando VII, es el Consejo de Regencia, autorizado interinamente por las Cortes generales y extraordinarias reunidas en Cádiz, el que lleva la iniciativa de atajar "uno de los más graves males que afligían a la Iglesia y a los Estados", a saber: "la propagación de la secta francmasónica, tan repetidas veces proscrita por los Sumos Pontífices y por los Soberanos Católicos en toda Europa". ${ }^{19}$

Por lo que se deduce de dicho documento, se había descubierto en los dominios de las Indias "alguno de estos perversos conventículos", y para impedir su propagación o que se introdujera por donde por fortuna no se conocía ese "crimen", el Consejo de Regencia - una vez oído al Fiscal y al Consejo

18 Solís, Ramón, El Cádiz de las Cortes, Madrid, Instituto de Estudios Políticos, 1958, p. 316.

19 Reales Cédulas y Órdenes, Archivo Nacional de Colombia, Bogotá, tomo XXXVIII, folio 313 . 
de Indias- mandaba a los jueces - una vez derogados todos los fueros privilegiados, incluso el militar- proceder contra los francmasones, arrestándolos y aprehendiendo los papeles que les encontrasen. Privados de empleo, título, hábito y cualquier otra distinción, debían ser remitidos a España bajo partida de registro; si fueren extranjeros, aun cuando tuvieran carta de naturaleza y hubieran residido muchos años en América con conducta arreglada, debían ser desterrados de esos dominios; asimismo, de no tener hijos se les debían confiscar todos los bienes.

Esta actitud del Consejo de Regencia, autorizado por las Cortes de Cádiz, coincide también con el anónimo autor de un escrito titulado Noticias de las sociedades secretas, conservado en el Archivo de Palacio entre los papeles de Fernando VII, donde se asegura que la historia del masonismo en esta época ofrece muy poca importancia, porque no se le dejó tener influencia en los asuntos políticos. Reacción, por otra parte, lógica, ya que la masonería había sido utilizada por Bonaparte y los afrancesados como vehículo de captación ideológica hacia una causa contra la que luchaban los de Cádiz. Es decir, que frente a un breve "poder" masónico entre los afrancesados y ejército de ocupación, nos encontramos que en Cádiz -símbolo de la libertad frente al invasor- dicho "poder" fue, de hecho, inexistente e irrelevante.

Entre las medidas adoptadas por la Real Cédula de Cádiz está el encargo dado "a los M.R. Arzobispos y Srs. Obispos" para que procuraran, "en ejercicio de su pastoral ministerio, por sí y por medio de los Predicadores y Confesores, impedir la propagación y curso de una secta prohibida por los sumos Pontífices, y que se presentaba tanto más perjudicial cuanto era mayor el secreto con que procuraban cautelarse sus sectarios". ${ }^{20}$

La unión del trono y el altar en la lucha antimasónica, ${ }^{21}$ tan característica del Antiguo Régimen, es enarbolada de nuevo por las Cortes Constituyentes de Cádiz, como un significativo preámbulo de lo que iba a ser una constante a lo largo de todo el reinado de Fernando VI, quien utilizará contra los masones las dos armas más poderosas a su alcance: la policía y la Inquisición.

Con el regreso de Fernando VII, en 1814, se agudizó la campaña que contra la masonería venían manteniendo ciertas ideologías, especialmente integristas y clericales.

Si el 1o. de mayo de 1814 derogaban la Constitución y la obra de Cádiz, unas semanas después, el 24 de mayo, se publicaba en Madrid un Real Decreto en el que se prohibían las asociaciones clandestinas por el perjuicio

20 Reales Cédulas y Órdenes, Archivo Nacional de Colombia, Bogotá, tomo XXXVIII, folio 313 .

21 Ferrer Benimeli, José Antonio, La Masonería actual, Barcelona, AHR, 1977, pp. 36-41. 
que causaban a la Iglesia y al Estado. Curiosamente, lo que más preocupa a Fernando VII en éste, su primer Real Decreto contra las asociaciones clandestinas, es el hecho de que, sin mencionar a ninguna de ellas, alude a los que, "seducidos de opiniones perjudiciales a la Religión y al Estado, aun personas eclesiásticas y religiosas, cuyo influjo en los demás es tan grande", se habían dejado llevar tanto de ellas que "habían escandalizado a los buenos y arrastrado a muchos a tan grave mal". ${ }^{22}$

De esta forma, Fernando VII establecía claramente la alianza del trono y el altar en una defensa mutua, ya que de "su armoniosa unión y mutua ayuda pendía la felicidad del Reino". ${ }^{23}$ Por otro lado, la clandestinidad o, si se prefiere, el secreto quedaban, una vez más, identificados con un presunto poder en la sombra, poder que, aunque no se menciona abiertamente, tenía un nombre entonces: la masonería, contra la que salía al paso el Real Decreto.

El 21 de julio de 1814, era restablecido el Tribunal del Santo Oficio, a causa de "las sectas anticatólicas introducidas en la nación durante la guerra de la Independencia". ${ }^{4}$ Nuevamente estamos ante el fantasma del "poder" masónico contra el que el inquisidor general Francisco Xavier Mier y Campillo publicaría, el 2 de enero de 1815, un Edicto de prohibición y condena, copia del dado por el cardenal Consalvi, el 15 de agosto de 1814, para los Estados Pontificios.

En él encontramos lo que ya venía siendo habitual en todas las prohibiciones eclesiásticas de la masonería: la unión de los intereses del trono y el altar; es decir, de los intereses políticos con los religiosos. Y en este punto el inquisidor español estaba plenamente de acuerdo con Fernando VII, quien, como hemos visto, ya el 24 de mayo había prohibido las asociaciones que perjudicaban "a la Iglesia y al Estado".

Unos meses más tarde -coincidiendo con los Edictos de Fe que se publicaban durante la cuaresma-, los Inquisidores Apostólicos contra la Herética Pravedad y Apostasía hacían saber a "los vecinos y moradores estantes y residentes de Madrid" que las juntas, congregaciones o hermandades de francmasones o Liberi Muratori eran "unas asociaciones de hombres de todo culto, estado y nación formados secretamente sin autoridad pública ni legítima, dirigidas a establecer el deísmo, el panteísmo, el espinosismo, materialismo y ateísmo".

Llama la atención que, frente a las escasas líneas dedicadas a la masonería en edictos semejantes en la segunda mitad del siglo XVIII, aquí el espacio dedicado a los masones es mucho mayor que el ocupado con la "ley de Moisés,

22 Gaceta de Madrid, núm. 81, 4 de junio de 1814.

23 Gaceta de Madrid, núm. 81, 4 de junio de 1814.

24 Valdelomar, Marqués de, El partido fernandino y la masonería, Madrid, Prensa Española, 1974, pp. 202-203. 
y sectas de Mahoma, Luterana y Alumbrados o Iluminados". Es igualmente sintomático el que se insista en la maldad de la masonería por "componerse de mezcla y adopción de hombres de todas las naciones, cultos y errores", así como por el "inviolable secreto" y "pérfido juramento" con el que se comprometían, todo lo cual era contrario a las leyes civiles y canónicas, al incurrir en la nota de "malvados, pervertidos y peligrosos a la Religión y al Estado". Por si esto fuera poco, identifican a los masones con los que se dedicaban "a la moderna, impía y vana filosofía de estos tiempos, estrechamente unida y hermanada con el Francmasonismo, cuyos profesores se distinguían hasta con el título de Indiferentistas, Deistas, Materialistas, Panteistas, Egoistas, Tolerantistas, Humanistas, etc.”. Esta filosofía encerraba el "veneno de la doctrina que hablaba de libertad, independencia, igualdad, tolerancia, despotismo, fanatismo, superstición, etc."; ideas que, en estrecha unión con el francmasonismo, habían inundado la Europa "de las perversas doctrinas para trastornar el orden público y religioso, procediendo temerariamente contra la piedad y justicia de los Soberanos de la Europa, y la santidad de la única verdadera religión Católica, Apostólica y Romana". ${ }^{25}$

Este edicto es un claro exponente del confusionismo mental que los inquisidores españoles tenían de la masonería, considerada como un auténtico "poder" identificado, en cierto sentido, con el ideario de los ilustrados de la época.

$\mathrm{Al}$ margen de prohibiciones y condenas, la masonería apenas tuvo importancia en el Cádiz de las Cortes. Sin embargo, sí la tuvo la antimasonería, principal protagonista y encargada de decir que casi todos los diputados de Cádiz pertenecían a sus filas, en las cuales se había elaborado la Constitución de 1812. ${ }^{26}$ En realidad, los hombres de Cádiz, ante el espectáculo de Bayona,

25 En el mismo edicto llama la atención la ligereza con la que se acusa a los masones de negar "la inmortalidad de nuestra alma, el Infierno, el Purgatorio, la Bienaventuranza y quanto enseña la Religión revelada; tratando el santo Evangelio de cuento y espantajo de muchachos; a sus Ministros de hipócritas y ambiciosos; a los Santos Mártires de hombres linfáticos, temerarios y sediciosos; a los Santos Padres de viejos supersticiosos, crédulos e idiotas, sin crítica ni filosofia; a la misma Religión Católica de invento político de Príncipes para nutrir sus intereses y despotismo; a los que profesan, rebaño de esclavos y bárbaros; a la Misa, Sacramentos y Sufragios, artificio de Clérigos y Frayles para estafar a los vivos y a los muertos; a los milagros, de cuentos y fábulas romancescas...". Edicto de la Fe del 19 febrero 1815.

26 En este tópico incurre, entre otros muchos, Tirado y Rojas en su Historia de la masonería en España, (Madrid, 1893, que es uno de los más citados por los llamados historiadores "universitarios". Más recientes pero con el mismo desconocimiento de la historia de la masonería son las obras de Alayza, Luis, La Constitución de Cádiz. El egregio limeño Morales y Duares, Lima, Lumen,1946, y Castillo, Abel Romeo, Defensa de Olmedo, Guayas, Guayaquil, 1965. Precisamente en ellas se apoya Berruezo León, María Teresa, "El funcionariado americano en las Cortes gaditanas, 1810-1813", Cuadernos Hispanoamericanos, Madrid, núm. 460, octubre de 1998, p. 68, para decir "Olmedo y Rivero parecen haber pertenecido a las logias que se propagaron en España con la ocupación francesa... Acerca de la posible militancia de estos dos diputados en las logias 
ante la invasión napoleónica, intentaron una reforma dentro de la monarquía e incluso dentro del catolicismo. Baste recordar la invocación a la Santísima Trinidad con la que empieza la Constitución, o las sesiones de Cortes en las que se pide la Bula de la Santa Cruzada, o aquéllas en las que se discute si la guerra de Independencia era un castigo de Dios o la prueba con la que distinguía a un pueblo escogido. ${ }^{27}$

También es importante recordar que los hombres, las ideas y las instituciones dan un cambio radical con la vuelta de Fernando VII. Los diputados doceañistas no son los mismos que vuelven a España durante el llamado trienio liberal. La etapa de transición entre ambos momentos, el de 1812 y el de 1820, con su implacable persecución, con los sinsabores del exilio, ha marcado a esos hombres.

Pero ésta es otra cuestión muy vinculada con la independencia de México, tema ya analizado en su momento y a los que me remito. ${ }^{28}$

véase Luis Alayza...". Desde luego en la rica documentación de que hoy disponemos de las logias propagadas en España con la ocupación francesa no figuran Olmedo ni Rivero. Sobre este particular Ferrer Benimeli, José Antonio, "El Tribunal de la Inquisición como fuente de información histórica de la masonería madrileña durante la ocupación francesa (1808-1812)", Perfiles jurídicos de la Inquisición española, Madrid, Universidad Complutense, 1989, pp. 841-889.

27 Sesiones de Cortes de los días 4 de marzo de 1811 y 27 de noviembre de 1810.

28 Ferrer Benimeli, José Antonio, "Las Cortes de Cádiz, América y la masonería", La Guerra de conciencias. Monarquía o independencias en el mundo hispánico y lusitano, Tlaxcala, Instituto Tlaxcalteca de Cultura, 2010, pp. 201-244; "Utopía y realidad del liberalismo masónico. De las Cortes de Cádiz a la independencia de México", Revista de Etudios Históricos de la Masonería Latinoamericana y Caribeña, Costa Rica, Special Issue UCLA-Grand Lodge of California, octubre de 2013, pp. 27-88; "Los diputados novohispanos en las Cortes de Cádiz (1810-1813): problemas y estado de la cuestión", Los novohispanos en las Cortes de Cádizy su impacto en el México nacional, México, Universidad Autónoma de Tlaxcala, 2013, pp. 23-56; "De las Cortes de Cádiz a la Independencia de México. La masonería entre la libertad de prensa y el imaginario popular", Una aportación a la Historia de la Iglesia en México, México, Libro Anual de la Sociedad Mexicana de Historia Eclesiástica, A.C. , 2011-2012, 2014, pp. 107-155. 


\title{
LAS SOCIEDADES SECRETAS \\ DE LOS GUADALUPES Y DE JALAPA, Y LA INDEPENDENCIA DE MÉXICO
}

\author{
Virginia Guedea RinCón-GaLlaRdo*
}

SumARIO: I. Los Guadalupes. II. La sociedad de Falapa.

Las políticas clandestinas utilizadas durante los años finales de la Nueva España y, muy en particular, las sociedades secretas, constituyeron una forma de resistencia al colonialismo español asumida por quienes, dentro de los centros urbanos controlados por el gobierno virreinal, se vieron obligados a encontrar nuevas maneras de enfrentarse al sistema. Estas asociaciones, incipientes y escasas al iniciarse el proceso de emancipación, sirvieron también para que se fueran formando y consolidando distintos grupos políticos que llegaron a conformar verdaderos grupos de poder y que, una vez obtenida la independencia de España, se convertirían en las principales organizaciones políticas que controlarían la vida pública del nuevo país. El presente estudio recupera algunos aspectos de las dos sociedades secretas que estuvieron directamente vinculadas con el movimiento insurgente novohispano (la sociedad de Jalapa y la de Los Guadalupes), y sus resultados han sido ya publicados. ${ }^{1}$

\footnotetext{
* Instituto de Investigaciones Históricas, UNAM.

1 En cuanto a Los Guadalupes, véase, entre otros de mis trabajos, En busca de un gobierno alterno: Los Guadalupes de México, México, UNAM, Instituto de Investigaciones Históricas, 1992, y sobre la sociedad jalapeña véase "Una nueva forma de organización política: la sociedad secreta de Jalapa, 1812" en Garritz, Amaya (comp.), Un hombre entre Europa y América, Homenaje a Juan Antonio Ortega y Medina, México, UNAM, Instituto de Investigaciones Históricas, 1993, pp. 185-208.
} 


\section{LOS GUADALUPES ${ }^{2}$}

La conformación de la sociedad secreta que conocemos como Los Guadalupes se remonta al golpe de Estado dado en septiembre de 1808 por un grupo de peninsulares, con el apoyo de la Audiencia de México, el cual no sólo canceló la posibilidad de establecer una junta de gobierno novohispana, sino que cerró las vías de acción política que la crisis de la monarquía española había abierto a los descontentos con el régimen colonial. Fue en los numerosos espacios de reunión que ofrecía la Ciudad de México - principalmente en las tertulias-donde se comenzó a pasar de la crítica al sistema, a precisar objetivos y a buscar las maneras de alcanzarlos. Y fue en estos espacios donde comenzaron a organizarse algunos de quienes participaron en los sucesos de 1808, así como varios abogados pertenecientes al Real e Ilustre Colegio, ${ }^{3}$ con el objetivo de lograr sus fines.

Apoyar la insurgencia iniciada por Miguel Hidalgo en septiembre de 1810 ofreció a algunos de los descontentos la posibilidad de debilitar al régimen sin enfrentársele directamente. Fueron varios y de distinta índole los intentos y varios también los fracasos que los llevaron a ir perfilando un organismo eficiente, como la fundación de un grupo secreto llamado El Águila, del que no sabemos mayor cosa que lo registrado por Anastasio Zerecero, ${ }^{4}$ y las conspiraciones contra el régimen virreinal descubiertas en abril y en agosto de 1811.5

2 La sociedad de los Guadalupes ha sido objeto de varios estudios, entre los que se cuentan el de Timmons, Wilbert H., "Los Guadalupes: a secret society in the Mexican Revolution for independence", The Hispanic American Historical Review, Durham, vol. XXX, núm. 4, noviembre de 1950, pp. 453-479, y el de Torre Villar, Ernesto de la, Los Guadalupes y la Independencia, con una selección de documentos inéditos, México, Jus, 1966.

3 Del Ayuntamiento lo eran Joaquín Caballero de los Olivos, José María Fagoaga y Francisco Manuel Sánchez de Tagle, mientras que los que pertenecían al Colegio de Abogados fueron el propio Fagoaga, Manuel Argüelles, Manuel Cortázar, Pedro Dionisio de Cárdenas, José María de la Garza Falcón, Manuel Díaz, José Ignacio Espinosa, Antonio Garcés, Benito José Guerra, José María Jáuregui, Félix Lope de Vergara, Antonio Ignacio López Matoso, Juan Nazario Peimbert y Hernández, Ricardo Pérez Gallardo, Juan Bautista Raz y Guzmán, Juan Wenceslao Sánchez de la Barquera y José Manuel Zozaya Bermúdez. Vinculado estrechamente con Los Guadalupes se encontraba Jacobo de Villaurrutia, miembro también del Colegio de Abogados.

4 Conformaron la sociedad de El Águila Antonio del Río, Félix Fernández, Benito José Guerra, Antonio Ignacio López Matoso, Juan Nazario Peimbert y Hernández, Juan Bautista Raz y Guzmán e Ignacio Velarde. Véase Zerecero, Anastasio, Memorias para la historia de las revoluciones en México, México, Imprenta del Gobierno, en Palacio, a cargo de José María Sandoval, 1869, p. 120.

5 Entre los cinco integrantes de la Junta de Gobierno que se estableció al triunfo de la conspiración de abril se contaron José María Alcalá, José María Fagoaga, Carlos María de Bustamante y Tomás Murphy; los dos primeros formaron parte de Los Guadalupes y los dos últimos estuvieron en estrecho contacto con el grupo. Entre los trece ministros que debían integrar la nueva Audiencia encontramos a Manuel Argüelles y a Juan Nazario Peimbert y 
La represión de la que fueron objeto algunas de estas actividades por parte de las autoridades virreinales convenció a los descontentos de la necesidad de organizarse mejor y en el más absoluto de los sigilos. Y fue la propia insurgencia, al establecer ese órgano de gobierno alterno que pretendió ser la Suprema Junta Nacional Americana, la que les brindó la oportunidad de canalizar sus esfuerzos de manera más eficiente.

Desde poco antes del establecimiento de la Junta se había entablado correspondencia directa entre Ignacio Rayón -sucesor de Hidalgo al frente de la insurgencia y quien había estudiado leyes en el Colegio de San Ildefonso- y varios abogados capitalinos, entre los que se contaron el doctor Manuel Díaz y los licenciados José María de la Garza Falcón, Benito José Guerra y Juan Bautista Raz y Guzmán. A su alrededor convergieron los intereses y los esfuerzos de otros autonomistas y descontentos, y así se conformó un grupo que se propuso (y logró) mantenerse en estrecho contacto con la Suprema Junta y proporcionarle una ayuda en verdad eficaz, sin declararse abiertamente contra el régimen y sin comprometer las posiciones personales de sus miembros.

El grupo, que se reunía en diferentes espacios, públicos y privados, de la Ciudad de México y de sus alrededores, logró llevar a cabo varias actividades. ${ }^{6}$ Destaca, desde luego, el envío y la recepción de información de diversa índole, en particular la referida a cuestiones militares y políticas, mediante una correspondencia regular y segura, que implicó establecer los conductos adecuados dentro y fuera de la capital, correspondencia que fue firmada con iniciales o con seudónimos que incluyeron determinados números. ${ }^{7}$ Otra actividad de interés fue el envío de individuos, varios de ellos abogados, como José Ignacio Jiménez, Andrés Quintana Roo y Manuel Fernández de San Salvador, para que brindaran a la insurgencia su apoyo directo, sobre todo en la organización política del movimiento. Por ello, los integrantes de la

Hernández, ambos Guadalupes, así como a Jacobo de Villaurrutia, vinculado estrechamente con el grupo. Para las conspiraciones de 1811, véase Guedea, Virginia, "The Conspiracies of 1811: How the Criollos Learned to Organize in Secret", en Archer, Christon I., (ed.), The Birth of Modern Mexico 1780-1824, Delaware, Scholarly Resources Inc., 2003, pp. 85-105.

6 Se celebraban tertulias en las casas de José María Alba, de Juan Nazario Peimbert y Hernández, de José Ignacio Espinosa y del marqués de San Juan de Rayas. Otro lugar de reunión era la hacienda de León, a las afueras de la Ciudad de México, propiedad del doctor Manuel Díaz y de su esposa, Antonia Peña.

7 Utilizaron iniciales como "M. P.", "J. M.” y "X”, y seudónimos como "El Uritames", "El Fiel Americano, alias El Incógnito", "Franz", "El de los Pantalones" (Benito José Guerra), "Clarisa" o "Serafina" (Antonia Peña). Son varias las cartas firmadas por el "Número 12", seudónimo utilizado por Juan Bautista Raz y Guzmán. Localicé una carta dirigida al "Caballero Número Primero", y hay menciones de cartas firmadas con otros números, como "Número Dos" y "Número Tres". 
sociedad se ocuparon tanto de facilitar las evasiones, como del cuidado y del sostenimiento de las familias de los emigrados. ${ }^{8}$ Otra actividad importante fue el envío de una imprenta y de un impresor, lo que permitió al movimiento insurgente contar con un medio de difusión y defensa que hasta entonces había podido utilizar de manera muy esporádica. ${ }^{9}$ Para llevar a cabo sus actividades, les fue de gran utilidad el hecho de que la capital del virreinato estaba, por entonces, rodeada de partidas de insurgentes que les sirvieron de enlace con los más altos dirigentes del movimiento, y a través de las cuales enviaron información, ayuda y hombres. Entre estas partidas se contó la que comandaba Felipe Lailson, encargado de conducir la correspondencia de la Suprema Junta con sus partidarios capitalinos. También les resultó muy útil la colaboración de varias mujeres, todas ellas vinculadas por lazos de familia con diversos miembros del grupo, y entre las que destacan Margarita Peimbert y Antonia Peña, quienes se ocuparon de la correspondencia, de ayudar a los que se fugaban y de sacar la imprenta de la ciudad.

La propia insurgencia dio ocasión a que el grupo replanteara sus objetivos, se reorganizara y se ampliara para alcanzar su máxima eficiencia. A finales de mayo de 1812, Lailson fue derrotado y la correspondencia que conducía cayó en manos de las autoridades coloniales, lo que les permitió poner presos a Nicolás Becerra, a José Ignacio Espinosa, a José María de la Garza Falcón y a Benito José Guerra, mientras que Margarita Peimbert fue detenida. Pocos días después, a principios de junio, Rayón fue derrotado en Tenango, donde fueron aprehendidos y fusilados varios de los fugados de la capital con quienes los integrantes del grupo mantenían estrecho contacto, entre los que se contó el licenciado José Ignacio Jiménez, novio de Margarita y compadre de Guerra. Esta derrota también marcó el inicio del proceso de desintegración de una Suprema Junta que nunca llegó a consolidarse, debido a que, poco después, sus tres vocales tuvieron que separarse. Mientras esto sucedía, la figura de José María Morelos cobraba cada día mayor importancia, tanto por sus exitosas acciones militares como por sus sostenidos esfuerzos por darle una mejor organización política al movimiento. A todo lo anterior se unió el establecimiento del régimen constitucional en la Nueva España, que abrió a los novohispanos nuevos espacios de participación política dentro del sistema.

8 En el intento de fuga de la capital de los licenciados José María Gallegos y José Mariano Martínez Lejarza, en febrero de 1812, tomaron parte Manuel Díaz, Antonia Peña y Francisco de Arce.

9 En la compra y envío de esta imprenta participaron Francisco de Arce, Nicolás Becerra, Manuel Díaz, Antonia Peña, Benito José Guerra y su esposa María Camila Ganancia, José María Jáuregui, José María de la Llave, así como Juan Bautista Raz y Guzmán y su esposa Luisa de Orellana y Pozo. El impresor se apellidaba Ferrándiz. 
A partir de septiembre de 1812, el grupo fijó cada vez más su atención en Morelos. Sin dejar de utilizar los seudónimos referidos a determinados números, en la correspondencia con este jefe insurgente comenzó a emplearse uno nuevo, ya no referido a personas particulares sino a un grupo de ellas, el de Los Guadalupes. ${ }^{10}$ El contenido de las cartas así suscritas deja ver que fueron varios los individuos que se ocuparon tanto de recabar la información que se deseaba hacer llegar a Morelos - más tarde también a Carlos María de Bustamante y a Mariano Matamoros- como de redactar y de remitir la correspondencia. Esto indica que, dentro del grupo, se conformó una sección especial dedicada a esta tarea en particular, pues ni siquiera en la correspondencia que simultáneamente sostuvieron algunos de sus integrantes con Rayón se utilizó este seudónimo, el cual resultó atinado. Además de mostrar su americanismo y su vinculación con una insurgencia que había escogido como patrona a la Guadalupana, sirvió su propósito inicial de ocultar la identidad de sus autores y del grupo al que pertenecían. Ni Morelos sabía con absoluta precisión quiénes lo integraban, y fue él mismo, al hacer extensivo a todos ellos el seudónimo de Los Guadalupes, quien acabó por darles el nombre con el que los identificamos.

Aunque se conocen los nombres de muchos de ellos, tampoco resulta fácil determinar con precisión quiénes integraban la sociedad. De acuerdo con la información recabada, los mencionados como integrantes de Los Guadalupes llegan casi a 50, entre los que se cuentan 17 abogados. También aparecen varios eclesiásticos, así como propietarios y comerciantes, amén de tres nobles, un cacique indígena y tres mujeres. Debo aclarar, sin embargo, que no he encontrado registro de las actividades desarrolladas por algunos de ellos en cuanto miembros de la sociedad. Y más difícil aún es establecer cómo se hallaba organizada, problema que en buena medida refleja el éxito que alcanzó y que se debe no sólo a la habilidad que tuvieron sus integrantes para guardar el secreto de su composición y estructura, sino también a la manera en la que se fue dando su conformación.

El grupo se articuló a partir de vínculos ya existentes de profesión, amistad, compadrazgo, familiares, sociales, de clientelazgo y hasta amorosos, lo que le dio una base sólida: ${ }^{11}$ asimismo se le fueron uniendo tanto autonomistas como

10 La primera carta firmada con este seudónimo es del 15 de septiembre de 1812. Véase Torre Villar, Ernesto de la, op. cit., 1985, pp. 1 y 2.

11 Como ejemplo, me referiré aquí a los lazos familiares. José María Alba y Llave era sobrino de Francisco y de José María de la Llave. Manuel Díaz estaba casado con Antonia Peña, la que al enviudar se casó con Juan Bautista Raz y Guzmán, quien también había enviudado. Éste era tío de Leona Vicario, mientras que Agustín Gallegos lo era de Anastasio Zerecero, el que a su vez era hijo de Valentín Zerecero; de estos dos era pariente Ignacio 
partidarios de la insurgencia y otros descontentos con el régimen colonial. Además, muchos de los que ayudaron en sus diversas tareas lo hicieron de manera ocasional. A ello se debió que, a pesar de contar con un núcleo que se podría calificar de permanente y que coordinó y dio continuidad a sus trabajos, del que formaron parte en distintos momentos el doctor Manuel Díaz y los licenciados Benito José Guerra, Juan Nazario Peimbert y Hernández, así como Juan Bautista Raz y Guzmán, sus integrantes y apoyos no fueron siempre los mismos ni se ocuparon de las mismas tareas. Esta diversidad de individuos, de relaciones y de intereses les permitió actuar de manera por demás flexible y dinámica. Como bien ha señalado Alfredo Ávila, no era tanto una sociedad sino una red.

La información que se tiene sobre la sociedad de Los Guadalupes deja ver que reunía algunos de los requisitos que hacen de un grupo una sociedad secreta. Actuar en secreto fue una de sus características, lo mismo que la selectividad y contar con cierta estructura y una eficiente organización. Por lo que de ellos sabemos, se puede inferir que el grupo se componía de pocos y bien escogidos individuos; igualmente, que ciertas actividades fueron llevadas a cabo por determinadas personas, o sea que funcionaba, por lo menos en parte, por secciones. Además, el grupo se compuso de individuos provenientes de diversos sectores socioeconómicos y contó con el apoyo de personas vinculadas de distintas maneras con miembros del grupo, pero sin formar parte de él, lo que daría gran amplitud a sus posibilidades de acción. Mas poco sabemos de una posible jerarquización dentro de esta sociedad, de la que puede ser un reflejo el uso de determinados números en sus seudónimos. Tampoco sabemos si se celebraron ritos de iniciación, si sus miembros hacían algún juramento especial o si contaban con determinados signos para reconocerse entre ellos.

Las líneas de acción seguidas por Los Guadalupes en relación con Morelos y otros jefes insurgentes fueron muy semejantes a las seguidas con Rayón y la Suprema Junta. De nueva cuenta destaca el envío y recibo de correspondencia en forma regular y segura, y, como había ocurrido con anterioridad, fueron los insurgentes quienes dieron ocasión a que fuera descubierta por las autoridades. Si bien la que conocemos está dirigida sólo a Morelos, a Bustamante y a Matamoros y se refiere sobre todo a remitirles información, ${ }^{12}$

Velarde. Diego Andrés Hurtado de Mendoza era cuñado de Joaquín Caballero de los Olivos y Margarita Peimbert era hija de Juan Nazario, además de novia de José Ignacio Jiménez, fusilado en Tenango, por lo que se casó más tarde con José Ignacio Espinosa.

12 En su obra, ya mencionada, Ernesto de la Torre publicó la correspondencia de Los Guadalupes con Morelos y con Matamoros. En cuanto a la que sostuvieron con Bustamante, algunas cartas se encuentran en el proceso seguido a Ignacio Adalid. Véase Bancroft Library, Causa de insurrección formada contra Ignacio Adalid y socios, 3 vols. 
sabemos que varios miembros de la sociedad mantuvieron correspondencia con otros jefes insurgentes, en la que se ocuparon de muy diversos asuntos, como la organización política del movimiento. Haber llevado felizmente a cabo esta actividad implicó establecer y controlar los canales adecuados para su recepción y envío, los cuales se efectuaban por distintos conductos. Involucradas en estas tareas encontramos a varias mujeres, como Antonia Peña y Leona Vicario, conocida esta última como "la correspondiente general". Como correos también participaron individuos dependientes de algunos de los integrantes del grupo, al igual que varios ajenos a él.

El envío de información se llevó a cabo primero a través de cartas y, más tarde, de manera ya sistematizada, mediante un Diario elaborado ex profeso. La información que contiene es variada e interesante, pues registra tanto lo que sucedía en la capital como las actividades emprendidas por las autoridades coloniales, principalmente en relación con el movimiento insurgente. Incluye también información sobre la propia insurgencia en distintas regiones, en particular sobre las partidas cercanas a la Ciudad de México, al tiempo que recoge información de fuera de la Nueva España. Haber podido reunirla da fe de que se contaba con diversos canales de comunicación dentro de la capital en muy distintos niveles -incluidas algunas altas instancias del gobierno colonial, como la Secretaría del Virreinato-; demuestra también que se tuvieron con otras regiones de la Nueva España y fuera de ella, y, finalmente, que esta tarea requirió coordinar muchos esfuerzos y que su éxito fue resultado de un buen trabajo de equipo.

Asimismo, Los Guadalupes prosiguieron con el envío de individuos que se incorporaron a la insurgencia para desempeñar diversas tareas y, como había ocurrido con anterioridad, el grupo se encargó del cuidado y del sostenimiento de sus familiares y dependientes. De igual manera, siguieron ocupándose de auxiliar al movimiento para que pudiera contar con imprentas adecuadas, por lo que, tanto el grupo que encabezaba Morelos, como el que dirigía Rayón, recibieron en distintas ocasiones prensas, impresores y hasta textos para ser publicados, lo que constituyó una de sus mayores aportaciones a un movimiento que, en una guerra en la que por escrito se libraron importantísimas batallas, se encontraba en posición de franca inferioridad frente a un régimen que controlaba casi todas las prensas.

Los Guadalupes abrieron, además, nuevas líneas de acción. Una de ellas fue prestar ayuda a varias partidas de insurgentes que se hallaban por los alrededores de la Ciudad de México, con algunas de las cuales el grupo llegó a tener relaciones muy estrechas, puesto que entre sus dirigentes se contaban individuos vinculados con Los Guadalupes por lazos de amistad, de depen- 
dencia y, al parecer, hasta de parentesco. ${ }^{13}$ Estas relaciones le fueron de vital importancia para controlar el acceso y salida de la capital y mantener un contacto seguro y constante con Morelos y otros jefes de la insurgencia.

Una línea de acción que resulta de gran interés - a pesar de haber terminado en fracaso- fueron las negociaciones emprendidas a fines de 1812 por varios integrantes del grupo para concertar una entrevista entre Rayón y el virrey Francisco Xavier Venegas, ya que pone de relieve la amplitud y el elevado nivel de los contactos, la capacidad de negociación y la posición de poder, tanto en relación con la insurgencia como con el régimen colonial, de algunos de Los Guadalupes, en particular, de Juan Bautista Raz y Guzmán, la figura principal de todas estas negociaciones y miembro destacado del núcleo directivo del grupo. ${ }^{14}$ También terminó en fracaso el intento -encabezado por José Antonio del Cristo y Conde y Francisco Manuel Sánchez de Tagle- de negociar con su sucesor en el cargo, el brigadier Félix María Calleja, con el que algunos de Los Guadalupes estaban en estrecho contacto. Esta última empresa deja ver los intereses un tanto diversos que animaban al grupo y la gran amplitud de acción que tuvieron sus integrantes. Los acercamientos a las dos figuras más destacadas del régimen colonial de aquellos años revelan también algo por demás importante, y es que, a pesar de su apoyo continuo y eficiente a la insurgencia, el grupo no había roto abiertamente con el régimen colonial ni dejado de buscar dentro del sistema un camino para hacer realidad sus aspiraciones políticas. Esto quedó plenamente demostrado a partir del establecimiento del régimen constitucional, el cual abrió a los novohispanos nuevos espacios de participación política, en particular mediante los procesos electorales que brindaban la posibilidad de ejercer una acción directa en el nivel local, en el regional y en el de la monarquía. Así, se abrió para Los Guadalupes una nueva vía de acción, en la que el primer paso fue su participación en el proceso electoral para designar al nuevo Ayuntamiento Constitucional de la Ciudad de México. ${ }^{15}$

13 Entre estas partidas se contaron la que comandaba Manuel Arriaga Díaz, quien estaba en estrecho contacto con Antonia Peña, y la de Eugenio María Montaño, administrador de una de las haciendas de Ignacio Adalid en los Llanos de Apan, con quien aquél mantenía correspondencia regular.

14 Para estas negociaciones, véase Hernández y Dávalos, Juan E., (dir.), Colección de documentos para la historia de la guerra de independencia de México de 1808 a 1821, México, José María Sandoval, 1877-1882, vol. IV, pp. 635-652.

15 Sobre estas elecciones, véanse Benson, Nettie Lee, "The Contested Mexican Elections of 1812", Hispanic American Historical Review, Durham, vol. XXVI, agosto de 1946, pp. 336350; Annino, Antonio, "Pratiche creole e liberalismo nella crisi dello spazio urbano coloniale. Il 29 novembre 1812 a Città del Messico", en Annino, Antonio y Romanelli, Raffaelle (eds.), Notabili, elettori, elezioni. Rappresentanza e controllo elettorale nell'800, Quaderni Storici Nuova 
El 29 de noviembre de 1812 se llevó a cabo la primera etapa del proceso, en la que debía designarse a los electores que se encargarían de nombrar a quienes debían integrar el Ayuntamiento, y en ella resultaron electos únicamente individuos nacidos en la Nueva España, muchos de ellos desafectos al régimen colonial y ninguno su incondicional. Estos resultados, debe señalarse, implicaron un considerable y bien coordinado trabajo previo, en el que tomaron parte individuos de muy diversa clase y condición. Se celebraron juntas para planear su organización, se seleccionaron los candidatos más idóneos, se elaboraron y repartieron papeletas con sus nombres y se efectuó una eficaz labor de convencimiento. De igual manera, se trabajó en forma coordinada y eficiente durante las elecciones mismas.

Varios de los integrantes de Los Guadalupes tomaron parte exitosamente en este proceso electoral, tanto de manera formal y abierta -ya que el antiguo Ayuntamiento capitalino debía ocuparse de la organización y cuidado de las elecciones-, como de manera informal y oculta, aprovechando tan favorable coyuntura para promover sus intereses. Así, salieron designados como electores varios miembros de la sociedad:José María Alcalá, Dionisio Cano y Moctezuma, Pedro Dionisio de Cárdenas, José María Fagoaga, Antonio Ignacio López Matoso y Juan Nazario Peimbert.

Los resultados de las elecciones, que produjeron manifestaciones de regocijo, de críticas al régimen y hasta de apoyo a la insurgencia, causaron gran preocupación a las autoridades coloniales. Temerosas de que descontentos e insurgentes se unieran contra el régimen y decididas a evitar que se debilitase su poder en la capital del virreinato, suspendieron tanto la libertad de imprenta como el proceso electoral. No obstante, las oportunidades que brindaba el sistema constitucional serían aprovechadas al máximo y con óptimos resultados por autonomistas y descontentos, en particular por Los Guadalupes. Al reanudarse el proceso electoral, a principios de 1813, los electores escogieron a individuos nacidos en la Nueva España y poco o nada afectos al régimen colonial; entre ellos se contaron Ignacio Adalid, Ignacio Moreno y Barrios, así como Francisco Manuel Sánchez de Tagle. Algo semejante sucedió con los procesos para designar diputados a Cortes, donde resultaron electos Manuel Cortázar y Félix Lope de Vergara, por la Nueva España, y José María Alcalá y el marqués de San Juan de Rayas, por Guanajuato. Lo mismo ocurrió en cuanto a las elecciones para integrar la Diputación Provincial, ya que salió electo José María Fagoaga y, como suplente, José Antonio del Cristo y Conde.

Serie, vol. 69, año XXIII, núm. 3, diciembre 1988, pp. 727-763, y Guedea, Virginia, "Las primeras elecciones populares en la ciudad de México: 1812-1813", Mexican Studies/Estudios Mexicanos, México, vol. 7, núm. 1, invierno de 1991, pp. 1-28. 
El establecimiento del régimen constitucional ocurrió al tiempo en el que la insurgencia alcanzaba su mayor fuerza y extensión y se organizaba políticamente, lo que permitió a muchos de los descontentos aprovechar las posibilidades que ofrecían ambas instancias. La instalación del Supremo Congreso Nacional Americano, en septiembre de 1813, fue resultado de una intensa labor de organización y de un proceso electoral en los que participaron de manera activa varios de los integrantes del grupo. También algunos de ellos tomaron parte en los procesos para designar a los otros dos poderes de la insurgencia, como fue el caso del marqués de Rayas, quien dio su voto a Morelos como Generalísimo encargado del poder Ejecutivo, y de Benito José Guerra, nombrado para el poder Judiciario.

Los Guadalupes se entusiasmaron con las perspectivas que les abría el establecimiento de un gobierno alterno, pero las derrotas insurgentes de finales de ese año y principios de 1814 -sobre todo la sufrida por Morelos en Tlacotepec, donde perdió su archivo- cancelaron tales perspectivas y dieron lugar a que el régimen colonial tuviera pruebas fehacientes de las relaciones que muchos americanos sostenían de manera encubierta con los insurgentes, entre ellos, un grupo capitalino que suscribía su correspondencia con el seudónimo de Los Guadalupes. A estas derrotas se sumó. en agosto de 1814, la vuelta al antiguo régimen que -entre muchas otras cosas-fortaleció a las autoridades coloniales y les dio libertad para proceder en contra de todos los descontentos. La sociedad de Los Guadalupes acabó por ver seriamente alteradas su composición y estructura, habida cuenta de que, por entonces, salieron de la capital o fueron desterrados José María de la Garza Falcón, José María Alcalá, Manuel Cortázar, Ignacio Adalid, Francisco de Arce, José María Alba, Francisco de la Llave, Antonio Ignacio López Matoso, el marqués de San Juan de Rayas y Félix Lope de Vergara. Por último, la opción insurgente acabó por desaparecer después de la prisión y muerte de Morelos, a finales de 1815, al perder su centro común la insurgencia y convertirse, de hecho, en una guerra de guerrillas.

\section{LA SOCIEDAD DE JALAPA ${ }^{16}$}

En el Cádiz de las Cortes hicieron su aparición diversas agrupaciones. Una de ellas fue la sociedad secreta establecida por el militar argentino Carlos de Alvear - con la ayuda de otros americanos-, en su casa del barrio de San Carlos, la que adoptó el nombre de Sociedad de los Caballeros Racionales, "porque

16 Para la sociedad de Jalapa véase, entre otros trabajos, "Logia de los 'Caballeros Racionales' en Jalapa. Fragmentos del proceso del canónigo Cardeña", Boletín del Archivo General de la Nación, México, vol. III, núm. 3, julio-septiembre de 1932, pp. 390-407, y "Retractaciones de algunos miembros de la logia de Jalapa”, en ibidem, pp. 408-440. 
nada es más racional que mirar por su Patria y sus paisanos", según explicaría el propio Alvear al padre Servando Teresa de Mier, quien fue iniciado en ella en septiembre de $1811 .{ }^{17}$ Lo fueron también otros novohispanos, entre los que se contaron Miguel de Santa María; José Francisco Fagoaga, segundo marqués del Apartado, y Vicente Vázquez Acuña. ${ }^{18}$ Conocido por el apodo de "Tacones", este último era un comerciante natural de Tlalpujahua, que había sido remitido a España en 1809 por escribir pasquines sediciosos en la Ciudad de México y por haber incitado a una rebelión contra los europeos "con el fin de que se coronara uno de los indios gobernador de esta República". ${ }^{19}$

Como miembro de la sociedad, y luego de haber sido amnistiado, Vázquez Acuña recibió la encomienda de pasar a la Nueva España, para lo que se le habilitó de todo lo necesario. ${ }^{20}$ A principios de 1812, se encontraba ya en Jalapa, a donde también habían llegado de la Península los oficiales del Regimiento de Lobera, Juan Bautista Ortiz y Evaristo Fiallo, el primero natural del Real del Rosario, en Sonora, y el segundo, de La Habana. Con ellos, Vázquez Acuña comenzó a hacer juntas en secreto para promover la independencia y reconocer un gobierno americano, en las que los participantes hacían juramento de defender a la religión, de no aceptar gobierno extranjero alguno y de guardar el secreto de sus actividades. ${ }^{21}$

Por entonces también había llegado a Jalapa -su ciudad natal- Ramón Cardeña, canónigo de Guadalajara. De la Península traía un apodo, puesto al parecer por el infante Francisco de Paula, el de "el cura bonito", al decir de Mier, ${ }^{22}$ o "el canónigo bonito", según Lucas Alamán. ${ }^{23}$ Cardeña, quien se enteró de la existencia de la sociedad fundada por Vázquez Acuña, Fiallo y Ortiz hasta mediados de marzo, fue iniciado en ella mediante la ceremonia

17 Declaración de Servando Teresa de Mier, México, 16 de noviembre de 1817, véase Hernández y Dávalos, Juan E., (dir.), op. cit., t. VI, p. 817.

18 Guzmán Rodríguez, José Refugio, "Una sociedad secreta en Londres al servicio de la independencia americana", Boletín del Archivo General de la Nación, México segunda serie, vol. VIII, núms. 1 y 2, enero-junio de 1967, pp. 120-122.

19 Causa seguida a Vicente Vázquez Acuña, Archivo General de la Nación (en adelante AGN), Infidencias, v. 128, ff. 32v-33v.

20 Declaración de Vicente Vázquez Acuña, Perote, 16 de junio de 1812, en Causa seguida al canónigo Ramón Cardeña, ibidem, v. 74, c. 1, ff. 99-99v.

21 Declaración de Juan Bautista Ortiz, México, 6 de noviembre de 1812, ibidem, v. 74, c..

22 Denuncia de Julián de Cortázar y Jacinto Floranes, México, 26 de septiembre de 1817, véase Rangel, Nicolás, "Cuatro diálogos insurgentes", Boletín del Archivo General de la Nación, México, vol. III, núm. 3, julio-septiembre de 1932, p. 334.

23 Alamán, Lucas, Historia de Méjico, desde los primeros movimientos que prepararon su independencia en el año de 1808 hasta la época presente, México, Imprenta de J. M. Lara, 1851, t. IV, p. 452. 
de rigor. ${ }^{24}$ Además del canónigo, fueron iniciados en la sociedad de Jalapa numerosos individuos. Según se desprende de la documentación contenida en el proceso seguido al canónigo, fueron cerca de 80 . No se registra la ocupación de 35 de ellos -casi la mitad-, pero, entre los que sí se precisa, encontramos siete eclesiásticos, seis militares, seis patriotas y seis comerciantes - dos de ellos ambas cosas-, cuatro licenciados, tres guardas, dos médicos, un notario de la Curia, un escribiente, un maestro carpintero, un relojero, un zapatero, un sastre, un platero, un literero, un maestro - no se especifica de qué- y un boticario. Además, se menciona a una mujer, de quien no se dice si fue iniciada o no, pero de la que se registra su asistencia a algunas de sus reuniones.

Fueron numerosos los iniciados que declararon sobre su participación en ella, y todos afirmaron que la sociedad se propuso sostener la religión, la patria y los derechos del rey. Además, varios de los declarantes precisaron haber preguntado antes de jurar si la de Jalapa era una sociedad proinsurgente, a lo que se les contestó de manera negativa. ${ }^{25}$ En todas estas declaraciones también quedó constancia de cómo se celebraba la ceremonia de iniciación. En tres sillas puestas en orden se sentaban los miembros de la sociedad que presidían la ceremonia y, detrás de ellos, en dos hileras, el resto de los asistentes. El iniciado se mantenía de pie junto a su padrino, mientras recibía la explicación de los propósitos de la sociedad, y a continuación se le preguntaba: "Señor Socio, extraño el verlo a V. aquí, ¿qué es lo que busca?", a lo que debía responder: "la tranquilidad mía y de mi familia es lo que busco", y entonces se le hacía firmar o poner la señal de la cruz y se le tomaban los juramentos del caso. ${ }^{26}$ Éstos, al decir de muchos de los iniciados, habían sido los de defender a la religión católica, no admitir dominación extranjera alguna -incluso la de Morelos, en caso de triunfar-, evitar la efusión de sangre y guardar el secreto de la sociedad bajo pena de la vida, ya que, de no respetar este juramento, el puñal o el veneno pondrían fin a la existencia del traidor. Los socios también debían socorrerse mutuamente en sus necesidades, además de dar dos pesos al ser iniciados y un peso más al mes para los gastos de

24 Declaración de Ramón Cardeña, Jalapa, 23 de septiembre de 1812, en Causa seguida al canónigo Ramón Cardeña, op. cit., v. 74, c. 1, ff. 95-97.

25 Véanse, por ejemplo, las declaraciones de Juan Bautista Ortiz, México, 8 de septiembre de 1813; Marcelino Montesinos, México, 10 de septiembre de 1813; Juan Ferrá, Jalapa, 28 de abril de 1814; Manuel Bezanilla, México, 7 de mayo de 1814, y José Juan González y Rentería, México, 10 de mayo de 1814, ibidem, v. 74, c. 13, ff. 6v-23; 23-37; 47v-53v; 56v-59v, y 59v-66.

26 Declaración de José Eugenio Jiménez, Jalapa, 1o. de agosto de 1812; Declaración de José Ricardo Graneros, Perote, 30 de diciembre de 1812, y Declaración de Dionisio González, Jalapa, 30 de julio de 1812, ibidem, v. 74, c. 2, ff. 3-8v; c. 15, y c. 2, ff. 26-27v. 
la sociedad y para ayuda de los hermanos en desgracia. ${ }^{27}$ En lo que se refiere a los gestos o símbolos para reconocerse entre sí, tenían unas señas especiales: debían tocarse la frente y la barba con el dedo de en medio y luego deletrear la palabra unión, a veces seguida de las palabras fortaleza $-\mathrm{O}$ constancia- $\mathrm{y}$ valor. ${ }^{28}$ Estas señas, cabe precisar, coinciden con las utilizadas por la logia de Caballeros Racionales establecida en Cádiz.

Sabemos que la sociedad contó con un presidente, un vicepresidente, un secretario, un segundo secretario y un tesorero. ${ }^{29}$ Así, un pequeño núcleo director coordinaba sus trabajos, constituido por Vázquez Acuña, Fiallo y Ortiz, en sus principios, y más tarde por Vázquez Acuña, Cardeña, Juan José del Corral -sobrino del canónigo-, el licenciado Manuel Apolbón, el cura Manuel Ortiz y Mariano Rincón. La documentación consultada deja ver que entre algunos de sus miembros había relaciones previas de profesión, de amistad y hasta familiares, las cuales influyeron en su entrada en la sociedad. ${ }^{30}$ A pesar de estos vínculos, no fue fácil la coordinación de tan alto número de asociados, muchos de quienes sólo asistieron a alguna de sus juntas, y el cobro de las cuotas tampoco pudo hacerse con regularidad.

La sociedad celebraba sus reuniones en distintos lugares. Se mencionan las casas de varios socios, como la de Manuel Cruz, dedicado al negocio de las literas; la de Mariano Rincón, quien más tarde se unió a la insurgencia y fue uno de sus jefes más connotados en la región de Veracruz, y la de José Mariano Lucido, maestro carpintero. Asimismo, se señalan las del sastre Manuel Téllez, del patriota Velasco, del licenciado Apolbón y de Montaño. Hubo otras reuniones celebradas en casa de doña Teresa Medina de

27 Véanse las declaraciones de Joaquín Ruiz, Jalapa, 28 de julio de 1812; Rafael Velad, Jalapa, 28 de julio de 1812; Andrés Boselo, Jalapa, 29 de julio de 1812; Juan Díaz, Jalapa, 30 de julio de 1812; Dionisio González, Jalapa, 30 de julio de 1812; Francisco del Corral, Jalapa, 2 de agosto de 1812; Jorge Ojeda, Jalapa, 3 de agosto de 1812; José María Pérez Oliva, Jalapa, 3 de agosto de 1812; Manuel Cárdenas, Jalapa, 5 de agosto de 1812; José Eugenio Jiménez, Jalapa, 1o. de agosto de 1812, y José María Pérez, Puebla, 29 de octubre de 1812, ibidem, v. 74, c. 2, ff. 12-13; 14-15v; 17-18v; 23-25; 26-27v; 20-20v; 69v-70; 70v-71v; 1-2; 3-8v, y c. 12, ff. 1-2.

28 Véanse las declaraciones de Vicente Vázquez Acuña, Perote, 16 de junio de 1812; Juan Bautista Ortiz, México, 6 de noviembre de 1812, y Ramón Cardeña, Jalapa, 23 de septiembre de 1812, ibidem, v. 74, c. 1, ff. 99-99v; c. 8, ff. 1-5v, y c. 1, ff. 95-97v.

29 Declaración de Ramón Cardeña, Jalapa, 23 de septiembre de 1812, en ibidem, v. 74, c. 1, ff. 95-97.

30 Como ejemplo, me referiré aquí a las ligas familiares. Andrés Boselo era pariente de Manuel Apolbón; Juan y Rafael Camargo eran padre e hijo; los Corral, Francisco y Juan José, eran hermanos, además de sobrinos de Cardeña; José María Tamariz era hermano del cura de Xico; el cura Joaquín Cardeña era primo del canónigo, y éste, a su vez, era tío de los Corral y primo de José Ortega, y un tal Guzmán era pariente de José María Rivera, quien era sobrino de Francisco Rivera. 
Sotarriba, aunque al parecer fueron informales. ${ }^{31}$ Igualmente, se tuvieron reuniones en el Potrero, en el billar propiedad de Manuel Cruz y en la botica de San Juan de Dios. ${ }^{32}$

A pesar de derivar de la Sociedad de los Caballeros Racionales de Cádiz, parece que la de Jalapa no mantuvo contactos directos con aquélla ni los estableció con las otras sociedades derivadas de la gaditana, aunque el propio Cardeña declaró haber oído que había socios en Veracruz y Vázquez Acuña manifestó "que en La Habana había conocido a varios hermanos y su junta en Veracruz". ${ }^{33}$ Pero, independientemente de sus relaciones con otras sociedades secretas, la de Jalapa poseía varias de las características formales que hacen de una agrupación una sociedad secreta. A pesar de no contar con una selección muy cuidadosa de sus integrantes, sí tuvo una jerarquización y una estructura, así como ciertos ritos, como el de la iniciación y el de prestar juramentos. También contó con gestos o símbolos para reconocerse entre los iniciados. Por último, lo más importante: tuvo una organización que le permitió actuar - aunque no muy eficientemente, hay que reconocerlo- para alcanzar sus objetivos, lo que llevó a cabo, dentro del más riguroso secreto, por lo menos durante algún tiempo.

En el breve periodo que funcionó (de febrero a mayo de 1812, aproximadamente), la mayor parte de sus energías fue empleada en organizarse y en reclutar nuevos miembros. Sin embargo, sí alcanzó a planear y a llevar a cabo algunas actividades concretas, casi todas en favor de los insurgentes de los alrededores de Jalapa, lo que parece dar la razón a Ortiz en cuanto a que el propósito fundamental de la sociedad era alcanzar la independencia y establecer un gobierno de americanos. ${ }^{34}$ Así, entre sus actividades se contaron entablar y mantener estrecho contacto con varios insurgentes, así como enviarles pólvora, armas y caballos. De igual manera, debían remitirles noticias

31 Declaración de María Rafaela de Villa, Jalapa, 24 de junio de 1812, en ibidem, v. 74, c. 1 , ff. 58-60.

32 Declaración de Andrés Rendón, Jalapa, 29 de junio de 1812, en ibidem, c. 1, ff. 60v-61.

33 Declaración de Ramón Cardeña, Jalapa, 26 de septiembre de 1812, y declaración de Vicente Vázquez Acuña, Perote, 16 de junio de 1812, en ibidem, c. 1, ff. 99v-105, y 99-99v.

34 Ortiz sostuvo algo un tanto distinto cerca de un año después de su primera declaración, y que iba más acorde con lo expuesto por los demás socios, cuando declaró que el juramento que había prestado era el de "defender a la Religión Católica, Apostólica Romana en todas sus atribuciones [...] no admitir ninguna dominación extranjera, defender la causa que sostienen nuestros hermanos los europeos, resistir a los rebeldes insurgentes y a cualquier otro intruso, evitar la efusión de sangre socorriéndose mutuamente los socios y guardar secreto de la existencia de la sociedad”. Declaración de Juan Bautista Ortiz, México, 8 de septiembre de 1813, en ibidem, vol. 74, c. 13, f. 15v. 
e información de interés, y coordinar la salida de la ciudad de simpatizantes del movimiento, los que fueron a incorporarse a sus filas. ${ }^{35}$

Pero la actividad de mayor interés que la sociedad llevó a cabo en relación con la insurgencia fue su estrecha vinculación con el establecimiento de la Junta Gubernativa Provisional de Naolingo, pues varios miembros de la sociedad pasaron a formar parte de aquélla, entre ellos, Mariano Rincón, su principal dirigente y organizador; ${ }^{36}$ el licenciado Apolbón; el presbítero Joaquín Cardeña - cura, al parecer, de Chichiquila y primo del canónigo-; el cura Manuel Ortiz; Juan José del Corral; José María Tamariz; Benito Ochoa; Jorge Ojeda, y el cura Rafael Cabañas. ${ }^{37}$ Pasaron también a Naolingo el relojero Martín Moreno, Juan Catarino Cabañas, Vicente Casas, José Cruz, el comerciante Juan Ferra, el sargento José Ricardo Graneros, Manuel Mejía, Guzmán, Montaño y Francisco Rivera, "El Naolingueño". Asimismo lo hicieron los oficiales

35 Manuel Cruz, quien fungió como vicepresidente de la sociedad, proporcionaba caballos a quienes querían pasar con los insurgentes a Naolingo, además de enviar a éstos armas y recibir de ellos noticias. El boticario Joaquín Ruiz, quien fuera tesorero de la sociedad, amén de prestar dinero para un banquete que se iba a ofrecer a Fiallo y a Ortiz, pagó a un correo para que pasase a San Andrés Chalchicomula a enterarse del estado en el que se hallaban los insurgentes. Varios de los socios proporcionaron armas a los insurgentes: el sastre Téllez y el carpintero Lucido entregaron un fusil, mientras que Gabriel Rosso proporcionó una escopeta y José Antonio Domínguez, quien también fungió como tesorero de la sociedad, una escopeta y un fusil, además de unas pistolas y varias libras de pólvora. A su vez, el patriota Carlos Guevara remitió a los insurgentes cartuchos de pólvora con Francisco Rivera, apodado "El Naolingueño", quien era dueño de una tienda y se ocupó de llevar diversos artículos a los insurgentes, proporcionándoles pólvora y piedras de lumbre; su sobrino, José María Rivera, les llevó pólvora. José Ortega, primo de Cardeña, llevaba y traía noticias de los insurgentes, y en su casa se depositaban las armas y los caballos para quienes querían pasar a Naolingo. El sargento Domínguez propuso apoderarse de las armas y de la pólvora del Regimiento del Fijo al que pertenecía, sorprendiendo a la guardia, y también apoderarse de las autoridades de Jalapa para establecer en la villa un nuevo gobierno. Igualmente propuso apoderarse del castillo de Perote, para lo que disfrazaría a cincuenta hombres con los uniformes de su Regimiento, lo que tampoco se lograría. A su vez, Cristóbal Capetillo intentó levantarse con la gente de los ranchos de Zoncuautla, aunque sin éxito, mientras que Benito Ochoa fue encargado de levantar gente en tierra caliente, lo que sí pudo verificar. Declaración de José Eugenio Jiménez, Jalapa, 1o. de agosto de 1812, en ibidem, v. 74, c. 2, ff. 3-8v. Ochoa fue acusado más tarde de estar encargado por la sociedad de degollar a las autoridades, lo que no pudo llevar a cabo, al decir de sus acusadores, por haber sido tomado preso. Declaración de Francisco León de Luna, Jalapa, 6 de abril de 1813 en ibidem, vol. 74, c. 11, ff. 3v-5v.

36 Alamán, Lucas, op. cit, t. III, p. 149.

37 Sobre algunos de ellos véase: Francisco Pérez, cura de Naolingo, a Juan Collado, 6 de agosto de 1812, en Causa seguida al canónigo Ramón Cardeña, AGN, Infidencias, vol. 74, c. 1, ff. $83-84 v$. 
Fiallo y Ortiz, fundadores con Vázquez Acuña de la sociedad, varios de ellos ocuparon posiciones de importancia dentro de la Junta. ${ }^{38}$

Fiallo y Ortiz habían dejado Jalapa y pasado a Perote con su regimiento poco después de haber fundado la sociedad. Igual había hecho Vázquez Acuña, quien pensaba pasar a la Ciudad de México. Los tres, con varios militares - entre los que se contaba Francisco Tisier, teniente del Regimiento Fijo de Infantería de Veracruz-, en Perote, tramaron una conspiración para entregar el fuerte a los insurgentes y dar muerte a los jefes realistas, aparentemente con el apoyo de la sociedad de Jalapa y de la Junta de Naolingo. Denunciados los conspiradores el 8 de junio de ese año, fueron juzgados por un consejo de guerra y condenados a muerte. Vázquez Acuña fue fusilado por la espalda como traidor, ${ }^{39}$ pero Ortiz, Fiallo y Tisier lograron escapar, se unieron a los insurgentes -Ortiz como coronel y Fiallo como brigadier-y se incorporaron a la Junta de Naolingo, ${ }^{40}$ de la que más tarde fueron vocales. ${ }^{41}$

De hecho, la formación de esta Junta Gubernativa Provisional de Naolingo fue el resultado del proceso de desintegración que sufrió la sociedad de Jalapa a poco de haberse establecido. El envío de la expedición realista que comandaba Ciriaco de Llano, así como el hecho de que varios de los miembros de la sociedad fueran acusados de actividades sospechosas -entre ellos el mismo Cardeña-, hizo que muchos de sus integrantes suspendieran sus trabajos o se fugaran de la ciudad. Otros consideraron que sus servicios a la causa serían más efectivos desde las filas insurgentes. Y algunos más simplemente dejaron de actuar. La Junta tuvo una vida muy corta. La provincia de Veracruz estaba por ese entonces llena de insurgentes y las comunicaciones interceptadas, por lo que varias zonas de su territorio fueron objeto de una seria campaña realista. Poco después de su llegada a Jalapa, Llano emprendió una expedición contra Naolingo, lo que obligó a Rincón a trasladarse con todo y Junta a Misantla, el 18 de julio. ${ }^{42}$ La Junta pasó después a la Hacienda de El Jobo y, al poco tiempo, fue disuelta.

38 Por declaración de José María Tamariz sabemos que para su establecimiento se reunió al pueblo y se efectuó una elección, en la que salió electo presidente el presbítero Mariano Guevara, cura de Jilotepec, y como vocales el licenciado Apolbón, Domínguez, el propio Tamariz y otro del que no se acordaba el nombre, y como secretario Juan José del Corral. Declaración de José María Tamariz, Puebla, 29 de octubre de 1812, en ibidem, vol. 74, c. 12, ff. 2-4v.

39 Alamán, Lucas, op. cit., t. III, p. 149.

40 Mariano Rincón a Sebastián Fernández Bobadilla, Naolingo, 14 de julio de 1812, en Causa seguida al canónigo Ramón Cardeña, AGN, Infidencias, vol. 74, c. 1, ff. 65-66.

41 Declaración de José María Tamariz, Puebla, 29 de octubre de 1812, en ibidem, c. 12, ff. 2-4v.

42 Alamán, Lucas, op. cit., t. III, p. 234. 
La conducta de los fundadores de la sociedad había despertado las sospechas de las autoridades coloniales desde un principio. La salida de Jalapa de Fiallo, Ortiz y Vázquez Acuña hizo que las sospechas se concentraran en Cardeña. ${ }^{43} \mathrm{Y}$, si bien el canónigo procuró ser más cauto en sus acciones, ${ }^{44}$ las inquietudes sobre sus actividades fueron en aumento, pues se le vio en compañías sospechosas, con quienes mantuvo conversaciones secretas..$^{45}$ También se supo que, en un viaje a Veracruz, había sido detenido en El Encero por los insurgentes, con quienes conversó un rato y de los que obtuvo no sólo su libertad sino la de sus criados, que eran europeos, y la de sus amigas, doña Micaela Barquiarena y doña Teresa Medina de Sotarriba, las cuales viajaban con él, lo que provocó las sospechas de varios testigos. ${ }^{46}$

No obstante, fue más de un mes después cuando se procedió en contra del canónigo, lo que quizá se debió a que hasta el 26 de mayo se creó la Junta de Seguridad Pública de Jalapa, medida provocada por la cercanía de los insurgentes, que por entonces amenazaban de continuo la villa, ${ }^{47}$ y por las actividades sospechosas de no pocos jalapeños. Dada la situación que se vivía, se había establecido también un consejo de guerra permanente. ${ }^{48} \mathrm{El} 29$ de mayo se inició causa contra Cardeña, por tratos y conversaciones con los insurgentes. ${ }^{49}$ Se mandó entonces asegurar su persona y que se le pusiera en el convento de San Francisco. ${ }^{50}$ Su detención tuvo lugar el 4 de junio, poco después de las tres de la mañana, y no resultó fácil, pues Cardeña se incomodó mucho y se resistió a la detención; finalmente, después de hora y media de alegato, logró que lo dejaran arrestado en casa del cura. ${ }^{51}$

43 Antonio Fajardo a Juan Collado, Jalapa, 13 de junio de 1812, en Causa seguida al canónigo Ramón Cardeña, AGN, Infidencias, v. 74, c. 1, ff. 36-36v.

44 Declaración de José Eugenio Jiménez, Jalapa, 1o. de agosto de 1812, en ibidem, v. 74, c. 2 , ff. $3-8 \mathrm{v}$.

45 Declaración de Matías Martínez de Espinosa, Jalapa, 30 de mayo de 1812, en ibidem, v. 74 , c. 1 , ff. $1-2$ v.

46 Declaración de Sebastián de Aguirre, Jalapa, 31 de mayo de 1812; declaración de Juan Manuel Cotarro, Jalapa, 31 de mayo de 1812, y declaración de Inés de la Jara, Jalapa, $1^{\circ}$ de junio de 1812 , en ibidem, v. 74, c. 1, ff. 3-4; 4-4v, y 5v-6v.

47 Bustamante, Carlos María de, Cuadro histórico de la Revolución Mexicana, comenzada en 15 de septiembre de 1810 por el Ciudadano Miguel Hidalgo y Costilla, Cura del pueblo de los Dolores, en el obispado de Michoacán, segunda edición, corregida y muy aumentada por el mismo autor, México, Imprenta de J. Mariano Lara, 1843-1846, t. II, 5 vols., p. 145.

48 Alamán, Lucas, op. cit., t. III, p. 233 y 234.

49 Oficio de la Comisión Ejecutiva, Jalapa, 29 de mayo de 1812, en Causa seguida al canónigo Ramón Cardeña, AGN, Infidencias, v. 74, c. 1, f. 1.

50 Auto de la Comisión Ejecutiva, Jalapa, 3 de junio de 1812, en ibidem, v. 74, c. 1, ff. $6 \mathrm{v}-7$.

51 Certificación de Juan de Bárcena, Jalapa, 4 de junio de 1812, en ibidem, v. 74, c. 1, ff. 11-11v. 
La prisión del canónigo provocó la desbandada de los miembros de la sociedad; así como manifestaciones de arrepentimiento entre algunos de ellos, las que en ciertos casos conllevaron acusaciones en contra de otros socios. ${ }^{52}$ La represión no se dejó sentir con igual rigor sobre todos los miembros de la sociedad. Así, Ortiz decidió indultarse junto con Tamariz y el sargento Graneros, y entre los tres apresaron a 22 de sus antiguos compañeros en El Jobo, de los que llevaron 19 a Teutitlán, por lo que consiguieron quedar libres. ${ }^{53}$ Por su parte, otros miembros de la sociedad alcanzaron también el indulto, como fue el caso de José María Pérez. ${ }^{54}$ Otros más ni siquiera fueron procesados, por haberse presentado de manera voluntaria a declarar; finalmente quedó Cardeña solo ante la justicia colonial. ${ }^{55}$

El canónigo inició su contraofensiva el mismo día en el que fue detenido. Protestó ante la Junta de Guerra por hallarse preso y desconocer el motivo; ${ }^{56}$ asimismo, al resistirse a pasar al convento de San Francisco, logró permanecer en casa del cura, donde se le puso una guardia. ${ }^{57}$ Cardeña no cesó en sus empeños de vindicar su inocencia, y el tono de sus escritos provocó que las autoridades decidieran ya no admitirlos, además de prohibir que se le proporcionase tintero y papel. ${ }^{58} \mathrm{El}$ canónigo fue finalmente llevado a la Ciudad de México para ser juzgado, si bien obstaculizó cada uno de estos pasos. En Puebla, se negó a moverse con el argumento de estar enfermo, ${ }^{59}$ y, ya en México, invocó motivos de salud para pedir su pase al convento de Santo Domingo, lo que acabó por lograr, si bien bajo fianza, a pesar de las objeciones del prior dominico fray Domingo Barreda. ${ }^{60}$ Cardeña insistió, sin éxito, en que estaba enfermo para que se le dejase salir a hacer ejercicio, pero

52 Oficio de Manuel Pérez y Suárez a Juan Collado, Jalapa, 16 de agosto de 1812, en ibidem, v. 74, c. 1, ff. 35-37.

53 Escrito de José Ricardo Graneros, c. noviembre de 1812, y declaración de Juan Bautista Ortiz, México, 4 de noviembre de 1812, en ibidem, c. 6, ff. 2-2v, y c. 6, ff. 4-5.

54 Ignacio Antonio Salamanca, Jalapa, octubre de 1812, en ibidem, v. 74, c. 14.

55 El fiscal del crimen Juan Ramón Osés, México, 19 de octubre de 1812, en ibidem, c. 1, ff. $115 \mathrm{v}-120 \mathrm{v}$.

56 Escrito de Ramón Cardeña al presidente y vocales de la Junta de Guerra, Jalapa, 4 de junio de 1812, en ibidem, v. 74, c. 1, ff. 17-17v.

57 Certificación de José García y Blanco, Jalapa, 9 de junio de 1812, en ibidem, v. 74, c. 1, ff. $19-19 \mathrm{v}$.

58 Juan Collado a Juan Camargo, Jalapa, 12 de junio de 1812, en ibidem, v. 74, c. 1, f. 38.

59 Oficio del conde de Castro Terreño al virrey Francisco Xavier Venegas, Puebla, 2 de septiembre de 1812, en ibidem, c. 5 .

60 Escrito de Ramón Cardeña a la Real Sala del Crimen, México, 12 de octubre de 1812, y escrito de fray Domingo Barreda al virrey Francisco Xavier Venegas, México, 5 de noviembre de 1812, en ibidem, v. 74, c. 1, ff. 124-125, y 127-129v. 
la falta de permiso no fue obstáculo para sus frecuentes salidas, por lo que, a principios de 1813, se le trasladó al convento de Betlemitas. ${ }^{61}$

El largo proceso seguido al canónigo no terminó en la ciudad capital: para enero de 1816 y por haberlo decidido el rey, Cardeña fue enviado a Guadalajara a disposición de su obispo pero, aparentemente, no llegó a dictársele sentencia. ${ }^{62}$ Esto se debió en buena medida a que no se le pudo probar nada de manera definitiva, a pesar de las graves denuncias presentadas en su contra y de los serios indicios con que contaban las autoridades respecto a su conducta infidente. ${ }^{63}$ Hubo, sin embargo, numerosos testigos que hablaron en su defensa, en particular los llamados a declarar por Cardeña mismo, cuya uniformidad en sus declaraciones hace ver que, además de estar todos a favor del canónigo, se hallaban muy bien aleccionados. ${ }^{64}$ El propio Cardeña intentó demostrar su inocencia en sus declaraciones y alegatos, negando todo lo referente a sus relaciones con los insurgentes e insistiendo en que los principios y las providencias de la sociedad de Jalapa eran en apoyo del gobierno realista ${ }^{65}$ Pero quizá lo que más pesó para que no se le castigara con mayor rigor fue el poco éxito que lograron sus trabajos y los de la sociedad de Jalapa. El movimiento insurgente no llegó a alcanzar por entonces una verdadera cohesión en la región de Veracruz y la insurgencia organizada sufrió con el tiempo severas derrotas, lo que hizo que esfuerzos como los emprendidos por la sociedad jalapeña dejaran de tener sentido.

Para terminar con lo ocurrido en Jalapa, me referiré a un asunto que destaca por su muy particular interés en relación con esa nueva forma de organización política que fueron las sociedades secretas. En descargo por haber formado parte de este tipo de asociaciones, muchos de los iniciados alegaron haberlo hecho a imitación de los europeos de la villa, los cuales también se reunían en secreto. Así, el canónigo Cardeña declaró que aceptó el sigilo y la clandestinidad dentro

61 Declaración de fray Juan Rivas, México, 22 de enero de 1813, y declaración de fray Felipe Valdés, México, 1o. de febrero de 1813, en ibidem, c. 7, ff. 2-3, y c. 1, ff. 3-3v.

62 Copia del escrito de Miguel de Lardizábal al virrey Félix María Calleja, México, 24 de enero de 1816, en ibidem, v. 74, c. 11.

63 Declaración de Juan Santos Noriega, Jalapa, 19 de junio de 1812, y declaración de Fernando González Pacheco, en ibidem, c. 1, ff. 46-47 y 56v-57v.

64 Véanse, entre otras, las declaraciones de Miguel Jiménez, Jalapa, 20 de junio de 1812; Joaquín Rodríguez, México, 12 de septiembre de 1812; Manuel Ramírez de Aguilar, México, 16 de septiembre de 1812; Juan Bautista Ortiz, México, 8 de septiembre de 1813; Marcelino Montesinos, México, 10 de septiembre de 1813, y Tomás Illanes, México, 4 de mayo de 1814 , en ibidem, v. 74, c. 1, ff. 47v-50; c. 13, ff. 37-41v; 44v-47; 6v-23; 23-37, y 53v-56v.

65 Véanse las declaraciones de Ramón Cardeña, Jalapa, 16 de agosto de 1812, y México, 23 y 26 de septiembre y 2 de octubre de 1812, en ibidem, v. 74, c. 1, ff. 75-80v; 91v-97v; 99v105, y $105 \mathrm{v}-113$. 
de la sociedad cuando observó las reuniones de los europeos celebradas en las casas de Francisco Sía, Marcelino Rugama y Juan Lucas de Olabarrieta; asimismo, declaró que de casa de este último vio salir dos veces a numerosos individuos pasadas las once de la noche. ${ }^{66}$ Por su parte, Juan Bautista Ortiz declaró que estuvo alojado por orden del gobierno en casa del europeo Rugama, y que en ella, en la de Olabarrieta, en la de Sía y especialmente en la del francés Pemartin, "había sociedades o juntas clandestinas a horas inusitadas" cuyos fines se desconocían, si bien el declarante oyó varias veces de boca de Rugama "que era necesario acabar con todos los criollos, no sólo con los insurgentes sino aun con los que estaban quietos". A estas reuniones asistía el cura de Jalapa, Manuel Pérez, quien hablaba también mal de los criollos, en particular de Cardeña, al que odiaba. Las expresiones de los europeos en contra de los americanos -ya que aquéllos públicamente manifestaron que habían de proceder a degüello de todos los criollos, así como a su prisión y total exterminio- provocaron que muchos americanos se pasaran con los insurgentes. ${ }^{67}$

No saber a ciencia cierta cuáles eran los fines de las juntas de los europeos llenaba de temor a los americanos, por el aparato misterioso con el que se celebraban y por ir armados todos los concurrentes. Además, Marcelino Montesinos, patriota voluntario de Jalapa, oyó decir a varios de los europeos "que era preciso aniquilar a todos los criollos, pues eran unos traidores insurgentes; igualmente oyó decir al europeo Nogueira que daba doscientos pesos para ayuda de costo de marcar con un fierro a los criollos". ${ }^{68}$ De manera semejante declaró Juan Ferrá, quien fuera miembro de la sociedad. ${ }^{69}$ Por su parte, el capitán José Nicolás Carrillo manifestó que, además de celebrar juntas, el europeo Olavarrieta - aficionado a la caza- organizó que los negros cazadores de la jurisdicción se reunieran "para ofender a los insurgentes, ofreciendo cierta cuota por cada uno que mataran". ${ }^{70}$

Por la documentación consultada, no llega a quedar claro si los europeos en Jalapa llegaron a formar una verdadera sociedad secreta o simplemente se reunían de manera oculta al cobijo de la oscuridad de la noche para organizarse, entre otras cosas, contra los criollos. Lo que sí resulta evidente gracias a la

66 Declaración de Ramón Cardeña, Jalapa, 26 de septiembre de 1812, en ibidem, v. 74, c. 1, ff. $99 \mathrm{v}-105$.

67 Declaración de Juan Bautista Ortiz, México, 8 de septiembre de 1813, en ibidem, v. 74, c. 13 , ff. $6 \mathrm{v}-23$.

68 Declaración de Marcelino Montesinos, México, 10 de septiembre de 1813, en ibidem, c. 13 , ff. $23-37$.

69 Declaración de Juan Ferrá, México, 28 de abril de 1814, en ibidem, c. 13, ff. 47v-53v.

70 Declaración de José Nicolás Carrillo, México, 16 de septiembre de 1813, en ibidem, c. 13 , ff. $42-44 v$. 
documentación es la profunda escisión que se daba en la villa entre europeos y americanos. En éste, uno de los centros urbanos novohispanos con una fuerte presencia peninsular y con estrechos lazos de diversa índole con España, el enfrentamiento entre ambas posturas alcanzó un grado muy alto.

Concluyo señalando que, en buena medida, la diferencia en los resultados que obtuvieron la sociedad capitalina y la jalapeña se debió a que la de Los Guadalupes - que actuaba de manera autónoma y sin ligas formales con ningún otro grupo dentro o fuera del virreinato- adoptó un modelo de organización por demás flexible, con un pequeño núcleo director que incluía a destacados personajes de la vida política y económica de la capital, varios de ellos abogados, y que se reunía aprovechando tertulias, paseos y demás espacios de sociabilización. Lo anterior le permitió actuar en secreto y por distintas vías, al tiempo que articulaba los intereses de numerosos descontentos, entre ellos varios indígenas, y utilizaba los apoyos que le brindaban individuos ajenos a ella. Mientras que la jalapeña constituyó el primer ensayo de utilizar con cierto rigor un modelo de fuera, el que brindaba la masonería, cuyos esfuerzos por organizarse de manera formal ocuparon gran parte de su tiempo y la llevaron a ser descubierta muy pronto por las autoridades coloniales. 


\section{LA IMPERIAL ORDEN DE GUADALUPE, PREGEDENTE DE LAS PRIMERAS CORPORAGIONES MASÓNICAS DEL MÉXICO NACIONAL}

\section{María Cristina Torales PACHECO*}

...se hizo con juicio y acierto, habiendo recaído con pocas é inevitables excepciones de alguna predilección de parentesco y amistad, en las personas más respetables por su carácter y servicios.

Lucas Alamán, Historia de México, t. 5.

Sumario: I. Preámbulo. II. El objeto de estudio: la Orden Imperial de Guadalupe. III. Los antecedentes de la condecoración. IV. Objetivos de la Orden Imperial de Guadalupe. V. Epílogo: a propósito de la masonería.

\section{PREÁmbUlo}

En los siglos XIX y XX la historiografía mexicana privilegió el estudio de algunos individuos que tuvieron incidencia en la conformación política y cultural de México, y con ello configuró lo que podríamos calificar como el "Panteón de los héroes de la Independencia y de la nación". En éste han tenido un lugar privilegiado, entre otros, Hidalgo, como padre de la patria, y Morelos, como iniciador del sistema parlamentario. En el presente artículo, sin descalificar esa historiografía que estuvo orientada a la construcción de la identidad nacional, quisiera ofrecer otra vía de comprensión que nos permita recuperar y apreciar a los numerosos actores sociales que tuvieron parte activa en la Independencia y en la construcción del México nacional.

\footnotetext{
* Universidad Iberoamericana, Ciudad de México.
} 
Es obligado hacer una breve mención de los antecedentes del presente texto. Dedicada, en la década de 1980, al estudio de los empresarios mercantiles que tuvieron el liderazgo económico novohispano durante la segunda mitad del siglo XVIII, me interesé por investigar a quienes -integrantes del sector productivo- se identificaron con los principios de la Ilustración. Una Ilustración asociada al cultivo de las ciencias y artes útiles. Esto me llevó a emprender un estudio prosopográfico de 545 individuos que, residentes en Nueva España, se inscribieron a la Real Sociedad Bascongada de Amigos del País (RSBAP). ${ }^{1}$

Entre las conclusiones derivadas de ese trabajo, afirmé que los miembros novohispanos de la RSBAP, formaron parte sustantiva de la generación ilustrada en cuyo seno surgió aquella que consolidó la Independencia y le correspondió la construcción del México nacional. Asumí entonces el reto de identificar a la generación cuyos miembros abrevaron las luces en el interior de los hogares o de las voces de mentores miembros de la RSBAP. Con ese objetivo, me aproximé al estudio de la Imperial Orden de Guadalupe, porque entre sus miembros, quedaron identificados quienes - apenas firmada la Independencia- fueron reconocidos como actores significativos en los movimientos de insurgencia dirigidos por Hidalgo, Morelos y Guerrero. Pero, también identifiqué a los realistas que se unieron al Plan de Iguala, participaron en la proclamación de la Independencia y, más tarde, fueron actores protagónicos del México nacional. Los primeros avances a ese propósito fueron difundidos en 2010. ${ }^{2}$ Dilucidado ese conjunto social, conviene identificar, entre los actores de la Independencia y los constructores de la nación mexicana, a los participantes en las logias masónicas que tuvieron un papel significativo en el devenir político de México. En el presente texto, además de reiterar algunas afirmaciones sobre la Orden Imperial de Guadalupe, ofrezco algunos avances a este propósito.

La historiografía mexicana del siglo XX que podemos calificar como "oficial", porque en mucho fue impulsada y divulgada por el Estado mexicano, puso escasa atención e incluso condenó el pasado hispánico y la concepción de un modelo monárquico para nuestro país. Poco se preocupó por estudiar a la sociedad novohispana que fue testigo del empeño colectivo por lograr la emancipación de la monarquía, y, específicamente, a la sociedad que le correspondió el tránsito al México nacional. La investigación sistemática de la Junta provisional gubernati-

1 Torales Pacheco, María Cristina, Ilustrados en la Nueva España: los socios de la Real Sociedad Bascongada de los Amigos del País, México, Colegio de las Vizcaínas-Real Sociedad Bascongada de los Amigos del País-Universidad Iberoamericana, 2001.

2 Una primera versión de lo mencionado en este artículo fue publicada con el título: "La imperial orden de Guadalupe: Condecorar a los líderes de la Independencia", Historia desconocida. Una aportación a la historia de la Iglesia en la Independencia de México, México, Libro anual 2009. Sociedad Mexicana de Historia Eclesiástica-Editorial Minos III Milenio, 2010, pp. 349-377. 
va, del Primer Congreso Constituyente y del Primer Imperio, son prácticamente asignaturas pendientes en nuestra historiografia. El estudio prosopográfico de quienes fueron condecorados con la Imperial Orden de Guadalupe puede ser un muy buen punto de partida para impulsar los estudios al respecto.

Son numerosos los individuos que recibieron la insignia de la Orden Imperial de Guadalupe que han pasado inadvertidos en la historiografía. La aproximación a cada uno de ellos nos permite apreciar la complejidad y diversidad social e intelectual de quienes configuraron el modo de ser político y cultural del México de la primera mitad del siglo XIX. Su estudio nos permite evidenciar que las grandes diferencias entre éstos explican, entre otros asuntos, la fractura inmediata del grupo luego de la firma del Acta de Independencia, el efímero imperio de Iturbide y la búsqueda de la opción republicana de inspiración anglosajona.

Para comprender esta condecoración hay que reconocer el contexto en el que surgió y la mentalidad de los mexicanos de entonces. Específicamente, debemos tener presente el Regio Patronato vigente durante trescientos años en el reino de Nueva España. Esto nos permite afirmar que, en la mentalidad de los novohispanos recién independizados de la monarquía española, no es posible concebir una separación entre la Iglesia católica y el gobierno monárquico. El corporativismo imperante en la sociedad novohispana, como herencia y tradición hispánica de la sociedad católica, habría que apreciarlo como una fortaleza de la sociedad recién independizada y no como un lastre que impidió la modernidad acorde al modelo liberal del México nacional.

Es obligado reconocer que entre las elites ilustradas novohispanas estaban funcionarios del gobierno, miembros de la jerarquía eclesiástica y el ejército; individuos de la nobleza y muchos de los que poseían los principales medios de producción: comercio, minas y tierra. Especial interés debemos tener en un signo característico de la Ilustración de los individuos de esa época: el aprecio y reconocimiento de su amor patrio.

A diferencia de lo que ha afirmado la historiografia por influencia del liberalismo que privilegió la individualidad sobre la corporatividad, la sociedad novohispana manifestó su comunión con las luces por medio de su ser corporativo. Los novohispanos fortalecieron su cohesión y sentido de cuerpo en su aspiración por el bien público; fomentaron el amor patrio, reconocieron la educación como el camino a la felicidad. Asumieron la práctica de las artes y de las ciencias útiles al servicio de la sociedad y se valieron de una pedagogía de premios y castigos. ${ }^{3}$ Sentido de corporeidad, amor patrio y valoración y reconocimiento del bien público son particularidades de los

\footnotetext{
3 Torales Pacheco, María Cristina, ibidem, caps. 1-3.
} 
Esta obra forma parte del acervo de la Biblioteca Jurídica Virtual del Instituto de Investigaciones Jurídicas de la UNAM www.juridicas.unam.mx

https://biblio.juridicas.unam.mx/bjv

ilustrados novohispanos que nos explican que, apenas firmada el Acta de Independencia, se instituyó la Orden Imperial de Guadalupe.

\section{El OBJETO DE ESTUdiO: LA ORDEN IMPERIAL DE GUADALUPE}

En el presente artículo me propongo reafirmar los antecedentes de la Orden Imperial, el carácter corporativo de la generación que la ostentó, las características de la condecoración y de quienes fueron distinguidos. A manera de conclusión, me refiero a cómo la conciencia y valoración del ser corporativo de esa generación de novohispanos-mexicanos favoreció la inserción de algunos de sus miembros en la masonería. Por los límites de este espacio, no incluyo como anexo la relación de los condecorados, en otro lugar ya la he publicado. Es el punto de partida de un estudio prosopográfico de quienes gestaron nuestra nación y puede también servir como puntal para la identificación de los integrantes de las primeras logias masónicas del México nacional.

La Imperial Orden no debe ser identificada como heredera de las órdenes de caballería de origen medieval que distinguían a la nobleza española por sus servicios en la expansión y defensa de la fe católica. Me refiero a las órdenes de Alcántara, Calatrava, Montesa y Santiago. Tampoco como el punto de partida de la nobleza mexicana del México nacional. ${ }^{4}$ Hay que comprender a la Imperial Orden de Guadalupe como parte de un conjunto de iniciativas de un ilustrado: Agustín de Iturbide, quien, consciente del ser corporativo de la sociedad novohispana, una vez firmada el Acta de la Independencia, propuso a la Junta Provisional Gubernativa la institución de la Imperial Orden de Guadalupe y de la Sociedad Económica Mexicana de los Amigos del País, fundada el 13 de febrero de 1822. La primera, signada por la exaltación de los valores cristianos de sus miembros; la segunda, por la identificación del emperador con los principios de la Ilustración. La primera, para distinguir a quienes habían contribuido a la consolidación de la Independencia. La segunda, para reunir a quienes aportarían, con sus luces y con sus obras, a la construcción de la nación. Aunque ya me he referido en otro lugar a ambas iniciativas, aquí retomo el estudio de la primera. ${ }^{5}$

\footnotetext{
4 Vélez y de Goribar, Joaquín, "La Orden Imperial de Guadalupe”, Divulgación Histórica. Revista mensual ilustrada, año I, núm.9, julio de 1940, pp. 391-395; Zárate, Verónica, "Tradición y modernidad: La Orden Imperial de Guadalupe. Su organización y sus rituales", Historia Mexicana, vol. XLV, núm. 2, 1995, pp. 191-220.

5 Torales Pacheco, María Cristina, ibidem, pp. 349-377 y Artículo en coautoría con Vergara, Luis, "Dos aproximaciones a las rupturas y continuidades en la historiografía torno a la Independencia" en Koprivitza Acuña, Milena; Ramos Medina, Manuel; Torales Pacheco, María Cristina; Urkía y SabinoYano, José María (eds.), Del mundo hispánico a la consolidación de las naciones, Tlaxcala, México, Gobierno del Estado de Tlaxcala, et al., 2010, pp. 417-433.
} 
Esta obra forma parte del acervo de la Biblioteca Jurídica Virtual del Instituto de Investigaciones Jurídicas de la UNAM www.juridicas.unam.mx https://biblio.juridicas.unam.mx/bjv

\section{LOS ANTECEDENTES DE LA CONDECORACIÓN}

Las condecoraciones con las que podemos asociar la Imperial Orden fueron otorgadas en reconocimiento a los servicios específicos a la monarquía, entre otros, la defensa de sus principios de gobierno y de sus territorios. Los vasallos condecorados eran quienes habían actuado en favor de su rey, con la palabra, con la letra impresa, con las armas, etcétera. Entre los méritos que fueron valorados entonces se incluyeron las aportaciones monetarias en favor de la Real Hacienda, en tiempos de guerra o en crisis económicas. Eran condecoraciones para la sociedad en general y no exclusivas para los miembros de la nobleza. Los monarcas las concibieron para distinguir a individuos que, aún lejanos a la Corte, se destacaron por defender los intereses reales.

Debemos estudiar la Orden Imperial como equivalente a las iniciativas de la monarquía española surgidas para distinguir a los vasallos que le manifestaron su apoyo y le ofrecieron sus servicios en favor de sus principios seculares. Entre estas condecoraciones podemos citar aquí la Orden de Armiño. El rey Fernando V la instituyó en 1463 para los vasallos napolitanos que defendieron su territorio en favor de la corona de Aragón. Otra que puede considerarse antecedente de la Orden Imperial de Guadalupe, es la Real y Distinguida Orden Española de Carlos III, instituida el 19 de septiembre de 1771, con motivo del feliz parto del primogénito del Príncipe de Asturias, a quien se le nombró Carlos Clemente Antonio. Con esta orden la monarquía reconoció a los ministros, prelados y miembros de la nobleza; a generales y almirantes, e, incluso, a empresarios que mostraron su identificación con el monarca. Hubo entre los condecorados individuos residentes en la Península Ibérica y en los virreinatos y gobernaciones allende el Atlántico. Para ser distinguido con esta condecoración se exigió a los aspirantes comprobar su limpieza e hidalguía. ${ }^{6}$

Otras condecoraciones que precedieron a la Orden Imperial de Guadalupe fueron las dos órdenes militares españolas reconocidas como "de mérito". La Real Orden de San Fernando, instituida por las Cortes de Cádiz, en su Decreto LXXXVIII de 31 de agosto de 1811. Con ésta, los diputados en Cortes pretendieron reconocer a los militares que se destacaron en la defensa de la monarquía española. Cabe añadir que, restituido en el trono Fernando VII, refrendó la decisión de las Cortes en su Real decreto de 28 de noviembre

6 Constituciones de la Real y distinguida Orden española de Carlos Tercero instituida á 19 de Septiembre de 1771 en celebridad del felicísimo nacimiento del Infante: con la Bula de confirmación, Madrid, Imprenta Real, 1772. 
de 1814, y en esa misma fecha instituyó la Real y Militar Orden de San Hermenegildo. ${ }^{7}$

Para los vasallos americanos, Fernando VII instituyó la Real Orden de Isabel la Católica, el 24 de marzo de 1815. Con ella se propuso rendir homenaje a dos mujeres: Isabel la Católica, quien impulsó la expansión castellana hacia el Atlántico, y Santa Isabel, reina de Portugal, quien restableció "la unión y buena armonía" en la Corona de Aragón. La Real Orden quedó bajo la protección espiritual de esta santa. El monarca solicitó el reconocimiento de esta condecoración por el papa Pío VII, quien la aprobó el 26 de mayo de 1816. En sus orígenes, hubo tres clases de miembros: Grandes Cruces, comendadores y caballeros. Esta insignia no era sólo para la nobleza; así, los candidatos no estuvieron obligados a presentar pruebas de nobleza "por extenderla a todos los que la merezcan," por sus "servicios personales y no de sus ascendientes". Sólo quedaron excluidos quienes hubieran sido procesados por haber cometido algún delito. ${ }^{8}$ Lucas Alamán advierte en su Historia de México que la distribución de esta condecoración en Nueva España fue "motivo de censura y disgustos", entre otras razones, porque se les concedió primero a funcionarios residentes en España y, de los primeros que fueron reconocidos en la capital mexicana, sólo uno era americano. $^{9}$

Para el propósito de este artículo, conviene recordar que en 1816, la $G a-$ ceta del Gobierno de México había dado noticia de cómo el 19 de marzo se había llevado a cabo la ceremonia para el ingreso de los primeros condecorados en Nueva España: el teniente coronel y alcalde ordinario Diego Fernández Peredo; el teniente coronel Tomás Ramón de Ibarrola; el coronel Manuel de Urquiaga; el teniente coronel conde de la Cortina, y el capitán José María Yermo criollo, hijo del empresario Gabriel de Yermo, todos ellos importantes empresarios. La ceremonia la había presidido el virrey Félix María Calleja, reconocido como "Canciller nato". ${ }^{10}$

También la Gaceta dio la noticia de que el 5 de julio, en la sala del Consulado de la Ciudad de México, los caballeros, conforme a Estatutos, habían celebrado la erección de la Asamblea Provincial, la cual había presidido el Comendador más antiguo, Fernández de Peredo, entonces alcalde ordinario de

7 "La Real Orden de San Fernando", Asociación de Amigos de la Defensa del Alcázar de Toledo y del Museo del Ejército, 7 de octubre de 2017, http://elalcazarorg/rosf.htm. "Orden de San Hermenegildo", Reales y Militares Órdenes, 7 de octubre de 2017, http://wwre.rmo.mde.es/ordensherme/historia..

$8 \quad$ Institución de la Real Orden Americana de Isabel la Católica, Madrid, Imprenta Real 1815, artículo 9 .

9 Alamán, Lucas, Historia de México, México, Jus, 1990, t. 5, p. 294.

10 Sus nombres fueron publicados en la Gaceta de México el 23 de marzo de 1816. 
la Ciudad de México. En esta reunión el también comendador José Mariano Beristáin, caballero de la Orden de Carlos III, deán de la Catedral y autor de la Biblioteca Hispano-americana, fue nombrado secretario, y Manuel de Urquiaga, ${ }^{11}$ maestro de ceremonias. Los caballeros hicieron pública la asamblea con el propósito de que quienes aspirasen a la Cruz de la Real Orden enviaran sus solicitudes. ${ }^{12}$ Esta convocatoria tuvo efecto entre numerosos novohispanos. Aquí cito como ejemplo a dos miembros de dos generaciones de una familia: Francisco Ignacio de Yraeta y Gabriel de Yturbe. Ambos comerciantes, miembros del Consulado de la Ciudad de México, fueron distinguidos como caballeros de la Orden de Carlos III. Ya difuntos, Gabriel Manuel de Yturbe Yraeta -hijo del segundo y nieto del primero- decidió enviar sus documentos y solicitud directamente a su tío, el general Gabriel María de Mendizábal, residente en Madrid, para que éste, con sus relaciones en la Corte, lo recomendara ante el monarca. El 8 de enero de 1817, le escribió, en respuesta a dos de sus misivas. Nos interesa la respuesta a la primera:

Veo por la $1^{a}$ que le había parecido bien mi ánimo de que llegasen a noticia de su majestad mis cortos méritos, y las solicitudes que había hecho para el grado de Teniente Coronel, y las cruces de Carlos $3^{\circ}$, y de doña Isabel la Católica, y que esperaba fuese yo comprendido en alguna de ellas cuando llegase nuestra reina a casarse. ${ }^{13}$ Por tanto favor, y por su eficacia, le quedo a vuestra merced sumamente reconocido, esperando que con su influjo se logre: y ojala fuese el grado de Teniente Coronel, que es lo que más me gusta: Sirviéndole de gobierno que desde junio último soy Capitán efectivo. ${ }^{14}$

Las gestiones tuvieron éxito, Gabriel Manuel obtuvo lo que prefería: fue ascendido a Teniente coronel. Se sabe que, meses después, su primo y cuñado, José María Icaza, envió sus papeles para obtener la condecoración de la Orden de Isabel la Católica. La madre de Gabriel Manuel y suegra de José María, Margarita de Yraeta, le escribió al General Mendizábal pidiéndole su intervención:

11 Albacea y heredero del capitán José de Oria, poseedor de un obraje de Cansinos en la plazuela de Vizcaínas. Acta de Cabildo de la Ciudad de México, 22 de julio 1791 y solicitó una carta de méritos y servicios, 16 de septiembre de 1816. Véase Torales Pacheco, María Cristina (dir.), "Guía de las Actas de Cabildo", La Ciudad de México. Su representación gráfica y visual, en wrere.bib.uia.mx.

12 Gaceta de México, México, t. VII, núm. 92, 18 de julio de 1816, pp. 699 y 700.

13 María Isabel de Braganza. Nació en 1797. Segunda esposa de Fernando VII, con quien contrajo matrimonio en 1816. Murió durante un parto en 1818.

14 Carta de Gabriel Manuel de Yturbe a Gabriel María de Mendizábal residente en Madrid, 8 de enero 1817. UIA, A.C. 2.1.52 fs. 196v.-197r. 
Mi muy estimado primo: Don José María de Ycaza, casado con mi hija mayor María Josefa, manda en esta ocasión los documentos más completos en apoyo de la solicitud que hace a su majestad, como instruirá por extenso la persona que pondrá ésta en manos de vuestra merced; y amándolos tiernamente como hijos acreedores a todo mi cariño, me intereso, como madre, en que tengan efectos sus deseos, por el bien que a ellos, y a sus hijos, mis nietos, les resulta: Pero no debiendo confiar tanto en los méritos y servicios que expone, cuanto en el poderoso influjo de vuestra merced, no dudo que tendrán su complemento, tomando vuestra merced por suya la pretensión, como lo espero de su favor, y pruebas inequívocas que le debemos de su singular afecto. ${ }^{15}$

Sobra decir que en México hubo numerosos individuos que, al haber contribuido a salvaguardar los derechos de la monarquía en Europa y en Nueva España, aspiraron a la Real Orden de Isabel la Católica, más acorde con el espíritu de la Ilustración que de la tradición, ya que fue propio del pensamiento de las luces distinguir a los individuos por sus virtudes en favor del bien público.

\section{OBJETIVOS DE LA ORDEN IMPERIAL DE GUADALUPE}

Bien conocidas eran para Iturbide las condecoraciones mencionadas. Algunos de sus contemporáneos, como lo fueron el obispo de Oaxaca, Antonio Bergoza y Jordán y el deán de la arquidiócesis de México, José Mariano Beristáin, habían sido distinguidos por la Real Orden de Carlos III y más tarde con la Real Orden Americana de Isabel la Católica.

Otros de ellos eran parientes o profesaban amistad con quienes habían colaborado en la guerra por la independencia de la Península Ibérica y por sus hazañas habían sido distinguidos con las órdenes militares de San Fernando y San Hermenegildo. Un ejemplo a este respecto es el ya citado general Gabriel María de Mendizábal, primer conde de Cuadro de Alba de Tormes, quien fue sobrino del ya citado comerciante Francisco Ignacio de Yraeta y primo del sucesor de su casa mercantil, Gabriel de Yturbe. Sobra decir que Yraeta e Yturbe tuvieron una relación estrecha con las familias vallesolitanas Iturbide y Huarte.

Iturbide, los miembros de la Junta Provisional Gubernativa, los integrantes de la Regencia y los del Primer Congreso Constituyente, en congruencia con el principio de procuración por el buen patriota, se propusieron premiar

15 Carta de Margarita de Yraeta a Gabriel María de Mendizábal residente en Madrid, 16 de enero de 1818, Universidad Iberoamericana, A.C. 2.1.52 f. $236 \mathrm{v}$. 
a quienes se distinguieron por su adhesión al Plan de Iguala y actuaron con las armas y con sus luces a su instrumentación. Aproximarnos a los condecorados con la Orden Imperial nos permite identificar al grupo rector que consolidó la Independencia y a la generación responsable de la construcción de México como nación independiente. Agustín de Iturbide (1783-1824) fue quien tuvo la iniciativa y se convirtió en el gran maestre de la Orden Imperial, así quedó asentado en los Estatutos. ${ }^{16}$

Natural de Valladolid Michoacán, Iturbide creció en un ambiente y en una familia de cara a la Ilustración. Su padre, Joseph Joaquín de Iturbide y Arregui, era poseedor de varias haciendas en la diócesis de Michoacán. El suegro de Iturbide, Isidro Huarte, se distinguió como el más poderoso mercader de la ciudad de Valladolid. Ambos dejaron huella de su identificación con las luces porque, además de registrarse como miembros de la Real Sociedad Bascongada de Amigos del País - primera sociedad ilustrada surgida en la Península Ibérica-, tuvieron un papel protagónico en las iniciativas, inspiradas en esta Sociedad, orientadas a procurar el bien del público. Específicamente, apoyaron a los más desvalidos durante la crisis agraria que tuvo lugar en el centro del territorio, en el periodo 1784-1785. Seguramente gracias a ellos Iturbide valoró los propósitos de esa corporación ilustrada, la cual, entre otros valores cívicos, fomentaba el amor patrio. En 1822, el emperador haría público su aprecio y respeto a ambos, al distinguirlos con la Gran Cruz de la Orden Imperial de Guadalupe.

A dos meses de firmada el Acta de Independencia, la Junta soberana, en su sesión del 7 de diciembre de 1821, otorgó a Iturbide la facultad para crear la Orden Imperial, la cual fue instituida por la Junta el 18 de febrero de 1822. Un día después, Iturbide entregó a la Junta los estatutos de la orden, los cuales fueron aprobados el 20 de febrero y estuvieron sujetos a lo que resolviera el Soberano Congreso Nacional que habría de instalarse para "fijar eternamente la gloria y felicidad de la nación".

La Junta Soberana, integrada por José María Fagoaga como presidente y como vocales secretarios, José Ignacio García Illueca, el sacerdote Isidro Ignacio de Icaza y el licenciado José María de Jáuregui, en el decreto de aprobación manifestó que:

[...] ha tenido la consideración debida al verdadero mérito, y acciones magnánimas con que muchos dignos hijos de este suelo se distinguieron con su valor, talento y virtudes cívicas, para conseguir la grande obra de su emanci-

16 Estatuto de la Imperial Orden de Guadalupe que propuso a S.M. la Suprema funta Provisional Gubernativa del Imperio, para su aprobación el Generalísimo Almirante. 
pación, y cimentar las bases de la felicidad pública, consolidando un gobierno moderado, equitativo y justo, que conduzca al más alto grado la prosperidad de todos los ciudadanos y la general del Imperio[...

El 21 de febrero de 1822, la Regencia del Imperio, gobernadora interina, dispuso que se guardara, cumpliera y ejecutara el decreto de la Junta así como que se imprimiera, publicara y circulara. Cabe recordar aquí a los miembros de la Regencia: Iturbide como presidente, Manuel de la Bárcena, arcediano y gobernador del obispado de Michoacán; José Isidro Yánez, oidor de la Audiencia de México; Manuel Velásquez de León, quien había sido secretario del Virreinato; Antonio Joaquín Pérez, obispo de Puebla, y José Domínguez. Para entonces ya había fallecido Juan O’Donojú, aunque se le consideró post mortem miembro de la Regencia.

La Imperial Orden tendría "el objeto exclusivo de premiar el valor y las virtudes de aquellos que todo lo sacrificaron por elevar á la Patria al alto rango que hoy obtiene, y que se dedicaren en lo sucesivo a contribuir á sus glorias y esplendor".

El 11 de junio de 1822, el vicepresidente del Congreso Constituyente, Mariano Marín, y los diputados secretarios, Bonifacio Fernández y Juan de Dios Rodríguez, firmaron el Decreto que confirmó el de la recién extinguida Junta Provisional Gubernativa, sancionado también por decreto de la Regencia, en el que se aprobó la Imperial Orden y sus Estatutos.

El 13 de junio, se mandó dicho decreto "a todos los tribunales, Justicias, Gefes, Gobernadores y demás Autoridades así civiles como militares y eclesiásticas", para que lo guardaran, lo hicieran cumplir y ejecutar. Asimismo, se dispuso que dicho decreto se imprimiera, publicara y circulara. El 25 de julio de 1822, finalmente fueron publicados en la Gaceta Imperial los nombres de quienes habrían de ingresar a la Imperial Orden de Guadalupe.

El primer artículo del estatuto nos revela que la constitución de la condecoración tuvo una intencionalidad histórica: preservar en la memoria "las glorias" de los ancestros. En los Estatutos, la Condecoración se propone como un documento histórico de "la época de la libertad mexicana". La Imperial Orden fue signada con el nombre de "La madre de Dios de Guadalupe", porque, además de haber sido declarada protectora del Imperio, se reconoció como la devoción que profesaban los mexicanos y era el signo de su unidad.

Las palabras que debieron expresar todos los condecorados con la Imperial Orden son reveladoras de la mentalidad imperante en una época en la que los fines de la religión católica y los del gobierno estaban estrictamente asociados. En el juramento se exalta la religión católica, la libertad, la inde- 
pendencia de la nación y la unión de sus habitantes. Se demanda a sus miembros, fidelidad y obediencia, así como servicio a quienes dirigen:

¿Juráis vivir y morir en nuestra Sagrada Religión Católica, Apostólica, Romana, defender la Constitución del Estado, la persona del Emperador mientras se sujete a ella, la libertad e independencia absoluta de la Nación, la Unión de los habitantes del Imperio, no emplearos jamás, directa ni indirectamente contra tan sagrados objetos; obedecer las disposiciones del Gran Maestre y de la Asamblea, en lo que manden arreglado a Estos Estatutos; servir bien y fielmente al estado y a los que lo dirigen en cuanto tengan relación con la felicidad pública y cumplir exactamente los Estatutos de la Orden en que se comprende la íntima devoción a su Patrona? Sí juro. Si así lo hiciereis Dios os lo premie, y si no os lo demande.

En los estatutos quedaron establecidas las tres celebraciones religiosas de la Imperial orden, a las cuales deberían asistir los condecorados. El día de la Virgen de Guadalupe se celebraría una misa solemne con sermón; el 2 de marzo - aniversario del pronunciamiento del Plan de Iguala- y el día de difuntos, debería haber misa solemne.

En los estatutos se delimitó el número y calidad de miembros. La orden podría tener 50 individuos designados Grandes Cruces, 100 numerarios y el número ilimitado de los supernumerarios, los cuales deberían ser designados por el Gran Maestre. Los individuos que formaran parte de la orden deberían ser "ciudadanos" del Imperio, tener como mínimo 25 años de edad, ser cristianos, apostólicos, católicos romanos; "gozar de concepto público", y haber contribuido al Estado con sus servicios distinguidos. Sólo podrían estar exentos de cumplir estos requisitos los reyes y príncipes extranjeros que fueran honrados.

Como fue común en la época, la distinción de estas categorías se hizo mediante las insignias. Los Grandes Cruces ostentaban la "gran banda trigarante" unida con una cinta también trigarante de la que pendía la insignia. Además, se les entregaba una placa de oro de la misma forma de la cruz, con los colores verde, blanco y rojo esmaltados. Al centro, en una elipse esmaltada de color esmeralda, estaba colocaba la imagen de la Virgen de Guadalupe. En la parte superior, tenía la corona sostenida por las garras de un águila. Bajo ésta una palma y una rama de olivo, símbolos de la dulzura y de la paz. Además, debía aparecer escrito el lema: Religión, independencia y unión. La insignia también debería incluir la frase: Al patriotismo heroico.

Los numerarios se distinguían llevando en el cuello la cruz, y bordada la insignia sobre su casaca. Los supernumerarios sólo tenían pendiente del ojal 
Esta obra forma parte del acervo de la Biblioteca Jurídica Virtual del Instituto de Investigaciones Jurídicas de la UNAM www.juridicas.unam.mx

la cruz sin el águila. Los estatutos asentaron con detalle las características de las insignias para cada miembro, quiénes podían serlo y el número de eclesiásticos que podrían ingresar en la orden. Para el gobierno de la orden, se dispuso un gran Canciller, un secretario y un tesorero. Asimismo, se consideró la importancia de contar con recursos económicos para los gastos de la orden, tales como la factura de las insignias, erogaciones relativas a las celebraciones religiosas, edificios y alhajas para "el decoro y servicio de la Orden", etcétera. Para ese propósito, los Grandes Cruces aportarían 500 pesos; 200 pesos los numerarios y 100 los supernumerarios.

¿A quiénes se les condecoró? La lista de quienes fueron distinguidos como miembros de la Orden Imperial nos revela el orden social estamentario reconocido al momento de la consolidación de la Independencia. Iturbide, como Gran Maestre, tuvo el privilegio de incorporar a la lista de Grandes Cruces, entre otros, a su padre, SS.AA., el príncipe del Imperio, y a sus tres hijos el Príncipe de la Unión, y los príncipes mexicanos Ángel y Salvador. Cabe mencionar que también se le otorgó la insignia de Gran Cruz al padre de la emperatriz, el empresario vallisoletano Isidro Huarte. En calidad de numerarios fueron incorporados José Ramón Malo e Iturbide, sobrino del emperador, y Ramón Huarte, intendente de Valladolid y después de la independencia, jefe superior político de Michoacán.

De la jerarquía católica, en calidad de Grandes Cruces fueron incorporados los doctores Juan Ruiz Cabañas, obispo de Guadalajara; Joaquín Antonio Pérez, obispo de Puebla; Manuel Isidro Pérez, obispo de Oaxaca; fray Ramón Casaus, arzobispo de Guatemala y fray Nicolás García, obispo de Nicaragua.

En la relación de Grandes Cruces aparecen -después de los jerarcas de la Iglesia- los Secretarios de Estado del Imperio, hombres de confianza de Iturbide: José Manuel de Herrera, del Despacho Universal de Relaciones Interiores y Exteriores; José Domínguez, del Despacho Universal de Justicia y Negocios Eclesiásticos; Manuel de la Sota Riva, del Despacho Universal de Guerra; Antonio Medina, del Despacho Universal de Hacienda.

Sigue en la lista de Grandes Cruces la jerarquía militar y los consejeros de estado: Pedro Celestino Negrete, Decano del Consejo de Estado y Teniente General de los Ejércitos Imperiales; Anastasio Bustamante, Capitán General de Provincias Internas; Luis Quintanar, Capitán General Interino de la Provincia de México; Domingo Estanislao Loaces, Capitán General de la Provincia de Puebla; Vicente Guerrero, Capitán General en el rumbo del Sur; Alejo García Conde, General de División; Melchor Álvarez, Capitán General de Mérida, y Miguel Cavaleri, Intendente del Ejército. Los Consejeros de Estado fueron el alférez real José Mariano Almanza, Manuel 
Esta obra forma parte del acervo de la Biblioteca Jurídica Virtual del Instituto de Investigaciones Jurídicas de la UNAM www.juridicas.unam.mx https://biblio.juridicas.unam.mx/bjv

Velázquez de León, miembro de la Regencia; el arcediano de la diócesis de Michoacán, Manuel de la Bárcena, y Pedro del Paso y Troncoso.

Como Grandes Cruces se incorporó a los más importantes títulos nobiliarios del virreinato: el Conde de San Mateo Valparaíso, III conde de Jaral de Berrio,Juan Nepomuceno Moncada, reconocido como "Gentil Hombre de S. M.”; el Marqués de Vivanco, quien era inspector general de Caballería; José Morán y del Villar, esposo de la tercera marquesa; III Conde de Regla, Pedro José Romero de Terreros, quien era el "Caballerizo Mayor del emperador"; V Marqués de San Miguel de Aguayo, José María Valdivieso y Vidal de Lorca, quien fungía como mayordomo mayor; VII Marqués de Salvatierra, Miguel María Gómez de Cervantes Capitán de la Guardia de S.M., y, de la misma familia, José María Cervantes, ayudante del Emperador; en esa misma calidad, el primo de Iturbide, Domingo Malo de Iturbide; el XIV Mariscal de Castilla, Gentil Hombre de Cámara, Francisco de Paula Gorráez y Beaumont; el II Conde de la Casa Heras, Manuel María Heras y Soto; el VIII Marqués del Villar del Águila, Juan Antonio Fernández de Jáuregui, y el Marqués de Aicinena.

Como signo de reconocimiento a su sustantiva participación en la consolidación de la Independencia, se condecoró como Gran Cruz a Juan O'Donojú, quien - como ya he dicho- había fallecido. Sumados a éstos, fueron distinguidos el Marqués de Aicinena, empresario mercantil de Guatemala y Manuel del Campo y Rivas, Decano de la Audiencia Territorial.

Referirnos a los numerarios y supernumerarios rebasa los límites del presente texto. No obstante, conviene hacer referencia a algunos de los brigadieres del ejército imperial, porque algunos de ellos tuvieron un papel protagónico en los espacios políticos, durante la primera mitad del siglo XIX. Me refiero a Antonio López de Santa Anna, de quien sobra mencionar aquí su importancia y controvertida participación política, y a numerosos militares que colaboraron estrechamente con él. Entre otros, Vicente Filisola, quien después de participar en la guerra de Texas, culminó su carrera militar como Presidente del Supremo Tribunal de Guerra. Nicolás Bravo, destacado insurgente, quien, además de Brigadier, fue Consejero de Estado de Iturbide, así como miembro de la Junta del Poder Ejecutivo hasta el nombramiento de Guadalupe Victoria como presidente; asimismo, Santa Anna lo nombró Jefe del Ejército del Norte y fue presidente interino en 1839, 1842 y 1846, y participó en el combate a los estadounidenses, como Comandante General de Puebla. José Antonio Echavarri, quien fue enviado a combatir a Santa Anna en 1823, se unió a él, y en 1827 fue desterrado porque se le reconoció entre los conspiradores del padre Arenas. Joaquín Parres, gobernador del Estado de Jalisco y nombrado, en 1833, Ministro de Guerra y Marina. Miguel 
Esta obra forma parte del acervo de la Biblioteca Jurídica Virtual del Instituto de Investigaciones Jurídicas de la UNAM www.juridicas.unam.mx

https://biblio.juridicas.unam.mx/bjv

Barragán, quien fue nombrado Ministro de Guerra por Santa Anna - cabe mencionar que éste lo dejó como presidente interino en un breve periodo 1835-1836-. José María Calderón, gobernador interino y más tarde Constitucional del Estado de Puebla. Manuel Rincón, quien, entre otros cargos, fue Secretario de Guerra, Gobernador de Veracruz, Presidente del Superior Tribunal Militar, Segundo Jefe del Ejército de Oriente durante la invasión estadounidense y Comandante General de México.

Podemos afirmar aquí que, de una primera aproximación prosopográfica, observamos que el Congreso y el emperador no se limitaron a condecorar a un grupo homogéneo. En la relación de miembros podemos apreciar la diversidad ideológica, social y económica de los condecorados. Eligieron individuos vecinos en distintas partes del territorio, e incluso, hubo interés por incorporar a algunos europeos que se distinguieron por su liderazgo intelectual. Ejemplo de éstos es Andrés Manuel del Río, mineralogista, quien representó a Nueva España en las Cortes en 1820, quedó a cargo de la dirección del Colegio de Minería cuando Fausto Delhúyar retornó a Europa y, al tiempo que lo condecoraron, fue reconocido como Introductor de Embajadores. Del estudio prosopográfico, podemos afirmar que, entre los condecorados, identificamos a los más relevantes actores políticos del Virreinato y a quienes participaron activamente en el México nacional de la primera mitad del siglo XIX, tanto los que se distinguieron por su convicción monárquica como los que más tarde optaron por el modelo republicano.

\section{EPÍLOGO: A PROPÓSITO DE LA MASONERÍA}

La Imperial Orden de Guadalupe fue efimera. A la caída del Imperio, esta corporación, asociada con Iturbide, con la jerarquía eclesiástica y con los altos mandos del gobierno, entre otros, fue cancelada. No obstante, la cohesión de muchos de los individuos que habían sido condecorados, sirvió como punto de partida para la formación de las logias masónicas en los primeros años del México nacional.

Para concluir, conviene dirigir nuestra atención a la mentalidad de quienes, condecorados con la Imperial Orden de Guadalupe y bajo el juramento de profesar la fe católica y promover la veneración a la Guadalupana, se inscribieron a las logias masónicas y difundieron su filosofía. Procede a este propósito, aproximarnos a dos libros: el primero, denominado El Monitor ó Guía de los franc-mazones utilísimo Para la Instrucción de sus Miembros é información de los que desean imponerse en sus principios. Escrito en inglés por un Franc-mazon, y traducido al Castellano. La edición de Nueva York no menciona el nombre del autor, 
pero sí nos informa que se hizo a costa del impresor Joseph Desnoues, de E. Bliss y E. White. En cambio, la edición publicada en la ciudad de Filadelfia, por H.C. Carey \& I. Lea, nos revela en el título quién fue su autor: El Monitor de los masones libres ó Ilustraciones sobre la masonería por Tomas Smith Webb, gran maestro pasado de la Gran Logia de Rhode Island, traducido del inglés al español. Estas ediciones, nos dejan ver cómo, mediante su patrocinio, los masones estadounidenses manifestaron el interés por sumar a los iberoamericanos a las filas de la masonería. Cabe mencionar que, hacia 1860, el texto se continuaba publicando en español. (Argentina). Podemos asegurar que quienes se propusieron difundir la obra, lo lograron. Tenemos certeza de que en México fue difundida. Los ejemplares consultados son testimonio de esto. El publicado en Nueva York ${ }^{17}$ fue de Francisco Tijerina, diputado propietario del primer Congreso constituyente del estado de Nuevo León, en 1824. ${ }^{18}$ La edición de Filadelfia incluye manuscrito lo siguiente: "Del H :. C:. De O.. Y O.. Patria".

Una primera lectura de la edición de Nueva York es reveladora de las aspiraciones de los francmasones al tiempo de la consolidación de nuestra independencia. El Prefacio inicia:

Los hombres todos nacemos hermanos: y la diferencia de las lenguas que hablamos, de las ropas que vestimos, del país que habitamos, y del puesto en que nos hallamos colocados, es puramente accidental y de ningún momento; pues el mundo entero no es más que una gran república, de la cual cada nación es una familia, y cada individuo un hijo: hallándose todo dispuesto por el grande y sapientísimo Arquitecto del Universo con el más exacto orden, con el más igual peso, con la más regular medida y con la más dulce y agradable armonía.

Entre las cualidades que, entonces, debería tener un francmasón advierte:

Si la honradez no es solo una prenda sino también una virtud, y si en la caridad de los demás hombres benignos influjos; todos somos interesados por lo que participamos de sus benignos influjos; el franc-Mazon es desde luego uno de los individuos más útiles de la sociedad, siendo sus principales obligaciones, Confiar en Dios, desconfiar de si mismo, ser diligente, contentarse con poco, huir de la grandeza, no hablar mucho, decir verdad, guardar secreto; ser tratable a los inferiores, sumiso a los superiores, fiel a los amigos e indul-

17 Los ejemplares se conservan en el Área de Acervos Históricos de la Universidad Iberoamericana, Ciudad de México.

18 Véase Galindo, Benjamín, El Provincialismo Nuevoleonés en la época de Parás Ballesteros, Monterrey, Universidad Autónoma de Nuevo León, 2005. 
gente a los enemigos, sufrir el mal, no mezclarse en los negocios ajenos, vivir para Dios, aprender á morir para el mundo, e imitar al ser supremo en la beneficencia. Tales son los principios que inculca el Instituto Franc-Mazónico; cuyas cualidades características están fundadas en las tres sublimes virtudes Fe, Esperanza y Caridad.

El autor concluye advirtiendo que el libro servirá a "la ilustración pública", sobre una materia de la que "tanto se ha hablado y escrito sin conocerla". Su lectura habría de permitir a quien la leyera comprender que "un Franc-Mazon es uno de los miembros que más honor hace á la sociedad".

A manera de hipótesis, puedo afirmar que comulgaron con los principios y valores expuestos en este libro numerosos ilustrados, habitantes de los territorios de la monarquía hispánica a finales del siglo XVIII, y también, con certeza, algunos miembros de la Orden Imperial de Guadalupe. Confirmar estas afirmaciones nos obliga a construir las nóminas de los integrantes de las logias masónicas de la primera mitad del siglo XIX, lo cual es un reto pendiente para los historiadores dedicados al estudio del México como nación independiente.

Aquí sólo damos un paso a este propósito. Vicente Guerrero, en su calidad de "Capitán General en el rumbo del Sur"; Anastasio Bustamante, Capitán General de las Provincias Internas, y José Manuel Herrera, Secretario de Estado del Despacho Universal de Relaciones Interiores y Exteriores de Iturbide, fueron distinguidos con la Gran Cruz de la Imperial Orden de Guadalupe, y, unos años más tarde, podemos identificarlos como entusiastas promotores de la masonería en el rito de York. Al coronel Manuel Gómez Pedraza y a Miguel Ramos Arizpe, también distinguidos con la Imperial Orden, los identificamos como activos miembros y promotores del rito escocés.

En una carta 19 "fechada en el Oriente de México, el 2 de $2^{\circ}$. Mes del año mazónico [sic.] de 5826 [era cristiana] 2 de abril de 1826, el gran maestre Lorenzo de Zavala y como gran secretario José Antonio Mejía de la M.: R.: G.: L.: N.: M.: se dirigieron a los hermanos masones del capítulo No. $1^{\circ}$, con el distintivo de La libertad, en respuesta a la comunicación en la que habían informado de la instalación y grandes progresos de la masonería del rito de york $[\ldots]$ y no puede menos que prometerse un porvenir alagueño $[\ldots]$ al considerar esa corporación en donde sin dependientes serán recompensados de su celo y eficacia en los trabajos". Cinco meses más tarde, el 27 de octubre del mismo año, Zavala como gran maestre y, para esa fecha, José Manuel Herrera en calidad de secretario, certificaron cómo por "escrutinio

19 Este documento y los siguientes citados forman parte de la colección del maestro Salvador Sotomayor, a quien agradezco que me haya permitido consultarlos y citarlos. 
secreto" y a "pluralidad absoluta" en la junta en la que asistieron 11 miembros de la logia se nombró a José Teurbe Tolón, Isidro Gondra y José María Aréchaga para visitar e inspeccionar las logias que se habían fundado en el Oriente. Éstos habrían de observar la "fuerza y arreglo de cada una, así como de la uniformidad y regularidad de sus trabajos". Todo esto necesario para "mantener el orden y asegurar el honor y lustre de nuestra fraternidad". Este nombramiento es testimonio de la proliferación de las logias del rito de York.

Un año después, Guerrero y Bustamante tenían a su cargo la Gran Logia de Oriente, el primero, Gran Maestre, y el segundo, secretario. El 3 de mayo de 1827 (3 días del 3er. Mes del año luminar de 1827), Guerrero, como Gran Maestre, le confirió poder al diputado Santiago Abreu, quien más tarde habría de ser Gobernador de Nuevo México, para que procediera a la instalación de la Logia 54, distinguida con el nombre de Apoteosis de Hidalgo, en el Oriente de Chihuahua.

El año masónico de 5828 (1828), José Manuel Herrera y José Manuel Palomino, integrantes de la comisión para "entender en el importante asunto de las elecciones de presidente y vicepresidente de la República", escribieron varias misivas dirigidas a los masones de la logia "A:. L..R:.L:. No. 54, nombrada Apoteosis de Hidalgo, en el Orte. de Chihuahua". La primera carta fue fechada el día 15 de mes 5o., en ésta expresaron cómo convenía al país que en las próximas elecciones votaran los hermanos masones por Vicente Guerrero para presidente, y para vicepresidente, eligieran entre los ciudadanos Anastasio Bustamante y José Ignacio Esteva, entonces Ministro de Hacienda. Advirtieron que no consideraran en la votación al entonces presidente Guadalupe Victoria ni a Manuel Gómez Pedraza. Al primero porque su postulación era anticonstitucional y al segundo, porque "no tiene a la verdad un mérito superior" a Bustamante y a Esteva, y en adición a ello, "habiendo pertenecido notoriamente al escocés sabemos a no poder dudarlo que mira con aversión positiva a nuestras sociedades patrióticas y que por consiguiente, elevado al Primer puesto de la Nación, trabajaría sin descanso para exterminarlas. Ya le hemos visto dictar providencias muy desfavorables a los Yorkinos, lo mismo que decir a la causa de la Patria, al paso que protege las misas siniestras de los escoceses, enemigos de nuestras libertades". Añadieron también que una gran sección de escoceses "o mejor enemigos de nuestra federación", trabajaban para llevar a la silla presidencial a Gómez Pedraza. Por ello se preguntaban:

$¿ \mathrm{Y}$ hemos de auxiliar nosotros esas maniobras? ¿Y no hemos de emplear todos nuestros esfuerzos para contrariarlas? Es pues de absoluta necesidad que no perdonemos medida ni diligencia que no contravenga a las leyes para 
concentrar los votos de los Estados en los patriotas Bustamante y Esteva que hemos designado para que cualquiera de los dos sea nombrado en unión del general Vicente Guerrero."

En otra epístola firmada el mismo día 15 del 5o. mes y dirigida también a la Logia Apoteosis de Hidalgo, Herrera y Palomino manifestaron cómo los enemigos, para impedir que las legislaturas de los estados votaran por Vicente Guerrero como segundo presidente de la República, decidieron difundir en las legislaturas de los estados que "aquel patriota digno de eternizarse para consuelo y gloria de los mexicanos" había fallecido. Les propusieron que no se dejaran sorprender y les comunicaron:: "el Gral. Guerrero disfruta buena salud y cada vez se retardan y debilitan los ataques que suele padecer de resultas de la última herida que recibió en defensa de la Patria".

El 19 del mismo mes 5o. del año masónico de 5828, Herrera y Palomino, manifestaron cómo Miguel Ramos Arizpe, junto con otros individuos, aspiraba que las legislaturas de los estados votaran para la presidencia de la República en favor del Ministro Manuel Gómez Pedraza, miembro del partido escocés. Contrarios a ese propósito, solicitaron a los masones de la Logia Apoteosis de Hidalgo que impidieran que en Chihuahua prosperaran las "intrigas de Ramos Arizpe".

Conviene decir que Gómez Pedraza y Ramos Arizpe también habían sido condecorados con la Orden Imperial de Guadalupe. No obstante que en las elecciones fue electo presidente Gómez Pedraza, sabemos que Lorenzo de Zavala y José María Lobato, brigadier del Ejército - este último también años antes condecorado con la Orden Imperial- le impidieron tomar posesión de su cargo y, en cambio, apoyaron a Vicente Guerrero como presidente sucesor de Guadalupe Victoria.

Estas epístolas son un testimonio de cómo, desde los primeros años del México independiente, los actores de la consolidación de Independencia que fueron condecorados con la Orden Imperial estaban divididos ideológicamente, pero también nos devela cómo las logias masónicas tuvieron un papel sustantivo en el devenir político nacional desde las elecciones para elegir al segundo presidente de la República y acentuaron las divisiones e incluso las fracturas entre quienes consolidaron la Independencia. 


\title{
IGLESIA CATÓLICA Y MASONERÍA. LAS GONDENAS PONTIFICIAS
}

\author{
Emilio MARTÍNEZ ALBESA*
}

\begin{abstract}
SUMARIO: I. Masonería y cristianismo. II. Las condenas pontificias prerrevolucionarias del asociacionismo masónico. Siglo XVIII. III. Las condenas pontificias de la conspiración masónica. Primera mitad del siglo XIX. IV. Las condenas pontificias por incompatibilidad de principios. Segunda mitad del siglo XIX. V. La censura de la masonería en los dos códigos de derecho canónico del siglo XX. VI. La masonería en el juicio y en la actitud de la Iglesia de hoy. VII. Bibliografia.
\end{abstract}

\section{MASONERÍA Y GRISTIANISMO}

\section{Acercamiento al fenómeno masónico}

En un tiempo convulso y de transformación, como lo es también el actual, el pensador de la insurgencia mexicana Carlos María de Bustamante, considerando que las logias masónicas proyectaban difundir en la nación "la indiferencia y menosprecio hacia la religión verdadera" contra el sentimiento general del pueblo, ${ }^{1}$ escribía con orgullo en 1838 que no se hacía masón "[porque] soy cristiano C. A. [Católico Apostólico] Romano, y no más que ciudadano mexicano, y no quiero ser más". ${ }^{2}$ Pero, entonces, ¿qué es la masonería?, ¿es inconciliable con el catolicismo?

* Ateneo Pontificio Regina Apostolorum.

1 Bustamante, Carlos María, Análisis crítico de la constitución de 1836, México, 1842, pp. 30 y 31, citado en Martínez Albesa, Emilio, La Constitución de 1857. Catolicismo y liberalismo en México, tomo II: Del nacimiento de la República a la guerra con los Estados Unidos, 1823-1848, México, Porrúa, 2007, pp. 1000 y 1001.

2 Bustamante, Carlos María, Continuación del Cuadro histórico. Historia del emperador D. Agustín de Iturbide, México, 1846, p. 89, citado en Martínez Albesa, Emilio, La Constitución de 1857. Catolicismo y liberalismo en México, tomo I: Del Reino borbónico al Imperio iturbidista, 1767-1822, México, Porrúa, 2007, p. 377. El texto citado data de 1838. 
La masonería moderna - la que se conoce como especulativa ${ }^{-3}$ es un tipo de asociacionismo que tiene su origen histórico en la fundación de la Gran Logia de Londres, el 24 de junio de 1717. A pesar de haber nacido como federación de logias preexistentes y con la intención de unificar intereses, la masonería perdió pronto su unidad institucional para, por vía de cismas, fragmentarse en múltiples obediencias, de forma que el fenómeno masónico ha llegado a ser variado, no sólo en cuanto a sus ritos, sino también en cuanto a sus autoridades y proyectos. Todas las asociaciones masónicas especulativas se colocan, no obstante, en continuidad con el espíritu o intención fundamental de lo efectuado en Londres en junio de 1717 y con el discurso y el método adoptados por aquella Gran Logia, según fueron expresados inicialmente en las llamadas Constituciones de Anderson de 1723. ${ }^{4}$ Esta pretensión de continuidad ha podido, ciertamente y en no pocos casos, traducirse en una reinterpretación a la luz de intereses presentes de ese evento inicial y ese texto originario, así como de la trayectoria histórica sucesiva, más que en un esfuerzo por acomodar estos intereses a las intenciones fundacionales; en cualquier caso, todas las masonerías se conciben como continuadoras de lo iniciado en Londres en junio de 1717, estén o no vinculadas en su obediencia a la Gran Logia Unida de Inglaterra - heredera directa de la Gran Logia de Londreslo que hace que sean o no reconocidas como masonería regular.

¿Cuál es entonces el denominador común de las masonerías? ¿Qué convierte en masona a una asociación? Hay quien, ante la variedad actual, niega que pueda individuarse un denominador común para todas ellas. Esto equivaldría a negar la existencia del fenómeno masónico en su conjunto o bien a restringirlo a una sola parte del que se autorreconoce como tal, por lo general, la parte ortodoxa, es decir regular, lo que ocasionaría que se prescindiera de todas las masonerías irregulares, las cuales son mayoría en la actualidad. Si fuera cierto que ningún elemento podría definir el contenido fundamental de las masonerías, carecería entonces de sentido y a su vez de contenido la condena global de la Iglesia católica a todas éstas; asimismo, si hubiera una diferencia esencial entre la masonería regular y las irregulares, esta condena podría circunscribirse en su alcance a alguna parte del fenómeno masónico y no generalizarse a su conjunto. Sin embargo, la común referencia de todas las masonerías a lo iniciado en

3 En este texto vamos a prescindir de la masonería operativa anterior, de origen medieval, hoy ya inexistente.

4 Incluso el cisma de los antiguos de mediados del siglo XVIII, del que hablaremos, no desdice de esta continuidad; pues aunque fuera una reacción frente al evento de 1717 y las constituciones de 1723/1738, aduciendo la supuesta mayor antigüedad de York, no deja de ser una división al interior de la masonería especulativa originada en Londres por más que se reivindiquen rituales de orígenes precedentes. 
Londres en 1717 permite sospechar que es posible que sí tengan algo en común, aunque ello no sea necesariamente lo convenido en aquella ocasión.

La masonería especulativa nació en un contexto histórico de división hostil entre confesiones cristianas, las cuales pretendían suplir, o al menos completar, en la tarea en la cual, según los iniciadores de esta masonería, habían fracasado: unir a los hombres. La masonería aspiraba a ser "el Centro de Unión y el medio de conciliar verdadera Fraternidad entre personas que hubieran permanecido perpetuamente distanciadas" ${ }^{5}$ precisamente porque su diferente confesionalidad religiosa les impediría entablar amistad. Representó un intento de respuesta y de superación del pluralismo religioso y cultural por medio del esoterismo y del racionalismo naturalista. Así, el fenómeno masónico es una modalidad gnóstica de secularización del cristianismo, pero revestido con el léxico de los viejos gremios de la construcción y enriquecido por una mitología con pretensiones históricas que se inspira en una interpretación fantástica de pasajes y personajes bíblicos, así como en fábulas sobre imaginarios secretos de los templarios ${ }^{6}$ y de los quiméricos rosacruces. ${ }^{7}$ Su objetivo es alcanzar para este mundo temporal y mediante una suerte de atajo esotérico- aquella meta de comunión universal que el cristianismo predica de la filiación divina de todos los seres humanos con Cristo como fruto escatológico; a su vez, este fenómeno predica que la razón natural es fruto de la tolerancia en este mundo. Las masonerías interpretan la masonería como un proceso gradual de formación humana con vistas a preparar hombres capaces de propiciar una fraternidad universal; se trata entonces de un método o arte pedagógico.

El masón aspira a llegar a pulir su propia mentalidad, actitud y comportamiento para que pueda insertarse como una perfecta piedra cúbica en la edificación de la ideal gran catedral de la humanidad (de acuerdo con la jerga arquitectónica tomada del gremio de los constructores o masonería operativa, precedente a la especulativa); esta depuración personal la va efectuando de manera progresiva mediante el diálogo dentro de la logia y por medio de las sucesivas ceremonias rituales de tipo iniciático que le dan acceso a un supuesto saber escondido al resto de los hombres. Las masonerías se definen como orden, un término cuyas raíces pertenecen a una época de distinciones de categorías de personas hoy ya superada, pero que contribuye

\footnotetext{
5 "Constituciones de los Franc-masones, 17 de enero de 1723", Museo Virtual de Historia de la Masonería, México, Universidad Nacional de Educación a Distancia, 5 de junio de 2017, p. 24, http://wrww2.uned.es/dptohdi/museovirtualhistoriamasoneria/3documentos_fundacionales/constituciones\%20anderson\%201723.pdf.

6 Véase Tangheroni, Marco, "La leggenda templare masonica e la realtà storica", en Introvigne, Massimo (ed.), Massoneria e religioni, Turín, Editrici Elle Di Ci, Leumann, 1994, pp. 63-77.

7 Véase Introvigne, Massimo, “Che cos'è la massoneria”, en ibidem, pp. 15-19.
} 
a alimentar esa aura de antigüedad, tradición y elitismo en la que les gusta envolverse a los masones. Entre ellos mismos, los masones son hermanos, mientras que los no masones son profanos, por ser ajenos al arte masónico y a la fraternidad que genera su práctica, de la que idealmente deberían ser beneficiarios. Las características principales de un "verdadero masón", según un antiguo ritual de la Gran Logia de Londres, serían "la fraternidad, la fidelidad y el silencio", que representarían "el amor fraternal, la ayuda mutua y la verdad (que reinan) entre todos los masones justos y perfectos". ${ }^{8}$

La masonería moderna se coloca en las antípodas del cristianismo, más allá de la conservación de elementos del imaginario cristiano en el que se gestó, pues augura un perfeccionamiento humano por una vía exclusivamente inmanente. Es decir, el Dios que admite o puede admitir es ajeno a dichoperfeccionamiento, y sería de eficacia inigualable por parte de otras propuestas humanizadoras, olvidando la dimensión trascendente del ser humano. Al señalar la oferta masónica como inmanente y excluyente de la trascendencia, no contradecimos el espiritualismo, que forma parte importante del horizonte masónico más generalizado; este espiritualismo no se refiere a nada que sea considerado ajeno e inalcanzable para la razón natural humana, sino que se trataría de una dimensión misma de lo natural, en cuanto a que lo existente no sería reducible a la sola materia; lo espiritual sería lo que escapa a los sentidos y a las ciencias experimentales; por ello, al hablar de trascendencia queremos indicar el horizonte de lo sobrenatural, no de lo inmaterial. Por lo tanto, el método masónico no resulta un complemento formativo para el hombre en un área determinada, sino que se presenta como el camino de perfeccionamiento ético superior a cualquier otro de los conocidos, incluidos los ofrecidos por las diversas religiones. La masonería se autocomprende como la realización del perfeccionamiento de una humanidad más acabada que la representada por las religiones positivas, y, por tanto, superior a éstas. ${ }^{9} \mathrm{~d} P e r o$ no

8 La institución de los Franc-masones, 1725, op. cit., http://wrerw2.uned.es/dpto-hdi/museovirtua lhistoriamasoneria/3documentos_fundacionales/institucion \%20de\%20los\%20francmasones \%201725.htm.

9 Véase "La Chiesa e la massoneria oggi", La Civiltà Cattolica, IV/3393, 1991, pp. 217-227, en Congregazione per la Dottrina della Fede, Dichiarazione circa le associazioni massoniche (23 [sic] novembre 1983). Testo e commenti, Ciudad del Vaticano, Libreria Editrice Vaticana, 2015, pp. 29 y 30; apoyándose en la obra de Faÿ, Bernard, La massoneria e la rivoluzione intellettuale del Settecento, de 1935. No faltan rituales que expresamente indican la superioridad masónica en la enseñanza de la moral más apta para formar al hombre para la sociedad, para la patria y para sí mismo: véanse Pellicciari, Angela, I Papi e la massoneria, Milán, Ares, 2007, p. 20 (traducción nuestra); "La Chiesa e la massoneria oggi”, La Civiltà Cattolica IV/3393, 1991, en Congregazione per la Dottrina della Fede, op. cit., p. 33, citando al masón Giuliano Di Bernardo: "La idea de perfección masónica está vinculada necesariamente solo con un ideal de mejora del hombre desde un punto de vista esencialmente ético [...] y limitado solo al campo de las posibilidades humanas" (traducción nuestra); y Conferencia Episcopal Filipina, Lineas guía sobre la masonería, 2003, véase en en Congregazione 
es compatible con la fe cristiana la ética filosófica derivada de la consideración de la naturaleza metafisica del hombre? Por supuesto que sí, pero sería ingenuo identificar la formación masónica con la enseñanza de la filosofia ética, dado que incorpora toda una serie de progresivos rituales iniciáticos y de referencias a saberes velados (precisamente lo que le dota de identidad específica y justifica su existencia), lo cual nada tiene que ver con el ejercicio racional de un discurso del entendimiento abierto a indagar, descubrir, comprobar, asumir y compartir la verdad sobre el bien y el fundamento de sus valores para normar moralmente la conducta del ser humano.

Si el fin del hombre es sobrenatural, como sostiene el cristianismo, su perfeccionamiento moral no puede alcanzarse si no es mediante la consideración de su dimensión trascendente. Por esto, para el cristiano, la ética natural sólo llega a encontrar un fundamento estable y una validez plenamente humanizadora en la llamada que Dios dirige al hombre para que sea administrador de la creación y colabore inteligente y libremente en la edificación del mundo (natural y social), para la gloria del mismo Dios por amor filial; en consecuencia, sólo la identificación con Jesucristo -Hijo de Dios encarnado- permitiría al hombre alcanzar su perfección, es decir, llegar a ser hijo de Dios en el Hijo agradable al Padre. La superioridad pretendida por los masones de su camino de perfeccionamiento humano respecto a la oferta que presentan las confesiones religiosas hace de la masonería un sustituto de éstas, de manera que quedan relegadas, pues nada mejor podrían ofrecer para el perfeccionamiento del hombre que lo que promete la masonería.

Para el cristiano, sin embargo, no podría existir ningún atajo posible para llegar a la perfección humana, porque considera que sólo Cristo es el Camino, la Verdad y la Vida; nadie va al Padre sino por Él (cf. fn 14, 6) y en Él están contenidos todos los tesoros de la sabiduría y del conocimiento (véase $\mathrm{Col} 2,3$ ). ${ }^{10}$ Para avanzar en este camino de perfeccionamiento del hombre, no habría saberes ocultos en los que iniciarse, pues Cristo nos habría revelado todo lo que ha oído al Padre sin reservarse secretos (véase fn 15, 15; Col 1, 26; Ef 3, 3-6). ¿Qué puede entonces buscar un cristiano en

per la Dottrina della Fede, op. cit., pp. 55-73; La masonería "busca la perfección del hombre solo en el desarrollo de sus virtudes naturales" sin dar espacio a la gracia (traducción nuestra) p. 58.

10 No debe malinterpretarse aquí el término griego áđóкрvфоı, generalmente traducido por "escondidos", en el sentido de cosas ocultas para no ser descubiertas por todos, sino que debe entenderse como que todo el conocimiento se encuentra contenido, encerrado, en la persona de Cristo, de forma que no es necesario buscarlo en otra parte. Este misterio de Cristo ya se nos ha revelado $(\operatorname{Col} 1,26 ; E f 3,3-6)$, si bien no todo su contenido está desvelado, ya que el hombre ha de abrirse a su conocimiento por medio del Espíritu Santo que Él mismo le ha entregado precisamente para hacer posible este pleno descubrimiento de lo que ya está en Él presente y revelado, pero que no resulta aún evidenciado al hombre (véase fon 16, 12-14). 
la masonería? La revelación cristiana se presenta como pública, completa, para hacer de cada hombre uno moralmente perfecto y al alcance de todos; por su parte, los saberes masónicos se presentan como secretos desvelados por dosis sólo a los iniciados y, por tanto, su acceso está cerrado a todo el que no se inicie.

Para el cristiano, gracias a la encarnación, Cristo se ha unido a todo lo humano; en consecuencia, todas las ciencias humanas tienen cabida en Él, y la autonomía de lo temporal respecto de lo eterno, y de lo natural respecto de lo sobrenatural, forma parte del orden establecido por Dios y está garantizada e incluso redimida por Cristo. Pero el proceso masónico no reivindica la autonomía de lo temporal y natural, sino la autosuficiencia de lo temporal y natural para la perfección del hombre; por tanto, niega el marco eterno y sobrenatural que dota a dicha autonomía de valor perfeccionador de la persona humana, cuyo fin es eterno y sobrenatural.Además, la fraternidad propugnada por los masones tampoco resulta compatible con la comunión universal que promueve el cristianismo.

En primer lugar, el secretismo y el fidelismo inherentes al proceso iniciático y gradual masónico proponen una hermandad necesariamente gradual, en la cuál unos son más hermanos que otros, lo que desnaturaliza el concepto de fraternidad. Lo anterior ocasiona que esta noción degenere fácilmente en amiguismo e incluso en servilismo, lo que, en definitiva, disuelve la hermandad en círculos exclusivistas y excluyentes, es decir sectaristas, por más que se propongan extender su benevolencia hacia los profanos.

En segundo lugar, la fraternidad masónica no contempla una igualdad universal, sino que se predica la acción de una elite, la formada por los hermanos masones (además, jerárquica en su composición), la cual, influyendo sobre el resto, generaría la nueva sociedad fraterna universal; sin embargo, en esta sociedad los profanos nunca se integrarían en régimen de igualdad, por lo que permanecerían como sujetos pacientes.

En tercer lugar, la parafernalia masónica ha sido utilizada sistemáticamente por múltiples masonerías como simple revestimiento de compromisos clientelares para el sostenimiento de intereses políticos, económicos, sociales o culturales.

Por el contrario, la fraternidad cristiana exige necesariamente la universalidad desde el reconocimiento de la igual dignidad de todos, garantizada por el don de la filiación divina, y por la aportación personal que Dios espera de todos para dar a la comunión de la familia humana en calidad de agentes y no de simples destinatarios; esta comunión - con Dios y con los demás en Dios- no es manipulable, porque se justifica en sí misma y no en otras causas. 
Esta obra forma parte del acervo de la Biblioteca Jurídica Virtual del Instituto de Investigaciones Jurídicas de la UNAM www.juridicas.unam.mx

https://biblio.juridicas.unam.mx/bjv

\section{Pinceladas históricas para encuadrar la relación entre masonería y cristianismo}

La intolerancia religiosa estuvo especialmente radicada en la Inglaterra anglicana de la Edad Moderna, que, desde 1603, compartía rey con Escocia, de la casa de los Estuardo. La Revolución Gloriosa de 1688 tuvo una motivación importante en el deseo de cerrar a los católicos el acceso a la Corona, una vez derrocado Jacobo II (1685-1688) - católico y casado con católica (la italiana María de Módena, 1658-1718)-, a quien acababa de nacer un heredero que presumiblemente habría de educarse en esta doctrina. Pensemos que pocos años atrás, entre 1679 y 1681, en el contexto del falso complot papista, se había ejecutado a varios sacerdotes católicos mediante el tradicional y última vez utilizado proceso de colgar, cortar y descuartizar. ${ }^{11} \mathrm{El}$ trono fue entregado a Guillermo de Orange (1689-1702), calvinista holandés, y su esposa María (1689-1694), hija anglicana del rey depuesto. A éstos, sucedió Ana (1707-1714), hermana de María, también anglicana. A su muerte, la Corona pasó a la dinastía de Hannover, en la persona de Jorge I (1714-1727), casado con la pariente protestante más próxima de la familia real británica, Sofía Dorotea de Brunswick-Luneburgo (1666-1726), con la exclusión de los candidatos católicos más cercanos en parentela, según lo establecido por el parlamento británico en 1701. Así, por el Acta de Unión entre ambos reinos, Inglaterra y Escocia, se constituyó la Gran Bretaña (1707-1801).

En este contexto radicalizado, el deísmo ${ }^{12}$ había encontrado formulación en la obra del irlandés librepensador John Toland (1670-1722), Christianity not Mysterious (Londres, 1696), que produjo no poco escándalo, pero que fue sólo el inicio de las expresiones del pensamiento cada vez más radicalizado de su autor, quien llegó incluso a optar por el panteísmo. Toland, nacido católico y convertido al protestantismo presbiteriano en su adolescencia, fundó en Oxford la filosófica Sociedad Sócrates ${ }^{13}$ desde cierto punto de vista, un precedente de la masonería especulativa. Defendió la libertad individual como elemento definitorio del hombre y la igualdad entre todos los hombres, tomando la razón y la tolerancia como herramientas privilegiadas de análisis social. Políticamente se sumó a la causa de los Hannover y del partido whig,

11 Ridley, Jasper, Los masones, Barcelona, Ediciones B, 2010, p. 97.

12 Creencia en una divinidad creadora o principio del mundo, pero que abandona el mundo a su suerte, sin velar o acompañarlo con su providencia -asumiendo que Dios "está ocioso o en huelga, que no se ocupa para nada de nosotros, y que no revela nada a los hombres" (Pío VI, Encíclica Inscrutabile divinae, 25 de diciembre de 1775, en Bellocchi, Ugo, op. cit., vol.II, p. 128; (traducción nuestra)-, dado que esta divinidad no es necesariamente personal y, si lo es, no está interesada en el mundo.

13 Ridley, Jasper, op. cit., p. 59. 
y radicalizó sus posiciones libertarias. Sus últimos dos años de vida los pasó sumido en la pobreza, en la bebida y en la enfermedad.

A finales del siglo XVII, los masones - quienes habían comenzado a recibir en sus logias a hombres ajenos al mundo de la construcción: los aceptados no operativos- eran vistos con sospecha por algunos. Sus reuniones secretas entre personas sin una clara homogeneidad comenzaban a hacerlos impopulares en algunos sectores, pese al prestigio del que habían gozado y que todavía conservaban en muchas partes. Jasper Ridley recoge el caso de un folleto denigratorio que circuló en Londres en 1698, cuyo autor parece haber sido un tory anglicano. ${ }^{14} \mathrm{~A}$ mediados de la segunda década del siglo XVIII, durante el final de la Guerra de Sucesión española, el ascenso al trono de Jorge I y la sofocada rebelión jacobita escocesa - un contexto políticamente delicado para los ingleses, y, en particular, para los whigs, quienes querían asegurarse las riendas del gobierno-, unos masones decidieron la federación de cuatro logias londinenses en febrero de 1717, y establecieron la Gran Logia de Londres el 24 de junio, la cual tendría a la cabeza un gran maestro y dos grandes vigilantes, elegidos anualmente en esos primeros tiempos. Este acontecimiento debe contextualizarse en la evolución histórica de las logias masónicas como forma de sociabilidad; en la hostilidad entre confesiones religiosas de la época; en los contrastes entre Inglaterra y Escocia y entre los partidarios de los Hannover y los jacobitas; en las rivalidades políticas entre whigs y tories y entre whigs moderados y radicales,, en la relación entre Gran Bretaña y sus colonias, y en la pugna entre Gran Bretaña y Francia por la hegemonía.

Entre los masones libres y aceptados que dieron origen a la masonería especulativa, destacan el ministro anglicano Jean-Théophile Desaguliers (1683-1744), instalado en la alta sociedad y apasionado de la ciencia empírica, hijo de un pastor hugonote francés, quien de niño tuvo que huir con su familia de La Rochelle a Inglaterra a consecuencia de la revocación del edicto de Nantes, por Luis XIV de Francia, en 1685, y el pastor presbiteriano James Anderson (1674-1739), quien, a pesar de su origen escocés, era partidario de los Hannover. ${ }^{15}$ Ridley ve probable que Desaguliers - quien desde niño había sufrido en carne propia las desavenencias religiosas confesionales, y que se vio obligado a huir de un acto de intolerancia de un monarca católico- aspirase a fomentar, por medio de la masonería, el desarrollo en la sociedad de un deísmo tolerante que la liberara de pleitos entre protestantes y católicos. ${ }^{16}$ Los

14 Idem.

15 Andrés, Juan Ramón de (ed.), El surgimiento de la Masonería: Eugene Michael Jones, Saarbrücken, Editorial Académica Española, 2015, p. 100.

16 Ridley, Jasper, op. cit., pp. 62-66. 
Esta obra forma parte del acervo de la Biblioteca Jurídica Virtual del Instituto de Investigaciones Jurídicas de la UNAM www.juridicas.unam.mx https://biblio.juridicas.unam.mx/bjv

primeros grandes maestros, elegidos siempre un 24 de junio, fueron Anthony Sayer (1717), George Payne (1718), Desaguliers (1719), Payne (1720), John duque de Montagu (1721), Philip duque de Wharton (1722) y Francis Scott conde de Dalkeith (1723). El 27 de diciembre de 1729, fue nombrado gran maestro Thomas Howard (1683-1732), séptimo duque de Norfolk, quien, a diferencia de los once anteriores grandes maestros, era católico, proveniente de una familia jacobita y había sido iniciado en la masonería en febrero del mismo año. Este nombramiento es recordado frecuentemente para argumentar contra el anticatolicismo de la naciente masonería especulativa, así como contra su encuadramiento político en favor de los Hannover y los whigs. En efecto, la masonería no excluía a los católicos ni a ninguna confesión cristiana, pero esto no demuestra que su sistema de principios y métodos fuera compatible con un cristianismo vivido en profundidad bajo la confesión católica. No siempre se recuerda que esta actividad masónica le costó a Howard su matrimonio, su mujer - decididamente católica y ardientemente jacobita- consideró a su marido un traidor a la causa, por pasar a sostener a un rey que ella calificaba de usurpador, y lo abandonó.

Del mismo modo, el caso del también católico Charles Radclyffe (16931746), quinto conde de Derwentwater, emparentado con los Estuardo, gran maestro de la Gran Logia de Francia entre 1738 y 1739, que murió ejecutado en Londres por su implicación en la segunda rebelión jacobita de 1745, no deja de ser un caso que debe considerarse dentro del entrelazado de las rivalidades políticas y masónicas de esos tiempos iniciales, donde las logias establecidas en el continente eran seno de acogida y de disputa para británicos que rivalizaban por las causas políticas del momento - algunos, incluso, emigrados por su radicalismo en uno u otro sentido- y donde la nueva masonería especulativa pugnaba por imponerse en las logias antiguas y modernas. Por ejemplo, es significativo que el establecimiento de la Gran Logia de Francia, quizá de 1728, y el de la primera logia española, hubieran sido promovidos por el polémico duque de Wharton (1698-1731), quien había sido expulsado de la Gran Logia de Inglaterra.

La redacción de las constituciones de la masonería moderna fue encargada por el duque de Montagu (1690-1749) a James Anderson en 1721. Debía partir de compilar los reglamentos antiguos de la corporación masónica operativa y extraer de ellos lo fundamental que sirviera a los nuevos fines. El resultado es deudor también de una contribución destacada de Desaguliers y de George Payne (1685-1757). ${ }^{17}$ Además, un comité de catorce personas revisó el proyecto. Las llamadas Constituciones de Anderson fueron aprobadas

17 Ridley, Jasper, op. cit., pp. 62-66. 
de manera definitiva en enero de $1723 .{ }^{18}$ Desde el punto de vista ideológico, las dos primeras partes son importantes: la primera es el relato legendario de pretensiones históricas sobre la masonería, partiendo de elementos bíblicos; la segunda presenta - sintetizados en seis- los antiguos deberes, con una formulación modernizada que incluye una interpretación novedosa, para descubrirnos el alma de esta nueva masonería. El primero de los deberes de un francmasón es la práctica de la moral natural y la profesión de una religiosidad interior:

El masón está obligado por su carácter a obedecer la ley moral, y si debidamente comprende el Arte, no será jamás un estúpido ateo ni un libertino irreligioso. Pero aunque en tiempos antiguos los masones estaban obligados a pertenecer a la religión dominante en su país, cualquiera que fuere, se considera hoy mucho más conveniente obligarlos tan sólo a profesar aquella religión que todo hombre acepta, dejando a cada uno libre en sus individuales opiniones; es decir, que han de ser hombres probos y rectos, de honor y honradez, cualquiera que sea el credo o denominación que los distinga. De esta suerte la masonería es el centro de unión y el medio de conciliar verdadera fraternidad entre personas que hubieran permanecido perpetuamente distanciadas..$^{19}$

La masonería estaba abierta a todas las confesiones religiosas; aunque en ese momento inicial se pensaba más bien en las cristianas, no se excluía a otras religiones, como lo demostró la pronta iniciación de judíos. El ateísmo era visto por entonces como una opción inmoral; sin embargo, no se prescribía el teísmo, ${ }^{20}$ puesto que resultaba suficiente la profesión de una religiosidad genérica, un deísmo. Sólo se prescribía la religión en la cual todos los hombres convergían y que se acreditaba por el comportamiento conforme a la ley moral, interpretado fundamentalmente como probidad y honradez. ¿Cuál es esta religión? Tiene como referencia al Gran Arquitecto del Universo, creador de Adán en la narración de Anderson, y del que el gran maestro del Gran Oriente de Italia, Ernesto Nathan (1845-1921), decía, en 1901 -y su sucesor, Guido Laj (1880-1948), repetía, citándolo, en 1945-: “'Se trata de Zeus, de Júpiter, de Dios? Lo que queremos es afirmar la causa primera, el infinito creador, no interpretarlo. Existe. Decir cómo sea, o cuál sea, es algo que tiene que ver con

18 Constitución de la antigua y honorable Fraternidad de Masones Libres y Aceptados, 17 de enero de 1723. Más tarde, se ordenó la quema de toda la documentación masónica antigua que Anderson había recopilado para su trabajo.

19 Constituciones de los Franc-masones (17 de enero de 1723), op. cit., p. 24. He suprimido las mayúsculas y cursivas.

20 Creencia en un Dios personal creador que interviene en la marcha del mundo y en la vida del hombre (monoteísmo), o en varios dioses que son personales e intervienen (politeísmo). 
la fe de cada conciencia individual". ${ }^{21}$ Esta religión de convergencia no es, por tanto, ninguna de las religiones confesionales, que se relegan al cúmulo de las opiniones individuales en materia religiosa, desprovistas de valor social. Éstas se respetan sólo en la medida en que alientan la honestidad de vida de sus creyentes - el mismo Nathan añadía en su discurso que, para los masones, "toda fe, sinceramente profesada y seguida, que guía y mantiene honesto al hombre a través de la vida es digna de todo respeto"-,22 pero no ameritan adhesión en cuanto vías de experiencia propiamente religiosa de comunicación con un Dios dispensador de gracia para el hombre.

En la declaración de propósitos generales de la Gran Logia Unida de Inglaterra de 1985, se precisa que la masonería "requiere de sus adeptos la creencia en un Ser Supremo, del cual, sin embargo, no ofrece una propia doctrina de fe", de modo que cada uno puede darle el contenido que estime apropiado. ${ }^{23}$ La conceptualización masónica del Gran Arquitecto del Universo viene presentada por los masones de nuestra época como compaginable con cualquier concepto de lo divino:24 sería "un Principio Regulador Trascendente, un Principio Creador, una fuerza ordenadora, el Geómetra", ${ }^{25}$ pero no tendría ninguna incidencia práctica en la vida de los masones y no podría concebirse como revelador o inspirador de leyes morales que requirieran creencia, dado que la conducta moral del masón debe regularse exclusivamente por su razón autónoma. ${ }^{26}$ Puede reconocerse como principio racional originador del mundo y, en este sentido, autor de las leyes racionales que lo rigen y de la razón humana misma, pero esta razón sería todo aquello con lo que el hombre contaría para regirse.

21 Citado en Giantulli, Florido, L'essenza della massoneria italiana. Il naturalismo, Florencia, Pucci Cipriani Editore Firenze, 1973, p. 22. La traducción española tomada de Ullate Fabo, José Antonio, El secreto masónico desvelado, Madrid, Libros Libres, 2007, p. 59, y de Bárcena, Alberto, Iglesia y masonería. Las dos ciudades, Madrid, Ediciones San Román, 2016, p. 44, quienes citan las palabras como de Laj sin advertir que éste citaba a Nathan.

22 Citado en Giantulli, Florido, op. cit., p. 22. Traducción nuestra. Pertenece al texto de Nathan citado por Laj.

23 Board of General Purposes of the United Grand Lodge of England, 21 de julio de 1985, citado en Guerra Gómez, Manuel, Algunos objetivos de la masonería en la celebración del tercer centenario de su fundación (3 de junio 2016), 12 de mayo de 2017, https://infovaticana.com/blogs/wpcontent/ uploads/sites/3/2016/06/blogmasonfrances.pdf.

24 Por ejemplo, Javier Otaola Bajeneta (nacido en 1956), ex gran maestro de la Gran Logia Simbólica Española y miembro del Supremo Consejo Masónico de España anota: "No es un concepto teológico, sino una imagen, solo un símbolo", citado en Guerra Gómez, Manuel, Algunos objetivos de la masonería... cit.

25 Serrano, Florencio y Altarriba, Francesc Xavier, La Masonería. Una Orden Iniciática, citado en Ullate Fabo, José Antonio, op. cit., p. 71.

26 Giantulli, Florido, op. cit., p. 31. 
En el decurso de su relato histórico, la referencia de Anderson a Jesucristo como Mesías de Dios y Gran Arquitecto de la Iglesia ${ }^{27}$ no implica ningún reconocimiento divino ni trascendente de su persona. Asimismo, la presencia de la Biblia en las logias inglesas desde 1780, o del libro considerado sagrado por la religión mayoritaria del lugar, no reviste un carácter confesional, sino que se ha de interpretar como un simple reclamo a esa religiosidad genérica que precedería a cualquier confesionalidad; en algunos casos, hoy se sustituye este libro por las constituciones masónicas o la constitución política nacional o incluso un libro con sus páginas en blanco, porque también pueden remitir a esa moralidad que representaría el elemento valioso y determinante de tal religiosidad. ${ }^{28}$ De hecho, el concepto mismo de la religión en la que todos los hombres concuerdan "implica una visión relativista de la religión, que no puede coincidir con la convicción fundamental del cristianismo" ${ }^{29}$ ni de las otras religiones teístas. No obstante, es una religión universal que deben profesar tanto teístas como deístas si aspiran a ingresar en la masonería, tal como se recuerda en el sexto deber: "como masones sólo pertenecemos a la religión universal". ${ }^{30}$ Se da por hecho que es de suyo compartida por todos los hombres, porque, al carecer de doctrina, en definitiva se identifica con un moralismo naturalista; es aquella que, unos años después, el introductor de los altos grados masónicos ligados a la leyenda templaria -el escocés Andrew Michael Ramsay (1686- 1743)31, entre otros- presentó como religión natural, sobre todo en su obra póstuma Principios filosóficos de la religión natural y revelada desplegada en el orden geométrico (Glasgow, 1749). Ya en sus discursos parisinos de 1736 y 1737, Ramsay había hecho referencia a la primitiva religión de Noé y los patriarcas, y había afirmado que en la masonería: "Todos los vicios del corazón y del espíritu están desterrados, así como la irreligión y el libertinaje, la incredulidad y el desenfreno". ${ }^{32}$ Desde el moralismo naturalista, la verdadera fraternidad o amistad consistiría principalmente en la relación franca y leal entre los masones.

En la segunda edición de estas constituciones, que data de enero de 1738, el primer deber -en atención a los judíos, presentes en las logias parece que

27 Constituciones de los Franc-masones (17 de enero de 1723), op. cit., p. 12.

28 Guerra Gómez, Manuel, Algunos objetivos de la masonería... cit.

29 Conferencia Episcopal Alemana, "Declaración sobre la pertenencia de los católicos a la masonería" (1o. de junio de 1980), véase en Congregazione per la Dottrina della Fede, op.cit. p. 48.

30 Constituciones de los Franc-masones (17 de enero de 1723), op. cit., p. 28.

31 Introvigne, Massimo, "Che cos'è la massoneria", op. cit., pp. 25 y 26.

32 Los discursos de Andrew M. Ramsay (1736-1737), Museo Virtual de Historia de la Masonería, op. cit. 
desde 1724 y con certeza en $1732-33$ presenta esta nueva versión, todavía más elocuente:

Un masón está obligado por su título [a] obedecer a la ley moral en tanto que verdadero noaquita [seguidor de Noé] y si comprende bien la profesión, él no será nunca un ateo estúpido, ni un libertino irreligioso ni actuará en contra de su conciencia. En los tiempos antiguos, los masones cristianos eran llamados a actuar de acuerdo con las costumbres cristianas de cada país donde ellos viajaban. Pero la masonería existente en todas las naciones, aun de religiones diversas, lleva a que los masones adhieran a la religión según la cual todos los hombres están de acuerdo (dejando a cada hermano sus propias opiniones), es decir, ser hombres de bien y leales, hombres de honor y de probidad, cualquiera sean los nombres, religiones o confesiones que ayuden a distinguirlos: pues todos se articulan sobre los tres artículos de Noé suficientes para preservar el fundamento de la Logia. De este modo la Masonería es el centro de la unión y el feliz medio de unir a las personas, quienes, de otro modo, habrían permanecido perpetuamente desconocidas entre sí. ${ }^{34}$

El moralismo elimina la división religiosa y la trasciende, en el sentido de que la hace intrascendente de frente a ese moralismo universalista. Los tres artículos de Noé son los más básicos de los siete preceptos que el Talmud judío recoge para los hijos de Noé, es decir, para la humanidad: abstenerse de la idolatría, del asesinato y del robo. Las religiones confesionales no son valoradas positivamente, sino sólo toleradas en cuanto opiniones personales. Para la masonería, la auténtica religiosidad correspondería al "concepto de «religión natural», racional y universal, que no tiene necesidad de ninguna revelación ni de ninguna autoridad o tradición de Iglesia, y viene opuesta a las religiones «positivas», consideradas formas corruptas de la única religión natural y víctimas de coartaciones dogmáticas". ${ }^{35}$ Esta religiosidad exigida no va más allá del deísmo e, incluso, desatendiendo la vivencia religiosa interior, sólo interesa en tanto sostiene un comportamiento moral que se considera adecuado, lo que consecuentemente degenera en moralismo.

En los deberes segundo y sexto de las Constituciones de Anderson, se recoge la conocida prohibición de tratar de política y de religión en las logias, partiendo de enfatizar el sostenimiento del statu quo:

33 Ridley, Jasper, op. cit., p. 71.

34 Constitución de los Franc-masones. Introducción, op. cit.

35 "La Chiesa e la massoneria oggi”, La Civiltà Cattolica, IV/3393, 1991, op. cit., p. 27. Traducción nuestra. 
El Masón ha de ser pacífico súbdito del Poder civil doquiera resida o trabaje, y nunca se ha de comprometer en conjuras y conspiraciones contra la paz y bienestar de la nación ni conducirse indebidamente con los agentes de la autoridad [...]. Así que si un hermano se rebela contra el Estado, no se le ha de apoyar en su rebelión, aunque se le compadezca por tal desgracia; y si no está convicto de ningún crimen, aunque la leal Fraternidad deba condenar la rebelión y no dar al Gobierno el menor motivo de recelo ni asomo de fundamento sobre el particular, no podrán expulsarlo de la Logia y su relación con ella permanece incólume (Deber $2^{\circ}$ ).

Por lo tanto, no se habrán de promover disputas ni discusiones en el recinto de la Logia y mucho menos contiendas sobre religión, nacionalidades y formas de Gobierno, pues como masones sólo pertenecemos a la religión universal antes citada y también somos de todas las naciones, razas y lenguas, y nos declaramos contra toda política, que nunca condujo ni conducirá al bien de la Logia. Este Deber se ha mantenido y observado siempre estrictamente; pero especialmente desde la Reforma en Britania y la secesión de la iglesia romana (Deber 6 $\left.6^{\circ}, 2\right) \cdot{ }^{36}$

Así, el masón debía respetar en todo lugar la autoridad civil constituida, que, en aquellos momentos, para Gran Bretaña, era la del rey Jorge I, a quien también mencionaba la constitución. La redacción del segundo deber es curiosa, pues mientras se afirma el deber de no conjurar contra la autoridad política, también se dice que quien incurra en esta falta no será sólo por ella apartado de la logia. Con este deber, se perseguía la tranquilidad de la masonería más que la del Estado. Se aseguraba un respeto a los gobernantes, lo cual alejaba el peligro de que la masonería fuera culpada de rebelión; pero, al mismo tiempo, entre los masones, debía dejarse impune al eventual conspirador, lo que abría la puerta a excepciones a lo antes afirmado. Por otra parte, con el fin de salvaguardar la concordia interna, se excluían las discusiones sobre religión y política. Esto permitió difundir muy pronto las logias en las colonias británicas, integrando a sus elites locales - a veces de otras religiones, como en la India - en la conservación del statu quo británico; así, la masonería demostró ser un instrumento útil para el colonialismo. ${ }^{37}$ Las constituciones mismas podían interpretarse como favorables a la política whig y pro Hannover; pero, yendo más allá de los textos constitucionales, las logias han operado con frecuencia y desde muy temprano como redes de influencia sociocultural

36 Constituciones de los Franc-masones (17 de enero de 1723), op. cit., pp. 24, 25 y 28.

37 Se fundarán pronto logias en América y en Asia: Antigua (1728), Bengala (1729), Calcuta (1730), Boston (1733), Jamaica (1742), Madrás (1752), Bombay (1758). 
y también de acción política al servicio de determinadas causas o facciones. ${ }^{38}$ La vinculación de la masonería regular inglesa con la Corona ha sido prácticamente continua y evidente. El segundo deber podría presentar como inocua la expansión masónica fuera del mundo británico, pero también podría dotarla de una valencia política de hecho cuando fuera el caso, en principio, obviamente, en favor de los intereses de la Corona británica, si bien no faltaban masones y masonería jacobitas en el continente europeo. Esto facilitó que, en general, la masonería en el mundo británico pareciera un factor de estabilidad política, mientras que fuera de él aparecía con frecuencia como factor desestabilizador. Según las Constituciones de Anderson, el masón tenía, además, obligación de guardar secreto frente a los no masones, pues debía ser "muy cauto en palabras y comportamiento, a fin de que el más sagaz profano no logre descubrir ni penetrar lo que no conviene revelar" (Deber $6^{\circ}$, 4). ${ }^{39}$ En 1737, los tories se pronunciaron contra las asambleas clandestinas que admitían "turcos, judíos, infieles, papistas y ateos" y podían conspirar contra el Estado e interferir en el reparto de cargos políticos. ${ }^{40}$ En sólo veinte años, las logias reunidas bajo la Gran Logia superaban ya largamente el centenar dentro de Inglaterra. ${ }^{41}$

El ideal de unidad universal masónica hubo de hacer cuentas desde el inicio con las divisiones internas. El mismo acto fundacional de 1717 representó una necesaria escisión frente a las logias no federadas que acarreó incomprensiones varias. En 1751, la Gran Logia de York se constituyó como Antigua Gran Logia (parece que con importante presencia de irlandeses y escoceses), primera escisión en la masonería especulativa; con ello, desafiaba a la Gran Logia de Londres, a la que acusaba de haberse constituido como una innovación descristianizadora. Este cisma entre antiguos y modernos -que llegaron a tener como respectivos grandes maestros a los hijos del rey Jorge III, los duques Eduardo de Kent (1767-1820) y Augusto de Sussex (1773-1843)- se recompuso mediante la reunificación del 27 de diciembre de 1813, en la Gran Logia Unida de Inglaterra, en la cual quedó como gran maestro el duque de Sussex, cuyas constituciones de 1815 fueron más respetuosas hacia el teísmo, aunque sin renunciar al moralismo de la supuesta religión natural; sin embargo, para entonces ya habían surgido otros cismas

38 Andrés, Juan Ramón de, op. cit., p. 101. En Inglaterra, favorecieron al gobierno whig encabezado por Robert Walpole (1676-1745; primer ministro, 1721-1742), quien no era masón, pero cuyo hijo Horace (1717-1797) sí lo fue. Sobre Horace Walpole, véase Ridley, Jasper, op. cit., p. 70.

39 Constituciones de los Franc-masones (17 de enero de 1723), op. cit., p. 28.

40 Andrés, Juan Ramón de, op. cit., pp. 128 y 129.

41 Ridley, Jasper, op. cit., p. 70. 
en Europa. La variedad de ritos no implica ruptura de comunión masónica: son los cismas los que provocan obediencias diversas, al margen del rito o de los ritos que se sigan.

La Revolución francesa fue ocasión para la lucha entre las dos principales facciones masónicas de Francia, en general, aunque no nítidamente. Agrupadas en la Gran Logia de Francia, de 1738, vinculada a la tradición de la masonería inglesa, y en el Gran Oriente de Francia, originado en 1773, más cercano a la tradición escocesa de Ramsay, el cisma más notable ha sido el de septiembre de 1877, cuando el Gran Oriente de Francia dispuso la posibilidad de admisión de ateos en sus logias, algo que la Gran Logia Unida de Inglaterra no pudo aceptar. ${ }^{42}$

En la consolidación del esoterismo masónico y de la ambigüedad de su simbología, merece mención particular el Arco Real, que sentó las bases para abrir nuevas series de grados en el proceso iniciático de formación masónica: los llamados altos grados, cuyo número varía según los ritos. Inicialmente, los grados masónicos eran los de aprendiz y compañero; en 1725 se añadió el de maestro, para formar los tres grados simbólicos de la llamada masonería azul, base de las demás. El ritual del Arco Real representa una muerte simbólica en vida, y está ligado a la leyenda del asesinato del mítico arquitecto del Templo de Salomón, Hiram Abif, personaje inspirado en el orfebre bíblico de $2 \operatorname{Cr} 2,12-13$ y $1 \operatorname{Re} 7,14$, el cual pasó a ser de conocimiento público mediante la obra Darkness Visible (1952), de Walton Hannah (1912-1966); parece que, antiguamente, hacía referencia a la muerte de Noé y la búsqueda de su cuerpo por sus hijos. No se sabe dónde y cuándo se originó, quizás en Irlanda (donde se practicaba ampliamente) o en Francia, y parece que, a pesar de haber sido suprimido por la Constitución de Anderson (por interpretarse como demasiado bíblico, judío-cristiano, frente a la no confesionalidad que se estaba implementando), lo practicaban los antiguos de York desde finales de la década de 1740 (con seguridad desde 1752) como tercer grado; después -quizá en 1766 o 1810- fue asumido por los modernos, como complemento al tercero o como cuarto grado. Mediante éste, el masón recibía la imaginada palabra perdida desde la muerte de Hiram y hallada bajo el arco real, la cual aparentemente era el verdadero nombre de Dios: Jahbulon; un término sincrético que aludía a la divinidad al reunir en uno a Yahvé (Jah), Dios en la tradición judeocristiana, a Baal (Bul), divinidad babilónica, y erróneamente a Osiris (On), divinidad egipcia - en realidad On es una localidad bíblica

42 Es, no obstante, significativa la comprensión demostrada en 1877 por el Gran Oriente de Italia hacia los planteamientos del Gran Oriente de Francia, que nos revela cómo la religiosidad masónica puede realmente conciliarse con el ateísmo: Giantulli, Florido, op. cit., pp. 27-30. 
Esta obra forma parte del acervo de la Biblioteca Jurídica Virtual del Instituto de Investigaciones Jurídicas de la UNAM www.juridicas.unam.mx

(cf. Gn 41, 45) que los creadores del ritual confundieron con una divinidad del antiguo Egipto-. ${ }^{43}$ Por lo tanto, se trata de una evocación por vía del sincretismo religioso de aquella religión natural que comentamos, todo lo más deísta y, como aquí vemos, nada respetuosa del teísmo. Más allá del deísmo y del sincretismo, hay también masonerías con ceremonias luciferinas, es decir, donde se rinden honores o se hacen referencias a Lucifer, presentado con rasgos positivos. ${ }^{44}$ Algunos masones establecen una diferencia entre Lucifer y Satanás, por lo cual admiten el luciferismo y rechazan el satanismo. También en algunos rituales masónicos - parece que en el grado 29 del tan difundido Rito Escocés Antiguo y Aceptado- encuentra espacio Baphomet, una especie de deidad andrógina monstruosa, presentada como portadora de la luz -en relación con Lucifer- y contrapuesta a la cruz. ${ }^{45}$

¿Qué nos dicen los masones sobre su compatibilidad con el cristianismo confesional? En general, sostienen la compatibilidad desde la idea de que las confesiones son respetadas por la masonería como cuestiones de conciencia personal. Quizás esta reducción de lo confesional a la conciencia personal puede compaginarse con la visión protestante del libre examen y ser consentida por confesiones protestantes, para las cuales la dimensión comunitaria de la fe no tiene el mismo valor teológico que para otras -las cuales requieren una visibilidad de su iglesia a partir de una sociedad eclesial independiente, como la católica- y para las que, conforme con el erastianismo, su sociedad eclesial viene sostenida desde la sociedad política. Ahora bien, la ambigüedad con la que se habla de la religión en la Constitución de Anderson ha permitido que, en el devenir histórico, haya periodos -como los del paso del siglo XIX al XX-en los que los masones insistan más en la incompatibilidad entre la religiosidad masónica y las comunidades confesionales cristianas - tal como éstas se conciben a sí mismas-, y otros periodos, como el actual, en los que insistan más en la compatibilidad entre la religiosidad masónica y la conciencia personal de pertenencia a una determinada comunidad confesional cristiana. La primera posición presenta a la masonería como opción religiosa, desde la etérea religiosidad masónica, tildando de superstición la confianza en las doctrinas y prácticas de una confesión, mientras que la segunda afirma que nada tiene que ver con la religión, desde la concepción de la religión como estricta opción particular de modalidad de relación con la divinidad. Ambas posiciones son manifestaciones históricas de una misma ideología que asume la idea

43 Ridley, Jasper, op. cit., pp. 114-117; Cierva, Ricardo de la, Los signos del anticristo. Iglesia, masonería totaly poderes ocultos ante el tercer milenio, Getafe, Fénix, 1999, pp. 136-139; Guerra Gómez, Manuel, Algunos objetivos de la masonería..., cit., e Introvigne, Massimo, op. cit., pp. 23-25.

44 Bárcena, Alberto, op. cit., pp. 33-50.

45 Ibidem, pp. 36 y 37. 
de que la religión natural es la única fundamental y, con el tiempo, adquiere expresiones confesionales varias; entre estas expresiones, las personas puedan escoger la que les parece más lograda y acorde con tal religión natural universal, sin embargo, permanece irreducible a una confesión determinada. El estudioso José Antonio Ullate, quien presenta varios testimonios de diversas épocas, concluye que la masonería acepta todas las religiones "siempre y cuando no sean más que distintos símbolos para la única religión natural que deduce la razón". ${ }^{46}$ Asimismo, a mediados del siglo XVIII, John Cockburn, escocés establecido en Nueva Jersey, había afirmado tempranamente: "Los credos surgen, tienen sus apogeos y pasan, pero la masonería permanece. Está construida sobre la roca de la verdad, no sobre las arenas movedizas de la superstición". ${ }^{47}$

Así, existe toda una corriente masónica de pronunciamientos recurrentes sobre la incompatibilidad entre masonería y catolicismo profesado como única religión verdadera. El estadounidense Albert Pike (1809-1891), Soberano Gran Comendador del Rito Escocés Antiguo y Aceptado (1859-1891) y gran promotor por el mundo de este rito -estructurado en 1801 en Charleston (Estados Unidos)- sostenía que la masonería "enseña, y ha preservado en su pureza, los principios cardinales de la antigua fe primitiva, que subyacen y son el fundamento de toda religión [...] La masonería es la moralidad universal que se adecua a los habitantes de cualquier clima y credo". ${ }^{48} \mathrm{E}$ insistía: "La masonería no propaga ningún credo más que el sublime y simple que enseñan la naturaleza y la razón. Nunca ha existido una religión falsa en el mundo. La revelación permanente, única y universal, está escrita en la naturaleza visible [...] No hay más que una religión, un dogma, una creencia legítima". ${ }^{49}$

Asimismo, Albert G. Mackey (1807-1881), en la Enciclopedia de la Francmasonería (1873-1878), califica a la masonería como "una eminente institución religiosa [...]. Pero la religión de la masonería no es sectaria [es no obstante obligatoria, pues] consiste, en general, en la naturaleza y en la revelación primitiva - transmitida a nosotros a través de algún sacerdocio antiguo y patriarcal- en la que todos los hombres pueden concordar, en la que los hombres no pueden

46 Ullate Fabo, José Antonio, op. cit., p. 105.

47 Citado en Andrés, Juan Ramón de, op. cit., p. 103. Como puede verse, las expresiones masónicas delatan continuamente su carácter de secularización del cristianismo, de cuyo vocabulario y metáforas se sirven abundantemente.

48 Idem. Procede de su obra Morals and Dogma of the Ancient and Accepted Scottish Rite of Freemasonry (Charleston, 1871).

49 Citado en Ullate Fabo, José Antonio, El secreto masónico desvelado, Madrid, 2007, p. 105. 
disentir", una revelación primitiva que no es sobrenatural..$^{50}$ La religión masónica de Mackey sostenía la práctica de la virtud, pero no la redención del pecado. Para Albert Churchward (1852-1925), a principios del siglo XX, la masonería era "la más grande, la más pura y más verdadera de las religiones, vacía de todo dogma". ${ }^{51}$ A mediados de siglo, la revista Lumen, del Gran Oriente de Italia, de Palazzo Giustiniani, sostenía una "religión enraizada en la naturaleza y por tanto racional y universal [que ha de ser] religión humana". ${ }^{52}$ No es imaginable poder profesar la religión como experiencia natural y también sobrenatural. Por esto, Salvatore Farina, de la Gran Logia de Italia de Piazza del Gesù, se preguntaba preocupado, a mediados de siglo: “¿Poner sobre el libre arbitrio las imposiciones de la Iglesia no es declararse preparado a las peores traiciones, cuando Roma ordenase el perjurio?". ${ }^{53}$ Ya el Léxico internacional francmasónico de Eugen Lenhoff y Oscar Posner (1932) había juzgado a la Iglesia católica como una institución que ejercía coerción al inculcar la fe. ${ }^{54}$ La desconfianza hacia los creyentes en religiones confesionales llevaba al gran maestro del Gran Oriente de Italia Ugo Lenzi (1875-1953) a afirmar: "quien profese una confesión dogmáticamente definida no puede simular no sentir la inhibición de entrar en comunión espiritual con quien ejercita la propia libertad de pensamiento y de conciencia en la libre búsqueda de lo Verdadero sin apriorismos, sin fabulaciones mitológicas, sino con la única guía del buen sentido, de la razón, de los descubrimientos de las ciencias naturales". ${ }^{55}$ Para Farina, el principio masónico superior e irrenunciable era incompatible con todo dogmatismo: "permanecer fiel exclusivamente a la fe en el progreso de la razón humana"; 56 así, todas las religiones habían sido "concebidas para responder al estado social de una época: todas han sido pasajeras: una sola fuerza es constante: el trabajo de la inteligencia", el cual utilizaría los gobiernos, las religiones, las instituciones y, después, los aplastaría. ${ }^{57}$

50 Citado en Conferencia Episcopal Filipina, Lineas guía sobre la masonería (2003), Congregazione per la Dottrina della Fede, op. cit., pp. 66 y 67 (pregunta 34). Mackey practicaba el Rito Escocés Antiguo y Aceptado.

51 Idem. De su libro Signs and Symbols of Primordial Man (Londres, 1910 y Nueva York, 1912).

52 Revista Lumen, febrero de 1954 y 1955, citada en Giantulli, Florido, op. cit., p. 16. Traducción nuestra.

53 Farina, Salvatore, Il Libro dei Rituali del Rito Scozzese Antico e Accettato (Roma, 1946), citado en Giantulli, Florido, op. cit., p. 18. Traducción nuestra.

54 Conferencia Episcopal Alemana, "Declaración sobre la pertenencia de los católicos a la masonería" (1o. de junio de 1980), Congregazione per la Dottrina della Fede, op. cit., p. 47.

55 Lenzi, Ugo, "L’Acacia Massonica" (1949), citado en Giantulli, Florido, op. cit., p. 18. Traducción nuestra.

56 Farina, Salvatore, 1946, citado en Giantulli, Florido, op. cit., p. 18. Traducción nuestra.

57 Ibidem, p. 17. 
Autores masones como Lucio Lupi, Mario Tanferna y Giuliano Di Bernardo también han testimoniado la incompatibilidad de la masonería con el catolicismo en la segunda mitad del siglo XX.$^{58} \mathrm{~A}$ finales del mismo siglo, Armando Corona (1921-2009), gran maestro del Gran Oriente de Italia de 1982 a 1990, declaró poco después como fundamental principio de la masonería la afirmación de que "no existe una única religión para alcanzar la salvación", mientras que "la Iglesia católica tiene sus dogmas y considera que la suya es la única verdadera religión"; ${ }^{59}$ por ello, él no podía juzgar posible la simultánea adhesión a ambas. La declaración de propósitos Tesis para el año 2000 (1980), de la masonería alemana, parte de la afirmación de que: "No existen sistemas de naturaleza filosófico-religiosa que puedan reivindicar una obligatoriedad exclusiva", promoviendo un indiferentismo religioso que excluye a priori una religión revelada. ${ }^{60}$ El Libro blanco de la laicidad (2007) del Gran Oriente de Francia testimonia la actualidad de los proyectos secularistas militantes de una masonería importante, que reivindica la "libertad absoluta de conciencia” y la interpreta, en primer lugar, como emancipación respecto a todos los dogmas, pues alienarían o pervertirían el pensamiento. ${ }^{61}$ Para estos masones, toda religión confesional es el opio de las conciencias; así, si bien en ocasiones la masonería prescribe a sus adeptos que respeten la religión en la que han nacido y en ella se conserven, esto no debe implicarles una limitación para su libre pensamiento. ${ }^{62}$

Según el pastor luterano Theodore Graebner (1876-1950), para pasar de la ignorancia y oscuridad a la sabiduría y la luz, la masonería exige de quien se adhiere a ella la renuncia a toda religión sectaria, y como sectario interpretaría a veces al cristianismo. ${ }^{63}$ William J. Whalen (1926-2008), católico experto en el estudio comparado de las religiones, explica que la masonería "se ve [a sí misma] como la religión universal, mientras el cristianismo es simplemente

58 “La Chiesa e la massoneria oggi”, La Civiltà Cattolica, IV/3393 (1991), Congregazione per la Dottrina della Fede, op. cit., pp. 31-33.

59 Citado en Introvigne, Massimo, "Che cos’è la massoneria", op. cit., p. 35. Traducción nuestra.

60 Conferencia Episcopal Alemana, "Declaración sobre la pertenencia de los católicos a la masonería” (1o. de junio de 1980), op. cit., p. 45. La declaración fue publicada en la revista Huamnistät (1/1980). Traducción nuestra.

61 Bárcena, Alberto, op. cit., p. 202. El Libro blanco de la laicidad ha sido publicado por Vidal, César, en su obra La masonería. Un Estado dentro del Estado, Barcelona, 2010.

62 Giantulli, Florido, op. cit., p. 18.

63 Graebner, Theodore, Is Masonry a Religion? (Saint Louis, 1946), citado en Conferencia Episcopal Filipina, op. cit., p. 67 (pregunta 35). 
otra de las decenas de sectas cuyas opiniones particulares han dividido la humanidad en el curso de los siglos". ${ }^{64}$

No obstante, también existe otra corriente masónica que presenta como compatible la pertenencia a la masonería con la profesión del catolicismo. Hoy esta corriente se hace escuchar más que la anterior en el mundo de los llamados profanos. El mismo Salvatore Farina se atrevía a declarar que la masonería no es una religión y que admite sin discriminaciones hombres que profesan cualquier culto y cualquier religión, pero, eso sí, "educándolos en la tolerancia y alejándolos del fanatismo y la superstición". ${ }^{65}$ Desde sus inicios, la masonería ha recibido creyentes cristianos de varias confesiones en sus filas, y ha cerrado sus puertas - al menos hasta 1877- a quien se proclama ateo, si bien la ambigüedad del concepto de Gran Arquitecto del Universo hace fácilmente compatible su aceptación con el agnosticismo. Existe incluso un rito minoritario -el Rito Escocés Rectificado- que se presenta a sí mismo como "masonería cristiana". ${ }^{66}$ Recientemente, el gran maestro del Gran Oriente de Italia, Stefano Bisi, escribía:

La Libera Muratoria Universal no es por su naturaleza una religión ni un sustituto de ella, no tiene posiciones dogmáticas, no propone vías salvíficas del alma, sino que para ser admitida pide solo a la persona creer en un Ser Supremo. Nosotros los llamamos simplemente y sin darle ningún atributo específico, a diferencia de lo que ocurre en la religión cristiana, el Gran Arquitecto del Universo. [...] La Masonería no es enemiga de la Iglesia, de ninguna Iglesia, y siempre ha sido la Casa del diálogo y de la Tolerancia. No se opone a ninguna religión y deja a los hermanos libres de seguir su propia fe. ${ }^{67}$

Si bien la masonería especulativa nació en un ambiente anglicano y presbiteriano, sin aparente interés de modificar el variado abanico confesional del cristianismo, sino más bien de superarlo en una unidad de horizonte superior, su convivencia con las comunidades cristianas ha sido complicada e incluso conflictiva. Desde luego, la conflictividad ha marcado las relaciones de las masonerías con la Iglesia católica, aun cuando haya habido experiencias históricas

64 Whalen, William J., Report on Freemasonry for US Bishops. The Pastoral Problem of Masonic Membership, citado en Conferencia Episcopal Filipina, op. cit. p. 67 (pregunta 34).

65 Farina, Salvatore, 1946, citado en Giantulli, Florido, op. cit., p. 15. Traducción nuestra.

66 Guerra Gómez, Manuel, Algunos objetivos de la masonería... cit.

67 Bisi, Stefano, "Carta al director de Il Sole 24 Ore" (15 de febrero de 2016), Roma, 22 de febrero de 2016, http://wwre.grandeoriente.it/lettera-del-gran-maestro-bisi-a-il-sole-24-ore-dopolarticolo-del-cardinale-ravasi-su-chiesa-e-massoneria/, y AGENPARL, 12 de mayo de 2016, http:// wrere.agenparl.com/364157-2/. Traducción nuestra. 
donde la doble pertenencia ha sido relevante ${ }^{68} \mathrm{Y}$ la acción política de los masones arribados a puestos de gobierno en los siglos XIX y XX en las naciones latinas - tanto europeas como americanas-, en la mayoría de los casos, ha sido anticlerical y secularista, lo que incluso ha llegado a provocar, en concomitancia con otros factores, situaciones de persecución violenta contra la Iglesia, como ocurrió en México y en España. Las iglesias ortodoxas, por su mayor vinculación a las naciones orientales, han atendido menos a la cuestión masónica; sin embargo, el Sínodo de los Obispos, de la Iglesia ortodoxa de Grecia, declaró la incompatibilidad entre masonería y cristianismo el 12 de octubre de $1933 .{ }^{69}$ En el mundo protestante y sobre todo en el anglicano, la tranquila convivencia y los casos de doble pertenencia entre masonería y cristianos han sido habituales; sin embargo, no han faltado cuestionamientos y tensiones que han aumentado con el tiempo. En algunas ocasiones, las comunidades presbiterianas han condenado la masonería en Escocia, Irlanda y Norteamérica, así como los metodistas ingleses, que lo hicieron en $1927 .{ }^{70} \mathrm{~A}$ mediados del siglo XX, el anglicano Walton Hannah escribió -sin duda demasiado categóricamente-: "ninguna Iglesia que haya examinado seriamente las enseñanzas religiosas y los principios de la masonería ha nunca dejado de condenarla". ${ }^{71}$

En Reino Unido, entre las dos guerras mundiales, era todavía notable la tradicional buena relación e interpenetración de la Iglesia anglicana y la masonería, y lo siguió siendo por varios decenios; no obstante, más recientemente, el Sínodo general de la Iglesia de Inglaterra de 1987, en York, buscó disuadir a los anglicanos de ingresar en la masonería, denunciando su gnosticismo y acusándola de blasfema, debido al supuesto verdadero nombre de Dios. ${ }^{72}$ En

68 Sobre la doble pertenencia en América latina en el último tercio del siglo XIX, véase Pazoz, Antón M., La Iglesia en la América del IV Centenario, Madrid, Mapfre, 1992, pp. 193-208, epígrafe "Masonería y religión". No obstante, la relación entre masonería y catolicismo en América latina ha sido principalmente de hostilidad, y la historiografía es abundante; para algunas referencias sobre la presencia del tema masónico como hostil en la conciencia histórica nacional de los autores católicos mexicanos, véase Martínez, Emilio, op. cit., pp. 1834-1843.

69 Bárcena, Alberto, op. cit., p. 19, (nota 15).

70 Ibidem, p. 19 (notas 16 y 17).

71 Darkness Visible. A Christian Appraisal of Freemasonry (Devon, 1952), citado en Stimpfle, Josef, monseñor, "Dall'indagine dei vescovi tedeschi (1974-1980) al documento vaticano del 1983", op. cit., p. 179, traducción nuestra. Sobre la obra de Hannah, también véase Bárcena, Alberto, op. cit., pp. 21 y 22; Ridley, Jasper, op. cit., p. 387, y Cierva, Ricardo de la, op. cit., pp. 137 y 138. Walton Hannah se convirtió al catolicismo.

72 Tomando como base el trabajo de la comisión establecida por el Comité del Sínodo General de la Iglesia de Inglaterra, Freemasonery and Cristianity: Are They Compatible?, Londres, Church House, 1987, Bárcena, Alberto, op. cit., pp. 21, 27 y 278, e Introvigne, Massimo, "Che cos'è la massoneria", op. cit., p. 24. Sobre el caso del ministro anglicano John Lawrence a inicios de la década de 1980, favorable a la compatibilidad, véase Stimpfle, Josef, mon- 
el ambiente germánico, la comunidad evangélica también se cuestionó en el siglo XX la compatibilidad entre cristianismo y masonería, si bien, en 1973, tras un diálogo entre representantes, dio su consentimiento para que sus fieles pudieran ingresar en las logias; no obstante, la respectiva comisión para el diálogo no llegó a conclusiones unánimes y consignó sus serias dudas sobre si las prácticas masónicas no podían concurrir a disminuir en los fieles la idea de la justificación por la gracia. ${ }^{73}$ La sospecha de incompatibilidad entre evangelismo y masonería permanece en nuestros días y un libro reciente ha tratado de demostrarla. ${ }^{74}$ Por otra parte, Massimo Introvigne documenta el antimasonismo del protestantismo fundamentalista americano, gestado en el nativismo estadounidense del siglo XIX y desarrollado en el transcurso del XX..$^{75}$ Respecto al mundo bautista -la denominación protestante que predomina en los Estados Unidos-, cabe decir que en junio de 1993 la Convención Bautista del Sur no acogió la propuesta formulada el año anterior por una de sus facciones de excluir a los masones del seno de su comunidad, lo que causó gran desconcierto en la masonería estadounidense; tras un año de estudio, el informe de los investigadores bautistas del 17 de marzo de 1993 señalaba que consideraba incompatibles algunos aspectos de la masonería con el cristianismo, pero dejaba a la conciencia individual discernir acerca de la eventual adscripción a las logias. ${ }^{76}$

\section{Las condenas pontificias. Objetivo de este estudio}

Como es bien sabido, la condena de la Sede Apostólica a la masonería ha sido constante y se ha reiterado frecuentemente en el transcurso de los años. Manuel Guerra Gómez estima que entre 1738 y 1980 ha habido 371 documentos pontificios de relevancia y más de dos mil referencias de los papas contra ella. ${ }^{77}$ Durante los pontificados de Pío IX y León XIII -la época

señor, "Dall'indagine dei vescovi tedeschi (1974-1980) al documento vaticano del 1983", op. cit., pp. 177 y 179. Una panorámica diversa a Lawrence la ofrece la obra del discípulo de Hannah y ferviente antimasón Knight, Stephen (1951-1985), The Brotherhood, Londres, 1984, veanse Stimpfle, Josef, monseñor, op. cit., pp. 176 y 177 y Ridley, Jasper, op. cit., p. 388-393.

73 Stimpfle, Josef, monseñor, op. cit., p. 178.

74 Giacinto Butindaro analiza diversos temas teológicos en La massoneria smascherata. Contro l'infiltrazione e l'influenza di questa diabolica istituzione nelle Chiese Evangeliche, http://wrerr.sentieriantichi.org/download/La-Massoneria-Smascherata.pdf.

75 Introvigne, Massimo "Che cos'è la massoneria", op. cit., pp. 44 y 45.

76 Ibidem, pp. 56 y 57. véase Interfaith Witness Department of the Home Mission Board of the Southern Baptist Convention, Atlanta, 17 de marzo de 1993.

77 Guerra Gómez, Manuel, Algunos objetivos de la masonería ... cit. 
de mayor intensidad en la emanación de estos documentos--, José Antonio Ferrer Benimeli cuenta más de cuatrocientos pronunciamientos. ${ }^{78}$

Las fuentes utilizadas por los papas para conocer la masonería - tal como ellos mismos lo asentaron en sus documentos- han sido los escritos de los masones, algunos de sus libros, constituciones y rituales, así como el testimonio de personas que abandonaron la masonería o permanecieron en ella. Asimismo, sus pronunciamientos no son estrictamente individuales, pues los pontífices siempre han consultado de manera previa a otras personas eclesiásticas y civiles.

El objetivo del presente estudio es historiar el desarrollo de los motivos que los romanos pontífices han aducido en sus condenas de las asociaciones masónicas a lo largo de los tiempos. Esto nos permitirá diferenciar unas etapas dentro de la reprobación a la masonería por parte de la Iglesia, para comprender mejor qué es lo que se condena y por qué.

En la respuesta de la Iglesia católica al fenómeno masónico, es necesario distinguir entre la descalificación o condena de la masonería desde el punto de vista doctrinal, como teológicamente inconciliable con el cristianismo, y la censura o pena canónica decretada jurídicamente a los fieles católicos hacia determinados comportamientos suyos en relación con la masonería, los cuales van desde la colaboración dispensada hacia algunos círculos masónicos hasta la conspiración activa contra el bien de la Iglesia desde el interior de la masonería, pasando por la adscripción a las logias masónicas. El hecho de que, en determinados momentos históricos, las penas canónicas contra los católicos vinculados con la masonería puedan variar y también reducirse no significa que la descalificación doctrinal de la masonería se redujera y que se relativizara la incompatibilidad entre catolicismo y masonería. Así, observaremos que el juicio doctrinal negativo de la Iglesia hacia el fenómeno masónico ha sido sostenido de forma persistente, mientras que las censuras canónicas han observado modificaciones a la baja, de acuerdo con la evolución del derecho penal universal, de la Iglesia del periodo del Antiguo Régimen a la actualidad.

78 Ferrer Benimeli, José Antonio, "El Vaticano y los masones", El País, 10 de marzo de 1985, p. 14. Este especialista ha tratado recientemente la relación entre Iglesia y masonería, con atención particular a las condenas pontificias; así, en su obra Masonería, Iglesia, Revolución e Independencia, Bogotá, 2015, presenta algunos datos interesantes, como que León XIII preparaba en 1903 una nueva encíclica sobre masonería que no llegó a publicar porque lo alcanzó la muerte. 
Esta obra forma parte del acervo de la Biblioteca Jurídica Virtual del Instituto de Investigaciones Jurídicas de la UNAM www.juridicas.unam.mx

https://biblio.juridicas.unam.mx/bjv

\section{LAS CONDENAS PONTIFICIAS PRERREVOLUGIONARIAS DEL ASOCIAGIONISMO MASÓNICO. SigLO XVIII}

\section{La primera condena pontificia. In eminenti, 1738}

El Papa Clemente XII (1730-1740) procedió a la condena de las asociaciones masónicas mediante la constitución apostólica In eminenti apostolatus specula del 28 de abril de $1738 .{ }^{79}$ En este documento - primero en el que un romano pontífice se pronunciaba contra la masonería-, el papa Corsini reconocía la pluralidad del fenómeno masónico y, al mismo tiempo, lo condenaba en su conjunto, pues censuraba todas las "sociedades, uniones, reuniones, asambleas, agregaciones o conventículos de los Libres Muratores o des Francs Maçons, o con cualquier otro nombre llamadas", las cuales entraban en la descripción que a continuación él mismo hacía. ${ }^{80}$ Descalificaba las asociaciones masónicas al considerarlas malas en sí mismas por fundarse en un pacto o convenio secreto entre hombres de diversas religiones, en virtud del cual quedaban vinculados de forma muy estrecha entre sí, bajo "una cierta fingida apariencia de honradez natural", ${ }^{81}$ con el compromiso de observar unos ordenamientos internos ocultos a los demás; esto los colocaba en una sociabilidad paralela e independiente de aquella protegida por las leyes civiles y eclesiásticas, de manera que se constituían ilegalmente y, además, pretendían garantizar su unión ilegal mediante un juramento religioso prestado sobre la Biblia y bajo penas de una gravedad tal que no podían justificarse.

Para el pontífice, este asociacionismo secreto e ilegal -ya por esto mismo deplorable ${ }^{-82}$ conllevaba como consecuencia un peligro de contaminación de la fe por esa vinculación estrecha entre "hombres de toda religión y secta", ${ }^{83}$ lo cual movía a pensar que las diferencias religiosas carecen de importancia a la hora de edificar la sociedad, pues ésta no debería prescindir del deber religioso del ser humano de buscar dar a Dios el culto verdadero que le es debido; es decir,

79 Clemente XII, Constitución apostólica In eminenti (28 de abril de 1738), en Bellocchi, Ugo, op. cit., pp. 289-291. Está tomada de la reproducción incluida en la constitución Providas de Benedicto XIV. Las citas en español de esta constitución son traducción nuestra del texto italiano publicado en esta obra.

80 Ibidem, p. 290.

81 Idem.

82 Toda sociedad secreta, por el hecho mismo de su clandestinidad, no consentiría en sujetarse a la eventual supervisión ni del Estado ni de la Iglesia; por lo tanto, se estima que no reconocería la autoridad civil ni eclesiástica, incurriendo en ilegitimidad.

83 Clemente XII, op. cit., p. 290. 
invitaba a un indiferentismo religioso, ${ }^{84}$ en el sentido de que todas las religiones son igualmente válidas para dar culto a Dios y para salvar al hombre. También representaba un parapeto a la hipocresía de quienes, jactándose de ser hombres honrados, no someten sus acciones al juicio de la luz pública y llegan a amparar maldades bajo apariencias de inocencia. Finalmente, tomaba el nombre de Dios en vano al recurrir al juramento para sellar un "silencio inviolable sobre todo lo que hacen secretamente", ${ }^{85}$ al estilo de lo que más adelante fue la famosa omertà mafiosa, ${ }^{86}$ con la pretensión de utilizar a Dios para obrar iniquidades con impunidad. Sin embargo, estas tres consecuencias implícitas a la descripción de la naturaleza de las asociaciones masónicas que hace Clemente XII no son explicitadas y desarrolladas por él, sino que sólo pueden entreverse en el hecho mismo de que presenta los tres rasgos de la reunión de creyentes de distintas religiones como motivo de reprobación: la apariencia de honradez aunada al secreto y el juramento de ocultar mediante el silencio.

Aun cuando no en todos los casos se produjeran males para el resto de la sociedad, el papa afirmaba que "ordinariamente", de estas asociaciones resultaban perjuicios tanto para "la tranquilidad de la vida pública temporal" como para "la salud espiritual de las almas". ${ }^{87}$ Por eso, estimaba que las asociaciones masónicas eran un peligro contra el bien común y la salvación de las almas, y que, además, se trataba de un peligro velado para muchas personas, las cuales podrían incautamente resultar embrolladas y pervertirse. En consecuencia, tras haber consultado y reflexionado, pasaba a las disposiciones jurídicas y prohibía a los fieles católicos que ingresaran en tales asociaciones y también que presentaran cualquier tipo de colaboración a las mismas, fijando como pena la excomunión latae sententiae para quienes contravinieran su prohibición.

La primera condena pontificia del fenómeno asociativo masónico incluía, por tanto, una denuncia de la incompatibilidad con el catolicismo, por la naturaleza misma de tales asociaciones: ilegales, secretas, hipócritas y blasfemas, y una pena canónica para los católicos que las favorecieran de

84 Por indiferentismo religioso, debe entenderse la equiparación de las diversas religiones en su validez para dar culto a Dios y, en consecuencia, en su utilidad para la salvación de la persona, es decir, la opinión de que todas las religiones son prácticamente iguales en sus efectos de relación del hombre con la divinidad. Este indiferentismo religioso se opone, por tanto, a la creencia de que exista una religión verdadera y otras religiones falsas o sólo verdaderas parcialmente.

85 Clemente XII, op. cit., p. 290.

86 En italiano, la palabra omertà significa la solidaridad entre personas dirigida a ocultar la identidad del autor de un delito; en su origen, indicaba la costumbre o norma no escrita de silencio vigente en asociaciones delictivas del sur de Italia por la que se debía mantener en silencio el nombre del autor de un delito para que no fuese sometido a las leyes del Estado, sino sólo a la venganza personal del ofendido (véase Vocabulario Treccani).

87 Clemente XII, op. cit., p. 290. 
cualquier modo: la excomunión latae sententiae de absolución reservada al romano pontífice. La gravedad de la pena responde al deseo del papa de prevenir posibles males graves; por tanto, su condena jurídica tiene un carácter fundamentalmente cautelar, preventivo, que aspiraba a disuadir a los católicos de entrar en relación con tales asociaciones para evitarles el peligro de convertirse en colaboradores del mal.

Con In eminenti, Clemente XII se solidarizaba con los juicios contrarios a la masonería que se habían difundido tempranamente en la Europa continental. La emigración desde Gran Bretaña hacia el continente de los más radicales de los whig antijacobitas, alentada por los whig moderados, había dotado a la masonería continental de una particular valencia revolucionaria allí donde habían prevalecido, como en Holanda; ${ }^{88}$ si bien, todas las logias -incluso las jacobitas- eran "una avanzada de la influencia británica" 89 y se desarrolló un natural temor hacia una sociedad secreta de origen inglés que podía estar vinculada a los intereses políticos británicos. ${ }^{90}$ En la década de 1730, además de estar presente en Gran Bretaña y en el mundo colonial británico, la masonería se ubicó en los Países Bajos, Francia, Alemania, Austria, España, Suecia y en estados italianos, y fue el gobierno holandés el primero en proscribir la masonería, el 12 de diciembre de $1735,{ }^{91}$ luego de que se fundara una logia whig en La Haya en 1731. ${ }^{92}$ Tras la condena pontificia, la masonería fue prohibida en Portugal, Toscana, Austria y España. En Francia, donde Luis XV había advertido en 1737 que no recibiría en la corte a masones, aumentó la oposición a la masonería por parte de las instituciones, a pesar de que la Corona -por galicanismo- se desentendió de la censura papal. ${ }^{93}$

La constitución apostólica In eminenti fue el punto de partida de las condenas papales a la masonería. Su contenido fue corroborado y desarrollado sucesivamente. En este sentido, cabe reconocer que se demostró clarividente al apuntar hacia los temas del indiferentismo religioso, del uso indebido de la religión (Sagradas Escrituras, juramento, etcétera), de la hipocresía masónica, del secretismo capaz de amparar maquinaciones contra la tranquilidad pública y seguridad de las personas, y de la corrupción o manipulación de personas ingenuas. Es necesario advertir que, en ella, todavía no aparecen tres de los temas con los que más adelante la Iglesia argumentó principal-

\footnotetext{
88 Andrés, Juan Ramón de, op. cit., pp. 119-121.

89 Ibidem, p. 119.

90 Ridley, Jasper, op. cit., pp. 81-83.

91 Ibidem, pp. 83 y 84.

92 Andrés, Juan Ramón de, op. cit., pp. 119 y 120.

93 Ridley, Jasper, op. cit., pp. 86-110.
} 
mente contra la masonería: la conspiración contra la Iglesia, el racionalismo y naturalismo iluminista y el relativismo filosófico y moral. El primero fue fruto de las experiencias históricas sucesivas, y el segundo y el tercero, de una profundización en el conocimiento del fenómeno masónico. Un cuarto tema importante en las condenas posteriores fue el de la manipulación de los ingenuos al servicio de causas desconocidas por ellos a modo de tontos útiles, el cual tampoco aparece claramente aquí, si bien sí es perceptible cierta utilización de la ingenuidad de las personas para corromperlas en la fe y la moral.

\section{Un papa ilustrado ratifica la condena. Providas, 1751}

Benedicto XIV (1740-1758) destacaba entre sus contemporáneos como hombre de cultura, docto y erudito, abierto al diálogo filosófico y condescendiente con el regalismo de los monarcas del despotismo ilustrado. Además, por formación, era un preciso canonista. Solicitado por los reyes Borbones Carlos VII de Nápoles y Fernando VI de España - según Ridley- o bien debido a su iniciativa para impeler a éstos a actuar -según Ferrer Benimeli, quien parece mejor documentado-, pero, con seguridad, preocupado por la persistencia de las logias napolitanas ${ }^{94}$ este pontífice reiteró la condena del asociacionismo masónico en la constitución apostólica Providas Romanorum, promulgada en forma de bula el 18 de marzo de $1751,{ }^{95}$ en la que reprodujo íntegramente la In eminenti de su inmediato predecesor en el solio pontificio para hacerla propia y confirmar el juicio negativo sobre este fenómeno, así como la pena de excomunión a los católicos que lo apoyasen. Como intelectual que era, ordenó y explicitó mejor que Clemente XII los argumentos que motivaban la condena pontificia tanto de su predecesor como de él mismo.

En su constitución, el papa Lambertini presentaba seis motivos jerarquizados de la reprobación tanto clementina como suya de las asociaciones masónicas. El primero era el peligro de "daño a la pureza de la Religión Católica", ${ }^{96}$ el cual residía en la vinculación mutua entre personas de cualquier credo religioso, es decir, el riesgo de contaminación de la fe, lo que podía incluso llegar a un indiferentismo religioso (expresión que ni Clemente XII ni Benedicto XIV emplearon en ese momento), es decir, a una equipa-

94 Véase ibidem, pp. 172 y 173, y Ferrer Benimeli, José Antonio, La masonería española en el siglo XVIII, Madrid, Siglo XXI, 1986, pp. 85-93. Sobre las repercusiones de la bula de Benedicto XIV, véase Bárcena, Alberto, op. cit., pp. 60-63.

95 Benedicto XIV, Constitución apostólica Providas Romanorum (18 de marzo de 1751), en Bellocchi, Ugo, op. cit., pp. 289-294. Las citas en español de este documento son traducción nuestra.

96 Ibidem, p. 292. 
ración del valor de todas las religiones. El segundo motivo era la promesa de secreto, que se traducía en el hermetismo de la asociación, a pesar de que - como afirmaban- lo honesto prefiere la luz y lo deshonesto la oscuridad. El tercero era el estricto juramento de guardar ese secreto, lo cual podía llevar a los miembros a justificarse en la negativa a responder a las autoridades legítimas cuando se les interrogaba con el objetivo de dilucidar si había en su asociación algo contrario a la estabilidad y a las leyes de la religión católica y de la vida civil. El cuarto motivo era su ilegalidad tanto civil como canónica, pues el derecho civil prohibía constituir asociaciones sin permiso de la autoridad pública desde las Pandectas de Justiniano (533 d.C.). El quinto era el ejemplo de muchos países, cuyas autoridades civiles habían prohibido expresamente esas asociaciones. El sexto era la mala fama que éstas tenían entre personas prudentes y honestas, quienes las consideraban centros de depravación y perversión.

Sin referirse a maquinaciones contra la Iglesia, este papa incluía la advertencia, en el tercer motivo, de que al amparo del secreto se pudieran esconder perjuicios a la estabilidad y leyes de la Iglesia y no sólo del Estado, lo que quizá podría entreverse bajo aquellos perjuicios contra la salud de las almas a los que Clemente XII aludía. En Providas, no encontramos todavía el argumento de conspiración contra la Iglesia como tal, pero es evidente una desconfianza hacia las asociaciones masónicas. Con Benedicto XIV, el papado parecía participar ya no sólo de la sospecha, sino también del temor que sentían los gobernantes civiles hacia estas asociaciones secretas. Por otra parte, es posible que el papa Lambertini, de carácter más sereno y racional, prestara menor atención que su predecesor al posible carácter blasfemo del juramento, pues no hacía referencia a los elementos religiosos del mismo, a pesar de que todo juramento se hacía ante Dios, lo cual establecía un vínculo entre conciencia y religión; no obstante, Lambertini señalaba la razón de la reprobación de ese juramento en el peligro que entrañaba para el bien común, pues podría utilizarse como excusa para ocultar la verdad ante las autoridades, las cuales debían conocerla para poder velar por el bien común.

Además de confirmar y hacer propia la condena de su predecesor, Benedicto XIV pedía la ayuda de los reyes y autoridades civiles para que esta condena surtiera todos sus efectos, puesto que los supremos poderes civiles eran "elegidos por Dios como defensores de la fe y protectores de la Iglesia". ${ }^{97}$

Aun cuando pudiera existir temor hacia los propósitos de los masones, la primera condena de la Iglesia hacia la masonería no parecía obedecer a una reacción de los papas para defender sus intereses políticos en cuanto jefes de

97 Ibidem, p. 293. 
los Estados pontificios, sino que se apoyó en motivaciones religiosas expresas y suficientemente argumentadas y precedió a los acontecimientos revolucionarios de finales del siglo XVIII y del XIX, que sí atentaron contra tales intereses. Se trata de una condena temprana y de la masonería en sí misma, es decir, por lo que ella era en cuanto institución, antes que por las acciones concretas de una u otra rama o sector del fenómeno masónico. Clemente XII y Benedicto XIV conderon esta forma de asociacionismo en su globalidad, sin limitarse a una u otra masonería específica y sin dejar fuera ni la vinculación a una institución masónica ni tampoco el apoyo indirecto a alguna de estas asociaciones. La condena no estaba restringida a las reuniones de masones, pues lo que se reprobaba era la masonería en sí misma, el fenómeno masónico en su conjunto. El peligro para la fe, el secretismo y ocultismo, los juramentos inapropiados e indebidos y la ilegalidad hicieron de las asociaciones masónicas algo reprobable en sí mismo para los papas.

La segunda mitad del siglo XVIII fue muy difícil para la Iglesia y el papado. El movimiento racionalista crítico de la Ilustración fue abriendo paso - primero de la mano del despotismo ilustrado y finalmente de la de los revolucionarios- a un reformismo social que, animado por el Iluminismo inmanentista, alcanzó aspectos ideológicos y religiosos con los que se puso en crisis la cosmovisión cristiana de la sociedad. En el campo eclesiológico, el regalismo, el episcopalismo y el jansenismo disciplinar cuestionaron el papel del papado. ${ }^{98}$ En el campo de la cultura, La Enciclopedia francesa (L'Encyclopédie, 1751-1772), bajo la dirección de Denis Diderot y Jean Le Rond D’Alembert, representó la concreción de la ideología iluminista anticristiana. ${ }^{99}$ Dentro de este contexto y casi a las puertas de la Revolución francesa, la encíclica programática de Pío VI (1775-1799) -el pontífice que murió prisionero de los revolucionarios-, sin mencionar a las sociedades masónicas ni secretas, dejaba entrever la necesidad que tendrían sus sucesores de atender a la peligrosidad de la acción de tales sociedades por estar animadas por el espíritu iluminista anticristiano. Así, la Inscrutabile divinae sapientiae denunciaba la actividad de hombres corruptos y embaucadores que - presentándose como filósofos y maestros- "introdu[cían] principios de perdición" en la sociedad. ${ }^{100}$ Éstos propugnaban una "filosofía llena de engaños, que bajo un nombre honesto escond[ía] su propia impiedad"101 y seducía a los pueblos, arrastrándolos al

98 Martínez Albesa, Emilio, La Constitución de 1857..., cit., pp. 5-8.

99 Probablemente su redacción no estuvo inmune a influjos masónicos: cf. Bárcena, Alberto, op. cit., pp. 69 y 70, y Cierva, Ricardo de la, op. cit., p. 80.

100 Pío VI, Encíclica Inscrutabile divinae (25 de diciembre de 1775), en Bellocchi, Ugo, op. cit., p. 128. Traducción nuestra.

101 Idem. Traducción nuestra. 
deísmo o al ateísmo, a la subversión contra los soberanos, e, incluso, a la disolución de los vínculos interpersonales, a la desconfianza hacia el sacerdocio y a la ruptura de la alianza entre el trono y el altar. Para el papa Braschi, el corazón de esta filosofía perversa era la máxima según la cual "el hombre nace libre y no está sujeto a nadie", ${ }^{102}$ pues absolutizaba de forma antinatural la libertad individual y conducía a la corrupción de las costumbres, a la licencia del pensamiento y la palabra, así como a la arrogancia y temeridad de la acción. Por tanto, el iluminismo traía, "una falsa luz [...] más dañina que las mismas tinieblas". ${ }^{103}$ A su juicio, resultaba especialmente peligroso que esta corrosiva doctrina estuviera siendo introducida subrepticiamente en las instituciones públicas de estudio académico, en la corte de los reyes e incluso en el ambiente eclesiástico. ${ }^{104}$

\section{LAS GONDENAS PONTIFICIAS DE LA CONSPIRAGIÓN MASÓNICA. PRIMERA MITAD DEL SIGLO XIX}

\section{Bajo el embate revolucionario, denuncia de la conspiración. Ecclesiam a Jesu Christo, 1821, y Quo graviora, 1825}

Pío VII (1800-1823) regresó a Roma de su prisión en Francia a finales de mayo de 1814. Como su inmediato predecesor, había conocido en carne propia la hostilidad revolucionaria y napoleónica contra la Iglesia. De talante abierto y de mentalidad política avanzada, este pontífice retomó la condena explícita contra la masonería que sus predecesores habían dejado de reiterar hacía setenta años con su constitución apostólica en forma de bula Ecclesiam a fesu Christo, del 13 de septiembre de 1821. ${ }^{105}$ En este documento, el papa Chiaramonti decretaba la excomunión latae sententiae reservada al Sumo Pontífice contra quienes se adhirieran o apoyaran a los carbonarios, a los que consideraba "quizá una propagación o ciertamente una imitación"

102 Pío VI, Encíclica Inscrutabile divinae (25 de diciembre de 1775), ibidem, p. 129 (traducción nuestra). Este papa volvió a reprobar esa "absurda invención de libertad" y su consecuente individualismo como falso fundamento de la sociedad al condenar la Declaración de los derechos del hombre y del ciudadano del 27 de agosto de 1789: Pío VI, Breve Quod aliquantum (10 de marzo de 1791), ibidem, pp. p. 156. Traducción nuestra.

103 Pío VI, Encíclica Inscrutabile divinae (25 de diciembre de 1775), en op. cit., p. 129. Traducción nuestra.

104 Ibidem, pp. 129-131.

105 Pío VII, Bula Ecclesiam a Jesu Christo (13 de septiembre de 1821), ibidem, pp. 408-411. Las citas en español de este documento son traducción nuestra. 
de aquellas "sociedades de Libres Muratores, o sea de los Francmasones, o llamadas con cualquier otro nombre", que Clemente XII y Benedicto XIV habían condenado en sus respectivas constituciones In eminenti y Providas, en cuya estela ahora Pío VII colocaba expresamente la suya. Extendía también la condena a la lectura y posesión de los libros de los carbonarios. ${ }^{106}$

Para cuando se expidió esta constitución, la carbonería había organizado ya complots en Macerata (1817), Nola, Avelino, Nápoles y Milán (1820) y en Turín (1821). Y, antes de este documento papal, el Secretario de Estado había publicado dos edictos prohibiendo esta asociación en el Estado Pontificio.

La carbonería era una sociedad secreta italiana que aspiraba a subvertir el orden político de la Restauración posnapoleónica mediante conspiraciones revolucionarias que implantasen regímenes constitucionales liberales. Nacida en el sur de Italia en la segunda década del siglo XIX, se había extendido rápidamente en el norte y había establecido contactos en Francia y en España. Operó hasta mediados de la década de 1830, dejando paso en la lucha política revolucionaria a la Giovane Italia de Giuseppe Mazzini (1805-1872) y al Risorgimento. No podemos afirmar que la carbonería fuese una asociación masónica, aun cuando fuera una sociedad secreta que compartiera determinadas ideas u objetivos con masonerías de la época y tuviera contactos con ellas desde su origen, pero su condena por parte de Pío VII nos sirve para comprender mejor los motivos de rechazo de la masonería misma, pues el papa avalaba su reprobación en la similitud que consideraba encontrar entre carbonería y masonería. ${ }^{107}$

Reafirmando todavía los argumentos contra la masonería de los pontífices anteriores, Pío VII puso sobre la mesa el tema de la enemistad hacia la Iglesia y de la conspiración, pues entre las dos constituciones apostólicas de sus predecesores y la suya median el desarrollo del iluminismo como movimiento cultural hostil a la revelación cristiana, y la experiencia de la Revolución francesa (1789) con sus consecuencias, incluida la ola de revoluciones liberales de 1820. No obstante, a pesar de escribir contra una asociación que conspiraba políticamente, el acento estaba puesto más en el fingimiento y engaño como estrategia de ataque a la Iglesia que en el hecho mismo conspirativo, del que apenas se hablaba en el documento pontificio. No cabe decir que este papa estuviera condenando aquí la carbonería y la masonería por intereses políticos personales, pues la atención seguía puesta en primer lugar

106 Ibidem, p. 410.

107 Sobre el debate histórico de la relación entre Carbonería y Masonería, véase Pellicciari, Angela, op. cit., pp. 58 y 59 . 
en el aspecto religioso y de salvación de las almas. ${ }^{108}$ De cualquier forma, el disimulo, la clandestinidad, el engaño y la traición fueron componentes necesarios para la conjura y, en función de ésta, encontraron su razón de ser. Los objetivos subversivos de los conspiradores se revistieron de "una vana y falaz filosofía" libertaria que no era otra que la del iluminismo y fueron "contra la Religión [católica] y contra la misma sociedad civil", pues su intención era "arrollar y subvertir a la Iglesia misma, engañando a los fieles [...] y substrayéndolos de la doctrina de la Iglesia", mediante la difusión del indiferentismo religioso, la profanación del cristianismo, el desconocimiento de la Sede Apostólica y la enseñanza de que se podía lícitamente fomentar rebeliones y despojar del poder a los reyes y autoridades civiles contra la obediencia debida y predicada por San Pedro y San Pablo (1Pe 2, 13; $R m$ 3, 14) ${ }^{109}$ Como necesitaban apoyos, se vestían con piel de corderos, aparentando virtud e incluso celo religioso, cuando en realidad eran lobos, para atraer a sus "ocultos congresos y sectas clandestinas" a quienes pretendían convertir en "cómplices de su conjura e iniquidad". ${ }^{110}$ En su desmedido afán de engaño, llegaron incluso a proclamar sacrílegamente a Jesús como "Rector y gran Maestro" de sus sociedades. ${ }^{111}$

Por tanto, conspiración, sí, pero, sobre todo, secretismo, indiferentismo religioso, profanación del cristianismo e inmoralidad caracterizaron a estas asociaciones, según Pío VII, a la luz de sus propios estatutos, ceremoniales y demás escritos, así como de los relatos de quienes habían dejado la asociación. El secreto exigido se imponía mediante un "juramento severísimo" y comprendía nunca revelar nada relacionado con la asociación a quienes no pertenecían a ella, pero también "no comunicar a quienes se enc[ontraban] en los grados inferiores cosa alguna que compe[tiera] a los grados superiores" (base para la manipulación, que el autor no mencionaba pero que dejaba entrever si se ligaba esto a su denuncia de la intención de los enemigos de la Iglesia de arrastrar individuos a la complicidad mediante reuniones ocultas); además, se amenazaba con la muerte (al menos en el texto del juramento, procedente de la tradición inglesa medieval) a quienes rompieran ese secreto. ${ }^{112}$ Destacaba el pontífice que los carbonarios introducían en "la Religión

108 Esto no obstante que, unos años después, León XII afirmaba que en la motivación de esta constitución apostólica estaba el deseo de Pío VII de liberar Italia -Estado Pontificio comprendido-, de la conjura de los carbonarios: véase León XII, Constitución apostólica Quo graviora (13 de marzo de 1825)..

109 Pío VII, Bula Ecclesiam a fesu Christo (13 de septiembre de 1821), en op. cit., p. 408.

110 Ibidem, pp. 408 y 409.

111 Ibidem, p. 409.

112 Ibidem, pp. 409 y 410. 
esa indiferencia" perniciosa resultado de considerar lícito que cada quien inventara con su propio ingenio y opiniones la religión que había de profesar. ${ }^{113}$ Además, los carbonarios eran acusados por el papa de profanar los misterios de la pasión de Cristo y otros con algunas "ceremonias nefandas" y de despreciar los sacramentos cristianos adoptando de manera impía ritos propios a imitación de ellos. ${ }^{114}$ La recta moral quedaría trastornada al justificar un rigorismo exasperado en la custodia de todo lo propio, lo cual, al mismo tiempo, justificaría la hipócrita apariencia de virtud, el engaño, la maquinación, la desobediencia y la violencia misma.

León XII (1823-1829) escribió su constitución apostólica contra la masonería el 13 de marzo de 1825 en términos alarmistas, como se desprende de su título Quo graviora. ${ }^{115}$ Se trataba fundamentalmente de una denuncia de la conspiración masónica contra la Iglesia y el Estado. No entraba en disquisiciones sobre la naturaleza de las asociaciones masónicas, sino que, en lugar de ello, optaba por reproducir íntegramente la In eminenti, la Providas y la Ecclesia a Jesu Christo, pues las constituciones de sus predecesores habían tratado suficientemente este tema. El papa Della Genga - procedente del grupo de los zelanti, partidarios de una alianza trono y altar como valladar frente al primer liberalismo político- enfatizaba la peligrosidad de la acción conspirativa y subversiva de estas asociaciones. La constitución Quo graviora era notablemente más extensa que las anteriores sobre el tema, aun sin considerar las reproducciones de las constituciones de sus predecesores, en una especie de intento de hacer énfasis en la importancia del asunto que estaba tratando. Al igual que su inmediato predecesor, comenzaba hablando de los "enemigos" de la Iglesia para contextualizar su escrito, algo que no hicieron los dos pontífices del siglo XVIII, quienes iniciaron sus documentos refiriéndose a peligros doctrinales. El sustantivo con el que León XII se refería a las asociaciones masónicas era ya el de sectas, pues las consideraba comunidades de personas con creencias erróneas en las que los miembros seguían ciegamente las indicaciones de sus mandos. Además, debido a que se había interesado personalmente por informarse del estado de las sociedades secretas, era consciente de la variedad del mundo masónico, por lo que reconocía que, a partir de las primeras "sectas masónicas, todavía activas, [habían] germinado muchas otras [sectas clandestinas], bastante peores y más audaces que aquellas" ${ }^{116} \mathrm{y}$, aunque presentaran

113 Ibidem, p. 409.

114 Idem.

${ }^{115}$ León XII, Bula Quo graviora (13 de marzo de 1825), en Bellocchi, Ugo, op. cit., pp. 3145. Las citas en español de este documento son traducción nuestra.

116 Ibidem, p. 37. 
diversidad de nombres y no tuvieran lazos institucionales entre ellas, todas estaban unidas en los objetivos que perseguían.

Este pontífice denunció principalmente dos cosas: el engaño y los depravados propósitos de los conspiradores masones. El "engaño de los sectarios" 117 -que maquinarían de manera incesante- había acarreado a Europa desórdenes y tumultos; estos confabulados habían penetrado furtivamente también la universidad, se servían de la imprenta para difundir ideas erróneas y subversivas, y sus engaños tenían acceso incluso a las cortes de los monarcas; los propios masones de grados inferiores eran también víctimas del ocultamiento de los de grados superiores, quienes los manipulaban como tontos útiles en favor de intereses que desconocían. Los "depravados propósitos" de los maquinadores se dirigían "a hacer caer a los Principados legítimos y a destruir la Iglesia desde sus fundamentos". ${ }^{118} \mathrm{El}$ autor constataba que lo que antes había sido temido como una posibilidad, se había convertido en una realidad, por no haberse escuchado las advertencias de sus predecesores en el solio pontificio.

Considerando la conspiración contra la Iglesia y el Estado la finalidad de todas las asociaciones secretas, León XII prohibió "todas las sociedades ocultas (cualquiera que [fuera] su nombre), tanto las [...] existentes, como las que [se constituirían] sucesivamente y que se propusieran las acciones arriba recordadas contra la Iglesia y las supremas potestades civiles"; 119 en consecuencia, pedía a los fieles abstenerse de toda adhesión y apoyo a ellas bajo la misma pena ya establecida para el caso de las masonerías de excomunión latae sententiae reservada al romano pontífice, y la extendía incluso a quienes no delataran a quienes se hubieran adscrito o dado su apoyo a tales sociedades. Añadía una reprobación y declaración de nulidad del juramento propio de estas asociaciones de secreto y de muerte de los delatores. La constitución se promulgó en el Año Santo Jubilar y el papa concedió por un año la suspensión de la obligación de denunciar a los compañeros de "secta" y el permiso a todo confesor de absolver de la excomunión a los arrepentidos. ${ }^{120}$ Della Genga pedía la colaboración de los obispos y los monarcas católicos, recordándoles que la causa de la religión católica estaba unida a la de la salvación de la sociedad y que esas "sectas" eran enemigos comunes. ${ }^{121}$

\footnotetext{
117 Idem.

118 Ibidem, p. 41.

119 Ibidem, p. 42.

120 Ibidem. p. 45.

121 Ibidem, pp. 43 y 44.
} 
En definitiva, lo que cautelarmente habían condenado los pontífices del siglo XVIII, se demostraba ahora fuente de un peligro para los del XIX. Aquellos temores de los primeros acerca de los daños que estas asociaciones podían acarrear para el bien común temporal y para el bien eterno de las personas, los segundos podían ahora confirmarlos, a la luz de la conspiración que estas "sectas" alentaban contra los legítimos poderes del Estado y de la Iglesia. Para los primeros, era necesario intervenir, con el objetivo de clarificar y salvaguardar la doctrina frente a errores y peligros eventuales; para los segundos, era preciso desenmascarar a los enemigos de la Iglesia, que pretendían y tramaban su ruina bajo disfraces ideológicos y moralistas. La denuncia de Pío VII y León XII de la conspiración masónica fue una denuncia de estilo alarmista, pero basada en la experiencia histórica que les tocó vivir. Los pontífices sucesivos sufrieron la persecución contra la Iglesia y, sobre todo, contra el catolicismo, desde un ámbito político en el que diversas masonerías influyeron de modo determinante.

2. De la conjura a su espiritu, pasando por la guerra. Traditi humilitati, 1829; Mirari vos, 1832, y Qui pluribus, 1846

Con Pío VIII (1829-1830) entramos en una fase nueva dentro de esta etapa marcada por la denuncia de la conspiración. Se trata de un periodo en el que, por parte del papado, de la condena motivada por el hecho mismo de la conjura contra la Iglesia se pasa a la de la conspiración por razón del espíritu que la anima. Ya vimos que, incluso en la fase anterior de esta etapa, los papas no olvidaron los motivos iniciales de condena de la masonería en sí misma, por la naturaleza del asociacionismo masónico y retomaron las constituciones de Clemente XII y Benedicto XIV, y que también anotaron algunos elementos ideológicos subyacentes a la conspiración que denunciaban; sin embargo, tanto Pío VII como León XII prefirieron poner el acento en la condena de la conjura misma más que en la profundización del espíritu que la animaba. Veremos ahora como desde Pío VIII los argumentos, si bien se reiteran, también se profundizan, preparando el camino a una ulterior etapa de mayor reflexión sobre la oposición e incompatibilidad de principios entre masonería y cristianismo, la cual alcanzó su ápice en la encíclica Humanum genus de León XIII.

Los tres pontífices de esta fase mencionaban que la situación de oposición a la Iglesia era ya de guerra y, por tanto, la conspiración prácticamente era pública, pues los enemigos "no ya ocultamente y con subterfugios [atacaban] la fe católica, sino abiertamente y bajo los ojos de todos se [movía] contra 
ella una horrible y nefanda guerra", ${ }^{122}$ sin que sintieran la necesidad de demostrarla, como hicieron los papas de la fase anterior. Más que destapar la conspiración en sí, estaban interesados en hacer comprender el espíritu que la animaba, ese combate abierto contra la religión cristiana. Debido a que el ataque a la religión católica parecía evidente, esa conspiración llegó a ser un lugar común en el magisterio pontificio para indicar la oposición al catolicismo, fuera o no orquestada de modo oculto y premeditado, siempre que se constatara la presencia de ese espíritu hostil y relativista que los documentos fueron describiendo. No obstante, el fingimiento, el engaño, la insidia y las maquinaciones no dejaron de estar presentes en las denuncias papales, pues correspondían al modo de actuar de los "aborrecedores de la luz", incluso en la esfera pública, para apoyar la impiedad en perjuicio de todo sentimiento "de justicia y de honestidad", para "corromper las costumbres", para menoscabar "los derechos divinos y humanos" y para destruir, arruinar y hacer desaparecer de raíz "la religión católica y la sociedad civil". ${ }^{123}$

La encíclica Traditi humilitati del 24 de mayo de 1829 abría el breve pontificado de Pío VIII, pues había sido escrita con ocasión de su toma de posesión de la Basílica de San Juan de Letrán. ${ }^{124}$ En ella, el papa Castiglione se dolía de los "estandartes de guerra" que "hombres malvados" habían levantado contra la religión católica. ${ }^{125}$ En línea con sus inmediatos predecesores, citando además la lista de las cuatro constituciones pontificias condenatorias de la masonería, denunciaba la conjura deshonesta que unos "sofistas" -es decir, engañadores- tramaban contra el catolicismo, con el objetivo de destruirlo, particularmente la conspiración de las sociedades secretas contra el "consorcio religioso y civil"; no obstante, también se detenía a exponer con rigor lógico el espíritu que animaba tal conjura. ${ }^{126}$

Para este pontífice, eran tres los rasgos característicos del espíritu que animaba la conjura contra la religión católica e, inscrita en ella, la conspiración masónica. El primero, la soberbia o presunción del racionalismo iluminista, que ya insinuaba Pío VII: los sofistas - autodefiniéndose doctores- recurrían a una filosofía falaz para atacar a la religión en nombre de la razón, califi-

122 Gregorio XVI, Encíclica Mirari vos (15 de agosto de 1832), en Bellocchi, Ugo, op. cit., p. 170. Se refiere aquí en concreto a las opiniones enseñadas en universidades y escuelas.

${ }^{123}$ Pío IX, Encíclica Qui pluribus (9 de noviembre de 1846), en Rodríguez, Federico (ed.), Doctrina Pontificia, Madrid, BAC, 1959, t. III, p. 74.

${ }^{124}$ Pío VIII, Encíclica Traditi humilitati (24 de mayo de 1829), en Bellocchi, Ugo, op. cit., pp. 116-121. Las citas en español de este documento son traducción nuestra.

125 Ibidem, p. 117.

${ }^{126}$ Ibidem, pp. 117 y 118. 
cándola de superstición y fábula. ${ }^{127} \mathrm{El}$ segundo, ampliamente desarrollado en esta encíclica, era el indiferentismo religioso, por el cual los sofistas "no admit[ían] alguna distinción entre las diversas profesiones de fe", sostenían "que est[aba] abierto a todos el puerto de la salvación eterna, cualquiera que [fuera] la confesión religiosa", de manera que tachaban "de fatuidad y estupidez a quienes abandona[ban] la religión en la que habían sido educados para abrazar otra, aun cuando fuera incluso la Religión católica", la cual era para el papa "la sola verdadera religión". ${ }^{128}$ Afirmaba el papa Castiglione: "Es de verdad letal esta forma de indiferencia religiosa y es rechazada por la luz misma de la razón natural, la cual nos advierte claramente que, entre religiones discordantes, si una es verdadera, la otra es necesariamente falsa". ${ }^{129}$ El tercer rasgo era la depravación moral, la cual se expresaba primero en la persecución contra la religión, por medio de múltiples estrategias, como las traducciones tergiversadas de la Biblia; la divulgación de libros perniciosos; el desprecio a los sacerdotes y a los ritos sagrados; la maquinación encubierta contra la autoridad eclesiástica y la civil; la injerencia en las escuelas para corromper a los adolescentes; el ataque contra la santidad e indisolubilidad del matrimonio. El pontífice intuía que el relativismo moral era fruto de esta depravación, al advertir: "es un horrendo prodigio de impiedad atribuir la misma alabanza a la verdad que al error, a la virtud que al vicio, a la honestidad que a la perversión". ${ }^{130}$

En definitiva, para Pío VIII, el relativismo filosófico, religioso y moral era el alma de la conspiración en curso contra la religión católica. En consecuencia, este papa convocó al episcopado católico a oponerse a "esas sociedades secretas de hombres facciosos que, enemigos de Dios y de los príncipes, se dedica[ban] por entero a procurar la ruina de la Iglesia, a minar a los Estados, a subvertir el orden universal y, roto el freno de la fe verdadera, [habían] abierto el camino a toda suerte de depravaciones". ${ }^{131}$

Gregorio XVI (1830-1846), en su encíclica Mirari vos, del 15 de agosto de 1832, ${ }^{132}$ escrita con ocasión de la toma de posesión de la Basílica Lateranense y tras las revoluciones liberales nacionalistas de 1830, reprobaba la connivencia con el liberalismo de algunos grupos católicos, como fue el caso

\footnotetext{
127 Ibidem, p. 117.

128 Idem.

129 Idem.

${ }^{130}$ Idem.

131 Ibidem, p. 118.

132 Gregorio XVI, Encíclica Mirari vos (15 de agosto de 1832), en Bellocchi, Ugo, op. cit., pp. 169-178. Las citas en español son traducción nuestra.
} 
de los promotores del periódico francés L'Avenir. También buscaba poner en evidencia el espíritu que animaba la conspiración y la guerra abierta que -según él- las sociedades secretas estaban orquestando contra el catolicismo y el orden constituido. El pontífice comenzaba aludiendo a "la más perversa conspiración de los impíos"133 y presentaba toda una serie abundante de males morales de la sociedad y de vejaciones contra la Iglesia que habían conducido a la ruina de la religión y a la perversión de las costumbres. El papa Cappellari estaba convencido de que la pérdida del aprecio social a la religión católica conllevaría el menoscabo de la obediencia a la autoridad civil y la subversión del orden público. Para él, "una mezcolanza tan grande de calamidades [debía] atribuirse particularmente a la conspiración de esas sociedades en las que parec[ía] haberse recogido, como en una inmunda sentina, todo cuanto [había] de sacrílego, abominable e impío en las herejías y en las más perversas sectas". ${ }^{134}$ Las asociaciones masónicas habían reunido en sí ideas y fuerzas con las que daban forma a la conspiración que estaba en la raíz de esa serie de males.

Cabe precisar que, si bien este papa no mencionaba aquí explícitamente a las asociaciones masónicas, no hay duda de que se refería a ellas porque las describía de modo semejante a como lo habían hecho sus predecesores: "ciertas asociaciones y determinadas reuniones en las cuales, hecha liga con personas de religiones falsas y cultos sectarios, se predican libertades de todo género, se suscitan perturbaciones contra los poderes sagrado y civil, y se conculca toda autoridad por más santa que sea, bajo la simulada pretensión de piedad religiosa, pero con objetivo de hecho de promover por todas partes novedad y sedición". Frente a esta conspiración, Gregorio XVI invocaba la urgente defensa de la unidad jerárquica de la Iglesia, de la disciplina eclesiástica - particularmente del celibato sacerdotal-y del matrimonio cristiano. Encontraba los remedios en la difusión de la palabra de Dios, en la promoción de la armonía entre las autoridades eclesiásticas y las civiles y, por supuesto, en la intercesión de la Virgen María y de los santos Pedro y Pablo.

Para este pontífice, el espíritu de la conspiración estaba caracterizado por el "indiferentismo" 135 religioso de pensar que "en cualquier profesión de fe [podía] conseguirse la salvación eterna del alma con tal que [hubiera] rectitud y honradez en las costumbres", ${ }^{136}$ inculcado "por obra fraudulenta de

133 Ibidem, p. 169.

134 Ibidem, p. 171.

135 Ibidem, p. 173. Gregorio XVI es el primero en usar el término indiferentismo; recordemos que Pío VII y Pío VIII hablaron de indiferencia.

136 Ibidem, p. 174. 
los incrédulos", ${ }^{137}$ con el que se abriría la puerta a todo un deterioro no sólo de fe, sino también de costumbres, lo que desembocaría en el relativismo, si bien esto último no llegó a expresarlo con la misma claridad de Pío VIII. Así, derivados del indiferentismo, también eran elementos integrantes del espíritu de la conspiración: la libertad de conciencia, que induciría al subjetivismo y a considerar innecesaria la búsqueda de la verdad objetiva; la libertad de imprenta, que divulgaría errores; la rebeldía contra la autoridad civil, que abriría las puertas al libertinaje y la anarquía, y la separación entre la Iglesia y el Estado, que destruiría esa concordia que había dado solidez al bien objetivo de la sociedad en lo religioso y en lo civil. 138

Durante este pontificado, el Santo Oficio se pronunció contra la masonería en sus respuestas del 5 de julio de 1837, 27 de junio de 1838 y 5 de diciembre de $1840 .{ }^{139}$

Con el beato Pío IX (1846-1878), el papado continuó expresándose contra la masonería en un contexto de denuncia de la conspiración persecutoria contra la Iglesia y desvelando el espíritu de la misma. Al igual que sus dos inmediatos predecesores, desde su encíclica de inicio de pontificado atendía a este argumento. Así, dedicaba la encíclica Qui pluribus ${ }^{140}$, del 9 de noviembre de 1846, a exponer los errores de su época difundidos por los múltiples enemigos de la Iglesia, entre los que estaban, en primer lugar, "las sectas clandestinas, brotadas de las tinieblas para la destrucción y ruina lo mismo de la sociedad sagrada que de la civil", ${ }^{141}$ ya condenadas por sus antecesores en varios documentos que él confirmaba. Como hicieron Pío VIII y Gregorio XVI, hablaba de guerra acérrima y terrible142 "contra todo lo que significa catolicismo por parte de esos hombres, que unidos entre sí por una alianza impía, no admitiendo la sana doctrina y apartando los oídos a la verdad", generaban y difundían "monstruosas opiniones". ${ }^{143}$ En continuidad con Gregorio XVI, también Pío IX señalaba que los enemigos de la Iglesia se habían concentrado en atacar a la Sede Apostólica; en utilizar las sociedades bíblicas; en promover el indiferentismo religioso -con la consecuente imposibilidad de distinguir "entre virtud y vicio, entre verdad y error, entre honestidad y torpeza", como si se pudiera "conseguir la salvación

137 Ibidem, p. 173.

138 Ibidem, pp. 174-177.

139 Müller, Gerhard, cardenal, "Introducción” (8 de diciembre de 2014), Congregazione per la Dottrina della Fede, op. cit., pp. 7 y 8.

140 Pío IX, Encíclica Qui pluribus (9 de noviembre de 1846), en Rodríguez, Federico, op. cit., pp. 72-91. Texto en español y latín.

141 Ibidem, p. 78.

142 Ibidem, p. 74: "acerricum ac formidolosissimum [...] bellum".

${ }^{143}$ Idem. 
eterna en cualquier religión"144-; en conspirar contra el celibato sacerdotal y el matrimonio; en infiltrarse en la enseñanza de la juventud; en la propaganda impresa; en difundir "esa abominable y sobre todas antirracional doctrina llamada del comunismo, que, de admitirla, acabaría por destruir desde sus cimientos los derechos, las cosas y las propiedades de todos y hasta la misma sociedad humana". ${ }^{145}$ Con todo, los remedios pastorales que proponía este papa eran abundantes y muy propios de un pastor de almas: pedía a los obispos actuar "condoliendo[se], con entrañas de misericordia, de los ignorantes y de los que [erraban], [...] dispuestos a buscar y rebuscar [...] las ovejas descarriadas [...] sin escatimar jamás ni desvelos, ni consejos, ni trabajos"; 146 asimismo, recordaba a las autoridades civiles que era su deber defender la causa de la Iglesia, pues así podrían contar con el amparo del Señor.

En la encíclica Qui pluribus, encontramos que el espíritu que animaba la conspiración masónica era el del racionalismo y del naturalismo, que se consolidaban en un relativismo (apenas entrevisto por el autor) que renunciaba a la verdad y encumbraba la mentira. El punto de partida de este espíritu estaba en la negación de la revelación sobrenatural como fuente posible de conocimiento - que es lo específico del racionalismo iluminista- $\mathrm{y}$, una vez negada la revelación y tachada de fábula su contenido, se abrazaba el naturalismo inmanentista como único criterio para el progreso posible del ser humano, de modo que la Iglesia misma pasaba a ser juzgada como un obstáculo para el progreso y bienestar de la sociedad humana, pues propondría una trascendencia que resultaría alienante en opinión de quienes creían que el hombre podía y debía realizarse en la inmanencia. Para Pío IX, la adopción de esta mentira sobre el hombre - es decir, la creencia en que el fin del hombre es inmanente, rechazando todo planteamiento de trascendencia- comenzaba por apagar la piedad, pero, tras ella, consecuentemente, también agotaba la justicia y la honestidad, para terminar por degradar la vida social mediante el relativismo moral, que corrompía las costumbres y menoscababa los derechos humanos y divinos, en lugar de hacerla progresar. El papa Mastai Ferreti denunciaba también la soberbia de estos racionalistas-naturalistas, quienes, "imaginándose estar ellos solos en el secreto de la prosperidad" y con pretensiones de convertirse en los maestros y guías del resto de la humanidad, no vacilaban "en arrogarse el nombre de filósofos, como si la filosofía, que consiste por entero en la investigación de la verdad, rechazara lo que el mismo supremo y clementísimo

144 Ibidem, p. 79. Habla de "ese horrendo sistema [...] sobre la indiferencia de cualquier religión".

145 Ibidem, pp. 79-80. Esta frase es la primera alusión al comunismo en un documento pontificio; aparece así como uno de los enemigos de la religión católica. Sobre masonería y comunismo, véase Bárcena, Alberto, op. cit., pp. 143-150 y 157-165

146 Ibidem, p. 88. 
autor de toda la naturaleza, Dios, por singular beneficio y misericordia, se dignó manifestar a los hombres a fin de que estos pudieran alcanzar verdadera felicidad y salvación". ${ }^{147}$ Contrariamente a lo que estos propugnaban, no había "oposición" ni desacuerdo alguno entre la fe y la razón, porque ambas tenían "su origen en la única y misma fuente inmutable y eterna de verdad". ${ }^{148}$ Tampoco habría enfrentamiento alguno entre la religión católica y el progreso humano porque también Dios era el origen y fin del catolicismo y del ser humano. ${ }^{149} \mathrm{El}$ pontífice que presidió el Concilio Vaticano I (1869-1870) reflexionaba ya en ésta, su primera encíclica, sobre la relación entre fe y razón, y hablaba de la infalibilidad de la Iglesia en materia de fe y costumbres, temas tratados respectivamente en las constituciones dogmáticas Dei Filius (24 de abril de 1870) y Pastor aeternus (18 de julio de 1870), aprobadas en ese concilio ecuménico.

Asimismo, Pío IX denunció la hipocresía de estos seudofilósofos "peritísimos artífices del fraude", lobos rapaces con piel de ovejas, pues albergaban la intención de "confundir a los incautos e ignorantes" y arrastrarlos al error para manipularlos como tontos útiles, y "engañar [...] a los pueblos". ${ }^{150}$ En esta misma línea, pocos años después, el 20 de abril de 1849, desde su exilio en Gaeta (Reino de las Dos Sicilias), ${ }^{151}$ pronunció su alocución Quibus, quantisque malorum, en el cual lamentaba los males que por entonces sufrían sus súbditos romanos en manos de los revolucionarios; en ella, reiteraba la condena, prohibición y proscripción de esas "sociedades y sectas", "perjudiciales en grado sumo no solo para la salvación de las almas, sino incluso para el bien y la tranquilidad de la sociedad civil", fundadas por "los fabricadores de mentiras [...] para inocular con más seguridad en los ánimos de los demás sus delirios, sistemas e innovaciones, corromper los corazones de los incautos y abrir un ancho camino a la impune perpetración de toda clase de crímenes". ${ }^{152}$

\footnotetext{
147 Ibidem, p. 75.

148 Idem.

149 Ibidem, p. 76.

${ }^{150}$ Ibidem, pp. 74 y 75 .
}

151 A consecuencia de la revolución en Roma, Pío IX se estableció en Gaeta del 25 de noviembre de 1848 al 12 de abril de 1850.

152 Pío IX, Alocución Quibus, quantisque malorum (20 de abril de 1849), en Rodríguez, Federico (ed.), op. cit., pp. 93-119, pp. 114 y 115. Texto en español y latín. Asimismo, el 8 de diciembre del mismo 1849, desde Nápoles, con la encíclica Nostis et nobiscum, Pío IX advierte al episcopado italiano acerca de quienes pretenden destruir la presencia de la Iglesia católica en Italia y que, habiéndolo intentado sin éxito mediante la guerra, ahora buscaban hacerlo, si no con abierta violencia, sí mediante otros medios fraudulentos, que él trata de desenmascarar; no menciona a las sociedades masónicas, pero no deja de denunciar maquinación contra la Iglesia y la sociedad, deteniéndose particularmente en el peligro del socialismo y del comunismo: véase Rodríguez, Federico (ed.), op. cit., pp. 122-148. 
Esta obra forma parte del acervo de la Biblioteca Jurídica Virtual del Instituto de Investigaciones Jurídicas de la UNAM www.juridicas.unam.mx

https://biblio.juridicas.unam.mx/bjv

\section{LAS GONDENAS PONTIFICIAS POR INCOMPATIBILIDAD DE PRINCIPIOS. SEGUNDA MITAD DEL SIGLO XIX}

\section{La oposición de principios en tiempos de Pio IX}

El más largo pontificado romano de la historia experimentó las consecuencias de las revoluciones liberales socialistas de 1848, con el establecimiento de la República Romana de febrero a julio de 1849, ${ }^{153}$ el movimiento de unidad política de la nación italiana, la pérdida definitiva del poder temporal del papado (20 de septiembre de 1870), así como el nuevo ciclo revolucionario de 1868-1871,154 y el ascenso de los masones a los gobiernos de los Estados occidentales. ${ }^{155}$ Giovanni Maria Mastai Ferretti (1792-1878) ascendió al trono pontificio con cincuenta y cuatro años y gobernó la Iglesia por otros treinta y dos años con el nombre de Pío IX. Sus pronunciamientos sobre el fenómeno masónico fueron muy numerosos. ${ }^{156}$ También el Santo Oficio se pronunció bastantes veces contra la masonería, como en sus respuestas de los días 1 de agosto de 1855, 28 de junio, 5 de julio y 7 de julio de 1865, 30 de enero de 1867, 12 de enero y 15 de junio de 1870, 1 de febrero de 1871, 23 de abril de 1873 y 8 de julio de 1874.157 Ya conocemos la encíclica programática de Pío IX de 1846 y su alocución del 20 de abril de 1849. En esa misma alocución, este papa condenaba también el recién nacido comunismo, que, para él, era sólo una nueva rama del liberalismo, pues compartía con éste la misma raíz naturalista cerrada a lo sobrenatural. La defensa del poder temporal del papado que hizo este pontífice la encuadró en la necesidad de la Iglesia de contar con una garantía de libertad respecto a los movimientos políticos anticatólicos alentados por la masonería, el liberalismo y el comunismo, que le permitiera ejercer más fácilmente su servicio espiritual a la universalidad de los fieles y a la comunidad internacional. ${ }^{158}$

Las medidas anticlericales y de reforma social secularizadora impuestas por parte de revolucionarios y gobernantes políticos afines a diversas masonerías en

153 Véase Bárcena, Alberto, op. cit., pp. 137-141.

154 Ibidem, pp. 117-123, 142 y 143.

155 Caso emblemático pero en absoluto excepcional fue el la Tercera República Francesa (1870-1940), véase Ridley, Jasper, op. cit., pp. 328 y 329 (libro escrito con la simpatía hacia los masones y desde el convencimiento de la inocuidad de la masonería).

156 Sobre Pío IX y la masonería, véase Pellicciari, Angela, op. cit., pp. 435-456.

157 Müller, Gerhard, cardenal, "Introducción” (8 de diciembre de 2014), Congregazione per la Dottrina della Fede, op. cit., pp. 7 y 8.

158 Por ejemplo, Pío IX, Alocución Ad gravissimum (20 de junio de 1859), en Bellocchi, Ugo, op. cit., pp. 186-189. 
el transcurso de la segunda mitad del siglo XIX en Italia, en el resto de Europa y en América Latina reafirmaron al papa en su convicción sobre la conveniencia de que la Iglesia siguiera contando con un Estado pontificio. La definición del dogma de la Inmaculada Concepción de María en 1854 tuvo también un valor de defensa de la dimensión trascendente de la persona humana y de la misión de la Iglesia en la sociedad temporal en este contexto difícil. ${ }^{159} \mathrm{Al}$ día siguiente de la proclamación del dogma, Pío IX dirigía una alocución alertando respecto a "una impía especie de incrédulos, que [querrían] ver exterminado, si fuera posible, todo culto religioso, [...] entre estos, debían citarse en primer lugar a los miembros de las sociedades secretas, quienes, ligados por pactos nefandos, usaban todo arte posible para turbar y destruir, violando todo derecho, la Religión y el Estado". Hablaba, además, principalmente contra el racionalismo y el indiferentismo religioso, dos elementos esenciales del espíritu masónico, según habían descrito varios pontífices. ${ }^{160}$

Sin hacer una presentación sistemática del fenómeno masónico, sino sólo referencias varias, Pío IX manifestaba suficientemente su convencimiento de la radical oposición de principios entre el cristianismo y la masonería. A diez años exactos de la proclamación del dogma de la Inmaculada, en la encíclica Quanta cura ${ }^{161}$ reafirmaba que "las sociedades secretas, prescindiendo de la exigencia o no exigencia del juramento de guardar secreto", ${ }^{162}$ estaban anatematizadas por sus predecesores (de quienes enunciaba la clásica lista de documentos) y por él mismo; lamentaba el destierro que sufría la religión católica respecto a la sociedad civil y lo atribuía al "naturalismo", ${ }^{163}$ traducido en secularismo ${ }^{164}$ y en indiferentismo religioso, pues esta corriente de pensamiento sostenía que "la forma más perfecta del Estado y el progreso civil exig[ían] imperiosamente que

${ }^{159}$ Así lo deja entrever la misma bula de proclamación: la Inmaculada "querrá hacer con su valiosísimo patrocinio que nuestra santa Madre, la Iglesia católica, superadas todas las dificultades y vencidos todos los errores, en todas partes y en todos los pueblos, sea cada vez más vigorosa y floreciente [...] y pueda gozar plenamente de toda paz, tranquilidad y libertad". Pío IX, Bula Ineffabilis Deus (8 de diciembre de 1854), en Marín, Hilario (ed.), Doctrina Pontificia, Madrid, s.e., 1954, t. IV, pp. 171-193.

160 Pío IX, Alocución Singulari quadam (9 de diciembre de 1854), en Bellocchi, Ugo, op. cit., p. 144. Traducción nuestra.

${ }^{161}$ Pío IX, Encíclica Quanta cura (8 de diciembre de 1864), en Gutiérrez García, José Luis (ed.), Doctrina Pontificia, Madrid 1958, t. II, pp. 5-18 (en español y latín).

162 Ibidem, p. 12.

163 Ibidem, p. 8.

164 Sobre los conceptos de secularismo y de laicismo, véase Martínez Albesa, Emilio, "Libertad religiosa y autoridad política a la luz de la encíclica Caritas in veritate de Benedicto XVI", en Rubio de Urquía, Rafael y Pérez-Soba, Juan José (eds.), La doctrina social de la Iglesia. Estudios a la luz de la encíclica, Madrid, Caritas in veritate, 2014, pp. 1005-1111 y 1088-1092. 
la sociedad humana [fuera] constituida y gobernada sin consideración alguna a la religión, y como si esta no existiera, o por lo menos, sin hacer diferencia alguna entre la verdadera religión y las religiones falsas", ${ }^{165}$ además, ratificaba la reprobaciones que Gregorio XVI había hecho de la libertad de conciencia, de la de culto ${ }^{166}$ y de la separación entre la Iglesia y el Estado, interpretadas al modo relativista y secularista. Como es sabido, la Quanta cura fue expedida por la Santa Sede con el Syllabus, un índice de los errores modernos compilados a partir de los documentos anteriores de Pío IX. ${ }^{167}$ Este índice constaba de ochenta afirmaciones calificadas de erróneas, organizadas por capítulos, más un párrafo que formaba el cuarto capítulo y que no se numeraba como afirmación, en el cual se recordaron las reprobaciones del "Socialismo, comunismo, sociedades secretas, sociedades bíblicas, sociedades clérico-liberales" ${ }^{\prime 168}$, es decir, las realidades consideradas enemigas de la Iglesia, opuestas a ella. Asimismo, los rasgos con los que se había venido caracterizando al espíritu de la conspiración masónica aparecían expresamente incluidos en esta colección de errores: naturalismo, racionalismo, indiferentismo o liberalismo. Esta inclusión en el Syllabus documenta la incompatibilidad de las asociaciones masónicas y el cristianismo en la posición de la Santa Sede.

El año siguiente, Pío IX volvió a expresarse sobre "esa sociedad perversa de hombres, vulgarmente llamada masónica" en su alocución Multiplices inter machinationes, del 25 de septiembre de 1865.169 En esta ocasión, el pontífice recordaba una vez más la lista de pronunciamientos de sus predecesores y afirmaba - contra la opinión de quienes consideraban inocuas a las asociaciones masónicas- que sus maquinaciones contra la Iglesia dañaban las causas inseparables de la religión y de la sociedad civil. Hacía una significativa oposición entre el asociacionismo masónico y el católico: mientras el primero reunía hombres de cualquier religión y fe y los vinculaba clandestinamente por medio de un juramento de secreto bajo penas atroces, el segundo reunía a los católicos abiertamente bajo vínculos y ordenamientos públicos con fines caritativos, y sus obras se practicaban a la vista de todos. Así, de un lado

165 Pío IX, Encíclica Quanta cura (8 de diciembre de 1864), op. cit., p. 8.

166 En puridad, la Mirari vos no condenaba expresamente la libertad de culto, pero puede considerarse su condena implícita en la del indiferentismo religioso y en la de la libertad de conciencia.

167 “«Ś́labo» o colección de los errores modernos”, en Denzinger, Enrique, El magisterio de la Iglesia, Barcelona, Herder, 1963, pp. 404-413.

168 Ibidem, p. 407. Se incluye una lista de documentos de Pío IX anteriores condenando estas doctrinas o realidades (véanse pp. 407 y 408).

169 Pío IX, Alocución Multiplices inter (25 de septiembre de 1865), en Bellocchi, Ugo, op. cit., p. 284. Las citas en español son traducción nuestra. 
estaba "la tenebrosa secta masónica, tan enemiga de Dios y de la Iglesia, tan peligrosa aun para la seguridad de los reinos", y de otro, "las piadosas sociedades de los fieles, que florec[ían] en la Iglesia Católica"; "en estas, nada [había] escondido o secreto; las reglas [estaban] a la vista de todos; y todos [podían] ver las obras de caridad que se practicaban según la doctrina del Evangelio". ${ }^{170}$ Para que no se engañara a los jóvenes y a las personas sencillas, el papa confirmaba que las constituciones apostólicas de sus predecesores anatematizadoras de las sociedades clandestinas eran válidas incluso allí donde la autoridad civil las toleraba, y solemnemente afirmaba: "por Nuestra autoridad apostólica, reprobamos y condenamos esa secta masónica y las demás sociedades del mismo género que con diversidad solo de apariencias cada día se constituyen y conjuran contra la Iglesia y los poderes legítimos, ya sea abiertamente, ya sea clandestinamente". ${ }^{171}$ El papa terminaba su alocución pidiendo a los católicos que, si habían ingresado en tales sociedades, las abandonaran y se mantuvieran todos en guardia contra sus miembros y sus seductores discursos, e, incluso, evitaran su trato.

En consecuencia, la constitución apostólica Apostolicae Sedis moderationi del 12 de octubre de 1869, de carácter penal, que regulaba las censuras latae sententiae de la Iglesia católica, derogando las que no recogía expresamente, incluía, entre las excomuniones latae sententiae reservadas al romano pontífice, la sanción de excomunión latae sententiae contra quienes daban su nombre a "sectas masónicas, carbonarias u otras del mismo género, que pública o clandestinamente maquina[ban] contra la Iglesia o contra las potestades legítimas, y contra los que favorec[ían] a estas mismas sectas, y los que no denuncia[ban] a sus corifeos, jefes o directores ocultos, mientras no verifi[caran] la denuncia". ${ }^{172} \mathrm{El}$

170 Ibidem, p. 285.

171 Ibidem, p. 286.

172 Apéndice a las Actas y decretos del Santo Concilio Ecuménico Vaticano que contiene la constitución Apostolicae Sedis de 12 de octubre de 1869 con algunas notas importantes para su más fácil inteligencia, Tipografía de D. José María Magallón, Zaragoza, 1873, p. 191. Véase texto latino original de la Apostolicae Sedis en p. 174: "Nomen dantes sectae Massonicae, aut Carbonariae, aut aliis ejusdem generis sectis quae contra Ecclesiam vel legitimas potestates seu palam, seu clandestine machinantur, nec non iisdem sectis favorem qualemcumque praestantes; earumve occultos coriphaeos ac duces non denunciantes, donec non denunciaverint". Aclara que las palabras "donec non denunciaverint manifiestan que una vez verificada la denuncia, aunque se haya incurrido en la censura por no haberla hecho dentro del tiempo señalado, que es el de un mes, cesa la reserva. Nótese además que sólo se incurre por no denunciar á los corifeos y directores ocultos, mitigando en esta parte las constituciones de varios Pontífices, que la imponían por no denunciar á cualesquiera miembros de estas sociedades nefandas", p. 191. 
4 de septiembre de 1871, la Santa Sede aclaró que estas denuncias debían hacerse al obispo diocesano o a su delegado. ${ }^{173}$

En la encíclica Etsi multa de noviembre de $1873,{ }^{174}$ posterior a la pérdida del Estado Pontificio y al Concilio Vaticano I, ${ }^{175}$ Pío IX lamentaba los males que sufría entonces la Iglesia, en particular, la usurpación de Roma y las medidas anticlericales del Estado italiano, el ataque en Suiza, la persecución en el Reino de Prusia, el cisma de los viejos católicos, las contradicciones en el continente americano; ${ }^{176}$ cabe señalar que todos éstos los atribuía a "los engaños y maquinaciones" de las masonerías y sociedades afines, pues "el carácter, modalidad y amplitud" mundial de esa "guerra" desatada contra la Iglesia correspondía al "carácter, objetivos y propósito" de éstas. ${ }^{177}$ En definitiva, el espíritu que animaba la contienda contra los intereses de la Iglesia era el mismo que animaba a las asociaciones masónicas y similares. Sirviéndose de la imagen de la meditación ignaciana de las dos banderas, el papa consideraba estas "sectas" "sinagoga de Satanás, que orden[aba] a su ejército contra la Iglesia de Cristo, levant[aba] su bandera y [venía] a la batalla". ${ }^{178}$ Así, la oposición entre la masonería satanizada y la Iglesia de Cristo resultaba irreconciliable.

173 Véase ibidem, pp. 205 y 207.

174 Pío IX, Encíclica Etsi multa (21 de noviembre de 1873), en Bellocchi, Ugo, op. cit., pp. 401-412.

175 Pío IX había ya escrito la encíclica Respicientes ea, con fecha del 1 de noviembre de 1870, para protestar del comportamiento del gobierno italiano y particularmente de la usurpación del dominio político sobre Roma y las localidades del Lacio el 20 de septiembre anterior. En ella, el pontífice atribuye esta usurpación a que se ha seguido "el consejo de las sectas de perdición”. Esta encíclica está publicada en Bellocchi, Ugo, op. cit., pp. 341-348.

176 Cuando se expidió la encíclica, además de casos de anticlericalismo de Estado no ajeno a la masonería como el de México, entonces bajo el presidente Sebastián Lerdo de Tejada, el de Colombia, bajo Manuel Murillo Toro, el de Venezuela, bajo el dictador Guzmán Blanco, el de Chile, bajo Federico Errázuriz Zañartu, el de Guatemala, bajo Miguel García Granados y en unos días más bajo Justo Rufino Barrios, el de Uruguay, bajo José Eugenio Ellauri Obes, resultaba significativo del influjo de la masonería el caso brasileño, relativo a los obispos Antonio Gonçalves de Oliveira, de Olinda-Pernambuco, y de Antonio Macedo Costa, de Paráde Belem, quienes trataron de oponerse a la presencia de masones en las hermandades católicas de sus diócesis, censurando a las hermandades que, con apoyo del Estado, se resistían a expulsar a los masones. Pío IX intervino con su carta en forma de breve del 29 de mayo de 1873 Quamquam dolores, lamentando la penetración de la masonería en Brasil. Sin embargo, los dos obispos recibieron reprobaciones de la Santa Sede por lo que se consideró un rigor demasiado imprudente y pasaron un año y medio en prisión por orden de la autoridad civil. El episcopado brasileño y la misma Santa Sede hubieron de tolerar que en Brasil se actuase de hecho como si masonería fuese compatible con el catolicismo. Sobre este caso brasileño, véase Martina, Giacomo, Pio IX (1867-1878), Roma, Pontificia Universidad Gregoriana, 1990, pp. 441-456.

177 Pío IX, Encíclica Etsi multa (21 de noviembre de 1873), op. cit., p. 410.

178 Idem. 


\section{La incompatibilidad de las "dos ciudades". León XIII y la encíclica Humanum genus, 1884}

Citando De Civitate Dei de San Agustín ${ }^{179}$ y bajo el influjo de las dos banderas de los ejercicios ignacianos, así como de las expresiones de Pío IX, León XIII (1878-1903) presentaba la masonería y la Iglesia como dos reinos, el de Satanás y el de Dios, respectivamente, semejantes a dos ciudades que, con leyes opuestas, avanzaban hacia fines opuestos, ${ }^{180}$ de manera que era incompatible la pertenencia simultánea a ambas realidades. Durante el pontificado del papa Pecci, a pesar de su talante conciliador, los pronunciamientos contra la masonería - ahora, como veremos, en singular- son abundantes. ${ }^{181}$ Era una época en la que algunos masones habían conquistado la mayoría de los gobiernos de las naciones occidentales y, desde la primera década del siglo XX - comenzando por Francia e Italia-, ejercieron una política de corte laicista, hostil a la presencia de la religión católica en la esfera pública, aduciendo el carácter laico del Estado bajo la doctrina del positivismo..$^{182}$

En su encíclica de 1882, Etsi nos, sobre los gravísimos peligros para la religión católica en Italia, León XIII advertía -sin mencionar expresamente a la masonería, pero en referencia a ella-: "una perniciosísima secta, cuyos autores y corifeos no ocultan ni disimulan nada sus miras, hace ya tiempo que ha establecido sus reales en Italia, y declarando guerra a Jesucristo, trabaja por despojar completamente al pueblo de toda institución cristiana". ${ }^{183}$ A través de medidas legislativas anticlericales, el objetivo de tal secta -la "más hostil

179 San Agustín, De Civitate Dei, Libro XIV, 28: "Fecerunt itaque civitates duas amores duo, terrenam scilicet amor sui usque ad contemptum Dei, caelestem vero amor Dei usque ad contemptum sui" " $D o s$ amores hicieron dos ciudades: el amor de sí mismo hasta el desprecio de Dios generó la ciudad terrena, y el amor de Dios hasta el desprecio de sí generó la ciudad celeste").

180 "Con aguda visión ha descrito Agustín estos dos reinos como dos ciudades de contrarias leyes y deseos": León XIII, Encíclica Humanum genus, 20 de abril de 1884, véase Gutiérrez García, José Luis, op. cit., p. 158.

181 Véase Pellicciari, Angela, op. cit., pp. 124-159.

182 "Lo característico del laicismo, en cuanto forma específica de secularismo [...], sería entonces la justificación de la exclusión de la religión de la esfera pública a partir de la afirmación de la del Estado [...]; algo que constatamos a partir del positivismo", Martínez Albesa, Emilio, "Libertad religiosa y autoridad política a la luz de la encíclica Caritas in veritate de Benedicto XVI", en La Constitución de 1857..., cit., pp. 1090 y 1091. "La adjetivación de laico para el Estado es tardía, procede ciertamente de una significativa trasposición del carácter laico de la educación pública positivista al ámbito del Estado completo", ibidem, p. 1089.

183 León XIII, Encíclica Etsi nos (15 de febrero de 1882), en Castro Alonso, Manuel de (dir.), Colección completa de las encíclicas de Su Santidad León XIII, en latín y en castellano, bajo la dirección y con un prólogo de [...], Valladolid, Tipografía y Casa editorial Cuesta, (s.a. 1903), t. I, p. 162. 
a la religión católica" - era "borrar de todas las instituciones públicas aquel sello y aquel carácter cristiano que, con razón, hizo siempre grande al pueblo italiano" e, incluso, como consecuencia de la pérdida pontificia de la soberanía temporal, "Roma, la más augusta ciudad del orbe Católico, se ha[bía] convertido en campo abierto para todos los enemigos de la Iglesia". ${ }^{184}$ En la misma encíclica, reivindicaba el servicio que el pontificado romano había hecho a lo largo de la historia a la civilización italiana y la manera en la que la extensión de la religión católica beneficiaba también el progreso de la vida civil, mientras que, al contrario, perdidos los bienes de la religión, seguiría la ruina de la sociedad hasta degradarse en el materialismo a causa del libertinaje y el desorden. Por esto, había que desenmascarar a "los enemigos del Cristianismo" para que no engañara a los incautos y hacer que los católicos defendieran "públicamente a la Iglesia, y al Romano Pontífice, es decir, su propia salvación". ${ }^{185}$

La oposición entre el espíritu que animaba la acción de las asociaciones masónicas tal como ha sido descrito por los papas y el cristianismo eran irreconciliable. Por ello, León XIII recogió bajo el nombre de "Masonería" (en singular y, en latín, con mayúscula) toda encarnación de ese espíritu, ${ }^{186}$ como si con ello materializara o diera un cuerpo a la "ciudad" de los enemigos de la Iglesia, transmitiendo la impresión equivocada de que hablase de una única institución, cuando el pontificado siempre fue consciente de la existencia -dentro del universo masónico y seudomasónico- de una pluralidad de asociaciones no necesariamente vinculadas institucionalmente, pero sí convergentes por el hecho de tener una organización similar, propósitos afines y un mismo espíritu; por otro lado, el pontífice dedicó proporcionalmente poco espacio al tema masónico en la que es su principal y más extensa encíclica

184 Idem.

185 Ibidem, p. 166. Sería muy urgente "hacer comprender a los pueblos el bien grande de poseer la fe católica, y la necesidad de custodiarla celosamente; y como los enemigos del Cristianismo, para engañar con más facilidad a los incautos, a menudo hacen descaradamente una cosa mientras piensan otra, ocultando realmente el objeto do sus esfuerzos, conviene mucho se ponga esto en descubierto y se despierte en los católicos el ímpetu valeroso de defender públicamente a la Iglesia, y al Romano Pontífice, es decir, su propia salvación" (idem). De hecho, "la situación de Italia no podrá nunca prosperar ni gozar de estable tranquilidad, hasta que no se haya atendido, como todas las razones lo demandan, a la dignidad de la Sede Romana y a la libertad del Sumo Pontífice" (p. 165), pues "importa con supremo interés a la sociedad cristiana que el Sumo Pontífice sea y aparezca libre de todo peligro, molestia y dificultad en el gobierno de la Iglesia, haciendo cuanto según las leyes sea posible en ventaja del Pontífice, sin darse reposo, hasta que en Nos en realidad, y no en apariencia, se reconozca aquella libertad, en la cual, por cierto necesario lazo, están unidos, no sólo el bien de la Iglesia, sino además la marcha próspera de Italia y la tranquilidad de los cristianos" (p. 167).

186 Ya vimos que, en la Etsi nos de 1882, se refirió también a una "secta", en singular. 
sobre la masonería, pero, por el contrario, fue pródigo en los temas del racionalismo y del naturalismo, es decir, en el tópico del relativismo filosófico y moral. Por esto, era necesario leer la encíclica Humanum genus en continuidad con el magisterio pontificio anterior sobre las asociaciones masónicas, al que el texto remitía y reafirmaba, pues, de lo contrario, podía malinterpretarse, pensando que lo que decía el pontífice podía no alcanzar a determinados grupos masónicos que no se reconocían en esas corrientes de pensamiento, cuando en realidad sí los alcanzaba.

Las dos ciudades agustinianas, identificadas por León XIII con los “dos campos contrarios" de los caudillos Cristo y Satanás, en línea con las dos banderas ignacianas, son, fundamentalmente, dos causas opuestas e irreconciliables. ${ }^{187}$ De esta manera la Iglesia y la masonería se encontraban frente a frente: "la Iglesia, amiga de la paz y madre de la concordia", y la masonería, "enemigo astuto y doloso que, halagando los oídos de los pueblos y de los gobernantes $[\ldots]$ con el cebo de la adulación" y calumniando a la Iglesia y a los monarcas, promovía la revolución contra las potestades eclesiástica y civil. ${ }^{188}$ Por tanto, desde la dicotomía de los dos campos o ciudades, el papa animaba a los gobernantes y a los pueblos a unirse "no con la masonería para destruir a la Iglesia, sino con la Iglesia para destrozar los ataques de la masonería". ${ }^{189}$ Para él, Iglesia y masonería eran la concreción histórica del reino de Dios y del de las tinieblas, los cuales se presentaban ante el hombre como dos opciones excluyentes de principios para informar su ideal y proyecto de vida. Por tanto, como causas o ideales, lo sustantivo de ellas, a efectos de la exposición de León XIII, eran sus principios, y mientras que los principios de la causa cristiana se encontraban en la doctrina católica, los de la causa diabólica se encontraban en el espíritu que venía animando la conspiración o guerra masónica contra la religión católica.

Por esto, con la encíclica Humanum genus del 20 de abril de 1884, ${ }^{190}$ León XIII se propuso exponer y reprobar la doctrina masónica, de forma paralela a como había hecho con el socialismo en 1878, mediante la encíclica Quod apostolici muneris. La masonería estaba ya condenada en su realidad misma desde 1738, y en su actuar desde 1825; él mismo lo había recordado en su encíclica sobre la autoridad política Diuturnum illud de 1881;191 por tanto, ahora

187 León XIII, Encíclica Humanum genus (20 de abril de 1884), véase Gutiérrez García, José Luis, op. cit., p. 158.

188 Ibidem, pp. 177-179.

189 Ibidem, p. 179.

190 Ibidem, pp. 158-185. Sobre esta encíclica, véase Bárcena, Alberto, op. cit., pp. 173-185.

${ }^{191}$ León XIII, Encíclica Diuturnum illud (29 de junio de 1881), en Gutiérrez García, José, op. cit., pp. 109-126. Alaba la firmeza de sus predecesores "al comprobar la audacia creciente 
se trataba más bien de justificar esta condena doctrinalmente. La prohibición de establecer, sumarse a o colaborar con asociaciones de corte masónico no necesitaba reiterarse, si bien no dejaba de ratificarse y confirmarse todo lo sancionado por los pontífices precedentes; ${ }^{192}$ en cambio, sí parecía muy conveniente especificar cuáles eran los principios masónicos, de forma que fuera más sencillo discernir qué sociedades estaban comprendidas en tal prohibición: lo estarían todas aquellas que profesaran esos principios y aceptaran en alguna medida su puesta en práctica, sin pretender entrar en la valoración moral de la responsabilidad personal de cada masón, la cual dependía de su nivel de participación en el mal. ${ }^{193}$

De cualquier forma, este tratado pontificio sobre los principios doctrinales subyacentes al fenómeno masónico (Humanum genus) también describía el sistema y la acción de la masonería - antes de desarrollar sus principios- y proponía remedios para oponerse a ella y contrarrestar su acción: desenmascarar sus propósitos y métodos; promover la instrucción religiosa del pueblo, así como la honestidad obrera y patronal; fomentar el asociacionismo católico (en particular, la Tercera Orden franciscana y las Conferencias de San Vicente de Paul); empeñarse en la educación de la juventud, y recurrir a la oración.

En cuanto al sistema o esencia del asociacionismo masónico considerado en sí mismo, León XIII decía que se trataba de un conjunto variado de "sectas" cuyo "punto de partida" y "centro de referencia" era la masonería, con la que "conc[ordaban] de hecho [...] por la unidad de intenciones y la identidad en sus principios fundamentales". ${ }^{194}$ Para él, las características esenciales de las sociedades masónicas y afines eran cinco. En primer lugar, eran sociedades clandestinas porque, aunque sostenían cierta vida pública, en ellas era ley fundamental el secreto acerca de algunas de sus cosas internas, las cuales ocultaban cuidadosamente bajo un halo de misterio, tanto a los ajenos como a muchos de sus adeptos, a quienes se les prometía ir desvelándoselas gradualmente. ${ }^{195}$ En efecto, si estas sociedades renunciaran a ofrecer conocimientos ocultos graduales, dejarían de tener razón de ser, aun cuando dichos conocimientos no fue-

de las sectas" para cortarles el paso (p. 124) y anima a los obispos a que amonesten a los pueblos "para que huyan de las sectas prohibidas, abominen las conjuraciones y que nada intenten por medio de la revolución" (p. 126).

192 Ibidem, pp. 179 y 180.

193 Véase Introducción de José Luis Gutiérrez García a la encíclica Humanum genus, en ibidem, pp. 155 y 156. Se lee en la encíclica Humanum genus: "Puede haber [...] entre sus afiliados [a la masonería] no pocas personas que, aunque culpables por haber ingresado en estas sociedades, no participan, sin embargo, por sí mismos en los crímenes de las sectas e ignoran los últimos intentos de éstas", p. 165.

${ }^{194}$ León XIII, Encíclica Humanum genus (20 de abril de 1884), op. cit., p. 163.

195 Idem. 
ran importantes más que para sus miembros o se consideraran banales, vanos, ilusorios, falaces o, incluso, se tratara de elementales resultados de un ejercicio de introspección o simple adquisición de hábitos mentales o de conducta. De manera que el secreto en la masonería, por una parte, podía considerarse irrelevante si se mostraba vacío de contenido, ${ }^{196}$ pero, por otra, al mismo tiempo lo era todo, pues posibilitaba este tipo de asociacionismo. En segundo lugar, eran sociedades fuertemente jerarquizadas, llenas de desigualdades pese a las iniciales pretensiones masónicas de fraternidad, con diversidad de derechos entre los miembros y con una severa disciplina interna, en las que el secreto mismo servía para la diferenciación interna de los miembros en categorías, pues no a todos les eran comunicados los asuntos que competían a la sociedad de la que formaban parte. ${ }^{197}$ En tercer lugar, eran sociedades de fingimiento, que exigían de sus adeptos una vida de "constante disimulo" y "engañosa apariencia" en sus relaciones sociales, para poder cumplir con el deber del secreto. ${ }^{198}$ Mostraban gran interés por el progreso del bienestar de los pueblos y por las causas filantrópicas, pero como estos "propósitos, aunque fuesen verdaderos, no [eran] los únicos" de sus reuniones y acuerdos, ${ }^{199}$ podía hablarse de "una moralidad fingida". ${ }^{200}$ En cuarto lugar, eran sociedades autoritarias, donde se exigía y practicaba una "ciega y absoluta obediencia" a los jefes, propia de "esclavos", bajo pena de muy "duros castigos, incluso la misma muerte", la cual -el pontífice estaba convencido- se daba con total impunidad. ${ }^{201}$ Finalmente, en quinto lugar, eran sociedades delictivas, donde se decidían, orquestaban y promovían crímenes que, gracias a sus condiciones de clandestinidad, de obediencia radical y de fingimiento, se efectuaban y quedaban impunes. ${ }^{202}$

Como consecuencia de esta manera de ser, la acción de las sociedades masónicas resultaba nefasta, según el pontífice, pues se encaminaban a "la destrucción radical de todo el orden religioso y civil establecido por el cris-

196 Ya desde los orígenes de la masonería especulativa algunos de sus críticos se preguntaban si de verdad el secreto masónico tenía algún contenido: véase Ridley, Jasper, op. cit., p. 77.

197 Idem. El papa menciona que no eran comunicadas a todos "las finalidades últimas y más íntimas, las jerarquías supremas de cada secta, ciertas reuniones íntimas y ocultas, los modos y medios con que deben ser realizadas las decisiones adoptadas", así como "sus signos y sus doctrinas".

198 Ibidem, 163.

199 Ibidem, p. 164.

200 Ibidem, p. 181.

201 Ibidem, p. 164. La amenaza del castigo de la muerte parece obedecer al texto que se emplea en el juramento o promesa que exigen determinadas obediencias y que tiene origen medieval británico. El papa piensa que, en estas sociedades, sí se decidía la muerte de personas y se llevaba a cabo.

202 Idem. 
tianismo y la creación, a su arbitrio, de otro orden nuevo con fundamentos y leyes tomados de la entraña misma del naturalismo", ${ }^{203}$ ya fuera recurriendo a la conspiración oculta o a la guerra abierta. En definitiva, la masonería - como movimiento que incluía diversidad de sociedades animadas por un mismo espíritu y convergentes en sus propósitos- aspiraba a sustituir el ideal de la sociedad cristiana - edificada sobre la fraternidad universal en Cristo desde la fe y la práctica de la caridad- por el de la gran "catedral" de la humanidad - cimentada sobre la fraternidad compartimentada de los secretos masónicos desde el racionalismo antropocentrista y los "trabajos" de las logias-. Aquella conspiración transformada en guerra que denunciaron los papas precedentes respondía a un espíritu cuyo principio fundamental era lo que León XIII llamaba naturalismo; desde este principio, podía articularse una doctrina masónica que nutriría las mentes e informaría la vida de los adeptos de todo el conjunto de asociaciones denominadas masónicas y de otras más similares a ellas.

\section{El relativismo filosófico y moral de la masonería según León XIII}

Para Florido Giantulli (1906-1974), la condena del naturalismo que hizo León XIII en la Humanum genus pertenecía a las "decisiones de principio tomadas por la Iglesia, que no pasaban con el tiempo", mientras que las partes de la encíclica que respondían a consideraciones históricas debían ser leídas con la necesaria perspectiva histórica. ${ }^{204}$ En su documentado ensayo acerca de la cosmovisión masónica, indicaba los presupuestos del naturalismo masónico en el antropocentrismo del humanismo renacentista y en el racionalismo iluminista del siglo XVIII. ${ }^{205}$

Efectivamente, el racionalismo masónico es antropocéntrico e iluminista. Los racionalistas "no aceptan verdad alguna que no pueda ser alcanzada por la razón humana" y, por tanto, sosteniendo que la razón es la única fuente de conocimiento, "niegan toda revelación divina" y no admiten la fe como fuente de conocimiento; ${ }^{206}$ para ellos, razón y fe son excluyentes sin síntesis posible. El racionalismo que nos ocupa, en cuanto antropocéntrico, tiene una confianza plena en el hombre y en sus capacidades para perfeccionarse por sí mismo; un hombre considerado principalmente como individuo y, por tanto,

203 Ibidem, p. 165. "Los frutos de la masonería son frutos venenosos y llenos de amargura", pp. 164 y 165.

204 Giantulli, Florido, op. cit., p. 43.

205 Ibidem, p. 36.

206 León XIII, Encíclica Humanum genus (20 de abril de 1884), op. cit., p. 166. 
colocado frente a un mundo del que ha de apoderarse y al que ha de dominar, así como frente a otros individuos. Ha existido (y existe) una auténtica religiosidad masónica; sus cultivadores consideran que está "radicada en la naturaleza y [es] por tanto racional y universal", ${ }^{207} \mathrm{y}$ su finalidad es la transformación interior del hombre mediante el progreso ilimitado de la razón humana, la cual, liberándolo de todo dogmatismo (interpretado como prejuicio y superstición alienante), lo hará dueño de sí mismo y del mundo; por ello, esta religiosidad idealiza a una humanidad que mesiánicamente se autorredime "no en el cielo sino en la tierra". ${ }^{208} \mathrm{Al}$ mismo tiempo, en cuanto racionalismo iluminista, concibe la ciencia experimental como medio instrumental de dominio - conforme al "saber es poder" del empirismo de Francis Bacon (1561-1626)-,209 mediante la crítica propia de la Ilustración, de manera que la razón es instrumento de crítica más que de conocimiento y apropiación de verdades; tiene una función de deconstrucción más que de afirmación; se aplica para desmantelar más que para convencer, así como para dominar más que para compartir.

Esta orientación de la razón hacia la crítica hace que, en realidad y curiosamente, las creencias de la masonería no provengan de la razón, sino de una supuesta gnosis alcanzada por vía esotérica que colorea y perpetúa unos prejuicios ideológicos, ${ }^{210}$ y que las conclusiones de los masones no sean verdades estables sostenidas por la razón, sino que se limiten a ser acuerdos razonables provisionales, resultando del diálogo entre ellos mismos a partir de un método de crítica dialéctica que -mediante la provisionalidad y el cuestionamiento sucesivo- diluye las verdades en ideas relativas y las convicciones en opiniones. ${ }^{211}$ Para León XIII, este racionalismo desembocaba en

207 "Lumen. Rivista di Palazzo Giustiniani”, febrero 1954, p. 14, en Giantulli, Florido, op. cit., p. 16. Traducción nuestra.

208 Ibidem, pp. 39-43. Traducción nuestra.

209 "La Chiesa e la massoneria oggi", La Civiltà Cattolica, IV/3393 (1991), op. cit., pp. 26 y 27. Sobre la afinidad de Bacon a los modos ocultistas de los futuros masones y el precedente que puede representar su novela utópica La nueva Atlántida (1626), cf. Andrés, Juan Ramón de, op. cit., pp. 15-39.

210 Sobre la real existencia de creencias masónicas y su contenido, cf. Giantulli, Florido, op. cit., también, Bárcena, Alberto, op. cit., pp. 23-33.

211 Sobre el método dialéctico masónico, véase Introvigne, Massimo, op. cit., pp. 13-62, 34-41 y 56-59. Apoyándose en Alain Gérard, dirigente masón del Gran Oriente de Francia, explica que el método "no impide a nadie tener opiniones bien definidas [...] sino que impone a todos 'poner en discusión' las propias opiniones cuando comienza el trabajo de logia, aceptando la hipótesis de que puedan eventualmente ser falsas (o deban ser superadas en una síntesis superior)", pp. 35 y 36; traducción nuestra. Afirma: "La masonería tal como emerge de sus documentos fundacionales anglosajones no es una doctrina, sino un método que propone la libre discusión de los problemas y su solución en conformidad con lo que parece verdade- 
relativismo filosófico, pues con él "perdían toda su certeza y fijeza incluso las verdades conocidas por la sola luz natural de la razón"; 212 asimismo, Massimo Introvigne precisaba:

Afirmar que el método masónico se sitúa en el horizonte del relativismo no significa acusar a los masones [...] de negar el conocimiento filosófico o la relevancia existencial de la verdad; significa solo constatar que se trata de un método que promueve una visión de la verdad como relativa y condicionada por variables independientes que la determinan: y esta es precisamente la definición de relativismo [que no es lo mismo que escepticismo, es decir, negación de la existencia de la verdad]. ${ }^{213}$

Esta consideración de que las verdades dependen de variables que las hacen siempre relativas y provisionales funda la aversión masónica hacia el concepto de dogma, el cual les hace ininteligible a los masones el de tipo católico, pues ellos consideran todo dogma como una absolutización de lo relativo y su afirmación como una pretensión de imposición arbitraria sobre la razón, lo cual nada tiene que ver con la dogmática católica. ${ }^{214}$

El naturalismo sostenía que "la naturaleza humana y la razón natural del hombre habían de ser en todo maestras y soberanas absolutas", ${ }^{215}$ es decir, que la naturaleza humana debía estar libre de dependencias externas y que la libertad del hombre no tendría otro límite que lo naturalmente posible - en sentido estricto de físicamente posible- ni otro criterio para gobernarse que la razón humana. ${ }^{216}$ Para los iluministas, la naturaleza era un dato al que se aproximaban desde una mentalidad mecanicista y no

ro y justo a la mayoría de los hermanos", p. 35, traducción nuestra. Similares explicaciones a las de Gérard, las ofrecen otros masones como Mitterrand, Jacques, Le politique des Francs Maçons, París, 1973, y Otaola Bajeneta, Javier, La masonería hoy. Razón y sentido, San Sebastián, 1996. En un difundido rito masónico de iniciación al primer grado, el iniciado escucha estas palabras: "en la logia aprenderá que ninguna verdad es indiscutible y que ninguna creencia está al abrigo de la duda", Caillet, Maurice, Yo fui masón, Madrid, Libros libres, 2010.

212 León XIII, Encíclica Humanum genus (20 de abril de 1884), en Gutiérrez García, José Luis, op. cit., p. 168.

213 Introvigne, Massimo, "Che cos’è la massoneria”, op. cit., p. 37. Traducción nuestra.

214 Véase Giantulli, Florido, op. cit., pp. 18 y 19, y "La Chiesa e la massoneria oggi”, La Civiltà Cattolica, IV/3393 (1991), op. cit., pp. 27, 30 y 31.

215 León XIII, Encíclica Humanum genus (20 de abril de 1884), en Gutiérrez García, José Luis, op. cit., p. 166.

${ }^{216}$ Giantulli, Florido, op. cit., p. 50: Para la masonería, "la libertad consiste en la exclusiva obediencia a la propia razón, y [...] actuar libremente significa someterse solo a las leyes racionales de la Naturaleza". "La naturaleza revela a la razón todo lo que se debe creer y esperar", ibidem, p. 39. Traducción nuestra. 
una instancia de valencia metafísica y de normatividad ética. ${ }^{217}$ Giantulli -apoyándose en Joseph Berteloot (1881-1955) y en diversos representantes masones- señalaba como convicciones masónicas tres principios que respondían a una secularización del cristianismo por vía naturalista: el destino sólo terreno del hombre ("es solo aquí en el mundo donde tiene que conseguir su plena felicidad"), principio antagónico del destino sobrenatural del hombre del cristianismo; la bondad natural del mismo (le bastaría dejarse llevar por su libertad de pensamiento para realizarse y ser feliz), principio antagónico del pecado original del cristianismo, y la fe en el progreso indefinido ("el hombre tiene asegurado [...] alcanzar la edad de oro en el porvenir que él mismo construye"), principio antagónico de la redención del cristianismo. ${ }^{218}$

Para la moral pública y privada, las consecuencias de esto eran no sólo rechazar las exigencias morales derivadas de la aceptación de una revelación sobrenatural, sino también las procedentes de la moral natural; con esto, se abrazaría el relativismo moral, pues la naturaleza sólo puede ser prescriptiva moralmente si se reconoce un orden creatural establecido por un dios que, además de creador, sea "gobernador providente" para salvación del hombre, y esta providencia divina es rechazada por el naturalismo al negar la posibilidad de un fin sobrenatural en el hombre. ${ }^{219}$ De esta manera, las posiciones de los masones acerca de la familia, la educación, la vida política resultaban inmorales, según la constatación del papa Pecci. ${ }^{220}$

Respecto a la religión, debido a que la masonería descartaba considerar la posibilidad de que un dios personal se comunicara con el hombre mediante una revelación sobrenatural -aun cuando exigiera de sus adeptos la fe en Dios y afirmase respetar su específica fe teísta-, en la práctica, esto los conducía al deísmo y relegaba la religión confesional al ámbito estrictamente individual e interior (o exterior sólo en formalidades), imponiendo "el indiferentismo religioso" en sus logias y propugnando "la igualdad de todos los cultos", así como su irrelevancia en la esfera pública de la sociedad. ${ }^{221}$

217 La ley natural se escindiría de la ley divina y se reduciría al mecanicismo racionalista, véase "La Chiesa e la massoneria oggi", La Civiltà Cattolica, IV/3393 (1991), op. cit., p. 27.

218 Giantulli, Florido, op. cit., p. 38. Traducción nuestra.

219 León XIII, Encíclica Humanum genus (20 de abril de 1884), en Gutiérrez García, José Luis, op. cit., pp. 169-170.

${ }^{220}$ Ibidem, pp. 172-173.

${ }^{221}$ León XIII, Encíclica Humanum genus (20 de abril de 1884), en Gutiérrez García, José Luis, op. cit., pp. 166-168. En nuestra época, la exclusión de lo religioso de la esfera pública de la sociedad ha sido alentada por el Gran Oriente de Francia, aduciendo ideas de la Ilustración, en su Libro blanco sobre la laicidad, 2007. 
Así, la autoridad religiosa de una jerarquía confesional sobre los respectivos creyentes aparecía ante sus ojos como un convencionalismo, y el sometimiento a ella -aun en el plano doctrinal- como degradante para la razón y la libertad del hombre. ${ }^{222}$

La masonería se autocomprendía como una realización más acabada del perfeccionamiento de la humanidad, es decir, superior a todas las religiones confesionales. ${ }^{223}$ Para León XIII, todo esto era una pretensión reaccionaria de sustituir la religión católica por el paganismo antiguo y despojar a la sociedad occidental de los beneficios de humanidad y civismo que había recibido gracias al influjo civilizador del cristianismo, como son, en el ámbito familiar, la unidad del matrimonio y estabilidad de la familia, la dignidad de la mujer y los derechos de los niños, bienes que se perderían con la disolución familiar, y, en el ámbito sociopolítico, la racionalidad y moralidad de las leyes, la observancia del derecho y el respeto a la autoridad, bienes que desaparecerían en aras de una anarquía igualitarista y licenciosa que favorecería las aspiraciones de los comunistas y socialistas; pero, además y sobre todo, León XIII señalaba que la intención de la masonería era organizar la vida pública como si Dios no existiese, faltando a los deberes religiosos que exigen a los pueblos y a sus Estados que lo reconozcan públicamente como creador de la sociabilidad humana y origen de los bienes sociales. ${ }^{224}$

Aunque el término relativismo no aparecía en la encíclica, es el contenido fundamental del espíritu que aquí se condena. ${ }^{225}$ Los principios subyacentes al espíritu masónico eran tales que, en definitiva, "nadie que estimara en lo que debía su profesión de católico y su salvación personal, juzgaría serle lícito por ninguna causa inscribirse en la masonería". ${ }^{226}$ León XIII consideraba que - tal como afirmó cien años después el cardenal Joseph Ratzinger, apoyándose en él-el proceso de iniciación masónica transformaba radicalmente

222 Idem.

223 "La Chiesa e la massoneria oggi”, La Civiltà Cattolica, IV/3393 (1991), op. cit., pp. 29-30

224 León XIII, Encíclica Humanum genus (20 de abril de 1884), en Gutiérrez García, José Luis, op. cit., pp. 174-177. Acerca del origen y sentido de la expresión como si Dios no existiese (etsi Deus non daretur), véase Martínez Albesa, Emilio, La Constitución de 1857... op. cit., pp. 10991104.

225 Así también se expone en Cantoni, Giovanni, "La massoneria nei documenti del Magistero della Chiesa Cattolica”, en Introvigne, Massimo, op. cit., pp. 140-146.

226 León XIII, Encíclica Humanum genus (20 de abril de 1884), en Gutiérrez García, José Luis, op. cit., p. 180. Este texto será recordado en el artículo de "L'Osservatore Romano" del 23 de febrero de 1985 . 
la estructura del acto de fe del cristiano. ${ }^{227}$ Por tanto, había una "sustancial inconciabilidad" entre fe cristiana y filosofía masónica. ${ }^{228}$

\section{Legado antimasónico de León XIII. Imposibilidad de la doble pertenencia}

En respuesta al continuo avance del predominio de las masonerías en la vida política de los Estados latinos -en particular de Italia-, durante los años de su pontificado, León XIII continuó pronunciándose contra la masonería en bastantes documentos de la última década del siglo XIX y los primeros años del XX. ${ }^{229}$ Estos pronunciamientos completaban su legado al magisterio sobre masonería y, si bien no tuvieron ya la entidad magisterial de la Humanum genus, corroboraban su conciencia de la incompatibilidad entre masonería y cristianismo, pues por masonería, siempre entendió esa "galaxia de asociaciones por diversos títulos emparentadas que la constituían", 230 cuyo principal denominador común era la hostilidad hacia el catolicismo. Así, la imposibilidad de una doble pertenencia - a la masonería y a la Iglesia- se hizo del todo explícita en esos años.

A tres años de distancia de la Humanum genus, el papa Pecci volvió sobre el tema masónico en su extensa carta Officio Sanctissimo al episcopado de Baviera, ${ }^{231}$ donde advertía del peligro que corrían los fieles católicos -especialmente los adolescentes- de sufrir "el contagio de los masones" y ser puestos al servicio de sus dañinos propósitos, pues éstos actuaban "de modo hipócrita y engañoso",

227 "Inconciabilidad entre fe cristiana y masonería. Reflexiones a un año de la declaración de la Congregación para la Doctrina de la Fe", L'Osservatore Romano, (23 de febrero de 1985), en Congregazione per la Dottrina della Fede, op. cit., p. 21; e Intervención de Joseph Ratzinger del 22 de octubre de 1981, en Suchecki, Zbigniew, Chiesa e massoneria. Congregazione plenaria della Pontificia Commissione per la revisione del Codice di Diritto Canonico tenuta nei giorni 20-29 ottobre 1981 riguardante quinta questione speciale dedicata alla riassunzione del can. 2335 el Codice di Diritto Canonico 1917, Ciudad del Vaticano, Libreria Editrice Vaticana, 2000, pp. 77-81. Aparentemente la fe continúa inmutada; pero "realmente muere en su raíz, la cual es fe en la verdad, y se desvanece porque de este modo [en la mentalidad masónica], no obstante, todos sus contenidos [o afirmaciones] son mudables, dado que se pueden definir de la misma manera verdaderos y falsos", la fe queda así transformada en mera costumbre; cualquiera "puede constatar que nuestra crisis incluso moral viene alimentada en sus fundamentos de este relativismo y, según mi opinión, este relativismo pertenece al núcleo de toda nuestra crisis". Traducción nuestra.

228 "La Chiesa e la massoneria oggi", La Civiltà Cattolica, IV/3393 (1991), op. cit., p. 25.

229 Pellicciari, Angela, op. cit., pp. 126-159.

${ }^{230}$ Ibidem, p. 158.

${ }^{231}$ León XIII, Carta Officio Sanctissimo (22 de diciembre de 1887), en Bellocchi, Ugo, op. cit., pp. 284-297. 
simulando piedad y caridad para ocultar su enemistad a la Iglesia. ${ }^{232}$ Otros tres años después, escribió la encíclica Ab Apostolici Solii, dirigida a la Iglesia y al pueblo de Italia ${ }^{233}$ y dedicada por entero a la obra de la masonería en ese país. En ésta, León XIII consideraba que la política italiana anticlerical respondía a un plan de las sectas masónicas contra la fe de la nación. Desde la lógica de la Humanum genus, partía de la oposición entre masonería y la Iglesia de Jesucristo, y acusaba que la guerra de la una contra la otra se vivía de modo especialmente virulento en Roma - sede de unidad de la Iglesia- y en Italia -donde la religión había hundido profundamente sus raíces-. Recorría la historia reciente de la legislación anticlerical italiana a través de lo que llamaba diversas fases de esta guerra. ${ }^{234}$

La supresión del poder temporal de los papas era un primer paso en la lucha por abatir su poder espiritual; asimismo, la erradicación de órdenes religiosas, la intervención sobre los clérigos seculares, la expropiación de bienes eclesiásticos, la laicización de la vida pública - con la consecuente intervención del matrimonio y la educación- fueron medidas para reducir la influencia moral de la Iglesia, conformes con las intenciones declaradas y promovidas por los masones. Así, se había formado un sistema político anticristiano que se aplicaba por doquier en varias partes del mundo, especialmente en los países donde los gobiernos se encuentraban más sometidos a la acción de la secta masónica. ${ }^{235}$ Italia era de éstos y su sometimiento al programa persecutorio de su gobierno masónico lo demostraron el tratamiento de asuntos eclesiásticos en el nuevo código penal, el monumento a Giordano Bruno en la plaza Campo dei Fiori de Roma (inaugurado en 1889), la difamación de la Iglesia y la expulsión de todo lo católico del ámbito público; todo ello, según las metas que los textos programáticos masónicos habían prefijado.

Para hacer frente a esto, León XIII invitaba a desenmascarar la situación tanto de persecución de la Iglesia como de perjuicio a la sociedad, ${ }^{236}$ formar al clero y educar al pueblo, oponerse por vías legales, recurrir al asociacionismo católico y a la prensa, hacer ver la necesidad social de la religión católica para conservar la moralidad y demás beneficios, así como para exorcizar el peligro del socialismo. Además, se necesitaba restablecer el buen entendimiento con el

232 Ibidem, p. 294. Traducción nuestra.

233 León XIII, Encíclica Dall'alto (15 de octubre de 1890), en Bellocchi, Ugo, op. cit., pp. 425435. En fuentes italianas se conoce con el título "Dall'alto", si bien en latín es "Ab Apostolici Solii".

234 Ibidem, p. 426. Traducción nuestra.

235 Ibidem, p. 427. Traducción nuestra.

236 Ibidem, p. 431: "la secta masónica, aunque ostente un espíritu de beneficencia y de filantropía, no puede ejercer más que una influencia funesta; y precisamente funesta porque combate e intenta destruir la religión de Cristo, verdadera bienhechora de la humanidad" (traducción nuestra). 
papado, pues la "guerra hecha al Papa quería decir para Italia división profunda dentro de sí entre la Italia oficial y la gran parte de los italianos verdaderamente católicos, y toda división es debilidad" también predisponía negativamente a los católicos de otras naciones hacia Italia. 237

De nuevo, dos años después, en la fiesta de la Inmaculada de 1892, León XIII escribió dos cartas: una, al episcopado italiano, ${ }^{238}$ y otra, al pueblo de Italia; ${ }^{239} \mathrm{en}$ ellas lamentaba la expansión de la masonería en Italia y recordaba la prohibición para los católicos de asumir una doble pertenencia, a la Iglesia y a la masonería, en la cual revivía "el espíritu de todas las sectas hostiles al catolicismo". ${ }^{240}$ Sólo unos días más tarde, en su alocución al colegio cardenalicio con motivo de la Navidad, el pontífice se dolía de la difícil situación moral y religiosa que padecía Europa, particularmente Italia, por causa de la penetración masónica. ${ }^{241}$ En esas cartas, hablaba de quienes - esperando ganar honores o favores- se incorporaban a la masonería, desconociendo la realidad de lo que estaban apoyando. Como no había entendimiento posible entre el evangelio y la revolución, "Cristo y Belial, la Iglesia de Dios y el Estado sin Dios", ${ }^{242}$ esta "incompatibilidad entre las dos profesiones de católico y de masón" no podía ni debía ser ignorada:243 "esencialmente inconciliables entre ellos cristianismo y masonería, $[\ldots]$ asociarse a esta era divorciarse de aquel". ${ }^{244}$

Unos años después, ante la represión por parte del Estado italiano de los tumultos populares de Milán y otras localidades a causa de la miseria de la gente, el papa Pecci retomó los conceptos expresados en 1890 y 1892 contra las ideas políticas reinantes en Italia a causa del influjo masónico, y lamentó que, mientras se vejaba a la religión católica, se concedía la más amplia libertad a la masonería; asimismo, reafirmó la necesidad de la justicia y probidad que, por el contrario, el cristianismo aportaba a la sociedad. ${ }^{245}$

La defensa más encendida de la civilización cristiana por parte de este pontífice la encontramos en su encíclica Praeclara gratulationis, escrita en 1894 como

237 Ibidem, p. 433. Traducción nuestra.

${ }^{238}$ León XIII, Carta Inimica vis (8 de diciembre de 1892), Bellocchi, Ugo, op. cit., pp. 32-35.

239 León XIII, Carta Custodi di quella (8 de diciembre de 1892), ibidem, pp. 36-41.

${ }^{240}$ León XIII, Carta Inimica vis (8 de diciembre de 1892), ibidem, p. 32. Traducción nuestra.

${ }^{241}$ León XIII, Alocución Prossimi come (23 de diciembre de 1892), ibidem, pp. 42 y 43.

${ }^{242}$ León XIII, Carta Custodi di quella (8 de diciembre de 1892), ibidem, p. 40. Traducción nuestra.

${ }^{243}$ Ibidem, p. 39. Traducción nuestra.

${ }^{244}$ Idem. Traducción nuestra. Este texto será citado en el artículo de "L'Osservatore Romano" del 23 de febrero de 1985 sobre el tema.

${ }^{245}$ León XIII, Encíclica Spesse volte (5 de agosto de 1898), ibidem, pp. 336-342.

DR @ 2018. 
un vivo llamamiento a todos los pueblos a la unidad eclesial. ${ }^{246}$ Lo impulsaba la responsabilidad de sentirse pastor universal y el ardor de su celo misionero y pastoral en ese momento difícil de la historia para los pueblos, que sufrían embates del nacionalismo, del imperialismo, del liberalismo positivista y laicista, del socialismo y, por supuesto, de las masonerías. La encíclica es muy rica y articulada en su temática, por lo que puede y merece analizarse desde diversos ángulos; aquí, no obstante, nos limitamos al aspecto que nos ocupa. En la parte en la que convocaba a los fieles católicos, exponía los dos peligros de entonces para la unidad de la Iglesia: 1) la adulteración de la idea de Iglesia por parte de teorías falsas, las cuales habían llegado a negar su naturaleza de sociedad perfecta en su género y su dimensión pública, con lo que muchos derechos de la Iglesia se habían conculcado y se había roto la armonía en su relación con los poderes civiles, y 2) la masonería, la cual oprimía a las naciones y favorecía las turbulencias sociales y políticas para extender su dominio. De acuerdo con el pontífice, ésta "se infiltraba en todas las clases sociales y penetraba en todas las instituciones del Estado para llegar, de ser posible, a constituirse árbitro soberano de todas las cosas"; ${ }^{247} \mathrm{su}$ raíz era el naturalismo: "el culto de la naturaleza humana" que conducía a "una moral y una conducta casi paganas". ${ }^{488}$ Con el pretexto de civilizar, "combatía las instituciones cristianas; rechazaba toda doctrina revelada; calificaba [...] [las realidades religiosas] como simples supersticiones; se esforzaba por descristianizar el matrimonio, la familia, la educación de la juventud, todo el conjunto de la vida pública y de la vida privada", y también por acabar con el principio de autoridad en la sociedad. ${ }^{249}$

Para Gutiérrez García, la encíclica Annum ingressi es "el testamento público" de León XIII. ${ }^{250}$ Se publicó en 1902, ${ }^{251}$ en el vigésimoquinto aniversario de su pontificado, y, en cierto modo, recapitulaba sus enseñanzas sociales y políticas, a pesar de que su objetivo no era tanto magisterial pastoral, y, más que teorizar, exponía la visión del papa sobre la guerra contra la Iglesia que se vivía en esos tiempos. De nuevo, nos circunscribimos al tema de nuestro estudio. Constatando el progreso de los masones en el control de la política de las naciones, el pontífice acusaba a la masonería de haber llegado a ser "un Estado invisible e irresponsable en el Estado

246 León XIII, Encíclica Praeclara gratulationis (20 de junio de 1894), en Gutiérrez García, José Luis, op. cit., pp. 321-342.

247 Ibidem, p. 334.

248 Ibidem, p. 335.

${ }^{249}$ Idem.

250 Gutiérrez García, José Luis, op. cit., p. 343.

${ }^{251}$ León XIII, Encíclica Annum ingressi (19 de marzo de 1902), en Gutiérrez García, José Luis, op. cit., pp. 345-375. 
legítimo" "252 y le atribuía un papel principal en la guerra contra la Iglesia,,253 así como en la decadencia moral de esos tiempos. Era una especie de cáncer para la sociedad, el cual se extendía como "una inmensa red" por casi todas las naciones, en mancomunión con otras asociaciones, a las cuales manipulaba, para imponer a los gobernantes sus proyectos. ${ }^{254}$ No olvidaba decir que la "secta" masónica estaba llena "del espíritu de Satanás" y que obraba fraudulentamente, alardeando de fines humanitarios para ocultar sus torcidas intenciones, además de acusar falsamente a la Iglesia de perjuicios sociales. ${ }^{255}$ Para León XIII, el auténtico remedio a los males del mundo - cuya causa estaba en el "sistema de ateísmo práctico" instaurado-256 se encontraba en el retorno de la sociedad "al seno del cristianismo". ${ }^{257}$ Este ideal restauracionista permaneció vigente en el magisterio universal de la Iglesia en la terrible época de los totalitarismos ideológicos y de las dos guerras mundiales hasta el Concilio Vaticano II, si bien durante el pontificado de Pío XII (1939-1958) se hizo evidente una evolución en la actitud hacia el mundo contemporáneo, por ejemplo, en relación con el sistema de la democracia.

\section{LA CENSURA DE LA MASONERÍA EN LOS DOS CÓDIGOS DE DERECHO CANÓNICO DEL SIGLO XX}

\section{El Código de Derecho Canónico de 1917 y el nuevo espiritu del Concilio Vaticano II (1962-1965)}

En congruencia con los pronunciamientos pontificios pasados y teniendo presente la herencia de León XIII, así como la fuerza de políticos masones en los gobiernos de Italia, Francia y tantas otras naciones de tradición católica, además de los de aquellas de tradición protestante, durante los primeros dos decenios del siglo XX, los codificadores del derecho canónico estimaron conveniente y necesario conservar la pena establecida en la constitución apostólica Apostolicae Sedis, de 1869, para quienes se afiliaran a asociaciones masónicas. No obstante, se suprimió la pena canónica a quienes favorecieran estas asociaciones y a quienes no delatasen a sus jefes, probablemente para evitar los problemas de conciencia que podía generar en los fieles la inseguridad sobre su situación jurídica en la Iglesia

\footnotetext{
252 Ibidem, p. 366.

253 Ibidem, p. 352.

254 Ibidem, p. 366. En lugar de cáncer, el texto menciona "enfermedad mortal".

255 Ibidem, pp. 365 y 366.

256 Ibidem, p. 353.

257 Ibidem, p. 359.
} 
si llegaran a entrar en contacto con personas vinculadas a las masonerías (la pena era la excomunión ipso facto), sobre todo por comportamientos no claramente definidos como una colaboración o una omisión. Por lo tanto, el Código de Derecho Canónico promulgado por Benedicto XV (1914-1922) el 27 de mayo de 1917, en su canon 2335, limitaba la excomunión latae sententiae a "los que dieran su nombre a la secta masónica o a otras asociaciones del mismo género que maquinaran contra la Iglesia o contra las potestades civiles legítimas". ${ }^{258}$

El canon 2336 establecía que los clérigos y los religiosos que se afiliaran a la masonería debían ser denunciados a la Sagrada Congregación del Santo Oficio, además de recibir la suspensión o privación de los beneficios, oficios, dignidades, pensiones o cargos que tuvieran en la Iglesia. También se privaba a los masones de la posibilidad de casarse por la Iglesia (canon 1065 §1; salvo algunas condiciones, §2), de ser padrinos de bautismo o de confirmación (cánones 765, 2o y 795, 2o), de ser admitidos en los noviciados y en las asociaciones de fieles (cánones 542 , 1 o y 693 §1) y de recibir sepultura eclesiástica (canon 1240 §1, 1o); de igual manera, se prohibían los libros en favor de la secta masónica u otras sociedades semejantes (canon 1399, 8o). Nos encontramos en el ámbito estrictamente penal, por lo que es erróneo - como algunos han tratado de hacer- recabar conclusiones sobre si era permisible o estaba prohibida la adhesión a las masonerías del tratamiento reservado a éstas en los cánones penales, puesto que no todo lo que carecía de pena canónica estaba permitido por la enseñanza moral de la Iglesia ni carecía necesariamente de prohibición expresa. Este mismo código pedía explícitamente a los fieles que se abstuvieran de inscribirse en asociaciones secretas, condenadas, sediciosas o que procuraran sustraerse a la legítima vigilancia de la Iglesia (libro II, título XVIII, canon 684). ${ }^{259}$

258 Codex Iuris Canonici, Piis X Pontificis Maximi iussu digestus, Benedicti Papae XV auctoritate promulgatus, (1917), Nueva York, 1918, p. 635: Can. 2335: "Nomen dantes sectae massonicae aliisve eiusdem generis associationibus quae contra Ecclesiam vel legitimas civiles potestates machinantur, contrahunt ipso facto excommunicationem Sedi Apostolicae simpliciter reservatam" ("Los que dan su nombre a la secta masónica o a otras asociaciones del mismo género que maquinan contra la Iglesia o contra las potestades civiles legítimas, incurren ipso facto en excomunión simplemente reservada a la Sede Apostólica"), Código de Derecho Canónico [de 1917] y legislación complementaria. Texto latino y versión castellana, con jurisprudencia y comentarios, por Miguélez Domínguez, Lorenzo, Alonso Morán, Sabino y Cabreros de Anta, Marcelino, Madrid, BAC, 1957, p. 852. Las fuentes principales en la redacción de este canon son la constitución apostólica Apostolicae Sedis y la alocución Multiplices inter.

${ }^{259}$ Ibidem, p. 195, Can. 684: "Fideles laude digni sunt, si sua dent nomina associationibus ab Ecclesia erectis vel saltem commendatisi caveant; autem ab associationibus secretis, damnatis, seditiosis, suspectis aut quae studeant sese a legitima Ecclesiae vigilantia subducere" ("Son dignos de alabanza los fieles que dan su nombre a las asociaciones fundadas o a lo menos recomendadas por la Iglesia; mas absténganse de las asociaciones secretas, condenadas, sediciosas, sospechosas o que procuran sustraerse a la legítima vigilancia de la Iglesia"). 
Ahora, si bien es necesario distinguir entre censura y prohibición, como ya había hecho el Santo Oficio en 1884, ${ }^{260}$ conviene notar que el código está tipificando la vinculación a la masonería como delito contra la Iglesia y no contra la religión, pues el canon 2335 viene incluido en el título sobre los "delitos contra autoridades, personas y cosas eclesiásticas" (libro V, "Delitos y penas", título XIII) y no en el anterior sobre "delitos contra la religión" (libro V, título XII). Esto revela que la causa específica de la imposición de la censura, el objeto formal del delito, era la maquinación contra la Iglesia y no la inscripción a esas asociaciones ni tampoco la maquinación contra las autoridades civiles. Esto no significa que estuviera permitida la eventual adhesión a una sociedad masónica que eventualmente no maquinara contra la Iglesia, sino sólo que tal posibilidad no quedaría censurada con la excomunión latae sententiae. No obstante, para la mente del legislador toda sociedad masónica maquinaba contra la Iglesia ${ }^{261}$ y la inscripción a ella se interpretaba como acto suficiente para incurrir en el delito aquí penado.

${ }^{260}$ En la instrucción del Santo Oficio del 10 de mayo de 1884, leemos: "[...] a fin que no haya error cuanto haya de determinarse cuáles de esas perniciosas sectas están sometidas a censura, y cuáles solo a prohibición, cierto es en primer lugar que están castigados con excomunión latae sententiae, la masónica y otras sectas de la misma especie que [...] maquinan contra la Iglesia o los poderes legítimos, ora lo hagan oculta, ora públicamente, ora exijan o no de sus secuaces el juramento de guardar secreto. Aparte de estas, hay otras sectas prohibidas y que deben evitarse bajo pena de culpa grave, entre las cuales hay que contar principalmente todas aquellas que exigen por juramento a sus secuaces no revelar a nadie el secreto y prestar omnímoda obediencia a jefes ocultos. Hay, además, que advertir que existen algunas sociedades que, si bien no puede determinarse de manera cierta si pertenecen o no a las que hemos nombrado, son sin embargo dudosas y están llenas de peligro, ora por las doctrinas que profesan, ora por la conducta de aquellos bajo cuya guía se reunieron y rigen [...]", Denzinger, Enrique, op. cit., pp. 434 y 435.

261 En esta línea, de desaprobar todas las masonerías conjuntamente, el Concilio Plenario Latinoamericano, de 1899, había indicado: "Como en muchos de nuestros países las maquinaciones y engaños de los impíos, tienden a hacer vanos los saludables decretos y mandatos Apostólicos contra la peste de las sociedades secretas, bajo el mentido pretexto varias veces condenado por Pío IX y León XIII, de que la índole de la secta Masónica no es la misma en todas las naciones, sino que la misma que en unas partes es peligrosa y digna de proscribirse, en otras es inocente y honrada, porque, como dicen, son diversos sus dogmas, sus fines y sus obras; procuren empeñosamente los pastores de almas que error tan pernicioso, pretensión tan audaz, excogitada por el padre de las mentiras para engañar a los incautos, sea eliminada por completo. Tal es la naturaleza y gravedad de la materia misma, y tal el tenor de las Constituciones Apostólicas, que no es posible dudar que los citados Pontífices hayan querido obligar con ellas a todos y cada uno de los fieles, sin diferencia de lugares, tiempos, naciones o ritos", Pontificia Comisión para América Latina, Acta et decreta Concilii Plenarii Americae Latinae, in Urbe celebrati Anno Domini MDCCCXCIX. Actas y Decretos del Concilio Plenario de la América Latina. Edición facsímil, Ciudad del Vaticano, Libreria Editrice Vaticana, 1999, pp. 109 y 110: Decretos, Título II. "De los impedimentos y peligros de la fe", Cap. VII "De la secta masónica y otras sociedades ilícitas", núm. 168. 
Los papas del siglo XX continuaron pronunciándose contra la masonería, si bien ya no con la frecuencia con la que lo habían hecho Pío IX y León XIII, probablemente - como considera Giovanni Cantoni ${ }^{262-}$ porque la sentencia de condena comprendida en el código de 1917 hacía menos necesarios pronunciamientos ulteriores, pero también porque el avance del comunismo ateo y antirreligioso robó protagonismo y atrajo más la atención de los pontífices a la hora de hablar de los enemigos de la religión católica. Por ejemplo, Pío X (19031914), en su alocución en el consistorio del 27 de noviembre de 1911, sobre la revolución en Portugal, mencionó que la "secta ímproba" -en referencia a la masonería- estaba detrás del cambio de régimen de monarquía a república, con el objetivo de oprimir más fácilmente al catolicismo. ${ }^{263}$ Pío XI (1922-1939) denunció la fuerza de la masonería en el gobierno anticlerical de Italia y se refirió a las sociedades secretas como antirreligiosas. ${ }^{264}$

El Santo Oficio emitió una declaración el 20 de abril de 1949, confirmando que nada había sucedido a la fecha que pudiera hacer a la Santa Sede cambiar sus decisiones sobre masonería. ${ }^{265}$ A las puertas del Concilio Vaticano II, el juicio negativo del papado en relación con la masonería se mantenía inalterado; así, la carta de la Secretaría de Estado de mayo de 1958, escrita por parte de Pío XII con ocasión de la VIII Semana Nacional de Actualización Pastoral de Italia, menciona a la masonería entre las causas del distanciamiento entre la cultura y la fe que llevaría a la apostasía moderna, ${ }^{266}$ y el Sínodo de la diócesis de Roma

262 Cantoni, Giovanni, "La massoneria nei documenti del Magistero della Chiesa Cattolica", op. cit., p. 137.

263 Pío X, Alocución consistorial Gratum quidem (27 de noviembre de 1911), "Acta Apostolicae Sedis”, Roma, Tipografía Políglota Vaticana, 1911, t. 3, p. 586.

264 Véase Pío XI, Encíclicas Non abbiamo bisogno (29 de junio de 1931) y Caritate Christi compulsi, (3 de mayo de 1932), ibidem.

265 Suchecki, Zbigniew, op. cit., p. 17. La declaración fue motivada por una consulta del obispo de Trento.

266 Dell' Acqua, Angelo, Carta del sustituto para los asuntos ordinarios de Secretaría de Estado al arzobispo de Milán Mons. Giovanni Battista Montini de parte del Papa Pío XII con ocasión de la VIII Semana Nacional de Actualización Pastoral, Vaticano, 23 de mayo de 1958, Secretaría de Estado, n. 428255, en "Orientamenti Pastorali" VI/3 (septiembre de 1958), p. 7, "Las raíces de esta apostasía teórica, además de práctica, se encuentran en el progresivo alejarse de las corrientes del pensamiento y de los diversos aspectos de la cultura de las verdades cristianas: la ruptura de la unidad cristiana en Europa, el ateísmo científico, el racionalismo, el iluminismo, el laicismo, el materialismo dialéctico, la masonería, son algunas de las causas de este lento proceso de desconcierto intelectual y moral del cual vemos hoy las últimas consecuencias. Restablecer el contacto vivo del pensamiento cristiano con la cultura moderna es, hoy, uno de los oficios más graves del sacerdocio y del laicado católico" (traducción nuestra; el texto original italiano dice: "Le radici di questa apostasia teoretica, oltre che pratica, vanno ricercate nel progressivo allontanarsi delle correnti del pensiero e dei vari aspetti della cultura dalle verità cristiane: la rottura dell'unità cristiana in Europa, l'ateismo scientifico, il raziona- 
del 24 al 31 de enero de 1960, presidido por Juan XXIII (1958-1963), en preparación del Concilio, confirmó la vigencia del canon 2335 en el artículo 247 de sus Constituciones Sinodales. ${ }^{267}$ El Concilio Ecuménico Vaticano II (19621965) no alteró el juicio de la Iglesia sobre la masonería. Si bien trajo una nueva actitud de la Iglesia hacia el mundo moderno -la cual puede calificarse como de encuentro y de diálogo, aceptando desarrollar su pastoral y su apostolado en sociedades plurales y renunciando a un restauracionismo inviable- nada dijo ni varió en el tema de la masonería. Por ello, ninguna de las tres intervenciones aisladas del obispo de Cuernavaca Sergio Méndez Arceo (1907-1992; obispo en funciones, 1952-1982) en favor de abrir la puerta a una reconciliación entre Iglesia y masonería encontró respaldo. ${ }^{268}$ Por su parte, el papa Pablo VI concedió benévolamente a todos los confesores la facultad de absolver de censuras a los pertenecientes a la masonería durante el año jubilar de 1966.269

Tras el fracaso del ex gran maestro de la Gran Logia Unificada de Alemania Theodor Vogel (1901-1977) de obtener en ámbito masónico inglés una declaración en favor de la reconciliación con la Iglesia, hubo un encuentro informal entre el arzobispo de Viena, cardenal Franz König (19052004; arzobispo en funciones, 1956-1985), y el exponente masón doctor Kurt Baresch (1921-2011), en Viena, el 21 de marzo de 1968. Después, bajo la iniciativa de Baresch y sin autorización de ninguna autoridad eclesiástica, se

lismo, l'illuminismo, il laicismo, il materialismo dialettico, la massoneria, sono alcune fra le cause di questo lento processo di smarrimento intellettuale e morale di cui vediamo oggi le ultime conseguenze. Ristabilire il contatto vivo del pensiero cristiano con la cultura moderna è, oggi, uno degli uffici più gravi del sacerdozio e del laicato cattolico: [...]"). En la Declaración del Episcopado Argentino sobre la masonería, del 20 de febrero de 1959, se anotaría errando que: "El 24 de julio de 1958 (en la Octava Semana de Formación Pastoral), S.S. Pío XII señaló como raíces de la apostasía moderna, el ateísmo científico, el materialismo dialéctico, el racionalismo, el laicismo, y la masonería, madre común de todas ellas"; sin embargo, la fecha no corresponde y las palabras atribuidas a Pío XII no debían ir entrecomilladas porque no son del pontífice (y no aparecen en "Acta Apostolicae Sedis") ni tampoco son literales de la carta de monseñor Angelo Dell'Acqua (1903-1972); además, que la calificación de madre común para la masonería habrá sido una interpretación de los obispos argentinos, porque no procede de la carta. La VIII Semana Nacional de Actualización Pastoral se celebró en Milán del 22 al 26 de septiembre de 1958. La declaración de los obispos argentinos está publicada en Gelonch Villarino, Edmundo, Las gracias y las desgracias de la Argentina: una visión política desde el Salmo II, San Rafael, 2016, pp. 407-412.

267 Sínodo Romano, Constituciones Sinodales (28 de junio de 1960), Libro II. Acción Pastoral, Parte I. Magisterio eclesiástico, sección I, título II. Sobre la profesión de fe, artículo 247. Sobre la significación de este sínodo para nuestro tema, véase Cantoni, Giovanni, "La massoneria nei documenti del Magistero della Chiesa Cattolica", op. cit., pp. 137, 149 y 150

268 Suchecki, Zbigniew, op. cit., pp. 26 y 27.

269 Ibidem, p. 27. Lo hizo mediante la constitución apostólica Mirificus eventus del 7 de diciembre de 1965, víspera de la clausura del Concilio Vaticano II. 
estableció una comisión mixta de católicos y masones para abrir un diálogo. Esta comisión sostuvo cuatro reuniones: en diciembre de 1968 en Austria; en mayo de 1969 en Alemania; en julio de 1969 en Suiza, y en julio de 1970 en Lichtenau (Austria). Como fruto de este diálogo, nueve masones y tres católicos firmaron la Declaración de Lichtenau, el 5 de julio de 1970, para informar el resultado al papa Pablo VI (1963-1978) y a la Congregración de la Doctrina de la Fe; en ella defendían la necesidad de una colaboración en favor de intereses comunes filantrópicos y proponían abolir la prohibición a los católicos de inscribirse en la masonería. En el ámbito católico, se ha considerado que la declaración contiene errores desde el punto de vista histórico y filosófico-teológico; el prefecto de la Congregación para la Doctrina de la Fe la desautorizó y no produjo ningún cambio en la actitud de la Iglesia hacia la masonería. ${ }^{270}$ En conformidad con esto, la Congregación para la Doctrina de la Fe respondió de la manera siguiente a una consulta del obispo auxiliar de Milán del 17 abril de 1973: "nada ha cambiado en la legislación que regula la materia [de los que se inscriben en la masonería]", y envió esta respuesta en forma de carta reservada a varias conferencias episcopales. ${ }^{271}$

Sin embargo, la carta reservada del prefecto de la Congregación para la Doctrina de la Fe, cardenal Franjo Šeper (1905-1981), Complures episcopi, del 18 de julio de 1974, a los presidentes de algunas conferencias episcopales hizo suponer erróneamente a algunos que la posición de la Santa Sede hacia la masonería estaba variando, sobre todo porque llegó a hacerse pública. ${ }^{272}$ Esta carta presentaba una interpretación restrictiva del canon 2335, recordando que las leyes penales debían interpretarse siempre en sentido estricto, por lo que se daba por válida la opinión de quienes aplicaban la censura dictaminada en ese canon sólo a aquellos católicos inscritos en asociaciones que realmente maquinaban contra la Iglesia, y reafirmaba la permanencia de la prohibición

270 Ibidem, pp. 28 y 29, y Stimpfle, Josef, monseñor "Dall'indagine dei vescovi tedeschi (1974-1980) al documento vaticano del 1983", en Introvigne, Massimo, op. cit., pp. 165 y 166. Los católicos firmantes eran un clérigo, el sacerdote Johann B. von Toth, que era consultor del Secretariado para los No Creyentes de la Santa Sede y procedía a título personal, y dos laicos, los doctores Engelberth Schwarzbauer y Hernert Vorgrimler.

271 Suchecki, Zbigniew, op. cit., pp. 27 y 28.

272 Ibidem, pp. 18-20. Texto de la carta en latín y en italiano. Algunos presentan como destinatario originario al arzobispo de Filadelfia, cardenal John J. Krol (1910-1996), presidente de la Conferencia episcopal estadounidense; de él partió la consulta a la Santa Sede que motivó esta carta e hizo declaraciones a propósito de esta carta en el periódico Catholic Star Herald, el 27 de septiembre de 1974, si bien, eran varios los obispos de diversos países que en esos años postconciliares estaban elevando consultas sobre la interpretación del canon 2335 a la Santa Sede. 
de inscribirse a asociaciones masónicas a clérigos, religiosos y miembros de institutos seculares - se sobreentendía que de acuerdo con el canon 2336-.273

Además, por entonces se publicó un artículo en La Civiltà Cattolica del padre Giovanni Caprile (1917-1993), en el que se sostenía que quedaba a juicio de la conciencia individual del fiel católico determinar si en la asociación masónica o secreta a la que se propusiera ingresar hubiera o no algo "sistemáticamente hostil u organizado contra la Iglesia y sus principios doctrinales, morales, etc." ${ }^{274}$ esto, si bien resultaba admisible para la valoración subjetiva del fiel sobre si había incurrido o no en la pena de excomunión latae sententiae, iba más allá de lo permitido por la Iglesia, pues podía entenderse como una posibilidad de aprobación para adherirse a alguna de estas asociaciones de manera legítima desde el punto de vista moral, ya que la prohibición de inscribirse en sociedades secretas permanecía claramente fijada en el canon 684. Cuando el presidente de la Conferencia episcopal brasileña pidió una clarificación, la Congregación para la Doctrina de la Fe le respondió, el 26 de febrero de 1975, en línea no muy diversa de lo afirmado en el artículo de la revista mencionada, que, en primer lugar, sería deseable que las asociaciones en cuestión hicieran una declaración pública de sus intenciones, si bien no podía esperarse que esto ocurriera y no sería suficiente: "parece, sin embargo, que se pueda dar fe a aquellos católicos que, inscritos desde muchos años en la masonería, solicitan espontáneamente ser admitidos a los sacramentos (lo que antes les era negado por este motivo), declarando, onerata ipsorum conscientia, que la asociación en la cual están inscritos no persigue y no les ha exigido nunca compromisos contrarios a su recta conciencia cristiana"; y que, en segundo lugar, la maquinación contra la Iglesia debía entenderse como un delito de la

${ }^{273}$ Idem. También, véase Müller, Gerhard, cardenal, "Introducción" (8 de diciembre de 2014), en Congregazione per la Dottrina della Fede, op. cit., p. 9. Nótese que, en la Complures episcopi nada se dice ya respecto de la maquinación contra la autoridad civil, que sí menciona el canon 2335; como está dicho en el cuerpo de este trabajo, la atención del legislador en este delito está en cuanto que lo es contra la Iglesia, según corresponde al título en que el canon está inserto. Así se explica que la expresión relativa a las autoridades civiles caiga en olvido y no se incorpore en la versión del Código de 1983.

${ }^{274}$ Suchecki, Zbigniew, op. cit., pp. 19 y 20. Cita en p. 20 (traducción nuestra). El artículo: Caprile, Giovanni, "Cattolici e Massoneria: un'importante dichiarazione sulla scomunica" (19 de octubre de 1974), La Civiltà Cattolica, 125, 1974/IV, pp. 159-162; afirmaba aquí: "Si su fe de católico no encuentra allí nada sistemáticamente hostil, que esté organizado en el grupo masónico al que pertenece, contra la Iglesia y sus principios doctrinales y morales, él puede permanecer en la asociación. No necesita una particular absolución de la excomunión desde el momento que esta, en su caso concreto, no está ya vigente" (traducción nuestra). Estas afirmaciones confunden la posible ausencia de excomunión como pena de un acto indebido con la aprobación de tal acto, por lo que no resultan conciliables con el canon 684 . 
asociación misma, y no de alguno de sus individuos. ${ }^{275}$ Como la carta Complures episcopi se había vuelto de dominio público, descontextualizándose y dando pie a interpretaciones erróneas, el 17 de febrero de 1981, el cardenal Šeper hizo una declaración pública en calidad de prefecto de la Congregación de la Doctrina de la Fe; en ella, se aclaraban tres cosas: 1) que hasta esa fecha no había cambiado en nada la disciplina canónica; 2) que no se había abrogado la excomunión ni demás penas, y 3) que el contenido de la carta de julio de 1974 debía entenderse como una referencia a los principios generales de interpretación de las leyes penales para los casos de personas individuales que pudieran ser sometidas al juicio de los ordinarios, mas no como un facultamiento a las conferencias episcopales para pronunciarse públicamente con un juicio de carácter general sobre la naturaleza de las asociaciones masónicas que implicara derogaciones de dichas normas. ${ }^{276}$

Por su parte, el padre Caprile, al comentar la declaración en un nuevo artículo de ese año, precisaba: "una cosa es abolir una excomunión, otra es declarar los casos en los que no se incurre en la excomunión no abolida", tal como había pretendido hacer la carta de 1974. ${ }^{277}$ No obstante, a pesar del carácter de comentario jurídico a un asunto penal que tenía la carta del cardenal Šeper de 1974 y pese a las clarificaciones hechas al caso, no faltaron quienes hicieran eco a la idea de que representaba una apertura de la Iglesia hacia la masonería que continuaría desarrollándose con la redacción del código de 1983 y que había sido abortada con la declaración del cardenal Joseph Ratzinger (1927), como prefecto de la Congregación de la Doctrina de la Fe, de noviembre de 1983, la cual representaba un paso atrás. Esta interpretación fue sostenida por Ferrer Benimeli en su interesante y sugerente artículo de marzo de 1985 en el diario español El País, en el que se calificaba de "golpe involucionista" la declaración del cardenal Ratzinger. ${ }^{278}$ Sin embargo, la investigación llevada a cabo más recientemente por Zbigniew Suchecki, con documentación que no estaba disponible en 1985, hace ver que dicha opinión no encuentra ya hoy el necesario sustento documental, pues, además de las

275 Carta del cardenal Franjo Šeper al Nuncio apostólico en Brasilia (26 de febrero de 1975), en Suchecki, Zbigniew, op. cit., p. 21 (traducción nuestra). En esos momentos, en Brasil, el nuncio era presidente de la Conferencia episcopal. Nótese que, a diferencia del artículo de Craprile, se trata de una carta reservada a un obispo para ofrecerle pautas de discernimiento sobre la actitud de los pastores hacia la conciencia de los fieles y no está ofreciendo un criterio de discernimiento para los fieles, que presupone deberán guiarse conforme al derecho y a la propia conciencia.

276 Suchecki, Zbigniew, op. cit., p. 21 (el texto de la declaración, en la nota 50).

277 Caprile, Giovanni, "La recente dichiarazione sull'appartenenza alla massoneria", La Civiltà Cattolica, 132 (1981/I), pp. 576-579. Cita en Suchecki, Zbigniew, ibidem, p. 22 (traducción nuestra).

278 Ferrer Benimeli, José Antonio, El Vaticano y..., op. cit., p. 14. 
explicaciones públicas que concuerdan con el principio general de interpretación del derecho de que las leyes penales se interpretan siempre en sentido estricto, encontramos precisamente al cardenal Šeper liderando, en octubre de 1981, el grupo de miembros de la comisión pontificia para la revisión del código partidario de conservar la condena expresa a las asociaciones masónicas en el nuevo código, grupo al que se sumó el cardenal Ratzinger con una argumentación semejante a la suya. ${ }^{279}$ Así, no resulta posible contraponer a estos cardenales como representantes de visiones opuestas, pero tampoco la supresión de la mención explícita a la masonería en el nuevo código -vista la discusión sobre el tema en el seno de la comisión pontifica, cuyas actas publica Suchecki- permite sostener que obedeciera a una apertura hacia la masonería como consecuencia del nuevo espíritu del concilio.

En la congregación plenaria de la Pontificia Comisión para la revisión del Código de Derecho Canónico, esfectuada del 20 al 29 de octubre de 1981, Šeper sostuvo una lectura del canon 2335 desde la Humanum genus, la cual, yendo más allá de la expresión heredada de la Apostolicae Sedis, interpretaba la maquinación contra la Iglesia como oposición irreconciliable de principios entre la masonería y la Iglesia. La expresión procedía de la Multiplices inter, cinco años previa a la conquista de Roma por las tropas italianas, y ya Benedicto XIV - a más de cien años- había advertido de la peligrosidad que la masonería encerraba tanto para la religión como para el Estado. Por lo tanto, la idea de una maquinación de la masonería contra la Iglesia dependía exclusivamente de la llamada cuestión romana ${ }^{280}$ y no podía desestimarse la experiencia de la Iglesia fuera de Italia, en otras naciones donde también se había resentido el peso de la masonería, como Francia y México, por mencionar sólo dos a las que el papado dispensó una notable atención. Šeper va algo más allá de la interpretación sugerida por la Conferencia episcopal alemana, según la cual la maquinación podía no ser "lucha abierta y directa", sino que bastaba la "acción subterránea y minadora" de los rituales masónicos, ${ }^{281}$ pues opina incluso que las mismas conclusiones del episcopado alemán hacían ver "que el máximo peligro consiste en la alienación de la doctrina católica y de

279 Suchecki, Zbigniew, op. cit., pp. 75-87. Suchecki responde al artículo de Ferrer Benimeli en pp. 122-124.

${ }^{280}$ Ferrer Benimeli, José Antonio, "El Vaticano y los masones", El País, 10 de marzo de 1985, p. 14, se sostiene la idea de la maquinación "sólo se puede comprender desde la óptica de la problemática planteada en Italia por la famosa cuestión romana o pérdida de los Estados pontificios", donde estaban coincidentes en una misma persona las potestades eclesiástica y civil.

281 Conferencia Episcopal Alemana, "Declaración sobre la pertenencia de los católicos a la masonería" (1o. de junio de 1980), en Congregazione per la Dottrina della Fede, op. cit., pp. 51 y 52. Citada en Suchecki, Zbigniew, op. cit., p. 45. Traducción nuestra. 
esta alienación proviene la misma maquinación contra la Iglesia, que es absoluto relativismo, por el que se rechaza todo dogma, dogmatismo"; por tanto, existía una oposición de principios y ahí residía, a su juicio, el fundamento de la llamada maquinación. ${ }^{282} \mathrm{El}$ todavía prefecto de la Congregación para la Doctrina de la Fe defendía la conservación de la condena a la masonería, también por una razón psicológica: para que no pareciera que la Iglesia iba poco a poco cediendo en su posición antimasónica, la cual no se fundaba en lo que la masonería hacía, sino en la incompatibilidad de principios. ${ }^{283}$ Por tanto, las intervenciones personales de Šeper en el seno de esta comisión pontificia nos demuestran que no era partidario de ninguna apertura hacia la masonería ni de ningún cambio de la legislación sobre el asunto hacia una mayor indulgencia; tampoco consta que lo hubiera sido en el pasado.

\section{En la estela del Concilio. El diálogo en Alemania (1974-1980) y el Código de Derecho Canónico de 1983}

Si bien el nuevo espíritu del Concilio Vaticano II de acercamiento al mundo alcanzó también la relación de la Iglesia con la masonería, no alteró el juicio de la primera respecto a la inconciabilidad de principios y la imposibilidad de una doble pertenencia. En los años posteriores al concilio y de acuerdo con la consigna de diálogo de la encíclica Ecclesiam suam (6 de agosto de 1964) de Pablo VI, en diversos países, como Suecia, Alemania, Gran Bretaña, Francia, Estados Unidos, Filipinas o Brasil, se produjeron algunas experiencias de acercamiento de los católicos hacia los masones con el impulso o beneplácito de los obispos para conocer mejor sus disposiciones contemporáneas. Por parte de algunos prelados de la Iglesia hubo deseos de verificar si en el seno de las masonerías se había operado algún distanciamiento de sus posturas anticatólicas y si se encontraban puntos que posibilitaban abrir vías para una reconciliación. No en todas las asociaciones masónicas se expresaba abiertamente un anticatolicismo ni la ideología masónica descrita por León XIII estaba asimilada en la misma medida. En este contexto de apertura y esperanza, se produjeron las consultas a la Santa Sede y las respuestas de la Congregación para la Doctrina de la Fe respecto a la aplicación del canon 2335, que ya conocemos.

282 Šeper, Franjo, cardenal, Intervención (22 de octubre de 1981), en Suchecki, Zbigniew, op. cit., p. 75. Traducción nuestra.

283 Suchecki, Zbigniew, op. cit., pp. 75-77. Šeper fue prefecto de la Congregación para la Doctrina de la Fe hasta el 25 de noviembre de 1981, cuando fue sustituido por Ratzinger. 
Puesto que en el caso de la masonería alemana regular parecía encontrarse un particular deseo de entendimiento con la Iglesia, la Santa Sede encargó a la conferencia episcopal alemana dialogar con sus representantes. En junio de 1974, la conferencia episcopal constituyó una comisión oficial para llevar a cabo este diálogo e indagar posibilidades de reconciliación. Durante varios años, esta comisión revisó textos de sus rituales facilitados por las grandes logias unidas de Alemania y se entrevistó con sus representantes. Los masones sólo accedieron a mostrar los rituales relativos a los tres primeros grados (aprendiz, compañero y maestro, que son comunes prácticamente a todas las masonerías bajo rituales similares); pero descartó que se buscase la compatibilidad con el catolicismo en los grados superiores. Del análisis de los documentos y de los coloquios llevados a cabo por la comisión, la conferencia episcopal concluyó, en abril de 1980, que los principios orientadores de esta masonería seguían siendo inconciliables con los del cristianismo, lo que, a su juicio, volvía inaceptable la doble pertenencia a la masonería y a la Iglesia católica; por ello, en mayo solicitó a la Santa Sede que el nuevo código de derecho canónico conservara el contenido del canon 2335 del de 1917 y que no se dejara al juicio particular de cada conferencia episcopal el pronunciamiento acerca de la doble pertenencia. La declaración de la Conferencia episcopal alemana fue acordada en Würzburg, el 28 de abril de 1980, y confirmada el 1o. de junio. ${ }^{284}$ Apareció publicada en L'Osservatore Romano el 9 de julio de 1980.285

Según la declaración del episcopado alemán, los motivos que fundan la inconciliabilidad son: el relativismo de los masones como convicción fundamental que vicia su visión del mundo, provoca un subjetivismo que impide creer en la objetividad de los sacramentos cristianos, cierra la posibilidad de un conocimiento objetivo de la verdad, y los lleva a conformarse con una irrealizable aspiración de la verdad y rechazar los dogmas como contrarios a la libertad; su indiferentismo religioso, según el cual todas las confesiones religiosas son intentos humanos de acceder a una verdad divina que, en realidad, se expresaría mejor mediante la ambigüedad de la simbología masónica, la cual deja al individuo la libertad de interpretarlos; su concepto deísta de la divinidad, que no admite la posibilidad de una relación personal con un dios personal fundada en el conocimiento objetivo de éste; su negación de la posibilidad de la revelación por parte de un dios personal, con rituales en los que se afirma que

${ }^{284}$ Conferencia Episcopal Alemana, "Declaración sobre la pertenencia de los católicos a la masonería" (1o. de junio de 1980), op. cit., pp. 41-52. Véanse Suchecki, Zbigniew, op. cit., pp. 29-35, y Stimpfle, Josef, monseñor, "Dall'indagine dei vescovi tedeschi (1974-1980) al documento vaticano del 1983", op. cit., pp. 166-169.

285 Bárcena, Alberto, op. cit., pp. 301 y 302. 
el cristianismo es una derivación de la religión sumeria y babilónica; su defensa de la tolerancia de las ideas y no sólo de las personas, al tildar de intolerante la adhesión a las verdades; sus ritos para alcanzar los tres primeros grados, acciones simbólicas que - con su carácter iniciático- pareciera que operasen un cambio real en la persona, a modo de sacramentos paralelos a los cristianos; su pretensión de que la masonería podría "mejorar al hombre hasta llevarlo al máximo grado [posible en el mundo de perfección] desde el punto de vista ético y espiritual", ${ }^{286}$ lo que volvería irrelevante la justificación cristiana del hombre mediante la gracia, y el carácter totalizante que dan a la condición masónica, en cuanto a que la masonería forma la conciencia del hombre y determina todo su habitus mental y su comportamiento, por lo cual requiere una pertenencia de por vida, lo que lo lleva a sustituir al cristianismo. ${ }^{287}$

Pese a la diversidad de corrientes masónicas, la que se presenta a sí misma como compatible con el cristianismo no es ajena a la cosmovisión masónica que resulta irreconciliable con él. De acuerdo con la Iglesia, habría masonería bien dispuesta, neutral y hostil, pero incluso en la bien dispuesta se estaría constatando la incompatibilidad de principios. ${ }^{288}$ Se recuerda que también la confesión evangélica mantenía dudas sobre la compatibilidad de los rituales masónicos con la justificación del hombre por la gracia, a pesar de dejar al discernimiento personal la doble pertenencia, en su resolución del 13 de octubre de 1973, al término de unos coloquios sobre el primer grado de la masonería entre evangélicos y masones. ${ }^{289}$ La declaración concluye que, a la luz de la investigación de la comisión, la masonería no había variado en su mentalidad, convicciones fundamentales y modo de actuar respecto al periodo anterior a los totalitarismos del siglo $\mathrm{XX}$, por lo que las oposiciones entre sus convicciones ideológicas y el cristianismo alcanzan los fundamentos mismos de la existencia cristiana y se debía excluir la doble pertenencia a la masonería y a la Iglesia católica. ${ }^{290}$

El Código de Derecho Canónico promulgado por Juan Pablo II el 25 de enero de 1983 entró en vigor el 27 de noviembre de ese año. La ausencia

286 Conferencia Episcopal Alemana, "Declaración sobre la pertenencia de los católicos a la masonería" (1o. de junio de 1980), op. cit., p. 49.

287 Ibidem, pp. 46-50. La declaración señala estos motivos como inconciabilidad en lo siguiente: visión del mundo, p. 46; concepto de verdad, pp. 46 y 47; concepto de religión, pp. 47 y 48; concepto de Dios, p. 48; concepto de Dios y Revelación, pp. 48 y 49; idea de tolerancia, p. 49; acciones rituales, p. 49; perfeccionamiento del hombre, pp. 49 y 50 y espiritualidad, p. 50 .

\footnotetext{
288 Ibidem, pp. 50 y 51.

289 Ibidem, p. 51.

290 Ibidem, pp. 51 y 52.
} 
de mención de la masonería se debió a razones jurídicas -como es natural en un texto de este género- y no obedeció a la voluntad de responder a ningún cambio en el juicio reprobatorio de la Iglesia a este fenómeno -debido a que no se había producido- y mucho menos a la voluntad de establecer ese cambio ni de procurarlo, pues el código no era instrumento para ello. Afortunadamente, conocemos ya el acta de las sesiones de la congregación plenaria de la Pontificia Comisión para la revisión del Código de Derecho Canónico donde se discutió y votó la conservación o no de la excomunión latae sententiae reservada a la Sede Apostólica para quienes se adhiriesen a una asociación masónica. ${ }^{291}$ La petición de la Conferencia episcopal alemana - como sabemos- fue conservar el texto del canon 2335 inalterado, porque de su investigación, no arroja resultados que mostraran algún cambio sustancial dentro de la masonería como para alterar el juicio y la disciplina eclesiástica. Sin embargo, la propuesta de los consultores de la comisión fue eliminar el canon, porque uno de los principios que el Sínodo de 1967 había fijado para la revisión del código en línea con el espíritu del Concilio era reducir al mínimo las penas latae sententiae, ${ }^{292}$ y porque, al mismo tiempo, sería difícil para los fieles interpretar en qué consistía la maquinación contra la Iglesia. - elemento esencial de la tipificación penal-. Por tanto, las razones en favor de la abolición de la excomunión latae sententiae fueron razones jurídicas y no teológicas ni morales.

Por su parte, la Congregación de la Doctrina de la Fe había avanzado la propuesta de redactar el canon en estos términos que eliminan la excomunión latae sententiae: "Quien da el nombre a una asociación que complota contra la Iglesia, sea castigado con una pena justa; quien además promueve o dirige tales asociaciones sea castigado con el entredicho" (número 1326 del esquema de nuevo código). ${ }^{293} \mathrm{El}$ argumento era que, de esta forma, las masonerías no estarían incluidas de manera expresa, pero tampoco excluidas, para aquellas cosas en las que verdaderamente tramasen contra el bien de la Iglesia. Recordemos que se estaba valorando la aplicación o no de la excomunión latae sententiae a un delito contra la integridad de la Iglesia, y no la

291 Actas de la congregación plenaria de la Pontificia Comisión para la revisión del Código de Derecho Canónico, 20-29 de octubre de 1981, publicadas en latín y en italiano en Suchecki, Zbigniew, op. cit., pp. 36-111.

292 Se habían reducido a seis los casos de excomunión latae sententiae en el proyecto del nuevo código y resultaría inapropiado equiparar el caso que nos ocupa a la gravedad de estos: violencia física contra el romano pontífice, profanación de las especies eucarísticas, violación del secreto de confesión, absolución del cómplice en el pecado sexual, ordenación de un obispo sin mandato pontificio y aborto. Véase Suchecki, Zbigniew, ibidem, p. 67.

293 Ibidem, p. 99. Traducción nuestra. 
compatibilidad de principios con la consiguiente legitimidad o no de la adhesión a la masonería, asunto que escapaba a las competencias de la comisión.

Las votaciones del 23 de octubre de 1981 en el seno de la comisión pontificia produjeron treinta y cuatro votos en favor del número 1326 del esquema, el cual suprimía la excomunión y no mencionaba la masonería; quince votos en favor de conservar el canon 2335, que sí conservaba la sanción y nombraba el asunto masónico, y nueve abstenciones, de un total de cincuenta y ocho miembros de la comisión presentes. ${ }^{294}$ Por tanto, aprobado el número 1326 del esquema, quedaba desestimada la excomunión latae sententiae como pena para quienes complotaran contra la Iglesia. También se sometió a votación una propuesta de enmienda formulada por el cardenal Šeper y otros, la cual incluía la mención expresa a la masonería y la adición -junto a la maquinación contra la Iglesia- de la alienación de su doctrina como objeto formal del delito en texto ya aprobado; ${ }^{295}$ esta propuesta logró cinco votos más que la de la conservación del canon 2335, es decir, veinte, pero no pasó. Nunca se votó en exclusiva la introducción de una mención a la masonería. En realidad, lo sustantivo de esta votación fue la supresión de la excomunión latae sententiae; asimismo, resultó evidente que la mayoría de los miembros de la comisión no quiso incluir una mención a la masonería en el nuevo canon.

Del debate, puede observarse que la mención resultaba superflua para unos, conveniente para otros e inapropiada para algunos más, ante la diversidad masónica, si bien ninguna de estas tres posturas puede considerarse predominante dentro de la comisión, a la luz de la documentación conocida. Resultaba superflua, por ejemplo, para quienes estimaban que, así como no se mencionaba el comunismo - de cuya incompatibilidad de sus principios con los del cristianismo ninguno de los presentes de atrevería a dudar y que en muchas ocasiones atacaba abiertamente a la Iglesia-, tampoco resultaba necesario nombrar la masonería, pues bastaba con señalar sólo una de esas realidades hostiles por ser imposible e improcedente mencionarlas todas en un texto jurídico penal. ${ }^{296}$ Algunos, sin embargo, propusieron mencionar tanto la masonería como el comunismo. ${ }^{297}$ Esto era conveniente para quienes

294 Ibidem, p. 111.

295 Idem. La propuesta decía: "Quien da su nombre a la secta masónica o a otras asociaciones que maquinan contra la Iglesia o que alienan la doctrina de la Iglesia sea castigado con una pena justa. Quien además promueve o dirige estas asociaciones sea castigado con el entredicho" (traducción nuestra).

296 Los consultores, mediante el voto del padre Esteban Gómez Gutiérrez (1910-2005) del 20 de marzo, habían introducido esta comparación con el comunismo. Véase ibidem, p. 60.

297 Fueron los cardenales Joseph Höffner (1906-1987) y Hyacinthe Thiandoum (19212004). Ibidem, p. 87. 
sostenían que nada había cambiado sobre el tema respecto a la primera mitad del siglo XX y que suprimir la mención podía inducir a error en los fieles haciéndoles creer que había variado el juicio de la Iglesia sobre la masonería y que ya no la veía tan mal como antes. ${ }^{298}$ Resultaba inapropiada para quienes pensaban que en algunos lugares la masonería no urdía proyectos contra la Iglesia. ${ }^{299}$ Lo que de ninguna manera se puede concluir de la ausencia de mención a la masonería en el nuevo código es que hubiera una mayoría de miembros de la comisión que considerara que la pertenencia a la masonería pudiera ser compatible en ciertos casos con la profesión del catolicismo. En consecuencia con el texto aprobado por estas votaciones, el Código de Derecho Canónico de 1983 en su canon 1374 asertaba: "Quien se inscribe en una asociación que maquina contra la Iglesia, debe ser castigado con una pena justa; quien promueve o dirige esa asociación, ha de ser castigado con entredicho", 300 con lo cual se abrogaba la excomunión latae sententiae reservada a la Sede Apostólica.

La víspera de la entrada en vigor del Código, se publicó la declaración Quaesitum est de la Congregación de la Doctrina de la Fe, firmada por su prefecto, el cardenal Joseph Ratzinger, en la cual se confirmaba que se mantenía inalterado el juicio negativo de la Iglesia sobre la masonería, pues se consideraban inconciliables los principios masónicos con la doctrina cristiana, y seguía en vigor la prohibición para un católico de inscribirse en la masonería, por ser materia de pecado grave hacerlo, con la consecuencia de no poder acceder a la comunión. ${ }^{301}$ Además, en ella se aclaraba que -en línea con la declaración del 17 de febrero de 1981- no competía a las autoridades eclesiásticas locales pronunciarse sobre la naturaleza de las asociaciones masónicas con un juicio que supusiera derogación de lo dicho por la Congregación. Para la interpretación del canon 1374, la declaración calificaba como error de redacción el motivo por el que se había omitido la mención de la masonería en su texto. En la comisión de revisión del código, Ratzinger se había manifestado partidario de mencionar expresamente la masonería, tanto porque

298 Como es el caso de los cardenales Šeper, Ratzinger, Paul-Pierre Philippe (1905-1984), Pietro Palazzini (1912-2000), Höffner, Thiandoum, Silvio Angelo Pio Oddi (1910-2001) y Gabriel-Marie Garrone (1901-1994). Ibidem, pp. 76-87, 93-95 y 103.

299 Como es el caso de los cardenales Jospeh Schröffer (1903-1983) y Raúl Silva Henríquez (1907-1999), y del arzobispo Román Arrieta Villalobos (1924-2005). Ibidem, pp. 71, 87 y 89-91.

300 Código de Derecho Canónico. Edición bilingüe comentada por los profesores de la Facultad de Derecho Canónico de la Universidad Pontificia de Salamanca, dirigida por Lamberto de Echeverría, Madrid, 1983, p. 670. Texto latino: "Qui nomen dat consociationi, quae contra Ecclesiam machinatur, iusta poena puniatur; qui autem eiusmodi consociationem promovet vel moderatur, interdicto puniatur" (ibidem).

301 Congregación para la Doctrina de la Fe, op. cit., p. 14 (en latín) y p. 15 (en italiano). 
estaba convencido de la incompatibilidad de principios entre ésta y el cristianismo, como porque estimaba conveniente hacer expresa su inclusión para claridad de los fieles, ante la ambigüedad con la que la masonería se presentaba a sí misma; también estaba a favor de conservar la pena de excomunión latae sententiae. Por lo tanto, es cierto que la declaración corresponde a la visión personal del prefecto, si bien no a su posicionamiento respecto a la pena de excomunión. Sin embargo, independientemente de los pareceres personales de Ratzinger y de los del resto de participantes en la comisión redactora del código, el contenido de su declaración correspondía perfectamente a la mente del legislador, pues el mismo Sumo Pontífice Juan Pablo II, que promulgó el código, era quien aprobaba contemporáneamente esta declaración.

\section{La argumentación sobre la incompatibilidad entre cristianismo y masonería en las "Reflexiones" de L'Osservatore Romano de 1985}

La declaración de la Congregación de la Doctrina de la Fe de noviembre de 1983 suscitó perplejidades y motivó algunas consultas. La respuesta vaticana ulterior fue el artículo publicado en L'Osservatore Romano, el 23 de febrero de 1985, de forma anónima y atribuido al propio Joseph Ratzinger, con el título "Inconciabilidad entre fe cristiana y masonería. Reflexiones a un año de la declaración de la Congregación para la Doctrina de la Fe" ${ }^{302}$ La argumentación de este artículo, que pretendía fundamentar el contenido de la declaración de 1983, partía del magisterio de León XIII, recordando su declaración de inconciabilidad de principios entre las ideas filosóficas masónicas y la fe cristiana, así como entre las concepciones morales masónicas y las exigencias morales cristianas; por tanto, más allá de las razones que pudieran calificarse de prácticas, por atender a su actividad subversiva contra la Iglesia -las cuales podrían cuestionarse en múltiples casos-, existían también razones doctrinales para la condena de la masonería.

$\mathrm{El}$ artículo buscaba responder a la doble objeción de que la masonería no impondría ninguna posición filosófica ni religiosa a los suyos, pues estaba en su esencia no imponer ningún principio y además reunía a personas que creían en el Gran Arquitecto del Universo o que, por lo menos, reconocían una moral universal de valores humanistas comprensibles y aceptables por todos, la cual no era distinta a la recogida, por ejemplo, en el Decálogo, de modo que "no

302 "Inconciabilidad entre fe cristiana y masonería. Reflexiones a un año de la declaración de la Congregación para la Doctrina de la Fe", L'Osservatore Romano, (23 de febrero de 1985), ibidem, pp. 19-23. Las citas en español de este artículo son traducción nuestra del texto italiano publicado en esta obra. 
habría una obligación explícita de profesar el relativismo como doctrina"303 ni se alejaría a nadie de su propia religión. El naturalismo racionalista y relativista era esa posición filosófica que se imponía mediante un sistema progresivo de símbolos cuya rígida y arcana disciplina reforzaba la interacción entre signos e ideas. Así, la adopción de la concepción simbólica relativista conduciría a un relativismo filosófico, moral y religioso. El valor de las religiones específicas sería relativo a una verdad más amplia que escaparía a todas ellas y que se alcanzaría mejor por medio del proceso formativo masónico que mediante alguna de ellas, las cuales en definitiva eran "simples institucionalizaciones" parciales, incompletas, de esa verdad que no lograban aferrar. ${ }^{304}$

Además, la fraternidad masónica se presentaba como incompatible con la cristiana; así, "un cristiano católico no podía al mismo tiempo participar en la plena comunión de la fraternidad cristiana y, por otra parte, mirar a su hermano cristiano, desde la perspectiva masónica, como a un «profano»" ${ }^{305}$ La fraternidad cristiana quedaba relativizada por la masónica.

En conclusión, según el artículo, la adscripción a la masonería y la consiguiente incorporación a la fraternidad masónica conducía de manera generalmente suave e incluso imperceptible a una degradación de la fe, pues "la fuerza relativizadora de tal fraternidad, por su misma lógica intrínseca tenía en sí la capacidad de transformar la estructura del acto de fe de un modo tan radical que no era aceptable de parte de un cristiano". ${ }^{306} \mathrm{El}$ cardenal Ratzinger había ya comentado en la comisión de revisión del código que el relativismo de la masonería desnaturalizaba el acto de fe, pues, aunque en apariencia la profesión personal de la fe continuaba inmutada, "realmente moría en su raíz, la cual era fe en la verdad, y se desvanecía porque de este modo, no obstante, todos sus contenidos eran mudables, dado que se podían calificar de la misma manera verdaderos y falsos". ${ }^{307}$ La adhesión a la verdad de Dios revelada en la Iglesia se reducía entonces a la pertenencia a una institución interpretada como una de las varias formas posibles de orientarse hacia la divinidad, abocándose al indiferentismo religioso.

Seis años después, en línea con estas "Reflexiones" vaticanas de 1985, otro artículo sin firma - esta vez de la revista La Civiltà Cattolica- insistía en que el verdadero católico no podía dejarse seducir por la masonería porque ésta educaba

\footnotetext{
303 Ibidem, p. 21.

304 Idem.

305 Idem.

306 Idem.

307 Intervención del cardenal Joseph Ratzinger (22 de octubre de 1981), en Suchecki, Zbigniew, op. cit., pp. 80 y 81 . Traducción nuestra.
} 
en una filosofía y una religiosidad incompatibles con la fe.308 Afirmaban que la masonería era, filosóficamente, un fruto del iluminismo - sin embargo, sería más correcto decir que era una expresión de éste-, y de él procedían el racionalismo y el naturalismo que lo caracterizaban y que conllevaban la desconfianza en la revelación sobrenatural -si no es que su negación- y, por tanto, de la fe como medio de conocimiento. Además, la masonería negaba la providencia divina y abrazaba el deísmo, estimando superior la considerada por ellos religión natural universal - una religiosidad interior que se autentifica en moralismo exterior- a las religiones confesionales, que eran sólo formas corruptas de aquélla. En definitiva, la ideología masónica se resolvía en un mesianismo naturalista por el que el hombre alcanzaba su plenitud a través de su razón. La masonería se autocomprendía así como una realización más acabada de la perfección de la humanidad que la ofrecida por las religiones confesionales.

\section{LA MASONERÍA EN EL JUICIO Y EN LA AGTITUD DE LA IGLESIA EN LA ACTUALIDAD}

\section{El juicio negativo sobre la ideología masónica y su asociacionismo}

La reprobación de las sociedades masónicas por parte de la Iglesia, debido a su naturaleza, su obrar y su ideología, así como la consecuente prohibición para los católicos de vincularse a ellas se han mantenido sin interrupción hasta hoy. La naturaleza del asociacionismo masónico está condenada desde el siglo XVIII; la actuación de las masonerías contra la Iglesia y las autoridades civiles, desde la primera mitad del siglo XIX, y la ideología masónica, desde la segunda mitad del mismo siglo.

Es cierto que los tiempos cambian y, como toda realidad humana y social, el fenómeno masónico puede mutar en el tiempo, ${ }^{309}$ con lo que las masonerías podrían evolucionar en su organización, en sus proyectos e, incluso, en sus principios ideológicos hasta el punto de llegar a separarse de aquellos contenidos condenados por la Iglesia. Esta evolución y mutación es posible en tanto los hombres que forman parte de ellas la lleven a cabo. Por esto, mantener un diálogo con masones puede ser útil para los católicos con el objetivo de man-

308 "La Chiesa e la massoneria oggi”, La Civiltà Cattolica, IV/3393 (1991), pp. 217-227, en Congregazione per la Dottrina della Fede, op. cit., pp. 25-35.

309 Por ejemplo, Ferrer Benimeli, José Antonio, El Vaticano y los masones, op. cit., p. 14, afirma que la masonería actual no tiene "nada que ver con la del siglo XIX". Además de cuestionarnos esto, es preciso preguntarnos también si no lo tiene con la del siglo XVIII, igualmente condenada. 
tenerse al tanto de sus posibles cambios e incluso favorecerlos. No obstante, no debe obviarse que la masonería - una ideología que funda un asociacionismo particular- es una ideología precisamente en la acepción de un cuerpo doctrinal con pretensión de interpretación de la entera realidad a partir de una hermenéutica apriorística y asumida de una manera conforme al fideísmo, y que las ideologías así entendidas no evolucionan sin romperse. Las personas pueden abandonar estas ideologías y, por lo tanto, mudar su pensamiento, actitudes y comportamientos, pero éstas -en tanto construcciones ideales y cerradas de interpretación integral e ilusoria de la realidad- no se desenvuelven más que en favor de la autoafirmación de sí mismas, pues, si lo hicieran en otro sentido, se desmoronarían.

Lo propio de una ideología de este tipo es que, al pretender tener la clave de interpretación de la realidad, ofrece siempre la misma respuesta -la misma receta de solución- a los problemas variantes que plantea la historia; ahora, como tal respuesta es un discurso utópico, nunca se desmiente a sí misma, sino que se reafirma, aunque tampoco nunca soluciona nada. Es esto lo que hace imposible dialogar con las ideologías, las cuales no tienen ninguna capacidad de cambio, pues no la tienen tampoco de escucha de los reclamos de la realidad ni de las voces provenientes de otras visiones. Es posible y deseable dialogar con quienes sostienen una ideología, para hacerlos caer en la cuenta de su alucinación e inmovilismo y ayudarles a abandonarla, pero es imposible hacerlo con la ideología misma.

Por supuesto, en su propio discurso utópico, los masones reafirman la inexistencia de una ideología masónica, no sólo en el sentido que aquí he referido, sino incluso en cuanto a conjunto de ideas fundamentales que caracterizan de modo permanente al pensamiento masónico, al sostener que el método masónico - fundado en el diálogo, la razón y la tolerancia- podría ser conciliable con cualquier posicionamiento ideológico, político y religioso. Sin embargo, el lenguaje y la simbología de los masones a lo largo de su historia y a lo ancho de su fenomenología los desmienten, puesto que su lenguaje y sus símbolos sí parecen derivar de una ideología y, además, una de carácter apriorístico y fideísta. No obstante su ambigüedad formal, el conocimiento que las masonerías ofrecen a sus afiliados es, en definitiva, una clave de interpretación para posicionarse ante toda realidad; clave que, sintetizada en un culto de la razón humana como herramienta de liberación intramundana, conduce a la tolerancia como actitud consecuente a la relatividad que todo saber guarda respecto del subjetivismo antropocéntrico personal, el cual deriva precisamente del culto de esa razón. Así, por referir sólo un ejemplo, los diversos significados que adquiere -según grados- la simbólica letra $\mathrm{G}$ introducida en el seno del pentagrama, del compás 
y la regla, de la estrella flamígera de cinco puntas, manifiestan la ambigüedad afectada del discurso masónico en su camino al relativismo filosófico y moral. ${ }^{310}$

La particular fascinación de esta ideología reside en su promesa de liberación mediante un uso terapéutico de la razón, por la que el iniciado, empeñándose en un ejercicio dialéctico con sus hermanos masones, va despojándose gradualmente de certezas y, haciendo espacio a los acuerdos y acomodamientos de opiniones, va también aceptando abrirse de manera gradual al horizonte de lo mistérico, con la sensación de probar -mediante el recurso a la simbologíaalgo de un escondido, arcano y omnipresente tesoro sapiencial, como prenda de una armonía sincrética universal con la cual el hombre se realizará plenamente en una libertad de raciocinio que, en realidad, es más venerada que practicada. A esto se añade el deseo de conocimiento, la búsqueda de la verdad, la duda cotidiana y la necesidad de quitar el velo a la misteriosa religión. ${ }^{311}$ Por ello, la palabra perdida, el secreto primordial, el múltiple secreto masónico es esa actitud de tolerancia que cumple la función de una clave gnóstica de interpretación de la realidad que la razón humana habrá de adquirir por vía de la purificación y que le permitirá alcanzar todo conocimiento verdadero, el cual, de momento, sólo pregusta por vía esotérica y que, como nunca es poseído del todo, exige un empeño sin fin que justifica abrazar la práctica masónica para toda la vida.

$\mathrm{Al}$ considerarse necesaria consecuencia del libre ejercicio de la razón, dicha actitud tolerante viene revestida por esta ideología de superioridad frente a las posturas firmes que se remiten a la seguridad en verdades; por ello, opera como disolvente contra todo afán de certeza, al considerar que no sólo quien tiene esta actitud tolerante carece de certezas definitivas y se abre al acuerdo razonable, sino que todas las personas deberían necesariamente carecer de ellas y sumarse al acuerdo razonable que ellos proponen. Al mismo tiempo, esta tolerancia viene entronizada como si fuese el único motor y el fin del auténtico progreso de la humanidad, al cual no sólo no se renuncia, sino que se considera inexorable, como fruto de la alineación de los tolerantes masones en las resoluciones convenidas por sus jerarquías y asimiladas por sus bases mediante el método de diálogo con el que otorgan el consenso a tales resoluciones. La veneración de esta tolerancia funda la soberbia masónica que ha sido frecuentemente denunciada por los papas. ${ }^{312}$ Curiosa, pero lógicamente, el masón queda -en virtud de su

310 Giantulli, Florido, op. cit., pp. 77-79. De lo que recaba el autor, la G, que en general indicaría God (Dios), en un momento indica la Geometría, más tarde la Generación, con unos contenidos antropocéntricos dentro de la cosmovisión masónica y conducentes al relativismo filosófico, religioso y moral.

311 Ibidem, p. 45.

312 Por ejemplo, León XIII, Encíclica Humanum genus (20 de abril de 1884), en Gutiérrez García, José Luis, op. cit., p. 178. 
tolerancia narcisista- a merced de los acuerdos que el consenso o los superiores impongan bajo apariencia de provisionalidad en un proceso supuestamente liberador, pero que puede ser utilizado en beneficio de intereses ajenos de muy variado orden. También los pontífices han advertido repetidamente el peligro de que los afiliados a la masonería sean manipulados a modo de tontos útiles para causas que desconocen o que no comparten plenamente. ${ }^{313}$

Como puede verse, el discurso masónico enraíza en un relato histórico insostenible, cuya primera expresión fue la parte inicial de las Constituciones de Anderson, el cual, si bien los masones de hoy pueden o deben interpretarlo en sentido simbólico, en su pretensión originaria se arrogaba un carácter propiamente histórico. En el corazón del discurso se encuentra un secreto hueco que admite contenidos variables, los cuales lo desmienten en su contenido, para reducirlo a las opiniones o acuerdos -incluso a los intereses- de los más poderosos o astutos, y cuya fragilidad se defiende mediante un formalismo reverencial empapado del elitismo del Antiguo Régimen en el que se gestó. Este mismo secretismo hace cuando menos curioso -si no dudoso- el afán filosófico y humanitario que muchas masonerías se atribuyen. Que el secreto masónico pueda, en determinadas circunstancias, favorecer la expropiación de los agentes sociales de su legítima capacidad de decisión en la organización de la vida pública es algo que debe verificarse mediante el estudio de la historia. Las masonerías se han convertido en redes más o menos ocultas de influencia y de poder político y social, donde ambiciones e intereses de diverso orden han podido encontrar vías de expresión y de eficacia, posiblemente desde tiempos muy tempranos. No faltan acusaciones hacia las masonerías de conspirar contra las autoridades establecidas, así como también de hacerse instrumentos conniventes de éstas para manipular al Estado y a la sociedad, al amparo del secreto y de la impunidad que éste posibilitaría. Este peligro ha sido también advertido por los papas a lo largo de toda la historia, como hemos visto.

En nuestra época, los obispos filipinos se han ocupado de exponer de nuevo el tema. El 6 de julio de 2002, hicieron una declaración sobre la situación canónica de los católicos que se adscribían a la masonería y, un año después,

313 Por ejemplo, ibidem, pp. 168 y 171. Lo hemos encontrado ya claramente desde León XII en 1825. Recientemente, también han expresado este peligro: el cardenal Pietro Palazzini en la comisión de revisión del código de derecho canónico (1981), en Suchecki, Zbigniew, op. cit., p. 83; Inconciabilidad entre fe cristiana y masonería (1985), en op. cit., p. 21: el clima de secretismo implica para los miembros el riesgo de llegar a ser "instrumento de estrategias por ellos ignoradas"; Conferencia Episcopal Filipina, Lineas guía sobre la masonería (2003), en Congregazione per la Dottrina della Fede, op. cit., p. 61, (pregunta 19). 
publicaron una serie de cuarenta y siete preguntas y respuestas ${ }^{314}$ para hacer entender a los fieles por qué la Iglesia "ha siempre declarado que los principios de la masonería son incompatibles con la fe cristiana". ${ }^{315}$ Para los obispos filipinos, los principios filosóficos base de la masonería son el deísmo, el naturalismo y el relativismo. ${ }^{316}$ De ellos se deducen cinco principios doctrinales o ideológicos por los cuales la masonería es incompatible con el catolicismo. El primero es que "la masonería considera a todas las religiones del mundo como meros intentos competitivos para conocer a Dios, que permanece incognoscible", 317 por lo tanto, abraza el indiferentismo religioso ${ }^{318}$ y no admite que se afirme el cristianismo como la verdadera religión; el segundo, que se juzga "fuente de unidad entre los hombres [...] por encima y más allá de todas las religiones [...] sostiene solo las creencias en las que todos los hombres concuerdan"; $319 \mathrm{el}$ tercero, que "pone la razón humana como única fuente de conocimiento", de forma que sería supersticioso admitir lo que la razón no puede conocer; $320 \mathrm{el}$ cuarto, que, por creer que la verdad sobre Dios y sobre el hombre es inalcanzable, rechaza como fanático todo lo que le suene a dogmático, ${ }^{321} \mathrm{y}$, el quinto, que "busca la perfección del hombre solo en el desarrollo de sus virtudes naturales", predicándola como obra del esfuerzo humano sin dejar espacio a la gracia que dispensan los sacramentos. ${ }^{322}$ Conforme a estos principios, "la masonería está constituida por un conjunto de creencias y rituales que la hacen en sustancia una religión naturalista". ${ }^{323}$

Respecto a la religiosidad masónica, los obispos filipinos reflexionan ${ }^{324}$ que la fraternidad nacida de ella no pasaría de ser un buen deseo, concretado a lo sumo en camaradería y formalismo, pues se necesita la paternidad de Dios para fundar una verdadera fraternidad entre los hombres. ${ }^{325}$ Asimismo, estos religiosos tienen en cuenta también la subjetividad de las personas que

314 Conferencia Episcopal Filipina, op. cit., pp. 55-73. Las citas en español de este documento son traducción nuestra del texto italiano publicado en esta obra.

315 Quevedo, Orlando B., "Introducción” del Presidente de la Conferencia Episcopal Filipina, en Conferencia Episcopal Filipina, ibidem, p. 55.

316 Conferencia Episcopal Filipina, op. cit., pp. 63 y 64 (preguntas 26-29).

317 Ibidem, p. 57 (pregunta 5).

318 Ibidem, p. 61 (pregunta 19).

${ }^{319}$ Ibidem, p. 58 (pregunta 5).

${ }^{320}$ Idem.

321 Idem.

322 Idem.

323 Quevedo, Orlando B., op. cit., p. 55.

324 Conferencia Episcopal Filipina, op. cit., pp. 66-68 (preguntas 34-38).

325 Ibidem, p. 70 (pregunta 41). 
ingresan en la masonería por razones variadas y con intereses particulares; por ello, no niegan que puede haber personas adscritas a la masonería que no se adhieren con plena convicción a sus principios; sin embargo, esto no hace que tales principios dejen de ser lo que son y que la adhesión deje de ser reprobable para un católico y peligrosa para la fe. ${ }^{326}$ Recuerdan que, como el fin no justifica los medios, no es lícito adherirse a las masonerías por conveniencia, buscando favores profesionales o sociales que quizá no se lograrían por vías legales y transparentes, y exponiendo además la propia fe al riesgo de deterioro. ${ }^{327}$ Observan cómo también otras confesiones cristianas prohíben o tienen reservas hacia la masonería. ${ }^{328}$

\section{En los tiempos nuevos del papa Francisco}

La posición de la Iglesia católica de reprobación a la masonería es lineal y se funda en razones de incompatibilidad de principios. Por parte de la Santa Sede, la última intervención oficial sobre el tema es la declaración Quaesitum est, de noviembre de 1983. Respecto a la doble pertenencia -la cual está prohibida, por lo que un católico no puede hacerse masón-, nada ha innovado el papa Francisco. Recientemente, en 2013, en Megéve (Suiza), diócesis de Annecy, fue cesado y censurado su obispo, el sacerdote Pascal Vésin, por preferir permanecer en una obediencia masónica que en la obediencia a la Iglesia. ${ }^{329}$ Francisco se ha referido públicamente a la masonería sólo un par de veces, con menciones de pasada, ambas en sentido negativo, en el curso de entrevistas en las que hablaba de manera improvisada: el 28 de julio de 2013, en el avión de regreso a Roma desde Brasil, cuando se le presentó sobre el caso de monseñor Battista Ricca y el lobby gay, se lamentaba de los lobby que buscan presionar en favor de intereses propios, refiriéndose a esta actitud como al problema que estimaba más grave en el contexto en el que hablaba; uno de los lobby que mencionó fue el de los masones; asimismo, el 21 de junio de 2015, en Turín, en una respuesta a los jóvenes, se refirió a finales del siglo XIX como una de las épocas más difíciles y feas de la historia de Italia, con "la masonería en pleno", los anticlericales y los satanistas. ${ }^{330}$ Parece ser que, en una carta reservada al cardenal

${ }^{326}$ Ibidem, pp. 60 y 61 (preguntas 14 y 18).

327 Ibidem, p. 61 (pregunta 18).

328 Ibidem, pp. 72 y 73 (pregunta 47).

329 Bárcena, Alberto, op. cit., p. 311.

330 Magister, Sandro, Los masones son hinchas de Bergoglio. Pero él los ve como la peste (3 de mayo de 2017), Settimo Cielo, 12 de mayo de 2017, http://magister.blogautore.espresso.repubblica. it/2017/05/03/los-masones-son-hinchas-de-bergoglio-pero-el-los-ve-como-la-peste/?refresh_ce. 
Raymond Leo Burke del 1 de diciembre de 2016, le pidió que interviniera en el asunto relativo a los Caballeros de la Orden de Malta, para impedir que hubiera entre ellos quienes mantuviesen una adhesión a asociaciones "contrarias a la fe católica o de carácter relativista", por ser incompatibles con la pertenencia a dicha orden. ${ }^{331}$

$\mathrm{Al}$ mismo tiempo, permanece abierta la posibilidad de dialogar con masones, de acuerdo con el espíritu del Concilio Vaticano II, ${ }^{332}$ pero sin comprometer la integridad de la doctrina católica. ${ }^{333} \mathrm{Al}$ respecto, en el pontificado de Francisco, es probable que, conforme a su consigna de fomentar una Iglesia en salida hacia todos, ${ }^{334}$ así como debido a que los masones son todavía varios millones de personas, a pesar de que sus números van a la baja, ${ }^{335} \mathrm{y}$ en una época en la que parte de la masonería está procurando ofrecer una imagen de apertura, la Santa Sede esté - por así decirlo- moviendo sus fichas. Varios pasos lo sugieren; en concreto, la publicación por parte de la Congregación para la Doctrina de la Fe en 2015 de un librito que reúne las principales declaraciones eclesiales contemporáneas sobre masonería; ${ }^{336}$ su presentación a los masones en febrero de 2016 mediante una carta abierta del presidente del Pontifico Consejo de la Cultura, considerando posible el diálogo, ${ }^{337}$ y las

${ }^{331}$ La carta no ha sido publicada oficialmente, por lo que no podemos asegurar su autenticidad. Véase "La Nueva Bussola Quotidiana/Infocatólica", 2 de febrero de 2017, http:// infocatolica.com/?t=noticia\&sod=28454; véase también, http://wrwr.lanuovabq.it/it/quella-letteradel-papa-al-cardinale-burke.

332 Véase Concilio Vaticano II, Constitución pastoral Gaudium et spes (7 de diciembre de 1965), núms. 21, 28 y 92; e idem, Declaración Dignitatis humanae (7 de diciembre de 1965), núm. 3.

333 Véase Di Fiore, Tullio, Massoneria e Chiesa Cattolica. Dall'incompatibilità alle condizioni per un confronto, Palermo, Dario Flaccovio, 2013; Guerra Gómez, Manuel, Masonería, religión y política, Madrid, Sekotia, 2012, y El árbol masónico. Trastienda y escaparate del Nuevo Órden Mundial, Manchester-Londres, Digital Reason, 2017.

334 Francisco, Exhortación apostólica Evangelii gaudium, núms. 20-24.

335 Recientemente, en una entrevista, Manuel Guerra sostuvo que el número de adeptos a las masonerías ha disminuido mucho durante el último siglo; así, dice que, en Estados Unidos, los masones habrían pasado de cuatro millones a principios del siglo XX a un millón trescientos mil a principios del actual; en Inglaterra, serían actualmente unos trescientos cincuenta mil, y, en España, unos treinta mil: Guerra Gómez, Manuel, Entrevista en Religión Confidencial. Reseña, 13 de junio de 2017, https://wrere.religionconfidencial.com/otras_religiones/Manuel-Guerramasoneria-Espana-masones_0_2946305362.html. El mismo estudioso, en otra entrevista, afirmó que, en Francia, el Gran Oriente de Francia (la masonería allí mayoritaria) tendría más de cincuenta mil miembros: Guerra Gómez, Manuel, La Iglesia Católica y la masonería son incompatibles. Entrevista realizada por Jorge Santana (1o. de julio de 2013), 21 de junio de 2017, http://wrerrebuenanueva.es/ entrevista-a-manuel-guerra-gomez.

336 Congregazione per la Dottrina della Fede, op. cit.

337 Ravasi, Gianfranco, "Cari fratelli massoni", Il Sole 24 Ore, suplemento semanal, domingo, 14 de febrero de 2016, p. 29. 
declaraciones del masón Jean-Claude Féraud-Gargantini. ${ }^{338}$ Pocas semanas después de la carta abierta a los masones, el 8 de marzo de 2016, FéraudGargantini firmó un documento en el que, presuponiendo la intención del papa Francisco de que se abriera un diálogo entre la Iglesia y la masonería, propone comenzar tal diálogo de modo directo y abierto. ${ }^{339}$ De acuerdo con este documento, el diálogo entre la Iglesia y la masonería ya se había iniciado, de hecho, y el propio Féraud-Gargantini se habría dirigido al pontífice en dos comunicaciones de 2013 y 2014; la segunda fue remitida a la Congregación para la Doctrina de la Fe, por tanto, es posible que su comunicación influyera en las motivaciones de la publicación que hizo ese dicasterio al año siguiente.

En la introducción del volumen publicado en 2015 por la Congregación de la Doctrina de la Fe, fechada el 8 de diciembre de 2014, su prefecto, el cardenal Gerhard Müller, expone de manera sintética todo el recorrido de las condenas pontificias de la masonería hasta la Humanum genus y el código de 1917, y, con citas de León XIII, reafirma la imposibilidad para el creyente de inscribirse en la masonería y que no debe dejarse engañar por sus apariencias de honestidad. Asimismo, recuerda los intentos de acercamiento y diálogo de la década de 1970, auspiciando el levantamiento de la excomunión y la posibilidad de admitirse una doble pertenencia, porque en el plano operativo podría haber algunas causas compartidas, como "la libertad y los derechos del hombre, las obras de beneficencia, la promoción de la paz", 340 así como la carta de julio de 1974 y la declaración de febrero de 1981 de su dicasterio. También, en ocho puntos, presenta las conclusiones de la comisión de la Conferencia episcopal alemana, de 1980.341 Termina con el código y la declaración de 1983 y con el artículo de febrero de 1985, para concluir que la inconciabilidad entre catolicismo y masonería "encuentra su fundamento en el contraste insanable existente entre los principios de la fe cristiana y los de la masonería, la cual tiende a degradar la vida cristiana

338 Véase Guerra Gómez, Manuel, Algunos objetivos de la masonería... cit.

339 Féraud-Gargantini, Jean-Claude, Arringa all'intenzione della sua Santità il Papa Francesco: Per la apertura di un dialogo tra la Chiesa e le Massonería [sic] (Mimet, 8 de marzo de 2016).

340 Müller, Gerhard, cardenal, "Introduzione", op. cit., p. 9. Traducción nuestra.

341 Ibidem, p. 10: "1) La masonería propone una visión relativista de la religión. 2) La posibilidad del conocimiento objetivo de la verdad es rechazada por la masonería. 3) Su concepción de Dios no permite pensar a una revelación de Dios, como sucede en la fe y en la tradición cristiana. 4) Su idea de tolerancia se funda sobre un relativismo ideológico que vacía la actitud de fe del creyente y degrada su asenso al magisterio eclesiástico. 5) Algunos ritos que hacen uso de palabras y símbolos son una parodia de ritos sacramentales. 6) El perfeccionamiento ético viene concebido de modo que excluye la necesidad de la justificación del hombre según la concepción cristiana. 7) La masonería pretende la dominación total sobre la vida y la muerte de sus miembros. 8) Aunque exista una tendencia cristiana en la masonería, permanece sin embargo en el interior de la estructura fundamental masónica y no es posible una conciliación teológica" (traducción nuestra). 
sacramental, el sentido de pertenencia eclesial y la fe en la Iglesia, depositaria de la verdad revelada". ${ }^{342}$ El secretario del dicasterio escribía: "La masonería expresa una concepción del hombre y de la realidad por la cual el hombre se realiza a sí mismo con sus solas fuerzas, intelectuales y morales. La fe católica, por el contrario, profesa la redención del hombre por medio de Jesucristo, «camino, verdad y vida» $\left(f n\right.$ 14, 6), único Salvador del hombre". ${ }^{343}$ Por lo tanto, el libro busca garantizar la claridad de ideas sobre las diferencias que permanecen netas entre catolicismo y masonería, condición necesaria para cualquier eventual diálogo que pretenda superar hostilidades y prejuicios sin incurrir en falsos irenismos.

Esto último es cuanto reconoce y plantea a los masones la carta abierta del cardenal Gianfranco Ravasi, presidente del Pontificio Consejo de la Cultura, publicada en el suplemento cultural semanal de Il Sole 24 Ore, el 14 de febrero de 2016. ${ }^{344}$ El cardenal les presenta el volumen publicado por la Congregación de la Doctrina de la Fe del año anterior y, después de recordarles las condenas pontificias y las declaraciones de incompatibilidad de pertenencia a la Iglesia y a la masonería, les aclara que éstas no impiden el diálogo en ámbitos como "la dimensión comunitaria, la beneficencia, la lucha al materialismo, la dignidad humana, el conocimiento recíproco", en línea con lo expresado por los obispos alemanes en 1980. Reconoce la fragmentación del mundo masónico y cómo ésta hace difícil "un mapa de su ideología", por lo que "quizá se puede hablar de un horizonte y de un método más que de un sistema doctrinal codificado". En este ámbito, encuentra "antropocentrismo y espiritualismo": una "antropología basada en la libertad de conciencia y de intelecto y sobre la igualdad de derechos, y un deísmo que reconoce la existencia de Dios, dejando no obstante móviles las definiciones de su identidad”. Al día siguiente, el gran maestro del Gran Oriente de Italia, Stefano Bisi escribía una carta al director de Il Sole 24 Ore, en respuesta a la del cardenal Ravasi, con el propósito de abrir un "diálogo constructivo en ámbitos nuevos y pacíficos y en el respeto a las diversas identidades", dado que habría "valores comunes" entre la masonería y la Iglesia. ${ }^{345}$ La carta es un alegato de la tolerancia masónica y de sus intentos y propósitos de diálogo con la

342 Ibidem, p. 12. Traducción nuestra.

${ }^{343}$ Ladaria, Luis F., "Prefazione", en ibidem, pp. 5 y 6. Traducción nuestra. Luis Francisco Ladaria Ferrer es el actual prefecto de la congregación.

344 Ravasi, Gianfranco, "Cari fratelli massoni", Il Sole 24 Ore, suplemento semanal, 14 de febrero de 2016, p. 29. Es competencia actual del Pontificio Consejo de la Cultura el diálogo con los no creyentes. Las citas en español de este documento son traducción nuestra del original italiano.

345 Bisi, Stefano, Carta al director de Il Sole 24 Ore, 15 de febrero de 2016, http://werere. grandeoriente.it/lettera-del-gran-maestro-bisi-a-il-sole-24-ore-dopo-larticolo-del-cardinale-ravasi-su-chiesa-e-massoneria/, y en AGENPARL-Roma, 22 feb 2016, http://wrwre.agenparl.com/364157-2/. 
Esta obra forma parte del acervo de la Biblioteca Jurídica Virtual del Instituto de Investigaciones Jurídicas de la UNAM www.juridicas.unam.mx

Iglesia (preferentemente en campo propio, como muestra su referencia a Porta Pía) y con cualquiera, acompañado de una muy masónica descalificación de los dogmas y de lo que considera posturas intransigentes desde una visión relativista de la verdad, que se puede buscar pero no alcanzar. Es difícil, a la lectura de esta carta, negar el enroque de su autor en la ideología masónica, con lo que su ensayo de diálogo parece predeterminado al fracaso. El tiempo nos hará ver si ha habido respuestas diferentes a la misiva del cardenal de otros masones o de él mismo. Una respuesta diferente puede haber sido el extenso documento de Jean-Claude Féraud-Gargantini, de marzo de 2016, que ya mencionamos y que se presenta optimista sobre un diálogo que, según él, estaría ya en curso.

El obstáculo principal para el diálogo con los masones está en la ideología masónica, que, como toda ideología apriorística y narcisista, en lugar de iluminar la vista de la realidad la oscurece con su deslumbramiento. No es un obstáculo invencible, porque el ser humano puede usar correctamente la razón y superar con ella cualquier ideología, incluida ésta.

\section{BIBLIOGRAFÍA}

ANDRÉS, Juan Ramón de (ed.), El surgimiento de la Masonería: Eugene Michael fones, Saarbrücken Editorial Académica Española, 2015, wrere.academia.edu.

Apéndice a las Actas y decretos del Santo Concilio Ecuménico Vaticano que contiene la constitución Apostolicae Sedis de 12 de octubre de 1869 con algunas notas importantes para su más fácil inteligencia, Zaragoza, Tipografía de D. José María Magallón, 1873.

BÁRCEnA, Alberto, Iglesia y masonería. Las dos ciudades, Madrid, Ediciones San Román, 2016.

BELLOCAHI, Ugo (ed.), Tutte le encicliche e $i$ principali documenti pontifici emanati dal 1740, vol. I-IV, Ciudad del Vaticano, Libreria Editrice Vaticana, 19931995.

Butindaro, Giacinto, La massoneria smascherata. Contro l'infiltrazione e l'influenza di questa diabolica istituzione nelle Chiese Evangeliche [diciembre de 2012], disponible en: http://wreresentieriantichi.org/download/La-Massoneria-Smascherata.pdf.

Caillet, Maurice, Yo fui masón, Madrid, Libros Libres, 2010.

Castro Alonso, Manuel de (dir.), Colección completa de las encíclicas de Su Santidad León XIII, en latín y en castellano, bajo la dirección y con un prólogo de [...], I, Madrid, Tipografía y Casa editorial Cuesta, Madrid, [s.a. 1903]. 
Esta obra forma parte del acervo de la Biblioteca Jurídica Virtual del Instituto de Investigaciones Jurídicas de la UNAM www.juridicas.unam.mx

Cierva, Ricardo de la, Los signos del anticristo. Iglesia, Masonería Total y Poderes Ocultos ante el Tercer Milenio, Getafe (Madrid), Editorial Fénix, 1999.

Codex Iuris Canonici, Pïs X Pontificis Maximi iussu digestus, Benedicti Papae XV auctoritate promulgatus, [1917], Nueva York, P. J. Kenedy \& Sons Typographi Pontificii, 1918.

Código de Derecho Canónico [de 1917] y legislación complementaria. Texto latino y versión castellana, con jurisprudencia y comentarios, por MiguéLEZ DOMínguEZ, Lorenzo, Alonso Morán, Sabino y Cabreros de Anta, Marcelino, Madrid, BAC, 1957.

Código de Derecho Canónico. Edición bilingüe comentada por los profesores de la Facultad de Derecho Canónico de la Universidad Pontificia de Salamanca, dirigida por Lamberto de Echeverría, Madrid, BAG, 1983.

Congregazione per la Dottrina della Fede, Dichiarazione circa le associazioni massoniche (23 [sic] novembre 1983). Testo e commenti, Ciudad del Vaticano, Libreria Editrice Vaticana, 2015.

Constituciones de los Franc-masones (17 de enero de 1722-1723), Museo Virtual de Historia de la Masonería, UNED, disponible en: http://wrerw2.uned.es/dptohdi/museovirtualhistoriamasoneria/3documentos_fundacionales/constituciones $\% 20$ anderson\%201723.pdf.

Constitución de los Franc-masones. Introducción, en Museo Virtual de Historia de la Masonería, UNED, disponible en: http://wrew2.uned.es/dpto-hdi/museovirtualh istoriamasoneria/3documentos_fundacionales/contitucionesdeanderson_introduccion.htm.

"Declaración del Episcopado Argentino sobre la masonería" (20 de febrero de 1959), en GELONCH Villarino, Edmundo, Las gracias y las desgracias de la Argentina: una visión política desde el Salmo II, San Rafael 2016, Verbo Encarnado.

Denzinger, Enrique, El magisterio de la Iglesia, Barcelona, Herder, 1963.

Di Fiore, Tullio, Massoneria e Chiesa Cattolica. Dall'incompatibilità alle condizioni per un confronto, Palermo, Dario Flaccovio, 2013.

Ferrer Benimeli, José Antonio, "El Vaticano y los masones", en El País, 10 de marzo de 1985.

Ferrer Benimeli, José Antonio, La masonería española en el siglo XVIII, Madrid, Siglo XXI, 1986.

Ferrer Benimeli, José Antonio, Masonería, Iglesia, Revolución e Independencia, Bogotá, Pontificia Universidad Javeriana, 2015.

GiAnTUlLI, Florido, L'essenza della massoneria italiana. Il naturalismo, Florencia, Pucci Cipriani Editore Firenze, 1973. 
Esta obra forma parte del acervo de la Biblioteca Jurídica Virtual del Instituto de Investigaciones Jurídicas de la UNAM www.juridicas.unam.mx

Guerra Gómez, Manuel, Masonería, religión y política, Madrid, Sekotia, 2012. GUERRA GómEz, Manuel, La iglesia católica y la masonería son incompatibles. Entrevista realizada por Jorge Santana (1o. de julio de 2013), disponible en: http://wrere.buenanueva.es/entrevista-a-manuel-guerra-gomez.

Guerra Gómez, Manuel, Algunos objetivos de la masonería en la celebración del tercer centenario de su fundación (3 de junio 2016), disponible en: https://infovaticana.com/blogs/wp-content/uploads/sites/3/2016/06/blogmasonfrances.pdf.

Guerra Gómez, Manuel, El árbol masónico. Trastienda y escaparate del Nuevo Orden Mundial, Manchester-Londres, Digital Reason, 2017.

Guerra Gómez, Manuel, Entrevista en Religión Confidencial. Reseña (13 de junio de 2017),disponible en: https://wrere.religionconfidencial.com/otras_religiones/Manuel-Guerra-masoneria-Espana-masones_0_2946305362.html.

Gutiérrez García, José Luis (ed.), Doctrina Pontificia, II. Documentos políticos, Madrid, BAC, 1958.

Introvigne, Massimo (ed.), Massoneria e religioni, Leumann (Turín), Centro Studi sulle Nuove Religioni (CESNUR)-Editrici Elle Di Ci, 1994.

Marín, Hilario, (ed.), Doctrina Pontificia, IV. Documentos marianos, Madrid s.e., 1954.

Martina, Giacomo, Pio IX (1867-1878), ("Miscellanea Historiae Pontificiae" 58), Roma, Pontificia Universidad Gregoriana, 1990.

Martínez Albesa, Emilio, La Constitución de 1857. Catolicismo y liberalismo en México, 3 tomos, México, Porrúa, 2007.

MARTínez AlBesa, Emilio, "Libertad religiosa y autoridad política a la luz de la encíclica Caritas in veritate de Benedicto XVI", en RUBIO DE URQUÍA, Rafael y PÉREZ-SOBA, Juan José (eds.), La doctrina social de la Iglesia. Estudios a la luz de la encíclica Caritas in veritate, Madrid, BAC, 2014.

Otaola Bajeneta, Javier, La masonería hoy. Razón y sentido, San Sebastián, Aramburu, 1996.

PAzos, Antón M., La Iglesia en la América del IV Centenario, Madrid, Mapfre, 1992.

Pellicaiari, ANGela, I Papi e la massoneria, Milán, Edizioni Ares, 2007.

Pío X, Alocución consistorial Gratum quidem (27 de noviembre de 1911), en Acta Apostolicae Sedis, Roma, Tipografía Políglota Vaticana, 1911, t. 3.

Pontificia Comisión para América Latina, Acta et decreta Concilii Plenarii Americae Latinae, in Urbe celebrati Anno Domini MDCCCXCIX. Actas y Decretos del Concilio Plenario de la América Latina. Edición facsímil, Ciudad del Vaticano, Libreria Editrice Vaticana, 1999.

RIDLEY, Jasper, Los masones, Barcelona, Ediciones B, 2010 (1a. ed. en inglés, 1999). 
Esta obra forma parte del acervo de la Biblioteca Jurídica Virtual del Instituto de Investigaciones Jurídicas de la UNAM

Rodríguez, Federico (ed.), Doctrina Pontificia, III. Documentos sociales, Madrid, BAC, 1959.

Suchecki, Zbigniew, Chiesa e massoneria. Congregazione plenaria della Pontificia Commissione per la revisione del Codice di Diritto Canonico tenuta nei giorni 20-29 ottobre 1981 riguardante quinta questione speciale dedicata alla riassunzione del can. 2335 el Codice di Diritto Canonico 1917, Ciudad del Vaticano, Libreria Editrice Vaticana, 2000.

UlLate Fabo, José Antonio, El secreto masónico desvelado, Madrid, Libros Libres, 2007. 


\title{
LA MIRADA DE LA SANTA SEDE SOBRE LA MASONERÍA MEXICANA
}

Paolo VALVO

\begin{abstract}
Sumario: I. La masonería en el magisterio pontificio de Pio IX a Pio XI. II. La Santa Sede y la masonería en México de la Reforma al Porfiriato. III. De la Revolución a la guerra Cristera. IV. La década de 1930. V. Epílogo: la mirada de la Santa Sede sobre la masonería mexicana del Concilio Vaticano II hasta la fecha.
\end{abstract}

\section{LA MASONERÍA EN EL MAGisterio PONTIFIGIO DE PíO IX A PÍO XI}

El 28 de junio de 1932, el entonces delegado apostólico en México, Leopoldo Ruiz y Flores, escribía una carta al cardenal secretario de Estado Eugenio Pacelli, en la que el arzobispo de Morelia contestaba unas preguntas de la Secretaría de Estado sobre la difusión del comunismo en el país, en el marco de una encuesta global promovida por el Vaticano. ${ }^{1}$ Hablando del Partido Nacional Revolucionario (PNR), en particular, Ruiz y Flores afirmaba que éste era "radicalmente anticatólico, porque cree que los católicos, gozando de un poco de libertad, podrían adueñarse del poder, y además es controlado por judíos, masones, socialistas y anticlericales". En lo que se refiere a la masonería, Ruiz y Flores añadía:

[...]manda sobre los miembros del Gobierno, de medida que es posible afirmar que nadie puede desempeñar un cargo público si no es, o si no se vuelve, masón. La masonería [sigue argumentando el delegado apostólico] no se declara comunista, sin embargo, favorece mucho el comunismo por su política antirreligiosa y ha demostrado públicamente su apoyo a la política antirreligiosa del

1 Segreteria di Stato, Sezione per i Rapporti con gli Stati, Archivio Storico, en adelante: S.RR.SS., Archivio della Sacra Congregazione per gli Affari Ecclesiastici Straordinari, en adelante: AA.EE.SS., Stati Ecclesiastici, pos. 474 (P.O.), fasc. 475, ff. 25r-26r. Al respecto, véase Giunipero, Elisa, "Le inchieste sul comunismo", en Pettinaroli, Laura (coord.), Le gouvernement pontifical sous Pie XI: pratiques romaines et gestion de l'universel, Actes du séminaire international 20102011, École française de Rome, Roma, s.e., 2013, pp. 191-202. 
gobernador de Veracruz, que es un verdadero bolchevique. Desde el tiempo de la presidencia del general Calles muchos judíos llegaron a México, y escuché de una persona que puede decirse bien informada, que la masonería está dominada por judíos, que a través de la misma hacen y deshacen aquí como quieren. No puedo sin embargo confirmar que esta sea la verdad. ${ }^{2}$

Unos meses antes, el 11 de febrero de 1932, el pontífice Pío XI recibía en el Vaticano al dictador italiano Benito Mussolini. Al margen del coloquio - que va a representar simbólicamente el inicio del apaciguamiento entre la Santa Sede y el régimen fascista, después de la crisis diplomática de 1931 sobre la Acción católica-, Mussolini tomaba algunos apuntes de la conversación con el papa. En ellos se puede leer que Pío XI habla de "un triángulo doloroso" que aumenta su dolor, es decir: 1) México, "país totalmente enfeudado a la masonería"; 2) España, "donde trabajan juntos bolchevismo y masonería", y finalmente 3) Rusia, con su obra de descristianización del pueblo. Detrás de todo esto - según el pontífice- había también "la aversión anticristiana del judaísmo". Al respecto, el papa recordaba que, cuando estaba en Varsovia, como nuncio apostólico, "todos los comisarios políticos de los regimientos bolcheviques eran judíos". 3

Estos documentos nos ofrecen ya elementos útiles para examinar el juicio de la Santa Sede - y de la jerarquía católica mexicana también- sobre el fenómeno masónico, en el marco de la estación revolucionaria en México, y particularmente en la década de 1930, cuando la Iglesia va a enfrentarse con el gobierno de Lázaro Cárdenas del Rio. Un primer tema que destaca es el nexo entre la masonería y el comunismo, que representa un aspecto fundamental del magisterio pontificio, particularmente en los años de Pío XI. En la encíclica sobre la situación de México Acerba animi, del 29 de septiembre de 1932, el papa habla de la necesidad de defender a los jóvenes contra los peligros de "la doctrina tan amplísimamente propagada de los ateos, masones y comunistas". 4 Poco después, en la encíclica Dilectissima nobis (3 de junio de 1933), sobre la "injusta situación creada a la Iglesia católica en España", Pio

2 S.RR.SS., AA.EE.SS., Messico, pos. 553 (P.O.), fasc. 294, ff. 3v-4r, carta de monseñor Ruiz y Flores al cardenal Eugenio Pacelli, 28 de junio de 1932.

3 Mussolini a Vittorio Emanuele III, Entrevista con el Papa, 11 de febrero de 1932, véase Corsetti, A., Scritti, Florencia, Le Lettere, 1999, p. 114. El texto fue publicato por primera vez en Corsetti, A., Dalla preconciliazione ai Patti del Laterano-Note e documenti, Florencia, Biblioteca Civica di Massa, 1968, pp. 149-225.

4 Pío XI, Acerba animi, Ciudad del Vaticano, 29 de septiembre de 1932. Todas las encíclicas pontificias a las que se hace referencia aquí se han consultado en línea en el sitio web de la Santa Sede, wrere.vatican.va. 
XI atribuye "la persecución movida contra la Iglesia en España, más que a incomprensión de la fe católica y de sus benéficas instituciones, al odio que «contra el Señor y contra su Cristo» fomentan sectas subversivas de todo orden religioso y social, como por desgracia vemos que sucede en Méjico y en Rusia". ${ }^{5}$ También en la carta encíclica sobre el comunismo Divini Redemptoris, del 19 de marzo de 1937, México se encuentra asociado a España y Rusia. En particular, en el párrafo 18, el papa, profundizando acerca de las causas de la rápida difusión del comunismo a nivel global, habla de

[...] la conspiración del silencio que en esta materia está realizando una gran parte de la prensa mundial no católica. Decimos conspiración porque no se puede explicar de otra manera el hecho de que un periodismo tan ávido de publicar y subrayar aun los más menudos incidentes cotidianos haya podido pasar en silencio durante tanto tiempo los horrores que se cometen en Rusia, en México y también en gran parte de España, y, en cambio, hable relativamente tan poco de una organización mundial tan vasta como es el comunismo moscovita. Este silencio, como todos saben, se debe en parte a ciertas razones políticas, poco previsoras, que lo exigen -así se afirma-, y está mandado y apoyado por varias fuerzas ocultas que desde hace mucho tiempo tratan de destruir el orden social y político cristiano. ${ }^{6}$

A pesar de la ausencia de referencias explícitas a la masonería, es muy probable -tomando en cuenta el magisterio pontificio en su conjunto- que a ésta se refiera la expresión "varias fuerzas ocultas que tratan de destruir el orden social y político cristiano". Más clara parece la encíclica Ingravescentibus malis, del 29 de septiembre de 1937, en la que el papa Achille Ratti invita a todos los fieles a recurrir a María Madre de Dios - a través del Santo Rosario- contra las graves amenazas del tiempo. Si bien el comunismo es el único peligro explícitamente nombrado en el texto pontificio, hay también referencias inequívocas al nacionalsocialismo alemán y a la masonería, que Pio XI define en esta carta (su última encíclica) como

[...] la artera y funestísima secta de los que, negando y odiando a Dios, se declaran enemigos del Eterno; se insinúan por doquiera; desacreditan y arrancan de las almas toda creencia religiosa, y conculcan en fin todo derecho divino y humano. Y mientras se mofan de la esperanza de los bienes celestiales, incitan a los hombres a conseguir, aún con medios ilícitos, una felicidad terrenal en todo y por todo mentirosa y los impulsan por lo mismo con

5 Véase Dilectissima nobis, Ciudad del Vaticano, 3 de junio de 1933.

6 Véase Divini Redemptoris, Ciudad del Vaticano, 19 de marzo de 1937, párrafo 18. 
audacia temeraria a la destrucción del orden social, suscitando desórdenes, sangrientas rebeliones y la misma conflagración de la guerra civil. ${ }^{7}$

La idea según la cual hay una alianza entre la masonería y los otros movimientos ideológicos y políticos anticatólicos tiene raíces antiguas. A este respecto, en el archivo de la Secretaría de Estado del Vaticano se encuentra - entre otros- un fascículo particularmente relevante, que contiene las respuestas a una consulta hecha por el papa León XIII a cuatro cardenales de la Curia romana, entre los últimos meses de 1883 y los primeros de $1884 .^{8}$ En vista de la publicación de la encíclica sobre la masonería Humanum genus (20 de abril de 1884), el papa sometió a sus cardenales a la siguiente pregunta: "Tomando en cuenta la áspera guerra movida por la secta anticristiana (masonería) a la Iglesia en todo el mundo, así como el dominio que ella supo obtener en los gobiernos de los Estados, ¿pueden los medios de defensa tradicionalmente adoptados por la S. Iglesia ser considerados suficientes todavía? O ¿hay necesidad de recurrir a otros medios extraordinarios?". ${ }^{9}$ Parece significativa la respuesta del cardenal Luigi Maria Bilio - quien en 1864 había sido uno de los autores del Syllabus de los principales errores de nuestro tiempo-, según el cual es necesaria "una nueva y solemne condena de la masonería por medio de una constitución apostólica", que debería explicar, entre otras cosas, la "estrechísima relación de la masonería con el internacionalismo, el socialismo y el nihilismo", ${ }^{10}$ condenados por León XIII, en la encíclica Quod apostolici muneris.

Desde el punto de vista de Bilio, era necesario un documento pontificio explícitamente dedicado al tema masónico. Conforme a sus sugerencias, la encíclica Humanum genus, después de haber enumerado los errores que a través de movimientos revolucionarios, querían difundir "muchas asociaciones comunistas y socialistas", afirma: "La masonería, que favorece en gran escala los intentos de estas asociaciones y coincide con ellas en los principios fundamentales de su doctrina, no puede proclamarse ajena a los propósitos de aquéllas". ${ }^{11}$ Precedentemente, la conexión entre el asunto masónico y el socialismo y el comunismo había sido señalada por Pío IX, en el transcurso de su pontificado; al respecto, cabe destacar el hecho de que el título IV del Syllabus fuera dedicado a "Socialismo, comunismo, sociedades secretas, sociedades

7 Véase Ingravescentibus malis, 29 de septiembre de 1937.

8 El asunto ha sido profundizado ampliamente en Miccoli, G., "Leone XIII e la massoneria”, Studi Storici, vol. 47, núm. 1, 2006, pp. 5-18.

9 S.RR.SS., AA.EE.SS., Stati Ecclesiastici, II periodo, pos. 1057, fasc. 340

10 Ibidem, f. 72r. Véase también Miccoli, G. op. cit., p. 12.

11 León XIII, Humanum genus, Roma, 20 de abril de 1884, párr. 18. Véase Miccoli, G. op. cit., pp. 19 y 20. 
bíblicas y sociedades clérico-liberales", ${ }^{12}$ y que la primera encíclica del papa Mastai-Ferretti, Qui pluribus (9 de noviembre de 1846), mencionara entre los "errores y engaños monstruosos, con los cuales los hijos de este siglo atacan a la Religión cristiana y a la autoridad divina de la Iglesia con sus leyes, y se esfuerzan en pisotear los derechos del poder sagrado y el civil":

1. "las sectas clandestinas salidas de las tinieblas para ruina y destrucción de la Iglesia y del Estado, condenadas por Nuestros antecesores, los Romanos Pontífices, con repetidos anatemas en sus letras apostólicas",

2. "las astutas Sociedades Bíblicas, que, renovando los modos viejos de los herejes, no cesan de adulterar el significado de los libros sagrados",

3. "el sistema perverso y opuesto a la luz natural de la razón que propugna la indiferencia en materia de religión”, y finalmente

4. "la nefanda doctrina del comunismo, contraria al derecho natural, que, una vez admitida, echa por tierra los derechos de todos, la propiedad, la misma sociedad humana". ${ }^{13}$

A la luz del enlace presente en el magisterio pontificio - en manera más o menos constante- entre la masonería y otras amenazas a la fe católica, como el comunismo y el proselitismo protestante, no sorprende que mucha información sobre la masonería mexicana en los archivos vaticanos (sobre todo en lo referente a las primeras décadas del siglo $\mathrm{XX}$ ) se encuentre en carpetas dedicadas al protestantismo en América Latina o en las encuestas promovidas por la Santa Sede, en la década de 1930, sobre la difusión del comunismo a nivel global. La ausencia de un dossier específicamente masónico en los archivos vaticanos se debe, probablemente, al hecho de que la masonería representa una amenaza más antigua respecto a la propagación del comunismo y al proselitismo de las sectas protestantes, las cuales afectan de manera progresiva al subcontinente latinoamericano al comienzo del siglo XX.

Mientras en estos casos se percibe la necesidad de comprender la naturaleza de fenómenos todavía poco conocidos, en sus contenidos y en sus formas expresivas, la masonería - al contrario- parece representar -sobre todo en el contexto mexicano- un hecho previsible, podríamos decir una parte esencial del panorama cultural, social y político. Sin embargo, no faltan zonas de sombra en la representación católica y pontificia de la masonería,

12 Pío IX, Syllabus complectens praecipuos nostrae aetatis errores; véase Quanta cura, Roma, 8 de diciembre de 1864, párrafo 4.

13 Pio IX, Qui pluribus, Roma, 9 de noviembre de 1846. 
como demuestran, por ejemplo, las afirmaciones citadas del delegado Ruiz y Flores acerca de la presencia de judíos detrás de la masonería mexicana. De todos modos, el papa Pío XI parece muy resuelto cuando afirma, frente a Mussolini, que México es un país "totalmente enfeudado a la masonería". ${ }^{14}$

Por eso, resulta interesante examinar las bases factuales a partir de las que la Santa Sede formula sus propios juicios sobre la masonería en el contexto mexicano. Al respecto, es lícito suponer que las afirmaciones del "centro" pontificio (por ejemplo, las encíclicas o las directivas enviadas periódicamente a la delegación apostólica) tengan mucho que ver con la información proveniente de la "periferia", como sugiere el famoso proverbio, según el cual "De Roma viene lo que a Roma va". El proceso informativo que alimenta las evaluaciones de la Santa Sede y funda el actuar de la misma envuelve como actores principales al episcopado mexicano y a la red diplomática pontificia, cuya actividad produce en el tiempo una amplísima documentación. Esta documentación, guardada en los archivos de la Santa Sede (actualmente abiertos hasta el fin del pontificado de Pío XI, es decir, 10 de febrero de 1939), representa una referencia obligada para iluminar la mirada vaticana sobre la masonería. Además de las fuentes de archivo y de los documentos oficiales de la Santa Sede, hay otras fuentes que pueden ofrecer elementos útiles a una profundización del tema. Se trata de periódicos como el cotidiano L'Osservatore Romano y la revista de los jesuitas La Civiltà Cattolica, cuyos artículos, si bien no hablan oficialmente en nombre de la Santa Sede, sí presentan opiniones conformes a la visión pontificia, aunque no sin excepciones. ${ }^{15}$ Cabe señalar que, con frecuencia, estas revistas - particularmente $L a$ Civiltà Cattolica- contienen los juicios más críticos e, incluso, desafiantes respecto a la presencia de la masonería en el contexto mexicano.

\section{LA SANTA SEDE Y LA MASONERÍA EN MÉXICO} DE LA REFORMA AL PORFIRIATO

Durante la segunda mitad del siglo XIX, la información relativa a la masonería mexicana que llegaba a Roma parece esporádica y no sistemática. En gran parte se trata de noticias genéricas y de testimonios de obispos sobre casos donde la relación de la Iglesia con la masonería fue particularmente conflictiva. Por ejem-

14 Lo que, sin embargo, parece confirmado por un análisis cuantitativo de la penetración de la masonería en todos los niveles del poder en México (gobierno federal/gobiernos estatales) entre las dècadas de 1920 y 1930. Véase al respecto el ensayo de Carlos Francisco Martínez Moreno en este volumen.

15 Véase, por ejemplo, el juicio más radical del periódico jesuita sobre la licitud de la "defensa armada" del pueblo mexicano la década de 1930. Al respecto, véase "Messico. Nostra Corrispondenza", La Civiltà Cattolica, vol. I, 1935, p. 445. 
plo, en un apunte de la Secretaría de Estado vaticana, fechado el 20 de septiembre de 1866, en el que se refieren noticias "sobre los asuntos religiosos de México, durante las negociaciones para la conclusión de un Concordato" con el gobierno imperial de Maximiliano de Habsburgo, el que escribe señala: "la propaganda protestante y la masonería están haciendo todos sus esfuerzos, valiéndose de mil medios para acrecentar el número de sus secuaces, y no temen de hecho a los católicos, pues existe la tolerancia y protección de que gozan". ${ }^{16}$ Unos años después, el arzobispo de México, monseñor Pelagio Antonio Labastida y Dávalos, informaba a la Santa Sede sobre la orden de expulsión emitida por el Gobierno contra monjas y sacerdotes de varias congregaciones, el 23 de mayo de 1873. Al respecto, el arzobispo, después de haber sido recibido por el presidente Lerdo de Tejada, afirmaba: "hay quienes creían que lo sucedido se debe a los masones, aunque esto lo niega el presidente, que no lo es, y otros aseguran que le ha movido el deseo de acreditarse de liberal para ganar las próximas elecciones de diputados". ${ }^{17}$

No faltan cartas enviadas directamente al papa, como la del obispo de León, José María de Jesús Diez de Sollano, que en 1875 denunciaba el silencio guardado por la mayoría de sus hermanos obispos frente a las Leyes de Reforma, y enfatizaba el hecho de que contra él se haya desencadenado el odio del Gobierno, así como de los protestantes, de los masones y de la prensa anticatólica. ${ }^{18}$ En otra carta, fechada el 30 de mayo de 1875, el obispo de Tamaulipas, Ignacio Montes de Oca, pedía al secretario de la Congregación para los Asuntos Eclesiásticos Extraordinarios, monseñor Marino Marini, que la Santa Sede le enviara instrucciones sobre los masones que querían ser padrinos de bautismo y de confirmación. En su carta, el obispo lamentaba la "guerra" movida contra él por los masones, así como los intentos de envenenamiento padecidos; pedía, además, que el pontífice le mandara una carta de estímulo, que pudiera ayudar a todos los obispos a mantener "una conducta uniforme y enérgica" frente a la masonería. ${ }^{19}$ De hecho, el lo de julio de aquel mismo año, Pío IX le contesta a Montes de Oca, por medio de una carta en la que el papa da muestra de aprobar incondicionadamente el actuar del obispo. Como precedente, el obispo también es autor de una carta pastoral que, entre otras cosas, señala la socarronería con la que los adeptos de la

16 El documento se encuentra publicado en Ramos, Luis (coord.), Del Archivo Secreto Vaticano. La Iglesia y el Estado mexicano en el siglo XIX, México, UNAM-Secretaria de Relaciones Exteriores, 1997, pp. 372-375.

17 S.RR.SS., AA.EE.SS., Messico, I periodo, pos. 221, fasc. 660, ff. 36r-37r, carta de monseñor Pelagio Antonio Labastida y Dávalos a la Congregación para los Asuntos Eclesiásticos Extraordinarios, 29 de mayo de 1873. El documento se encuentra también en Ramos, Luis (coord.), op. cit., p. 498.

18 S.RR.SS., AA.EE.SS., Messico, I periodo, pos. 233, fasc. 661, ff. 57r-58v, carta de monseñor José María de Jesús Díez de Sollano a Pío IX.

19 S.RR.SS., AA.EE.SS., Messico, I periodo, pos. 237, fasc. 661, f. 87r/v, carta de monseñor Ignacio Montes de Oca a monseñor Marino Marini, 30 de mayo de 1875. 
masonería intentaban convencer a la gente de que la naturaleza de la masonería en América no era anticatólica, ni tampoco hostil a la autoridad, lo que permitía a los masones ganar muchas adhesiones. ${ }^{20}$ Este aspecto -es decir la disimulación de los reales objetivos de la masonería- es muy acentuado por Pío IX en su respuesta a Montes de Oca. Más en general, se trata de uno de los temas centrales de la reflexión de la Santa Sede sobre la masonería, no sólo en México sino en todo el contexto latinoamericano, del siglo XIX hasta finales del XX..$^{21}$

Otras noticias, en aquel mismo periodo, proceden del vicariato apostólico de la Baja California, cuyo obispo, monseñor Ramón María de San José Moreno y Castañeda, en 1877, estaba en Roma "por hallarse exiliado bárbaramente por el gobierno mexicano". En el Vaticano, el prelado sometía a la atención de la Congregación para los AA.EE.SS. una carta pastoral dirigida a sus diocesanos, en la que -según relata un apunte de la misma Congregación- "hace una larga historia sobre la guerra implacable, que desde su llegada a la diócesis le ha hecho la masonería, a la que de su parte ha hecho todo lo posible por desenmascarar y combatir". ${ }^{22}$ En una aclaración del estado de su diócesis, el mismo obispo hace algunas peticiones concretas a Pío IX; ${ }^{23}$ en particular, "expone que en la Baja California los masones tienen establecidas muchas escuelas tanto para

20 Ibidem, ff. 97r-98v, carta de Pío IX a monseñor Montes de Oca, 1o. de julio de 1875.

21 Cabe mencionar al respecto las actas del Concilio Plenario latinoamericano celebrado en Roma en 1899, donde el argumento es tratado difusamente en el capítulo séptimo del título segundo ("De secta Massonica aliisque sodalitatibus illicitis"). Véase, por ejemplo, el párrafo 168: "Et quoniam plurimis in regionibus nostris impiorum machinationes et fallaciae eo tendunt, ut saluberrima contra pestem societatum clandestinarum decreta et mandata Apostolica inania faciant, sub ementito praetextu, a Pio IX et Leone XIII pluries damnato, scilicet non eamdem ese naturam sectae Massonicae in ómnibus nationibus, sed eam quae alibi periculosa est ac omnino proscribenda, alicubi innocuam esse ac honestam, quia, aiunt, diversa sunt dogmata, fines, actiones; sedulo curent animarum pastores, ut tam perniciosus error, tam audax praetensio, a patre mendacii excogitata, ut incautos decipiat, penitus eliminetur". Acta et decreta Concilii Plenarii Americae Latinae in Urbe celebrati anno Domini MDCCCXCIX, Roma, Typis Vaticanis, 1902, pp. 83-84.

22 Ramos, Luis (coord.), op. cit., p. 514.

23 "Que no pudiéndose por la Ley del Sínodo 3o. mexicano unir en matrimonio, según el rito de la Iglesia, aquellos esposos que no se hayan acercado primero al Sacramento de la Penitencia, sucede que los masones que son públicos y notorios, y no se confiesan por temor a verse obligados a abjurar de la secta, no son admitidos a celebrar el matrimonio religioso, de donde se sigue o el concubinato o a veces se van a la frontera con los Estados Unidos y ahí los obispos, contando como dicen con una especial facultad de la Propaganda, los unen religiosamente en matrimonio. Para evitar este mal el vicario apostólico cree que el matrimonio de masones podría celebrarse con la sola asistencia del Párroco y que después fuesen unidos en matrimonio en San Francisco. [...] El vicario apostólico pide en estancia separada las mismas facultades que la Sagrada Congregación de Propaganda suele conceder a los obispos de los Estados Unidos”. Ibidem, p. 515. Véase al respecto Enríquez Licón, Dora Elvia, "La Iglesia Católica en Baja California. Péndulo entre misión y diócesis", Frontera Norte, vol. 20, núm. 39, 2008.

DR @ 2018. 
muchachos como para muchachas, y que él no tiene medios para contraponer alguna escuela católica". 24

A finales del siglo XIX, la celebración en Roma del Primer Concilio Plenario Latinoamericano ofrecía a los obispos mexicanos -quienes, a pesar de las contrariedades iniciales hacia el proyecto de un concilio continental, representaban el grupo nacional más numeroso entre los 53 obispos participantes-25 la oportunidad de tomar una postura unitaria sobre la masonería, percibida como una de las principales amenazas al catolicismo en el país. ${ }^{26}$ Fundadas en los documentos pontificios y en las relaciones de los obispos enviadas a la Santa Sede, las decisiones del Concilio reiteraban la incompatibilidad entre la fe católica y la pertenencia a la masonería, así como la imposibilidad para los masones de acceder a los sacramentos. ${ }^{27}$ Unos años después, llamada la Santa Sede a informar acerca de la aplicación de la encíclica antimodernista Pascendi, los obispos mexicanos y latinoamericanos seguirán señalando en sus informes el influjo negativo ejercido por la masonería en la sociedad y en la cultura nacional. ${ }^{28}$

\section{De la Revolución A LA GUERRA GRISTERA}

Desde el punto de vista de la jerarquía católica y de la Santa Sede, la Revolución representa el coronamiento de las luchas anticlericales de todo un siglo, las cuales se concretan particularmente en la constitución de Querétaro de 1917. Después de las décadas de la pax porfiriana, el estallido del conflicto entre el Estado y la Iglesia llevó consigo un renovado interés en la masonería, a la cual los obispos mexicanos y los delegados apostólicos generalmente atribuyen la responsabilidad principal de la persecución anticatólica. Como

24 Ramos, Luis (coord.), op. cit., p. 515.

25 Cannelli, Riccardo, Nazione cattolica e Stato laico. Il conflitto politico-religioso in Messico dall'indipendenza alla rivoluzione (1821-1914), Milán, Guerini, 2002, pp. 106-109. Para un panorama sobre el Concilio Plenario Latinoamericano, véase en particular Pazos, Anton M. y Piccardo, Diego R., El Concilio Plenario de América Latina (Roma 1899), Madrid, Iberoamericana-Vervuert, 2002 .

26 Véase, al respecto, Piccardo, Diego R., "Historia del Concilio Plenario Latinoamericano (Roma, 1899). Extracto de la Tesis Doctoral presentada en la Facultad de Teología de la Universidad de Navarra", Cuadernos Doctorales de la Facultad de Teología, vol. LIX, núm. 6, 2012, pp. 458-460.

27 Acta et decreta Concilii Plenarii Americae Latinae, op. cit., párr. 166-178, pp. 82-88.

28 Véase, al respecto, Russo, Maurizio, "De modernismi vestigiis in America Latina", en Claus, Arnold y Vian, Giovanni (coord.), The Reception and Application of the Encyclical Pascendi, Venecia, Edizioni Ca’ Foscari, 2017, pp. 209-230. 
consecuencia, a partir de la década de 1910, las noticias sobre la masonería que llegaban al Vaticano crecieron de manera exponencial en cantidad, aunque no siempre en calidad.

El papel desempeñado por los masones durante la breve presidencia de Francisco Madero es enfatizado por el delegado apostólico Boggiani, quien, el 9 de julio de 1912, describiría a Madero como "un hombre de corazón", no hostil hacia la institución eclesiástica, sin embargo, "rodeado por masones y jacobinos muy enemigos de la Iglesia". ${ }^{29} \mathrm{Al}$ día siguiente, al comentar el resultado de las elecciones políticas, Boggiani enfatizaba la irritación de los masones por el éxito del Partido Católico Nacional, así como la influencia de los mismos sobre Madero, quien, debido a las presiones masónicas, asumió una postura muy polémica hacia el Partido Católico. ${ }^{30}$ En septiembre, Boggiani hablaba de la "feroz oposición" de la masonería contra el arzobispo de Durango, quien había invitado a sus fieles a tomar parte en el movimiento social católico. ${ }^{31}$ Asimismo, el 16 de diciembre, después de haber sido recibido por el secretario de Gobernación, Rafael Hernández, con el objetivo de ganar el apoyo de la Iglesia para la conciliación y la paz, el delegado escribía una carta al secretario de Estado vaticano, en la cual criticaba el hecho de que el mismo Hernández se hubiera puesto en contacto con las logias masónicas y los ministros de culto protestante; por ello señalaba que, según la opinión de todos, "los grandes males que afectan a la república se deben atribuir a la masonería". ${ }^{32}$ El 12 de marzo de 1913, después del golpe antimaderista, Boggiani volvía a hablar de la masonería, afirmando que el general Victoriano Huerta no era masón, mientras sí lo era Félix Díaz, candidato a las elecciones presidenciales. ${ }^{33}$ A finales de enero de 1914, la Secretaría de Estado le ordenaba a Boggiani regresar a Roma, así que la delegación apostólica quedaba cerrada. ${ }^{34}$ Sin embargo, las informaciones sobre la masonería en México

29 Archivio Segreto Vaticano, en adelante: ASV, Arch. Deleg. Messico, busta 27, fasc. 90, f. 44r, carta de monseñor Tommaso Pio Boggiani al cardenal Rafael Merry del Val, 9 de julio de 1912.

30 Ibidem, f. 45r, carta de monseñor Boggiani al cardenal Merry del Val, 10 de julio de 1912.

31 Ibidem, f. 54v, carta de monseñor Boggiani al cardenal Merry del Val, 1o. de septiembre de 1912.

32 Ibidem, f. 73r, carta de monseñor Boggiani al cardenal Merry del Val, 16 de diciembre de 1912.

33 Ibidem, f. 89r, carta de monseñor Boggiani al cardenal Merry del Val, 12 de marzo de 1913. Véase, al respecto, Valvo, Paolo, Pio XI e la Cristiada. Fede, guerra e diplomazia in Messico (19261929), Brescia, Morcelliana, 2016, p. 68.

34 Véase al respecto Valvo, Paolo, Pio XI e la Cristiada. Fede, guerra e diplomazia in Messico (1926-1929), Brescia, Morcelliana, 2016, p. 68 . 
seguían llegando al Vaticano por medio de otros canales, como la delegación apostólica en Estados Unidos.

De igual manera, el 5 de octubre de 1914, al relatar al secretario de Estado, cardenal Domenico Ferrata, la persecución religiosa en México, y la postura de Estados Unidos al respecto, el delegado apostólico en Washington, Giovanni Bonzano, afirmaba que la política del presidente Wilson en los asuntos mexicanos -es decir, no haber reconocido a Victoriano Huerta y apoyar a Venustiano Carranza y a Francisco Villa - era "un misterio", cuya "sola posible explicación es [...] que las influencias ocultas masónico-protestantes, con el favor del gobierno americano, se han unido para destruir el catolicismo, lo que es el único medio eficaz para garantizar el control absoluto de los Estados Unidos sobre México". ${ }^{35}$ Las afirmaciones de Bonzano se fundaban en un memorándum (The Freemasons and Protestants of the United States, and the Mexican Revolt), escrito por el jesuita Carlos M. Heredia, -radicado en Estados Unidos debido a la persecución-; según este memorándum: "el apoyo brindado por la masonería estadounidense de rito escocés a las revoluciones, es un hecho comprobado por la historia mexicana desde la independencia del país", y los centros masónicos junto con los protestantes seguían ejerciendo una influencia decisiva en México bajo el perfil político, económico y religioso. ${ }^{36}$

La triangulación entre persecución religiosa, masonería y Estados Unidos es un tema muy común en los relatos de aquellos años, como demuestra, por ejemplo, el largo memorial sobre la situación de la Iglesia mexicana que el arzobispo de Guadalajara, Francisco Orozco y Jiménez, entregó al papa Benedicto XV, en nombre de todos los obispos, el lo. de enero de 1916, durante su estancia en la Ciudad Eterna. En el documento, la masonería mexicana es descrita como fiduciaria del gobierno estadounidense desde la época en la que el primer ministro estadounidense en México Joel Roberts Poinsett estableció en el país las primeras logias de rito yorkino. ${ }^{37}$ Según Orozco, Estados Unidos era responsable también de la difusión de las sectas protestantes en toda América Latina. Con ocasión del memorial, el arzobispo de Guadalajara desmentía las acusaciones de los revolucionarios contra la Iglesia católica -particularmente contra el arzobispo de México José Mora y del Rio-, juzgada como culpable de haber apoyado el golpe del general Victoriano Huerta contra el presidente legítimo Francisco I. Madero. ${ }^{38}$

35 ASV, Segr. Stato, año 1915, rubr. 251, fasc. 7, f. 45r/v, carta de monseñor Giovanni Bonzano al cardenal Domenico Ferrata, 5 de octubre de 1914.

36 Heredia, S.J., Carlos M., The Freemasons and Protestants of the United States, and the Mexican Revolt, ibidem, ff. 65r-68r.

37 S.RR.SS., AA.EE.SS., Messico, pos. 755, fasc. 130, ff. $61 \mathrm{r}$ y ss., memorial de monseñor Francisco Orozco y Jiménez para Benedicto XV, 1 de enero de 1916.

38 Ibidem, f. 46r. 
Orozco calificaba como "absurdas" estas acusaciones y señalaba que la lucha anticlerical de la masonería había comenzado en 1911, inmediatamente después de la caída de Porfirio Diaz. ${ }^{39}$ Muy diferente era la opinión del delegado apostólico en México, Tommaso Pio Boggiani, quien, repetidamente, confirmaba ante la Curia romana el fundamento de los cargos contra el arzobispo de México, protagonista de una dura confrontación con el mismo delegado, desde mediados de 1913 hasta el regreso de este último a Roma, a finales de enero de 1914. En una carta al secretario de la Congregación Consistorial, el cardenal Gaetano De Lai, del 10 de diciembre de 1914, Boggiani afirmaba: "Los Estados Unidos y el dinero de los protestantes tienen por supuesto que ver con la persecución religiosa sufrida en México por los liberales y masones. Los persecutores mexicanos, sin embargo, encontraron en la perniciosa política de monseñor Mora un pretexto muy fuerte para legitimar su violencia hacia el clero y la Iglesia". ${ }^{40}$

El convencimiento de que la masonería transnacional estadounidensemexicana estaba detrás de toda manifestación de anticlericalismo en México parece acompañar también la breve experiencia del primer sucesor de Boggiani en el cargo de delegado apostólico, monseñor Ernesto Filippi. Este último manifiestaba una actitud extremadamente favorable hacia el presidente de la República Álvaro Obregón; de hecho, en sus informes de 1922 para la Secretaría de Estado, llegó a presentar como muy probable la reanudación de las relaciones diplomáticas entre México y la Santa Sede. ${ }^{41}$ Sin embargo, como escribiría Filippi al secretario de Estado, cardenal Pietro Gasparri, el 14 de diciembre de 1922:

[...] hay que tomar en cuenta el trabajo desempeñado por las sectas y sobre todo por la masonería norteamericana, que desde hace algún tiempo se preocupa por la tranquilidad que goza actualmente la Iglesia en México. No soy [sigue explicando el delegado] un fetichista [textual] ni tampoco miedoso de la supuesta superpotencia masónica, pero pienso que hay que tomar en cuenta el poder económico de las logias newyorkinas [sic] que aquí en México gastan sin freno. No quiero faltar de respeto a esta nación, afirmando que en esta se puede hacer mucho comprando conciencias, porque desafortunadamente este deplorable comercio se ha desarrollado mu-

39 Ibidem, f. $59 \mathrm{r}$

40 ASV, Segr. Stato, año 1915, rubr. 251, fasc. 7, f. 95r, carta de monseñor Tommaso Pio Boggiani al cardenal Gaetano de Lai, 10 de diciembre de 1914.

41 Véase Valvo, Paolo, op. cit., pp. 109-122 y Alejos, Carmen José, "Pío xi y Álvaro Obregón. Relaciones a través de la Delegación Apostólica en México (1921-1923)”, Anuario de Historia de la Iglesia, vol. 23, 2014, pp. 403-431. 
cho en la vida pública, debido a las sectas que no pueden luchar con medios honestos. ${ }^{42}$

Unas semanas después, luego de ser expulsado del país por su participación en la ceremonia religiosa en el Cerro del Cubilete, con ocasión de la colocación de la primera piedra del monumento a Cristo Rey (11 de enero de 1923), monseñor Filippi no disimulaba su desilusión por lo que le parecía una verdadera traición de su antiguo amigo Obregón. De todas maneras, la "decisión sectaria" tomada por el presidente se debía necesariamente -según Filippi- a una "imposición sufrida por parte de la masonería". 43

En el transcurso de la estancia de Filippi en el país, la postura de la Santa Sede hacia las sociedades secretas puede ser apreciada también gracias a los juicios que el Vaticano expresaba con respecto a una asociación católica fundada en 1915, por el futuro obispo auxiliar de Morelia, y luego arzobispo de México, Luis María Martínez y Rodríguez. ${ }^{44}$ Se trata de la Unión de Católicos Mexicanos, mejor conocida como la "U", cuya secrecía despertaba temores muy grandes entre los cardenales de la Congregación para los Asuntos Eclesiásticos Extraordinarios, la cual se reunía el 2 de julio de 1922 para debatir el tema. Sí, por una parte, los cardenales admitían, desde el punto de vista teórico, la licitud de una asociación que no es secreta para los obispos, sino únicamente para las autoridades civiles, por otra, coincidían en prohibir a los obispos involucrarse de cualquier modo en una asociación secreta que perseguía fines políticos, y a cuyos miembros les gustaba llamarla "nuestra masonería". 45

En el verano de 1923 tenía lugar el primer intento de la Santa Sede -y quizás el único, a la luz de la documentación actualmente disponible-- de fotografiar la consistencia y la difusión de la masonería en el territorio mexicano. La oportunidad de hacerlo se presentaba gracias a la encuesta sobre

42 S.RR.SS., AA.EE.SS., Messico, pos. 479 (P.O.), fasc. 1, ff. 28v-29r, carta de monseñor Ernesto Filippi al cardenal Pietro Gasparri, 14 de diciembre de 1922.

43 S.RR.SS., AA.EE.SS., Messico, pos. 486 (P.O.), fasc. 6, f. 41 r, carta de monseñor Ernesto Filippi al cardenal Pietro Gasparri, 25 de enero de 1923.

44 Sobre el tema, véanse González, Fernando M., Matar y morir por Cristo Rey. Aspectos de la Cristiada, México, UNAM, Instituto de Investigaciones Sociales, 2001, pp. 31-39; Solís, Yves, "El origen de la ultraderecha en México: la U", El Cotidiano, México, núm. 149, 2008, pp. 25-38; Andes, Stephen J.C., The Vatican and Catholic Activism in Mexico and Chile. The Politics of Transnational Catholicism, 1920-1940, Ofxord, Ofxord University Press, 2014, pp. 53-60 y Valvo, Paolo, op. cit., pp. 113-116.

45 El cuestionario, enviado por el secretario de la Delegación apostólica, monseñor Tito Crespi, a todos los obispos con fecha del 8 de agosto de 1923, se encuentra junto con las contestaciones de los mismos en ASV, Arch. Deleg. Messico, busta 45, fasc. 205. 
la difusión del protestantismo en toda América Latina, que la Secretaría de Estado lanzaba mediante las nunciaturas y las delegaciones apostólicas en el subcontinente. De hecho, el primer punto del cuestionario sometido a la atención de cada obispo consistía en peguntar "cuáles sectas no católicas y sociedades teosóficas y espiritistas existen en esa diócesis: cuánto tiempo hace que penetraron en ella y de qué manera: cuántos son los templos, las capillas, los ministros de las mismas: cuál es el número y calidad de sus adherentes: si estos han aumentado o disminuido: si son practicantes o simplemente inscritos en la secta por conveniencias personales o ventajas económicas". ${ }^{46}$

En conjunto la información aportada por los obispos mexicanos sobre la masonería parece inorgánica y tal vez imprecisa. No se hacía mención de la presencia de logias masónicas en las diócesis de Cuernavaca, Querétaro, Chihuahua, Aguascalientes, Huajuapan de León, Zamora, Sonora, Sinaloa, Chiapas, Tacámbaro, San Luis Potosí, Huejutla y Saltillo. Además, la presencia masónica no parece muy significativa en Oaxaca, ${ }^{47}$ Tehuantepec, ${ }^{48}$ Baja California, ${ }^{49}$ Tulancingo, ${ }^{50}$ Durango y Colima. ${ }^{51}$ En cambio, en otras diócesis

46 Aquí, según el obispo José Othón Núñez, sólo hay treinta masones en la ciudad arzobispal. Ibidem, ff. 24r-25v.

47 "Con excepción de los empleados oficiales, el número de adherentes a la masonería es casi nulo y prácticamente los pocos inscritos a ella no les estimula más que sus conveniencias personales". Ibidem, ff. 32r-33r.

48 Donde a pesar de ser presente en muchos lugares la masonería "de este lugar tiene actualmente 18 miembros, que han disminuido notablemente de 1920 a esta parte, pues no cuentan con el apoyo oficial local, con que antes contaban. En las demás poblaciones no pasan de tres a cuatro los miembros en cada lugar, excepción de San José del Cabo que tiene ocho. Únicamente los de alta graduación son practicantes, la mayor parte (únicamente) están inscritos y únicamente por conveniencias personales y no por convicción”. Ibidem, f. 41 r.

49 "En la ciudad episcopal hay una logia masónica casi desorganizada. En la ciudad de Pachuca hay logia masónica y sociedad teosófica, establecida recientemente y con pocos adherentes". Ibidem, ff. 44r-45r.

50 "Los masones como aún no se dan a conocer, porque están apenas organizándose, no se puede saber cuántos ni de que significación o valor serán”. Ibidem, f. 75r/v.

51 "La masonería entró en esta región desde el año de mil ochocientos cinco, para fomentar la rebelión en contra de España y para atacar al catolicismo. Están divididos en la actualidad en cinco logias y tiene cinco templos. Debido a que el Gobierno actual exige ordinariamente, para conceder un empleo, que el solicitante se afilie a la masonería, va en aumento el número de empleados masones desde hace once años, adhiriéndose muchos de estos a la referida secta tan solo por conveniencia. Esta sección consta de mil trescientos once masones y está formada por muchos de los profesores de las escuelas oficiales, los ferrocarrileros que dependen del Gobierno civil y la mayor parte de sus empleados. Hay otra sección que está formada de los que se afiliaron a la masonería sin ser obligados por el Gobierno civil, siendo su número de doscientos veintitrés y en ella hay profesionistas, comerciantes y agricultores acaudalados que se encuentran muy distanciados de la Iglesia, aunque muchos de estos continúan llamándose católicos. En las clases media e ínfima son masones únicamente cuando sirven al Gobierno. Los centros masónicos tienden con tenacidad a 
el fenómeno alcanzaba dimensiones más relevantes. Véase, por ejemplo, Veracruz, donde el obispo Rafael Guízar y Valencia ofrecía una representación bastante detallada del fenómeno. ${ }^{52}$

La tendencia de la masonería a reclutar a sus adherentes en sectores profesionales definidos (empleados públicos, ferrocarrileros, profesores, militares) es evidenciada en las relaciones de los obispos de Puebla, Colima, Tehuantepec y Tepic, mientras que, en la diócesis de Yucatán, la pertenencia "a la masonería y al socialismo es casi condición indispensable para conseguir empleos del gobierno o favores oficiales". ${ }^{53}$ En Monterrey, la masonería debe su difusión a la obra de Bernardo Reyes, quien, según monseñor Herrera y Piña, fundó 48 logias en el transcurso de su jefatura del Estado de Nuevo León. ${ }^{54}$ En Papantla, "en la ciudad de Tuxpam hay la Logia masónica del rito Escocés con más de cien adherentes". ${ }^{55}$ Respecto a los diferentes ritos masónicos, los informes obispales no ofrecen información detallada, con excepción del caso de Puebla, en el que se sostiene que "la masonería -introducida en México a raíz de la Independencia- hizo su aparición oficial en Puebla poco antes de 1857, estableciendo logias bajo los ritos escocés y yorkino: después se puso de moda el masonismo de rito mexicano cuya propaganda recibió gran impulso de los prohombres de la revolución, reclutando sus adeptos principalmente de entre los empleados del gobierno". ${ }^{56}$

La creciente tensión entre la Iglesia católica y las autoridades civiles, la cual alcanzó su ápice bajo la presidencia de Plutarco Elías Calles (1924-1928), favoreció una narrativa menos profundizada y más superficial del fenómeno masónico, cuya conexión con el judaísmo y el bolchevismo parece indudable para la mayoría de los observadores eclesiásticos, en México y en el Vaticano. Es lo que ocurre, por ejemplo, con el exdelegado apostólico (luego cardenal) Boggiani, quien, en mayo de 1925, unos meses después del llamado cisma de La Soledad, escribía al cardenal Gasparri para compartir información recibida de una fuente mexicana no especificada. De acuerdo con esta información,

hostilizar a la Iglesia Católica, y se aprovechan de las tendencias sectarias de nuestro Gobierno civil, para llevar a cabo sus negros fines y conquistar más adeptos. Generalmente sus ataques contra la Iglesia se hacen en forma oculta pero decisiva". Ibidem, ff. 2r-3v.

52 Ibidem, ff. 49r-53r.

53 Ibidem, f. $59 \mathrm{v}$.

54 Ibidem, f. 88r/v.

55 Ibidem, ff. 114r-117r. Respecto al rito nacional mexicano, véanse el texto Constitución y estatutos generales del R[ito] Mas[ónico] $\mathcal{N}$ [acional] Mex[icano], N. Chavez, México, 1868, recién republicado por Carlos Francisco Martínez Moreno y José Luis Soberanes Fernández.

56 S.RR.SS., AA.EE.SS., Messico, pos. 499 (P.O.), fasc. 21, ff. 22r-23v, carta del cardenal Boggiani al cardenal Gasparri, 12 de mayo de 1925. 
Calles, antes de tomar posesión del cargo presidencial, había viajado a Europa para platicar con los soviéticos y organizar una amplia migración de bolcheviques y judíos a México, lo que era "naturalmente favorecido por la masonería y los protestantes yanqui". ${ }^{57}$ La teoría de la conspiración judaico-masónica - que en estos años es todavía un elemento fundamental del horizonte ideológico y cultural del catolicismo- representa el fondo de muchos juicios. Véanse, por ejemplo, las palabras de La Civiltà Cattolica, que el 23 de abril de 1926, con ocasión de la publicación de la letra pontificia Paterna sane, afirmaba que los perseguidores de la Iglesia eran quienes habrían invitado a México a "la escoria de extranjeros, judíos, masones, protestantes para ayudarlos". ${ }^{58}$

La idea según la cual las ideologías sociales y las creencias religiosas diferentes de la católica compartían una estrategia común para hostilizar a la Iglesia parece muy arraigada en hombres como el director del periódico jesuita, el padre Enrico Rosa, quien, en carta al cardenal Gasparri, enfatizaba la escasa formación del clero latinoamericano, lo cual no le permitía afrontar "las luchas acuciantes de la masonería, del protestantismo, del comunismo y de otras similares corrientes de apostasía religiosa y de anarquía social conjuradas". ${ }^{59}$

Cabe señalar, que esta visión encuentra una prueba confirmatoria - aunque parcial- en afirmaciones como las del protestante estadounidense Robert A. Greenfield, publicadas en el Osservatore Romano en su primera plana, el 26 de junio de 1928:

Como México es un país en el que domina el catolicismo, es natural que la agresión más fuerte del gobierno sea precisamente contra esta religión. Los radicales mexicanos se dieron cuenta muy pronto de que algunos elementos del protestantismo y de la masonería de los Estados Unidos simpatizaban con la idea de destruir el catolicismo y, creyendo que con esta táctica se ganarían el apoyo norteamericano para realizar todo su programa revolucionario, los políticos mexicanos se pusieron de acuerdo con las instituciones anticatólicas más potentes. Es cierto, sin embargo, que en la lucha de exterminio contra el catolicismo estamos forzosamente de acuerdo masones y protestantes, y que le hemos prestado en este terreno un apoyo leal y suficientemente amplio al régimen de Calles.

57 "La parola del Papa e la persecuzione religiosa del Messico", La Civiltà Cattolica, vol. II, 1926, p. 206.

58 S.RR.SS., AA.EE.SS., Messico, pos. 502 (P.O.), fasc. 23, f. 46r, carta del padre Enrico Rosa al cardenal Gasparri, 12 de diciembre de 1925.

59 El texto se encuentra reproducido y acompañado por un comentario en González Morfin, Juan, 1926-1929 Revolución silenciada. El conflicto religioso en México a través de las páginas de L'Osservatore Romano, México, Porrúa-Universidad Panamericana, 2014, p. 125. 
El artículo de Greenfield, publicado originalmente por la agrupación masónica y protestante Internacional Civic Organization, puntualizaba: "con excepción de algunos dirigentes de sectas protestantes y de algunos eminentes masones, todos reprobamos la forma bárbara con la que el gobierno del general Plutarco Elías Calles ha combatido los fieles de la religión católica". ${ }^{60}$ La convicción de que había una alianza tácita, de naturaleza transnacional, en contra de la Iglesia mexicana, se refleja en la denuncia de la llamada conspiración del silencio, que - según la Santa Sede- afectaba la narración periodística de los asuntos religiosos de México, y que se convirtió en una nota dominante de la postura del Vaticano en los años de la guerra Cristera. La Civiltà Cattolica, a finales de 1926, al comentar la encíclica de Pio XI Iniquis afflictisque, sobre la persecución de la Iglesia en México, definía esta conspiración "universalmente aprestada y ordenada" como "parte de la campaña persecutoria -verdadera conspiración contra la verdad- apoyada por los masones, por los liberales -viejos y nuevos- y por los socialistas". ${ }^{61}$ Se trata de una visión compartida también por miembros de la diplomacia pontificia, como atestiguan, por ejemplo, las palabras del nuncio apostólico en Argentina, monseñor Filippo Cortesi, quien, en una carta al cardenal Gasparri, lamentaba: "la prensa liberal y masónica persevera en la que ha sido justamente llamada la 'conspiración del silencio' sobre los hechos criminales de México". ${ }^{62}$ Curiosamente, cuando el obispo de Chiapas, monseñor Gerardo Anaya, propuso a la Santa Sede, en junio de 1927, someter la situación religiosa de México a la atención del Consejo Central de la Cruz Roja en Ginebra, para intentar abrir una brecha en ese muro de silencio, la Secretaría de Estado rechazó la propuesta porque -según se lee en los documentos vaticanos- la Cruz Roja es masónica. ${ }^{63}$

\section{LA DÉCADA DE 1930}

La identificación -o más bien la superposición- de masonería y bolchevismo se volvió más fuerte durante la segunda mitad del pontificado de Pío XI, con una precedencia del bolchevismo respecto a la masonería como enemigo número uno de la Iglesia universal. La relación entre los dos fenómenos parece invertirse en la visión vaticana: de hecho, ya no se trataba del comunismo al servicio de la masonería, sino de la Internacional Comunista, la cual, desde su sede central

\footnotetext{
60 "Il martirio della Chiesa nel Messico", La Civiltà Cattolica, vol. VI, 1926, pp. 407 y 408.

61 ASV, Arch. Nunz. Argentina, busta 113, fasc. 565, f. 31 r, carta de monseñor Filippo Cortesi al cardenal Gasparri, 16 de abril de 1928.

62 Véase Valvo, Paolo, op. cit., p. 269.

63 S.RR.SS., AA.EE.SS., Stati Ecclesiastici, pos. 474 (P.O.), fasc. 475, ff. 25r-26r.
} 
en Moscú, actuaba en países como México y España, gozando del apoyo -más o menos transitorio- de los viejos enemigos de la Iglesia, es decir, liberalismo, masonería y, en el caso de México, protestantismo. Es lo que puede leerse en los documentos preparatorios de la encuesta global sobre el comunismo, que la Secretaría de Estado lanzaba en 1932, mediante un cuestionario enviado a todos los nuncios y delegados apostólicos: "La lucha del comunismo se concentra dentro y fuera de Rusia especialmente en contra de todo lo que es católico, aunque fuera necesario servirse de aliados provisorios como las sectas anticatólicas, el protestantismo militante, la masonería y el liberalismo ateo o antirreligioso". ${ }^{64}$ Los datos recogidos sobre México por el Vaticano, en el marco de otra encuesta, efectuada en 1936 - mientras en la Curia ya se trabajaba la futura encíclica de Pío XI sobre el comunismo Divini Redemptoris-, no hacen sino confirmar esta hipótesis. Así se lee en un comentario de la Congregación para los Asuntos Eclesiásticos Extraordinarios:

Si por una parte el comunismo no es el origen de los males [de México], ya que la responsabilidad de las primeras luchas antirreligiosas pertenece sobre todo a la masonería, por otra parte, es el Comunismo el que ha tomado la guía de la lucha. Calles, de hecho, quiso seguir los pasos de Mosca y alcanzar los objetivos de la misma. Algunos jefes de la lucha actual pasaron unos años en Rusia para aprender. El mismo lenguaje de la polémica antirreligiosa, así como en el ámbito económico y moral, refleja lo de Mosca. ${ }^{65}$

En este marco, desde el punto de vista vaticano, la figura del presidente Lázaro Cárdenas - por lo menos al comienzo de su sexenio presidencial- parece representar una síntesis perfecta de los dos peligros: el masónico y el bolchevique, debido a su política "socialista" en los ámbitos social y educativo. Al respecto, destaca un comentario muy crítico de La Civiltà Cattolica, la cual, en 1935, hablaba del papel desempeñado por la masonería mexicana en la lucha anticristiana de Calles y ahora en la política escolar cardenista, la llamada enseñanza socialista:

Un programa escolar anticatólico había ya sido propuesto en 1933 por el Rito Nacional Mexicano. Además, los democráticos, así como los marxistas y los liberales hostiles a la religión son llamados "yorkinos", por su afiliación a la Gran Logia Mexicana del rito de York. Es masón Plutarco Elías Calles, que es el más alto dignitario de la Logia Helios de Guaymas en Sonora; Emilio Portes Gil, presidente interino desde 1928 hasta 1930, pertenecía a la Logia

64 S.RR.SS., AA.EE.SS., Stati Ecclesiastici, pos. 474 (P.O.), fasc. 488, ff. 60v-61r. 
Valle de México. Ortiz Rubio también, que fue elegido presidente en 1930, era masón. ${ }^{66}$

En otro artículo del periódico, con fecha del 28 de diciembre de 1935, no faltaba una referencia al papel de Estados Unidos en la persecución: "Parece un destino fatal que la obra de los EE.UU. haya sido siempre la de favorecer la tiranía en México, y que esta obra haya gozado de la alianza de la masonería, en vista de destruir la religión católica en el país". ${ }^{67}$

Asimismo, en 1935, La Civiltà Cattolica publicaba una carta del delegado apostólico Ruiz y Flores a los obispos, al clero y a los católicos mexicanos, con fecha del 12 de diciembre 1934, en la cual advertía: "los católicos no pueden pertenecer al Partido Nacional Revolucionario, que es abiertamente ateo, ni tampoco ser miembros de la masonería, ya que, además de ser una sociedad secreta condenada y prohibida por la Iglesia, es la causa de la persecución que sufrimos y de casi todas las desventuras nacionales". ${ }^{68}$ Un año después, en la misma revista se afirmaba: "[el presidente Cárdenas es una] criatura de Calles, y [...] su reciente ruptura con el mismo Calles no significa para nada un cambio en la política persecutoria, ya que el nuevo jefe del partido revolucionario, Portes Gil, es otro Calles, con respecto al odio antirreligioso, y Cárdenas es un violento ateo, masón y comunista". ${ }^{69}$

Sin embargo, a partir de 1936, la Secretaría de Estado - a la luz de la información que recibía de muchas fuentes- pareció darse cuenta de que en México la situación religiosa, bajo ciertos aspectos, estaba mejorando, y por eso enviaba al país, en el verano de aquel mismo año, al delegado apostólico en Filipinas, monseñor Guglielmo Piani, con el encargo de visitar todas las diócesis para recoger información sobre la situación de la Iglesia mexicana. ${ }^{70}$ Con esta acción, resulta evidente que la Secretaría de Estado ya no confiaba más en la capacidad del entonces delegado apostólico monseñor Ruiz y Flores - desterrado en Estados Unidos para ese entonces- de aportar información fidedigna. En su informe final, redactado después de una estancia de más de dos meses, Piani señalaba el hecho de que Cárdenas haya expulsado del gobierno a algunos de los elementos más anticlericales. Sin embargo, esta decisión se debía a que estaban en contra de sus planes, pues -señalaba-

66 “Chi pensa al Messico?”, La Civiltà Cattolica, vol. I, 1936, p. 51.

67 "Messico. Nostra Corrispondenza", op. cit., vol. II, 1935, p. 553.

68 “Chi pensa al Messico?”, op. cit., p. 53.

69 Véanse, al respecto, Andes, Stephen J.C., op. cit., pp. 167-174, y Valvo, Paolo, op. cit., pp. 467 y 480 .

70 S.RR.SS., AA.EE.SS., Messico, pos. 583 (P.O.), fasc. 379, ff. 74r-76r, Informe de monseñor Piani cerca de su viaje a México para el cardenal Eugenio Pacelli, 24 de septiembre de 1936. 
Cárdenas "sigue siendo rodeado por elementos muy malos y nefastos para la Iglesia". Por otro lado, Piani afirmaba que, entre los hombres que formaban el gobierno, muy pocos eran anticatólicos por íntima convicción personal: "Hay que admitir, en efecto, que muchos son esclavos de ciertas asociaciones secretas, y experimentan el influjo tiránico de la masonería y además de núcleos de propaganda comunista, que dirigen la campana sectaria de descristianización y de persecución. Se percibe la influencia de un centro directivo, al que están sujetos los mandatarios, la misma soberanía de los Estados, el poder legislativo y judiciario". ${ }^{71}$

A pesar de la postura más bien cauta de la Santa Sede (cabe señalar al respecto la ausencia de referencias polémicas hacia el gobierno de Cárdenas en la tercera y última encíclica de Pio XI sobre la situación religiosa de México, Firmissimam constantiam, del 28 de marzo de 1937), La Civiltà Cattolica siguió atacando la política cardenista. Así lo mostraba, por ejemplo, un artículo publicado en febrero de 1937:

El presidente Lázaro Cárdenas no solo sigue actuando la obra empezada por Calles de destrucción del catolicismo, en una nación de 16 millones de habitantes en su casi totalidad católicos, sino también la reforzó, organizándola de manera que, por una parte, los extranjeros, especialmente los estadounidenses, no se percaten de la persecución religiosa, por otra parte, los católicos sigan perseguidos legalmente, sin derramamiento de sangre. Lo que, sin embargo, tampoco falta ${ }^{72}$.

En un comentario a la propia encíclica de Pío XI, el periódico jesuita, enfatiza que a pesar de los conflictos entre los enemigos de la Iglesia (Obregón y Calles; este último y Cárdenas), "[ellos, de todos modos], siempre se encontraron conjurados en la misma lucha insana en contra de la Iglesia y de los católicos, que naturalmente se opusieron a su delincuencia privada y pública, fuente de corrupción y de pobreza nacional, y además explotadora de todos los derechos más saludares, bajo la apariencia de libertad, de democracia o algo similar". ${ }^{73}$

71 "Nel Messico come prima e peggio di prima", La Civiltà Cattolica, vol. I, 1937, p. 290.

72 Rosa, Enrico, "L'enciclica sul Messico e l'opera della ristaurazione sociale", La Civiltà Cattolica, vol. II, 1937, p. 321.

73 Acta et documenta Concilio Oecumenico Vaticano II apparando, series I (Antepraeparatoria), vol. II: consilia et vota episcoporum ac prelatorum, párrs. VI: America septentrionalis et centralis, Roma, Typis Polyglottis Vaticanis, 1960, p. 234. 
Esta obra forma parte del acervo de la Biblioteca Jurídica Virtual del Instituto de Investigaciones Jurídicas de la UNAM www.juridicas.unam.mx

https://biblio.juridicas.unam.mx/bjv

\section{EPILOGO: LA MIRADA DE LA SANTA SEDE SOBRE LA MASONERÍA MEXICANA DEL CONCILIO VATICANO II HASTA LA FECHA}

Después del 10 de febrero de 1939, fecha del fallecimiento de Pío XI, los archivos vaticanos callaron, de modo que el análisis de la postura de la Santa Sede frente a la masonería se vuelve más ardua. Cabe señalar, de todos modos, que la pacificación religiosa de facto, efectuada durante la presidencia de Lázaro Cárdenas (de acuerdo con los últimos hallazgos), contribuyó a una progresiva disminución de interés por la masonería y su anticlericalismo, en las décadas siguientes.

Parece significativa, al respecto, la constatación de que entre las relaciones enviadas por los obispos mexicanos a la comisión preparatoria del Concilio Vaticano II, el tema de la masonería se encuentre mencionado de forma explícita únicamente en la del entonces obispo de Tampico (y futuro arzobispo de México) monseñor Ernesto Corripio Ahumada, el cual proponía que la excomulgación prevista en el canon 2335 del Código de Derecho Canónico se aplicara sólo a quienes se obstinaran en pertenecer a la masonería, pues, según el obispo, había muchos católicos que se inscribían en las logias por ignorancia, curiosidad o necesitad de trabajo. ${ }^{74}$ Otros obispos, enumerando los peligros que amenazaban a la fe católica, no mencionaban la masonería sino el "materialismo", el "comunismo", el "liberalismo", el "modernismo", el "laicismo", el "naturalismo" y el "existencialismo". ${ }^{75}$

Por otro lado, los debates conciliares demuestran la importancia que la cuestión masónica seguía teniendo en el contexto mexicano; de hecho, no es casual, que el tema fuera planteado en tres ocasiones por un obispo mexicano, es decir el obispo de Cuernavaca, monseñor Sergio Méndez Arceo. ${ }^{76}$ El 6 de diciembre de 1962, en el transcurso de la trigésima quinta congregación general, Méndez Arceo afirma:

74 Véanse, por ejemplo, los informes del cardenal arzobispo de Guadalajara José Garibi Rivera y del obispo de Montterrey, Espino y Silva, ibidem, pp. 201 y 224. Al respecto, véase también Casas García, Juan Carlos, "La Iglesia en México durante el Vaticano II: el contexto nacional y eclesial y la participación de los obispos mexicanos en el Concilio", Efemérides Mexicana, México, vol. 33, núm. 97, 2015, pp. 28-41.

75 Para un panorama sobre la participación de Méndez Arceo a los trabajos del Concilio, véase Olimón Nolasco, Manuel, Una lúcida voz mexicana en el Concilio: Don Sergio Méndez Arceo, ibidem, pp. 78-111.

76 Acta synodalia Sacrosancti Concilii oecumenici Vaticani II, vol. I, periodus I, pars IV, Congregationes Generales XXXI-XXXVI, Typis polyglottis Vaticanis, Roma, 1971, pp. 340 y 341. Véase, al respecto, también Casas García, op. cit., p. 57. 
Existen además otros hombres, entre los cuales se cuentan no pocos de la fe de casa, tanto católicos como cristianos no católicos, que casi por dos siglos existieron y continúan existiendo a pesar de las amenazas y acusaciones históricas de la Iglesia; me refiero a los masones. 1) Los católicos no pueden de algún modo dar su nombre a las logias masónicas, y han sido establecidos castigos para que sean disuadidos. Sin embargo, la cura pastoral de estos católicos que por cualquiera razón se volvieron masones no cesa. 2) Si ponemos la atención en los hermanos no católicos y en sus ministros que dieron su nombre a la masonería, hay que tomar en cuenta dos consecuencias: a) por una parte todos estos encontrarán en su afiliación masónica un obstáculo relevante a la unión comunitaria con la Iglesia; b) por otra parte, estos ministros no católicos podrían contribuir a eliminar de la misma masonería los elementos anticristianos y anticatólicos, si conocieran mejor, comprendieran y quisieran la Iglesia católica. Propiamente el origen de la masonería no fue anticristiano y existen indicios, aunque mínimos, de la posibilidad de alguna reconciliación con la Iglesia. [Que] la buena fe de ambas partes y la historia, que es maestra de la vida, ayuden a sanar esta deplorable división. ${ }^{77}$

Estas ideas fueron retomadas por Méndez Arceo un año después, el 20 de noviembre de 1963; en esta ocasión, el obispo hacía referencia al paso evangélico del trigo y de la cizaña para justificar su actitud favorable hacia un acercamiento a los miembros de la masonería - la gran mayoría, según Méndez- que compartían la fe cristiana y estaban deseosos de reconciliarse con la Iglesia. ${ }^{78} \mathrm{El}$ auspicio de una pronta pacificación con la masonería fue reiterado por Méndez Arceo el 29 de septiembre de 1964. ${ }^{79}$

A pesar de que no existe referencia alguna al tema de la masonería en los documentos finales del Concilio, el debate sobre el tema sigue envolviendo los episcopados y la Curia romana. Un episodio significativo en este camino es la carta reservada que la Congregación para la Doctrina de la Fe remitía a algunas Conferencias Episcopales, el 19 de julio de 1974, "sobre la interpretación del can. 2335 del Código de Derecho Canónico, que prohíbe a los católicos, bajo pena de excomunión, inscribirse en las asociaciones masónicas y otras semejantes". En ella se afirma la imposibilidad de "que la Santa Sede cambie la legislación general que hasta hoy se encuentra en vigor", aunque en "los casos particulares se debe tener en cuenta que la ley penal está sometida a interpretación

77 Ibidem, vol. II, periodus II, pars V, Congregationes Generales LXV-LXXIII, Typis Poliglottis Vaticanis, Roma, 1973, pp. 617 y 618. Véase Casas García, op. cit., pp. 60 y 61.

78 Ibidem, vol. III, periodus III, pars III, Congregationes Generales XC-XGV, Typis Poliglottis Vaticanis, Roma, 1974, p. 19.

79 El texto de la carta se encuentra publicado en calce a la sucesiva declaración de la Congregación fechada 17 de febrero de 1981 (véase la nota siguiente). 
estricta. Por ello se puede enseñar y aplicar con seguridad la opinión de aquellos autores que consideran que el canon 2335 se refiere sólo a aquellos católicos que se inscriben en asociaciones que realmente maquinan contra la Iglesia". ${ }^{80}$

Debido a las "interpretaciones erróneas y tendenciosas" suscitadas por el documento en la opinión pública, en una declaración del 17 de febrero de 1981, la Congregación precisa que "no ha sido modificada en modo alguno la actual disciplina canónica que permanece en todo su vigor", y, "por lo tanto, no ha sido abrogada la excomunión ni las otras penas previstas. En cualquier caso, permanece la prohibición para los clérigos, religiosos y miembros de los Institutos seculares de inscribirse en cualquier tipo de sociedad masónica". ${ }^{81}$ Otras interpretaciones confundidas siguen la aprobación en 1983 del nuevo Código de Derecho Canónico, en cuyo canon 1374 la masonería no queda mencionada explícitamente, mientras se formula una prohibición genérica de pertenecer a "una asociación que maquina contra la Iglesia".

$\mathrm{Al}$ respecto, la Congregación para la Doctrina de la Fe intervenía otra vez, el 26 de noviembre de 1983, declarando que, a pesar de que en el nuevo Código se hubiera quitado la pena de excomulgación reservada a la Santa Sede para los masones (prevista en el viejo canon 2335), "no ha cambiado el juicio negativo de la Iglesia respecto de las asociaciones masónicas, porque sus principios siempre han sido considerados inconciliables con la doctrina de la Iglesia; en consecuencia, la afiliación a las mismas sigue prohibida por la Iglesia. Los fieles que pertenezcan a asociaciones masónicas se hallan en estado de pecado grave y no pueden acercarse a la santa comunión". ${ }^{82}$

Esto, por supuesto, no excluía la posibilidad para los católicos de colaborar en dadas circunstancias con los masones en vista del bien común, como demuestra -entre otros casos- el actuar del delegado apostólico en México, monseñor Girolamo Prigione, quien, a lo largo de su permanencia en el país (1978-1997), logró obtener el apoyo de importantes exponentes de la masonería mexicana a la reforma constitucional en materia religiosa, promovida

80 Congregación para la Doctrina de la Fe, Declaración sobre la disciplina canónica que prohibe, bajo pena de excomunión, que los católicos se inscriban en la masonería y otras asociaciones de ese tipo, Roma, 17 de febrero de 1981.

81 Congregación para la Doctrina de la Fe, Declaración sobre la masonería, 26 de noviembre de 1983.

82 Congregación para la Doctrina de la Fe, "Reflexiones sobre la Declaración de la Congregación para la Doctrina de la Fe referente a las asociaciones masónicas", L'Osservatore Romano, s. l. i., Edición semanal en Lengua Española, 24 de marzo de 1985, p. 22, http:// wrere.vatican.va/roman_curia/congregations/cfaith/documents/rc_con_cfaith_doc_19850223_declaration-masonic_articolo_sp.html. 
Esta obra forma parte del acervo de la Biblioteca Jurídica Virtual del Instituto de Investigaciones Jurídicas de la UNAM www.juridicas.unam.mx

al comienzo de la década de 1990 por el presidente Carlos Salinas de Gortari. En este sentido, cabe mencionar el ultimo pronunciamiento oficial de la Santa Sede sobre la masonería, es decir la Nota de la Congregación para la Doctrina de la Fe, del 23 de febrero de 1985, la cual, retomando los argumentos de sus precedentes declaraciones, afirma: "Que también la Iglesia católica estimula a una colaboración entre todos los hombres de buena voluntad, no es necesario subrayarlo después del Concilio Vaticano II. Pero asociarse en la masonería sobrepasa esta colaboración legítima y tiene un significado más relevante y determinante". ${ }^{83}$

83 http://www.vatican.uva/roman_curia/congregations/cfaith/documents/rc_com_cfaith_ doc_19850223_declaration-masonic_articolo_sp.html. 


\title{
EL LIBERAL MODERANTISMO DURANTE EL GOBIERNO DE IGNACIO COMONFORT
}

\author{
Silvestre VILLEGAS REVUELTAS*
}

\begin{abstract}
¿Qué cosa es preferible? ¿Una reforma gradual que vaya paulatinamente corrigiendo los abusos, disminuyendo las influencias políticas, y estableciendo un prudente equilibrio en la sociedad, o una reforma absoluta, completa, que aniquile lo malo, lo mismo que lo bueno, que destruya las mies y la maleza, para sembrar después en un campo fértil, pero enteramente desierto? ¿Es preferible componer el viejo edificio o derribarlo, a riesgo de no poderlo construir mejor?
\end{abstract}

Manuel PAYNO, 1860

SUMARIO: I. Introducción. II. Revolución y ejercicio del poder. III. Una muestra del conflicto religioso. IV. El catolicismo y la tolerancia religiosa. V. La constitución excomulgada. VI. El golpe de Estado

\section{INTRODUCGIÓN}

El lapso histórico que va de la firma de los Tratados de Guadalupe-Hidalgo en 1848, continúa a lo largo de las administraciones moderadas de los generales Herrera y Arista para terminar con el "golpe de Estado" de Ceballos -el cual aceleró la llegada de Antonio López de Santa Anna (1853)-, provocó en la clase política mexicana, compuesta por liberales y conservadores, una aversión por la manera en que se modificaban los planes políticos y luego debido a los excesos en que incurrió "la dictadura" de don

\footnotetext{
*Instituto de Investigaciones Históricas-UNAM.
} 
Antonio. ¿Qué tipo de forma de gobierno era la más conveniente para la felicidad de la nación? ¿Qué límites a los poderes de la unión debían ser establecidos? ¿Cuál había sido el papel que desempeñó el clero católico en la maduración de la sociedad mexicana? ¿Era necesario llevar a cabo una "reforma", una "revolución" o retrotraer las cosas a como estaban antes de 1810 para que el país transitase hacia la modernidad? Éstos fueron algunos de los cuestionamientos que se hicieron, en aquellos años críticos de 1850, una serie de "políticos prácticos" -que no "ideólogos"- hacedores de todo un andamiaje teórico. El presente texto, en sus diversas secciones, expone y quiere explicar dichas preocupaciones y algunos planteamientos para que México pudiera "alcanzar la felicidad a la que estaba destinada". Dicho afán preocupaba a uno y otro bando.

\section{REVOLUCIÓN Y EJERCICIO DEL PODER}

Luego de seis meses en el poder, la segunda administración suriana se había caracterizado por una división política entre los triunfantes liberales puros y moderados; haber protegido la instalación de los trabajos del Congreso Constituyente; haber promulgado una ley que regulaba la libertad que debería ejercer una prensa crítica pero responsable, y enfrentar exitosamente "la revolución" que, al grito de "ireligión y fueros!" comenzó en la Sierra Gorda queretana y terminó a un par de cuadras de la catedral de la ciudad de Puebla. ${ }^{1}$ Dicho alzamiento tuvo como característica que contrapuso a la joven oficialidad liberal con la conservadora, las cuales incesantemente se combatirán durante los siguientes once años. Además de lo anterior, el gobierno de Ignacio Comonfort se enfrentó al problema histórico de todos los gobiernos mexicanos: cómo hacer viable la suma y división de facultades entre los diversos poderes, ya fuese bajo un sistema federal o centralista, y el de aquellos tres poderes respecto a las autoridades de gobierno en las diversas entidades de la República.

El Plan de Ayutla, reformado en Acapulco, prometía la pronta elaboración de un estatuto, el cual obedecía a la preocupación de los surianos y de los miembros al interior del gabinete presidencial, ante la experiencia de las facultades omnímodas con las que se manejó la última administración santannista - la cual lo estaba llevando a una "tiranía como la del sultán turco o el

1 Para mayor información sobre dicha insurrección, véase, Villegas Revueltas, Silvestre, "Santannismo, reforma liberal y las campañas de Puebla en 1856", Estudios de Historia Moderna y Contemporánea de México, México, vol. 40, julio-diciembre de 2010, pp. 13-53. 
emperador chino"-, y también debido a los amplios poderes que ejerció Juan Álvarez -que igual se utilizaron para promulgar la Ley Juárez "que encendió la guerra civil", que para nombrar a Comonfort presidente sustituto, más allá de lo que opinara el Consejo de Gobierno que la propia Revolución de Ayutla había creado, y ante la falta de un genuino marco constitucional que por el momento se estaba construyendo-. Por ello, el Presidente y sus secretarios consideraron que la revolución materializada en un nuevo gobierno sólo podría resultar en la instalación de otra dictadura, liberal, sí, pero al fin y al cabo dictadura. Así lo percibió el historiador y periodista Anselmo de la Portilla al calor de los sucesos ocurridos entre 1855 y 1856. Un siglo después, Andrés Serra Rojas escribía: "Comonfort tenía razón en su punto de partida como estadista [...]La acción del Estado [se guía] por la prudencia política[...] por una política de frenos y contrapesos, de constantes limitaciones a la concentración del poder. En una palabra, un adecuado régimen de derecho". ${ }^{2}$ Bajo la anterior y central preocupación de los moderados en el poder, José María Lafragua, secretario de Gobernación - quien había consensuado con el gabinete el Programa de Gobierno que debía seguirse--, indicaba que, mientras el Constituyente continuara elaborando la carta fundamental de la República, regiría un estatuto orgánico. En éste se fijaría "de una manera clara la autoridad que debe ejercer el gobierno general, y las bases a que debe arreglarse la administración interior de los estados".

El Estatuto Orgánico Provisional de la República Mexicana se publicó el 15 de mayo de 1856 y contiene 126 artículos divididos en nueve secciones; la palabra provisional se debía a que sólo regiría hasta que se sancionara la nueva Constitución. No era un texto original, pero sí se le podía considerar así desde la perspectiva de la historia constitucional, porque recogía ideas de la carta fundamental de 1824 y de las Bases Orgánicas de 1843: "porque en uno y otro se encuentran consignados principios democráticos. Sin embargo se han introducido pensamientos nuevos y se han hecho alteraciones importantes, porque las ideas de mejora y de progreso que forman parte del programa de este gobierno, han exigido concesiones a favor de los extranjeros y mayores explicaciones en algunos puntos". ${ }^{3}$

2 Serra Rojas, Andrés, "Los caudillos de la Revolución de Ayutla", en de la Cueva, Mario et al., Centenario de la Revolución de Ayutla, México, UNAM, 1954, p. 238.

3 Siguiendo las ideas del texto de Acapulco el Estatuto planteaba rebajar los aranceles al comercio, una política de reducir los monopolios y fomentar la inversión extranjera, especialmente en el rubro de construcción de obra pública. Véase Lafragua, José María, "Defensa del Estatuto Provisional", en Galeana de Valadés, Patricia (comp.), Fosé María Lafragua, México, Senado de la República-LIII Legislatura, 1987, p. 234. 
La estructura del Estatuto contiene 126 artículos divididos en nueve secciones y la sección quinta se refiere a las garantías individuales. Al incluir estos preceptos, el gobierno de Comonfort actuaba en concordancia con su plan de trabajo aprobado en el pasado diciembre y, en un sentido más general, iba más allá del contenido del Plan de Ayutla reformado en Acapulco, que fue su enseña durante dos años, como puede apreciarse en todos los edictos del Ejecutivo. Es más, tales garantías incluidas en el Estatuto pueden considerarse como el antecedente del Título I, Sección Primera, artículos 1o al 29 de la futura Constitución Federal de 1857, que últimamente ha sido considerada como un texto constitucional garantista. ${ }^{4}$

Lafragua comentaba que, si bien en la década de 1820 los federalistas habían hecho una constitución que resolvió algunos problemas, había ocasionado otros que no se tenían durante la administración española; habían pasado varias décadas y todavía no se les encontraba una solución satisfactoria para la partes involucradas. El Estatuto también se inspiraba en los trabajos constituyentes de 1841 y 1842, y agregaba que, después de aquellas experiencias, los centralistas, a pesar de los errores del texto de 1836, en 1843 habían hecho otra constitución donde, de una manera imprudente, afirmaron los poderes de la presidencia más que normar una eficiente autoridad centralizadora. Para inicios de 1856, don José puntualizaba que, después de "la revolución" (Ayutla), se había instalado el gobierno de Comonfort, lo cual significaba que había llegado el tiempo para que el moderantismo llevara a cabo "un programa de reformas", que bajo la idea de "libertad y orden" reflejara la clase de país que pretendían. Vivir bajo la "égida de la ley" era contribuir a la tranquilidad de la ciudadanía; imponer reglas a los poderes de la República era asegurar a la sociedad contra los avances del despotismo, pero también vigilar "y poner freno" y las pasiones a las creencias de los individuos. ${ }^{5}$

Asimismo, en una afirmación que pinta muy bien al ministro de Gobernación, indicaba que en los pasados congresos, y en el constituyente que estaba trabajando por aquellos días y cuyos diputados estaban inmersos en discusiones acerca de modelos de filosofía política, todos los anteriores textos constitucionales habían mezclado la opinión de las distintas facciones políticas del momento. En cambio, el Estatuto integraba una visión orgánica -la suya- acerca de los temas y necesidades que harían feliz a la nación

4 Pantoja Morán, David, "El estado de necesidad en el Derecho Público en el Congreso Constituyente Extraordinario de 1856-1857", en Villegas Revueltas, Silvestre (coord.), A cien años de la Constitución de 1917. Reflexiones en torno a la Carta Magna de 1857, México, Secretaría de Hacienda y Crédito Público, 2017, pp. 70-105.

5 Villegas Revueltas, Silvestre, El liberalismo moderado en México (1852-1864), México, UNAM, Instituto de Investigaciones Históricas, 1997, p. 125. 
mexicana. Lafragua podía reunir en su Estatuto la prohibición de imponer distinciones que no estuviesen acordes con la igualdad republicana o pronunciarse por la libertad de enseñanza, pero también por hacer efectiva una centralización política; su patente preocupación era "fortificar el vínculo de la unión nacional, factor siempre necesario pero más cuando los enemigos de la libertad fomentan todo tipo de disturbios y fortalecen la amarga duda entre los ciudadanos sobre la idoneidad del proyecto que pretende implementar la actual administración".

Frente a la falta de una declaración expresa en torno al establecimiento de la federación y, en cambio, ante la mención de que el centralismo no se oponía a que la República fuera una sola, indivisible e independiente, y que en una federación la independencia de los Estados sólo correspondía a su régimen interior, gobernadores como Manuel Doblado y Benito Juárez afirmaron que: "[el Estatuto] centralizaba de tal modo la administración pública que sometía al cuidado inmediato del poder general hasta los ramos de simple policía de las municipalidades". ${ }^{6}$ Para 1856, el Benemérito suscribía las tesis más radicales del federalismo, pero dos años después y cada vez más al calor de la guerra civil y la intervención extranjera -cuando como figura presidencial incesantemente tuvo que negociar y estar a merced del parecer de gobernadores, comandantes militares y hombres fuertes locales- se decantó decisivamente por una preeminencia del Ejecutivo frente a los otros dos poderes de la unión, y, en particular, ejercitar un control presidencial en lo referente al sistema electoral que caracterizó las elecciones durante el tiempo conocido como la restauración de la República. ${ }^{7}$ Finalmente, para aquellos interesados en el derecho constitucional, una lectura comparativa entre el Estatuto de 1856 y la Constitución federal de 1857 sin duda resultará un ejercicio interesante; más aún, terciar con el estatuto que promulgó el gobierno de Félix Zuloaga (1858) y que como el de Lafragua, salió a la luz pública cuando las pasiones de la guerra civil los hicieron redundantes.

6 Juárez, Benito, Apuntes para mis hijos, México, Futuro, 1963, p. 38.

7 Francisco Bulnes, un furibundo crítico de Juárez, describió el ambiente electoral durante la república restaurada de la siguiente manera: "Desgraciadamente Juárez, calcinado por ardiente ambición personal, quiso ir a la dictadura imposible, descarnada,lúgubre, famélica. La federación quedó dividida en estados amigos, donde florecía el régimen de gobierno africano o demagógico, y en estados enemigos que debían soportar el peso de los privilegios concedidos a los estados amigos. Se exoneraba de todas sus obligaciones constitucionales, sociales y humanitarias a los estados reeleccionistas; se conspiraba con los elementos federales contra los estados antirreelecionistas", El verdadero fuárez y la verdad sobre la intervención y el imperio, México, Instituto de Investigaciones Dr. José María Luis Mora-Instituto Nacional de Estudios Históricos de las Revoluciones de México, 2009, p. 581. 


\section{UNA MUESTRA DEL CONFLICTO RELIGIOSO}

Ni el Plan de Ayutla, ni el documento reformado en Acapulco explicitaron en sus respectivos articulados alguna observación, crítica o medida referente a la Iglesia católica; ello levantó la suspicacia y los temores entre los miembros más conservadores de la administración santannista, así como de aquellos individuos que, detrás de la filosofía política de Lucas Alamán, estaban ligados a los puntos de vista ventilados en la muy ácida polémica pública entre el gobernador, Melchor Ocampo y "un cura de Michoacán” - quizás el muy combativo, erudito e intolerante obispo, Clemente de Jesús Munguía- ${ }^{8}$ Por su lado, Emilio Rabasa y, posteriormente, Felipe Tena Ramírez, ${ }^{9}$ señalaron que la estrategia seguida por los moderados en Ayutla era reunir adeptos, y, para ello palabras como federalismo, religión, democracia más bien dividían los potenciales apoyos que necesitaba el movimiento suriano; asimismo, el abogado de la Escuela Libre de Derecho entendió que, el moderantismo podía utilizar la vaguedad de un término o la omisión de algún tema, pero que en la práctica de gobierno se podría llegar a lo que planteaba el liberalismo más extremo, sin vociferarlo, como ansiaban personajes como Francisco Zarco.

Páginas atrás señalamos que la proclamación de la Ley Juárez -durante la administración de Álvarez- provocó el levantamiento de Tomás Mejía, el cual terminó con la derrota de los conservadores en Puebla (abril, 1856), e inmediatamente se dio la confiscación de bienes de la diócesis poblana. Se planteó exigir un millón de pesos para resarcir al gobierno central y a los particulares de los daños sufridos durante el levantamiento, pues, además del costo humano, el centro de la ciudad fue verdaderamente destruido. A esta medida se opusieron las autoridades eclesiásticas, lo cual provocó que para mayo se ordenara el exilio de Pelagio Antonio de Labastida y Dávalos, primera expatriación de un obispo en tiempos republicanos: "a Europa a conspirar” enfatizó Justo Sierra en su finisecular libro sobre el tiempo de Juárez. Pero si todo lo anterior ya era un enfrentamiento abierto entre las autoridades eclesiásticas y el gobierno de Comonfort, éste procedió a promulgar el 23 de junio la Ley de desamortización de Bienes de Corporaciones Civiles y Eclesiásticas (o Ley Lerdo) que, sin duda alguna, fue el ordenamiento más radical

8 Sobre este interesante personaje consultar el excelente texto de Mijangos y González, Pablo, The Laweyer of the Church. Bishop Clemente de Jesús Munguia and the Clerical Response to the Mexican Liberal Reforma, Lincoln, University of Nebraska Press, 2015, pp. 137-188.

9 Rabasa, Emilio, La Constitución y la Dictadura, México, Porrúa, 1982; Tena Ramírez, Felipe, "Comonfort, los moderados y la Revolución de Ayutla", en Cueva, Mario de la, op. cit., p. 27. 
de la reforma liberal, porque la modificación de la propiedad inmueble en la República "creó los intereses necesarios" para que particulares y gobiernos extranjeros se vieran involucrados en el cumplimiento de lo estipulado por la ley, y años después defendieran, por la vía del hecho, las transacciones que en su momento fueron efectuadas bajo un orden jurídico positivo. Compraron propiedades de la Iglesia católica en México miembros del "partido liberal", extranjeros que no tuvieron problemas de conciencia, algunas familias conservadoras como la Haro y Tamariz y, en el peor de los casos, individuos que se ofrecieron a proteger las propiedades del clero y pasados los años no se las devolvieron. ${ }^{10}$

Cuando, meses después, el sentido de la ley de desamortización se incluyó en el texto constitucional de 1857, el obispo de Michoacán -el ya mencionado Munguía- entró al debate entre el ministro de Justicia y Negocios Eclesiásticos, Ezequiel Montes y el arzobispo de México Lázaro de la Garza; Munguía señalaba que los obispos mexicanos jamás habían sostenido que la propiedad eclesiástica fuera invendible: "es enajenable cuando de acuerdo a la utilidad y necesidad de la Iglesia así lo exigen”. El argumento de Munguía era preciso por su sencillez: resultaba incorrecto vender en contra de la voluntad de la Iglesia. Puntualizaba, si no se respetan tales derechos primigenios e imprescriptibles, el resultado será la más completa y omnímoda absorción de la propiedad por parte de los gobiernos. Como consecuencia, ellos serían los únicos dueños de todo y los ciudadanos de la nación "simplemente usufructuarios de la propiedad social". Frente a tan nefasta realización el obispo consideraba que, si la obediencia era una virtud, nunca podría darse tal nombre al vasallaje de una ley contraria a la ordenación de Dios. Por tanto, no podía calificarse de desobediencia al acto moral de resistirse a la ley de desamortización, ni de apellidar incitación a la desobediencia al llamamiento que hicieren los clérigos a la comunidad de fieles, en el sentido de que no les era lícito obedecer el ordenamiento del gobierno. Munguía terminaba su diatriba razonando lo que la prensa y la correspondencia particular daban cuenta:

Es un verdadero escándalo lo que pasa hoy[...] esas angustia y agitaciones de los moribundos, esos cismas domésticos, esas retractaciones repentinas, ese

10 De la enorme bibliografía sobre el proceso desamortización y nacionalización de la propiedades de la iglesia en México hemos escogido solamente tres: Bazant, Jan, Los bienes de la Iglesia en México (1856-1875). Aspectos económicos y sociales de la Revolución liberal, México, El Colegio de México, 1984; Connaughton, Brian (coord.), México durante la guerra de Reforma, México, Universidad Veracruzana, 2011, t. I: Iglesia, religión y Leyes de Reforma; Escobar Ohmstede, Antonio, et al., La desamortización civil desde perspectivas plurales, México, El Colegio de México-El Colegio de Michoacán-Centro de Investigaciones y Estudios Superiores en Antropología Social, 2017. 
desconcepto sobre sí de los que no las hacen. Esas fortunas improvisadas sin resultado de importancia para el erario público, esos desórdenes diversos[...] Suplico al gobierno revoque dicho decreto y vuelva la Iglesia con sus preciosas garantías a la conservación e incremento de los hospitales, casas de beneficencia, colegios $[\ldots]$ y culto sagrado. ${ }^{11}$

En agosto, la fuerza policial de la Ciudad de México, encabezada por el gobernador, el liberal radical Juan José Baz, descubrió una serie de reuniones misteriosas que hacían pensar en la existencia de una conspiración al interior del convento de San Francisco. Durante una operación nocturna, las autoridades de la ciudad ingresaron violentamente al inmueble y procedieron a aprehender a los sospechosos ahí reunidos. Según el historiador Niceto de Zamacois, en dicho claustro jamás se desarrolló algún contubernio y, en el momento de la acción policíaca, efectivamente se apresó a diversos individuos que por casualidad se encontraban en el inmueble; los religiosos insistieron en que aquellos buscaban consuelo espiritual y que, además, algunos eran sus amigos, pero que, en efecto, no formaban parte de la comunidad de frailes. ${ }^{12}$ Fuese o no verdad, el infatigable gobernador Baz procedió a fincarles responsabilidades y a encarcelarlos, porque en el inmueble se encontró una importante cantidad de armas y municiones, ajenas a la misión espiritual que debían llevar a cabo los sacerdotes; asimismo, fueron hallados papeles considerados subversivos. Por su lado y, en consecuencia, el gobierno de Comonfort tomó otra medida que volvió a dejar atónitos a los capitalinos: el 17 de septiembre se decretó la demolición del convento franciscano, para conservar únicamente el templo. La orden fue firmada por el ministro de Justicia y Negocios Eclesiástico, Ezequiel Montes, y en ella se declaraban bienes nacionales los que le habían pertenecido al convento de franciscanos, "exceptuándose la iglesia principal y capillas, vasos sagrados, paramentos sacerdotales, reliquias e imágenes". Indicaba que el ministerio de Fomento se haría cargo del aseguramiento y enajenación de dichos bienes nacionales y señalaba que el producto de su venta se repartiría entre "el colegio de educación secundaria para niñas y la Escuela de Artes y Oficios de esta capital". ${ }^{13}$ Lo anterior significaba

11 Suárez Cortina, Manuel, et al., Cuestión religiosa. España y México en la época liberal, Santander, Universidad de Cantabria, 2013. Véase Opúsculo escrito por el Ilmo. Sr. Obispo de Michoacán, Lic. D. Clemente de Jesús Munguía, en defensa de la soberanía, derechos y libertades de la Iglesia..., citado en Villegas Revueltas, Silvestre "De religiosos, abogados y literatos. La discusión entre conservadores y liberales sobre las dos potestades y la tolerancia religiosa, 1855-1867”, México, UNAM, Instituto de Investigaciones Históricas, p. 93.

12 Zamacois, Niceto de, Historia de Méjico, desde sus tiempos más remotos hasta nuestros días, Barcelona, J. F. Parres, 1880, t. XIV, pp. 368-370.

13 "Decreto de Gobierno", Giudad de México, septiembre 7 de 1856, en, Velázquez Nieto, Roberto Antonio, Los caminos de la justicia en los documentos de Ezequiel Montes, México, 
echar por tierra la construcción del clero regular más importante de la ciudad: San Francisco era un edificio de los más antiguos y su templo resultaba ser una joya del barroco novohispano, así como referencia religiosa para los capitalinos -su última reconstrucción se llevó a cabo alrededor de 1710-. El claustro era inmenso y tenía en su haber magníficas obras de arte que adornaban sus múltiples pasillos; en la magnífica huerta de los terrenos adyacentes los monjes cultivaban frutas y verduras, en términos generales, el inmenso inmueble era una isla verde con magníficos árboles. Cabe agregar, además de su valor estético, que las tierras de San Francisco constituían una joya para los especuladores de bienes raíces, quienes no dejaron pasar mucho tiempo para efectuar el fraccionamiento del terreno y llevar adelante las transacciones de compra-venta cuando el cada vez más violento enfrentamiento faccional terminó por materializar el proyecto desamortizador del liberalismo más jacobino.

Durante el último tercio del siglo XIX y entrado el XX, con el otrora terreno franciscano se obtuvieron jugosas ganancias, pero para el tiempo de Comonfort - que es lo que nos concierne- lo más significativo fue que el caso del Convento de San Francisco constituyó la primera acción importante del espíritu iconoclasta reformista que, con el transcurso de los años, modificó el plano urbano colonial de la Ciudad de México. ${ }^{14}$

La demolición del convento fue una medida provocada por la creencia de la administración suriana de que el clero católico respaldaba a un organismo llamado el Directorio Conservador Central de la República; se decía que, económica y políticamente, éste propiciaba los levantamientos. Pero, desde aquellos años, los conservadores negaron la existencia de tal directorio argumentando - entre otras cosas- la carencia de una uniformidad en los criterios que regían los pronunciamientos que aparecían por doquier en el territorio nacional. Sin embargo, por medio de los archivos de Manuel Doblado y Mariano Riva Palacio, sabemos que, por ejemplo, entre 1859 y 1861, un militar como el general Leonardo Márquez, así se encontrara en Guadalajara o en alguna serranía del país antes y durante la Intervención Francesa, estaba perfectamente informado de los asuntos de la capital, del movimiento de la tropas liberales (luego republicanas), y le llegaban partidas de dinero para mantenerse en armas. Semejante tipo de información y respaldo económico

Suprema Corte de la Nación, 2009, p. 74. Sobre la Escuela de Artes y Oficios construida durante la administración de Comonfort, véase la ficha histórica de Chapa, Arturo, "Comentarios de imagen", en Villegas Revueltas, Silvestre (coord.), op cit., p. 321.

14 En torno a los cambios urbanísticos producto del álgido tiempo de la Reforma, el Segundo Imperio y la restauración de la república, véase Castrillo Dávila, Fernando G., "De la conmemoración histórica a la celebración nacional. Fiestas cívicas y discurso patriótico en la Ciudad de México, 1855-1872", tesis de maestro en Historia, UNAM Facultad de Filosofia y Letras, 2014. 
se sostuvo durante su exilio en la década de 1870 y 1880. Por último, cabe mencionar que el 17 de febrero de 1857, cinco meses después del decreto de demolición, una serie de liberales como Francisco Zarco, Guillermo Prieto o Benito Gómez Farías pidieron al presidente Comonfort que otorgase el permiso necesario para que volviera a ofrecerse el culto divino en la iglesia de San Francisco. El presidente accedió a dicha petición, mostrando nuevamente el carácter contemporizador que le costaría tan caro en los sucesos próximos a desarrollarse en la capital del país y en la República.

\section{EL GATOLICISMO Y LA TOLERANCIA RELIGIOSA}

Otro asunto que volvió a estremecer a los capitalinos -ventilado por la prensa citadina y de los estados- fue la discusión en torno al proyecto de artículo constitucional referente a lo que se dio en llamar libertad de cultos o religiosa. Desde los Sentimientos de la Nación de Morelos, pasando por los textos constitucionales de 1824 y 1836, se había continuado con la norma de señalar a la religión católica apostólica romana como la única fe permitida en el país. Sin embargo, para los diputados constituyentes de 1856-1857 hacer efectivas la libertades del individuo significaba dejarlo enteramente libre para que pudiese escoger y practicar cualquier tipo de creencia religiosa; reiteraban que la libertad religiosa era el camino civilizado y el acorde con la modernidad de la segunda mitad del siglo XIX. Los diputados Ponciano Arriaga y José María Mata fueron los encargados de redactar la propuesta del artículo 15, la cual establecía lo siguiente: "No se expedirá en la República ninguna ley, ni orden de autoridad que prohíba o impida el ejercicio de ningún culto religioso, pero habiendo sido la religión exclusiva del pueblo mexicano la Católica Apostólica Romana, el Congreso de la Unión cuidará por medio de leyes justas y prudentes, de protegerla en cuanto no se perjudiquen los intereses del pueblo, ni los derechos de la soberanía nacional". ${ }^{15}$

La administración de Comonfort intervino directamente, pues sabía que el tema de la tolerancia religiosa provocaría otro problema que sería utilizado por los conservadores para atizar la llama de la discordia a las parcelas de un terreno más sensible: las formas de creencia al interior de la familia, así como el culto externo y su influencia respecto al entorno social e importancia en las actividades comerciales. Los ministros Ezequiel Montes y José María Lafragua argumentaron en las discusiones del Constituyente que México era un país católico casi en su totalidad, por lo que resultaba ocioso legislar en este sentido, además de que

15 Zarco, Francisco, Historia del Congreso Extraordinario Constituyente (1856-1857), México, El Colegio de México, 1956, p. 331. 
la Constitución no podía normar en asuntos del fuero interno de la persona, y la creencia religiosa entraba en esa categoría. Los sectores más radicales señalaron que si el gobierno había asumido el contenido programático de la Revolución de Ayutla, el programa liberal de la reforma buscaba la emancipación política del hombre, quería la implantación de un generalizado sistema educativo que además desarrollara el pensamiento científico, pugnaba por una sociedad más abierta a las influencias culturales del exterior y más democrática a partir de las costumbres al interior de las relaciones familiares hasta los procesos electorales. ${ }^{16}$ En todo este sentido, la libertad religiosa constituía el eje de la libertad de pensamiento y de expresión que desterraría al fanatismo religioso, el cual siempre se ha opuesto a la felicidad del hombre y a la modernidad del país.

De lo anterior se derivó otra argumentación que no pretendía discutir las bondades de la tolerancia y desde su perspectiva tampoco lastimaba el dogma católico; sostenía que en lo único que el Constituyente podía legislar era en lo relativo a los asuntos del culto externo, porque la libertad de conciencia era un derecho natural del hombre, una facultad intrínseca que resultaba independiente a toda acción legal; para ejemplificar, Lafragua sostuvo que si el hombre era libre para pensar, no lo era en lo relativo a la forma de expresar sus pensamientos: "la ley es impotente para sofocar el pensamiento pero fuerte cuando la expresión de las ideas perjudica a la sociedad; no es el culto privado sino el ejercicio del culto público lo que el congreso debe considerar, porque es el que está bajo la acción de la sociedad". ${ }^{17}$ Cuando el obispo Munguía conoció la postura discursiva del secretario de gobernación, respondió señalando que "[era necesario] asistir a las augustas ceremonias donde se nos recuerdan los misterios de nuestra redención"; asimismo, bajo dicho ambiente que estaba confrontando posturas, la revista $\mathrm{La}$ Cruz reeditó diversos textos del teólogo catalán Jaime Balmes, para que ilustraran el debate que se estaba desarrollando en el constituyente y fuera del recinto. De acuerdo con el pensamiento balmesiano, durante el transcurso de los siglos la Iglesia Católica conoció el corazón humano y supo que al hombre no le bastaba conocer las máximas de Dios: "necesita[ba] oírl[a]s incesantemente predicad[a]s, repetid[a]s e inculcad[a]s". Agregaba que había sido el esplendor y la magnificencia del culto católico una de sus armas más poderosas para que

16 En sus crónicas constumbristas, Francisco Zarco retrató a su parecer cómo las añejas y conservadoras costumbres mexicanas producían noviazgos imposibles, matrimonios arreglados que generaban infidelidades y vidas familiares que en el peor de los casos terminaban en violencia e inclusive homicidios. Véase Villegas Revueltas, Silvestre, "La experiencia literaria de Francisco Zarco", en Clarck de Lara, Belem y Speckman, Elisa, La república de las letras. Asomos a la cultura escrita del México decimonónico, México, Galería de Escritores-UNAM, 2005, vol. III, pp. 301-318.

17 Lafragua, José María, Discurso sobre el proyecto de la libertad de conciencias, México, Colección Lafragua-UNAM, Fondo Reservado, Biblioteca Nacional México, s.f. 
el clero aumentase su ascendencia sobre los fieles: las "ceremonias llamadas de culto externo ofrecen a los espíritus más sencillos" todos los misterios del dogma de una manera más comprensible. E insistía: el culto externo es proporcional a la intensidad con la cual se vive el sentimiento religioso y los altos objetos de la religión: "todos los pueblos en la historia han levantado monumentos religiosos de gran magnificencia proporcionalmente a sus recursos, a la intensidad de la fe y a la maduración de su cultura". ${ }^{18}$ Poco menos de un año después, cuando el texto constitucional había sido terminado y se estaba obligando la juramentación de los empleados públicos, el obispo Munguía remató sobre el particular de la siguiente manera: "El culto religioso es la totalidad de la religión y la disciplina externa es la totalidad de la acción administrativa de la Iglesia en el orden exterior y público. En el culto religioso están comprendidos los elementos dogmáticos del culto, sus formas litúrgicas, la religión por entero... Quítese a la religión sus formas externas y ¿qué queda?... Nada". ${ }^{19}$

El llamado Partido Liberal, que primero triunfó después de una guerra civil y luego se impuso a una intervención extranjera, cuando volvió a gobernar desde la Ciudad de México (1867) ya había madurado un esquema que impuso la prohibición de celebrar en la vía pública procesiones religiosas, fiestas y ferias patronales; inhibió el tañido de las campanas para llamar a misa; vedó el uso de la indumentaria religiosa fuera de los templos, amén de otras medidas que embarazaban la práctica religiosa en la República. Sin embargo, con los años la propia administración juarista, de hecho y sin modificar la ley, fue flexibilizando sus prohibiciones y mirando a la izquierda.

El tema de la libertad religiosa provocó - como situación inusitadamanifestaciones femeninas en el recinto parlamentario y quizá produjo algunas de las mejores piezas oratorias, tanto de algunos diputados como del Ejecutivo, quien podía participar en las discusiones del constituyente. En un momento dado, Lafragua señaló que, si bien los diputados podían discutir civilizadamente acerca de las particularidades del culto externo, los pros y contras de la tolerancia, las bondades en torno a las tres religiones monoteístas y, particularmente, las diferencias teológicas entre la Iglesia católica y las diversas "sectas cristianas", era un hecho que en los pueblos remotos y en las comunidades de indios, cuando empezaran a establecerse templos protestantes y entraran en discusión los sacerdotes de uno y otro credo o, peor, cuando éstos subrayaran flamígeramente la verdad de su Dios y la falsedad

18 Balmes, Jaime, "La influencia religiosa", Selecta colección de los escritos del señor doctor don faime Balmes, México, Imprenta de la Voz de la Religión, 1850, pp. 192-195.

19 Representación del Ilmo.. Sr. Obispo de Michoacán al Supremo Gobierno protestando contra varios artículos de la Constitución Federal de los Estados Unidos Mexicanos decretada en 1857, manifestando las razones que tuvo para declarar que no era lícito jurarla, Morelia, Imprenta de Arango, 1857, p. 14. 
del contrario, el indefectible resultado sería la división de la comunidad. Se verificarían expulsiones de las minorías religiosas y al final de cuentas - como lo demuestra el desarrollo de la humanidad- una posible guerra civil con toda la cauda de atrocidades cometidas en nombre de la religión. Como muestra de semejantes temores, ignorancia y otro tanto sentido común, el literato conservador José Joaquín Pesado escribió: "La libertad de cultos equivale a abrir la puerta a todos los errores, a todas las abominaciones... ¿quieren que volvamos a las turbulentas fiestas de Baco? ¿Desean que los impuros misterios de Venus perviertan a la juventud? Que adoremos a dioses sanguinarios como Huitzilopochtli y que nos veamos invadidos de los polígamos de una secta estadounidense que ha sido condenada por la sociedad y el gobierno de aquella nación. Si se concede a todos los cultos la facultad de establecerse quedarán incluidos hasta los más desvergonzados, pero si se excluyen algunos por considerárseles opuestos al bien público: aquí comienza la intervención del gobierno en asuntos religiosos. Para algunos sectarios o impúdicos dicha acción será una muestra de la intolerancia católica, otros la considerarán una legítima defensa para con la ciudadanía". ${ }^{20}$

En semejante discusión terció otro pequeño grupo de diputados que introdujo un argumento de peso y de pesos. Era evidente -y, entre otros, el gobierno de Comonfort lo sabía- que muchos inversionistas provenientes de Prusia, Inglaterra, Estados Unidos, así como algunos franceses se inhibían de establecerse en la República porque no podían construir sus templos de fe luterana, anglicana, metodista, bautista y presbiteriana. Peor aún, sabían del monopolio que ejercía el clero católico en cuanto a los enterramientos en campo santo; ello evitaba que los protestantes se sintiesen tranquilos de terminar sus días con la propiedad debida. Estas razones eran tan reales, que la correspondencia diplomática inglesa pone en evidencia que ambas solicitudes -templos y panteones- fueron reiteradamente enviadas a los diversos gobiernos mexicanos; de ello dan cuenta los respectivos reportes que llegaban al Foreign Office de Londres. Sin embargo, el claridoso José Joaquín Pesado, en su citada diatriba, también incluyó semejante polémica:

Se ha argumentado que la tolerancia religiosa sería el medio más adecuado para que los extranjeros industriosos se avecindasen en la república. Ello es una falacia. En México no se molesta a los europeos y estadounidenses por

20 "Exposición sobre la tolerancia religiosa", La Cruz, 3 de julio de 1856, p. 430, Biblioteca Digital-Fondo Resevardo, Biblioteca Nacional-México. Véase Villegas Revueltas, Silvestre, "De religiosos, abogados y literatos. La discusión entre conservadores y liberales sobre la dos potestades y la tolerancia religiosa, 1855-1857”, en Suárez Cortina, Manuel, et al., (coord.), Cuestión religiosa España y México en la época liberal, Santander, Universidad de Cantabria, 2013, p. 117. 
motivos religiosos, lo que retrae a aquéllos de venir a México es el estado de perpetua revolución en que vivimos, es la falta de seguridad en las poblaciones y caminos, es la impunidad de los malhechores, es la paralización del comercio, son las enormes exigencias del fisco que absorbe las utilidades de la industria e inhibe el establecimiento de muchas otras, es, en fin, que la última legislación [Ley de desamortización] hace imaginaria la auténtica propiedad privada y se anuncian ya los principios disolventes del comunismo. ${ }^{21}$

El 11 de abril de 1857, el gobierno de Comonfort se enfrentó de nueva cuenta con la jerarquía eclesiástica en otro asunto que minaba el poder económico de la Iglesia y representaba un entrometimiento en su administración interior. La llamada Ley de Obvenciones Parroquiales o Ley Iglesias señalaba que la administración de sacramentos y demás funciones efectuadas por los sacerdotes se harían sin costo alguno para los feligreses, debido a que el gobierno mexicano les asignaría un sueldo a los religiosos y se encargaría de administrar los fondos necesarios para todos los asuntos relacionados con el culto divino. En las consideraciones de la ley, el nuevo ministro de Gobernación, José María Iglesias - quien sustituyó a Lafragua, cuando éste fue enviado para tratar de resolver los urgentes problemas con España- explicaba que habían sido frecuentes las quejas relativas a los abusos cometidos por los curas contra quienes, por su extremada pobreza, no podían satisfacer los derechos que importaban la realización de los sacramentos; la situación había llegado a tal punto que era indispensable la intervención de la autoridad civil. El gobernador de Guanajuato, Manuel Doblado, cuyo estado formaba parte de la diócesis de Michoacán, señaló lo siguiente: "El pueblo esperaba con ansia esa ley, porque se prometía de ella el alivio de sus necesidades; porque creía que ella le venía a librar de una de las cargas que más le hacen sufrir... para libertarse de la coacción con que se le exige un tributo que sus padres han pagado por más de tres siglos". 22

El obispo Munguía contestó que no permitiría que la ley fuera fijada en los cuadrantes de las parroquias y, aunque por fuerza se pusiese, no se le tomaría por ley ni mucho menos sería obedecida. Agregaba que, aunque los sacerdotes fueran forzados a no cobrar por la administración de sacramentos, la obligación de conciencia subsistía entre los fieles y, si por falta de sustentación o a consecuencia de los destierros llegaren a faltar eclesiásticos, ninguno de los males

21 Ibidem, p. 118.

22 Doblado, Manuel, Memoria leída en la inauguración del H. Congreso del Estado el día 31 de julio de 1857, Archivo Manuel Doblado, Universidad de Guanajuato, pp. 13 y 14, véase en Villegas Revueltas, Silvestre, "Los obispos y la reforma liberal", Metapolítica, La tradición:memoria desterrada, vol. 6, núm. 22, marzo-abril de 2002, p. 98. 
relativos a la falta de administración de los sacramentos serían responsabilidad de los sacerdotes, sino de la ilegalidad de la ley y su carácter abusivo. Finalmente señaló una verdad inobjetable: el gobierno mexicano, por su perpetua bancarrota y por el permanente déficit en el pago a los empleados de gobierno y del ejército, estaba imposibilitado para cubrir no sólo los gastos relativos al divino culto sino que, en particular, tampoco podría solventar los sueldos de una población de individuos - las diversas clases de religiosos- que, diseminados por todo el país, diariamente, con método y de una manera rigurosa, cumplían con una labor esencial en la vida cotidiana de los mexicanos. ${ }^{23}$ Asimismo y para terminar, Munguía enfatizó que los sacerdotes no querían - mucho menos él, en particular- convertirse en empleados de los gobiernos mexicanos.

\section{La Constitución EXCOMUlgada}

Uno de los propósitos más importantes del Plan de Ayutla reformado en Acapulco fue la formación de un congreso constituyente que se encargaría de redactar una carta fundamental. Al integrarse la planilla con los nombres de los diputados que integraron el constituyente, se pudo ver que una gran mayoría estaba compuesto por liberales moderados y algunos radicales distinguidos por su combatividad; cabe señalar que los gobiernos estatales designaron diputados de principios disímiles e incluso, antagónicos dentro del liberalismo. Los abiertamente conservadores no participaron porque les desagradaba el proyecto y el personal "revolucionario", y porque tampoco fueron escogidos por las autoridades locales. El congreso comenzó a trabajar bajo la amenaza del primer levantamiento en Puebla y, a lo largo de dos años de conocer las múltiples asonadas militares, de padecer genuinas presiones de conciencia y de no estar realmente convencidos con lo que se prescribía en algunos artículos de la Constitución, todo ello produjo en los miembros de la asamblea dos actitudes distintas. La primera fue que algunos diputados vieran en los alzamientos cuartelarios, en los reclamos públicos y en lo suscrito por la prensa más refractaria, una legítima preocupación sobre el tipo de Estado que pudiera resultar de la Constitución y una negativa frente a temas muy particulares - "exaltados" en el fraseo decimonónico- que se debatían en el Constituyente. Teniendo en mente lo anterior, ciertos diputados modificaron sus principios de un término medio -que ellos llamaban ordenado y racional- a un "conservadurismo ilustrado", que igualmente estaba lejos de lo preconizado por un Mejía o el padre Miranda.

23 Decreto del Ilmo. Obispo de Michoacán, normando la conducta de los sres.curas, sacristanes mayores y vicarios de su Diócesis con motivo de la ley del 11 de abril de 1857sobre derechos y obvenciones parroquiales, Morelia, Imprenta de Arango, 1857, vid. Infra. 
La otra postura -la llamada radical, jacobina y roja- pretendía materializar un giro completo procurando que las medidas prometidas y resultantes de "la revolución” se llevaran a su último extremo. Sostenían (en ello tenían razón) que el clero -en particular los conservadores seculares- combatiría de igual manera tanto las medidas liberales "a medias" como aquellas "radicales" que representaran un cambio absoluto.

El Congreso comenzó sus trabajos en armonía con el presidente Comonfort, pero existía un divorcio fundamental respecto a lo señalado en el párrafo anterior. El Presidente había señalado que los diputados constituyentes tenían la experiencia legislativa de los congresos anteriores y de toda la suma constitucional abolida en la década de 1830, 1840, así como en la primera mitad de la de 1850. Por tales razones, les recomendaba a "los representantes populares" hacer una ley fundamental que tomara en cuenta "los buenos legados del pasado, buscara una reforma positiva en los temas que preocupan a la ciudadanía", y que dicha reforma reflejara la situación real del país, amén de ser acorde con los sentimientos del pueblo mexicano; era indispensable respetar esta última pretensión en el caso de que los diputados fueran realmente democráticos y hubiesen comprendido el sentir de sus representados. Por su lado, un núcleo fundamental de los representantes populares pensaba que se debía reformar a fuerzas y violentamente a la sociedad mexicana. Tenían la idea de que impulsar hasta sus últimas consecuencias los principios revolucionarios arrastraría a la sociedad a estadios superiores, a pesar de que muchos de los cambios que pudieran establecerse en el texto constitucional de primera intención fuesen desagradables, abrumasen conciencias y no fueran comprendidos por ese pueblo al que estaban destinados. Al final, se acabaría por comprender lo positivo de aquellos ordenamientos que buscaban transformar los hábitos y creencias del pueblo mexicano: muy dieciochescamente se le quería modernizar desde arriba. En cambio, para estos liberales radicales, moderarse llevaría al inmovilismo, quizás al retroceso o a la tiranía, como se convirtió el último gobierno de Santa Anna con sus diversas acciones persecutorias. Reiteraban que, resultante de tales políticas persecutorias promovidas por el santannismo, los dos planes surianos incluyeron en las tareas propias del constituyente, la facultad de revisar y juzgar los actos del general Santa Anna durante su gobierno y vigilar las acciones que pudiera desarrollar el Ejecutivo provisional, pues debido a que la revolución había "derrotado a una dictadura y creó otra dictadura", ambas naturalmente tendían al despotismo. ${ }^{24}$ Esta facultad revisora provocó un permanente enfrentamiento entre el Poder Eje-

24 Respecto a la innata aversión del radicalismo frente al Ejecutivo y la manera como llegó Santa Anna al poder en 1853, véase Villegas Revueltas, Silvestre, "El golpe de estado en 
cutivo y el Congreso. Es decir, la revolución le dio a la asamblea constitutiva funciones injerencistas respecto a la política diaria de la administración de Comonfort. Para Emilio Rabasa:

La acción del [Ejecutivo quedó bajo la tutela] de la Cámara y subordinaba al voto de los diputados todos sus procedimientos, destruía con unas cuantas palabras las facultades omnímodas que se habían creído indispensables para darle vigor al gobierno revolucionario, y lo hacía más pobre de medios y más escaso de facultades que cualquier gobierno constitucional. La facultad de revisión otorgada al Congreso estuvo a punto de producir las más violentas escisiones... [las cuales no llegaron hasta la ruptura final de diciembre de 1857], debido a la prudencia de Comonfort y el respeto que merecía su honradez política. ${ }^{25}$

En la perspectiva de los diputados del Constituyente y para los que seguían la teoría radical de la representación popular, el Ejecutivo siempre había buscado - veladamente y no- la obtención de poderes extraordinarios más allá de lo prescrito por la Constitución. Los diputados de 1857 tenían presentes todas aquellas iniquidades que se habían sucedido en México por la falta de un Congreso que hubiese limitado los autoritarios afanes del Ejecutivo, o debida a la complicidad de la cámara en asuntos esenciales; en la opinión de aquellos, sin un cambio en las formas de hacer política, los presidentes mexicanos propenderían todas las veces a ser los jefes natos de la nación. Los constituyentes querían llegar al estadio donde la "Asamblea Nacional" era el Ejecutivo; hacer práctica la teoría del jacobinismo francés, hacer una "revolución a la Quinet le había espetado Melchor Ocampo a Comonfort en octubre de 1855 y eliminar una herencia cultural hispánica de autoritarismo y centralización del poder". ${ }^{26}$

Pero el momento de la segunda administración suriana y la discusión constitucional todavía no llegaban a la ruptura. En cambio, el México entre 1855 y diciembre de 1857 se caracterizó por la de un enemigo -la última y joven oficialidad santannista y los apellidados conservadores de la misma generación del presidente y su gabinete- resuelto a acabar con todas las reformas liberales. El tiempo de Ayutla fue el de un Congreso combativo y un Presidente que, durante dos años, y debido a las facultades extraordinarias

el imaginario juarista" en Vázquez, Josefina (coord.), fuárez historia y mito, México, El Colegio de México, 2010, pp. 215-242.

25 Rabasa, Emilio, La constitución y la dictadura, México, Porrúa, 1982, p. 58.

26 Véase Ocampo, Melchor, "Mis quince días de ministro", Obras completas, México, El Caballito, 1978, t. II: Escritos Políticos. 
que le concedían los planes surianos, se convirtió en un legislador paralelo que produjo las leyes más radicales del periodo.

Se vislumbraban los pródromos de la guerra civil que, hablando con más propiedad, era o sería la guerra de facciones. El enfrentamiento entre el Ejecutivo y el Legislativo era directo y el ministro de Fomento, Manuel Siliceo, señalaba: los reaccionarios han conseguido dividir al partido liberal, "aprovechando la mentecatería de tanto animal como hay en el Congreso". En el mismo sentido, Comonfort expresaba: "son a veces tan ridículas y exageradas las pretensiones del partido puro... que verdaderamente me vienen ganas de abandonar la presidencia y largarme fuera de la república". ${ }^{27}$ El pleito se efectuaba cuando en ambos poderes de gobierno los liberales trabajaban para lograr una reforma modernizadora y el encono afectaba su conceptualización. Era "en esas horas de fiebre cuando el Congreso constituyente conspiraba contra el Ejecutivo usando la Constitución como arma de intriga y éste conspiraba contra aquél levantando una opinión adversa, y el militar y el cura conspiraban contra todos los poderes", vociferaba Daniel Cosío Villegas desde el plano de la perspectiva histórica. ${ }^{28}$

El 15 de diciembre de 1856, el papa Pío IX sentenciaba que el gobierno le había declarado cruda guerra a la Iglesia, a sus intereses y a sus derechos. Asimismo, señalaba que la Cámara de Diputados había elaborado una constitución compuesta de muchos artículos en oposición a la divina religión, su doctrina, santísimos preceptos y derechos. El decreto pontificio - que algunos consideraron apócrifo- condenó el todavía inacabado y mucho menos publicado texto constitucional, además de reprobar toda la legislación reformista-liberal llevada a cabo en ese año por el gobierno de Comonfort: "Declaro írritos y de ningún valor los mencionados decretos y todo lo demás que haya practicado la autoridad civil con tanto desprecio de la autoridad eclesiástica y de esta Silla Apostólica... Por lo tanto prevenimos... a aquellos... que mediten severamente sobre las penas y censuras que conminan las constituciones apostólicas y los Cánones de los Concilios contra los violadores de las personas y cosas sagradas". ${ }^{29}$

El sentido del texto pontificio planteaba un cisma de conciencia para todos aquellos mexicanos, fuesen o no diputados, que se considerasen católicos,

27 Carta de Ignacio Comonfort a Joaquín Moreno, 24 de julio de 1856, Archivo Comonfot, Universidad de Texas, véase en Villegas Revueltas, Silvestre, El liberalismo moderado..., op cit., p. 168.

28 La Constitución de 1857 y sus críticos, México, Secretaría de Educación Pública-Diana, 1980 , p. 40 .

29 Jiménez Codinach, Lourdes, "La reividicación de los derechos del estado laico frente a la Iglesia Mexicana", México, Biblioteca Jurídica Virtual del Instituto de Investigaciones Jurídicas-Universidad Nacional Autónoma de México, 23 de julio de 2017, https://archivos. juridicas.unam.mx/were./bjo/libros/7/3100/24.pdf.. 
seguidores de sus dogmas y obedientes de sus pastores. Siguiendo semejante debate, Emilio Martínez Albesa, sin duda uno de los estudiosos más concienzudos de la problemática relación entre el Estado y el clero católico mexicano, apuntó las razones por las cuales el articulado de la Constitución de 1857 resultaba negativo para éste último y para el sumo pontífice, cuando al final de cuentas el texto llegó a Europa:

Con los artículos $3^{\circ}, 6^{\circ}$ y $7^{\circ}$ se trata de garantizar unas libertades [enseñanza, expresión e imprenta] retirando a la Iglesia su facultad de supervisión o de control de tales actividades. Con el artículo $5^{\circ}$ se confirma el retiro del reconocimiento civil en torno a los votos religiosos y se abre el camino a la supresión religiosa. Con el artículo $9^{\circ}$ [libertad de asociación] se abre la puerta a la licencia de cultos no católicos, a pesar de la reprobación del art. 15 del proyecto original [ver p. 10, nota 15]. El artículo 13 eleva a principio constitucional la supresión del fuero eclesiástico[...] El segundo párrafo del artículo 27 hace otro tanto con la prohibición de adquisición de bienes raíces por parte de la Iglesia contenida en la Ley Lerdo[...] Los artículos 56 y 57 excluyen a los eclesiásticos de intervenir directamente en la vida política nacional, si bien no se les niega el voto activo. Claramente estos artículos tienen por objeto en cuanto respecta a las relaciones del Estado con la Iglesia alejar a éste de las fuentes de poder ideológico, social, económico y político. ${ }^{30}$

Los trabajos del Constituyente terminaron al despuntar 1857. Cada discusión había sido una erupción volcánica que estremecía hasta las entrañas a la sociedad, pero a nadie satisfacía. La prensa del momento indicaba que los conservadores miraban a la Constitución como la expresión de todos los delirios demagógicos; los liberales moderados decían que picaba por exceso en las trabas que imponía al poder público, en particular al Ejecutivo; los exaltados ("pocos pero gritan mucho") creían que todavía se había quedado atrás en materia de innovaciones, y los hombres religiosos encontraban

30 La Constitución de 1857, catolicismo y liberalismo en México, México, Porrúa, 2007, t. III, De la paz con Estados Unidos a la caída del Segundo Imperio, 1848-1867, p. 1320. En cuanto al problema de la tolerancia de cultos, la propuesta de artículo 15 se transfirmó en el artículo 123, el cual fue presentado para su discusión y aprobación el 26 de enero de 1857. El texto dice: "Corresponde exclusivamente a los poderes federales ejercer en materias de culto religioso y disciplina externa, la intervención que designen las leyes". Para Martínez Albesa, "el artículo es claramente regalista, por el cual el poder civil presupone su derecho a intervenir en materias de culto y disciplina... Éste derecho...no depende de concesiones pontificias, ni de convenios con la autoridad papal... sino que se presupone inherente a la soberanía nacional" (vid. Infra). Asimismo, el Estado liberal se dota "de un artìculo que le permite intervenir sobre la vida eclesiàstica, de manera que vigilara y mantuviera la actividad de la Iglesia restringida a esa esfera en la que se le consentirìa desenvolverse", p.1321. 
en ella un compendio de impiedades. El 5 de febrero de 1857, Comonfort juró la Constitución y con ello cumplió con lo ofrecido en el Plan de Ayutla reformado en Acapulco, pero el 17, el presidente en sesión de la Cámara le señaló a los diputados: "sólo [al] pueblo soberano, a cuyo bien consagrasteis vuestros desvelos y de cuya voluntad dependen la estabilidad y vigor de las leyes constitutivas, toca[...] la calificación inapelable de lo que os pidió". El diputado Francisco Zarco respondió al discurso presidencial indicando que los miembros del Congreso entendían que la humanidad evolucionaba constantemente y que dicha característica era la razón de existir en los tiempos actuales; por ello, habían dejado en el texto constitucional una vía expedita para su reforma, con la precaución de que las modificaciones fueran reclamadas y, una vez llevadas a cabo, fueran aceptadas por el pueblo. Y agregó: "Si queréis libertades más amplias que lo que os otorga el código fundamental, podéis obtenerlas por medios legales y pacíficos. Si creéis, por el contrario, que el poder de la autoridad necesita más extensión y robustez, pacíficamente también podéis llegar a este resultado". ${ }^{31}$

El sentido del discurso de Zarco respondía a una serie de rumores ya extendidos desde principios de 1857, en el sentido de la posibilidad de un golpe de Estado en contra de la Constitución. Los miembros del Poder Ejecutivo y algunos gobernadores que tenían nexos con los diputados les señalaron reiteradamente que el Presidente de la República se consideraba sin poderes suficientes para enfrentar los diversos alzamientos que paradójicamente fueron menguando a lo largo del año, como se presagia la atmósfera antes de una tormenta.

\section{EL GOLPE DE ESTADO}

La situación de 1857 no era normal. Desde una perspectiva histórica, lo que sucedió durante aquellos doce meses fue el punto previo a la conflagración generalizada. Fue el tiempo cuando, durante las procesiones de Semana Santa, el clero de la catedral metropolitana avisó que, a pesar de la costumbre, no dejaría entrar a las autoridades municipales, encabezadas por el radical Juan José Baz, quien, a pesar de la negativa decidió tumbar las puertas e ingresó a caballo al templo -el episodio se dio en llamar La batalla de Jueves Santo- ${ }^{-}$También era el tiempo cuando se arrestó al arzobispo Lázaro de la Garza y cuando el famoso cura Ortega de Zacapoaxtla previno directamente

31 "Editorial", El Siglo Diez y Nueve, 5 de julio de 1857, en Villegas Revueltas, Silvestre, op cit., p. 170. 
Esta obra forma parte del acervo de la Biblioteca Jurídica Virtual del Instituto de Investigaciones Jurídicas de la UNAM www.juridicas.unam.mx https://biblio.juridicas.unam.mx/bjv

al presidente Comonfort que en esos días se tramaba asesinarlo. Era, en fin, el tiempo en el que el Poder Ejecutivo lanzó las últimas leyes reformistas que afectaban los intereses de la Iglesia, cuando, debido a los gastos militares, la quiebra del erario era inminente y se murmuraba un golpe de Estado. Era el ambiente patológico donde todos se veían con desconfianza, donde la Constitución con todos sus aciertos y sus defectos era el blanco más fácil para echarle en cara los males de la nación.

Con el objetivo de entrar de lleno al régimen constitucional se verificaron elecciones para la Presidencia de la República. Los moderados tenían en Comonfort su candidato, porque pensaban que si bien seguiría con la línea de las reformas liberales, no caería en el "delirio demagógico de los exaltados". Estaban conscientes de que la mayoría del ejército lo apoyaba y, a pesar de su enfrentamiento con el clero, era el candidato más flexible en asuntos de política interior, particularmente en aquellos que todavía no habían sido tocados por la reforma liberal y preocupaban a los conservadores.

Por otro lado, "los puros" veían a Comonfort con desconfianza porque repetía con imprudente frecuencia, que, si bien no repugnaba los principios del partido puro, aunque le parecían bellas teorías, "al personal grosero de ese partido no lo podía tolerar". Los radicales no eran un grupo político compacto, no era fácil que aceptaran a jefes como cabezas de una organización y más bien los unía la comunión de ideas amén de un proyecto de país. Tres figuras podían competir como candidatos a la Presidencia. Melchor Ocampo, que en opinión de Lafragua siempre estaba en las nubes y desde aquellos lugares etéreos no se podía gobernar un país convulsionado, era un candidato que sulfuraba de inmediato "al partido conservador". El otro era el gobernador de Oaxaca, Benito Juárez, personaje todavía circunscrito a la política provinciana, aunque ya había conmovido al mundo judicial y del ejército, así como al clero con la ley, que -como un solo acto de gobierno-identificó a la brevísima administración de Juan Álvarez. Finalmente, se lanzó a la contienda electoral el exministro de Hacienda, Miguel Lerdo de Tejada, quien concibió la ley más importante del régimen, la que provocó docenas de pronunciamientos y generó que la clerecía lanzara sus anatemas más severos en contra de los adjudicatarios de bienes eclesiásticos. La campaña política duró de marzo a junio de 1857 y, como todas, estuvo acompañada de comentarios y escritos difamantes. En un panfleto - prohibido por la ley Lafragua que regulaba la aparición de impresos- se leía: "Si votáis por Comonfort tendréis un gobierno fuerte, progresista y protector que os hará felices. Si votáis por Lerdo tendréis un gobierno débil, despilfarrador $y$ prostituido que os hará desgraciados sin remedio $y$ os envilecerá". 
Comonfort ganó las elecciones abrumadoramente y fue declarado presidente electo el 13 de julio. El periódico El Tiempo publicó un editorial donde analizaba la situación de la nueva administración constitucional: "No sabemos qué sucederá cuando este fantasma de poder tenga enfrente de sí, y probablemente en su contra al Congreso... No sabemos que será de la república cuando sin tener un supremo poder regulador, una autoridad central se enfrente a los principios divergentes de los representantes populares y cuando más de veinte asambleas legislativas, cada una de las cuales se tendrá por soberana". ${ }^{32}$

Pasados los comicios, se acercaba el 16 de septiembre, día en el que la Constitución empezaría a regir. El gobierno organizó magníficas fiestas para resaltar el aniversario de la Independencia y el inicio de la senda de la legalidad para México. Durante el desfile principal, Comonfort ciñó la banda de coronel en su paso por las calles de la capital, no la de general de división. La razón de ser de esta postura probablemente fuera el hecho de que en 1856 el Congreso se negó a reconocerle el grado de general concedido por Juan Álvarez en sus últimos días de gobierno, grado que de una manera informal se le había dado desde la campaña de Ayutla, pero que contrastaba con los papeles privados donde reiteraba su orgullo de ser coronel de la guardia cívica de Puebla. ${ }^{33}$ También, aunque es una apreciación subjetiva y más romántica, suponemos que Comonfort no se sentía mal de repetir el ejemplo de Napoleón Bonaparte, quien, a pesar de ser emperador y mandar a generales y mariscales, gustaba de usar el uniforme de coronel de artillería.

Relativo a los sucesos narrados de septiembre debe tomarse en cuenta que habían transcurrido cinco años (1852-1857) de inestabilidad política. Se sumaron siete presidencias y el país transitó de un federalismo de acuerdo con el código de 1824, a la implantación de otro, de acuerdo con el novel código de 1857, que, en el caso de la presidencia constitucional, empezaría a funcionar a partir del primero de diciembre. Los documentos privados, los editoriales de la prensa y los posteriores libros que historiaron el periodo - de acuerdo con los cánones de la historiografía inmediata, como los dos textos

32 Hemeroteca Nacional-Mèxico, 16 de julio de 1857, p.1.

33 Para las campañas en el noreste mexicano bajo la comandancia de Santiago Vidaurri y posteriormente todo el lapso de su incorporación a las fuerzas repúblicanas que combatieron durante el segundo sitio de Puebla (1863) y su final nombramiento como ministro de la guerra del presidente Juárez en San Luis Potosí, los documentos oficiales hablan de Comonfort como general de división; desde su exilio parisino Miguel Miramón desdeñosamente lo llamó: el aduanero de Acapulco. 
Esta obra forma parte del acervo de la Biblioteca Jurídica Virtual del Instituto de Investigaciones Jurídicas de la UNAM www.juridicas.unam.mx https://biblio.juridicas.unam.mx/bjv

de Anselmo de la Portilla-34 calificaron a todos los gobiernos del periodo como dictaduras, a pesar de que en su momento los presidentes fueron llamados interinos, sustitutos, Alteza Serenísima o jefe de la revolución (a la administración de don Ignacio le agregaron el apellido de liberal).

Para octubre y noviembre de 1857 no había ningún movimiento reaccionario de importancia, pero sí se palpaba algo así como una quietud que encubría dudas, condenas pasadas y temores al interior de las filas "partidistas". Comonfort veía en el horizonte que se acercaba un conflicto mayúsculo, que sus relaciones familiares se estaban deteriorando, además de soportar las presiones para que se verificara un cambio de orientación en la política nacional y se limaran las asperezas con la jerarquía eclesiástica. Guillermo Prieto narró a posteriori que lo que ganaban los políticos durante la mañana, se perdía en las noches, cuando el Presidente se dirigía a la casa materna en Tacubaya, donde confluían socialmente la familia del compadre Félix Zuloaga, otras más pertenecientes a la oligarquía de la Ciudad de México y diversos eclesiásticos cercanos a Munguía y al arzobispo De la Garza.

Aunado a lo anterior y ya en el plano de la diaria administración de gobierno, al Presidente le rondaba la incesante idea de que la Constitución no era la adecuada para la República; sus amigos le señalaron que lo era mucho menos para cualquier gobierno que se ligara a ella. Por estas razones, cuando juró como Presidente constitucional el primero de diciembre, el discurso de Comonfort fue distinto al de los meses anteriores, al advertirles directamente a los diputados que, para salvar la existencia de la Constitución y consolidar un clima de paz necesarísimo para la República, el remedio más eficaz era hacerle al código saludables y convenientes reformas: "A este fin el gobierno os dirigirá en breve las iniciativas que estime necesarias y espera que serán resueltas con la prontitud y acierto que demandan los más caros intereses de la sociedad. La rapidez con que he llenado las promesas de la revolución de Ayutla me hacen esperar que mis indicaciones serán escuchadas". ${ }^{35}$

El primer gabinete constitucional de Comonfort estuvo integrado por Antonio de la Fuente, en Relaciones; Manuel Ruiz, en Justicia, Manuel Payno, en Hacienda; José García Conde, en Guerra; Bernardo Flores, en Fomento. Benito Juárez fue nombrado secretario de Gobernación, pero, además, había

34 Historia de la Revolución de México contra la Dictadura del General Santa Anna, México, Imprenta de Vicente García Torres, 1856; Méjico en 1856 y 1857. Gobierno del General Comonfort, Nueva York, Hallet \& Co., 1858; [Ignacio Comonfort], Política del General Comonfort durante su gobierno en Méjico, Nueva York, s/e, 1858.

35 Villegas Revueltas, Silvestre, "La Constitución de 1857 y el golpe de estado de Comonfort", Estudios de Historia Moderna y Contemporánea de México, núm. 22, julio-diciembre de 2001, p. 76 (las cursivas son mías). 
sido elegido presidente de la Suprema Corte de Justicia; de acuerdo con la Constitución de 1857, frente a una ausencia temporal o renuncia del titular del Ejecutivo, aquél se convertiría en Presidente interino. A los pocos días, Payno renunció al ministerio y Comonfort supo de un rumor acerca de que don Manuel, en conjunción con Juan José Baz y el general Félix Zuloaga, conspiraba contra la Constitución. Los mandó llamar y ellos le expusieron cuál era el estado de la situación. Para 1860 y todavía bajo el gobierno de Miramón, Payno publicó un texto titulado Memoria sobre la Revolución de diciembre de 1857 y enero de 1858. En éste relataba que los confabulados le expresaron a Comonfort que la Constitución era un estorbo y no había otro remedio más que hacerla a un lado; el siguiente paso era quitar también al Congreso. Comonfort estaba perplejo, la franqueza con que le decían las cosas lo dejaba apesadumbrado; preguntó sobre la Ley de Desamortización. Baz y Payno coincidieron en que sus efectos en la traslación de dominio sobre bienes inmuebles eran irreversibles. Le preguntó a Zuloaga sobre el estado de su división y éste le contestó que era difícil controlarla. Una vez expuestas las razones y circunstancias, Comonfort les comentó que para el éxito de la empresa era necesario contar con el apoyo del general Parrodi, en Jalisco; de Doblado, en Guanajuato; del Distrito Federal, y del gobernador De la Llave en Veracruz. Se convino en enviar a diversas personas para informar a los gobernadores acerca del plan que se estaba tramando. Doblado, quien llegó a la capital por los primeros días de diciembre, tuvo tres conferencias con los confabulados, les reiteró que era un error acabar con la legalidad constitucional para cimentar un estado de orden, cualquiera que fuese su orientación. Le recomendó a Comonfort que le planteara al Congreso la urgencia de algunas reformas y que sólo si eran desechadas podría disolverlo, pero nunca renunciar a su legítimo cargo y poderes. $\mathrm{Al}$ respecto, Payno relataba lo siguiente en su texto: "Reprodujo las mismas razones que a nosotros nos habían dado sobre las nefastas consecuencias de un golpe, y recuerdo que trazó con tanta exactitud un cuadro tan vivo y tan completo de todo lo que podía suceder al romperse el orden legal, y en efecto está pasando, que parece que detrás de un espejo estaba mirando el porvenir caracterizado por la guerra civil", ${ }^{36}$

El 17 de diciembre, en la villa de Tacubaya se pronunció la división Zuloaga con un plan que, en esencia, desconocía la Constitución federal de 1857, pero ratificaba a Comonfort como Presidente de la República, otorgándole facultades extraordinarias. Dos días después, en medio de un sinfín de vacilaciones, Comonfort firmó el documento. Al hacerlo, dijo: "acabo en este momento de cambiar mis títulos legales de Presidente, por los de un miserable re-

36 México, Ignacio Cumplido, 1860, pp. 95-97. 
volucionario; en fin, ya está hecho y no tiene remedio. Acepto todo y Dios dirá por qué camino debemos marchar". Para Justo Sierra, jamás un César más modesto y con menos confianza en sí mismo y en el porvenir pronunció el alea jacta est: lo pronunció a media voz. Al mismo tiempo que aceptaba el Plan de Tacubaya, Comonfort publicó un desplegado donde explicaba cuáles habían sido las razones para secundar el alzamiento y cómo habría de gobernar para alcanzar el consenso entre los grupos políticos. En este documento apuntaba que el carácter suave y las costumbres sencillas del pueblo mexicano debían guiarlo para que, de acuerdo con los principios liberales, encontrara el camino de la prosperidad y del engrandecimiento que finalmente había sido abrazado por otras naciones. Reiteraba que estaba convencido de que en México tendría que verificarse una prudente y sabia reforma, pero señalaba que no dictaría ninguna medida que atacara las creencias y las costumbres de los ciudadanos, porque una libertad bien entendida debía respetarlas: "libertad y religión son los dos principios que forman la felicidad de las naciones". ${ }^{37}$

El gobierno revolucionario instaló un Consejo de Estado formado por algunos liberales y una mayoría conservadora; obviamente no se ponían de acuerdo y, dado que los días pasaban, el conservador José María Cuevas se entrevistó con Comonfort. Ambos discutieron el rumbo político que debería tomar el nuevo gobierno y cuáles eran los principales problemas del país. En un momento dado de la conversación, Comonfort lo interrumpió y le preguntó:

Prescindamos ahora de comparaciones entre principios liberales y principios opuestos, y veamos en sustancia lo que de mi se exige: se exige que yo reniegue de mis principios, de los principios que proclamé en el Plan de Ayuda, que he sostenido durante mi presidencia y que he proclamado al aceptar el Plan de Tacubaya; se exige que yo abandone a mis amigos, que los entregue a la persecución de sus adversarios y que yo mismo sea el que decrete sus persecuciones. ¿Qué haría usted en mi lugar? - a lo que Cuevas contestó- que como caballero no lo haría, concluyendo Comonfort: ¡Gracias, yo no lo haré jamás!38

$\mathrm{Al}$ día siguiente de esta conversación, la brigada Zuloaga y otras más se pronunciaron nuevamente, pero en esta ocasión desconocieron a Comonfort. El general José de la Parra -testaferro del alzamiento- señalaba que la cuestión del momento no era de principios sino personal: Comonfort había continuado con una conducta de contemplación, equívoca y vacilante, ante todos los partidos. Tal postura lo colocaba en una falsa posición, que era incompatible

37 Ignacio Comonfort, [hoja suelta], 19 de diciembre de 1857, García Papers, F.17, Benson-Latin American Collection, Universidad de Texas/Austin.

38 Zamacois, Niceto de, op. cit., p. 696. 
con la conservación pública de la paz y la organización de un nuevo estado de cosas. Con este segundo cuartelazo se llegaba a la situación lógica del error fundamental de Comonfort, el cual consistió en romper con la legitimidad que la elección constitucional le había otorgado y que todavía podría mediar entre las facciones políticas cuando éstas ya le habían dado la espalda. Durante su exilio en Nueva York y al tiempo que liberales y conservadores lo culpaban de la guerra civil que abrumaba al país - conflicto que estaba resultando más largo y más violento de lo que originalmente se pensó en Tacubaya-, llegó a México una carta que explicaba su conducta como gobernante, fue muy mal recibida por los dos bandos, pero pinta muy bien al personaje:

[La administración suriana adoptó] una política prudente y reformadora, que satisfaciendo en lo que fuera justo de las exigencias de la revolución liberal, no chocara abiertamente con los buenos principios conservadores ni con las costumbres y creencias religiosas del pueblo. La principal misión de mi gobierno debía ser quitar pretextos a las reacciones y nada más a propósito para lograr este fin que reformar lo antiguo para conservarlo, y marchar por la senda del progreso sin precipitaciones ni violencias. ${ }^{39}$

Dentro del proceso que caracteriza la construcción de un estado nacional en México, la administración de Ignacio Comonfort debe ser considerada, a su vez, como el último intento por evitar la ruptura que necesariamente desembocaría en un conflicto que la historiografia tradicional ha llamado la guerra civil de Reforma, pero que más bien fue un enfrentamiento entre élites, cuyos miembros habían nacido durante el periplo insurgente y habían estudiado en los mismos colegios - como los casos de Lafragua, Haro y Comonfort-; se conocían porque "la sociedad" en las provincias era sumamente pequeña: Ocampo, Munguía y Santos Degollado, y tenían preocupaciones sobre lo que le había sucedido a México en las últimas décadas -particularmente las consecuencias culturales de la derrota frente a Estados Unidos- y lo que pudiera sobrevenirle al país en el futuro inmediato.

Por otro lado y como segunda lectura, el gobierno de Comonfort - por las muy amplias facultades que el plan de Ayutla le concedía a su administración- llevó adelante toda una legislación y acciones de gobierno que potencializaron la división entre la clase política que incluía al clero, cuyos intereses se vieron afectados, luego de haber sido amenazados desde la década de 1830. Consecuencia de esto último fue que la legislación reformista comenzó, en noviembre de 1855, con la Ley Juárez; tuvo con la ya mencionada Ley de

39 Villegas Revueltas, Silvestre, "La Constitución...", op. cit., p. 80 (las cursivas son mías). 
Desamortización, con la Constitución de 1857 y luego con las leyes promulgadas en el puerto de Veracruz en 1859 y 1860 sus momentos más radicales, pero el movimiento de Reforma no concluyó sino hasta diciembre de 1867, cuando el gobierno de Juárez desconoció el carácter diplomático que tenían las deudas mexicanas con los diversos tipos de acreedores extranjeros. Por su lado, el golpe tacubayista de 1857, además de haber sido un error cuartelario, ahondó la falta de legitimidad que habían ostentado la inmensa mayoría de los gobiernos mexicanos, problema que continuó siendo una piedra de toque para las administraciones conservadoras/liberales, republicanas y monárquicas de la llamada gran década nacional.

El golpe de Estado contribuyó a desencadenar una lucha cruenta que sumaba muchos muertos desde el sitio de Acapulco, de abril de 1854, y que tuvo sus momentos más encarnizados en 1859, 1861, 1865, los cuales sirvieron de punto de referencia para materializar las ejecuciones queretanas de 1867. Los fusilamientos fueron catárticos en el plano nacional y muy bien ponderados por las potencias europeas, las cuales, las décadas de 1870 y 1880, no intentaron otra intervención militar sino que enfocaron sus esfuerzos diplomáticos para aumentar las relaciones comerciales, buscar la realización de obra pública en México, como una forma de inversión en el extranjero, y servirse de la banca "imperial" para que ésta respaldase estos tipos de proyectos económicos. Pero ello es otra historia. 


\title{
LA LUGHA ENTRE MASONES Y CATÓLICOS EN EL PORFIRIATO. LA GREACIÓN DE LA GRAN DIETA SIMBÓLICA DE MÉXICO EN 1890
}

\section{Salvador GÁRDENAS GUTIÉRREZ*}

Ya viene la última era de los Cumanos versos: ya nace de lo profundo de los siglos un gran orden...

$$
\text { VIRGILIO, Égloga cuarta }
$$

Esa existencia del mundo está constituida lingüísticamente...

GADAMER, Verdad y Método

\begin{abstract}
SUMARIO: I. La masonería como hecho lingüístico. II. Del orden medieval al orden moderno. III. El control por la distribución de grados. IV. La creación de la Gran Dieta Simbólica en 1890. V. La reacción de los católicos. VI. La prensa católica de la época. VII. Las grandes líneas del discurso antimasónico en la prensa católica. VIII. León Taxil, Diana Vaughan y el antimasonismo de Trinidad Sánchez Santos.
\end{abstract}

\section{LA MASONERÍA COMO HECHO LINGÜÍSTICO}

Nuestro punto de partida es la consideración de la masonería mexicana del Porfiriato como un hecho lingüístico y no como una ideología compacta y uniforme. De hecho, no creo que haya sido ni lo uno ni lo otro, pues las logias mexicanas no tuvieron la unidad ni la uniformidad que a veces se piensa. Ni siquiera Porfirio Díaz - para quien parecía no haber obstáculo que se le resistiera- consiguió unificarlas, pues, a pesar de haber creado en 1890 la llamada Gran Dieta Simbólica de México, que pretendía ser la logia madre y

* Doctor en Derecho por la Universidad de Navarra. 
cuyo Gran Maestre ad honorem fue él mismo, su duración como dieta de unidad fue efímera.

He dicho que la masonería es un hecho lingüístico y también podría haber dicho un hecho hermenéutico o, incluso, hermenéutico normativo, pues el punto de coincidencia entre las múltiples agrupaciones masónicas es la idea de formar una gramática política y legal para resignificar el mundo a partir de coordenadas distintas a las existentes hasta el siglo XIX. Siendo así, me parece que lo primero que deberíamos hacer al emprender su estudio es una suerte de glosario o vocabulario, pues la masonería creó un lenguaje sumamente sofisticado en el que las palabras no sólo denotan, sino que también tienen un sentido connotativo de realidades complejas. Por ello, aun cuando se han hecho interesantes aportaciones para ahondar en el conocimiento de la historia de la masonería en México, se echan en falta trabajos de investigación en los que se considere lo masónico como un hecho lingüístico, tema sobre el cual Augusto Cochin llamara la atención a principios del siglo XX, señalando que las sociedades masónicas eran, antes que nada, sociedades de pensamiento,${ }^{1}$ es decir, laboratorios de ideas que se traducen en palabras resignificadas.

\section{DEL ORDEN MEDIEVAL AL ORDEN MODERNO}

Una de esas palabras - quizá la más revulsiva de las creadas en el seno de las logias y de las sociedades secretas del siglo XVIII- es orden. Ese vocablo, en su sentido antiguo (medieval), se entendía como la correcta disposición de las partes en el todo, lo cual no significa que las partes sean iguales, sino que contribuyen a dar vida al todo a pesar de ser diferentes en tamaño, función y naturaleza. El todo constituía el ordo medieval, cuyo fundamento era una imagen teocrática del mundo, según la cual las sociedades humanas eran reproducciones en pequeña escala del Cuerpo Místico de Cristo (Corpus Mysticum Christi). De ahí se deducía que, como en todo cuerpo, en el social había diversos órganos que cumplían distintas funciones, a los cuales se dio el nombre de estamentos (nobleza guerrera, clero y artesanado); éstos, a su vez, se dividían en múltiples corporaciones, cada una de las cuales cumplía funciones aun más específicas (órdenes religiosas, municipios, gremios, etcétera). ${ }^{2}$

1 Meaux, Antoine de, Génesis de las revoluciones (según Augustín Cochin), Madrid, Juan de la Cierva, 1945, p. 54.

2 La ideología de la masonería se resume, según un periódico alemán traducido y publicado en México (Die Kölnische Volkszeitung), como una "destrucción de la autocracia y la teocracia", en orden a la creación de repúblicas democráticas y libres. La fuente de donde emanan esos principios ideológicos es la Revolución francesa: "1789 - dice un autor catalán- esa fecha inolvidable 
Esta obra forma parte del acervo de la Biblioteca Jurídica Virtual del Instituto de Investigaciones Jurídicas de la UNAM www.juridicas.unam.mx

https://biblio.juridicas.unam.mx/bjv

La hermenéutica de la masonería se colocó en las antípodas del corporativismo, pues el orden que deseaban instituir no se daba a partir de los estamentos, las corporaciones o la diversidad, sino a partir de una imagen geométrico-lineal de la sociedad. Para ello era necesario destruir la imagen corporativa, plural y gremial, y construir una sociedad de individuos colocados en pie de igualdad ante la ley.

Imagen 1. Simbolo masónico del Gran Oriente, formado por el compás y la escuadra

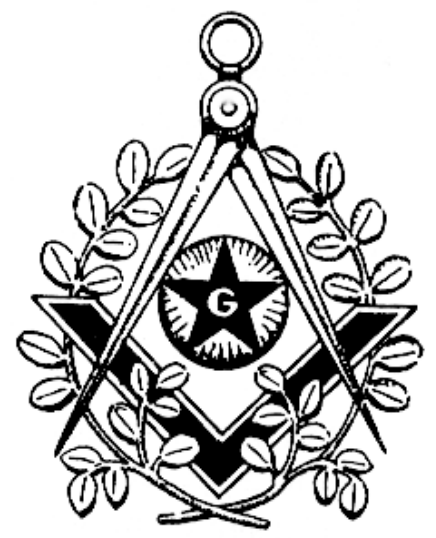

En ese marco de ideas y creencias, la masonería creó una panoplia metafórica asociada a la edificación del nuevo orden: el mandil, el compás, la escuadra y el gramil; la plomada, el cincel, el skirrett y el lápiz, con los que se representaba su tarea de "reconstrucción social" o racionalización hecha a partir de los principios de la geometría. Es suficiente con recordar a este respecto que la primera logia mexicana, fundada en 1806, se llamó Arquitectura Moral, haciendo alusión a ese carácter de su actividad constructiva o reconstructiva del hombre y de la sociedad, a partir de los principios de la razón ocultos en la naturaleza. ${ }^{3}$ Ésta es la explicación que leemos en el famoso Monitor de los Masones Libres, publicado en Estados

en la cual los pueblos rompieron las cadenas de la tiranía debe ser muy apreciada de toda la masonería del mundo, gloria de nuestra orden, que, en este gran suceso, el más glorioso de la historia moderna, tan importante papel le cupo en suerte". "La masonería en el extranjero", El Tiempo, México, 16 de enero de 1890. Y sobre lo mismo, véase Mateos, José María, Historia de la masonería en México, desde 1806 hasta 1884, México, Bancroft Library, 1884, pp. 141 y ss.

3 Ramírez, Esteban M., Apuntes sobre la masonería en México durante los años de 1806 a 1921, por el Gran Luminar, Gran Maestro del Rito Nacional Mexicano..., México, Talleres Linot. Soria, 1921, p. 5. 
Unidos a principios del siglo XIX: "por la geometría podemos penetrar en los ocultos senos de la naturaleza". ${ }^{4}$ No es mera casualidad que cada organización de francmasones se denominara orden, pues con esa expresión se hacía alusión directa y explícita a los "órdenes de la arquitectura", es decir, al arte del diseño y de la construcción basados en el cálculo matemático. Como es sabido, la palabra masón proviene del francés maçon, que significa alarife, arquitecto, constructor, albañil.

La palabra se emplea como metáfora de la destrucción del orden medieval corporativo -también conocido como Antiguo Régimen-, porque, de acuerdo con la lógica racionalista y geométrica de los masones, la diversidad de cuerpos y estamentos autónomos no hacen sino producir asimetrías disfuncionales y caos. De ahí la necesidad de llevar a cabo una obra de cimentación, fundamentación, construcción y reconstrucción de un nuevo orden secular, republicano y liberal (Novus ordo saeculorum, había dicho Voltaire parafraseando a Virgilio), en el que las antiguas corporaciones estamentales desaparecerían, dejando libres a sus miembros y agremiados para asumir su papel de ciudadanos universales, de individuos regidos por un orden matemático y geométrico al que se denominó genéricamente República. Este proceso complejo las sociedades masónicas solían resumirlo en el lema Ordo ab chao, que literalmente quiere decir "orden a partir del caos", una de las máximas de la orden del Rito Escocés Antiguo y Aceptado. Algo parecido se expresa en el otro lema de ese rito, que se abrevia con las siglas: "D:· M: · I: ", que significan Deus meumque Ius, es decir, "Dios y mi Derecho", escrito con los tres puntos ${ }^{5}$ que se empleaban normalmente en la escritura y en las rúbricas de los miembros de la masonería para referirse a la destrucción, construcción y reconstrucción de la sociedad.

Según uno de los más importantes combatientes de la masonería a finales del siglo XIX en México, y de quien hemos de ocuparnos in extenso en las siguientes páginas, don Trinidad Sánchez Santos ${ }^{6}$ los dos pilares filosóficos en los que reposa el discurso de la masonería en torno al orden son el deísmo y el gnosticismo. En la doctrina deísta se dice que el universo fue creado por Dios o por un principio de vida divino llamado Gran Arquitecto del Univer-

\footnotetext{
4 Smith Webb, Thomas, El Monitor de los Masones Libres, Filadelfia, H. C. Carey \& I. Lea, 1822, pp. 40-55.

5 "Una circular notable de la Masonería", El Tiempo, México, 8 de noviembre de 1887.

6 "Hércules del periodismo de combate", don Trinidad Sánchez Santos (1862-1912) es, con mucho, el más importante de los periodistas católicos que dieron la batalla contra lo que ellos consideraban el principal enemigo de su fe: la masonería. Véase Valverde Téllez, Emeterio, Crítica Fillosófica o Estudio bibliográfico y crítico de las obras de filosofía, escritas, traducidas o publicadas en México desde el siglo XVI hasta nuestros días, concluyen con las "Apuntaciones históricas sobre la Filosofia en México", México, Tipografía de los Sucesores de Francisco Díaz de León, 1904, y Márquez, Octaviano, "Trinidad Sánchez Santos, semblanza biográfica”, Obras selectas de Trinidad Sánchez Santos, México, Jus, 1962, t. I.
} 
so. Una vez que ese ser o principio concluyó su obra arquitectónica, abandonó a los seres humanos a su suerte, es decir, no es un Dios-Providente, ${ }^{7}$ como afirma el catolicismo, que se valga de signos sacramentales, cleros e iglesias para asistir al ser humano. Para la mayoría de los masones del siglo XIX, el Gran Arquitecto era un principio indeterminado al que se le solía considerar como un ser superior: "Quien dice arquitecto [leemos en un editorial del periódico El Partido Liberal] da a entender que se refiere a una persona real ocupada en obras de construcción, y quien agrega del Universo, distingue a esa persona de todos los demás arquitectos" ${ }^{8}$ Según los filósofos deístas, cuando el Gran Arquitecto creó el universo dejó ínsito en él un conjunto de principios (eones) de proporcionalidad geométrica, racionalidad y armonía universal que, juntos, forman el pleromo o plenitud de la ciencia, ${ }^{9}$ el cual sólo puede ser conocido por unos cuantos "iniciados en la verdadera ciencia [oculta]". Ciencia que -como señala Eric Voegelin- no ha de ser entendida como un proceso cognitivo que sigue la lógica racional de la relación causa-efecto, sino como el resultado de un salto desde los límites de la finitud de la razón humana hasta los insondables e infinitos misterios de un verdadero saber. ${ }^{10}$ Se trata de un saber iluminado por una luz mítica, como la que se atribuye en la antigua mitología egipcia a Isis, viuda de Osiris, a quien aparentemente se debe la denominación común de los masones en aquella época como "Hijos de la viuda". ${ }^{11}$ Los católicos utilizaban esta expresión en sentido peyorativo, pues el mito de Osiris era empleado por las logias de la masonería mexicana para remontar sus orígenes a épocas ancestrales.

7 Esta idea tiene en Thomas Chubb (1679-1747) uno de sus más claros exponentes. Escribió un libro titulado The True Gospel of Jesus Christ asserted (El auténtico Evangelio de Fesucristo [Londres, T. Cox, 1738]) en el que, además de negar la divinidad de Cristo y sostener que "el verdadero Evangelio es el de la religión natural", afirma que "Dios es un ser que no tiene por qué ocuparse del bien o del mal que existe entre los hombres, ni la Providencia se inquieta por saber si algunos hombres viven en la felicidad mientras que otros se encuentran en la miseria; nada de esto le corresponde".

8 Cosmes, F. G., "La masonería es esencialmente deísta (II)", El Partido Liberal, México, vol. 07, núm. 1, 1896.

9 Sánchez Santos, Trinidad, Historia sintética..., cit., p. 331.

10 Voegelin, Eric, Ciencia, Política y Gnosticismo, Madrid, Rialp, 1973, p. 53.

11 "El Abogado cristiano (II)", El Tiempo, 14 de noviembre de 1893, p. 2; y su continuación en el mismo diario, vol. 16, núm. 11, 1893. 
Esta obra forma parte del acervo de la Biblioteca Jurídica Virtual del Instituto de Investigaciones Jurídicas de la UNAM www.juridicas.unam.mx

https://biblio.juridicas.unam.mx/bjv

\section{EL CONTROL POR LA DISTRIBUCIÓN DE GRADOS}

Normalmente los masones del siglo XIX se agrupaban jerárquicamente en grupos denominados logias de perfección, que formaban capitulos y consistorios y eran gobernados por supremos consejos, integrados por un grupo de masones distinguidos, encabezados por un Soberano Gran Inspector grado $33^{\circ}$, cuya función primordial era administrar los grados de iniciación (también llamados grados de perfección) a los miembros de las logias que fueran demostrando conocimiento de las doctrinas gnósticas y deístas y, sobre todo, lealtad a los altos jerarcas. Los tres primeros grados (metáfora de los niveles de conocimiento secreto en las antiguas corporaciones de artesanos y arquitectos) eran: aprendiz, compañero y maestro, y simbolizaban las etapas de la vida por las cuales el iniciado se transformaba en un ser humano integral. Los demás grados variaban según los ritos.

Para 1867, la mayoría de las logias mexicanas, aunque gozaban de cierta autonomía, obedecían al Supremo Consejo de México, que contaba entre sus más destacados miembros al insigne abogado, hombre de letras y miembro de la Gran Logia del Valle de México, Ignacio Manuel Altamirano. En 1870, un grupo de masones dirigidos por Juan de Dios Arias se rebeló contra ese consejo y creó un nuevo organismo de gobierno llamado Supremo Gran Oriente de México, en donde ya se empieza a hablar de crear una gran logia madre, a la que se denominaría Gran Oriente. Cabe señalar que la palabra oriente significa el lugar por el que sale el Sol, símbolo de la luz, y se emplea para expresar la "luz de la razón que ilumina el camino del masón hacia el conocimiento del orden gnóstico". En el fondo de ésta y sucesivas fragmentaciones de la masonería latía la lucha por el control de los grados. Desde su creación, el Supremo Consejo de México ejerció el control sobre los tres primeros grados, mientras que el Supremo Gran Oriente lo hizo sobre los demás.

Proclamado el Plan de Tuxtepec, en 1877, Porfirio Díaz hubo de hacer frente a los sectores que se le oponían, especialmente a los amigos de Sebastián Lerdo de Tejada, quien al parecer pertenecía al Rito Nacional Mexicano, representado en el campo político por el intelectual Alfredo Chavero, Comendador del Supremo Consejo. En 1878, Chavero y Altamirano encabezaron una nueva partición de la masonería mexicana: representando los intereses de Porfirio Díaz, Altamirano acusó a Chavero y a su consejo de haber violado la constitución de la orden al negarle el control sobre los grados lo a 30 de su propia logia. Fue entonces cuando "el hermano Altamirano [decía un cronista de la masonería] en virtud de sus poderes se declaró por 
sí y ante sí Soberano Gran Inspector Grado $33^{\circ{ }^{\circ}}{ }^{12}$ y, con Emilio G. Cantón, creó el Supremo Consejo del Oriente de México. Así, durante el Porfiriato, se dio la explosión asociativa, en la que proliferaron los ritos, compuestos por diversas logias, las cuales se fueron disipando en diversas facciones con la consecuente pérdida de buena parte de la fuerza que hasta entonces habían logrado entre la burguesía y el funcionariado alto y medio. Éste es el panorama de la época, según Jean-Pierre Bastian:

Al principiar 1890 existían unas 193 logias y 15 grandes logias vinculadas al Gran Valle de México; una cantidad menor pertenecía al Rito Nacional, dirigido por Benito Juárez Maza; otras pocas pertenecían al cisma masónico realizado en 1883, y estaban ligadas a la Gran Logia de Libres y Aceptados Masones, cuyo dirigente era Ignacio A. de la Peña; un número también reducido formaba el Rito Mexicano Reformado, que era una disidencia contra la tentativa del control de Díaz surgida en 1890 y encabezada por Jesús Medina. ${ }^{13}$

En medio de ese caos, la Gran Oriente de México $^{14}$ fundada por Altamirano logró reunir en su seno a un buen número de logias de diversos ritos.

A finales de 1889, según el Boletín Masónico (órgano oficial de la Gran Dieta Simbólica), el Gran Oriente de México, ${ }^{15}$ con la idea de unir todos los elementos masónicos de la República, había celebrado tratados con el Supremo Consejo del grado $33^{\circ}$, por medio de su Gran Logia Valle de México No. 1. En virtud de ellos quedó disuelto el Gran Oriente y, como se ha dicho, se fundó la Gran Dieta Simbólica de los Estados Unidos Mexicanos. La creación de ese rito fue obra del presidente Porfirio Díaz, quien convocó en 1890 a todas las logias del país para que se sumaran al esfuerzo por crear una nueva organización masónica nacional. La convocatoria y posterior reunión provocó una reacción de la crítica de la prensa conservadora y de buena parte de la jerarquía de la Iglesia católica, las cuales vieron aquel hecho

12 Chism, Richard, Una contribución a la historia masónica de México, México, Erbasa, 1958, p. 82.

13 Bastian, Jean-Pierre, "Jacobinismo y ruptura revolucionaria durante el Porfiriato" en Hernández, Alberro S. y Trabulse, E. (coords), La Revolución francesa en México, México, El Colegio de México, 1992, pp. 237-252.

14 La expresión Gran Oriente se refiere a la corporación masónica que reúne varias logias, generalmente congregadas por la práctica del mismo rito. Como ya se señaló, la palabra oriente significa el lugar por el que sale el sol, símbolo de la luz, y se emplea para expresar la "luz de la razón", contenida en los principios de la logia. Véase Daza, Juan Carlos, Diccionario Akal de la Masonería, Madrid, Akal, 1998, sub voce.

15 Tradicionalmente el Gran Oriente define a la federación de logias de diferentes ritos, como fue el caso de la que se creó en 1890 en México. En cambio, la expresión Gran Logia se utiliza para referirse a la federación de logias que utilizan el mismo rito. A la cabeza de éstas está Gran Maestre, idem, sub voce. 
como una revigorización de la masonería mexicana y, como consecuencia, una afectación grave a sus intereses y a su labor pastoral.

\section{LA CREACiÓn DE LA GRAN Dieta Simbólica EN 1890}

El 24 de febrero de 1890, apareció publicada una noticia que causó revuelo dentro y fuera de los ámbitos de la masonería en todo el país. Los periódicos anunciaban la reciente celebración del pacto de unificación entre la Orden del Gran Oriente de México y el Supremo Consejo de la Masonería Escocesa. ${ }^{16}$ El producto de esa fusión fue la creación de la Gran Dieta Simbólica, que supuestamente uniría a todos los grupos en una sola jurisdicción.

El hecho ocurrió el 16 de febrero, cuando tuvo lugar una gran tenida, ${ }^{17}$ que era como se solía llamar a las reuniones de las logias. Más allá de su objetivo político, me centraré aquí en el aspecto ideológico y en la reacción que suscitó en la prensa católica. El objetivo de la tenida era cerrar filas en el frente ideológico mediante la homologación de tácticas de acción, del acuerdo acerca de las políticas de secularización y de la unificación del simbolismo o filosofía masónica de las diversas agrupaciones, así como conseguir la promoción de la "fraternidad y mutuos auxilios" de los iniciados en los diversos ritos. ${ }^{18}$ Como mencioné antes, la creación de la Gran Dieta fue orquestada por Porfirio Díaz, quien en todo momento se mostró favorable a la iniciativa de la fusión, pues sabía bien la fuerza que podría encontrar en las logias unidas y gobernadas por un órgano central. No estaba equivocado: unos años más tarde recibió el apoyo absoluto de la Gran Dieta, que pretendió disciplinar a todas las logias "en la única obra política en que está radicado el porvenir de la patria: en la reelección del actual Primer Magistrado de la Nación" ${ }^{19}$ Por eso, Díaz participó hasta ese año con relativa frecuencia en las ceremonias y actos más relevantes de la Gran Dieta Simbólica. Y, quizá por esa misma razón, una vez que hubo obtenido el apoyo más importante para su propósito de reelección, prácticamente dejó de lado su participación directa en las tenidas

16 La masonería escocesa se refiere a los diversos ritos que, desde el siglo XVIII, se caracterizaron por su ideología fundamentalista, pues proponían la renovación (recuperación) del carácter iniciático de las logias masónicas. Daza, Juan Carlos, idem, sub voce.

17 Tenida es el nombre que se daba a las sesiones en las logias. Las había de distinto tipo para los diversos grados. Eran fundamentalmente de dos clases: las solemnes y las de comité o puramente administrativas. Las tenidas solemnes estaban perfectamente reglamentadas y se seguían con todo rigor ciertos "pasos" o etapas del ritual.

18 "La unidad de la masonería en México", El Siglo XIX, México, vol. 24, núm. 2, 1890.

19 "Festividad masónica", El Tiempo, México, 24 de diciembre de 1895, pp. 1-3. 
y ceremonias de la Gran Dieta Simbólica. ${ }^{20}$ Pero volvamos al hecho acaecido el 16 de febrero de 1890 .

El pacto de unidad se firmó en una solemne reunión que duró más de tres horas en el Templo Masónico del Gran Oriente, en el edificio de la antigua aduana de la Ciudad de México. Se otorgó al presidente Porfirio Díaz el cargo honorífico de Gran Maestre y Gran Comendador ad honorem et vita, ${ }^{21}$ lo cual significaba que, por principio, a él le correspondería regir los destinos de la nueva obediencia. ${ }^{22}$

En los días siguientes, la prensa liberal daba la noticia augurando toda suerte de éxitos para la nueva organización de la masonería mexicana. Para celebrar la fusión se convocó a todos los hermanos masones pertenecientes a los altos grados a un banquete, al que, en el sociolecto de las logias, se denominaba ágape masónico, el cual tuvo lugar en el Tívoli de San Cosme en la Ciudad de México. Este acto se convocó y llevó a cabo con "la idea de amalgamar los elementos fusionados" $[$ sic $] .{ }^{23}$ Como era la costumbre de la época - en donde la facundia estaba a la orden del día-, por más de seis horas se pronunciaron un gran número de discursos. De la lectura de las notas publicadas en la prensa de la época podemos decir que los dos temas fundamentales eran: 1) la masonería era una "escuela moralizadora de la sociedad", cuyo objetivo fundamental era la "regeneración del país", ${ }^{24}$ y 2) se abría una "nueva era de la masonería" en México. ${ }^{25}$

20 En la prensa católica se criticó ampliamente esta reelección. Especialmente en $E l$ Tiempo, El Nacional y La Voz de México. Véase Ruiz Castañeda, María del Carmen, "La prensa durante el Porfiriato" en Novo, Salvador (coord.), El periodismo en México (450 años de historia), México, UNAM, 1980, p. 237.

21 "Documento masónico", El Tiempo, México, 26 de abril de 1890. Los nombramientos de Gran Vigilante, se otorgaron a Agustín Arroyo de Anda y a José M. Castellanos, ambos masones de viejo cuño y grado 33 de sus respectivos ritos. Ahí mismo se eligieron y nombraron para los diversos cargos de gobierno de la Gran Dieta Simbólica a Luis Pombo, Francisco Medina, Porfirio Parra, Sóstenes Rocha, Emilio G. Cantón, José M. Martínez, Eugenio Soriano, Andrés Horcasitas, Agapito Ojeda, Manuel T. Gutiérrez, Agustín Amor, Enrique Aragón, Carlos Ventimilla, Agustín Arellano, Miguel Rodríguez Gabatti, Juan N. Castellanos, Francisco R. Blanco, Eusebio Fuentemilla, José B. Aragón, Joaquín Zapiain. Posteriormente Díaz fue nombrado "Soberano Gran comendador", también ad vitam, del Supremo Consejo del Rito Escocés Antiguo y Reformado.

22 Obediencia, en el lenguaje de la masonería, significa "federación de Logias organizada en potencia suprema". En virtud del principio de unidad territorial, sólo podía haber una obediencia o potencia suprema en el país.

23 “Banquete masónico", El Siglo XIX, México, vol. 3, núm. 4, 1890.

24 Ibidem.

25 "La unificación masónica en la República”, El Siglo XIX, México, vol. 23, núm.06, 1890. 
Esta obra forma parte del acervo de la Biblioteca Jurídica Virtual del Instituto de Investigaciones Jurídicas de la UNAM www.juridicas.unam.mx

https://biblio.juridicas.unam.mx/bjv

Imagen 2. Emblema de la Gran Dieta Simbólica de los Estados Unidos Mexicanos, fundada en 1890

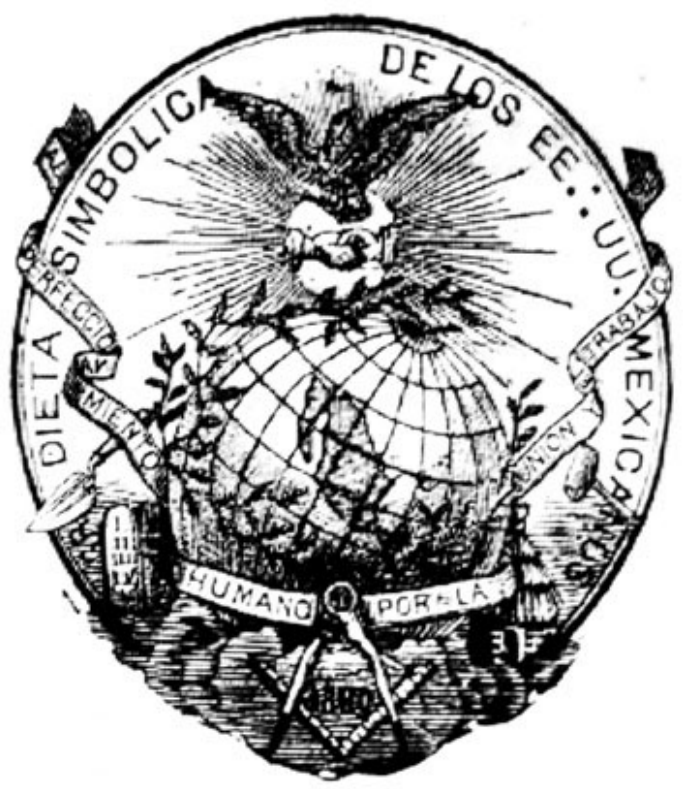

Pero no todos los masones veían la unificación con el mismo optimismo que los escoceses. Como ha señalado Jean Pierre Bastian, el intento de unidad fracasó "en gran parte debido al principio de autonomía constitutivo de la masonería", ${ }^{26}$ principio que se tradujo en una pugna entre las diversas logias que resistieron a las pretensiones centralizadoras de los masones de la Gran Oriente y de Porfirio Díaz. Además, gracias a los registros de la prensa de la época, es perceptible que, una vez que Díaz consiguió su objetivo, dejó de ir a las tenidas, con lo cual debilitó la supuesta unidad conseguida con la Gran Dieta que había promovido.

\section{LA REACGiÓN DE LOS CATÓLICOS}

Más allá de los efectos que habría de tener (y tuvo) la pretendida unión de las logias, los católicos la veían como una posibilidad real de renuevo de la masonería mexicana y de sus programas ideológicos, lo cual traería como

26 Bastian, Jean-Pierre, op. cit., p. 239. 
consecuencia un aumento notable de la presencia directa de las logias en la sociedad y de su "acción anticatólica" entre las élites gobernantes del país, pues hay que recordar que, a pesar de que las Leyes de Reforma habían sido incorporadas a la Constitución en 1873, éstas se violaban constantemente. Incluso, se sabe que el arzobispo de México, Pelagio Antonio Labastida y Dávalos, visitaba con cierta frecuencia al presidente de la República, a quien -según Francisco Sosa- en ocasiones llegó a prestar dinero. ${ }^{27}$ Por ese motivo, cuando se creó la Gran Dieta con el apoyo del presidente, un buen número de católicos y algunos miembros de la jerarquía rompieron la actitud conciliadora que hasta entonces habían tenido con el poder político ${ }^{28}$ y desplegaron su propia acción propagandística de defensa y ataque, haciendo eco a la política trazada por el papa León XIII en la encíclica Humanum Genus, que había sido publicada en Roma el 20 de abril de 1884.

Como antecedente más directo de esta campaña, destaca una publicación del obispo de León, José María Díez de Sollano y Dávalos. Éste fue sin duda uno de los personajes de la curia mexicana que, con más valentía incluso que el prelado de México, defendió a la Iglesia y, sobre todo, a los católicos de más bajos recursos. ${ }^{29}$ Lo que más le preocupaba -a decir de uno de sus más importantes biógrafos- era el estado de "descuido" en el que se encontraba la fe de la mayoría de los católicos, debido a la acción de los enemigos de la Iglesia, que se habían encargado de difundir en el seno de las familias las ideas contenidas en "las obras mortíferas de Voltaire, de Rousseau, del Barón de Holbach y otros cien impíos". ${ }^{30}$ Según el obispo, los dos vehículos más importantes para esta acción doctrinal anticatólica eran los periodistas (especialmente los de El Monitor Republicano) y algunos intelectuales vinculados a las logias de la masonería. Por ello, publicó una bula de León XIII, así como otros documentos condenatorios de la masonería en sus diversas manifestaciones de organización mundial. ${ }^{31}$

La prensa fue el medio ideal para influir en la sociedad, para afianzar la creencia popular y advertir de los "errores" que planteaban los enemigos de

27 Sosa, Francisco, El Episcopado Mexicano, México, Jus, 1961, t. II.

28 Romero de Solís, José Miguel, El aguïón del espiritu Historia contemporánea de la Iglesia en México (1892-1992), México, Imdosoc, 1994, cap. I, passim.

29 Véase Agüeros, Victoriano, Apuntes biográficos del Ilmo y Rmo. Sr. Dr. Y Mtro. D. Fosé M. de Jesús Díez de Sollano y Dávalos, dignísimo primer obispo de León, tomados del ilustrado periódico "El Imparcial", de la capital de México, León, Tipografía de José M. Monzón, 1883.

30 Yermo y Parres, José María de, Apuntes biográficos y colección de los escritos del Ilmo Sr. Dr. Y Mtro. D. Fosé María de Jesús Díez de Sollano y Dávalos, dignísimo primer obispo de León, León, Imprenta de Jesús Villalpando, 1882, p. 326.

31 Díez de Sollano y Dávalos, José María de Jesús, Duodécima Carta Pastoral que el Ilmo. $Y$ Rmo. Sr. Obispo de León, Dr. Y Maestro... dirige a su Ilmo. y venerable Cabildo, Señores curas, venerable clero y fieles diocesanos, contra la Masonería, León, Imprenta de J. Monzón, 1872. 
la Iglesia ${ }^{32}$. Por ello, cuando el arzobispo de Guadalajara, Pedro Loza, publicó su Carta pastoral sobre los malos periódicos (1897), señalaba que la lectura de la prensa producida en las filas de los grupos enemigos de la Iglesia dañaba la conciencia de los católicos, razón por la cual instaba a éstos a comprar la "prensa católica", a sostenerla económicamente, a apoyarla por todos los medios posibles en su labor de combate frente a los "malos periódicos": "entre todas las producciones debidas a la ilimitada libertad de imprenta [dice] ninguna quizá produce mayores daños que el periódico inmoral e impío". ${ }^{33}$ Estos daños se referían al aspecto doctrinal y, consecuentemente, al debilitamiento o a la pérdida de la fe que podía llegar a causar en los católicos "esa pestilencial influencia que ejerce por doquiera la mala prensa periódica". ${ }^{34}$

Como acertadamente ha señalado Manuel Ceballos, ese carácter doctrinal no siempre fue igual ni el mismo en todos los autores de la época. Debemos recordar que en la última década del siglo XIX, León XIII había publicado algunos documentos que culminaban con la encíclica Rerum Novarum, la cual contiene una serie de principios y orientaciones que ponían en tela de juicio los valores constitucionales, morales y económicos en los que se basaba el Estado liberal creado por los gobiernos republicanos, con apoyo en las sociedades de pensamiento y, dentro de éstas, especialmente en las logias de la masonería. En la Rerum Novarum, el papa habla de los derechos de los trabajadores, de la justicia social y de la necesidad de que el Estado intervenga (bajo el principio de subsidiaridad) en la vida de la sociedad. Fue así como se produjo una escisión entre católicos liberales y católicos intransigentes; entre estos últimos existían también divisiones, sobre todo si se atiende a lo que cada grupo entendía por orden. Para los católicos liberales, la idea o imagen de orden social cristiano era compatible con el orden republicano y liberal. Caso particular, en este sentido, sería el de monseñor Eulogio Guillow, obispo de Oaxaca, para quien el prototipo del orden social era Estado Unidos. ${ }^{35}$

Llama la atención que, en la mayoría de los periódicos de esta orientación, prácticamente no se publican ataques o condenas de la jerarquía mexicana. Sólo aparecen los del papado romano y los de la jerarquía de otros países, lo cual nos lleva a plantearnos la cuestión de esa especie de silencio por parte de los obispos nacionales. Creo que podemos encontrar algunas explicaciones a

32 “Aspiraciones de los Francmasones", El Tiempo, México, 13 de marzo de 1897.

33 Loza, Pedro, Carta Pastoral del Ilmo. y Romo. Sr. Doctor... sobre los malos periódicos, Guadalajara, Ant. Tipografía de N. Parga, 1897, p. 7.

34 Ibidem, p. 10.

35 Ceballos Ramírez, Manuel, "Conservadores e intransigentes en la época de Porfirio Díaz", Los rostros del conservadurismo mexicano, México, Publicaciones de la Casa Chata-CIESAS, 2005, pp. 123-137. 
esta ausencia del episcopado: una sería suponer que la jerarquía de México estaba conforme con el sistema liberal implantado por Porfirio Díaz (con el apoyo de la masonería). Algo parecido podemos decir respecto al obispo E. Guillow, de Oaxaca, y quizá del obispo sucesor de Labastida, Próspero María Alarcón. Ceballos recoge una carta del obispo Gillow al presidente en la que - tras alabar la pax porfiriana y sus beneficios para el desarrollo social en el esquema de una relación armónica entre la Iglesia y el Estado- señala el peligro que entrañaba para esa paz conciliatoria "la prensa que se dice católica". ${ }^{36}$ Y concluye Ceballos: "de modo que podemos afirmar que, en sus inicios, la conciliación tenía al menos dos obstáculos dentro de la Iglesia: la prensa y los escritos de León XIII".37

\section{LA PRENSA CATÓLICA DE LA ÉPOCA}

Volviendo a los católicos seglares que actuaron en contra de la masonería, entre los periódicos más activos dirigidos por éstos podemos destacar El Tiempo, fundado en 1883 por el connotado periodista, abogado y hombre de letras, Victoriano Agüeros. Este diario circuló en la Ciudad de México hasta 1912. El nombre que sobresale de entre los articulistas y columnistas que colaboraron en esta guerra informativa y de opinión es el de uno de los más destacados y talentosos periodistas de la época: Trinidad Sánchez Santos.

Con un lenguaje menos agresivo y quizá menos combativo o crítico que el anterior, también participó en esta campaña el periódico capitalino $E l$ Pájaro Verde, fundado en 1861 por Mariano Villanueva Francesconi. En este periódico se publicaron sobre todo documentos de la Jerarquía romana y una enorme cantidad de documentos masónicos, identificados en cuanto a su procedencia y autoría. Con la publicación de ese tipo de documentos, a veces incluso sin comentarios añadidos de los católicos, la prensa buscaba transparentar a las órdenes masónicas.

Asimismo, participó El Heraldo, órgano informativo de corte conservador fundado (re-fundado) por el ya mencionado periodista Trinidad Sánchez Santos, en el que también se publicaron interesantes artículos sobre el mismo tema. La Voz de México, de Rafael Gómez y Miguel Martínez, fue otro de los órganos de opinión que se sumaron al debate planteado por los católicos mexicanos. En él escribían hombres notables de la Sociedad Católica de

\footnotetext{
36 Idem.

37 Idem.
} 
México, ${ }^{38}$ como Ignacio Aguilar y Marocho en su última etapa, José Joaquín Terrazas, Juan N. Tercero, Joaquín María Castillo, Manuel Filomeno Rodríguez y el célebre y combativo promotor de la Rerum Novarum en México, José de J. Cuevas, entre otros. ${ }^{39}$ Aun con su estilo más moderado, este periódico presentó la batalla de modo paralelo a El Tiempo, y, en algunas ocasiones, con un estilo incisivo e irónico, al menos cuando recurría a esa forma sutil de dejar al descubierto las paradojas y contradicciones profundas del "enemigo", incluso sin hacer mención explícita a ellas, pues solía decirse en este tipo de diarios que "la masonería al descubierto" dejaba de ser lo que era y "trabajando a la luz del día" se volvía prácticamente inofensiva. ${ }^{40}$

Desde mi punto de vista, ninguno de estos diarios puede ser considerado como clerical, aun cuando la actividad periodística de los católicos se considerara parte del "apostolado secular, auxiliar y suplementario del sacerdocio". ${ }^{41}$ No lo son, si por clericalismo entendemos - en sentido estricto- la defensa de los intereses materiales del clero y de la jerarquía, así como su injerencia en materias políticas. Sería demasiado restrictivo considerar que ese era el quid del combate periodístico de los católicos, pues por la amplitud del tema analizado en la prensa se observa una realidad muy distinta a ésa. Además, en los casos de defender al clero, lo hacen en cuanto tal, es decir, como conjunto de personas dedicadas al ministerio propio de la Iglesia, pero no para fortalecer su presencia en los ámbitos de decisión. Incluso, en la mayor parte de los documentos pontificios y en las cartas pastorales publicadas en México se hace alusión directa a la "responsabilidad" directa de los seglares en las cuestiones relativas a la vida política del país. Esto, claro está, sin perder la directriz de la jerarquía y del clero acerca de los mejores modos posibles de llevar a cabo los principios contenidos en la doctrina social articulada especialmente por el papa León XIII, quien había alentado y casi reglamentado asociaciones de socorros, cajas de ahorro para los trabajadores y varias sociedades de carácter educativo y cultural. Tampoco creo que puedan considerarse clericales en sentido eclesiástico, si clericalismo se entiende como la actitud de ciertos laicos

38 Sociedad fundada en 1868, en la que se reunían católicos de diversa tendencia política, dedicados a difundir ideas y prácticas religiosas. Véase Adame, J., El pensamiento..., cit., p. 21.

39 Bravo Ugarte, José, Periodistas y periódicos mexicanos (hasta 1935), México, Jus, 1966, pp. 59 y 69. Más tarde se unirá a este tipo de prensa conservadora El País de Trinidad Sánchez Santos. Reed Torres, Luis, "De Juárez a don Porfirio", en Novo, Salvador (coord.), El periodismo..., op. cit., pp. 215 y 223. Y lo mismo en Toussaint, Florence, "La prensa y el Porfiriato", Las publicaciones periódicas y la Historia de México (50 Aniversario de la Hemeroteca Nacional), México, UNAM, 1995, pp. 45-51.

40 Idem. "La masonería al descubierto", El Tiempo, México, 30 de septiembre de 1896.

41 Sartigue S. J., El apostolado y la acción seglar en pro de la causa católica (sermón predicado en -francia y traducido al castellano en Guanajuato), Guanajuato, Imprenta del Colegio de Artes y Oficios, 1881. 
de dejar en manos de la jerarquía la responsabilidad de tomar las decisiones más importantes en materias temporales, es decir, en aquellas cuestiones que por principio les atañen a ellos de manera directa, como serían las de orden político, económico, jurídico o cultural. ${ }^{42}$ Justo Sierra admiraba el apostolado de los seglares en terrenos como la economía, el campo y el comercio; señalaba que León XIII, con sus encíclicas sociales, había "liberado al catolicismo del clericalismo" ${ }^{43}$ pues no hacía responsables a los obispos y al clero de llevar a cabo los principios de justicia social contenidos en esos documentos, sino a los laicos, quienes debían estar directamente involucrados en esas actividades.

Parte de esa acción social de los católicos era la defensa de la fe ante el ataque de sus enemigos. Por ello, a partir de 1890, estos órganos de prensa católica, dirigidos y organizados por laicos, iniciaron una fuerte campaña de detracción, proscripción y denuncia de la masonería, señalando especialmente las tácticas ideológicas que empleaban en el proselitismo, así como las formas de indoctrinación y disciplinamiento de sus miembros. ${ }^{44}$ La campaña antimasónica desatada por los católicos no se hizo esperar. Varios periódicos lanzaron la contraofensiva, ${ }^{45}$ encabezados por El Siglo XIX, el cual había sido fundado en 1841 por Ignacio Cumplido. Buena parte de su contraataque se basaba en la convicción de muchos de sus colaboradores de que la masonería promovía el liberalismo, mientras que la Iglesia proponía doctrinas críticas a ese modelo económico, con el objetivo de restablecer la sociedad corporativista y jerárquica, es decir, el orden social basado en el impulso asociacionista. Por otra parte, El Universal, fundado en 1848 y tras muchas vicisitudes nuevamente abierto en 1888 por Reyes Spíndola, también se hizo cargo de la defensa de la masonería frente a la prensa católica durante esta época. ${ }^{46}$

42 De hecho, la Jerarquía, que organizó otros "frentes" en la lucha contra el laicismo y la actividad de las logias masónicas, no organizó ni articuló la actividad propagandística de la "prensa católica”. Véase Sánchez Santos, Trinidad, El apostolado seglar..., cit., p. 440.

43 Citado por González Navarro, Moisés, Sociedad y cultura en el Porfiriato, México, Consejo Nacional para la Cultura y las Artes, 1994, p. 124.

44 Esta acción que, a diferencia de otros países, fue hasta cierto punto articulada, dio fuerza a la prensa católica a partir de la década de 1880 de aquel siglo. Véase "Los masones en acción", El Tiempo, México, 8 de febrero de 1890, p. 1; en el mismo diario: "La masonería", 3 de mayo de 1893, p. 2; y sobre la necesidad de la defensa pública del catolicismo frente a la masonería: "Hablemos claro", La Voz de México, 22 de abril de 1888.

45 Véase "Cuatro palabras a S. S. León XIII", La Bandera Roja, Durango, 15 de agosto de 1885, pp. 1 y 2; y sobre la denuncia de la campaña de la "prensa clerical": “¿ué es un masón?", El Siglo XIX, México, 4 de junio de 1890.

46 "La prensa", El Siglo XIX, México, 30 de junio de 1890. 
Estos periódicos - hasta cierto punto gobiernistas- hicieron cuanto pudieron por deslucir la crítica de la "prensa reaccionaria" o "ultramontana", ${ }^{47}$ a la que se acusó de desatar una campaña de "adorables vociferaciones teológicas en el tono más verduleramente católico" [sic $].{ }^{48}$ Los defensores de las logias señalaban con insistencia que no había contradicción entre ser católico y pertenecer a uno de esos grupos, ${ }^{49}$ pues, como lo había publicado el periódico La Prensa, dirigido por uno de los altos jerarcas de la Gran Dieta Simbólica de México, Agustín Arrollo de Anda, una gran cantidad de sacerdotes católicos pertenecían a la masonería, algunos de los cuales ostentaban el Grado $33^{\circ} .{ }^{50}$ Incluso decían que el papa Pío IX había sido masón ${ }^{51}$ y llegaron a afirmar que había sido grado $18^{\circ}$ y que su supuesto nombre simbólico dentro de la masonería italiana era "Mucio Scævola" [ sic $].{ }^{52}$ Esta cuestión aparentemente se había inventado en Italia, en donde algunos masones recortaron una fotografia de la cara del pontífice para montarla sobre el busto de un masón sacando a la luz pública un retrato en el que aparecía con todos los atributos de una logia de ese país. ${ }^{53}$ Lo mismo llegó a decirse de León XIII, a quien también se le hizo aparecer en la prensa como "Venerable Hermano de la Francmasonería". Tal cosa se afirmaba a partir de los informes del jesuita D’Alberti, publicados en 1871, en Bolonia, en un libro titulado Chiesa e Riforma.

47 "La esponja masónica", El Tiempo, México, 10 de agosto de 1893.

48 El Siglo XIX, México, 30 de junio de 1890.

49 La Iglesia había condenado reiteradamente esa postura a la que denominó "indiferentismo religioso". El papa León XIII publicó el 20 de junio de 1888, la carta encíclica Libertas Praestantissimum en la que afirmaba al respecto: "En lo que toca a la religión, el decir que entre distintas y aun contrarias formas de culto lo mismo da una que otra, es venir a confesar que no se quiere aprobar ni practicar ninguna; lo cual, si difiere en el nombre del ateísmo, en realidad es la misma cosa, supuesto que quien cree en la existencia de Dios, si es consecuente y no quiere caer en un absurdo, ha de confesar necesariamente que las formas acostumbradas del culto divino tan diferentes, discordantes y opuestos entre sí, aun en cosas de suma importancia, no pueden ser todas igualmente aceptables ni igualmente buenas o agradables a Dios". Encíclicas, editorial El Siglo XIX, 30 de junio de 1891, p. 281.

50 Sobresalen entre estos "curas-masones" señalados por la prensa, los nombres de José María Alpuche, cura de Tabasco y Miguel Ramos Arispe, que había sido canónigo de Puebla. Menciona, además, entre muchos otros, los nombres de los curas seculares y regulares, como el Guardián de San Cosme, el cura párroco de Santa Prisca, el Comendador de la Merced y varios canónigos más que trabajaban en diversas ciudades de la República. "La prensa", El Siglo XIX, México, 30 de junio de 1890.

51 "Pío IX y la Francmasonería / Indagaciones minuciosas", El Universal, México, 6 de enero de 1892. Unos decían que había entrado en Palermo, otros que en Sicilia e incluso que "había entrado a la Francmasonería en una logia de Filadelfia, en los Estados Unidos".

52 "Los masones y el Papa", El Eco de Colima (tomado de El Siglo XIX), 13 de octubre de 1872.

53 Tirado y Rojas, Mariano, La masonería en España, Madrid, Imprenta de Enrique Maroto y Hermano, 1892, p. 19. 
Según la prensa liberal, este sacerdote poseía información de primera mano para afirmar que, siendo obispo de Perusa, el pontífice "se había comprometido con la masonería" en una supuesta tenida efectuada en Anvers el 8 de diciembre de 1871, en donde había pronunciado un elocuente discurso en el que afirmaba que "los dos ideales [el de la masonería y el del catolicismo] se confunden, pues en las dos luces no hay interferencias". ${ }^{54}$

La historia resulta demasiado fantasiosa, pues, además de conceder al desconocido D'Alberti (a quien nadie había leído en México) una "probidad absoluta" [sic], afirma que en la reunión estaban presentes príncipes, reyes y un sinnúmero de científicos del mundo. Sin embargo, por más grotesca que fuera aquella leyenda, sembró dudas en cierto sector de católicos mexicanos demasiado liberales o (quizá) demasiado conservadores (todo depende de la perspectiva desde la cual se mire), los cuales se habían mostrado temerosos y desconfiados por las "avanzadas" teorías sociales o "socialistas" de este pontífice, sobre todo desde que publicó la encíclica Rerum Novarum, en la que, sin embargo, condenaba el liberalismo y la propiedad sin sentido social (latifundismo). ${ }^{55}$ Pero al margen de la credulidad o de posturas un tanto exageradas en ciertos sectores de la sociedad mexicana, un gran número de fieles católicos se mostraron confundidos, por lo que las baterías de los periodistas de esta orientación ideológica se enderezaron sobre todo a disuadir a aquellos correligionarios (sus principales lectores) que creían en la compatibilidad de su fe con la pertenencia a las logias y pretendían ingresar a una o, habiendo sido aceptados, se arrepentían sin encontrar el modo adecuado y conveniente para salirse sin tener que padecer las amenazas y ataques a su persona o sin faltar a su palabra juramentada. ${ }^{56}$

Se reactivó así una antigua condena de la jerarquía eclesiástica y se volvieron a publicar algunas encíclicas y cartas pontificias en las que se proscribía la

54 “León XIII ¡masón!”, El Siglo XIX, México, 30 de junio de 1890.

55 Esta imagen llegó en efecto a tener aceptación entre algunos católicos, sobre todo franceses e italianos, a quienes la doctrina social y la visión renovadora de aquel papa les parecía sospechosa, pues había intentado integrar las instituciones liberales en una concepción católica del Estado, por lo que llegaron a dudar de su "ortodoxia católica", para acusarlo de liberal, condescendiente con las posturas modernistas, y de heterodoxo; llegaron, incluso a tacharlo de socialista, ya que sus postulados de justicia social les resultaban atentatorias contra la propiedad y el régimen establecido por la industria capitalista. Aubert, Roger, "La Iglesia católica desde la crisis de 1848 hasta la Primera Guerra Mundial", Nueva Historia de la Iglesia, Madrid, Ediciones Cristiandad, 1984, t. V, p. 51.

56 "Un consejo a los masones arrepentidos", El Pájaro Verde, México, 8 de enero de 1873, p. 2. Artículos como éste se refieren a "muchos masones que ingresan al masonismo no por perversión, sino engañados por su exterior de beneficencia o creyendo encontrar en los hermanos la protección que no han hallado[...] Estos infelices[...] temen la realización de las amenazas con que aquella filantrópica, benéfica, amante y derrotada asociación sanciona la ciega obediencia que exige a estos hombres libres". 
masonería: desde las de Clemente XII y Benedicto XIV hasta las últimas de Pío IX y León XIII. ${ }^{57}$ Se divulgaron en los periódicos algunas instrucciones pastorales de obispos extranjeros y mexicanos. ${ }^{58}$ Asimismo, se publicaron una gran cantidad de artículos aparecidos en la prensa católica europea y sudamericana, así como documentos reveladores escritos por los miembros de las logias o por sus críticos, los cuales fueron traducidos al castellano parcial o íntegramente. Entre todos, destaca la obra del exmasón francés León Taxil.

\section{LAS GRANDES LÍNEAS DEL DISGURSO ANTIMASÓNICO EN LA PRENSA CATÓLICA}

\section{Apologética contra el gnosticismo y el deísmo}

El gnosticismo y el deísmo fueron duramente combatidos tanto por la jerarquía de la Iglesia de Roma, ${ }^{59}$ como por la prensa católica europea e hispanoamericana mediante una extensa labor doctrinal, pastoral y apologética, pues eran vistas como formas de incredulidad o más bien de credulidad supersticiosa e irracional, en las que la religión quedaba reducida "a una mera teoría filosófica". ${ }^{60}$

Típica del siglo XIX, la Apologética o "Defensa y propagación de la fe" se convirtió en la principal herramienta doctrinal de los católicos mexicanos para enfrentar las posturas gnósticas y deístas, contrarias a su credo y a la acción de la jerarquía de la Iglesia. ${ }^{61}$ En el Concilio Vaticano I, celebrado en 1870, se había

57 Estas condenas fueron recogidas en el Código de Derecho Canónico del año 1917, en cuyo canon 2335 se disponía: "Los que dan su nombre a la secta masónica o a otras asociaciones del mismo género que maquinan contra la Iglesia o contra las potestades civiles legítimas, incurren ipso facto en excomunión simplemente reservada a la Sede Apostólica".

58 "La masonería y El Tiempo", La Libertad, México, 5 de junio de 1884, p. 2.

59 El 28 de abril de 1738, el Papa Clemente XII publica la encíclica In Eminenti, en la que se condena por primera vez la masonería y sus propuestas doctrinales (gnósticas y deístas), y se prohibe a los fieles afiliarse a ella o asistir a sus reuniones, "bajo pena de excomunión".

60 García, Francisco, "El catolicismo y la masonería", El Pájaro Verde, México, 6 de junio de 1874 , p. 2.

61 La primera publicación típicamente apologética que apareció en el México del siglo XIX, fue el periódico $\mathrm{La}$ Cruz, que empezó a circular en 1855, y cuyo título completo decía que era exclusivamente religioso, establecido ex profeso para difundir las doctrinas ortodoxas y vindicarlas de los errores dominantes. Su director fue José Joaquín Pesado, quien, además de publicar temas en defensa del clero, como Exposición a favor de la Iglesia Mexicana, mantuvo una interesante polémica con Juan Bautista Morales, el "Gallo Pitagórico". Colaboraban en él intelectuales como José María Roa Bárcena, Alejandro Arango y Escandón, Manuel Baranda y el célebre jurista conservador José Bernardo Couto. Después de la Revolución de Tuxtepec, decayó esta corriente apologética. En 1890, el 
alentado a los fieles a salir en defensa de la religión ante aquellas corrientes de pensamiento que habían centrado sus ataques en la crítica de la cultura cristiana forjada por la Iglesia a través de los siglos. Muchos apologistas reescribieron la historia (universal y nacional) exaltando las aportaciones del cristianismo a la formación de la cultura humana. En este sentido, podemos recordar la inmensa obra de François-René de Chateaubriand, El Genio del Cristianismo (Bellezas de la religión cristiana), que inspiró a nuestro Aristeo Rodríguez Escandón, para escribir su Breve reseña de la vida pública y hechos notables de los miembros del clero mexicano, publicada en 1900. Algo parecido encontramos en el México del Porfiriato, en la obra intelectual de personajes como el citado Rodríguez Escandón o Trinidad Sánchez Santos, así como de intelectuales destacados por su actividad en defensa de la Iglesia y de la religión, como José Juan Tablada, José de Jesús Cuevas, Ignacio Aguilar y Marocho, Emeterio Valverde Téllez, Manuel Berganzo, Manuel Gargollo y Parra, Miguel Martínez, Francisco Lucas García, Francisco Elguero, Bonifacio Sánchez Vergara, Luis Gutiérrez Otero, Remigio Tovar, Agustín Rivera y José Sebastián Segura, entre otros de los laicos más destacados. La misma intención de defensa encontramos en algunos obispos, como Próspero María Alarcón y José María Díez de Sollano, y en un buen número de sacerdotes del clero secular y regular. A todos -clérigos y seglares- había alentado la jerarquía para que echaran mano de la "espada divina de la palabra" con el fin de abatir la "propagación del error". ${ }^{2}$ En primer lugar, por el laicismo, que constituía el desiderátum de la ideología masónica o lo que los periodistas conservadores llamaron doctrinas impías, lo mismo para referirse a las de Arrio y Juliano el Apóstata, que a las de Maquiavelo, Lutero, Calvino, Voltaire, D'Alambert, Condorcet, Dantón, Lafayette, Napoleón y "el impostor Renan", 63 o bien a las "sectas"

arzobispo de México trató de restablecer aquella labor catequética y de propagación misionera a través de la organización de los laicos en toda la Arquidiócesis, para lo cual estableció en la ciudad una institución pontificia, creada en París por Pauline Marie Jaricot (1822), llamada Asociación de la Propagación de la Fe, obra fundamentalmente piadosa, pero cuyo sentido era levantar el ánimo de los seglares, evocando los principios de la catolicidad o universalidad del cristianismo. Labastida y Dávalos, Pelagio A., Carta pastoral, México, Imprenta La Voz de México, 1890.

62 Labastida y Dávalos, Pelagio A., Breve discurso... con que terminó la distribución de premios del Colegio Clerical Josefino el día 19 de julio de 1885, México, Imprenta Religiosa C. M. Trigueros y Hermano, 1885, p. 5.

63 "Protestantes y masones", El Pájaro Verde, México, 9 de junio de 1874, p. 2. Estados Unidos era visto como el vivero de las sectas, tanto de masones, como de protestantes y mormones. El amigo de la verdad, recogido en "Mormones", El Pájaro verde, México, 3 de mayo de 1876, p. 3. Las relaciones entre la "tenebrosa secta" y la "secta protestante", como asociaciones que obedecían al mismo fenómeno anticatólico, es constantemente denunciada por la prensa conservadora, llegando a acusar a las diversas sectas metodistas y bautistas, de apoyar hasta con el préstamo de sus templos y salones a las logias de la masonería mexicana. Véase "Protestantes y masones", El Tiempo, México, 20 de agosto de 1893, p. 2. 
protestantes $^{64}$ y a los diversos grupos espiritistas, ${ }^{65}$ e incluso a los judíos, así in genere, ${ }^{66}$ por lo que no rara vez se hablaba de la "hermandad entre judería y masonería". ${ }^{67} \mathrm{Y}$, en segundo, como hemos visto, por la pretensión secularizadora de la educación en México, a lo cual había que oponerse, tal como lo señalaba el citado catecismo de la Humanum Genus de León XIII. ${ }^{68}$

\section{Acusación de satanismo}

Siguiendo con esta tradición semántica y de gran arraigo en nuestra cultura política, la prensa católica del siglo XIX acusó a la masonería de sectaria y, por ende, de satánica. Esto en dos sentidos, según se desprende de la lectura de los editoriales de la época: por una parte, en sentido metafórico, como recurso denigratorio; por otra, en sentido literal, pues no eran pocos los que acusaban a las logias - especialmente atendiendo a sus ritos- de ejercer el culto satánico. ${ }^{69}$ Esta cuestión la había avalado el atrevido francés León Taxil, al referir una "invocación a Lucifer" en el rito de iniciación de uno de los "grados místicos".70 Además, este autor - en quien hemos de detenernos más adelante- sostuvo en varias de sus obras -especialmente en el libro sensacionalista Les soeurs maçonnes (Las hermanas masonas) - el culto al demonio, llamado palladismo o paladismo. Siguiendo esta idea del fabulista francés, muchos autores mexicanos acusaron de nigromancia, ocultismo y demonología a las logias masónicas. En la mencionada obra, Taxil - cuya imaginación parecía no encontrar límites, según Ferrer Benimeli- inventó a un personaje llamado Sophia Walder, la bisabuela del Anticristo, quien el 21 de enero de 1870 fue presentada como la "Gran

64 En este sentido resulta muy ilustrativa la polémica desatada entre el periódico de la Iglesia Metodista Episcopal de México, El Abogado Cristiano, y el católico, El Tiempo, pues este último acusaba al primero de defender a la masonería, ya que, según los redactores de $E l$ Abogado Cristiano, le era lícito a un pastor de esa Iglesia pertenecer a una logia de la masonería. Publicada en El Tiempo, México, 16 de noviembre de 1893.

65 El Pájaro Verde, México, 3 de mayo de 1876, p. 3.

66 "La Cuaresma/Calumnias masónicas", El Tiempo, México, 14 de febrero de 1894.

67 "Francmasón y judío", El Tiempo, México, 23 de noviembre de 1893.

68 El Tiempo, México, 3 de agosto de 1887.

69 "El culto de Satanás en las logias", tomado del periódico La Información, El Tiempo, México, 18 de febrero de 1894. Se refiere, entre otros, al culto satánico de París, llamado Triángulo Paládico, así como al culto de Satanás en Charleston, en donde se había levantado un templo, en cuyo interior había un altar en el que "Lucifer llevaba por todo vestido un cordón masónico negro formando triángulo, en el cuello y el escudo paládico, también negro".

70 "La masonería", El Tiempo, México, 30 de octubre de 1893. 
Maestra del Paladismo". ${ }^{71}$ La imagen de esta mujer sorprendió a los mexicanos, especialmente a los lectores asiduos de El Tiempo, quienes siguieron la historia ahí narrada, tanto de su vida como de la de su padre, un supuesto masón norteamericano, expastor protestante, quien, en una logia de Charleston, la había entregado al demonio. Aparentemente poseída, la mujer rezaba al demonio una vez por semana, en un santuario de aquella ciudad estadounidense, llamado Sanctum Regnum. Ahí creció hasta que, más tarde -según la versión de Taxil- se convirtió en "inspectora" al servicio de Alberto Pike, fundador del rito paládico de la masonería, y a quien se conocía en Canadá y Estados Unidos como el "Papa de los Masones". ${ }^{72}$

Según la versión mexicana de El Tiempo, Walder se dedicó a promover el culto a Satanás, empleando un discurso apocalíptico simbolizado en una serpiente que le servía como medium. Al parecer, tuvo una supuesta revelación, por la que sabía que, a los treinta y tres años de edad, sería madre de una niña, la cual tendría también otra hija a la misma edad; luego de una sucesión de hijas, la última sería la madre del Anticristo. De acuerdo con esta creencia, el número de los papas católicos quedaba limitado a nueve sucesores de León XIII: "entonces Lucifer reinará para hacer la felicidad de la humanidad" [sic]..$^{73}$ Es de suponer que el Anticristo nacería durante el penúltimo pontificado (después de León XIII), el día del coronamiento del penúltimo papa católico. Desde esa fecha, tendrían que pasar treinta y tres años para que el Anticristo reinara y aboliera el pontificado católico.

\section{Imagen 3. Masón revestido con insignias ${ }^{74}$}

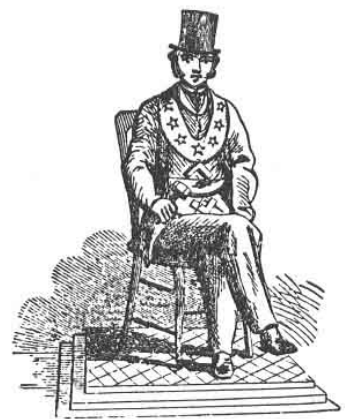

71 Ferrer Benimeli, José Antonio, La masonería..., cit., p. 105.

72 “¿Nueva Religión?”, El Tiempo, México, 25 de febrero1894.

73 "El culto de Satanás...", El Tiempo... cit., p. 2.

74 Estas insignias son: venera con la escuadra, mandil con el compás y la escuadra bordados al centro y el mallete en la mano derecha, con el que se representa la jerarquía de Gran Maestre o Gran Comendador en una tenida.

DR @ 2018. 
Un año antes de que se publicara esta macabra noticia en la capital de México, apareció en el mismo diario un artículo editorial titulado "El diablo y la masonería", en el que se leía la siguiente acusación explícita recogida de un periódico extranjero. La cito aquí sólo a modo de ejemplo, pues son muchos los artículos periodísticos en los que aparece la referencia a dicho culto y filiación ideológica:

Es una verdad como un templo que los masones adoran al diablo, toman consejo de él y lo invocan en sus reuniones. Sabido es que la masonería reconoce una multitud de grados $[\ldots]$ Los candorosos iniciados que no son otra cosa que instrumentos nuevos de la alta masonería ignoran estas cosas los pobrecitos; y ni siquiera saben que la forma más completa de este culto diabólico se llama Rito Paládico nuevo reformado, practicado por los eminentes Kadosch del Paladión, por los Jerarcas y Magos elegidos $[\ldots]^{75}$

No es casualidad que algunos periodistas e intelectuales católicos enfaticen el nombre de Palladión o Paladión, como se hace en el editorial citado, para referirse a este aspecto del "sectarismo masónico", pues, si bien es expresión tomada de los textos de la masonería estadounidense y mexicana, la idea de idolo (del griego eidôlon: visión, imagen falsa, reflejo sin realidad) que encierra la palabra palladias -el nombre de las estatuas de Atenea- está siempre presente en la crítica católica para destacar el uso indebido que hacían los masones de la imagen como vehículo de engaño; en este caso, del conjunto de imágenes contenidas en el ritual y de los símbolos como expresión del supuesto satanismo.

\section{Acusación de secta secreta}

Otro de los focos de la crítica antimasónica fue el del uso de una simbología que tendía a manipular y ocultar la verdadera intención de las logias, haciendo de estas asociaciones auténticas sociedades secretas. Así lo advertía, entre otras fuentes citadas en los periódicos de la época, la Instrucción pastoral... del citado obispo brasileño Macedo Costa, publicada en México el mismo año de la creación de la Gran Dieta Simbólica, en donde encontramos la detracción de la masonería con estas características: "Sociedad secreta es aquella que oculta sus doctrinas y sus instituciones bajo un velo de símbolos misteriosos, los cuales van siendo manifestados poco a poco a los adeptos por iniciaciones sucesivas, después de prometer guardar inviolable secreto, no solamente respecto a los

75 Fulvio, presbitero. "El diablo y la masonería", El Tiempo, México, 24 de agosto de 1893. 
extraños a esa sociedad, sino también con los miembros de ella que ocupan grados inferiores". ${ }^{76}$

La masonería, en efecto, se autodefinía como una organización basada en la filosofía simbólica, esto es, un sistema de pensamiento en el que se incluye el misterio. Este carácter provocaba, por una parte, la necesaria diferenciación de grados entre sus miembros con base en la posesión de cierto nivel de conocimiento y comprensión de algunos misterios o secretos: "77 "Concurren maravillosamente a esta ley del secreto [decía un editorialista de El Tiempo] la división de derechos, cargos y oficios de los asociados, la división jerárquica de órdenes y grados, sabiamente organizada". ${ }^{78}$ Por otra parte, y como consecuencia de esta reserva, se producía la separación de los masones en dos grandes grupos: los vulgares y los filósofos. Los primeros eran definidos por un documento masónico citado en la Instrucción pastoral... de Macedo y Costa, ${ }^{79}$ como aquellos que eran "satisfechos con una apariencia embaucadora [...] turbamulta de ilusos que concurren con su dinero, comen y beben en las logias, y satisfechos con una apariencia engañadora, se contentan con pronunciar algunas palabras cuyo verdadero sentido ignoran". Los segundos, en cambio, "conducen a la turbamulta como un rebaño de Panurgio, conociendo bien las causas primeras y los fines reales de la secta, tan sólo dados a conocer a un cierto número". ${ }^{80}$

Parte importante de la crítica que la prensa católica hacía al secretismo masónico es la denuncia de sus reuniones ocultas, las cuales - como he señalado- eran comúnmente llamadas tenidas, o bien trabajos o arte real. Éstas se llevaban a cabo en grandes salones a los que se solía denominar con distintos nombres un tanto extravagantes como templos masónicos o talleres. En la prensa de orientación católica se habla comúnmente de las logias como sectas: "sectas impías", "sectas mandileras", "sectas del compás y la escuadra", "sectas satánicas" o "paládicas" o bien, "sectas de los tres puntitos".

Además, se decía que, debido a que en ellas existían altares, era necesario contar con un ritual sacro, ceremonial, cultual, y, por ello, con sacerdotes o

76 Macedo y Costa, Antonio de, Instrucción pastoral sobre la masonería, considerada bajo el aspecto moral, religioso y social, El Tiempo, México, 26 de junio de 1890.

77 Siguiendo la doctrina del escritor francés León Taxil, El Tiempo señalaba este carácter del uso del símbolo: "A medida que un afiliado adelanta en instrucción masónica, los jefes ocultos de la secta retiran gradualmente el velo del símbolo". "La masonería", El Tiempo, México, 3 de mayo de1893.

78 "Las víctimas de la Francmasonería (1a. parte)", El Tiempo, México, 22 de octubre de 1887

79 La Instrucción cita como fuente la obra Biblioteca Maçonica ou Instruccao completo do Francmason (18 volúmenes), publicada en 1833, escrita por un caballero rosacruz para el Gran Oriente de Portugal y Brasil, obra que sirvió como "libro litúrgico" en los trabajos de las logias en esos países.

80 Macedo y Costa, Antonio de, op. cit. 
personas que recibieran los juramentos, dirigieran las tenidas o simplemente guiaran las ceremonias como maestros. Los "Hermanos Rosacruces" - decía aquel periódico- eran los encargados de fungir como tales; éstos "oficiaban" refiriendo sus actos a un "Tabernáculo", ayudados de hermanos de las logias revestidos con "estola", a quienes se solía dar el nombre de levitas. Según el denunciante, los mismos "Caballeros Kadosch" (supuesto grado máximo de los templarios) tenían cierto carácter sacerdotal y fungían como tales en los "templos".

\section{Crítica a la simbología masónica}

En general, los símbolos que usaban los masones en sus reuniones eran considerados por la prensa católica como "ridículos"; sus espacios ceremoniales, como "cloacas de inmundicias", "antros masónicos", y sus rituales de juramento (para efectuar el ascenso en los diversos grados) como "grotescas farsas" o tachados de "tenebrosos", "horrendos", "cómicos" "farsantes" "infantiles" y "bufos". ${ }^{81}$ Lo cierto es que estos rituales se fueron sofisticando en el transcurso del siglo XIX, según el protocolo del astrónomo Lefrancois; llegaron a ser tan complejos que implicaban la imposición de pruebas físicas a los iniciados, así como una asombrosa puesta en escena en la que, a decir de sus denunciantes, se incluían "ruidos, tumultos, lluvias de granizo, huracán, caída de un lugar elevado... [todo] bajo la dirección de un Hermano Terrible". ${ }^{82}$

Sin embargo, durante la última década del siglo se redujo el simbolismo, de acuerdo con el nuevo ritual masónico, publicado en 1890, en el diario parisino L'Univers. La Gran Oriente de México sometió a revisión sus "cuadernos de iniciación" y, tras escuchar varios dictámenes de expertos, resolvió "desterrar todas las antiguas pruebas y el formulismo de antaño"; desapareció también el "antiguo moblaje astronómico". Según los editorialistas de El Universal y El Tiempo, aquello significaba, por una parte, la inutilización de la crítica que los escritores católicos habían hecho a aquellas ceremonias excesivas; por otra, dejaba ver la radicalización del materialismo de las logias:

81 Los católicos afirmaron que sus críticas a la ridiculez de las ceremonias masónicas no eran exclusivas de ellos. Al parecer había antecedentes de esta crítica en William Morgan, quien, después de su abducción de una logia había publicado una obra titulada Ilustrations of Masonry by One of the Fraternity Who Has Devoted Thirty to the Subject "Good Said, Let There Be Light, and There Was Light" (Nueva York, s.e., 1826), en la que da a conocer los emblemas y rituales de la masonería norteamericana. Lo mismo había hecho Andrienx, antiguo jefe de policía en París y alto dignatario de la masonería francesa, quien había señalado el "chantaje" que se escondía detrás de la simbología de los ritos. Véase "Lo que son los masones/A Tata Siglo", El Tiempo, México, 14 de junio de 1890.

82 "Nuevo ritual masónico", El Tiempo, México, 14 de junio de 1890. 
"El Sol, la Luna, la Eclíptica, el Zodiaco, etc., hasta hoy respetados, han cedido el puesto a las fórmulas de fisiología de Paul Bert, y el Gran Arquitecto del Universo ha desaparecido como superfluo". ${ }^{83}$ Estas críticas se referían especialmente a una nueva forma de explicar la masonería imbuida del positivismo un tanto ingenuo y dogmático del siglo XIX. Según esa visión, las órdenes masónicas debían explicarse sin acudir a otro método que no fuese el de la Historia, pues, al ser entes históricos, no podían ser enjuiciadas ni entendidas desde otro ángulo metodológico. Para ejemplo de este cientificismo racionalista, bástenos el del ya citado F. G. Cosmes, quien a principios de 1896 publicó una serie de artículos sobre la masonería y el deísmo en el periódico El Partido Liberal. ${ }^{84}$ En el primero de ellos se dedicaba a refutar la crítica de la prensa católica a la tendencia desacralizadora o atea de las logias. En el segundo trataba de demostrar que las logias eran el producto de una evolución de los gremios medievales de canteros, y que, si éstos se regían por principios religiosos, sus herederos masones no podían ni debían abandonar esos principios por una especie de coherencia histórica, es decir, por el "lógico" desarrollo de la institución. Luego, en respuesta a los católicos, defendía la creencia que tenían los masones en Dios, pero entendido desde la perspectiva que señala como científica. Dicho en otros términos, podríamos identificar en esa época el surgimiento de una especie de masonería positivista. Al menos así lo entendieron algunos de sus detractores y de sus defensores.

Así, esta irrupción del cientificismo - tal como lo señalaba la misma prensa crítica- había hecho mella en los masones de nuevo cuño a finales del XIX, lo cual, como hemos señalado, se manifestó en la depuración de su ritual y de su simbolismo, o, quizá deberíamos decir, en la transformación de ese ritual, pues el simbolismo, entendido como conjunto de creencias y referencias mentales, no había desaparecido del fondo doctrinal de las logias, tal como lo afirmaba Cosmes.

La masonería no era sólo un movimiento social o una asociación humanista y filantrópica, pues, tal como lo señaló la prensa católica de la época, contaba entre sus prácticas y creencias muchos ritos de carácter liminal, es decir, de señalamiento del paso de una etapa de la vida de sus miembros en la que supuestamente habían imperado el fanatismo y la ignorancia, a otra en la que verían el mundo con ojos distintos. Por ello, desde el primer capítulo, enfaticé lo que a mi juicio constituye el núcleo de la crítica católica antimasónica, especialmente

83 Idem.

84 Cosmes, F. G., “La masonería es esencialmente deísta II”, El Partido Liberal, México, 7 de enero de 1896. 
la publicada en la prensa: las prácticas gnósticas y deístas, que proponían ese paso de la realidad al misterio que ésta encierra.

El término liminal hace referencia precisamente al limen, es decir, a la línea divisoria entre una etapa inferior de subdesarrollo y otra superior, o como solía decirse en el siglo XIX, entre la barbarie y la civilización, entre el retraso y la prosperidad, entre las tinieblas de la ignorancia y la luz de la razón. Es precisamente ese carácter liminal el que, a mi juicio, constituye la médula de todo mito. Por ello, todos los símbolos de la masonería representan de muy diversas maneras ese paso - de cada hombre en particular y, en un futuro, de las sociedades enteras- hacia un estadio superior de la existencia y de la conciencia. De ahí que en los diversos ritos se recurriera a la iconografía clásica de los haces de luz que iluminan y esclarecen la vida humana, o al de las escalinatas que culminaban en el momento liminal del hallazgo y del encuentro del individuo con la verdad, es decir, de la incursión de su conciencia en una nueva y superior dimensión del ser. De ahí deriva también la evocación de lo antediluviano, de los arcanos de la antigüedad, como las columnas estriadas y las imágenes de los grandes sabios de la historia universal -los grandes iniciados- enmarcados normalmente en un conjunto iconográfico de carácter mítico o, como he dicho, liminal.

Nada de esto es racional, aun cuando evoque la racionalidad. Por ello el recurso constante de la masonería decimonónica al lenguaje de la religión, pues ese paso dista mucho de entenderse como un proceso propiamente racional. El encuentro es catártico, conversional; en última instancia, pertenece al ámbito de la conciencia humana, y lo mismo sucede con los rituales que lo representan. Cada paso del ritual es expresión del misterio, o quizá debería decir del misterioso momento en el que el hombre se encuentra con el principio de la racionalidad del mundo o en el que se le revela de un modo más claro ese principio, según el grado de conocimiento del que se trate. Por ello, la masonería de la época que nos ocupa era esencialmente gradual y jerárquica, pero, sobre todo, secreta, pues en el arcanum está contenido el saber. Y, por la misma razón, su ritual era secreto, porque se partía de la idea de que el masón no era igual a los demás, a los profanos, a los que yacían en los abismos de la ignorancia. Su lenguaje era distinto. Tanto como lo era su modo de comprensión del mundo y su nivel de conciencia de la realidad.

Estas ideas, típicamente gnósticas, se manifiestan en la mixtificación, no sólo formal sino también filosófica y moral, de sus ceremonias y ritos. En el fondo, se trata de una visión racionalista de la religión. Racionalista porque la masonería del XIX buscaba reducir la comprensión del mundo a lo meramente racional; pero, racional o no, era una visión religiosa. Por ello, aunque 
secularizadas, las prácticas rituales de las logias no dejan de pertenecer a ese difícil campo interpretativo de la sociología de la religión, de la antropología e, incluso, de la teología. Una de esas prácticas era la del juramento, cuya naturaleza era esencialmente religiosa, pues se invocaba a Dios o a un principio divino como el Gran Arquitecto del Universo, por testigo del encuentro, de la conversión y, finalmente, del paso del masón de un estadio de su existencia a otro de nivel más elevado.

\section{Furamentos y ceremonial de paso}

Por estas razones, el juramento era el eje de todas sus ceremonias. En él se comprometía el masón a ser leal, y, más que eso, a ser fiel guardián y apóstol del saber gnóstico, es decir, del arcanum, del secreto contenido en su derecho estatutario y en las constituciones de la orden que le era dado conocer, según el grado que tuviera dentro de la logia. Así, la conciencia se veía constreñida y constantemente conjurada ante la posibilidad de la traición. La retórica de la fidelidad, ahincada en el juramento, iba siempre unida a la conminación y al miedo de la persecución por parte de las logias, motivos más que suficientes para generar una gran preocupación de los católicos, sobre todo cuando intentaban recuperar a las ovejas perdidas para el rebaño de su grey, pues, como veremos en las siguientes páginas, los masones juramentados siempre tuvieron dos enemigos para desandar el camino de los pasos perdidos: su conciencia constreñida por el juramento y el miedo al boicot de sus ex hermanos, que generalmente consistía en el cierre de puertas en su camino profesional. Pero, ¿cómo eran aquellas ceremonias de la conciencia que tanto preocuparon a los católicos? Este tipo de actos formales - los cuales tuvieron sus variaciones a lo largo del tiempo y de un rito a otro- se regían por un cuerpo normativo llamado ritual. Había uno para cada grado, del 1o al $33^{\circ}$. De los más complicados eran el $18^{\circ}$, el cual correspondía al Rosacruz, y el $30^{\circ}$, que era el último grado de conocimiento (los tres restantes eran administrativos), al cual se denominaba Kadosch. Los miembros de estos dos grados-decían los católicos- formaban la verdadera élite de las logias y de las órdenes. Eran los de mayor confianza y a quienes se encomendaban las tareas más claramente anticatólicas. Formaban la "alta masonería", y las ceremonias de sus juramentos eran más complejas porque implicaban mayores responsabilidades en la jerarquía y en la dirección de sus hermanos. Pero ya volveré sobre esto más adelante, por ahora me es suficiente con dejarlo señalado.

No es mi objetivo describir aquí cada uno de los rituales de paso, sino en la medida en la que provocaron reacciones de los católicos, quienes, como ha 
quedado dicho, los daban a conocer en la prensa con el objeto de restarles fuerza y valor. En una de estas ceremonias se solía vendar los ojos al iniciado, se le ataban las manos y se le colocaba una soga al cuello. Luego, el maestro lo conducía hacia un pequeño escenario montado en la logia, que simulaba una cámara subterránea a la que se daba el nombre de catacumba. Lo acercaba haciendo como que descendían a ese lugar y ahí tenía lugar la ceremonia. Ésta siempre se llevaba a cabo a puerta cerrada, incluso dentro de la logia, es decir, se cerraban las puertas de la galería que daba acceso al vestíbulo o área de pasos perdidos, según la nomenclatura masónica, pues no podían entrar ni los miembros de la logia. De acuerdo con el ritual, la disposición secreta del espacio era para que "no se [temiera] la indiscreción profana" ${ }^{85}$ Antes de dar inicio a la ceremonia, se colocaba una silla de asiento triangular para el recipiendario, se colgaban de las paredes algunas tarjas con inscripciones sobre el compromiso que adquiría el nuevo masón o el que se incorporaba a un grado superior, y al lado se ponía un féretro, cráneos, huesos y piedras. Colocaban, además, una pequeña mesa, también triangular y pintada de negro, con la imagen grabada o pintada de un compás y una escuadra, y sobre ella se ponían un vaso con agua, un pedazo de pan y un poco de sal en un salero. Así lo dispone el ritual de la Gran Dieta Simbólica de México, elaborado y aprobado - como se ha dicho- por Emilio Cantón e Ignacio Manuel Altamirano, en el cual se indica el significado de cada uno de estos elementos simbólicos del juramento, que, como veremos, corresponde a la idea básica de compromiso de la conciencia en el proceso de conversión y transformación personal del masón.

La venda en los ojos significaba la ignorancia de aquellos que permanecían en las creencias religiosas según el magisterio de la Iglesia, las cuales eran vistas como fanatismo. La cuerda era el símbolo de la atadura del hombre que no es virtuoso, es decir, que "vive esclavo de sus pasiones" [sic]. El compás y la escuadra, a los que ya hemos hecho referencia en páginas anteriores, en este caso (en el juramento) significaban respectivamente, la "moderación de los deseos" y la "equidad de las acciones", es decir, eran suma y síntesis de los más caros ideales de la ascética de la masonería. El candelabro con tres luces era símbolo de la ciencia, la virtud y la fraternidad. La sal, el pan y el agua significaban bienestar y salud. ${ }^{86}$ Con estos símbolos se auguraba un feliz y prometedor futuro al nuevo masón o al que adquiría

85 RIT: · ESC: · ANT: · Y ACEP: · Liturgia de la Gran Dieta Simbólica de los EE: · UU: · Mexicanos. Primer grado de Aprendiz (a catgo de Emilio G. Cantón), México, Oficina Tipográfica de Francisco Cosío, 1894, p. 6. (En adelante citado como Liturgias.)

86 Idem. 
el grado superior. Además, se le hacía partícipe del arcanum de la sabiduría, mismo que iba implícito en cada uno de los símbolos. Al final se le entregaba un mandil, un martillo, un yunque y una regla. El primero era "símbolo del trabajo", el segundo representaba la fuerza para "batir los vicios" en el "yunque de la razón", y la regla le recordaba que nunca debía separarse de la "línea inflexible del deber". ${ }^{87}$

Previo a la admisión de una persona como candidato o aspirante, y hasta obtener el primer grado, un instructor designado por los directores de la logia le daba algunas clases en las que aquél debía ir aprendiendo, poco a poco, los principios fundamentales de la gnosis masónica. Concluida esta etapa, se preparaba al nuevo miembro para que se desenvolviera con soltura en el acto ceremonial del juramento, repasando cada paso que debía darse, así como las fórmulas que pronunciarían el representante de la logia y el candidato. Esto se hacía repitiendo cada una de las preguntas que, a manera de catecismo, debía aprender a responder de modo literal.

En el acto de juramento del primer grado no se hacían más compromisos con la orden que los elementales de lealtad y silencio. Siempre el silencio. Además, se le comunicaban algunas fórmulas a manera de santo y seña, para que se identificara como miembro del rito al que se iba a incorporar y para que reconociera a los demás masones hermanos cuando viajara a otra ciudad. El ritual de la Gran Dieta de México, de 1894, contiene algunas de estas fórmulas de identificación secreta. Por ejemplo, si un masón llegaba a una logia a la que no pertenecía, se le debían hacer algunas preguntas clave como ésta: “Qué nos tenéis?" y la respuesta debía ser literalmente: "Salud, Alegría, Prosperidad". ${ }^{88}$ Una vez que se identificaba, se le daba acceso a la logia y se le permitía participar en las reuniones a las que le estaba permitido, según su grado. Además, se le enseñaba "el signo, el tocamiento y la palabra", con los que debía aprender a identificarse e identificar a los de su misma gnosis. Esto significa que debía aprender a saludar con apretones de manos específicos, decir las palabras adecuadas para componer una expresión que significaba fuerza, usar en sus escritos los tres puntitos, y algunos otros conocimientos reservados para los miembros de la familia masónica.

Para la recepción en otros grados, el masón o candidato se revestía con una túnica blanca manchada de sangre, se le hacía colocar la mano derecha sobre un cadáver o una calavera, y la izquierda sobre los estatutos de la orden. El espacio se disponía de modo semejante al descrito para la ceremonia

\footnotetext{
87 Ibidem, p. 54.

88 Ibidem, p. 55.
} 
de aprendiz y la preparación que recibía por medio de charlas instructivas seguía también el mismo formato.

En estas ceremonias todo era secreto. Los rituales o libros que contienen las reglas del ceremonial hacen constante alusión a la necesidad de cerrar puertas, advertir si hay personas ajenas a la ceremonia ahí presentes; en fin, la reserva para que nadie pudiera enterarse de lo que ahí sucedía más que aquellos a quienes estaba permitido por las reglas. Con esto, además de garantizar la protección al secreto del saber, se aumentaban el misterio y el sentido de separación y privilegio del candidato respecto a sus hermanos de grado inferior y, sobre todo, frente a los profanos de la masonería. Cuestión que los católicos trataron de desarticular, publicando cuanto reglamento, ritual o parte de éstos caía en sus manos.

$\mathrm{Al}$ parecer, lo más sagrado no eran los movimientos corporales ni las imágenes que se colocaban en los recintos para la ceremonia, sino las palabras del juramento, en las que se contenía buena parte del simbolismo, especialmente en lo tocante a los compromisos del masón para hacerse uno con el conjunto de su logia, cerrar filas y defenderse de todos aquellos a quienes la masonería consideraba enemigos, empezando, en muchas ocasiones, por la Iglesia católica. Pero veamos directamente lo que dispone en este sentido el ritual, cuyo contenido fue dado a conocer por la prensa católica.

Una vez recibida la preparación previa y luego de que los venerables aprobaban la incorporación del hermano a una logia, tenía lugar la ceremonia en la que éste pronunciaba las palabras de juramento con las que comprometía su conciencia:

Juro por lo que respeto como más sagrado, cooperar a la destrucción de los traidores y perseguidores de la francmasonería, exterminarlos por todos los medios que están a mi alcance. Juro reconocer como el azote de los desgraciados y del mundo a los reyes, a los fanáticos religiosos, y tenerles siempre horror. Juro proclamar donde quiera que me encuentre, los derechos del hombre, y no seguir jamás otra religión que la que la naturaleza ha grabado en nuestros corazones. Juro obediencia sin restricción al jefe de este Consejo o a quien lo represente. Que todas las espadas vueltas contra mí se hundan en mi corazón si alguna vez tengo la desgracia de apartarme de mis compromisos, contraídos con mi libre y plena voluntad. Así sea. ${ }^{89}$

89 "Juramento del masón", El Pájaro Verde, México, 11 de mayo de 1874. Cita como fuente la obra Anales Masónicos, tomo V, pp. 219 y 226, publicados por Caillot en Francia, entre 1807 y 1810. 
Como puede observarse, el nivel de exigencia de un grado inferior a uno superior iba aumentando, no sólo en cuanto a los compromisos que adquiría, sino también en lo que respecta al secreto del que era depositario, es decir, a la confianza que los jerarcas iban depositando en él para promoverlo en los siguientes grados y darle encargos de mayor responsabilidad dentro de la orden. Parte del señalamiento que la prensa católica hacía contra las logias iba dirigida precisamente a aquellos que, por las razones que fueran, habían adelantado en sus compromisos y en los niveles de involucramiento que exigían los grados y los cargos directivos.

Como se ha señalado, por su propia naturaleza, todo juramento consiste en empeñar la palabra poniendo a Dios como testigo. Y así se hacía en la masonería decimonónica. Sin embargo, se trataba de un dios que no coincidía con el de la Revelación ni menos con el del magisterio de la Iglesia, pues, como se dijo al principio, en muchos ritos se le denominaba así, pero se hacía referencia a un principio, a una fuerza abstracta del Universo.

Así, por ejemplo, según el Rito de Misraim (nombre hebreo de Egipto), ${ }^{90}$ recogido por el citado crítico y controvertido converso, León Taxil, en su obra sobre el símbolo de Los hermanos de los tres puntos (Les Fréres Trois-Points), el juramento del paso de los grados inferiores al Rosacruz se hacía en estos términos:

Juro en nombre del Todopoderoso, Arquitecto Supremo del mundo, no revelar jamás los secretos, signos, toques, palabras, doctrinas y usos de los Francmasones y de guardar sobre esto un eterno silencio. Prometo y juro al Todopoderoso de no hacer jamás traición sobre esto, ni por la pluma, ni por señales, ni por palabras, ni por gestos, ni escribir sobre ello... Yo me someto en caso de faltar al juramento a las penas siguientes: A que me quemen los labios con un hierro ardiendo, que me corten la mano, que me arranquen la lengua, que me sieguen la garganta, que mi cadáver sea suspendido en una logia durante el trabajo de admisión de un nuevo hermano para servir de espanto a aquellos que como yo se sientan tentados a faltar al juramento, que sean quemados mis odiosos restos y sean arrojadas mis cenizas para que no quede recuerdo ni rastro de mi traición..$^{91}$

Enseguida "firmaba con su sangre el Gran libro de la arquitectura y de la correspondencia secreta", y el Gran Maestre le preguntaba la época en la que

90 El rito masónico de Misraim - leemos en el Diccionario de Daza- conocido también como rito egipcio o judaico fue fundado en 1814. Daza, Juan Carlos, sub voce.

91 "Las víctimas de la Francmasonería (parte I)", El Tiempo, México, 22 de octubre de 1887. 
estaban, a lo que él debía responder: "En la regeneración del mundo". ${ }^{92}$ Esta regeneración no necesariamente estaba vinculada a la ciencia matemática, sino, en algunos casos -según lo dice el ritualista José María Ragon-93 a la regeneración sexual.

A partir del momento en el que el poseedor de un nuevo grado juraba, la vida del masón debía ceñirse a los estatutos y controles de los jefes de las logias. Su vida entera quedaba comprometida con ese juramento que lo obligaba bajo amenazas y lo constreñía para siempre, incluso hasta el momento de su muerte. Esta cuestión la Iglesia la señaló siempre con enorme preocupación, pues generalmente los hermanos de un masón moribundo impedían el paso de los sacerdotes a administrarle la extremaunción y a rezar en sus funerales. De ello la prensa católica también se hizo cargo, dando a conocer las normas disciplinares en la materia. ${ }^{94}$

\section{El problema del proselitismo}

Una de las más grandes mentiras de las que se acusaba a la masonería en este tipo de periódicos era su constante negativa acerca de su oposición al catolicismo. Pero las logias mexicanas se resistieron a esta acusación de los católicos, pues las denigraba ante la opinión pública y alejaba a sus posibles seguidores católicos. Sostuvieron constantemente lo contrario y se mostraron como instituciones humanitarias, por lo que defendieron a capa y espada su neutralidad en materia política y religiosa. Afirmaban que no eran sino sociedades cívicas en las que se impulsaba la instrucción, el amor a la naturaleza, el deseo de mejora personal y la filantropía. A modo de ejemplo, puede verse esta propaganda proselitista aparecida en la prensa liberal como respuesta a

92 "Juramento del masón", idem. Recuérdese que en el origen mítico de la masonería escocesa se encuentra esta idea representada en Osiris, deidad egipcia que significa "regeneración del Nilo". Por ello se le tomó como símbolo al lado de la pirámide de Keops.

93 En el Diccionario Enciclopédico de la Masonería, de Lorenzo Frau Abrines (México, Editorial Del Valle, 1980) se señala a José María Ragón como uno de los masones más destacados de su tiempo. A partir de 1814 viajó por algunos países y muy especialmente por América. Enriqueció su colección de rituales (de los que llegó a reunir más de 400) y otros interesantes documentos que tan abundante material le facilitaron para escribir numerosos artículos y obras. Tomó una parte muy activa en todos los trabajos de reforma que llevó a cabo el Gran Oriente, del que fue siempre partidario, especialmente en los que se llevaron a cabo para la introducción y propagación en Francia del rito de Misraim.

94 "El enterramiento de los francmasones", El Tiempo, México, lo. de marzo de 1890, p. 1. Y sobre el mismo tema: "Política menuda / Intolerancia masónica", El Tiempo, México, 15 de junio de 1894, y "Política menuda. Intolerancia masónica", ibidem, p. 2. 
la denuncia de la "corte romana" y la "prensa reaccionaria" [sic]: "¿Queréis perfeccionaros? ¿Anheláis un freno a vuestras malas pasiones? ¿isentís la fuerza de voluntad necesaria para matar los odios [...] encontrar grandes alicientes para cumplir los dos grandes mandamientos de la ley natural? Venid a la asociación masónica, cuyo ideal es la fraternidad universal, cuya práctica es la virtud, cuya mira es la perfección del hombre". ${ }^{95}$

Tratábase, según la versión oficial de la masonería mexicana, de una fraternidad universal de beneficencia social y solidaridad humana que en nada afectaba las creencias particulares de sus miembros y de sus simpatizantes. Como tal se presentaba a los profesionistas, empleados públicos y oficiales, quienes a menudo se acercaban a las diversas asociaciones masónicas con la esperanza de mejorar como personas, pero, sobre todo, con la ilusión de llegar a tener un mejor modo de vida por medio de la consecución de un puesto o de la recomendación de un hermano para generar mayor número de vínculos personales.

A decir de sus denunciantes católicos, las logias encontraron un terreno especialmente fértil y abonado para hacer prosélitos en la juventud: "son víctimas de las sociedades secretas [leemos en El Tiempo] esas almas inocentes de infinitos jóvenes que frecuentan escuelas y liceos". Se refería a los más jóvenes, a quienes las logias reclutaban aprovechándose de "la flexibilidad de edad tan tierna". ${ }^{6} \mathrm{Y}$ aquí debo mencionar una de las prácticas adoptadas por la Gran Dieta Simbólica de México, aunque ya para entonces era de tradición antigua entre las logias. Me refiero a la "adopción de niños" o de Louvetones, como se les denominaba. Este pregrado se formaba por los hijos de los masones que tenían menos de doce años y eran inscritos por sus padres en la logia, mediante una solicitud y correspondiente ceremonia en la que se practicaba la ablución o bautismo y se imponía a cada niño recién ingresado su "Medalla de Louveton". ${ }^{97}$

Pero el problema era el de los jóvenes católicos, especialmente aquellos que destacaban en los estudios o daban muestras de distinción y ascendiente entre sus compañeros. A eso se debe el esfuerzo del arzobispo de México, Próspero María Alarcón, para obtener el reconocimiento oficial del gobierno a los estudios del Seminario Diocesano (Studium Generale), pues de ese modo evitaría que la juventud asistiera a la Escuela Nacional Preparatoria, donde, además del positivismo que desde la restauración de la República habían

95 Netzahualcóyotl, "En lo que se ocupan los masones", La Bandera Roja, Durango, 15 de mayo de 1885 .

96 "Las víctimas de la Francmasonería (2a. parte)", El Tiempo, México, 23 de noviembre de 1887.

97 Liturgias..., cit., pp. 34 y ss. 
impuesto Gabino Barreda y Porfirio Parra en los programas de estudio de esa institución, los masones de las diversas logias hacían constante labor proselitista entre los estudiantes. ${ }^{98}$

El periódico jesuítico El Mensajero del Corazón de Jesús no dudó en llamar a los grandes masones, es decir, a los que poseían grados de dignidad, "Grandes compra-chicos", ${ }^{99}$ pues, aparte de la rara práctica de los Louvetones, se valían de sus tácticas de seducción y reclutamiento para inscribir en sus filas al mayor número de jóvenes estudiantes, quienes, inexpertos, se dejaban impresionar por el altruismo humanitario de la institución, por la supuesta ejemplaridad y edificación moral de sus camaradas y compañeros de aula que se sabía pertenecían a la masonería o, dicho en los términos del ritual masónico de la Gran Dieta de México, "por los consejos de la amistad y el ejemplo de las virtudes". ${ }^{100}$ Por la misma razón, otro periódico católico de la capital advertía sobre el constante recurso de la masonería a la táctica de fascinación por medio de falsas muestras de amistad e imágenes humanitarias de generosidad; señalaba que "muchos jóvenes se dejaban seducir creyendo que tan sólo se asociaban en una compañía amistosa y bienhechora". ${ }^{101}$

Así, la "amistad" se transformó en uno de los instrumentos más eficaces para el proselitismo masónico, al grado de que las logias llegaron a representar para muchos jóvenes el camino ideal de socialización. En el citado ritual de la Gran Dieta Simbólica de México se preveía que el instructor de la ceremonia de admisión del aprendiz le hiciera esta pregunta: “Quién os proporcionó la ventaja de ser masón?", a lo cual el solicitante debía responder: "un amigo prudente que he reconocido después como hermano". ${ }^{102}$ Por supuesto, en la mayoría de los casos, la "amistad" entre el invitado y el invitador concluía una vez que se transformaba en "fraternidad". De ese fenómeno de utilización de las relaciones se ocupó la crítica de los católicos de modo reiterado.

98 En el Seminario estudiaban muchos jóvenes católicos, a quienes se enseñaban los errores del positivismo, así como del gnosticismo, el deísmo, el maniqueísmo, y las teorías naturalistas e inmanentistas de la creación. Valverde nos da noticia de uno de los libros que por entonces se escribieron con este fin: el del padre Nicanor Losada, Apuntes de Lógica, Cosmología y Psicología para alumnos del Seminario Conciliar, aparecido en 1880. Ahí mismo: "El positivismo en la Escuela Nacional Preparatoria" y "José María Vigil". Véase ValverdeTellez, Emeterio., op. cit., pp. 351 y ss.

99 "La masonería”, El Mensajero del Corazón de Jesús, México, 19 de febrero de 1878.

100 Liturgias... cit., p. 41.

101 Conde de Campagny, F. "La masonería (a propósito de un estudio sobre la masonería por el señor Obispo de Orleans)", El Pájaro Verde, México, 26 de octubre de 1875.

102 Liturgias... cit., p. 52. 
Por los relatos de la prensa que aquí estamos analizando es evidente que no sólo a los periodistas preocupó esa forma de tergiversar la amistad y de utilizarla con fines proselitistas. También a la Iglesia jerárquica le inquietaba el fenómeno, especialmente el que se daba entre los jóvenes, quienes, por su edad, era lógico que sintieran la urgente necesidad de una identidad personal, amén del deseo de pertenencia a un grupo que los acogiera y protegiera. Y es que, según la denuncia de los periódicos y libros escritos por los católicos, lo más destacable en la propaganda de las logias era el recurso de los masones a tres tácticas muy comunes en las logias de todo el mundo: 1) el ofrecimiento que se les hacía a los jóvenes de adscribirse a un universo simbólico -un mundo distinto y renovado- que los dotaba de singularidad e identidad mediante una iniciación, es decir, de la entrada en una nueva dimensión existencial que los separaba del resto de sus iguales; 2) la promesa que les hacían de alcanzar un futuro profesional y social pleno de éxitos y de fortuna si se incorporaban a la masonería y eran leales a sus principios secretos, guardando el sigilo conjurado en un rito, y 3) la seguridad absoluta de contar con la protección que recibirían de sus hermanos siempre y en cualquier lugar del mundo en el que se encontraran.

Acerca de la primera, la prensa católica destacó la potencialidad seductora de sus ideales de servicio a la humanidad, a los que la juventud solía responder con el entusiasmo y la generosidad característicos de su edad. Creo que algo de razón tenía esta crítica en lo referente al entusiasmo de la juventud ante la idea de entregarse a una causa, pues el masón neófito, es decir, el principiante renovado, sabía que entraba a una nueva extensión de su existencia terrena, en la que debían primar los principios de servicio generoso a sus semejantes antes que sus propios intereses. Así, por ejemplo, cuando uno de éstos entraba al primer grado, se le preguntaba: “¿Por qué os habéis hecho masón?", a lo cual el candidato debía responder: "Porque vivía en las tinieblas y deseaba la Luz". La luz en sentido gnóstico era un saber que le llevaría necesariamente a un despojo de sí mismo para dedicarse con ahínco a la práctica de la filantropía, "cualidad inseparable del masón para el que nada valen las riquezas, comparadas al honor", decía el ritual. ${ }^{103}$

Respecto a la segunda de las tácticas, un editorialista de El Pájaro Verde advertía: "Los jóvenes deben tener también en cuenta que las promesas con que los reclutadores tratan de seducirlos, son por punto general, irrealizables [...] Ni la riqueza ni los honores, ni los empleos, ni los asensos en la carrera son infinitos, y ni siquiera son tantos como los que los desean". ${ }^{104}$ El funda-

103 Ibidem, pp. 52 y 53.

104 “Sociedades secretas”, El Pájaro Verde, México, 1o. de junio de 1874. 
mento de la crítica a la tercera de estas tácticas lo podemos encontrar en un documento masónico, publicado por uno de estos periódicos, en el que se dice literalmente: "El buen masón nunca debe temer verse abandonado. En los países cultos, donde quiera que haya hermanos está cierto de encontrar amigos". Incluso aseguraba a los futuros agremiados que, de caer en la adversidad, "no les habrían de faltar socorros, recibiéndolos de aquellos que pudieran proporcionarlos". ${ }^{105}$

A la Iglesia católica mexicana le preocupaba también la amplitud del criterio selectivo que se había verificado en la masonería durante la época del Porfiriato, pues prácticamente cualquier joven burgués de clase media podía ser aceptado en las logias. Incluso a algunos masones viejos, les parecía que aquella apertura de las logias era expresión de una crisis de la institución, pues haber abierto sus famosas "tenidas blancas", a las que podía entrar cualquiera como "oyente profano", no tenía otra finalidad que aprovecharse del mayor número posible de jóvenes ingenuos, con fines meramente económicos o de aumento del número de los miembros. Dicho de otra manera, los propios masones recelaron de tal apertura, pues en la antigua tradición de las logias no entraba toda clase de gente. No les convenía ni siquiera que perseveraran en ella todos los que entraban, ni mucho menos que ascendieran en los grados más altos los que perseveraban. La iniciación servía como coladera que no dejaba entrar y continuar en las logias a aquellos que ofrecieran o representaran muestras de rebeldía. Y es que, como ya he señalado, el gnosticismo que se practicaba en la masonería daba "saltos" de lo racional a lo misterioso, los cuales no se prestaban a la criba de espíritus curiosos, preguntones o rebeldes. Me refiero a la prohibición de preguntar de la que también ya se ha hecho mención. Así, estas prácticas se habían ido debilitando en la medida en que las logias mexicanas se fueron abriendo.

La prensa católica publicó algunos de los artículos en los que ciertos francmasones de viejo cuño manifestaban su nostalgia por otras épocas en las que la entrada era más restringida y elitista, así como su profundo resentimiento por tal reblandecimiento y degeneración en los criterios selectivos. ${ }^{106} \mathrm{Y}$ no les faltaba algo de razón a aquellos masones viejos y a la Iglesia misma, pues a partir de la última década del siglo XIX es notoria la insistencia en ese fenómeno de debilitamiento y apertura por reblandecimiento institucional. Bastaba con que

105 “Derechos del masón”, La Bandera Roja, Durango, 1o. de agosto de 1885.

106 "La masonería" (artículo tomado de La Época, de Madrid) El Tiempo, México, 15 de febrero de 1895. Y lo mismo se decía años atrás de aquellos viejos masones que habían perdido el espíritu de los "tiempos gloriosos", quienes no hacían sino poner en evidencia una crisis profunda de las logias. "La masonería" (tomado de La Gaceta de Parma), El Tiempo, México, 28 de diciembre de 1893. 
cualquier joven, tras su asistencia a una de esas tenidas blancas manifestara a un Gran Maestre o a un Venerable su deseo de buscar la verdad, ejercer el humanitarismo y practicar la filantropía universal, para que fuera admitido en la iniciación, primero como candidato, luego como aspirante, y, tras la llamada prueba de la iniciación, como recipiendario y neófito. Todos cabían, salvo aquellos que no quisieran o no pudieran cumplir con el principal fin de la masonería, el cual era "enseñar el amor al trabajo": "sólo se proscribe en su seno al vago y al holgazán". ${ }^{107}$ Como consecuencia, tampoco se aceptaba al joven de condición social y económica bajas, pues, por una parte, se suponía su escasa capacidad laboral, y, por otra, era considerado como persona poco apta para influir directamente en los altos círculos de la sociedad.

Además, la crítica que hacían los periodistas católicos a esta situación también se dirigía a las sumas de dinero que los miembros de las logias debían aportar regularmente, depositando su óbolo en el saco de beneficencia, también llamado saco de los pobres, que circulaba en las solemnidades masónicas o entregándolo a alguna autoridad de la logia para que lo depositara en la caja, que era como llamaban al depósito de las contribuciones, el cual luego era repartido entre los miembros de las logias del modo que consideraran conveniente los directores. Por estas razones, una persona de recursos exiguos difícilmente podría cubrir las cuotas que se exigían a los iniciados, y menos aun efectuar los pagos extraordinarios para el gran número de festejos, ágapes y ceremonias a las que las logias mexicanas parecen haber sido muy afectas. ${ }^{108}$ Así, la solvencia económica garantizaba de algún modo que el nuevo miembro aportaría fuerzas y recursos a la organización y en ningún momento los restaría o significaría un lastre para los demás agremiados. Ésta era la nota que destacaba un hermano mayor de la masonería en España, reproducida en México por el diario El Tiempo con fines de denuncia: "Recordad hermanos [decía un Gran Maestro] que la masonería no es una corporación en la cual los miembros han de vivir a costa de otros [...] No presentéis jamás a la admisión de nuestra Orden a hombres que puedan extender la mano para pedir, y no alargarla para dar". ${ }^{109}$

107 Idem.

108 "Fiesta masónica", El Tiempo, México, 28 de diciembre de 1893. Y lo mismo en "Festividad masónica", idem., donde aparece la descripción pormenorizada de la fiesta de conmemoración del 35o. aniversario del rito escocés en México, los menús, las bebidas y demás elementos con los que el diario católico busca dar a conocer lo que considera un "derroche".

109 "Las víctimas de la Francmasonería (2a. parte)", El Tiempo, México, 23 de septiembre de 1887. 
Esta obra forma parte del acervo de la Biblioteca Jurídica Virtual del Instituto de Investigaciones Jurídicas de la UNAM www.juridicas.unam.mx

https://biblio.juridicas.unam.mx/bjv

\section{LEÓn TAXIL, DiAna VAUghan Y EL ANTIMASONISMO DE TRINIDAD SÁNCHEZ SANTOS}

En su campaña, la prensa católica mexicana se valió de artículos e informes que llegaban a sus oficinas, pero de modo particular empleaba la obra del controvertido y un tanto descocado personaje de la época, el francés León Taxil, la cual encontramos citada en innumerables artículos, alegatos, e incluso en algunas cartas e instrucciones pastorales publicadas en los diarios y traducidas en su gran mayoría por el ilustre periodista mexicano Trinidad Sánchez Santos. En todas ellas se hace referencia a Taxil como fuente fidedigna de orientación para conocer el trasfondo de la masonería y prevenir la acción de las logias en la sociedad. Pero, ¿quién era este personaje tan singular en el que creyeron, no sólo un buen número de periodistas católicos mexicanos, sino también clérigos de México y de todo el mundo, y hasta el mismo pontífice de Roma? Para empezar, León Taxil era un seudónimo literario o periodístico, pues su verdadero nombre era Gabriel Antoine Jogard-Pagés.

Antes de convertirse en el adalid del antimasonismo católico en todo el mundo y en el más terrible detractor del satanismo o paladismo de la masonería, fue un masón dedicado a combatir a la Iglesia desde el periódico revolucionario Le Petit Eclarieur. "Sus armas favoritas [dice un editorialista mexicano de la época] eran la mentira, la sátira, la calumnia, el crimen. Los títulos son por demás expresivos de su actividad anticlerical: La papisa Juana, historia de aquella mujer que asumió el pontificado disfrazada de hombre, no obstante que estaba embarazada et in processionem peperit ("Papa Pater Patrum peperit Papisa Papellum": Un Papa, padre de los padres, parió siendo papisa una papita). Asimismo, escribió Los libros secretos de los seminarios, en donde cuenta un sinfin de historias morbosas producto de su fantasiosa imaginación, y en el mismo sentido novelístico y fantasioso, escribió El hijo del jesuita, Abajo los curas, Las sotanas grotescas, León XIII el envenenador y Giordano Bruno. Para este último, su imaginación no tuvo límites: inventó un supuesto instrumento de tortura utilizado en el tiempo de Bruno, llamado la araña arranca pechos, el cual fue enriqueciendo con gran creatividad en las sucesivas conferencias, al añadirle picos, ganchos, cadenas, garfios y arpones. Fue tal el éxito que tuvo su descripción de aquel imaginario artefacto macabro, que mandó hacer uno con un herrero parisino para exponerlo al público como objeto curioso, supuestamente rescatado de los conventos medievales. Todo esto, como he dicho, según confesión del propio Taxil. Además, para dar más teatralidad a su ya acrecentada fama periodística, mandó falsear e imprimir 
una bula apócrifa en la que el papa, supuestamente muy preocupado por él, lo excomulgaba.

A decir del propio Taxil, las oraciones de su madrina, sor María de los Siete Dolores, fueron determinantes en su conversión. En 1887, publicó un comunicado, en el cual había renovado su sumisión a la Iglesia "a los pies del Santo Padre". Tras abjurar de la logia a la que pertenecía y renunciar a su columna en el periódico, se dedicó con igual ímpetu y vehemencia a escribir y publicar varios libros en los que se contenían la doctrina, el simbolismo y las tácticas políticas y revolucionarias de las logias.

Como he señalado, en México se conoció y leyó la traducción de la principal obra de Taxil: La masonería revelada, que circulaba en sus diversas traducciones. ${ }^{110}$ Pero sobre todo se leyó la que había hecho el connotado luchador social y colaborador del periódico católico El Tiempo, Trinidad Sánchez Santos, quien corrigió la primera traducción hecha en España, por parecerle de mala calidad y plagada de omisiones, errores de estilo e, incluso, de afirmaciones que no hizo Taxil y que por la mala traslación de significados parecían inducir a "herejías" [sic]. ${ }^{111}$ Esta edición mexicana apareció con el título de La francmasonería revelada y explicada ${ }^{112}$ se imprimió en rústica y se vendía a muy bajo precio, con el fin de que fuese ampliamente difundida entre todas las clases sociales: "Esta obra [leemos en El Tiempo] es una de las más interesantes que se hayan publicado en el presente; las revelaciones verdaderas y completas que contiene están llamadas a producir inmensos desengaños, e instrucción preciosísima para los católicos y no católicos". ${ }^{113}$

Si bien estaba dirigida al gran público, en una presentación publicitaria de la obra aparecida en la prensa en octubre de 1887, Sánchez Santos señalaba que su objeto primordial era advertir a los católicos sobre los engañosos usos de la masonería, pues por más que hubieran estudiado la estructura y fines de esa ideología o secta, "nada se sabrá de ella antes de leer a Taxil [...] Todo católico debe leerla; es una necesidad vital de los días que vivimos; el católico que, en este último tercio del siglo, no conozca a la Masonería, es un soldado que entra a la batalla con los ojos vendados". ${ }^{114}$

110 Circularon las ediciones españolas de Joaquín Cots y de Cots, con un prólogo de Jaime Cararach e Ibarra, publicado en Barcelona, en 1887; y una de Angel Z. Cancio, publicada el mismo año.

111 Sánchez Santos, Trinidad, "A los lectores de Taxil”, El Tiempo, México, 17 de diciembre de 1887.

112 "La Francmasonería revelada y explicada por León Taxil, traducida al español por Trinidad Sánchez Santos”, El Tiempo, México, 30 de noviembre de 1887.

113 "Leo Taxil", El Tiempo, México, 13 de septiembre de 1887.

114 Sánchez Santos, Trinidad, "Al público”, El Tiempo, México, 22 de octubre de 1887. 
Para la prensa católica mexicana, la obra del autor francés se convirtió en una referencia obligada por ser un "libro providencial". ${ }^{115}$ Por ello, se solía citar al lado de la encíclica Humanum Genus, como la fuente más fidedigna: "Ahora, y después de las preciosas revelaciones de León Taxil [decía el editorialista de $E l$ Tiempo] ya podemos hablar con plena conciencia respecto a la masonería". ${ }^{116}$

La creencia ciega en el masón arrepentido o en el papista converso León Taxil empezó a tambalearse en las crónicas que la prensa mexicana hizo del Congreso antimasónico de Trento de 1896, en el cual se reunieron 36 obispos, 50 delegados episcopales y otros 700 delegados de diversas agrupaciones. Taxil fue el centro de atención de muchos de los asistentes. A él se dirigían muchas miradas de clérigos y laicos, que lo consideraban como protagonista de la lucha antimasónica.

En medio del congreso salió el tema de la amiga de Taxil, Diana Vaughan, una supuesta hija del demonio Birtú, que había sido poseída en el Templo Paládico de Charleston por el demonio Asmodeus. ${ }^{117}$ Esta mujer, "Gran Maestra del Perfecto Triángulo Phébé-la-Rose en el Oriente de Nueva York", "Maestra Templaria Soberana y Honoraria de la Logia de Londres", había escrito sus experiencias y una gran cantidad de secretos masónicos que aparecieron publicados bajo el título Memorias de una Ex-Palladista, los cuales se publicaron en París entre 1895 y 1896. Inmediatamente fueron traducidos por el connotado intelectual mexicano F. Ibarrán Ponce y publicados en el segundo tomo de la Biblioteca Anti-Masónica de Victoriano Agüeros, quien, como hemos dicho, fue el fundador del periódico El Tiempo.

En una de las sesiones de aquel congreso, un obispo austriaco, extrañado por la ausencia de Diana Vaughan, preguntó si alguien de los ahí presentes conocía personalmente a esa señora, pues nadie la había visto nunca, con lo cual sembró la duda sobre su existencia real. A los pocos meses de haber concluido el congreso, mediante un anuncio de la prensa, Diana convocó a una reunión abierta que debería llevarse a cabo en el salón de la Sociedad de Geografía de París. Además de presentarse por primera vez en persona ante el público, dictaría una conferencia en la que informaría de cosas todavía más estremecedoras que las reveladas en su libro y en algunos folletos de gran circulación en todo el mundo. El día anunciado acudió numeroso público procedente de varios países de Europa y América. Los asistentes, con gran inquietud y curiosidad, tomaron sus asientos y se dispusieron a

115 Idem.

116 "A las familias", El Tiempo, México, 16 de noviembre de 1887.

117 Ferrer Benimeli, José Antonio, La masonerí..., cit., p. 106. 
conocer por fin a la famosa señora. Después de un entremés, consistente en sortear una máquina de escribir, tendría lugar una conferencia sobre el culto paladista. El público quedó pasmado cuando vio que, del fondo del estrado, salió nada menos que León Taxil, afirmando con todo descaro y cinismo que Diana Vaughan era invención suya (mixtificación, decía). Se jactaba, además, de que nadie como él había logrado engañar a tantos católicos buenos, bienintencionados y piadosos, incluyendo a curas, obispos, cardenales y ¡al propio papa!

En un periódico francés de diciembre de 1896 (Le Matin), se dio a conocer la noticia del embuste de Taxil en forma escueta; sólo se hacía una advertencia a los católicos para que en adelante no creyeran tan fácilmente en cualquier persona o doctrina. El artículo, tal como aparece publicado en la traducción española, concluye con una frase en italiano con la que el autor intentaba poner punto final a la cuestión de Taxil y la Vaughan: "É finita la commedia". 


\title{
MASONES: ¿IDEÓLOGOS Y FUNDADORES DE LA CONSTITUCIÓN MEXICANA DE 1917?
}

\section{Carlos Francisco Martínez MOReno*}

\begin{abstract}
Sumario: I. Introducción. II. Justificación. III. Masones, del final del Porfiriato a la Decena Trágica. IV. Reestructuración de la masonería nacional desde 1915. V. Generaciones de masones constituyentes. VI. Cobertura nacional. VII. Ocupación. VIII. Constituyentes masones gobernadores de Estado. IX. Postura politica. X. Constituyentes masones grado 33․ XI. Constituyentes presos en 1913 por Victoriano Huerta. XII. El Control del Congreso. XIII. Contribución de los masones ideólogos. XIV. Conclusiones.
\end{abstract}

\section{INTRODUCGIÓN}

El propósito de esta investigación es analizar a un grupo de diputados del Congreso Constituyente de 1916-1917 que fueron masones; indagar sobre el significado de su participación, su perfil, su ideología, y ponderar su influjo en el contenido de la Constitución de 1917.

De las fuentes masónicas consultadas, resultó importante transcribir dos documentos inéditos en los anexos 2 y 3 . El primero es un pronunciamiento del 15 de enero de 1915, firmado en Veracruz, entre otros, por dos médicos que más tarde fueron constituyentes, Arturo Méndez y José María Rodríguez. Al haber sido redactado con fines políticos, puede entenderse que su contenido sea ideológico e incluya imprecisiones históricas; no obstante, nos permitirá comprender su trasfondo programático. El segundo documento refiere la expulsión de varios masones, entre los que destaca Victoriano Huerta.

* Mexicano, precursor de la cátedra de Historia de la Masonería en México de la Facultad de Filosofía y Letras de la UNAM. Asesor y catedrático en el Colegio de Defensa Nacional. Catedrático en: el Centro de Estudios Superiores Navales (Cesnav) de la Secretaría de Marina Armada de México; en la Escuela Superior de Guerra de la Universidad del Ejército y Fuerza Aérea, y en el Instituto Tecnológico Autónomo de México (ITAM). Doctor en Historia con Mención Honorífica (UNAM). Miembro del Sistema Nacional de Investigadores (SNI). 
Para este estudio resultaron irrelevantes los datos masónicos de los diputados constituyentes, así como los nombres de sus grupos y de sus grados, salvo de quienes poseían el grado $33^{\circ}$ escocés, por las razones que se harán explícitas.

Sólo resta enunciar el plan de la exposición. En principio, se plantea una breve justificación del tema y un análisis de los antecedentes: del final del gobierno de Porfirio Díaz a la Decena Trágica y hasta la reestructuración de la masonería nacional, a partir de 1915. Después continúa el estudio de los masones diputados, sus cohortes generacionales, la cobertura nacional, su ocupación, los constituyentes gobernadores de estado, sus posturas políticas, los masones grado $33^{\circ}$, los presos por Huerta, el control que ejercieron sobre el Congreso y, finalmente, la contribución de los masones ideólogos a la Constitución de 1917.

\section{JUSTIFICACIÓN}

Se corroboró que 58 diputados elegidos para el Congreso de 1916-1917 fueron masones, pero fue necesario reducir la muestra a 57, puesto que Herminio Pérez Abreu, el representante electo por Campeche, no se presentó en el constituyente. ${ }^{1}$

Además, 10 de los 57 diputados dejaron evidencias masónicas públicas en la Constitución de 1917, al agregar a su firma tres puntos, según la usanza de quienes se ostentaban como masones. Así lo hicieron Cristóbal del Castillo, Antonio Guerrero, Francisco J. Múgica, Luis T. Navarro, Luis G. Monzón, Santiago Ocampo, Zeferino Fajardo, Fortunato de Leija, Epigmenio A. Martínez y Porfirio del Castillo (véase el anexo 1).

Heriberto Jara ingresó a una logia hasta junio de 1926, por ello en este estudio no se le cuenta entre los masones del constituyente. Asimismo, aunque de Francisco J. Múgica sabemos que también ingresó después a una logia - puesto que agregó el tripunteado masónico al firmar la Constitución de 1917-, debemos considerar que ya pertenecía antes a otra, probablemente de diferente rito u obediencia. ${ }^{2}$

1 Marván Laborde, Ignacio, Cómo hicieron la Constitución de 1917, México, Secretaría de Cultura-Fondo de Cultura Económica-Centro de Investigación y Docencia Económicas, 2017 , p. 71.

2 Heriberto Jara ingresó a la masonería nueve años después de haber pertenecido al Constituyente de 1916-1917; no obstante, se ha afirmado lo contrario sin prueba, como lo apunta Vargas Márquez, Wenceslao, "La masonería, Heriberto Jara y Maples Arce", http://wrwrw532. blogspot.mx/2017/01/la-masoneria-heriberto-jara-y-maples.html. Por ello, debe revisarse la historiografía con fuentes documentales. Martínez Moreno, Carlos Francisco, "Balance", en Jiménez Guzmán, Manuel (coord.), Influencia de la Masonería en la Constitución de 1917, México, Secretaría de Cultura-INEHRM, 2016, pp. 91-95. En cambio, Francisco J. Mújica sí firmó como masón la Constitución de 1917, al igual que otros diputados identificados en listados masónicos. 
Desde una perspectiva cuantitativa, los 57 masones identificados fueron una minoría respecto del total de 218 diputados $^{3}$-sólo poco más de la cuarta parte, 26.15\%-; empero, si nos centramos en los 21 ideólogos pertenecientes al núcleo fundador de la Constitución de 1917, ${ }^{4}$ fueron mayoría, porque 16 de ellos eran masones (76.19\%). Nos referimos a Cándido Aguilar Vargas, Manuel Aguirre Berlanga, Esteban Baca Calderón, Enrique Colunga Meade, Alfonso Cravioto Mejorada, Romano Froylán Cruz Manjarrez Romano, Juan de Dios Bojórquez León, Félix Fulgencio Palavicini, Fernando Lizardi Santana, Hilario Medina, Luis G. Monzón, Francisco J. Múgica, Luis Manuel Rojas Arreola, Jesús Romero Flores, Alberto Terrones Benítez y Gerzayn Ugarte Rodríguez. ${ }^{5}$

Su influencia en la Carta Magna ha sido reconocida y justifica por sí misma este estudio y nos obliga a analizar algunos aspectos vinculados con los masones constituyentes y el aporte al contenido de la Constitución; comencemos por exponer algunos antecedentes que pudieron motivar y dar significado a su participación.

\section{Masones, Del Final del Porfiriato a la Decena Trágica}

A inicios del siglo XX, masones de diferentes vertientes eran leales a Porfirio Díaz y respaldaban su reelección, si bien disputaban por conquistar la vicepresidencia para Bernardo Reyes, Teodoro A. Dehesa o Ramón Corral; así, aunque de diferentes bandos, masones reeleccionistas fueron Luis Pombo, Benito Juárez Maza, Rafael Zubarán Capmany, José López Portillo y Rojas, y los científicos Joaquín Diego Casasús, José Castellot y Emilio Rabasa. ${ }^{6}$

3 Marván Laborde, cit., pp. 72, 283-311. El autor menciona 217 constituyentes por estado en su cuadro II.1, si se suman los números parciales, que no corresponden con el total de 218 en el mismo cuadro, ni con el de 221 de su anexo.

4 Universidad Nacional Autónoma de México, La Constitución Mexicana de 1917: Ideólogos, El Núcleo Fundador y otros constituyentes, México, UNAM, Instituto de Investigaciones Jurídicas, 2016.

5 El libro dedica un capítulo a Emilio Rabasa, masón escocés que no consideramos aquí por no participar en el Congreso Constituyente; él reconoció como presidente al también masón escocés Victoriano Huerta.

6 Iglesias González, Román (introducción y recopilación), Planes políticos, proclamas, manifiestos y otros documentos de la Independencia al México moderno, 1812-1940, México, UNAM, Instituto de Investigaciones Jurídicas, 1998, pp. 511-515, 529-535, 554-561, 572-575. Mac Gregor, Josefina, "Intentos democratizadores: las campañas presidenciales de 1910 y 1911 ”, en Georgette, José (coord.), Candidatos, campañas y elecciones presidenciales en México. De la República Restaurada al México de la alternancia: 1867-2006, México, UNAM, Instituto en Investigaciones Sociales, 2012, p. 186. "Supremo Consejo del 33 y último grado del Rito Escocés Antiguo y Aceptado para la jurisdicción masónica de los Estados Unidos Mexicanos”, Boletín, México, Souligny \& Schmidt Sucr., 1927, p. 157. 
En el bando contrario a Porfirio Díaz, también había. El Partido Antirreeleccionista Nacional, dirigido por el masón José María Pino Suárez, en Yucatán, en 1909, contaba en la Ciudad de México con los masones Francisco I. Madero como vicepresidente y Filomeno Mata como secretario; afín a ellos era el también masón Juan Sánchez Azcona, uno de los promulgadores del Plan de San Luis. ${ }^{7}$

A Francisco I. Madero lo acusaban de traicionar el liberalismo y la revolución - por ser candidato del Partido Católico Nacional y ofrecer al arzobispo de México no cumplir las Leyes de Reforma- y de ser parte de un plan neo-ocultista jesuita para derogar dichas leyes y aniquilar la escuela laica, por medio de un grupo fiel al Papa y de una rama de una liga anarquista internacional, con la que podían atentar contra el Estado. ${ }^{8}$

Desde otro bando, algunos pedían al general masón Bernardo Reyes impedir que el clero impusiera un vicepresidente clerical que pudiera dar un golpe de Estado. En su contra, los hermanos Flores Magón publicaron en 1905 "jalerta, masones!", contra el intento de formar logias para llevar a la presidencia de la República al "tirano" Bernardo Reyes; por lo que también ellos querían ganarse el apoyo de los masones, pero contra Reyes. ${ }^{9}$

Jesús Flores Magón era masón afiliado al Supremo Consejo de México, afín a Porfirio Díaz. Para su hermano Ricardo, "el Judas Madero" engañaba, compraba y embaucaba liberales, y buscaba cambiar de "amos" al vender México a la Standard Oil Company, y asesinaba liberales y obreros con armas pagadas por John D. Rockefeller. ${ }^{10}$

7 Iglesias González, Planes políticos, op. cit., pp. 543-545, 562-565, 578 y 579. González Ramírez, Manuel, Planes políticos y otros documentos, 1812-1940, México, Secretaría de la Reforma Agraria (SRA)-Centro de Estudios Históricos del Agrarismo en México (CEHAM), 1981, pp. 33-46. Madero, Francisco I., Plan de San Luis, facsímil del original mecanográfico, con correcciones de puño y letra de Francisco I. Madero, LXX aniversario de su promulgación, México, Secretaría de Gobernación, 1980.

8 Mac Gregor, op. cit., p. 207; La Patria. Diario de México, t. XXXV, núm. 9995, 26 de agosto de 1911, p. 2; t. XXXV, núm. 9988, 12 de agosto de 1911, pp. 1 y 2; Peña y Troncoso, Gonzalo, El Dosamantismo es la Religión Científica en oposición al Ocultismo Semita, que es una Liga de Internacional Anarquismo. La Sintesis Científico-Religiosa del maestro Jesús Ceballos Dosamantes, México, Editores J. I.-Guerrero y Cía., Sucs. de F. Díaz de León, 1904, 2a. parte, cap. I, III; cap. II, I, II; cap. III, II; 3a. parte, cap. VIII.

9 La Patria. Diario de México, t. XXXV, núm. 9988, 12 de agosto de 1911, p. 2; Regeneración Periódico Independiente de Combate, 16 de septiembre de1905, p. 2; Flores Magón, Ricardo, "Carta a Antonio Balboa de la Hacienda del Parral Chihuahua", Saint Louis, Missouri, 14 de agosto de 1905, citado el 15 de noviembre de 2015, http://archivomagon.net/obras-completas/ correspondencia-1899-1922/c-1905/cor56/.

10 "Supremo Consejo del 33 y último grado del Rito Escocés Antiguo y Aceptado para la jurisdicción masónica de los Estados Unidos Mexicanos", Boletín Anual del Supremo Consejo del Rito 
Lo anterior muestra la gran división que había entre diferentes bandos políticos encabezados por masones; y si bien después Porfirio Díaz renunció a la presidencia de la República el 25 de mayo de 1911, y la Gran Logia "Valle de México" celebró la restauración de la paz a finales de junio, la disputa fratricida creció hasta la Decena Trágica de 1913. ${ }^{11}$

\section{REESTRUGTURAGIÓN DE LA MASONERÍA NAGIONAL DESDE 1915}

Los trágicos asesinatos de Madero y de Pino Suárez, como corolario de las reyertas masónicas, dan significado al pronunciamiento que el 15 de enero de 1915, desde Veracruz, firmaron los masones Antonio Luca grado $33^{\circ}$, doctor Arturo Méndez $33^{\circ}$, doctor Gral. José María Rodríguez 33, Modesto Rolland 14․, Antonio Herrejón López $3^{\circ}$, doctor Andrés C. Castro $3^{\circ}$, Rafael Canto, e ingeniero Pascual Ortiz Rubio $3^{\circ}$, para convocar a la creación del Rito Simbólico Mexicano, mediante el cual denunciaron que miembros indignos de la masonería degeneraron y desnaturalizaron los principios de libertad, igualdad y fraternidad; que olvidaron sus deberes por cuarenta años (una exageración, a menos que incluyeran en su crítica a Sebastián Lerdo de Tejada); traicionaron sus juramentos; protegieron déspotas, y dominaron, explotaron y esclavizaron al pueblo, hasta pretender nulificar sus sentimientos y su personalidad jurídi$\mathrm{ca}^{12}$ (véase el anexo 2).

Años atrás, el 19 de mayo de 1909, el ingeniero Modesto C. Rolland había participado en la creación del Centro Nacional Antireeleccionista, que lideraría junto con Francisco I. Madero, Roque Estrada, Aquiles Elorduy, Eduardo Hay, Félix Palavicini y Emilio Vázquez Gómez. Asimismo, el

Escocés Antiguo y Aceptado para los Estados Unidos Mexicanos, año $2^{\circ}$ del $8^{\circ}$ quinquenio, mayo de 1899 a abril de 1900, México, Tip. El Faro, p. 28; INEHRM-Comisión para las Celebraciones del 175 Aniversario de la Independencia Nacional y 75 Aniversario de la Revolución Mexicana, Últimos meses de Porfirio Díaz en el Poder. Antología Documental, México, Talleres Gráficos de la Nación, 1985; Regeneración. Semanal Revolucionario, 1911: 6 de mayo, p. 2; 18 de mayo, p. 2; 3 de junio, p. 1; 10 de junio, p. 2; 16 de septiembre, p. 3; Martínez Moreno, Carlos Francisco, "Coaliciones y traiciones masónicas. De la primera reelección de Porfirio Díaz a los inicios de la Revolución Mexicana, 1887-191 1", en REHMLAC+. Revista de Estudios Históricos de la Masonería Latinoamericana y Caribeña, vol. 7, núm. 2, diciembre de 2015-abril de 2016, pp. 149-177.

11 Diario del Hogar, México, 1911, A. XXX-N. 10772, t. 47, núm. 123, junio 28, p. 1; López, Chantal y Omar Cortés (recopilación), Madero y los Partidos Antirreeleccionista y Constitucional Progresista, México, Ediciones Antorcha, 1988, pp. 94 y 95, 122-133, 227-231; Serrano Álvarez, Pablo, Porfirio Díaz y el Porfiriato. Cronología (1830-1915), México, INEHRM, 2012, y Martínez Moreno, Carlos Francisco, "Coaliciones y traiciones masónicas", cit., pp. 149-177.

12 Luca Antonio $33^{\circ}$ et al., Pronunciamiento para la creación del Rito Simbólico Mexicano, Veracruz, 15 de enero de 1915 . 
ingeniero Pascual Ortiz Rubio había sido diputado en la Legislatura XXVI, electa para el periodo 1912-1914, y fue apresado por el gobierno impuesto del general Victoriano Huerta, masón escocés grado $30^{\circ}$. Más adelante será retomada esta línea de análisis para tratar el tema de los constituyentes masones que fueron encarcelados junto con él. ${ }^{13}$

Por ello, los firmantes del pronunciamiento de enero de 1915 denunciaron que la historia de la masonería de los últimos años era corrupta y sangrienta: desde los asesinatos de los masones de Veracruz, el 25 de junio de 1879, que imputaron a Porfirio Díaz, ${ }^{14}$ hasta los de los masones grado $33^{\circ}$ Francisco I. Madero y José María Pino Suárez, presidente y vicepresidente de la República, respectivamente, el 23 de febrero de 1913. Crímenes que atribuyeron principalmente al plan y a la orden de los masones Rodolfo Reyes $33^{\circ}$ (licenciado), Victoriano Huerta $30^{\circ}$ y Félix Díaz $32^{\circ}$ (generales).

Además, culparon de traición a Huerta y de la matanza del pueblo en la Ciudad de México; de ladrones y asesinos a Félix Díaz $32^{\circ}$, Victoriano Huerta $30^{\circ}$, Joaquín Clausel $33^{\circ}$ y Rodolfo Reyes $33^{\circ}$; al jefe de la masonería escocesa, José Castellot $33^{\circ}$, de apropiarse de los fondos del Banco de Campeche; a Ricardo O'Farril $33^{\circ}$, de denunciar a la policía -como revolucionarios- a los miembros de la logia "Libertad y Progreso", y a los del Consejo Kadosch grado $30^{\circ}$-e incluso a la mayoría de masones- de no trabajar por miedo a la cárcel o a la muerte; en cambio, reconocieron el movimiento armado del pueblo mexicano contra los gobiernos crueles y ladrones, y afirmaron que la masonería no sintió el deber de ayudar y dirigir el movimiento revolucionario, que, por el contrario, trabajó por la reacción y para instaurar un nuevo gobierno militar con Félix Díaz a la cabeza ${ }^{15}$ (véase el anexo 2).

13 De cómo vino Huerta y cómo se fué... Apuntes para la historia de un régimen militar, 5a. ed. facsimilar, México, Ediciones El Caballito, 1975, pp. 377 y 378.

14 El gobernador de Veracruz, general Luis Mier y Terán, fue expulsado el 29 de junio de 1879 por el Supremo Consejo de México del grado $33^{\circ}$, acusado de mandar a fusilar ilegalmente, el 24 de junio, a 9 ciudadanos, 5 de ellos masones, contra sus juramentos masónicos. Martínez Moreno, Carlos Francisco, Masonerías, intervencionismo y nacionalismo en México. De la segunda mitad del siglo XIX a los primeros años del XX, Tesis de Doctorado, México, UNAM, 2016, pp. 106, 134 y ss. Murieron un soldado de la guardia y ocho presos acusados de revolucionarios: Vicente Capmany, Jaime Rodríguez, Dr. Ramón Albert Hernández, Antonio P. Ituarte, Francisco Cueto, Luis Alva y Lorenzo Portilla. El 18 de mayo de 1880, el Gran Jurado de la Cámara de Diputados absolvió a Mier, por 83 votos contra 16 y 43 abstenciones. Proceso instruido por la Segunda Sección del Gran Furado con motivo de los acontecimientos ocurridos en la ciudad de Veracruz la noche del 24 al 25 de junio de 1879, México, Imprenta del Comercio, de Dublán y Compañía, 1880, pp. VIII y ss, anexo 4: Averiguación practicada por la comandancia militar de Veracruz, Acta de la Sesión del Gran Jurado, presidencia del C. Coutolenne, mayo 18 de 1880, pp. 19-22.

15 Luca Antonio et al., Pronunciamiento, cit. 
Por otra parte, sostuvieron que tras la huida de Victoriano Huerta y la llegada a la Ciudad de México del ejército constitucionalista de Venustiano Carranza, masones honrados depuraron y expulsaron a más de ochenta miembros, como traidores, asesinos e indignos de pertenecer a ella. Asimismo, denunciaron que la mayoría de masones restantes se opusieron a la expulsión de Félix Díaz, porque esperaban que fuera presidente de la República y les diera concesiones y empleos; por esta misma razón se negaron a publicar y a notificar el nombre de los expulsados, pues creían en el triunfo de la reacción y en su readmisión.

Venustiano Carranza llegó a la Ciudad de México el 20 de agosto de 1914, y dos meses después se llevó a cabo la expulsión por unanimidad, el 30 de octubre; no obstante, ésta fue difundida hasta dos años después, el 29 de enero de 1916. Entre los destituidos se encontraban Victoriano Huerta grado $30^{\circ}$, José Ricardo $\mathrm{O}^{\prime}$ Farril $33^{\circ}$, Joaquín Clausell $33^{\circ}$ y José Castellot $33^{\circ}$ (véase el anexo 3).

De vuelta a los pronunciados de 1915, en su diagnóstico, afirmaron que por treinta años la masonería en México abandonó los principios rituales, cuyo objeto principal era explotar a los ingenuos y sacarles dinero, a cambio de grados no merecidos ni comprendidos. Pero, al mismo tiempo, consideraron un momento histórico para la patria el hecho de que el pueblo armado condenara la "carcomida" masonería, que por cuarenta años interrumpió el progreso de la nación y apoyó a déspotas y bandidos. ${ }^{16}$ Por ello, decían cumplir sus juramentos de maestros masones, al desenmascarar a los hipócritas traidores de la justicia, de la ley y del honor, y al desconocer los actos y la personalidad de los representantes de la masonería en México; de igual manera, llamaban a crear una nueva masonería simbólica, del grado $1^{\circ}$ al $3^{\circ}$, con ciudadanos honrados y resueltos a restablecer el dominio de la verdad, para que la libertad, la igualdad y la fraternidad volvieran a ser su programa.

El objeto de su nuevo rito sería propagar y difundir las enseñanzas masónicas en la República, cooperar efectivamente al establecimiento de las reformas sociales, por las que luchaba el pueblo desde 1910. Por ello, en su programa, lo primero sería la redención del pueblo, "que durante cuatro siglos ha sufrido todos los tormentos morales y materiales, bajo la férula de tiranos militares y religiosos" (véase el anexo 2).

Su Rito Simbólico Mexicano tendría dos principios: las autonomías de la logia y del masón, el masón libre en la logia libre. Mantendría "lazos de unión" con la masonería universal, al adoptar signos y estudios esotéricos, bajo la divisa: Estudiar para pensar, pensar para obrar. Además, constituirían la confederación de sus logias libres, conservarían la acción colectiva mediante el aprovechamien-

16 Luca Antonio et al., Pronunciamiento, cit. 
to de los esfuerzos individuales y la colaboración fraternal sin polémicas personales, regidos por el amor: fraternal, a la patria y a la humanidad.

$\mathrm{Al}$ final de este estudio, será claro que esas aspiraciones e ideales fueron el contexto de la ideología de los masones diputados en el Congreso Constituyente de 1916-1917.

\section{Generaciones de masones COnstituyentes}

El rango de edad de los diputados masones identificados osciló entre los 23 años (Froylán Cruz Manjarrez Romano, representante de Puebla), y los 61 (Cristóbal del Castillo Llavén, diputado por Chiapas). Con relación a la frecuencia de individuos por edad, cinco diputados del grupo analizado tenían 27 años, y cuatro 31, 33, 34 y 46 (véase la gráfica 1).

Además, con base en el análisis de Marván Laborde, y considerados los diputados en relación con el año en el que cumplieron 20 años, ${ }^{17}$ resultan cinco cohortes generacionales vinculadas con los periodos de gobierno de Porfirio Díaz. De la revolución de Tuxtepec, en 1876, a su primera reelección en 1884; de ésta al empoderamiento de los científicos, entre 1885 y 1892; durante el auge de su administración, de 1893 a 1900; del inicio del siglo al año anterior a las elecciones, es decir, de 1901 a 1909, y, el último, a partir de 1910, cuando comenzó la revolución.

Gráfica 1. Edad de los Constituyentes Masones, 1917 (elaboración propia)

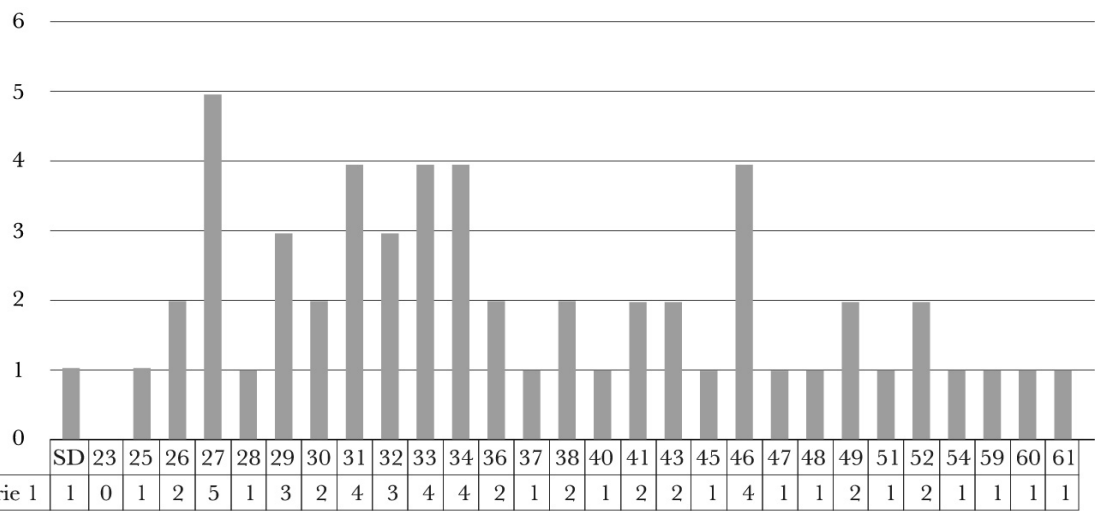

17 Marván Laborde, op. cit., pp. 87-89. 
Esta obra forma parte del acervo de la Biblioteca Jurídica Virtual del Instituto de Investigaciones Jurídicas de la UNAM

A pesar de que Marván Laborde no cuenta con la edad de dos constituyentes y que a este estudio le falta la del diputado masón Epigmenio A. Martínez Ponce, al comparar entre los datos de 216 diputados y de 56 de ellos masones, con las mismas cohortes, puede advertirse que entre 1876 y 1884 la muestra fue $0.6 \%$ menor entre los masones, en la época de las glorias tuxtepecanas del "demócrata" Porfirio Díaz que dejó la presidencia; en cambio, de la generación siguiente, entre 1885 y 1892, en la que surgió la inconformidad por el inicio de sus dos primeras reelecciones apegadas a la ley por la complicidad de varios congresistas, se incrementó el número proporcional de individuos en $9.78 \%$ con relación al total, y triplicó el porcentaje de $7.27 \%$ al alcanzar $14.55 \%$.

Además, los diputados masones de la generación del apogeo de la administración de Díaz y los científicos, entre 1893 y 1900, fue menor en 10.55\% con relación al total; en tanto que la de 1901 a 1909 también se mostró $2.62 \%$ inferior respecto al todo; finalmente, fue mayor en $3.9 \%$ la generación de los inicios de la revolución, bajo el mismo criterio (véase la tabla 1).

Por tanto, puede afirmarse que fueron menos los diputados masones de la generación de la época de gloria y "democracia" del héroe de Tuxtepec, Porfirio Díaz, defensor del sufragio efectivo y de la no reelección contra Sebastián Lerdo de Tejada; del tiempo democrático cuando dejó la presidencia en manos de Manuel González, y menos también los que "gozaron" el "apogeo" del orden y del progreso de la industrialización del país, de la pacificación y el crecimiento de la época de Los Científicos.

Tabla 1. Número de diputados por cohorte generacional (1876-1918) (elaboración propia)

\begin{tabular}{|c|c|c|c|c|c|}
\hline & $\mathbf{1 8 7 6 - 1 8 8 4}$ & $\mathbf{1 8 8 5 - 1 8 9 2}$ & $\mathbf{1 8 9 3 - 1 9 0 0}$ & $\mathbf{1 9 0 1 - 1 9 0 9}$ & $\mathbf{1 9 1 0 - 1 9 1 8}$ \\
\hline Total & 17 & 26 & 54 & 96 & 23 \\
\hline$\%$ & 7.87 & 12.04 & 25.00 & 44.44 & 10.65 \\
\hline Masones & 4 & 12 & 8 & 23 & 8 \\
\hline$\%$ & 7.27 & 21.82 & 14.55 & 41.82 & 14.55 \\
\hline
\end{tabular}

En contraste, fueron más los diputados masones de las generaciones que crecieron con el descontento por el régimen de Porfirio Díaz y por los excesos de la clase política leal a él, incluidos tanto miembros del clero político - que gozó de la política de la reconciliación- como masones que lo acompañaron y sostuvieron en el poder y que también se corrompieron al practicar el cacicazgo y el latifundismo contra los intereses de las clases ex- 
Esta obra forma parte del acervo de la Biblioteca Jurídica Virtual del Instituto de Investigaciones Jurídicas de la UNAM www.juridicas.unam.mx

cluidas del progreso. En consecuencia, fue también mayor el número de los constituyentes masones que eran parte de las cohortes generacionales que anhelaban y contribuían al ocaso de ese régimen.

\section{GOBERTURA NAGIONAL}

Los 57 diputados masones representaron 20 entidades federativas de las 29 que contaron entre los constituyentes, $69 \%$ de la cobertura nacional. Ocho representantes del Distrito Federal y seis de Jalisco; cuatro de Coahuila, Durango, Guanajuato, México, Michoacán y Puebla; dos de Chiapas, Hidalgo, Oaxaca, Sinaloa, Sonora, Tabasco, Tamaulipas y Yucatán, y uno de San Luis Potosí, Tepic, Veracruz y Zacatecas (véanse la gráfica 2 y el mapa 1).

Si consideramos los números relativos, con relación al total de diputados por entidad, fueron Tamaulipas y Coahuila los estados que mayor porcentaje de masones representaron; le siguieron Durango, Distrito Federal, Yucatán y Sonora (véase la gráfica 3).

Gráfica 2. 57 masones en el Congreso Constituyente de 1916-1917, por entidad federativa (elaboración propia)

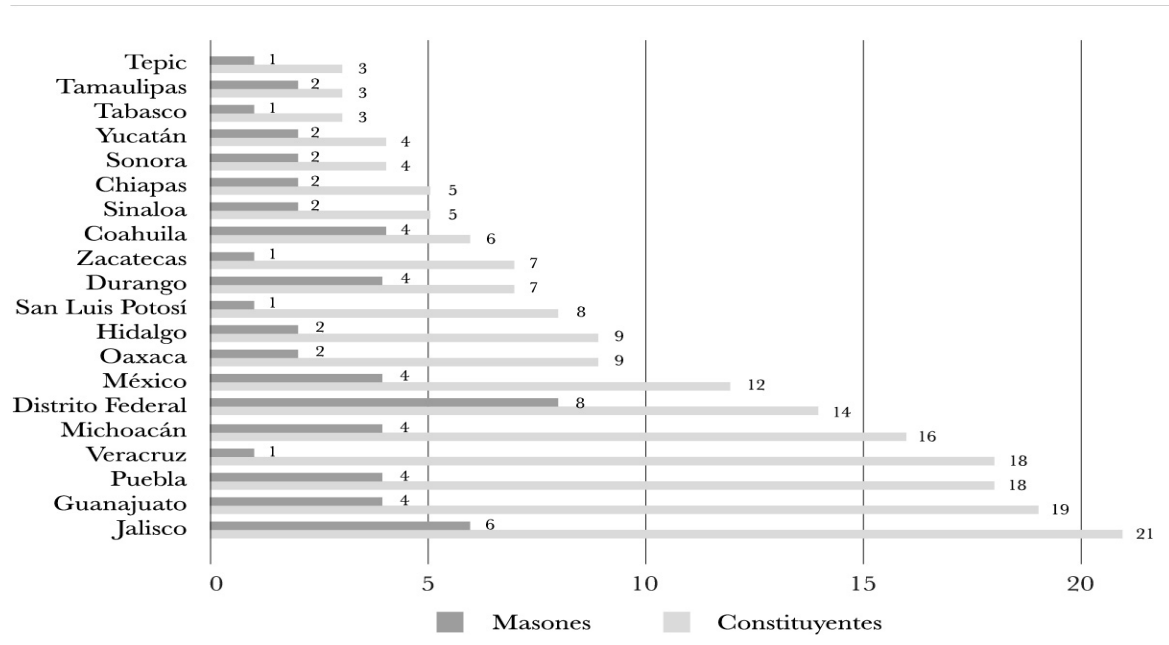

DR @ 2018. 
Esta obra forma parte del acervo de la Biblioteca Jurídica Virtual del Instituto de Investigaciones Jurídicas de la UNAM www.juridicas.unam.mx

Mapa 1. Veinte entidades con diputados masones en el Congreso Constituyente de

1916-1917 (elaboración propia)

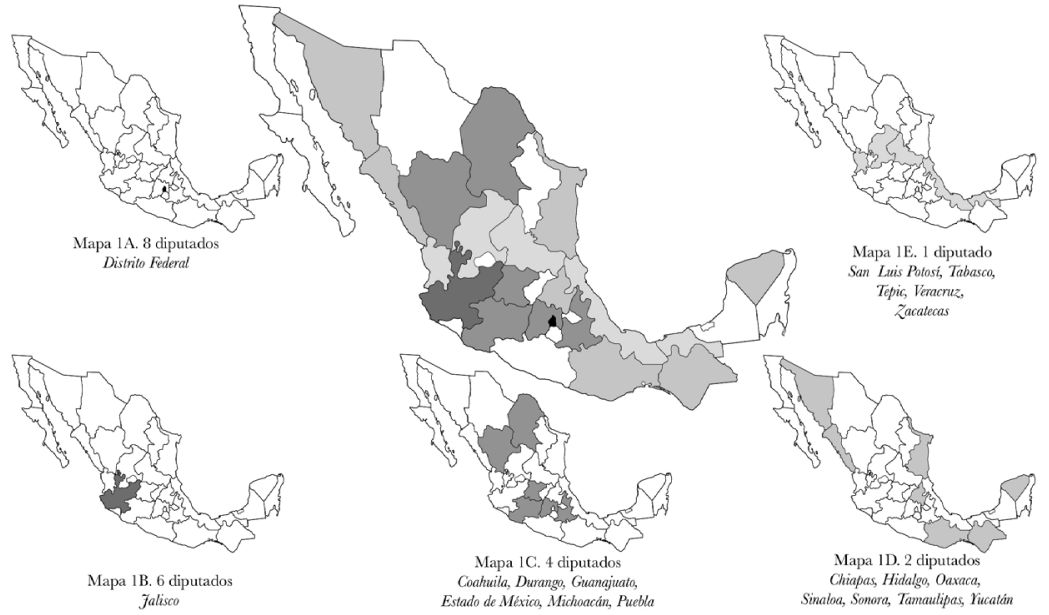

Gráfica 3. 57 masones en el Congreso Constituyente de 1916-1917 (elaboración propia)

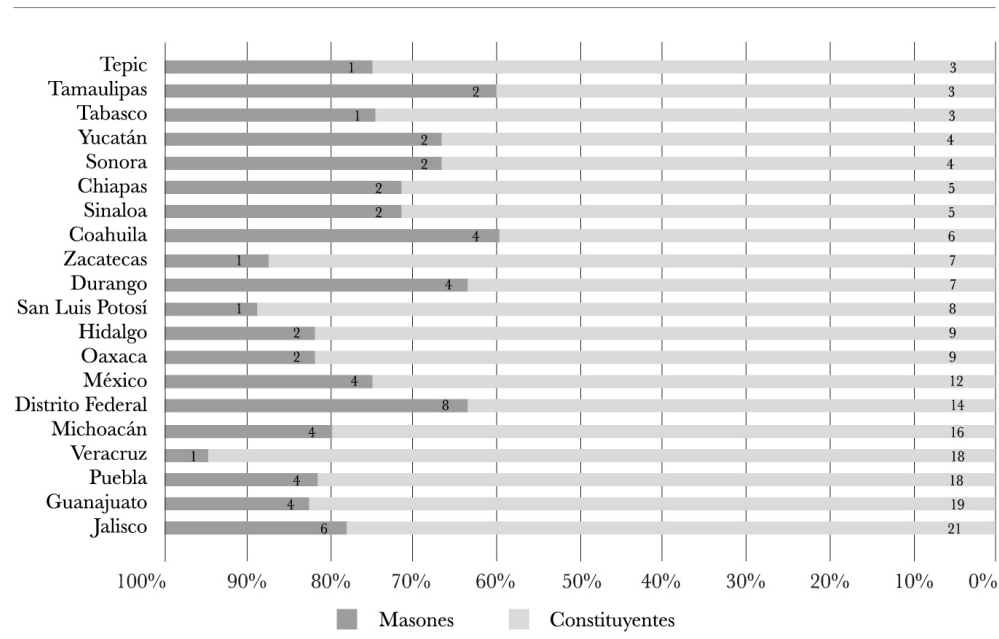

DR @ 2018

Universidad Nacional Autónoma de México- Instituto de Investigaciones Jurídicas 


\section{OCUPACIÓN}

Podemos dividir a los 57 diputados masones en dos grandes grupos: el de 36 civiles, quienes representaron 18 entidades federativas, y el de 21 militares, representantes de 12 entidades (véanse la gráfica 4, los mapas 2 y 3, y el anexo 4).

Gráfica 4. 57 masones constituyentes, civiles y militares por entidad

(elaboración propia)

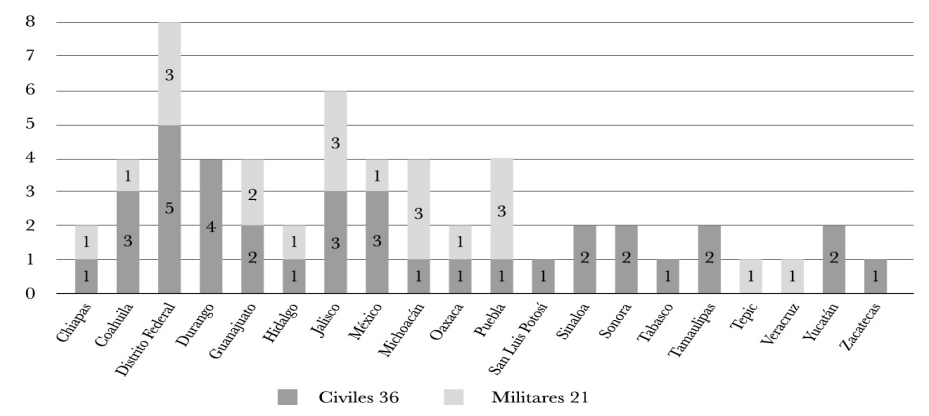

De los 57 diputados masones, 63\% se concentraba en tres profesiones: 19 abogados $(33 \%)$, nueve ingenieros $(16 \%)$ y ocho maestros (14\%); también había médicos y empleados (4); periodistas, ferrocarrileros y empleados públicos (2); contador, economista, agricultor e impresor encuadernador $(1)^{18}$ (véanse las gráficas 5 y 6 ).

Mapas 2 y 3.57 diputados masones, 36 civiles y 21 militares, Congreso Constituyente de 1916-1917 (elaboración propia)

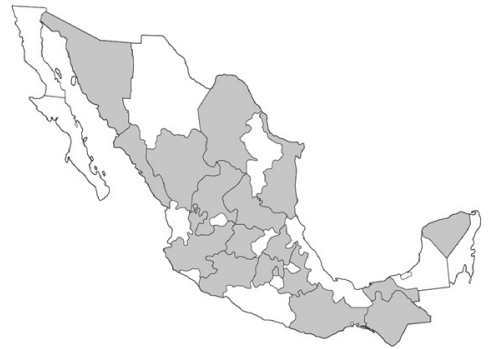

Mapa 2.- 18 entidades con 36 diputados masones civiles

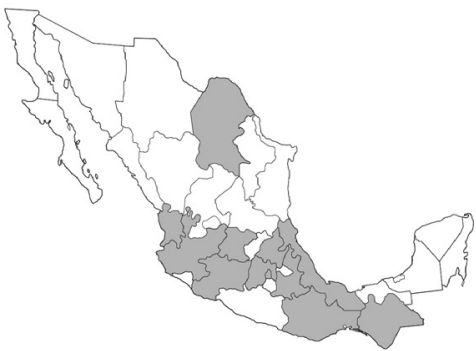

Mapa 3.- 12 entidades con 21 diputados masones militares

18 No fue posible comparar la cifra con el número total, porque en tres casos no hubo dato y alguno puede no ser confiable, como bien lo señala Marván Laborde, op. cit., p. 75.

DR @ 2018. 
Esta obra forma parte del acervo de la Biblioteca Jurídica Virtual del Instituto de Investigaciones Jurídicas de la UNAM www.juridicas.unam.mx

https://biblio.juridicas.unam.mx/bjv

Gráfica 5. Número de diputados masones por ocupación (elaboración propia)

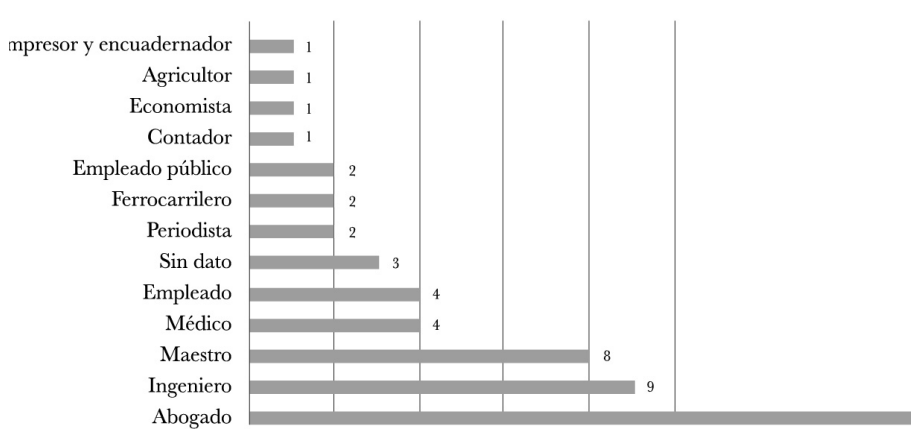

Gráfica 6. Porcentaje de diputados masones por ocupación (elaboración propia)

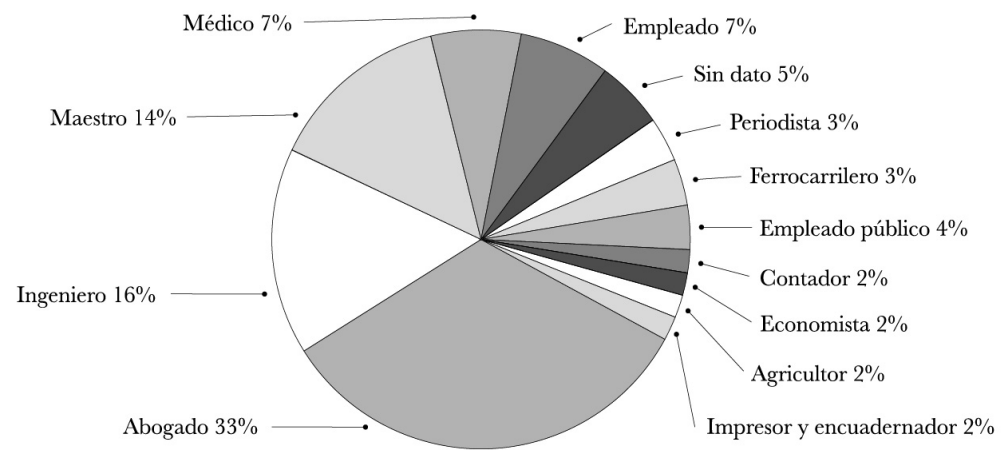

VIII. Constituyentes MASONES GOBERnADORES DE EstAdO

Hasta 1917, gobernadores fueron los diputados masones Ignacio I. Pesqueira de Sonora (1913); Cándido Aguilar Vargas, de Veracruz, Amado Aguirre y Manuel Aguirre Berlanga, de Jalisco, y Esteban Baca Calderón, de Colima (1914); Porfirio del Castillo, de Tlaxcala (1915); Fernando Castaños, de Durango (1916), y nuevamente Ignacio I. Pesqueira, esta vez de Sinaloa (1917) (véase el mapa 4).

DR @ 2018. 
Esta obra forma parte del acervo de la Biblioteca Jurídica Virtual del Instituto de Investigaciones Jurídicas de la UNAM www.juridicas.unam.mx

https://biblio.juridicas.unam.mx/bjv

Mapa 4. Siete masones constituyentes gobernadores de estado, 1913-1917

(elaboración propia)

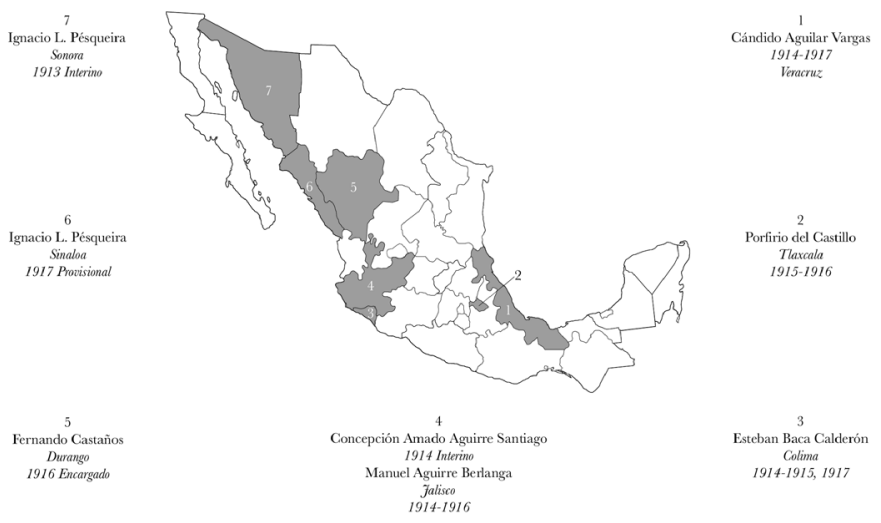

IX. POSTURA POLÍTICA

De los 57 diputados masones, 45 fueron maderistas y, tras el asesinato de Madero en 1913, 36 se manifestaron carrancistas y seis obregonistas; además, 10 fueron carrancistas sin haber sido maderistas, uno fue obregonista sin ser maderista, y de uno no hubo noticia (véase la gráfica 7).

Gráfica 7. Bando político de los masones constituyentes (elaboración propia)

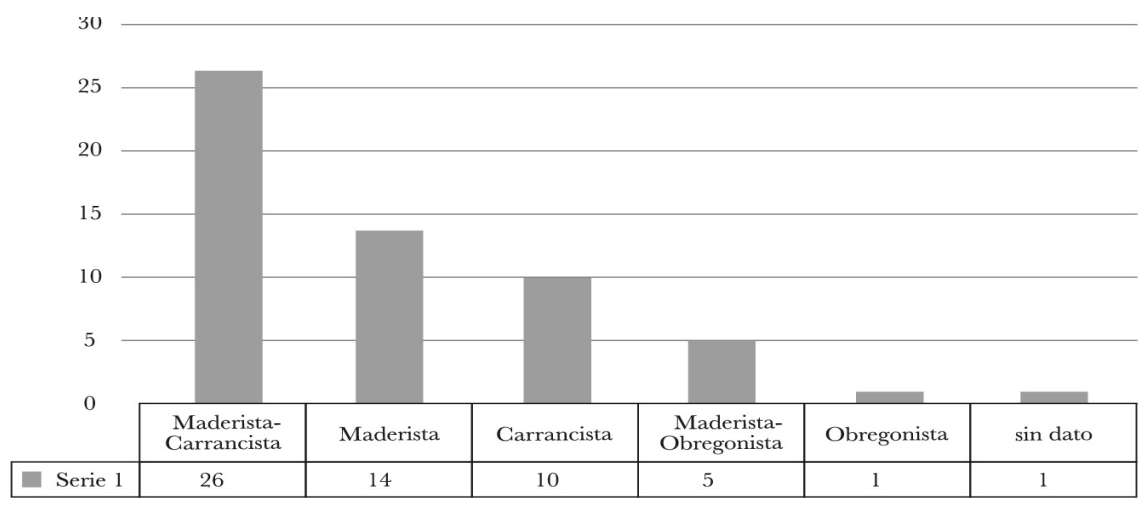

La diferencia generacional de los masones diputados pudo haber influido en su división ideológica en cuatro bandos: 22 radicales, 14 renovadores,

DR @ 2018.

Universidad Nacional Autónoma de México- Instituto de Investigaciones Jurídicas 
11 equilibristas y 9 moderados; de uno no encontramos información (véase la gráfica 8).

Gráfica 8. Postura política de los constituyentes masones

(elaboración propia)

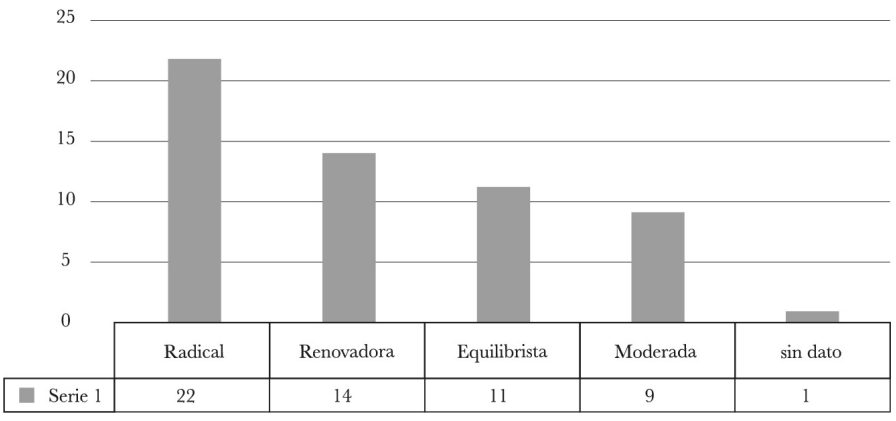

Ya antes advertimos que la mayoría de los diputados masones estudiados pertenecieron a generaciones inconformes con el régimen de Porfirio Díaz y con sus aliados, del clero y de la masonería, lo que pudo influir para que se formara una corriente radical o jacobina, defensora del laicismo y hasta de la educación racional. Éste fue el caso de Luis G. Monzón, para quien la educación no debía ser laica sino racional, con el objetivo de eliminar la enseñanza religiosa que él consideraba fanatizadora (sesiones del 13 de septiembre y 10 y 14 de diciembre de 1916).

También Román Rosas y Reyes asumió una postura semejante. Él pedía ayuda para: "destruir esas escuelas católicas, [...] fábricas de frailes, en donde se acapara [...] el pequeño espíritu, la conciencia, la razón, en donde [...] se enseña al hombre a ser hipócrita, a ser egoísta, a ser falaz, a ser mentiroso: $[\ldots]$, en donde se sentencia desde temprano a la niñez a llevar una vida de degradación, de dudas, de obscurantismo, de miseria moral". ${ }^{19}$

El radicalismo no era la postura de Venustiano Carranza. Al convocar al Congreso Constituyente esperaba que la posición moderada ganara, que lograra triunfar la educación oficial laica y gratuita, y que se dejara en libertad a la educación particular para ser religiosa; al final, el grupo radical fue el que se impuso y vetó las corporaciones religiosas y prohibió a sus ministros establecer y dirigir escuelas, si bien no prevaleció la propuesta de la educación racionalista. ${ }^{20}$

$19 D D C$, pp. 467 ss.

$20 D D C$, t. I, n. 19, 7a. Sesión Ordinaria, (16 dic. 1916), p. 345; n. 28, (16 dic. 1916). DOO, t. V, 4a. Época, n. 30, (5 feb. 1917), p. 149. 
El hecho de que, antes de ser convocado el Congreso Constituyente, El Universal difundiera que algunos esperaban que los constitucionalistas defendieran a la Iglesia católica mexicana y que Venustiano Carranza la liberara del "yugo papal", apoya la postura moderada carrancista:

En vista, pues, de que las tradiciones han sancionado la continuidad de la Iglesia católica mexicana, como derivada de la primitiva, y siendo indispensable para adquirir de una manera completa la libertad nacional, por la cual ha venido luchando el constitucionalismo, que la Iglesia mexicana se independice de todo poder extranjero, como lo es el emanado de Roma, apelamos de modo más solemne al C. Venustiano Carranza, Primer Jefe del Ejército Constitucional, se sirva tomar en consideración con el interés que la cuestión demanda, la separación de la Iglesia católica mexicana, del yugo papal, restaurando sus antiguas libertades y estableciendo su completa independencia. ${ }^{21}$

No obstante, esa posibilidad fue cancelada desde la convocatoria al constituyente y con la integración de sus comisiones, por el posicionamiento de masones de todos los bandos ideológicos, principalmente radicales, quienes excluyeron a los partidos con denominación religiosa; ratificaron el sentido liberal de la constitución de 1857 y de las Leyes de Reforma; limitaron las intenciones políticas del clero, y le negaron personalidad jurídica a la Iglesia. Esta postura podemos ilustrarla con un fragmento del discurso del general Francisco J. Múgica al discutirse el artículo 3o, en parte recogido también por El Universal, el 13 de diciembre de 1916:

Soy un enemigo irreconciliable del clero, porque ¿qué ideas puede llevar el clero a nuestras masas? (Aplausos nutridos, bravos y vivas.) [...] ¿Qué puede enseñar a nuestros hijos el clero, a quien le debemos tantos males, si continúan en sus manos? [...] no pueden, bajo ningún concepto, educar a nuestras generaciones, $[\ldots]$ es necesario que la enseñanza sea quitada de las manos del clero. [...] El clero es el único responsable de las maquinaciones que tanto aquí como en el extranjero, se están fraguando en contra del gobierno constitucionalista; que el clero es el eterno rebelde, que no se da nunca por vencido, sino que quiere luchar hasta el fin. ${ }^{22}$

A su vez, debió influir en los radicales el hecho de que Francisco I. Madero fuera traicionado por eclesiásticos y por masones afines a ellos, pues, a pesar de haber sido el candidato del Partido Católico Nacional y de haberse difun-

21 El Universal. El Gran Diario de México, Las relaciones Iglesia Estado en México 19161992, México, El Universal, 1992, t. I, Capítulo 1. (1916-1929) El Enfrentamiento, p. 4.

22 Ibidem, pp. 6 y 7. 
dido en la prensa que ofreció al arzobispo de México no cumplir las Leyes de Reforma, ${ }^{23}$ tras el golpe de estado Luis Cabrera dijo que el clero político se había aliado con Victoriano Huerta, ${ }^{24}$ quien - por supuesto- también era masón. Ahora bien, sobre la tesis anterior de que el clero traicionó a Madero y se alió a Huerta, José Luis Soberanes Fernández afirma que no hay pruebas; aun así, según Blancarte y Reyes Heroles, de esa apreciación derivó que el anticlericalismo marcara la Constitución de 1917, porque se identificó a la Iglesia católica con la dictadura militar huertista. ${ }^{25}$

Mapa 5. Quince estados representados por 22 masones diputados radicales, 1916-1917 (elaboración propia)

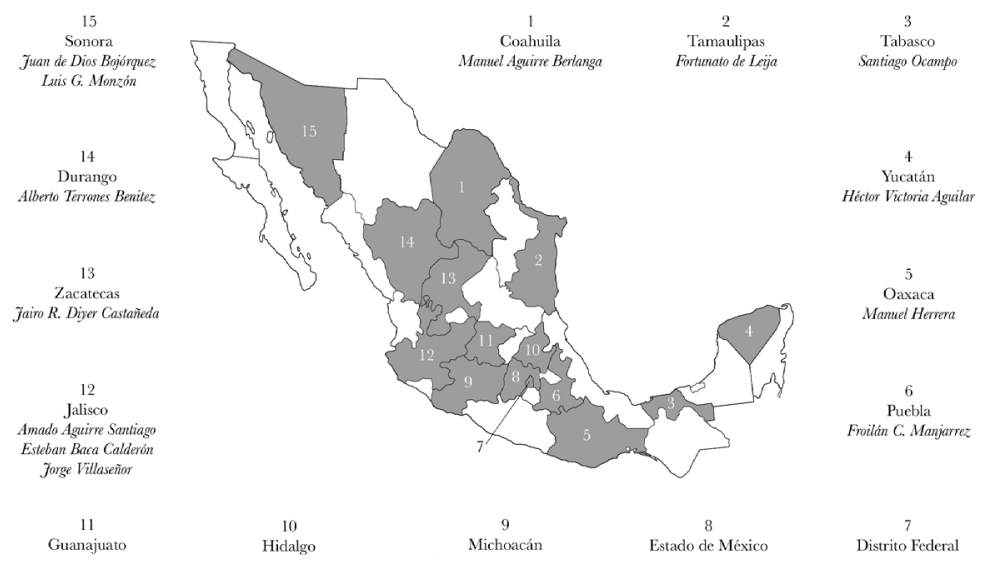

Asimismo, cabe aclarar que los radicales o jacobinos no sólo eran obregonistas, como se ha creído, sino también maderistas y carrancistas, y representaron, por lo menos, 15 entidades federativas, entre quienes podemos citar a Héctor Victoria Aguilar, Manuel Aguirre Berlanga, Amado Aguirre Santiago, José Álvarez y Álvarez de la Cadena, Esteban Baca Calderón, Donato Bravo Izquierdo, Enrique Colunga Meade, Juan de Dios Bojórquez

23 La Patria. Diario de México, t. XXXV, núm. 9995, 26 de agosto de 1911, p. 2, y t. XXXV, núm. 9988, 12 de agosto de 1911, pp. 1 y 2.

24 Martínez Moreno, Carlos Francisco, "Masonerías y construcción de una geopolítica nacional”, en Ponce Urquiza, Arturo (coord.), Escenarios geopolíticos para el México global. Un acercamiento a los temas del siglo XXI, México, Centro de Estudios Superiores Navales CESNAV/Grupo Editorial Cenzontle, 2015, pp. 161-164.

25 Soberanes Fernández, José Luis, "El anticlericalismo en el Congreso Constituyente de 1916-1917", Cuestiones Constitucionales. Revista Mexicana de Derecho Constitucional, núm. 36, enero-junio, 2016, p. 210. Blancarte, "Laicidad", p. 54. 
León, Froylán Cruz Manjarrez Romano, Fortunato de Leija, Jairo R. Dyer Castañeda, Antonio Guerrero, Manuel Herrera, Alfonso Herrera Mendoza, Hilario Medina, Luis G. Monzón, Francisco J. Múgica, Ignacio L. Pesqueira, Santiago Ocampo, Jesús Romero Flores, Alberto Terrones Benítez, y Jorge Villaseñor (véase el mapa 5).

Los renovadores -o El Apostolado- defendían el proyecto de Carranza, como bien señala Soberanes Fernández: que hubiera "plena libertad de enseñanza"; que la enseñanza oficial fuera laica, y la primaria superior y elemental, gratuita; respecto a la Constitución de 1857, aceptaban: "la laicidad y gratuidad de la educación oficial.” ${ }^{26}$ Pero la comisión no aceptó la propuesta, si bien el proyecto excluía al clero de la educación con el artículo 27 -según Luis Manuel Rojas-, mediante la formulación de la "perfecta neutralidad del gobierno en la enseñanza pública, respecto a todas las instituciones o creencias religiosas o filosóficas"; no obstante, el sustituto negaba a toda corporación religiosa, ministro de culto o persona de alguna asociación semejante establecer o dirigir escuelas de instrucción primaria e impartir enseñanza personalmente. ${ }^{27}$ Además, al discutirse el artículo 3o., presidió Cándido Aguilar Vargas, con la presencia de Venustiano Carranza; Rojas - a favor de la libre enseñanza- señaló que entendía que Benito Juárez y los hombres de la Reforma fueron jacobinos, inconsecuentes con el criterio liberal inglés clásico, pero, para él, por el proyecto de reforma (artículo 31 o.) cada Estado debía reglamentar el precepto a su gusto.

Alfonso Cravioto pidió la neutralidad del Estado en asuntos de Iglesia y de la educación pública, laica y gratuita; que la educación religiosa fuera cuestión del hogar, no de la escuela, y combatir el México "retrógrado reaccionario" con la multiplicación de escuelas; que muchos creían que no podía haber verdadera libertad "si no se cuelga a los frailes", pero que el verdadero maestro no era el fraile sino el padre, y que era tiempo de obrar a favor de la patria y no de un partido. ${ }^{28}$ Félix F. Palavicini defendió el liberalismo contra el jacobinismo. ${ }^{29}$ Por su parte, Luis Manuel Rojas apoyó a los renovadores contra quien los consideraba reaccionarios, vendidos al clero e incondicionales de Carranza; en cuanto a los jacobinos, se refirió a una carta del ministro de la Guerra, general Álvaro Obregón, publicada por un periódico, que se

26 DDC, p. 367. Soberanes Fernández, op. cit., pp. 215, 219 y 220.

27 Idem.

28 El Universal. El Gran Diario de México, Las relaciones Iglesia Estado en México 19161992, México, El Universal, 1992, Capítulo 1. (1916-1929) El Enfrentamiento, p. 10.

29 DDC, t. I, núm. 26, 14 de diciembre de 1916; Sánchez, Derecho, pp. 95-97, 99. 
creía que habían recibidos algunos diputados en la cual se les recomendaba "un radicalismo absoluto e intransigente ante todo y por todo". ${ }^{30}$

Por su parte, el también maderista López Lira, aunque no era considerado radical, dijo de sí mismo ser ateo, y sobre la educación laica o religiosa, se declaró a favor de enseñar con hechos positivos y conocimientos comprobados y no con errores ni mentiras. ${ }^{31}$

La red de 14 diputados masones renovadores identificados representó 9 estados, eran maderistas, carrancistas y algunos artífices del proyecto de la constitución; entre ellos identificamos a Luis Manuel Rojas, Gerzayn Ugarte (secretario particular de Venustiano Carranza), Félix Fulgencio Palavicini, Alfonso Cravioto Mejorada (antes ministros de Instrucción Pública), Cándido Aguilar Vargas, Antonio Ancona Albertos, Marcelino Dávalos, Carlos Manuel Ezquerro, Jesús López Lira, Luis T. Navarro, Enrique O’Farril, Guillermo Ordorica, José J. Reynoso y Pedro R. Zavala (véase el mapa 6).

Mapa 6. Nueve estados representados por 14 diputados masones renovadores, 1916-1917 (elaboración propia)

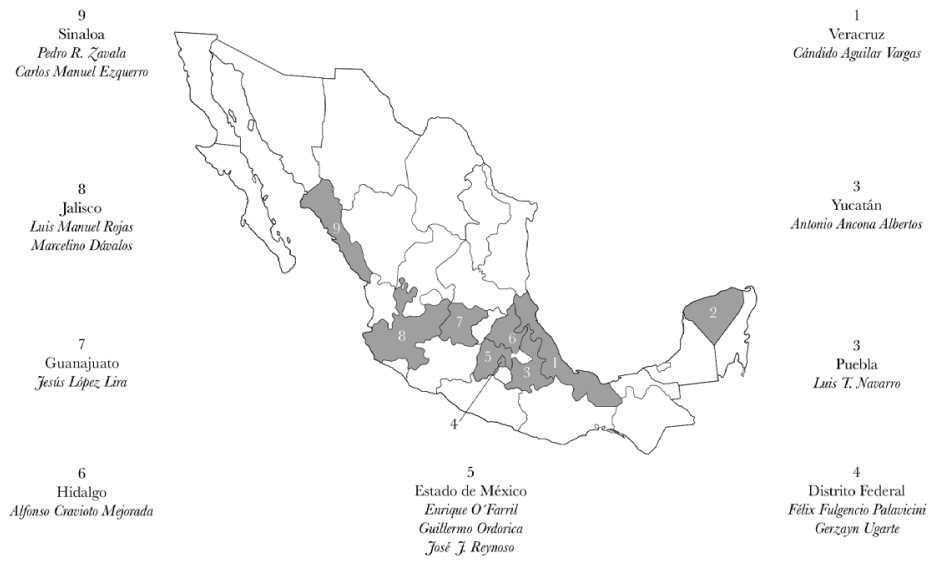

Entre los masones equilibristas, votantes con los otros grupos sin una postura ideológica definida, encontramos 11 diputados representantes de ocho estados: Fernando Castaños, Manuel Cepeda Medrano, Cristóbal del Castillo, Zeferino Fajardo, Antonio Gutiérrez Rivera, Cristóbal Limón López, Fernando Lizardi Santana, José María Rodríguez y Rodríguez, Ramón Rosas y Reyes, José I. Solórzano y Amílcar Vidal (véase el mapa 7).

\footnotetext{
30 Ibidem, p. 8.

31 DDC, t. I, núm. 25, 13 de diciembre de 1916; Sánchez, Derecho, p. 97.
} 
Lizardi Santana suponía radical pedir el laicismo, pero advertía las dos razones de la comisión: la psicológica, por la cual el niño no comprende verdades abstractas religiosas, y la patriótica, por los peligros para la nación, si la enseñanza cayera en manos del clero. ${ }^{32}$

Finalmente, en el mapa 8 pueden observarse ocho entidades (Coahuila, Distrito Federal, Durango, Michoacán, Puebla y San Luis Potosí) representadas por nueve masones moderados: Martín Castrejón, Rafael L. de los Ríos, Porfirio del Castillo, Silvestre Dorador Minchaca, Francisco Espinosa, Amador Lozano, Arturo Méndez y José Rodríguez González.

Mapa 7. Ocho estados representados por 11 diputados masones equilibristas, 1916-1917 (elaboración propia)

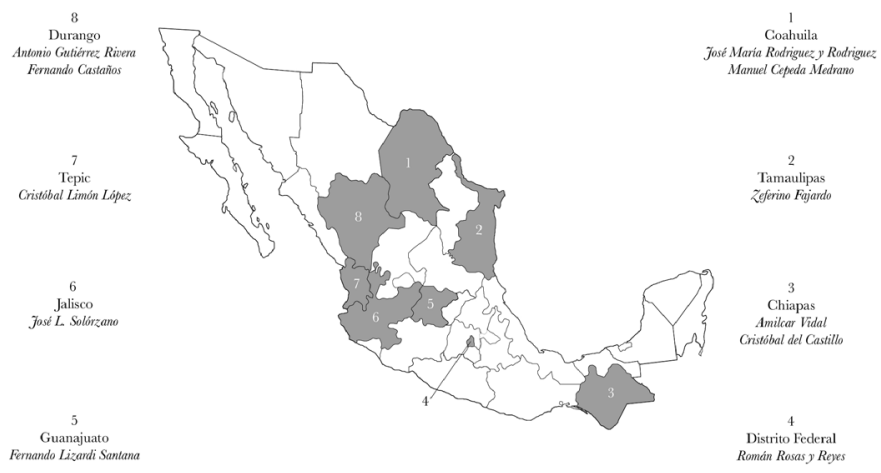

Mapa 8. Seis estados representados por nueve diputados masones moderados, 1916-1917 (elaboración propia)

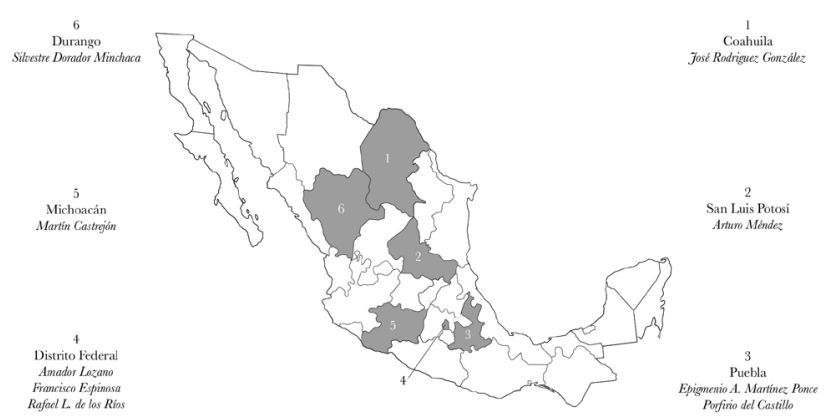

32 DDC, t. I, núm. 28, 16 de diciembre de 1916; Sánchez, Derecho, p. 101.

DR @ 2018. 


\section{Constituyentes MAsones GRAdO $33^{\circ}$}

De los diputados constituyentes masones encontrados, José J. Reynoso recibió el grado $33^{\circ}$ el 21 de abril de 1909 y fue gran maestro de la York Grand Lodge of Mexico. Luis Manuel Rojas recibió el grado $33^{\circ}$ el 12 de enero de 1913 y fue gran maestro de la Gran Logia Valle de México, cargo desde el que acusó al embajador de Estados Unidos de estar detrás del asesinato de Francisco I. Madero; además, fue miembro activo del Supremo Consejo de México desde 1916. Arturo Méndez recibió el grado $33^{\circ}$ el 10 de octubre de 1914 y José María Rodríguez tres semanas después, el 31 del mismo mes. ${ }^{33}$

Así, cuando el Supremo Consejo de México del Rito Escocés Antiguo y Aceptado expulsó el 30 de octubre de 1914 a Victoriano Huerta y a José Castellot quien había sido jefe de la masonería escocesa-, Reynoso tenía cinco años con el grado $33^{\circ}$, Rojas uno, Arturo Méndez 20 días, y un día después lo recibiría Rodríguez. De esta manera, ellos representaban en el Congreso Constituyente una generación de nuevos masones grado $33^{\circ}$ que buscaba depurar a su institución y a la sociedad, de lo que denunciarían precisamente Rodríguez y Méndez, con el pronunciamiento de Veracruz (1915).

Mapa 9. Cinco diputados masones grado $33^{\circ}$ en el Congreso Constituyente de 1916-1917

(elaboración propia)

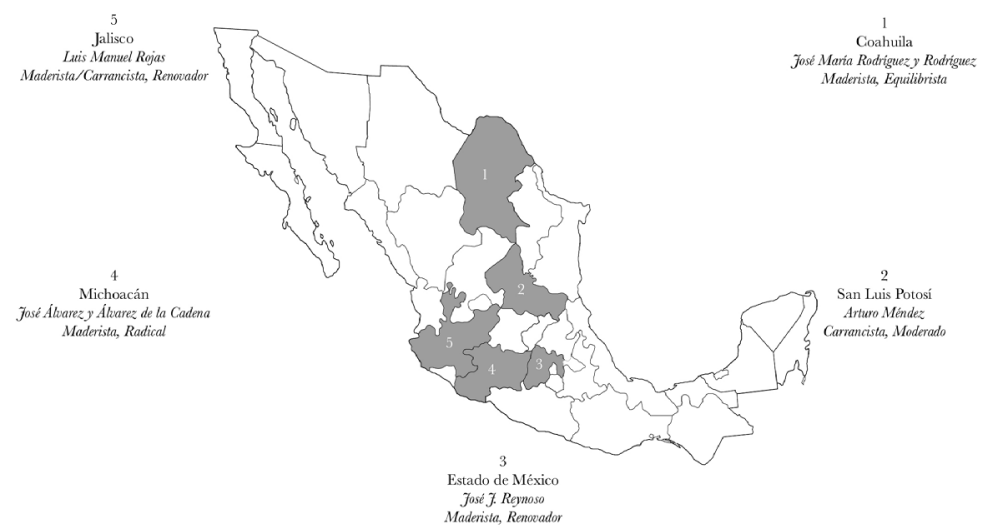

33 "Supremo Consejo del 33 y último grado del Rito Escocés Antiguo y Aceptado para la jurisdicción masónica de los Estados Unidos Mexicanos", Boletín, México, Souligny \& Schmidt Sucr., 1927, pp. 157 y 158.

DR @ 2018. 
Tres eran militares, Rodríguez y Rodríguez, Álvarez y Álvarez de la Cadena y Luis Manuel Rojas, y dos civiles, José J. Reinoso y Arturo Méndez. Había cuatro maderistas, Rodríguez, Reinoso, Álvarez y Rojas; y éste y Méndez después fueron carrancistas. Además, Rojas y Reynoso -los grandes maestros de los ritos escocés y york- fueron renovadores; Álvarez, radical; Rodríguez, maderista, y Méndez, moderado. Por tanto, en los cuatro grupos ideológicos del Congreso Constituyente hubo por lo menos un masón con el grado masónico máximo escocés (el grado $33^{\circ}$ ) y representaron el centro y el norte del país (véase el mapa 9).

\section{Gonstituyentes PResos en 1913 POR Victoriano Huerta}

Como dijimos antes, el ingeniero Pascual Ortiz Rubio, firmante del manifiesto de 1915, como diputado de la Legislatura XXVI electa para los años 1912-1914, fue aprehendido por el gobierno de Victoriano Huerta.

Mapa 10. Catorce diputados masones del Congreso Constituyente de 1916-1917, presos por Huerta en 1913 (elaboración propia)

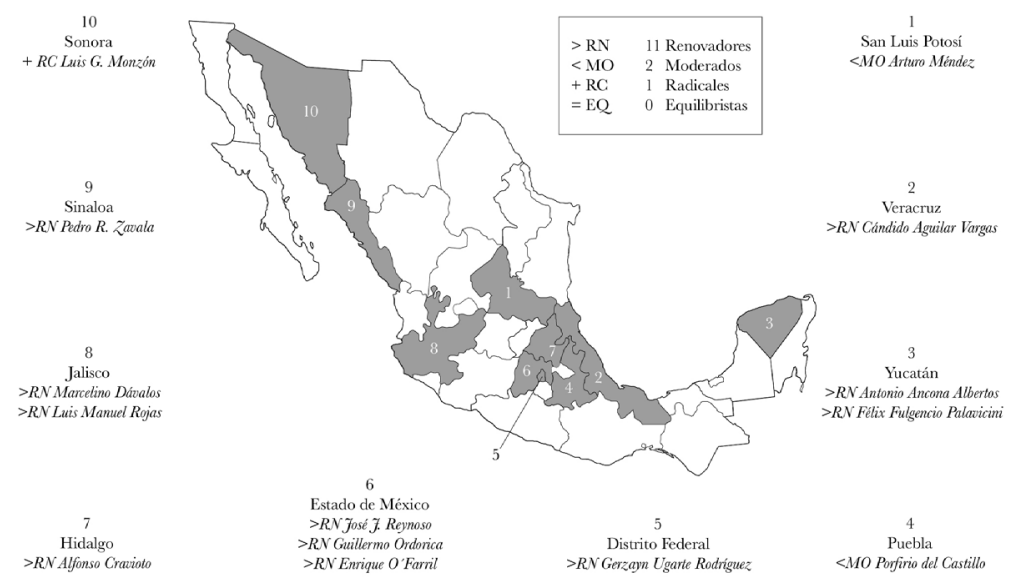

También fueron recluidos los 14 masones siguientes: Cándido Aguilar Vargas, Antonio Ancona Albertos, Alfonso Cravioto Mejorada, Marcelino Dávalos, Porfirio del Castillo, Arturo Méndez, Luis G. Monzón, Enrique O’Farril, Guillermo Ordorica, Félix Fulgencio Palavicini, José J. Reynoso, Luis Manuel 
Rojas, Gerzayn Ugarte Rodríguez y Pedro R. Zavala. ${ }^{34}$ Todos ellos se reorganizaron en tres bandos en el constituyente de 1916-1917: la mayoría eran renovadores (1 1) y constituían una minoría los dos moderados y un radical (véase al mapa 10). No nos sorprende que entre los presos hubiera algunos masones de grado $33^{\circ}$ que luego llamaron a formar el nuevo rito en 1915 .

\section{El GONTROL DEL GONGRESO}

Entre los 11 miembros de la Mesa Directiva del Congreso Constituyente instalada el 30 de noviembre de 1916 fueron identificados siete masones: el presidente Luis Manuel Rojas (preso en 1913 y grado 33º), el vicepresidente Cándido Aguilar Vargas (preso en 1913), el primer secretario Fernando Lizardi, el cuarto secretario Antonio Ancona Albertos (preso en 1913), y los pro-secretarios primero Jesús López Lira, segundo Fernando Castaños y tercero Juan de Dios Bojórquez.

Además, el Congreso Constituyente fue integrado con 12 comisiones y en todas hubo por lo menos un masón. Desde la primera comisión revisora de credenciales, encontramos en cuatro de sus cinco secciones a siete masones: Carlos Manuel Ezquerro, Esteban Baca Calderón, Fernando Castaños, Antonio Ancona Albertos, Alfonso Cravioto Mejorada, Porfirio del Castillo y Guillermo Ordorica (los últimos cuatro, presos en 1913).

En la segunda comisión revisora de credenciales, masón fue José María Rodríguez (grado $33^{\circ}$ ). En la primera comisión de constitución, Enrique Colunga Meade, Luis G. Monzón (preso en 1913) y Francisco J. Múgica. En la segunda de Constitución, Hilario Medina y Francisco J. Múgica. En la primera del gran jurado, Manuel Aguirre Berlanga, Concepción Amado Aguirre Santiago y Silvestre Dorador Minchaca.

También hubo masones en la segunda comisión del gran jurado: José Álvarez y Álvarez de la Cadena (grado 33º y Esteban Baca Calderón. Y dos en las comisiones de estilo: Alfonso Cravioto Mejorada (preso en 1913) y Marcelino Dávalos; administración, José J. Reynoso (grado $33^{\circ}$ y preso en 1913) y Antonio Ancona Albertos (preso en 1913); archivo y biblioteca,

34 De cómo vino Huerta, cit., pp. 377 y 378; Romero Flores, Jesús, Historia del Congreso Constituyente 1916-1917, México, Secretaría de Educación Pública-UNAM, Instituto de Investigaciones Jurídicas-INEHRM, 2014; Cámara de Diputados. LXIII Legislatura, Los Diputados Constituyentes de Querétaro, perfiles de una generación. Notas biográficas de Jesús Romero Flores, t. II, México, Consejo Editorial H. Cámara de Diputados, 2016; Mac Gregor, Josefina, "Los Diputados Renovadores de la XXVI Legislatura al Congreso Constituyente", Historia Mexicana, vol. LXVI, núm. 3, 2017, pp. 1384-1387. 
Esta obra forma parte del acervo de la Biblioteca Jurídica Virtual del Instituto de Investigaciones Jurídicas de la UNAM www.juridicas.unam.mx

https://biblio.juridicas.unam.mx/bjv

Amador Lozano y Enrique O'Farril; en peticiones y diario de debates Fernando Lizardi Santana, y, finalmente, Esteban Baca Calderón en la comisión de reformas al reglamento de debates (véanse la gráfica 9 y el mapa 11).

Gráfica 9. Presencia de los diputados masones en las doce comisiones del Congreso Constituyente (elaboración propia)

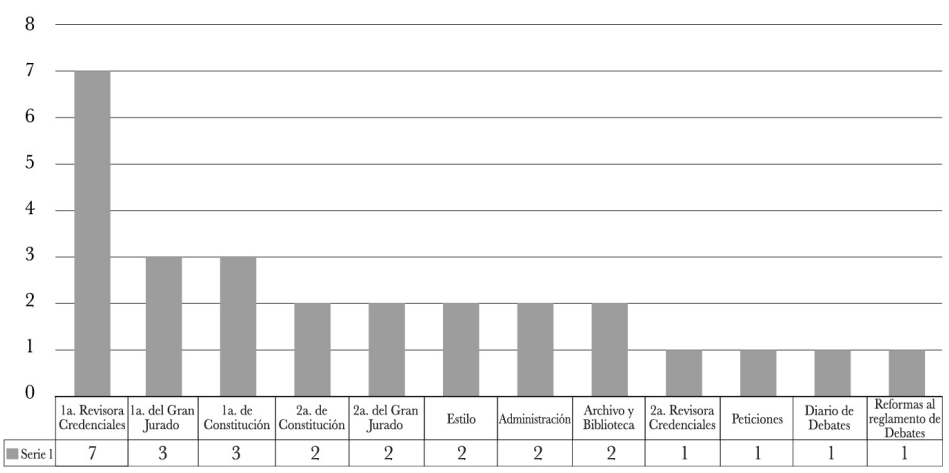

Mapa 11. Veintiún diputados masones en las doce comisiones del Congreso Constituyente de 1916-1917 (elaboración propia)

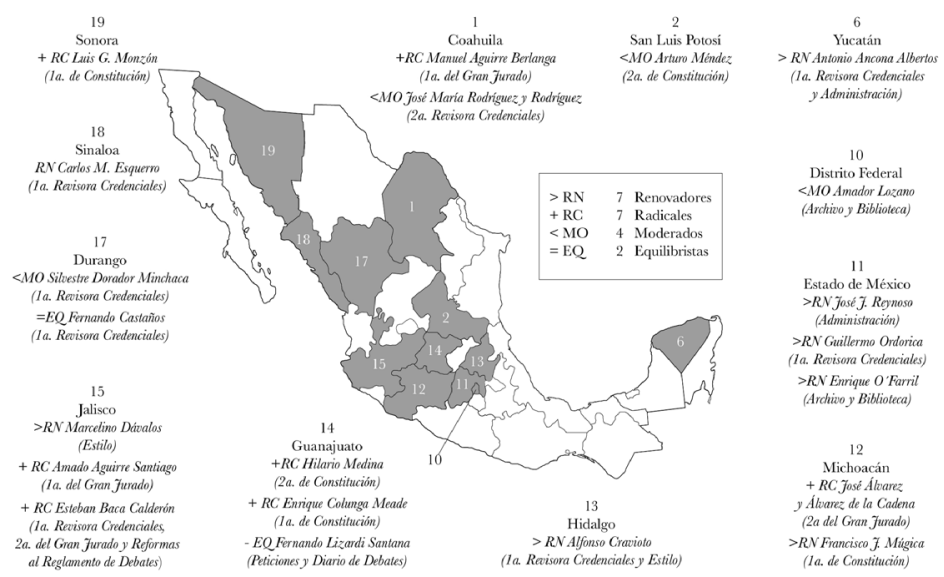

\section{GONTRIBUCiÓN DE LOS MASONES IDEÓLOGOS}

Para el siguiente análisis, fue tomada una muestra de 56 artículos del Diario de Debates del Congreso Constituyente de 1916-1917, en cuyas discusiones los diputados masones se posicionaron y votaron por la afirmativa. Recordemos que

DR @ 2018. 
al principio dijimos que identificamos a 16 diputados masones entre los 21 ideólogos y fundadores de la Constitución de 1917 (76.19\%). Por bandos, la postura ideológica mayoritaria fue la de los radicales Manuel Aguirre Berlanga, Esteban Baca Calderón, Enrique Colunga Meade, Froylán Cruz Manjarrez Romano, Juan de Dios Bojórquez León, Hilario Medina, Luis G. Monzón, Francisco J. Múgica, Jesús Romero Flores y Alberto Terrones Benítez.

En la muestra analizada, influyeron en 50 de los 56 artículos de la Constitución. Y, entre los radicales, Luis G. Monzón fue el diputado con más participaciones y votos a favor, con presencia en 38 de los 50 artículos; seguido por Colunga, en 15 artículos; Terrones Benítez (14); Múgica (10); Medina y De Dios Bojórquez (9); Romero (6); Baca (5); Aguirre (4) y Cruz (3) (véase el anexo 5).

El interés principal de estos radicales estuvo en la educación laica (artículo 3o.); el combate al monopolio (28o.); el régimen estatal interior y el municipio libre (115o.); las limitaciones al gobierno estatal (117o.); los contratos laborales de obreros, jornaleros, empleados, domésticos y artesanos, y la previsión social (123o.); además de que sólo los radicales parecieron interesarse por dos artículos vinculados con el Congreso, sobre los requisitos para ser diputado (55o.) y las facultades del senado (76o.).

Asimismo, los jacobinos contribuyeron a prohibir el trabajo personal obligado (artículo 5o.) y las leyes privadas, así como a limitar el fuero militar (13o.); a salvaguardar las libertades de expresión y de imprenta (7o.); a velar porque nadie fuera molestado en su persona, familia, domicilio, papeles y posesiones (16o.), y a normar sobre la prisión preventiva y el sistema penal (18o.).

De igual manera, ayudaron a reglamentar la propiedad nacional; las expropiaciones; el derecho exclusivo de los mexicanos y de las sociedades mexicanas para adquirir tierras; las concesiones para explotar minas, aguas y combustibles minerales; la prohibición de las iglesias para adquirir, poseer o administrar capitales impuestos sobre ellos, sobre la propiedad nacional de los templos, sobre las instituciones de beneficencia pública o privada; los organismos comerciales, los bancos, condueñazgos, pueblos y congregaciones; la limitación del excedente territorial (27o.), y la calidad de ser mexicano (30o.). Véase el detalle de éstos y otros artículos en los que influyeron en el anexo 5.

Los cinco diputados identificados como masones e ideólogos moderados fueron: Cándido Aguilar Vargas, Alfonso Cravioto Mejorada, Félix Fulgencio Palavicini, Luis Manuel Rojas Arreola y Gerzayn Ugarte Rodríguez. Quien más destacó entre ellos fue Ugarte (12 artículos), seguido de Aguilar (6), Palavicini (5), Cravioto (3) y Rojas (2). Los temas en los que más se involucraron fueron la educación (artículo 3o.), la prohibición del trabajo personal 
obligado (5o.), la propiedad nacional (27), el régimen estatal interior y el municipio libre (115) y el trabajo y la previsión social (123).

En otra postura ideológica, al equilibrista Fernando Lizardi Santana lo encontramos en siete artículos, sobre la libertad de elección de profesión lícita y la determinación de las que requieren título para ejercer (artículo 4o.); la prohibición del trabajo personal obligado (5o.); la protección de las personas, familias, domicilios, papeles y posesiones (16); la prohibición de las penas de mutilación, de infamia y de muerte, el tormento, los azotes, la confiscación de bienes (22); las facultades del congreso (73) y la limitación de la autoridad militar sólo a las funciones vinculadas con la disciplina castrense en tiempo de paz (129); y sólo a Lizardi, en el tema de los proyectos de ley o decreto y los procedimientos para su aprobación por las Cámaras (72).

Con relación a los artículos a los que se adhirió la mayoría de los diputados ideólogos masones -sin distinguir su tendencia radical, moderada o equilibrista-, encontramos que los temas a los que se adhirieron más de la mitad de ellos fueron, por prelación: la educación (artículo 3o.); el régimen estatal interior y el municipio libre (115); las limitaciones al gobierno estatal (117); el trabajo y la previsión social (123); las facultades del senado (76); la prohibición del trabajo personal obligado (5o.); la protección de las personas, sus familias, domicilios, papeles y posesiones (16); la propiedad nacional (27; los requisitos para ser diputado (55 y 76). Otros temas relevantes para la mitad de ellos (o menos de la mitad) fueron el combate al monopolio (28) y las libertades de expresión y de imprenta (7o.); si bien, con relación a la muestra, también influyeron en los otros 45 artículos (véase el anexo 5).

Finalmente, tienen razón quienes atribuyen a los masones haber disminuido el poder del clero en México: fueron los responsables de establecer la educación laica (artículo 3o); prohibir las comunidades religiosas y el voto religioso (5o.); desconocer los títulos de nobleza y sus prerrogativas (12); negar las leyes privativas y el fuero eclesiástico (13); despojar al clero de bienes (22); prohibir los actos de culto fuera de los templos y proteger la libertad religiosa (24); negar la propiedad o administración de bienes al clero y fijar los templos como propiedad de la nación (27), así como negar la personalidad jurídica a las iglesias, establecer la obligación de ser mexicano por nacimiento para ser ministro de culto, sujetarlo a las leyes del Estado, prohibirle heredar por testamento con quien no tenga parentesco dentro del cuarto grado y reconocer sólo el matrimonio civil (129, después 130). ${ }^{35}$

35 Navarrete, Félix, La Masonería en la Historia y en las Leyes de Méjico, 1a. ed., México, Jus, 1957, pp. 149, 228-233. 
Esta obra forma parte del acervo de la Biblioteca Jurídica Virtual del Instituto de Investigaciones Jurídicas de la UNAM

\section{Gonclusiones}

Los diputados masones identificados fueron minoría entre los congresistas, pero mayoría entre los ideólogos y fundadores de la Constitución Mexicana de 1917. Su participación constituyente obedeció a un reclamo social, ante el que eran doblemente responsables, por ser formar parte de generaciones hartas del régimen de Porfirio Díaz y sus aliados, y porque la causa del deterioro social se debía a la corrupción de algunos malos masones que traicionaron sus principios, se aliaron al clero político católico contra el liberalismo y asesinaron y encarcelaron a sus "hermanos" antes, durante y después de la Decena Trágica.

Lo anterior explica por qué los masones grado $33^{\circ}$ expulsaron a Victoriano Huerta, Félix Díaz y a otros, así como el pronunciamiento del 15 de enero de 1915 de Veracruz, para la creación de un nuevo rito y la reestructuración de la masonería nacional vinculada con el compromiso de asumir como propios los reclamos del pueblo mexicano, mediante redes de miembros de distinta profesión (civiles y militares, maderistas, carrancistas y obregonistas), de diferentes posturas ideológicas (radical, moderada, renovadora y equilibrista) e incluso la participación de aquellos que serían gobernadores de Estado, quienes se empoderaron desde un inicio en la Mesa Directiva y en todas las comisiones del Congreso Constituyente.

Si bien sólo fue identificado un diputado masón grado $33^{\circ}$ radical y otro radical preso por Victoriano Huerta, en contraste, en el Constituyente de 1916-1917, fueron los radicales quienes se impusieron y modificaron el proyecto original de Venustiano Carranza, hasta hacer prevalecer un espíritu liberal, progresista y laico.

De todo lo anterior y del análisis de la contribución a una muestra de 56 artículos, podemos afirmar que los masones sí fueron los ideólogos y los fundadores de la Constitución Mexicana de 1917. A ellos debemos, entre otros logros, su avanzado proyecto social y la disminución del poder del clero político en México; la educación laica; la ratificación de las Leyes de Reforma; la libertad religiosa, de expresión y de imprenta; la salvaguarda de los bienes, propiedades e intereses nacionales; los derechos laborales y la previsión social; el municipio libre; la protección de las personas, familias, domicilios, papeles y posesiones; la limitación de las funciones del Estado y del ejército. Todos éstos, logros que, paradójicamente, la generación actual de congresistas está empeñada en extinguir con las llamadas reformas estructurales, ante el silencio de los actuales líderes masones. 
Esta obra forma parte del acervo de la Biblioteca Jurídica Virtual del Instituto de Investigaciones Jurídicas de la UNAM www.juridicas.unam.mx https://biblio.juridicas.unam.mx/bjv

ANEXO 1. Firmas de constituyentes con tripunteado masónico ${ }^{36}$

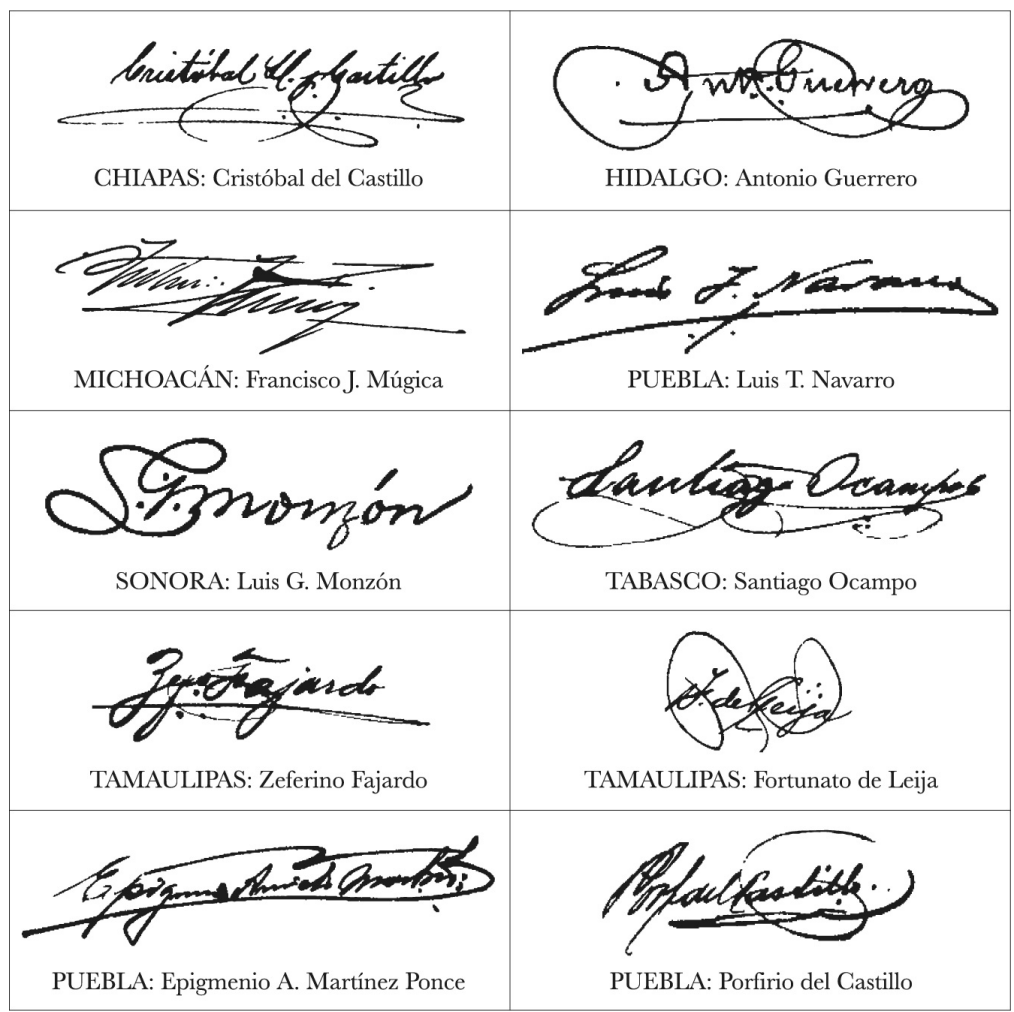

Seleccionamos 10 firmas de la Constitución Política de los Estados Unidos Mexicanos del 5 de febrero de 1917. En ellas, ocho diputados incluyeron tres puntos en triángulo con la punta hacia arriba y la base abajo: Cristóbal del Castillo, Antonio Guerrero, Francisco J. Múgica, Luis T. Navarro, Luis G. Monzón, Santiago Ocampo, Zeferino Fajardo y Fortunato de Leija; los dos restantes, con el triángulo invertido: Epigmenio A. Martínez y Porfirio del Castillo.

Luis T. Navarro, Porfirio del Castillo y Luis G. Monzón, combinaron los puntos con los propios de las letras o de las siglas de sus nombres.

36 Fotos tomadas de la Constitución Política de los Estados Unidos Mexicanos. Decretada el 5 de febrero de 1917, México, Miguel Ángel Porrúa, 2017, pp. 183 y ss.

DR @ 2018. 
Esta obra forma parte del acervo de la Biblioteca Jurídica Virtual del Instituto de Investigaciones Jurídicas de la UNAM www.juridicas.unam.mx

https://biblio.juridicas.unam.mx/bjv

MASONES: ¿IDEÓLOGOS Y FUNDADORES...?

ANEXo $2^{37}$

MAASONERÍA [SIC] UNIVERSAL.

FAMILIA MEXICANA.

LIBERTAD. IGUALDAD. IRATERNIDAD. [SIC]

$\mathrm{A}[\therefore] \mathrm{L}[\mathrm{A}] \mathrm{G}[\mathrm{LORIA}] \mathrm{D}[\mathrm{EL}] \mathrm{G}[\mathrm{RAN}] \mathrm{A}[\mathrm{RQUITECTO}]$ [DEL] U[NIVERSO]

A todas las Potencias Masónicas Regulares del Mundo.

A todos los Hermanos Filosóficos y Simbólicos del Mundo.

Sabed:

Queridos Hermanos:

Sería imposible negar que la Masonería en la República Mexicana, había degenerado hasta su último término, Masones indignos han llenado los Templos desnaturalizando los principios de la Libertad, Igualdad y Fraternidad; cometiendo faltas tan graves que han merecido juicios severos y hasta el desprecio del público sobre la Masonería.

Durante los últimos cuarenta años, los masones en la República Mexicana, olvidaron sus deberes, traicionando sus juramentos, y solo [sic] buscaron el amor y la protección de los déspotas, que han dominado al pueblo, explotándolo y esclavizándolo, hasta pretender la nulificación de sus sentimientos y de su personalidad jurídica.

La historia de los últimos años de nuestra Masonería es de corrupción y sangre. Empieza con los asesinatos de los masones de Veracruz el 25 de Junio de 1879, ordenados por el Gran Maestro de la Logia Valle de México, Gral. "Porfirio Díaz, "Presidente de la República, 39 y termina con los

37 Luca Antonio $33^{\circ}$ et al., Pronunciamiento para la creación del Rito Simbólico Mexicano, Veracruz, 15 de enero de 1915 .

38 Porfirio Díaz no fue gran maestro de la Gran Logia Valle de México. Siete logias lo eligieron, en junio de 1883, como gran maestro de la Gran Logia Simbólica Soberana e Independiente de Libres y Aceptados Masones del Distrito Federal, pero no ejerció el cargo. Sí fue gran patrono del Gran Campamento de Caballeros Templarios de la República Mexicana entre 1888 y 1893, y también gran maestro de la Gran Dieta Simbólica de los Estados Unidos Mexicanos entre 1889 y 1895. Martínez Moreno, Carlos Francisco, Masonerías, intervencionismo, cit., pp. 152 y ss., 192, 212, 215.

39 El responsable fue otro. El gobernador de Veracruz, general Luis Mier y Terán fue expulsado el 29 de junio de 1879 por el Supremo Consejo 33, acusado de mandar fusilar

DR @ 2018.

Universidad Nacional Autónoma de México- Instituto de Investigaciones Jurídicas 
asesinatos de los Grandes Inspectores G [ene]rales Grado 33, HH[ermanos] Francisco I. Madero y José María Pino Suárez, Presidente y Vice-Presidente de la República respectivamente el 23 de Febrero de 1913. Asesinatos que fueron ideados y ordenados por los masones: Lic. Rodolfo Reyes Grado 33, Gral. Victoriano Huerta Grado 30, Inspector Gral. de Policía entonces Gral. Félix Díaz Grado 32 y otros.

Si no hubiéramos presenciado los crímenes de Febrero de 1913, la traición de Huerta, la matanza del pueblo en la Ciudad de México (seis mil muertos en el bombardeo), nos sería difícil creer en la existencia de masones

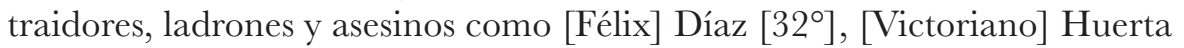

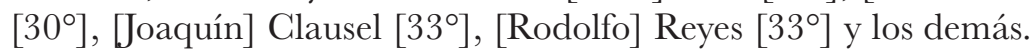

Durante el dominio de Porfirio Díaz y Victoriano Huerta, la corrupción llegó a tal punto entre algunos hermanos que creemos difícil encontrar ejemplos semejantes en la Historia de la Masonería Universal.

Los Cuerpos Filosóficos y las Logias Simbólicas se vaciaron, los masones honrados se vieron obligados a declararse en sueños. El Soberano Gran Comendador del Supremo Consejo Grado 33, José Castellot, fué acusado en el periódico "El Heraldo Mexicano" de haberse apropiado los fondos del Banco de Campeche y no sintió la necesidad de depurar su conducta. Ricardo O'Farril Grado 33, denunció a la policía, como revolucionarios, a los miembros de la Logia "Libertad y Progreso" y a los del Consejo Kadosch, la mayoría de los masones cerraron cobardemente los trabajos por miedo a la cárcel o a la muerte.

El valiente pueblo mexicano, cansado de Gobiernos crueles y ladrones, acude á las armas, para reconquistar sus derechos conculcados y establecer el reinado de la Ley y de la Justicia.

La Masonería no sintió el deber de ayudar y dirigir el movimiento revolucionario, sino que trabajaba por el triunfo de la reacción y hacía grandes esfuerzos para que un nuevo Gobierno Militar, presidido por el cobarde asesino Félix Díaz tomara asiento en el Palacio Nacional.

Después de la huida del bandido, beodo y ladrón Gral. [Victoriano] Huerta y a la llegada a la Capital de la República del glorioso Ejército Constitucionalista mandado por el Primer Jefe Gral. [sic] Don Venustiano Carranza, ${ }^{40}$ los masones honrados, quisieron depurar la Institución y lograron expulsar de su seno, como traidores, asesinos e indignos de pertenecer a ella, a más de ochenta miembros, y entre ellos se contaron José Castellot, Grado 33; Ex-

ilegalmente, cinco días antes, el 24 de junio, a 9 ciudadanos, 5 de ellos masones, contra sus juramentos masónicos. Ibidem., pp. 106, 134 y ss.

40 Venustiano Carranza no fue general del Ejército Mexicano. 
Soberano Gran Comendador; a Ricardo O'Farril, Grado 33; al Lic. Juaquín [sic] Clausel, Grado 33 Victoriano Huerta, Grado 30, etc., etc.

La mayoría de los masones restantes hipócritas y reaccionarios se opusieron a la expulsión del asesino Félix Díaz, porque tienen la esperanza de que algún día llegue a ser Presidente de la República, y les pueda dar concesiones y empleos. La misma mayoría se opuso a la publicación y notificación de los expulsados a las Potencias Masónicas y a la Nación por creer próximo el triunfo de la reacción y posible la admisión en los Templos de todos los expulsados.

Desde hace treinta años, la Masonería en México abandonó los principios ritualísticos y entró resueltamente en el período de la más absoluta irrgularidad, [sic] siendo objeto el principal de los trabajos masónicos, explotar a los ingénuos, [sic] sacándoles la mayor cantidad posible de dinero, a cambio de grados no merecidos y menos comprendidos.

En la actualidad tenemos en el Oriente de México, cuatro Ritos Masónicos Simbólicos que son: La Gran Logia Valle de México[,] La Gran Logia del Distrito Federal, La Grán Logia Yorkina ${ }^{41}$ y la Logia Alemana; ${ }^{42}$ Tres Cuerpos Filosóficos Escoceses para Mexicanos, y los Cuerpos Filosóficos Escoceses para Yankis. Todos estos Cuerpos hacen iniciaciones, conceden cartas patentes y grados, se hacen la guerra los unos a los otros y causan el desprestigio absoluto de la Masonería ante el Mundo Masónico y profano.

En este momento histórico para el porvenir de nuestra Patria, el pueblo en armas lanza el anatema de la infamia sobre la carcomida Masonería Simbólica y Filosófica, que durante cuarenta años, ha sido rémora para el progreso de la Nación y cómplice y apoyo de déspotas y bandidos.

Los que subscribimos, fieles a nuestros juramentos de Maestros Masones, desenmascaramos a los hipócritas que han traicionado a la Justicia y fieles a la Ley al Honor DESCONOCEMOS A LA ACTUAL MASONERÍA SIMBÓLICA Y FILOSÓFICA Y CONSTITUIMOS UNA NUEVA MASONERÍA SIMBÓLICA, CON CIUDADANOS HONRADOS Y RESUELTOS A RESTABLECER EL DOMINIO DE LA VERDAD, PARA QUE LA LIBERTAD, LA IGUALDAD Y LA FRATERNIDAD VUELVAN A SER NUESTRO PROGRAMA.

Nuestro Rito Simbólico, que lleva por nombre "mexicano", cuyo objeto es propagar y difundir en toda la República, las grandes enseñanzas Masónicas, cooperará efectivamente al establecimiento de las Reformas Sociales, por las cuales lucha el pueblo desde 1910.

41 La York Grand Lodge of Mexico, Free \& Accepted Masons.

42 Años atrás, la logia Germania 219 había trabajado bajo la Gran Dieta Simbólica de los Estados Unidos Mexicanos en idioma alemán. Martínez Moreno, Carlos Francisco, Masonerías, intervencionismo, cit., p. 215, nota al pie 424. 
En nuestro programa, figura en primer término, la redención del pueblo mexicano, que durante cuatro siglos ha sufrido todos los tormentos morales y materiales, bajo la férula de tiranos militares y religiosos.

El Rito Simbólico Mexicano a semejanza del Rito Simbólico Italiano, se funda, en estos dos indiscutibles principios: la Autonomía de la Logia, la Autonomía del Masón. El Masón Libre en la Logia Libre.

Tendrá además sus lazos de unión con la Masonería Universal, signos y estudios esotéricos especiales.

Tal es y será nuestra divisa masónica: ESTUDIAR PARA PENSAR, PENSAR PARA OBRAR.

Nuestro Rito Simbólico lo constituirá la confederación de sus Logias Libres, y conservará la acción colectiva aprovechando todos los esfuerzos individuales de sus miembros; siendo así una verdadera colaboración fraternal, ecenta [sic] de polémicasppersonales. [sic].

En nuestros Templos reinará el amor fraternal, el amor a la Patria y el amor a la Humanidad, y nuestro Rito representará un mundo mejor que aquel, en el que cumplimos nuestros cuotidianos [sic] deberes profanos.

Como masones Escoceses desconocemos los actos y personalidad de sus representantes en la República Mexicana, mientras tanto, no se sinceren de los cargos que pesan sobre ellos.

Dado y firmado en el Oriente de Veracruz, el 15 de Enero de 1915.

Dr. Antonio Luca, 33; Dr. Arturo Méndez 33; Dr. Gral. José María Rodríguez, 33; Modesto Rolland, 14; Antonio Herrejón López, 3; Dr. Andrés C.Castro, [sic] 3; Rafael Canto Dr., $\therefore$ M $\therefore$ Ingeniero Pascual Ortíz Rubio, 3.

N O T A:- Todos los Hermanos que deseen regularizarse y que consideren poseer las condiciones que nuestro Rito exige, deben públicamente adherirse a este manifiesto y dirigir sus solicitudes al Secretario de la Logia del Rito Simbólico Mexicano "Evolución número 1". 
Esta obra forma parte del acervo de la Biblioteca Jurídica Virtual del Instituto de Investigaciones Jurídicas de la UNAM www.juridicas.unam.mx

https://biblio.juridicas.unam.mx/bjv

\section{ANEXo $3^{43}$}

UNIVERSI TERRARUM ORBIS ARCHITECTONIS AD GLORIAM INGENTIS.

SUPREMO CONSEJO DEL $33^{\circ}$ Y ÚLTIMO GRADO DEL RITO ESCOCÉS ANTIGUO Y ACEPTADO PARA LA JURISDICGIÓN MASÓNICA

DE LOS ESTADOS UNIDOS MEXICANOS.

BALAUSTRE No. 52.

ACUERDO 642.

$$
\text { SAL[UD] } \quad \text { EST[ABILIDAD] } \quad \text { POD[ER] }
$$

Desde el Asilo Sagrado en que reside el Supremo Consejo de los MM[uy] PP[oderosos] SS [oberanos] GG[randes] II[nspectores] GG[enerales] del $33^{\circ}$ y último grado del $\mathrm{R}$ [ito] $\mathrm{E}$ [scocés] $\mathrm{A}$ [ntiguo] y $\mathrm{A}$ [ceptado] para la jurisdicción masónica de los EE[stados] UU[nidos] Mexicanos bajo el C[ampo] $\mathrm{C}$ [eleste] del Zenit cerca de la $\mathrm{H}$ [oguera] L[uminosa] que corresponde a

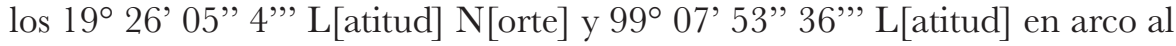
$\mathrm{O}$ [riente] del Meridiano de Grenwich.

A todos los Supremos Consejos confederados del Rito Escocés Antiguo y Aceptado.

A todos los masones regulares que la presente vieren.

SABED:

El desprestigio en que estaba incurriendo la Masonería Mexicana con motivo de la mala conducta masónica y profana de varios hermanos, impuso la necesidad de poner remedio radical á mal tan trascendental; y al efecto, este Supremo Consejo nombró una comisión de su seno para que adquiriese todos los informes respecto de aquellos hechos de que la voz pública acusaba a algunos hermanos de la jurisdicción, y que una vez comprobados, propusiera la expulsión de los hermanos cuya permanencia entre nosotros fuera motivo de nuestro desprestigio que cada día se acentuaba más y más.

La comisión con todo juicio, cordura e imparcialidad presentó dictamen consultando fuesen borrados del Cuadro aquellos hermanos que se encontraban en ese caso.

43 Supremo Consejo de los Estados Unidos Mexicanos, Balaustre 52. Acuerdo 642, 29 de enero de 1916. 
Después de maduro estudio, inspirándose en ideas de salvación para la Institución, el supremo Consejo en la sesión que verificó el dia [sic] 30 de Octubre de 1914, por unanimidad de votos decretó que debian [sic] borrarse, como en efecto quedaron borrados de los Cuadros de los Cuerpos de esta jurisdicción los $\mathrm{HH}$ [ermanos] siguientes:

Ricardo Suárez Gamboa, 4 ${ }^{\circ}{ }^{44}$ Luis Monroy Durán, 14º 45 Vicente Mariscal, $14^{\circ}$, Fernando Gil, $18^{\circ}$, Joaquín González Gandarillas, $18^{\circ}$, Manuel R. García, $18^{\circ}$, Julián Deletrás, [sic] 30 $0^{\circ}$, Juan Marmolejo, $30^{\circ},{ }^{46}$ Octavio Serrano, $30^{\circ}$, Julio Muñoz, $30^{\circ}$, Cesar E. Estrada, $30^{\circ}$, Victoriano Huerta, $30^{\circ}$, Antonio Valenzuela de la Torre, $30^{\circ}$, Victoriano Morelos, $30^{\circ}$, Antonio B. López y Sierra, $30^{\circ},{ }^{47}$ Gabriel González Mier, $30^{\circ},{ }^{48}$ Juan N. Avendaño, $31^{\circ}$, Alberto Rodríguez Aréchiga, $32^{\circ},{ }^{49}$ Leopoldo Blum, $32^{\circ}$, Alberto Beteta, $32^{\circ}$, Santiago G. Paz, $32^{\circ}$, Teodulo [sic] Montemayor, $32^{\circ},{ }^{50}$ Ignacio Aristain, $32^{\circ}$, Gumersindo Enriquez. $33^{\circ},{ }^{51}$ José Ricardo Ofarrilll, [sic] $33^{\circ}$,

44 Ricardo Suárez Gamboa fue médico maderista, graduado de la Escuela Nacional de Medicina de México (1894). Perteneció al Cuerpo Médico Militar. En Europa, comisionado por el gobierno federal, perfeccionó su técnica quirúrgica. Fue miembro de la Academia Nacional de Medicina (1899), http://148.226.12.161:8080/egvadmin/bin/view/biografia/ Su\%C3\%A1rez+Gamboa\%2C+Ricardo.

45 Luis Monroy Durán fue autor de la obra sobre la rebelión delahuertista en Michoacán: El último caudillo: apuntes para la historia de México, acerca del movimiento armado de 1923, en contra del gobierno constituido, México, José S. Rodríguez Editor, 1924.

46 Juan Marmolejo fue licenciado penalista.

47 Antonio B. López Sierra. Años después, en 1931, ex obispo, expulsado de la Iglesia Ortodoxa, Católica, Apostólica Mexicana.

48 Gabriel González Mier era antirreleccionista; en 1889 se libró de ser capturado por la policía porque estudiantes lo impidieron. Autor de la Oda a Atenas que recitó en las honras fúnebres de Sebastián Lerdo de Tejada; debido a que el gobierno mandó retirar sus impresiones en la Ciudad de México, fue impresa en 10 mil ejemplares en San Antonio Texas. En 1892, escapó con Joaquín Clausell, cuando aprendieron e incomunicaron en Belén a los principales líderes antirreeleccionistas Antonio Rivera G. J. Huelgas, Francisco Mascareñas, Daniel Cabrera. Díaz y de Ovando, Clementina, La Escuela Nacional Preparatoria. Los Afanes y Los Días 1867-1910, I, 2a. ed., México, UNAM, 2006, pp. 164, 174.

49 Alberto Rodríguez Aréchiga fue Juez Primero de Instrucción en el gobierno del presidente Francisco I. Madero. Fue el encargado de esclarecer la muerte de Belisario Domínguez. Mac Gregor, Josefina, Belisario Domínguez: el porvenir de una ética, México, Senado de la República-Instituto Belisario Domínguez-UNAM, 2013, pp. 147 y ss.

50 Teódulo Montemayor fue general y licenciado. Gran Maestro (1909-1912) y fundador de la Gran Logia de Libres y Aceptados Masones de Tamaulipas, el 5 de mayo de 1909, con las logias Victrix, Bernardo Reyes y Justicia, autorizadas por la Gran Logia Unida Mexicana de Veracruz.

51 Gumersindo Enríquez. No se le debe confundir con su homónimo nacido en Jilotepec y muerto en 1888, liberal, radical, anticlerical, quien fue diputado, senador y gobernador del Estado de México en 1876. 
Joaquín Clausell, $33^{\circ},{ }^{52}$ Lorenzo B. Spyer, $33^{\circ}$, Cassius O. Smith. $33^{\circ}$, John

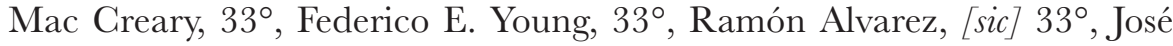
Castellot, ${ }^{53} 33^{\circ}$.

Por el estado anormal de esta República en los últimos años no había comunicaciones con otros lugares del País y del Extranjero, no se hizo saber lo decretado a los Cuerpos de la Amistad y jurisdicción, pero como esto trajera por consecuencia nuevos malos manejos de algunos hermanos expatriados, en la sesión de 23 de Enero último se resolvió que se haga saber al Mundo Masónico lo acordado.

Dado, firmado y sellado a 29 de Enero de 1916, E[ra] V[ulgar].

$$
\begin{gathered}
\text { El Soberano Gran Comendador en Funciones } \\
\text { Manuel Leví, }{ }^{54} 33^{\circ}
\end{gathered}
$$

Ante mí

El Gran Secretario General

Alberto Pró, $33^{\circ}$

El Gran Ministro del Estado

Aurelio de la Parra $^{1} 33^{\circ}$

52 Joaquín Quirico Marcelino Clausell Traconis fue abogado, activista y pintor mexicano autodidacta impresionista, así como caricaturista político y periodista. Colaboró en: Diario del Hogar, La Campaña Electoral, La República, El Hijo del Ahuizote, El Monitor Republicano y El Universal. En 1892, formó un partido antirreeleccionista. Fundó y dirigió el periódico de oposición El Demócrata (1893-1895), donde difundió la represión a los indios tomochitecos en Chihuahua, razón por la cual fue apresado y cerrado su periódico.

53 José Castellot fue gobernador de Campeche, banquero, senador, miembro del grupo Los Científicos, de la Convención y del Partido Reeleccionista, así como jefe de la masonería escocesa. En su calidad de gran comendador del Supremo Consejo de México, "coronó" a Francisco I. Madero como grado $33^{\circ}$. En su momento, Castellot se manifestó contra los derechos laborales y, además, fue secretario de la embajada de México en Washington para el gobierno del presidente golpista de Victoriano Huerta. Martínez Moreno, Masonerías, intervencionismo, cit, pp. 225-229, 237 y 238, 244.

54 Manuel Leví fue gobernador interino de Veracruz en 1892, y diputado federal durante el gobierno de Francisco I. Madero, http://juridico.segobver.gob.mx/gobernadores/37B.pdf. 
Esta obra forma parte del acervo de la Biblioteca Jurídica Virtual del Instituto de Investigaciones Jurídicas de la UNAM www.juridicas.unam.mx

Anexo 4. Diputados masones en el Constituyente de 1917 (elaboración propia) ${ }^{55}$

\begin{tabular}{|c|c|c|c|c|c|c|}
\hline & 36 & Diputados Civiles & Entidad & Diputados Militares & 21 & \\
\hline Chiapas & 1 & Amílcar Vidal J. & Chiapas & Cristóbal del Castillo Llavén & 1 & Chiapas \\
\hline Coahuila & 3 & $\begin{array}{c}\text { José Rodríguez González (suplente) } \\
\text { Manuel Aguirre Berlanga (Ideólogo) } \\
\text { Manuel Cepeda Medrano }\end{array}$ & Coahuila & José María Rodríguez y Rodríguez & 1 & Coahuila \\
\hline $\begin{array}{l}\text { Distrito } \\
\text { Federal }\end{array}$ & 5 & $\begin{array}{c}\text { Alfonso Herrera Mendoza } \\
\text { Amador Lozano } \\
\text { Francisco Espinosa (suplente) } \\
\text { Gerzayn Ugarte Rodríguez (Ideólogo) } \\
\text { Rafael L. de los Ríos }\end{array}$ & $\begin{array}{l}\text { Distrito } \\
\text { Federal }\end{array}$ & $\begin{array}{c}\text { Ignacio L. Pésqueira } \\
\text { Román Rosas y Reyes (suplente) } \\
\text { Félix Fulgencio Palavicini (Ideólogo) }\end{array}$ & 3 & $\begin{array}{l}\text { Distrito } \\
\text { Federal }\end{array}$ \\
\hline Durango & 4 & $\begin{array}{l}\text { Alberto Terrones Benítez (Ideólogo) } \\
\text { Antonio Gutićrrez Rivera } \\
\text { Silvestre Dorador Minchaca } \\
\text { Fernando Castaños }\end{array}$ & Durango & & & Durango \\
\hline Guanajuato & 2 & $\begin{array}{c}\text { Hilario Medina (Ideólogo) } \\
\text { Enrique Colunga Meade (Ideólogo) }\end{array}$ & Guanajuato & $\begin{array}{l}\text { Jesús López Lira } \\
\text { Fernando Lizardi Santana (Ideólogo) }\end{array}$ & 2 & Guanajuato \\
\hline Hidalgo & 1 & Alfonso Cravioto Mejorada (Ideólogo) & Hidalgo & Antonio Guerrero & 1 & Hidalgo \\
\hline Jalisco & 3 & $\begin{array}{l}\text { Marcelino Dávalos } \\
\text { José I. Solórzano } \\
\text { Jorge Villaseñor }\end{array}$ & Jalisco & $\begin{array}{c}\text { Esteban Baca Calderón (Ideólogo) } \\
\text { Luis Manuel Rojas Arreola (Ideólogo) } \\
\text { Amado Aguirre Santiago }\end{array}$ & 3 & Jalisco \\
\hline México & 3 & $\begin{array}{l}\text { Enrique O'Farril } \\
\text { Guillermo Ordorica } \\
\text { José J. Reynoso }\end{array}$ & México & Donato Bravo Izquierdo & 1 & México \\
\hline Michoacán & 1 & Jesús Romero Flores & Michoacán & $\begin{array}{c}\text { Martín Castrejón } \\
\text { Francisco José Múgica Velázquez } \\
\text { (Ideólogo) } \\
\text { José Álvarez y Álvarez de la Cadena }\end{array}$ & 3 & Michoacán \\
\hline Oaxaca & 1 & Manuel Herrera & Oaxaca & Manuel García Vigil & 1 & Oaxaca \\
\hline Pucbla & 1 & Froylán Cruz Manjarréz Romano (Ideólogo) & Pucbla & $\begin{array}{c}\text { Porfirio del Castillo } \\
\text { Epigmenio A. Martínez Ponce } \\
\text { Luis T. Navarro }\end{array}$ & 3 & Pucbla \\
\hline $\begin{array}{l}\text { San Luis } \\
\text { Potosí }\end{array}$ & 1 & Arturo Méndez & $\begin{array}{l}\text { San Luis } \\
\text { Potosí }\end{array}$ & & & $\begin{array}{l}\text { San Luis } \\
\text { Potosí }\end{array}$ \\
\hline Sinaloa & 2 & $\begin{array}{c}\text { Pedro R. Zavala } \\
\text { Carlos Manuel Ezquerro }\end{array}$ & Sinaloa & & & Sinaloa \\
\hline Sonora & 2 & $\begin{array}{l}\text { Juan de Dios Bojórquez León } \\
\text { (suplente/Ideólogo) } \\
\text { Luis G. Monzón (Ideólogo) }\end{array}$ & Sonora & & & Sonora \\
\hline Tabasco & 1 & Santiago Ocampo C. & Tabasco & & & Tabasco \\
\hline Tamaulipas & 2 & $\begin{array}{l}\text { Fortunato de Leija } \\
\text { Zeferino Fajardo }\end{array}$ & Tamaulipas & & & Tamaulipas \\
\hline Tepic & & & Tepic & Cristobal Limón López & 1 & Tepic \\
\hline Veracruz & & & Veracruz & Cándido Aguilar Vargas (Ideólogo) & 1 & Veracruz \\
\hline Yucatán & 2 & $\begin{array}{l}\text { Antonio Ancona Albertos } \\
\text { Héctor Victoria Aguilar }\end{array}$ & Yucatán & & & Yucatán \\
\hline Zacatecas & 1 & Jairo R. Dyer Castañeda & Zacatecas & & & Zacatecas \\
\hline
\end{tabular}

55 Elaboración propia, con datos de Romero Flores, Jesús, Historia del Congreso Constituyente 1916-1917, 3a. ed., México, Secretaría de Educación Pública-UNAM, Instituto de Investigaciones Jurídicas-INEHRM, 2014; Marván Laborde, op. cit.; Naranjo Lara, Antero, "La participación militar en el constituyente de 1916", Ponencia presentada en la Universidad Tecnológica del Norte de Guanajuato, Dolores Hidalgo, Guanajuato, 3 de febrero de 2017.

DR ㄷ 2018.

Universidad Nacional Autónoma de México- Instituto de Investigaciones Jurídicas 
Esta obra forma parte del acervo de la Biblioteca Jurídica Virtual del Instituto de Investigaciones Jurídicas de la UNAM www.juridicas.unam.mx

https://biblio.juridicas.unam.mx/bjv

Anexo 5. Influencia del grupo de diputados masones ideólogos en una muestra de 56 artículos (elaboración propia) ${ }^{56}$

Anexo 5.1. Influencia de 10 diputados masones radicales en 50 artículos

\begin{tabular}{|c|c|c|c|c|c|c|c|c|c|c|c|c|c|c|c|c|c|c|c|c|c|c|c|c|c|c|c|c|}
\hline & RADICALES & 1 & 2 & 3 & 4 & 5 & 6 & 7 & 8 & 9 & 10 & 11 & 12 & 13 & 14 & 15 & 16 & 17 & 18 & 19 & 20 & 21 & 22 & 23 & 24 & 25 & \\
\hline & & ARTÍCULOS & 1 & 2 & 3 & 4 & 5 & 6 & 7 & 8 & 9 & 10 & 11 & 12 & 13 & 14 & 16 & 18 & 20 & 21 & 22 & 23 & 24 & 25 & 26 & 27 & 28 & \\
\hline 1 & 38 & MONZÓN & 1 & 1 & 1 & 1 & 1 & 1 & & 1 & 1 & 1 & 1 & 1 & 1 & & 1 & 1 & 1 & 1 & 1 & 1 & 1 & 1 & 1 & 1 & 1 & \\
\hline 2 & 15 & COLUNGA & & & 1 & 1 & & & & & 1 & & & & & & 1 & 1 & & 1 & & & & & & 1 & & \\
\hline 3 & 14 & TERRONES & & & 1 & & 1 & & 1 & & & & & & & 1 & 1 & & & & & & & & & 1 & 1 & \\
\hline 4 & 10 & MÚGICA & & & 1 & & & & & & & & & & 1 & & 1 & & & & & & & & & 1 & 1 & \\
\hline 5 & 9 & MEDINA & & & & & & & 1 & & & & & & 1 & & & 1 & & & & & & & & & & \\
\hline 6 & 9 & DE DIOS & & & 1 & & & & 1 & & & & & & & & & & & & & & & & & & 1 & \\
\hline 7 & 6 & ROMERO & & & 1 & & & & & & & & & & & & & & & & & & & & & & 1 & \\
\hline 8 & 5 & BACA & & & & & 1 & & & & & & & & 1 & & & & 1 & & & & & & & & & \\
\hline 9 & 4 & AGUIRRE & & & \begin{tabular}{|l|}
1 \\
\end{tabular} & & & & & & & & & & & & & & & & & & & & & & & \\
\hline 10 & 3 & CRUZ & & & & & & & & & & & & & & & & & & & & & & & & & & \\
\hline & & & \begin{tabular}{|l|}
1 \\
\end{tabular} & 1 & 7 & 2 & 3 & 1 & 3 & 1 & 2 & 1 & 1 & 1 & 4 & 1 & 4 & 3 & 2 & 2 & 1 & 1 & 1 & 1 & 1 & 4 & 5 & \\
\hline
\end{tabular}

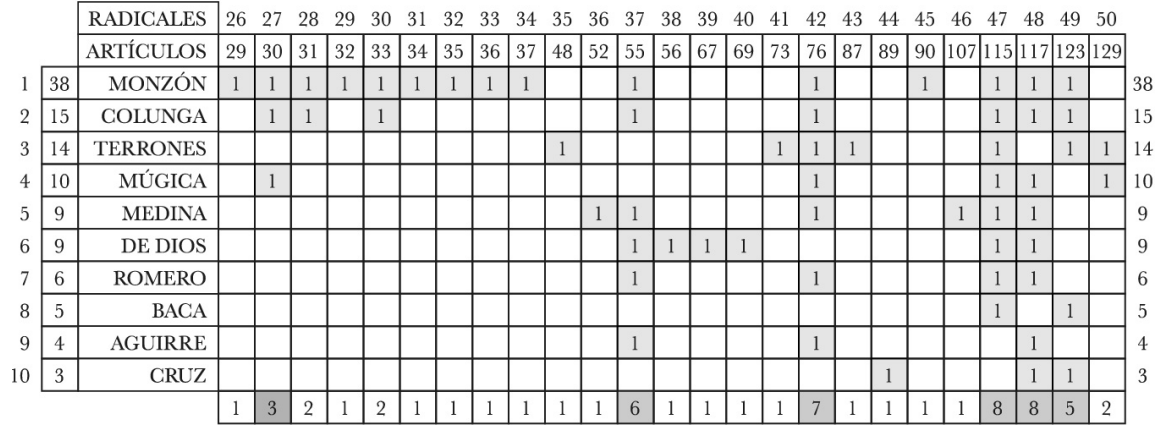

Anexo 5.2. Influencia de 5 diputados masones moderados en 19 artículos

\begin{tabular}{|c|c|c|c|c|c|c|c|c|c|c|c|c|c|c|c|c|c|c|c|c|c|c|}
\hline & MODERADOS & 1 & 2 & 3 & 4 & 5 & 6 & 7 & 8 & 9 & 10 & 11 & 12 & 13 & 14 & 15 & 16 & 17 & 18 & 19 & \\
\hline & & ARTÍCULOS & 1 & 3 & 5 & 7 & 16 & 18 & 21 & 27 & 32 & 38 & 73 & 79 & 82 & 108 & 115 & 117 & 123 & 129 & 160 & \\
\hline 1 & 24 & UGARTE & 1 & 1 & 1 & 1 & & \begin{tabular}{|l|}
1 \\
\end{tabular} & & & & & 1 & 1 & 1 & 1 & 1 & 1 & 1 & & & 1 \\
\hline 2 & 12 & AGUILAR & & 1 & 1 & & & & & 1 & 1 & & & & & & 1 & & 1 & & & 6 \\
\hline 3 & 10 & PALAVICINI & & & & & 1 & & 1 & 1 & & & & & & & 1 & & & 1 & & 5 \\
\hline 4 & 6 & CRAVIOTO & & 1 & & & & & & & & & & & & & & & 1 & & 1 & 3 \\
\hline 5 & 4 & ROJAS & & 1 & & & & & & & & 1 & & & & & & 1 & & & & \\
\hline & & & 1 & 4 & 2 & 1 & 1 & 1 & 1 & 2 & 1 & 1 & 1 & 1 & 1 & 1 & 3 & 1 & 3 & 1 & 1 & \\
\hline
\end{tabular}

56 Con datos del Diario de Debates.

DR @ 2018. 
Esta obra forma parte del acervo de la Biblioteca Jurídica Virtual del Instituto de Investigaciones Jurídicas de la UNAM

Anexo 5.3. Influencia de 1 diputado masón equilibrista en 7 artículos

\begin{tabular}{c|c|c|c|c|c|c|c|c|}
\cline { 2 - 8 } \multicolumn{1}{c|}{} & EQUILIBRISTA & 1 & 2 & 3 & 4 & 5 & 6 & 7 \\
\cline { 2 - 8 } & & 4 & 5 & 16 & 22 & 72 & 73 & 129 \\
\hline 7 & LIZARDI & 1 & 1 & 1 & 1 & 1 & 1 & 1 \\
\hline
\end{tabular}

Anexo 5.4. Número de diputados masones ideólogos que influyeron en los 56 artículos de la muestra

\begin{tabular}{|c|c|c|c|c|c|c|c|c|c|c|c|c|c|c|c|c|c|c|c|c|c|c|c|c|c|c|c|c|c|c|c|c|c|c|}
\hline & 1 & 2 & 3 & 4 & 5 & 6 & 7 & 8 & 9 & 10 & 11 & 12 & 13 & 14 & 15 & 16 & 17 & 18 & 19 & 20 & 21 & 22 & 23 & 24 & 25 & 26 & 27 & 28 & 29 & 30 & 31 & 32 & 33 & 34 \\
\hline ARTÍCULOS & 1 & 2 & 3 & 4 & 5 & 6 & 7 & 8 & 9 & 10 & 11 & 12 & 13 & 14 & 16 & 18 & 20 & 21 & 22 & 23 & 24 & 25 & 26 & 27 & 28 & 29 & 30 & 31 & 32 & 33 & 34 & 35 & 36 & 37 \\
\hline
\end{tabular}

$\begin{array}{lllllllllllllllllllllll}35 & 36 & 37 & 38 & 39 & 40 & 41 & 42 & 43 & 44 & 45 & 46 & 47 & 48 & 49 & 50 & 51 & 52 & 53 & 54 & 55 & 56\end{array}$

\begin{tabular}{|l|l|l|l|l|l|l|l|l|l|l|l|l|l|l|l|l|l|l|l|l|l|l|}
\hline ARTÍ́CULOS & 38 & 48 & 52 & 55 & 56 & 67 & 69 & 72 & 73 & 76 & 79 & 82 & 87 & 89 & 90 & 107 & 108 & 115 & 117 & 123 & 129 & 160 \\
\hline
\end{tabular}

\begin{tabular}{ll|l|l|l|l|l|l|l|l|l|l|l|l|l|l|l|l|l|l|l|l|l|l|} 
& 1 & 1 & 6 & 1 & 1 & 1 & 1 & 3 & 7 & 1 & 1 & 1 & 1 & 1 & 1 & 1 & 11 & 9 & 8 & 4 & 1 \\
\hline
\end{tabular}

DR @ 2018. 


\section{MASONERÍA Y ANTICLERICALISMO EN LA DÉCADA DE 1920}

Jean MEYER*

La masonería mexicana no ha sido realmente estudiada, sobre todo desde un punto de vista histórico y sociológico; apenas si disponemos de algo más que de anécdotas, listas y rituales. El material no falta, sin embargo, ni las buenas voluntades masónicas que permitirían devolver su justo lugar a un movimiento que desempeñó un papel especialísimo en México, si se piensa que el presidente Portes Gil, en el ejercicio de sus funciones, pudo exclamar: "En México, el Estado y la masonería en los últimos años han sido una misma cosa". ${ }^{1}$

En efecto, masonería y gobierno estaban estrechamente relacionados, a tal punto que era preciso ser hermano masón para llegar a ocupar un puesto de importancia; gobernadores, ministros, senadores, diputados y generales se hallaban relacionados de cerca o de lejos con las logias. El gobernador y general Heriberto Jara, el presidente Ortiz Rubio, el general Urquizo y el general Roberto Gruz eran masones; en cuanto a Portes Gil, fue Gran Maestre en 1933-1934. ${ }^{2}$ El general Cárdenas, masón también, trató de nacionalizar la masonería cuando llegó a la presidencia.

Si el político era lógicamente masón, puede decirse que, en la práctica, los oficiales eran hermanos: "La gran mayoría de los oficiales pertenece a la orden masónica y por consiguiente están resentidos contra la Iglesia Romana por haber condenado dicha orden". ${ }^{3}$ Orden de dirigentes, la masonería recluta adeptos también en ciertos sectores populares, como los ferrocarrileros y los albañiles. No se adscribe necesariamente a un oficio, ya que, en el norte, los braceros propagan la orden en los municipios rurales. Responde a dos impulsos: uno negativo,

* División de Historia, CIDE.

1 Crisol, agosto de 1929, p. 116.

2 Zalce y Rodríguez, Luis J., Apuntes para la historia de la masonería en México, México, 1950, t. II, 2 vols., pp. 90, 92, 102, 130 y 131.

3 Department of State Records (DSR) 812.00/Coahuila 17, del 25 de febrero de 1929: "A large majority of the officers being members of the Masonic order - and therefore resentful of the ban placed on that order by Roman Church"-. 
puramente anticlerical: "los curas abusan del pueblo y de las mujeres", que se traduce por la fijación anual, con motivo del 16 de septiembre, del edicto de excomunión de Hidalgo por la Iglesia; el otro positivo: la fraternidad que busca una eficacia profesional (entre los ferrocarrileros es anterior y paralela al sindicalismo; es una protesta contra el sindicalismo gubernamental) y social. Nunca se insistirá demasiado sobre el dimorfismo sexual que hace de la masonería un asunto de hombres, por oposición a una religión vivida, por lo general, como cosa de mujeres. La mujer, la madre, suele asegurar la continuidad católica exigiendo los actos católicos del matrimonio, del bautismo y de la extremaunción para todos, y trasmitiendo su práctica a las hijas. El varón se incorpora en edad temprana con su padre en el campo de los librepensadores. ${ }^{4}$

La masonería, controlada y restringida por Porfirio Díaz, había recobrado desde 1914 el papel activo que ejercía en la época de la Reforma, y proporcionaba al gobierno una organización y unos mandos: presidentes municipales y de comunidades agrarias, jefes sindicales y maestros eran con mucha frecuencia masones. Nada más normal, en tales condiciones, que el apoyo incondicional que la orden daba en público a la política religiosa del gobierno. La masonería tenía una pesadilla: el clero romano, causa del mal en el mundo. Dio, de esta manera, a Calles la medalla del Mérito por su obra educativa, la Logia del Valle de México organizó una "manifestación pública de respaldo a la política de intolerancia religiosa, y los integrantes de las logias regulares e irregulares en la capital desfilaron con sendos estandartes". ${ }^{5}$ El 25 de agosto de 1927, el Gran Comendador Rojas, de México, telegrafiaba al presidente Coolidge: "En nombre del Antiguo y Aceptado Rito Escocés de esta nación, en el de la Masonería Mexicana en general [...] le presentamos nuestro reconocimiento por su firme posición al rehusarse a participar [...] en el llamado Conflicto Católico Mexicano". ${ }^{6}$

La masonería militante topaba con el clero: "Bajo el dominio clerical, esas logias [de Jacala y Huejutla, Hidalgo] tuvieron corta vida [...] el medio fanatizado y hostil hacía imposible el concurso de masones de arraigo". ${ }^{7}$ No ocultaba la masonería su intención de destruir el poder maléfico de Roma apoyándose en el Estado, y se comprenden mejor así las denuncias católicas: "La Revolución, que es una aliada fiel tanto del protestantismo como de la masonería, sigue en marcha tenaz hacia la demolición del catolicismo [...]

4 Véase los testimonios de Romeo Flores sobre Ciudad Anáhuac, Nuevo León, y de Roque González Salazar sobre General Terán, Nuevo León, Tean Mever, 1969.

5 Zalce, op. cit., t. II, pp. 92 y 93.

6 Segunda parte del memorándum presentado a Su Eminencia el cardenal Spellman por el Lic. Agustín Navarro Flores, presidente de la Unión Nacional de Padres de Familia de México, Nueva York, 10 de noviembre de 1951, p. 4, en sJ.

7 Zalce, op. cit., t. II, p. 295. 
Nos hallamos en presencia de una triple e inmensa conjuración contra los principios sagrados de la Iglesia". ${ }^{8}$

Los católicos disponían, para fundar sus temores y la tesis del complot, de las actas del Congreso Masónico de Buenos Aires, de 1906, que proclamaban la urgencia de combatir a la Iglesia católica, ${ }^{9}$ y de un texto muy curioso del doctor Robert A. Grennfield, publicado en Nueva York, el 20 de diciembre de 1927, y citado por la International Civic Organisation, con motivo de la VI Conferencia Panamericana, reunida en Cuba: ${ }^{10}$

Como protestante que soy y partidario de la masonería [...] en la lucha de exterminio contra el catolicismo, sí estamos seguramente de acuerdo masones y protestantes, y hemos impartido al régimen de Calles una ayuda leal bastante amplia [...] Salir del catolicismo para entrar en el campo amplísimo del protestantismo es, sin duda, un adelanto; y además nosotros los norteamericanos hemos creído siempre, desde el siglo antepasado, que la religión católica es un obstáculo insuperable para la fusión de todos los países de la América en una gran Anfictionía.

La ideología de los defensores de la razón y de los "desfanatizadores" está definida así por el general Joaquín Amaro, el mismo a quien los oficiales festejaban el día de su santo patrono, en la iglesia de San Joaquín, de México, con una parodia de oficio santo, con sermón en púlpito y champaña en cálices:

Tenemos la opinión, fundada en la enseñanza, en la experiencia de los siglos, de que el clero apostólico, católico, romano, transformando en partido político rapaz, de oposición, conservador y retrógrado, ha sido la única causa de las desdichas que han afligido a México desde los tiempos de la conquista española hasta nuestros días [...] Nosotros, los militares mexicanos, hijos de la Revolución [...] hemos tenido la satisfacción de combatir a ese clero de oposición y criminal [...] En la larga serie de alzamientos y de golpes de Estado que han devastado el país a lo largo de siglos, EL CLERO HA SIDO EL INSTIGADOR MÁS FUERTE Y EL ELEMENTO MÁS PODEROSO, a causa de sus grandes riquezas y de su identificación absoluta con todos los enemigos de la Revolución. ${ }^{11}$

8 González Flores, Anacleto, El plebiscito de los mártires, México, s.p.i., 1930.

9 Diario Masónico de Caracas, Caracas, 1906, núm. 10, citado por Moctezuma, Aquiles, El conflicto religioso de 1926, México, Jus, 1960.

10 Comité Central de la International Civic Organisation, La querella de México ante la VI Conferencia Panamericana en Cuba, San Antonio de los Baños, s.e., 1928, p. 21.

11 MID 2657 G 616 36, Extracts referring to the Clergy and clericalism from the speech of General Joaquin Amaro minister of war, on the occasion of the inauguration of the Historical Section of the General Staff, on October 22, 1929. 
Amaro, interesado personalmente por la historia del conflicto religioso, constituyó una biblioteca, que después de su conversión legó a los jesuitas. Confió al coronel Ernesto Higuera la redacción de una memoria sobre la actividad sediciosa del clero en 1926-1929, ${ }^{12}$ donde se encuentra denunciada la "neurosis mística" de las masas populares engañadas por "estos inhumanos embaucadores [que] fueron cayendo en el campo uno a uno, pagando con la vida sus criminales yerros y su carencia absoluta de sentimientos cristianos [...] Pero más criminal resulta la perfidia frailesca si se toma en cuenta que las llamadas huestes reivindicadoras se componían, en su mayor parte, de jóvenes no mayores de veinte años".

Los curas rurales [...] después de haber lanzado sus excomuniones furiosas y excitado hasta el paroxismo el sentimiento idolátrico de los ignorantes feligreses, se tornaron feroces cabecillas, alimentando la cohesión de sus chusmas en los campamentos con sus constantes prédicas y sus misas de campaña. La gravedad litúrgica de estas ceremonias, el brillo de los paramentos sacerdotales, su tradicional dominio sobre las conciencias incultas, les daba un prestigio excepcional entre las gentes sencillas que los seguían ciegamente $[\ldots]$ Los sacerdotes $[\ldots]$ explotaron habilidosamente su ceguedad supersticiosa, y los lanzaron $[\ldots]$ a un sacrificio estéril, galvanizados por sus odios frenéticos $[\ldots]$

Furioso enemigo de Roma, el general Amaro hacía una propaganda intensa contra ella por medio de la prensa y del libro. "Su actitud, bien conocida, es muy hostil a la jerarquía de la Iglesia, y la publicación en sus oficinas de La Patria y del libro Iglesia católica, ${ }^{13}$ dos publicaciones muy mordaces contra la Iglesia, demuestran la índole de sus sentimientos". ${ }^{14}$ El Soldado, revista mensual, llena de caricaturas y de anécdotas representando a Pío XI, a los obispos, a los sacerdotes y a las monjas como obsesos sexuales, se difundía gratuitamente entre los soldados, lo mismo que el semanario La Patria, publicado bajo la dirección del general Cristóbal Rodríguez. Este último publicó una serie de libros y de folletos que son muy representativos de la actitud de los militares en general y del secretario Amaro en particular.

12 Diversos aspectos de la propaganda del clero, 1930, manuscrito de 50 p. mecanografiadas, sJ, legado Amaro.

13 SJ, legado Amaro.

14 MID 2257 G 70/7, del 2 de octubre de 1930, Mexican War Department attitudes towards U.S. by Col. Gordon Johnston: "His attitude, however, is well known as being hostile to the hierarchy of the Church, and the publication in his office of La Patria and the issue from his office of the book Iglesia católica, both bitter anti Church publications, are evidence of his feeling toward the Church". 
Del general Rodríguez, Juan Gil Preciado -futuro gobernador, futuro secretario- hacía esta presentación a la Gran Logia de Occidente:

[... tras de blandir la espada en defensa de las instituciones y de la patria, vuelve con el laurel de la victoria, no para tener una tregua, sino para empuñar la pluma y continuar la campaña con el verbo de combate, con más ardor, con más convicción y con más habilidad. Por eso su gesto de luchador y de patriota se ha comparado con el de CERVANTES DE ESPAÑA. Los libros inspirados por el numen del general [...] son de idénticas tendencias a éste: desfanatizar al pueblo. Porque él escribe para el pueblo en su lenguaje sencillo y llano, pero en forma decisiva y sacando conclusiones que son axiomas. Tal parece que su cerebro es una máquina trituradora de frailes. Predica la justicia para los oprimidos y la libertad para las conciencias envilecidas por el cura. Sabemos que el poder del clero es una cadena vergonzosa para la humanidad, que el evangelio de la razón y de la liberación del pensamiento debe gobernar. ${ }^{15}$

Para el general Rodríguez, "el cristianismo no fue, por consiguiente, sino el resultado de la leyenda judía que transforma aquella religión, ya improductiva por vieja, en otra flamante que diera a los eternos exploradores más oportunidad para vivir de la credulidad y el miedo de los demás". ${ }^{16}$

El discurso pronunciado durante la guerra Cristera, por el general J. B. Vargas, ante la población de Valparaíso es una síntesis de todos los temas de la ideología "desfanatizante":

El abnegado 84 regimiento de caballería no trata de quitarles su religión, que ni siquiera se las envidiamos porque no somos idólatras ni fanáticos. A esta corporación la mandan a exterminar las chusmas de bandidos clericales compuestas de individuos que no les gusta trabajar y que ya están acostumbrados a vivir de lo ajeno. Hombres de pésimos antecedentes, prófugos de las prisiones y de la justicia, que el clero se vio obligado a echar mano de ellos por haber más quien secundara la causa del Papa de Roma, quien trató de hacer otra revolución en contra de nuestro devastado país y que, en complicidad con los frailes, creyó que todos los mexicanos éramos fanáticos y confiados en su poderío de oropel, soñaron ilusamente enfrentársele al supremo gobierno de la República, contra quien siempre han conspirado y en esta vez, aprovechando la tirantez de relaciones de México contra el poderoso país de los Estados Unidos del Norte y la insurrección de los indios yaquis en Sonora, vieron el momento propicio para tirarle el guante al gobierno de la nación so pretexto también de desconocer nuestras leyes por

15 Rodríguez, Cristóbal, Cauterios y látigos, Jalapa, edición del gobierno, 1933, pp. 5 y 6.

16 Ibidem, p. 238. Del mismo autor: Puyas y puyazos, México, 1944; ;Mujer, confiésate y verás!, Labor liberal, Sobre la brecha, Banderilla de fuego: libro de doctrina desfanatizante, Tepic, Gobierno de Tepic, 1938 y muchas otras sobre el mismo tema. 
instrucciones del cabecilla italiano (a) el Papa que tiene su cuartel de idiotas, cínicos y degenerados en Roma [...] para poder volver a implantar la odiosa y criminal Inquisición de tan triste memoria, así como también ver realizados sus sueños dorados en volver al trono de México a otro príncipe europeo que, como Maximiliano de Austria, volviera el clero a sus antiguos fueros.

Afortunadamente hay mucho pueblo patriota y liberal que se dio cuenta de las criminales maquinaciones del Vaticano y sus esbirros, y ya conocedor de la tristemente célebre historia del funesto clero traidor a la patria y que depende de un jefe extranjero que siempre conspira por buscarle a México intervenciones con el fin de asegurar sus dominios y privilegios. Es nocivo porque su misión es embrutecer al pueblo ignorante para poderlo explotar y fanatizarlo hasta el idiotismo [...] para vivir del pueblo indolente y analfabeto que es donde el fraile impera. Basta tener nociones de la funesta historia de la Inquisición para que los curas y las sotanas huelan a prostitución y crimen.

La confesión ${ }^{17}$ es una industria que se inventó para seducir doncellas, conquistar damas católicas y convertir a los padres y esposos en castos José. Es una maniobra corruptora de las sociedades en provecho de los inicuos placeres clandestinos de los frailes y demás jerarquías de la mafia de esta clase de pillos.

El Sultán de Turquía, según sus costumbres es poseer en su harem muchas mujeres a la vista del mundo y las mantiene a todas. La costumbre de los frailes es tener también muchas mujeres clandestinamente, pero las mujeres los mantienen a ellos [...] Ni el papa de Roma es tampoco representante de Dios porque no podría justificarlo. Es un extranjero inteligente que acumula riquezas en complicidad de los frailes explotadores que estafan al pueblo tonto de pro de un país enteramente extraño al nuestro [...] si Jesucristo bajara lo primero que haría era mandarlos ahorcar [a los cristeros] como perros rabiosos al lado de los curas sus cómplices. La historia del 57 se repite en esta región. Imitemos a los patriotas liberales [...]

Nunca he sido católico, menos romano; me enorgullezco de ser mexicano, pero librepensador $[\ldots]$

Todas las religiones que mal conozco se concretan en creer en Dios y ser útiles a la humanidad, teniendo por base la moralidad y el trabajo y son nacionales. Pero la religión católica depende de un extranjero, venera millares de ídolos y aparecidos y a cuanto santo lanza a la circulación forzosa la martirología romana y en el que más poco se preocupan es por el Creador del universo teniendo por base la inmoralidad, hipocresía y el cinismo.

La excomunión y la maldición es arma ridícula del cobarde consciente de su impotencia y bajeza; es el escupitajo del canalla despechado. Todas las excomuniones que lance el Sumo Pontechango y socios las acepto gratuitamen-

17 Además de los debates del Congreso Constituyente sobre este asunto, véase La mujer en el confesionario, por el doctor X, dedicado exclusivamente a los hombres, México, 1925, pp. 4 y 5, 10, y Cristóbal Rodríguez, libros ya citados. ¿Traumatismo que se remonta a la colonia? 
te, que me las echen en la cabeza de mi columna, que es la que más avanza y la que va más cerca de la victoria.

Pueblo liberal y patriota $[\ldots]$ date cuenta que el enemigo del progreso y el de tu patria es el clero [...] decláralo perro del mal, mátalo a pedradas. Cuando esto se lleve a cabo, la prosperidad y felicidad de México será un hecho. ${ }^{18}$

El general José Álvarez y Álvarez, colaborador del general Calles, profesor de la escuela de guerra, veía en el problema religioso un tema militar, pues los ejércitos verde (los campesinos), blanco (los intelectuales) y rojo (los obreros) estaban en guerra contra el ejército negro (la Iglesia) y amarillo (los capitalistas), enemigo del progreso de la humanidad. ${ }^{19}$ Nacido en la levítica Zamora, discípulo de escuelas religiosas y más tarde del colegio noviciado de los jesuitas, había pasado después un año de internado en el seminario de Zamora y tres más con los maristas. En el seminario fue condiscípulo de otro librepensador, el general Francisco José Mújica. Masón desde el 5 de julio de 1906, escribió en el seminario anticlerical de Guadalajara El Sermón del Cura, y quemó en Zamora el periódico La Bandera Clerical delante del obispado. Jefe de policía al principio de la revolución, se dedicó a desfanatizar. ${ }^{20}$

En 1914, estaba a las órdenes del general Amaro, a quien consideraba su "maestro espiritual", y fundó con él y con el general Amado Aguirre la Confederación Nacional de Librepensadores. ${ }^{21}$ Diputado constituyente por Querétaro, protestó contra el concepto de laicismo y rechazó la neutralidad: en su opinión, el maestro debía destruir la religión. ${ }^{22}$ Fue uno de los inspiradores del artículo 130. El general Álvarez consideraba la Iglesia católica "una organización político-comercial destinada en realidad a explotar la credulidad de quienes dicen profesar los dogmas. El 90\% de los mexicanos son católicos y no saben siquiera lo que creen". Después de haber estudiado el tema e interrogado a la gente, el general se convenció de su ignorancia crasa. Además, el catolicismo es aberrante:

Cómo creer que el dogma constituya la salvación de la humanidad, que según un cuento chino la humanidad ha nacido de una pareja que cometió el delito de comer una manzana, lo que originó un disgusto tan grande del Creador que siendo Dios sabía que la dicha pareja [...] y permitió al legendario ser llamado

18 Original fijado en las calles de Valparaíso (Zacatecas). Un ejemplar en poder del autor.

19 Álvarez y Álvarez, José, El problema religioso de México, conferencia en la Escuela Superior de Guerra, 10 de noviembre de 1934, pp. 6 y 7 sJ, legado Amaro.

20 Ibidem, pp. 11-14.

21 Ibidem, p. 17.

22 Diario de los Debates..., op. cit., t. I, pp. 525-7, 744, t. II y pp. 720 y 826. 
demonio inducirlos a faltar a su deber. Aquella falta es un asunto de muy poca importancia y sin embargo el disgusto del Creador fue tan grande que nos arrojó del paraíso y maldijo a la humanidad y pasaron los siglos y quiso redimir a la humanidad y para lograrlo se convirtió en hombre y vino a este pedacito de tierra. La humanidad actual está de hecho cometiendo crímenes inauditos que jamás pudieron pasar por la imaginación de los pobres que comieron la manzana. ¡Fracaso de la redención! ¡Y todo es abracadabrante! ¿Quién creerá en la presencia de Cristo en todas las hostias consagradas al mismo tiempo? El que quiera utilizar su razón no puede creer en eso. Yo soy católico porque mis padres me bautizaron y porque creo en Dios, y eso es todo. ${ }^{23}$

El general nos habló largamente del paganismo idolátrico de los católicos mexicanos, escándalo para la razón, término lógico de la monstruosidad de una conquista hecha por la espada y por la cruz. Una evangelización superficial que bautizaba 5000 hombres de un golpe ha mantenido hasta nuestros tiempos la idolatría y el paganismo que se manifiesta a diario en la basílica de Guadalupe. La conjunción entre los dogmas irracionales de Roma y la idolatría inveterada de los indígenas ha sido fatal para México. El culto al Sol de los indios vuelve a encontrarse en las custodias en forma de sol. La razón tardará siglos en disipar estas tinieblas.

La literatura anticlerical y antirreligiosa publicada entre 1914 y 1940 repite sin cesar estos temas; el ejército, la CROM y la Educación Nacional eran los grupos de presión más activos, que aseguraban lo esencial de la propaganda y de la empresa editorial, con el leitmotiv:

El buey es el indio - el yugo la cruz, y detrás va el cura - pinchándole el lomo, en nombre de Dios - y de su hïo Jesús ${ }^{24}$

Las minas han sido proclamadas territorio yanqui

$y$ las iglesias territorio romano.

Bandera norteamericana sobre las unas, bandera del Vaticano sobra las otras.

La primera izada por los ingenieros yanquis, la segunda por los curas españoles.

23 Jean Meyer/general Álvarez, Cuernavaca, 7 de agosto de 1968.

24 Véase además la serie de los "folletos antirreligiosos", publicada por la CROM a partir de 1926; la publicada en los estados de Veracruz y Tabasco, con el mismo título; las reediciones de folletos del siglo XIX y del XVIII, Mirabeau, Biblioteca erótica; Gicca, Francisco, Las víctimas del confesionario y El catolicismo romano; Vargas Vila, J. M., A los católicos de México; Tovar, Mariano, La revolución y Dios, México, Secretaría de Educación Pública, 1934, p. 32, y Catecismo de la revolución; teniente coronel Calvo Ramírez, Roberto, La revolución ante el conflicto religioso, folleto manuscrito, sJ, legado Amaro. 
A continuación, dos documentos masónicos inéditos, de la época del Conflicto Religioso. Se encuentran en el Archivo General de la Nación, en el Ramo de Presidentes Obregón-Calles. ${ }^{25}$

Asunto:

Poniendo en su superior conocimiento del sentir de esta $\mathrm{R}$.

Logia, por la invasión que han hecho los Caballeros de Colón en los puestos públicos del Gobierno del Estado.

Or. Aguascalientes, Ags. (México)

Número 1000-Kn. Diciembre 20 de 1925

Al C. General de Divn. Don Plutarco Elías Calles, Presidente de la República. Palacio Nacional.----MÉXICO. D. F. Venerable y Querido Hermano:

Esta Respetable Logia que siempre ha estado alejada de toda clase de política profana, de acuerdo con las bases fundamentales de la Institución, por primera vez ante Ud. Respetuosamente expone, no con carácter político, sino como un beneficio a la población y buen nombre del Estado de Aguascalientes, y en general de nuestra querida Patria, que ha llegado a su conocimiento que elementos netamente reaccionarios como son los llamados Caballeros de Colón, (que en nada honran al País) han venido introduciéndose en distintos puestos públicos del Gobierno actual del Estado, cosa que nos hace presumir no sea con muy sanas intenciones, ya que son conocidos sus antecedentes, pues siempre han sido enemigos del progreso de las masas y acérrimos contrarios de los Gobiernos liberales, pues no hay que desconocer que dichos individuos son los genuinos representantes del enemigo común que en distintas épocas han puesto de luto al País. (El fatídico Clero)

$\mathrm{Al}$ efecto citamos algunos nombres de quienes sabemos son caballeros de Colón y que desempeñan los siguientes puestos:

Agente del Ministerio Público---Lic. A. Cabeza de Vaca, Juez $1^{\circ}$ de lo Civil y Hda.--------Lic. José G. Avila, Juez 2 o “ " " " " Lic. Manuél M. Casillas,

25 Masónica Universal A.G.G.: D:. G:. A:. D:. U:. Jurisdiccionada a la muy Resp.: GR.: LOG: de AA:. LL: y AA:. Mm:. "VALLE DE MÉXICO" Aguascalientes, Ags. (México) Diciembre 20 de 1925. 
Srio. del Juzgado $1^{\circ}$ civil y Hda. Gonzalo Méndez Acuña, “ " " $2^{\circ}$ “ " "Juan Martín del Campo,

Primer Magistrado del Supremo Tribunal de Justicia---Lic. Florencio Padilla, Segundo Magistrado del Supremo Tribunal de Justicia: Eduardo Rodriguez Lariz,

Oficial Mayor del Supremo tribunal de Justicia: Francisco Ruiz, Oficial primero de Gobierno---José Medina, Secretario de la Presidencia Municipal-Francisco Zamarripa, Oficial Mayor del Consejo superior de salubridad-Florentino Villalobos (Ex fraile)

Encargado del Registro Público de la propiedad-J. Refugio Zúñiga, Oficial primero de la Presidencia Municipal-Victorio A. Medina, Secretario de la Dirección de Instrucción- Faustino Villalobos, Delegado de Instrucción-Ing. Miguel N. Rodriguez.

Además tenemos conocimiento que tanto la Cámara Local como el Ejecutivo del Estado hacen que reine una completa anarquía que no les permite ponerse de acuerdo, pues la primera se encuentra con sus componentes divididos y alternativamente cambiándose de filiación lo que ha originado que ni siquiera hayan logrado constituir la Comisión permanente, y en cuanto al segundo, son notorias sus tendencias imposicionistas y arbitrarias, consistentes en sostener en las elecciones Municipales a elementos incondicionales, debiéndose esto probablemente a la influencia que ejercen sobre él elementos netamente clericales, pues tenemos conocimiento que frecuentemente en su domicilio particular sostiene entrevistas con distintos frailes.

Para mayor acopio de datos, agradeceríamos a Ud. Señor Presidente y digno Hermano, los obtuviera mas precisos y detallados del Señor Gral. Jefe de las Operaciones Militares en el Estado, quien creemos podrá rendirlos por estar mas al corriente de las dificultades que reinan en las diversas actividades sociales, y en las cuales hemos notado que dicho Jefe Militar, cuenta con grandes simpatías, cosa que se puede corroborar con el entusiasmo que se ha notado en algunas partes del Estado como podrá Ud. verlo por el adjunto periódico.

Esperamos muy Venerable Hermano, que ya que está en sus manos volver a la calma este desdichado Estado, así como retirar esos elementos retrógradas que chupan las arcas del Estado, lo que haga por bien a la humanidad, teniendo la seguridad de que le agradeceremos mucho lo que haga a favor de nuestra petición, y nos sentiremos satisfechos de haber contribuido en alguna forma al bienestar del Estado.

Protestamos a Ud. nuestro mayor respeto y adhesión, saludándolo muy fraternalmente. 
Esta obra forma parte del acervo de la Biblioteca Jurídica Virtual del Instituto de Investigaciones Jurídicas de la UNAM www.juridicas.unam.mx

El Venerable Maestro. El Secretario

Ricardo T. Villalpando. Antonio Calva.

Correspondencia del sob:. gran comendador

Jurisdicción mexicana del Rito E:. A:. y A:

México, D.F., a 9 de enero de 1926.

Sr. Gral. Dn. Plutarco Elías Calles.

Jefe del Poder Ejecutivo de los Estados Unidos Mexicanos, Palacio Nacional.

Respetable Señor Presidente:

Los brotes de una nueva rebelión que ha logrado sofocar en estos días el Gobierno, castigando severamente a los que han aparecido complicados en tal aventura, a la vez que las discusiones de la Prensa norte americana sobre las recientes leyes de extranjería, del trabajo y del petróleo que fueron aprobadas a últimas fechas por nuestras Cámaras de la Unión, me han hecho pensar en que debe haber alguna conivencia entre ambas órdenes de actividad. En otras palabras, supongo que la mala inteligencia o prevención que se deja sentir en los Estados Unidos con respecto a las leyes antes mencionadas, ha servido para renovar las esperanzas y poner en movimiento a los antiguos partidarios del señor de la Huerta, cuyos principales líderes residen precisamente desde hace dos años en aquel país.

Un rumor público venía insistiendo desde hace algunas semanas sobre que los representantes de ciertos intereses que tienen su asiento al otro lado del Bravo y se suponen más o menos afectados por la reciente legislación mexicana, había ofrecido ayudar con muchos millones de Dólares para otra revuelta entre nosotros, y para cumplir lo cual solo se ponía por condición que de algún modo demostrasen los de la huertistas ser capaces todavía de formalizar el movimiento armado. Los últimos acontecimientos vienen a dar fundamento a aquéllas versiones y, por lo menos, es de suponerse que sin estas emergencias que ha provocado un cierto estado de la opinión del pueblo americano, los de la huertistas no hubieran pensado ya en renovar su desdichada intentona de trastornar el orden legal en nuestro país.

Con estos antecedentes, al Supremo Consejo del Rito Escocés Antiguo y Aceptado para la Jurisdicción Mexicana, que tengo el honor de presidir (y el cual ha mantenido siempre en los últimos años de conmociones políticas su compromiso solemne de ser leal al Gobierno en cuya jurisdicción trabaja), tuvo la idea de que puede ayudar de algún modo a la actual Administración Pública mexicana, así como lo ha hecho con toda voluntad y bastante éxito en las dos ocasiones que en seguida se mencionan:- 
Esta obra forma parte del acervo de la Biblioteca Jurídica Virtual del Instituto de Investigaciones Jurídicas de la UNAM

El año de 1912 figuraba el señor Dn. Francisco I. Madero, Presidente de la República, entre los miembros del Supremo Consejo, a cuyas reuniones asistía de vez en cuando, y en una de ellas nos informó de que iba a estallar o había estallado ya la rebelión de Pascual Orozco en Chihuahua, indicándonos su deseo de que aprovechase el Supremo Consejo de México su buena amistad con el Supremo Consejo de Washington para preparar la opinión en las esferas oficiales de la vecina República a favor del régimen maderista y a fin de que se impidiera el contrabando de armas y se apoyara en todo a Madero. Aceptada la sugestión, enviamos desde luego un miembro con las explicaciones, datos y referencias que se nos ministraron por la Secretaría Particular de la Presidencia.

Ahora bien como sucede que la mayor parte de los miembros que forman ordinariamente las Cámaras de Diputados y Senadores en la Republica Norte Americana pertenecen a la Masonería del Rito Escocés, y también gran número de funcionarios públicos prominentes, periodistas u hombres de negocios, recordando entre otros nombres los del Presidente Tat, el Presidente Harding y el actual Secretario de Estado Mr. Kellog, se comprende la razón de por qué las insinuaciones o recomendaciones que extra-cátedra quiere hacer el Supremo Consejo de Washington directamente o por los diferentes Cuerpos de su Jurisdicción, producen un efecto sensible y valioso. Así fue como en el caso del señor Madero preparó el ánimo de los funcionarios norte americanos para ayudar eficazmente a la Administración mexicana de entonces, o cuando menos así lo creíamos el señor Madero y nosotros.

El Supremo Consejo de México ayudó así mismo con ocasión del asunto del Cubilete, que también produjo grande exitación en el pueblo americano, por su sincera inclinación religiosa y por el influjo que positivamente ejercen sobre el sentimiento público las organizaciones protestantes y aun la católica, maxime cuando unas y otras están de acuerdo, como ocurría en el asunto del Cubilete y la expulsión del país decretada por el Presidente Obregón, contra Monseñor Filippi, Delegado Apostólico en la República Mexicana.

Esta vez se calmó la exitación pública por obra de las declaraciones escritas expresamente para el caso por el señor William L. Vail, Ciudadano norte americano y uno de los miembros más antiguos del Supremo Consejo de México (donde ha residido hace más de cuarenta años). El señor Vail estuvo en contacto directo para ilustrarse en la cuestión con la Secretaría de Hacienda, a cargo entonces del Sr. Dn. Adolfo de la Huerta, y sus declaraciones fueron publicadas en "Los Angeles Times" y en los otros sesenta y ocho periódicos que edita en diferentes poblaciones Mr. Harry Chandler, viejo amigo personal del señor Vail y un buen amigo de México, como lo ha demostrado muchas veces con ocasión de las dificultades internacionales 
Esta obra forma parte del acervo de la Biblioteca Jurídica Virtual del Instituto de Investigaciones Jurídicas de la UNAM www.juridicas.unam.mx

que se han venido sucediendo desde hace más de quince años entre México y los Estados Unidos del Norte. Además, Mr. Vail envió un mensaje explicativo del caso a todos los templos de "Shriner" y a los Cuerpos pertenecientes al Rito Escocés Antiguo y Aceptado. A poco de esto fue muy notable la reacción que se operó en la opinión pública americana, y creo que de las gestiones de qué hago mérito debe haber algunos antecedentes en la misma Secretaría de Hacienda.

Por lo que toca a la cuestión del momento, estoy convencido de que asiste a México Justicia en el fondo de todas las nuevas leyes que trata de implantar, fijando para el porvenir principios fundamentales que sirvan de salvaguardia a su soberanía y protejan los intereses de nuestra raza contra influencias excesivas del capital extranjero. Pero a pesar de esta circunstancia, también creo sinceramente que el Gobierno de México no tiene absolutamente la intención de hacer un uso agresivo de dichas leyes, y que, por el contrario, se halla dispuesto a solucionar equitativamente y en buena forma las dificultades concretas que naturalmente deben surgir con los particulares al aplicarse las leyes. Todo tiene posible arreglo cuando hay buena voluntad de ambas partes, y esto es lo que creo que de ponerse en evidencia para ayudar a que cese la inquietud internacional.

Mr. Vail está actualmente bien enterado de los puntos de vista de la Embajada de los Estados Unidos con respecto a las observaciones o protestas que allí se hacen por ciertos puntos de vista que se establecen en la reciente legislación, así como de las dificultades anteriores por la aplicación de las leyes Agrarias y Obreras. Sin embargo de esta circunstancia, él me ha manifestado que se halla enteramente dispuesto a desempeñar una comisión semejante a la que hizo con ocasión del Cubilete a favor del Gobierno mexicano, y para lo cual solo necesitaría cerciorarse personalmente de los verdaderos propósitos que aquí se abrigan con alguno de los altos funcionarios del Gobierno mexicano, y poder formar así su convicción en el sentido que se desea, creyendo también él que es posible y oportuna la gestión que he proyectado.

En el Supremo Consejo del Rito Escocés Antiguo y Aceptado para la Jurisdicción de los Estados Unidos Mexicanos hay algunos miembros del Gobierno y personas bien conocidas que pueden informar directamente a Ud., Señor Presidente, del sincero mexicanismo del Sr. Vail y de su idoneidad para la comisión en proyecto. Entre esas personas está el señor Senador Dn. Abel S. Rodríguez, el señor Senador Dn. José J. Reynoso, el Sr. Lic. Dn. Enrique V. Anaya, el señor Dn. Camilo E. Pani (hermano del señor Secretario de Hacienda y empleado prominente de los ferrocarriles) y el señor Elías A. de Lima, Consejero de Hacienda, del Banco de México y de los Ferrocarriles, y amigo personal de Ud., según entiendo. También figura como 
miembro del Supremo Consejo, el señor Dn. Manuel Mascareñas padre del Sr. Dn. Alberto, Director del Banco de México (grado 32 del Consistorio de Arizona); pero actualmente se halla ausente de esta Ciudad.

Es notoria la firmeza y habilidad con que el señor Licenciado Dn. Araon Sánez Secretario de Relaciones Exteriores va afrontando la situación, y estoy seguro que a la postre alcanzará un completo triunfo para nuestro país por lo que respecta a las dificultades referidas pero no se me oculta que el camino y el conducto oficial o directo es laborioso y dilatado, mientras que la vía privada puede dejarse sentir mucho más pronto y coadyuvar a la feliz solución de las negociaciones oficiales. A mayor abundamiento no es precisamente el Gobierno americano sino Empresas americanas las que pueden estar favoreciendo o haciendo promesas para fomentar otra rebelión en México.

Por lo demás el señor Vail puede enviar sus declaraciones y mensajes confidenciales, como lo hizo antes o bien ir personalmente a hacer las gestiones en el seno del Supremo Consejo de Washington.

Con el deseo de que este memorial merezca la atención de Ud. y pueda ser útil, tengo el honor de repetirme de Ud. como atento y seguro servidor.

(firma) Luis Manuel Rojas 


\title{
JURISTAS MASONES DEL EXILIO REPUBLICANO ESPAÑOL EN MÉXICO
}

\author{
Eva Elizabeth MARTínez CHÁvez*
}

\begin{abstract}
SUMARIO: I. Introducción. II. Las leyes y las instituciones. III. Los procesos del Tribunal Especial para la Represión de la Masonería y el Comunismo. IV. La masonería mexicana y su apoyo a los hermanos en peligro. V. El mundo laboral mexicano. VI. Archivos históricos. VII. Bibliografia.
\end{abstract}

\section{INTRODUCGIÓN}

La Guerra Civil (1936-1939) es sin duda uno de los acontecimientos más terribles que ha vivido el pueblo español: fue la causa de incontables muertes durante los años de enfrentamientos armados y sus secuelas continuaron por décadas. Es bien sabido que el Generalísimo y sus seguidores señalaron a aquellas personas y grupos a los que consideraron contrarios a su movimiento con el fin de reprimirlos. Dentro de esta represión, dos de los grupos más afectados fueron los masones y los comunistas. Las siguientes páginas están dedicadas al primero de estos colectivos, los masones, en concreto a los juristas señalados como masones, quienes, escapando de la represión, dejaron su patria para residir en México. En este texto, me centro en el análisis de estudiosos del derecho que se desempeñaron como profesores de universidad -ya fuera en España o en México-y dejé de lado a aquellos que se dedicaron a otras actividades, como es el caso de Álvaro Pascual-Leone Forner ${ }^{1} \mathrm{o}$ Ángel Galarza Gago, ${ }^{2}$ a cuyo estudio me enfoco en otras investigaciones.

* Centro de Estudios Históricos de El Colegio de Michoacán. Correo: elizabeth.martinez. chavez@gmail.com. La presente investigación se hizo gracias a una beca posdoctoral otorgada por el CONACYT. Miembro del Sistema Nacional de Investigadores (SNI).

1 Centro Documental de la Memoria Histórica (CDMH), legajo 117-B, exp. 16. Expediente personal de Álvaro Pascual-Leone Forner. Nombre simbólico "Vicente Peris", Logia Germanies de Valencia. También se le formó proceso por el Tribunal Especial para la Represión de la Masonería y el Comunismo (TERMC), legajo 148, exp. 7365 y TERMC, exp. 14521.

2 En CDMH, TERMC, exp. 213. 
El recorrido inicia en España, ofreciendo un panorama general sobre la reglamentación y las instituciones que se crearon para la represión de los masones; posteriormente, se tratan los procesos formados por el Tribunal Especial para la Represión de la Masonería y el Comunismo (TERMG) a juristas que radicaron en tierras mexicanas. Una cuestión más que se toca es el apoyo que prestó la masonería mexicana a los hermanos masones y, finalmente, se tratan las actividades que desarrollaron en el país de asilo.

\section{LAS LEYES Y LAS INSTITUCIONES}

La copiosa legislación que siguió al levantamiento armado proporcionó el marco jurídico que reguló la persecución y el castigo de aquellos a quienes se consideró enemigos del bando nacional. Dos de las leyes más representativas del arsenal legislativo franquista fueron la Ley de Responsabilidades Políticas (LRP) ${ }^{3}$ y la Ley para la Represión de la Masonería y el Comunismo (LRMC). ${ }^{4}$ Estas leyes se complementaban, ya que los procesados por el TERMC "se veían sometidos, además, a expediente de responsabilidades políticas, correspondiendo a los Tribunales de esta jurisdicción imponer la sanción económica" ${ }^{5}$ Esta complementación en las tareas represivas de las dos jurisdicciones especiales se confirmó políticamente al ser nombrado Wenceslao González Oliveros ${ }^{6}$ - presidente del

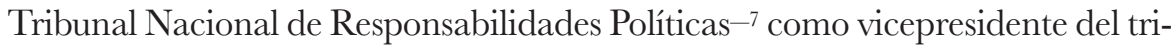
bunal de masonería y comunismo. ${ }^{8}$

Por ser la primera en tiempo, voy a iniciar este breve análisis con la Ley de Responsabilidades Políticas, en cuyas normas se incluyó a los masones. En su preámbulo se menciona que esta ley debía servir para liquidar culpas "contraídas por quienes contribuyeron con actos u omisiones graves a forjar la subversión roja, a mantenerla viva durante más de dos años y a entorpecer el

3 Ley de Responsabilidades Políticas, de 9 de febrero de 1939. En Boletín Oficial del Estado (BOE), núm. 44, 13 de febrero de 1939, pp. 824-847.

4 Ley Sobre Represión de la Masonería y del Comunismo, de primero de marzo de 1940. En BOE, núm. 62, 2 de marzo de 1940, pp. 1537-1539.

5 Álvaro Dueñas, Manuel, "Por ministerio de ley y voluntad del caudillo". La jurisdicción especial de responsabilidades politicas (1939-1945), tesis doctoral, Departamento de Historia Contemporánea, Madrid, Universidad Autónoma de Madrid, 1997, p. 168.

6 De 1940 a noviembre de 1944 se desempeñó como vicepresidente del TERMC. Véase en Coma Fort, José María, "González Oliveros, Wenceslao (1890-1965)”, Diccionario de catedráticos españoles de derecho (1847-1943), Universidad Carlos III de Madrid, Instituto Figuerola de Historia y Ciencias Sociales, 2011, http://wrere.uc3m.es/diccionariodecatedraticos.

7 Véase el decreto del nombramiento en BOE, núm. 360, 25 de diciembre de 1940, p. 8851.

8 Álvaro Dueñas, Manuel, op. cit., nota 6, p. 168. 
triunfo providencial e históricamente ineludible, del Movimiento Nacional". ${ }^{9}$ En su primer artículo se declara la responsabilidad política, tanto de personas jurídicas como físicas, que, desde el lo de octubre de 1934 y antes de 18 de julio de 1936, "contribuyeron a crear o a agravar la subversión de todo orden de que se hizo víctima a España y de aquellas otras que, a partir de la segunda de dichas fechas, se hayan opuesto o se opongan al Movimiento Nacional con actos concretos o con pasividad grave". En el artículo segundo se declaran fuera de la ley a partidos y agrupaciones políticas y sociales que se hubieran opuesto al Movimiento Nacional, entre ellas "las Logias masónicas y cualesquiera otras entidades, agrupaciones o partidos filiales o de análoga significación a los expresados, previa declaración oficial de hallarse, como los anteriormente relacionados, fuera de ley".

$\mathrm{El}$ artículo tercero estableció las sanciones a las que se enfrentarían aquellos declarados fuera de la ley, los que sufrirían la pérdida absoluta de sus derechos de toda clase y de sus bienes. Estos bienes pasarían íntegramente a ser propiedad del Estado español. El artículo cuarto complementaba lo antes establecido, pues mencionaba que, en virtud de lo dispuesto en el artículo primero, quedaban incursos en responsabilidad política y sujetos a las sanciones que se les impusieran en los procedimientos que contra ellos se siguieran a quienes pertenecieran o hubieran pertenecido a la masonería; aunque se consideraban exceptuados aquellos que hubieran salido de ella antes del 18 de julio de 1936, por baja voluntaria, por haber roto explícitamente con ella o por expulsión fundada en actuaciones contrarias a los principios en los que se inspira o de los fines que persigue.

También consideraba como circunstancia agravante para los integrantes de la masonería el haber obtenido alguno de los grados "dieciocho al treinta $\mathrm{y}$ tres, ambos inclusive, y el haber tomado parte en las Asambleas de la Asociación Masónica Internacional y similares o en las Asambleas Nacionales del Gran Oriente Español, de la Gran Logia Española o de otras cualesquiera organizaciones masónicas residentes en España" (artículo 7o.).

Las sanciones establecidas para castigar a los responsables políticos se establecieron en el artículo octavo y quedaron comprendidas en tres grupos: en el grupo I, se ubicaron las penas por medio de las cuales se restringía la actividad del individuo con, por ejemplo, la inhabilitación absoluta o la inhabilitación especial. El grupo II limitaba la libertad de residencia y suponía la posibilidad de relegar al sancionado a las posesiones africanas, el confinamiento o el destierro. El grupo III regulaba las sanciones de tipo económico,

9 Ley de Responsabilidades Políticas, ibidem, nota 4, p. 1. Las posteriores menciones a esta ley se tomaron de esta misma referencia. 
que incluían la pérdida total de bienes, el pago de una cantidad fija o la pérdida de bienes determinados.

En cuanto a los órganos encargados de aplicar este ordenamiento, en el cuerpo de la misma ley se estableció que conocerían en materia de responsabilidades políticas - con exclusión de cualquier otra jurisdicción- los siguientes: el Tribunal Nacional de Responsabilidades Políticas, la Jefatura Superior Administrativa, los Tribunales Regionales, los Juzgados Instructores Provinciales, las Audiencias y los Juzgados Civiles Especiales (artículo 18). ${ }^{10}$

$\mathrm{Al}$ año siguiente se emitió la Ley para la Represión de la Masonería y el Comunismo. En el preámbulo de este ordenamiento se acusaba a masones y comunistas de ser algunas de las causas de la decadencia de España. En ella se argumentó que era necesario determinar la calificación jurídica y las sanciones que merecían quienes secundaban a la masonería y al comunismo "y demás sociedades secretas y organizaciones contrarias al orden social". ${ }^{11}$ Estipulaba que, con esta ley y sus consecuencias jurídicas, se buscaba frenar los "últimos estertores de las fuerzas secretas extranjeras en nuestra Patria y se inicia la condenación social de las organizaciones más perniciosas para la unidad, grandeza y libertad de España".

En el primer artículo de este cuerpo legal se especificó que pertenecer a la masonería constituía un delito y la declaró prohibida y fuera de la ley, así como confiscados sus bienes, que serían puestos a disposición de la jurisdicción de responsabilidades políticas (artículo 2o.). En el artículo cuarto se definió a masones y comunistas; dentro de los primeros se consideraría "a todos los que han ingresado en la masonería y no han sido expulsados o no se han dado de baja de la misma o no han roto explícitamente toda relación con ella, y no dejan de serlo aquéllos a quienes la secta ha concedido su autorización, anuencia o conformidad, bajo cualquier forma o expediente, para aparentar alejamiento de la misma".

Los castigos para masones y comunistas incluían reclusión menor y mayor, esta última asignada en los casos en que concurriera alguna circunstancia agravante (artículo 5o.). ${ }^{12}$ También se contemplaba la separación definitiva de cualquier cargo del Estado, corporaciones públicas u oficiales, entidades

10 En los artículos 19 al 34 se detalla la actuación de cada uno de estos órganos judiciales.

11 Ley Sobre Represión de la Masonería y del Comunismo, op. cit., nota 5. Las menciones siguientes a esta ley corresponden a esta referencia.

12 El artículo sexto estableció las circunstancias agravantes. Se consideraron circunstancias agravantes dentro de la calificación masónica, el haber obtenido alguno de los grados del 18 al 33, ambos Inclusive, "o el haber tomado parte en las asambleas de la asociación masónica internacional y similares, o en las asambleas nacionales del gran oriente español, de la gran logia española o de otras cualesquiera organizaciones masónicas residentes en 
subvencionadas y empresas concesionarias, gerencias y consejos de administración de empresas privadas, así como cargos de confianza, mando o dirección en las mismas, y se decretaba, además, su inhabilitación perpetua para los referidos empleos y su confinamiento o expulsión. A estas penas se sumaba el procedimiento para imposición de sanción económica, conforme a la LRP (artículo 8o.). Después de la promulgación de esta ley, se estableció el Tribunal Especial para la Represión de la Masonería y el Comunismo, organismo encargado de ejecutarla. ${ }^{13}$

Así, en un corto periodo se logró incorporar al sistema legal e institucional esta legislación, así como las instituciones, los procesos, las sentencias y todo el aparato represivo estatal encargado de aplicar estas normas. La legitimidad de todo este tipo de normatividad y las instituciones que de ella derivaron queda en entredicho, no sólo por la represión que respaldaron, sino también porque quien las formuló llegó al poder por medio del levantamiento armado en contra de un gobierno legalmente establecido. Al lograr el triunfo en el campo de las armas era menester que el bando ganador contará con los elementos que formalmente dieran legitimidad y legalidad a sus actos, por lo que resultó muy útil el campo del derecho y las instituciones. Podemos hablar de una legislación de los vencedores, cuya finalidad era eliminar a los vencidos, y no me refiero a una eliminación física - por lo menos no sólo a ésta-, pues el ámbito de acción debía ser necesariamente complejo, para abarcar lo social, lo económico, y esparcirse en el espacio laboral, incluso llegar al íntimo refugio de la familia.

No obstante, para que los tribunales especiales funcionaran fue necesario establecer también otro tipo de órganos que les proveyeran de la información necesaria para poder cumplir con su cometido. Así, durante el franquismo se idearon y ejecutaron diversas iniciativas, ${ }^{14}$ con la finalidad de recopilar y ordenar la información existente sobre la masonería y el comunismo. Se puede considerar que el primero de estos organismos que mantuvo cierta unidad de criterios en la selección de documentos fue la Oficina de Investigación y Propaganda Anticomunista (OIPA) ${ }^{15}$ creada en 1937. Su finalidad era recoger, analizar y catalogar documentación, principalmente propaganda del

España o el haber desempeñado otro cargo o comisión que acredite una especial confianza de la secta hacia la persona que la recibió".

13 Sobre este tribunal véase Portilla, Guillermo, La consagración del derecho penal de autor durante el franquismo. El Tribunal Especial para la Represión de la Masonería y el Comunismo, Granada, Comares, 2009.

$14 \mathrm{Al}$ inicio de esta labor no se puede hablar de un solo organismo encargado de esta tarea, pues participaron ejército, Falange y policía. Portilla, Guillermo, ibidem, p. 13.

15 Dependía de la Secretaría General del Jefe de Estado. 
enemigo, para estudiarla y hacer la correspondiente contrapropaganda. ${ }^{16}$ En la orden de creación de la OIPA se hace ya referencia a la masonería entre las organizaciones perseguibles. ${ }^{17}$

Posteriormente, se creó la Delegación de Asuntos Especiales (DAE), ${ }^{18}$ con facultades para "intervenir en todos los asuntos referentes a actividades de las sectas secretas. Su fin era combatir especialmente a la Masonería", a la que encuadraban entre los enemigos más peligrosos de la patria. Con este objetivo la Delegación recogió, analizó y catalogó todo el material de propaganda en las zonas conquistadas y ocupadas por el bando franquista, con la finalidad de identificar y castigar a sus enemigos, con el apoyo de autoridades civiles, militare ${ }^{19} \mathrm{y}$ todas aquellas que llegaron a componer las extensas redes que la maquinaria franquista necesitó para funcionar. ${ }^{20}$

El otro organismo creado ${ }^{21}$ fue la Delegación del Estado para la Recuperación de Documentos ${ }^{22}$ (DERD). ${ }^{23}$ Esta institución "proporcionó a los diferentes Tribunales, Comisiones de Depuración, etcétera, los datos y antecedentes que existían en sus archivos sobre los sujetos y entidades sometidos a procedimiento". ${ }^{24}$

Más tarde, en 1944, Franco unificó la Delegación de Asuntos Especiales y la Delegación del Estado para la Recuperación de Documentos en la Delegación Nacional de Servicios Documentales. ${ }^{25}$ Estos organismos fueron los principales encargados de proveer de información a las diversas autoridades represoras, que en su desempeño cometieron errores graves y trascendentales.

16 Turrión García, María José, "La biblioteca de la Sección Guerra Civil del Archivo Histórico Nacional (Salamanca)", Boletín ANABAD, vol. XLVII, núm. 2, 1997, p. 90.

17 Portilla, Guillermo, op. cit., p. 14.

18 Creada por Orden de mayo de 1937.

19 Portilla, Guillermo, op. cit., pp. 14 y 15.

20 Esta Delegación incautó documentación y objetos relacionados con la masonería, dando lugar a un archivo que por su volumen e importancia es único en el mundo, se trata de la sección de masonería del Centro Documental de la Memoria Histórica. Véase Turrión García, María José, op. cit., p. 90.

21 También por iniciativa del Cuartel del Generalísimo, creada por Decreto en 1938.

22 Con la finalidad de recuperar, clasificar y custodiar todo el material incautado en las zonas ganadas a la República y susceptible de suministrar al Estado información sobre la actuación de sus enemigos. Véase Portilla, Guillermo, op. cit., p. 15.

23 Aunque inició su operación desde junio de 1937 al conquistar Bilbao el bando franquista. Véase Turrión García, María José, op. cit., p. 91.

24 Portilla, Guillermo, op. cit., p. 15.

25 Dependiente de la Presidencia del Gobierno. Véase Turrión García, María José, op. cit., p. 92. 
Por ejemplo, al jurista Felipe Sánchez-Román y Gallifa, ${ }^{26}$ se le acusó de masón y se le formó el sumario número 210/46, el 23 de marzo de 1946, por el juzgado especial número uno del TERMC. ${ }^{27}$ De las averiguaciones efectuadas se supo que había huido al extranjero y que, al parecer, se encontraba en México, como en efecto sucedió. Un oficio fechado el 9 de abril de 1946 menciona: "Diríjase oficio al Ilmo. Sr. Director General de Prisiones para que comunique a este Juzgado si se halla el encartado en alguna de las Prisiones del Estado"; en el mismo documento se ordena se proceda a su busca y captura.

A pesar de las gestiones, no se logró localizar a Sánchez-Román y Gallifa, por lo que el 22 de mayo de 1946 el TERMC decretó el archivo provisional de las actuaciones "en tanto el encartado se presente o sea habido". Todo esto resulta interesante y arroja información acerca del funcionamiento del Tribunal, así como sobre los argumentos para procesar a este jurista, pero, sobre todo, nos deja ver el peligro que suponía para estos encausados un error en la información proporcionada. En los expedientes que se conservan en el CDMH, se confunde y mezcla la información de Felipe Sánchez-Román y Gallifa con la de su padre Felipe Sánchez Román, quien había muerto en 1916. La confusión se debe principalmente al nombre y aumenta con la profesión de jurista. Sin embargo, la documentación que relaciona al jurista exiliado en México con la masonería no corresponde a él, sino a su padre. ${ }^{28}$

En el informe sobre masonería que se le formó a Sánchez-Román se indicó que existía una nota de 1889 que lo mencionaba como deudor de la logia Matritense número uno. En esa fecha, el Felipe Sánchez-Román asilado en México aún no había nacido, pues él vio la luz de este mundo en 1893. Sin duda la información incautada hacía referencia a su padre, don Felipe Sánchez-Román, quien, según el informe consultado, ostentó el nombre simbólico de Paulo, perteneció a la logia Matritense número uno de Madrid y fue grado 33. Así, tenemos a Sánchez-Román y Gallifa procesado por el TERMC, utilizando como base de dicho proceso documentación que no se refería a él. Por otra parte, se

26 Felipe Sánchez Román y Gallifa (1893-1956), fue un abogado, político republicano y catedrático de Derecho Civil en la Facultad de Derecho de la Universidad Central de Madrid. Fue diputado por Madrid a las Cortes Constituyentes de 1931, encabezó el Partido Nacional Republicano y formó parte de la Agrupación al Servicio de la República. Se exilió en México, país en el que se incorporó a la planta de profesores de la Universidad Nacional Autónoma de México, adscrito a la cátedra de Derecho Comparado de la Facultad de Derecho. Murió en el exilio. Su padre fue Felipe Sánchez Román, natural de Valladolid y catedrático de Derecho Civil de la Universidad Central de Madrid.

27 El sumario pasó a la Fiscalía número 1 el día 9 de mayo del mismo año.

28 En el CDMH se encuentran dos expedientes de Felipe Sánchez-Román y Gallifa: CDMH, TERMC, legajo 595-B, exp. 60 y CDMH, TERMC, exp. 17499. 
le procesó por el Juzgado Instructor Provincial de Responsabilidades Políticas de Madrid, con el expediente número 287. En este caso, la información sí hacía referencia a su actuación durante los años de la Segunda República, ya que se le acusó de haber sido Diputado a Cortes por las Constituyentes de 1931 y de formar parte del Socorro Rojo Internacional. ${ }^{29}$

\section{LOS PROGESOS DEL TRIBUNAL ESPEGIAL PARA LA REPRESIÓN DE LA MASONERÍA Y EL COMUNiSMO}

Fueron varios los estudiosos del derecho exiliados en México que siguieron la misma suerte de Sánchez-Román y Gallifa y terminaron procesados por el TERMC. Cabe hacer una observación antes de adentrarnos en los procesos seguidos contra estos juristas. No necesariamente fueron procesados todos los que pertenecieron a la masonería. Se encausó a aquellos sobre los que se logró recabar información documental que los identificó como masones; sin embargo, existe la posibilidad de que las logias lograran resguardar su documentación de la incautación franquista. Con esta salvedad, nos adentraremos a analizar los procesos seguidos contra los profesores universitarios Victoria Kent, Gabriel Bonilla Marín, Demófilo de Buen Lozano, ${ }^{30}$ Julián Calvo Blanco, ${ }^{31}$ Manuel Martínez Pedroso ${ }^{32}$ y Mariano Ruiz-Funes. ${ }^{33}$

Los registros documentales permiten conocer que se archivaron los expedientes en los casos en los que no se detectó una participación decidida y notoria en las filas de la masonería o no se logró obtener documentación que relacionara directamente al procesado con estas actividades; así sucedió en los casos de Manuel Martínez Pedroso, Felipe Sánchez-Román y Gallifa y Mariano Ruiz-Funes; esto no significa necesariamente que no tuvieran una participación importante en la masonería, sino que no se logró incautar la documentación que lo probara.

Por otra parte, sí se sentenció a aquellos estudiosos del derecho de quienes localizó información que los relacionara directamente con la masonería y que alcanzaron un lugar importante dentro de su estructura, como fue el caso de Gabriel Bonilla Marín, a quien se le formó proceso por el TERMC el 23

29 CDMH, TERMC, legajo 595-B, exp. 60.

30 CDMH, legajo 5, exp. 4-A. Expediente personal de Demófilo de Buen Lozano.

31 CDMH, legajo 50-B, exp. 20. Expediente personal de Julián Calvo Blanco.

32 CDMH, legajo 88-A, exp. 2. Expediente personal de Manuel Martínez Pedroso. En el documento se plasmaron sus actividades dentro de la masonería, así como su baja de la misma por falta de asistencia.

33 CDMH, legajo 421-B, exp. 1. Expediente personal de Mariano Ruiz-Funes García. 
de mayo de 1942. La documentación en su proceso indica que perteneció a la masonería, con el nombre simbólico de Iliberi. En cuanto a su trayectoria en esta sociedad, se menciona que fue iniciado en noviembre de 1924, en la Logia Trabajo número 12 de Sevilla. El 13 de junio de 1925, la Logia Alhambra de Granada lo nombró Maestro; en esta misma, en 1927, fue Venerable Maestro. En 1927 recibió una carta de Diego Martínez Barrio, en papel membretado de la Gran Logia Regional del Mediodía de España, en la que se refiere a Bonilla como "querido amigo y h[ermano]" y le informa de un viaje que haría Martínez Barrio a Granada, además de transmitirle "los recuerdos más expresivos para V. de parte de Demófilo [de Buen], queda suyo afmo. Buen amigo y h[ermano]". En la documentación consta un certificado a nombre de Gabriel Bonilla Marín, en el que se expresa que en 1924 era masón regular y está firmado por el Gran Maestre, Diego Martínez Barrio. ${ }^{34}$

Esta documentación respaldó el proceso seguido contra este jurista y el 16 de septiembre de 1942 se fechó el auto de su procesamiento, en rebeldía del inculpado. El TERMC lo sentenció, el 30 de octubre de 1942, como autor de un delito consumado de masonería, sin la concurrencia de circunstancias modificativas de la responsabilidad criminal, a la pena de doce años y un día de reclusión menor "y accesorios legales de inhabilitación absoluta perpetua para el ejercicio de cualquier cargo del Estado, Corporaciones Públicas u Oficiales, Entidades Subvencionadas, Empresas Concesionarias, Gerencias y Consejos de Administración de Empresas Privadas, así como cargos de confianza, mando y dirección en las mismas, separándolo definitivamente de los aludidos cargos". Para la fijación de responsabilidades civiles, se remitió testimonio de la sentencia al presidente del Tribunal Nacional de Responsabilidades Políticas; además, se envió testimonio al Ministro de la Gobernación a efectos de su publicación en el BOE y se comunicó la sentencia al Director General de Seguridad para que procediera a la busca, captura y prisión de Bonilla Marín, ${ }^{35}$ lo que no sucedió porque para ese tiempo ya se encontraba en México. ${ }^{36}$

La pena más severa de las que impuso el TERMC a los profesores de universidad exiliados en México se reservó para Victoria Kent y Demófilo

34 CDMH, caja 75/1190; legajo 201-A, expediente personal número 3; TERMC, legajo 184, expedientes 9194 y 2897.

35 Idem.

36 El 13 de junio de 1939 arribó al mexicano puerto de Veracruz en el vapor Sinaia. Asentó su residencia en la ciudad de México, D. F. Viajó con su esposa Gertrudis Cañadas y sus hijos Gabriel y Margarita Bonilla Cañadas. Véase en Martínez Chávez, Eva Elizabeth y Conde Naranjo, Esteban, "Bonilla Marín, Gabriel (1888-1965)", Diccionario de catedráticos..., cit. 
de Buen Lozano; ${ }^{37}$ a este último lo sentenciaron a treinta años de reclusión mayor, al considerar que su participación en la masonería fue decidida y destacada. La Dirección General de Seguridad lo catalogó como "integrante de Unión Republicana, masón y muy peligroso". 38

Fue denunciado como masón por un nutrido grupo de personas, lo que lo colocó en la mira de los perseguidores de la masonería. Así, no es extraño encontrar que el juzgado especial número uno del TERMC le formara expediente el 3 de noviembre de 1941. Al mes siguiente, el 11 de diciembre de 1941, fue declarado procesado y en rebeldía se decretó su prisión preventiva, se mandó testimonio del auto al ministerio fiscal y se dio cuenta al Tribunal de Responsabilidades Políticas. Ese mismo día, el juez declaró terminado el sumario con la propuesta de pena de reclusión mayor y accesorias correspondientes.

El 18 de diciembre de 1941, el TERMC, después de valorar la documentación que integraba su expediente, consideró que Demófilo de Buen había ingresado a la masonería en la Logia Condorcet número 343 de Madrid, con el nombre simbólico de Kant. Perteneció a las logias Ibérica número 7 de Madrid y a la Isis y Osiris 377, y a Trabajo, ambas de Sevilla; alcanzó el grado 33, Sublime Gran Inspector General; desempeñó los cargos de Venerable Maestro de la logia Trabajo de Sevilla. Fue Juez Instructor nombrado por la logia Resurrección número 3, para depurar los hechos cometidos por un hermano de La Línea; fue presidente del Gran Consejo Federal Simbólico del Gran Oriente Español, Gran Maestre de la Gran logia del Mediodía y Gran Maestre del Consejo Federal Simbólico.

Estos hechos se declararon probados y constituyentes de un delito de masonería definido en los artículos primero y cuarto de la Ley para la Represión de la Masonería y el Comunismo, debido a que el procesado ingresó en la masonería, alcanzó el supremo grado 33, desempeñó numerosos y elevados cargos sin que constara su baja o hubiera presentado declaración de retractación

37 Su relación con Diego Martínez Barrios quedó plasmada en un documento que se conserva en su expediente y en el que se menciona que en 1929 una enfermedad le impidió desempeñar sus actividades dentro de la masonería. Así, el 4 de mayo de 1929, Demófilo de Buen, Gran Maestre del Grande Oriente Español, Soberano Gran Inspector de la Orden, Grado 33, informó a todas las grandes logias, talleres y masones de la Federación que encontrándose enfermo e imposibilitado para desempeñar con la habitualidad debida las funciones de su cargo, resignó "el Gran Mallete, durante el tiempo que mi enfermedad persista, en el Primer Gran Vicepresidente del Gran Consejo Federal Simbólico... Diego Martínez Barrio, grado 33, a quien desde esta fecha se tendrá y obedecerá como Gran Maestre interino del Grande Oriente Español”. Véase en Martínez Chávez, Eva Elizabeth y Conde Naranjo, Esteban, "Buen Y Lozano, Demófilo de (1890-1946)", Diccionario de catedráticos..., cit.

38 CDMH, TERMC, exp. 478. Proceso por masonería seguido contra Demófilo de Buen Lozano. 
ordenada por la LRMC. Del delito de masonería lo consideraron responsable en concepto de autor y grado de consumación, además de darse como concurrentes en dicho delito las circunstancias agravantes que definía el artículo sexto de la citada ley, puesto que el procesado alcanzó el más elevado grado en la masonería, lo que lo hacía merecedor de la máxima confianza en la logia.

Por todo lo anterior, el TERMC lo condenó a la pena de treinta años de reclusión mayor, además de las contempladas en el artículo octavo de la LRMC. Para la fijación de sus responsabilidades civiles se remitió testimonio de la sentencia al presidente del Tribunal Nacional de Responsabilidades Políticas. Se notificó también "esta sentencia en la forma que la Ley previene para los rebeldes" al ministro de la Gobernación, a efectos de su publicación en el $B O E$, y se informó al Director General de Seguridad, para la busca, captura y prisión del condenado. Esta sentencia se declaró firme el 16 de febrero de 1942. Para ese tiempo ya estaba lejos del alcance de las fuerzas franquistas, pues desde 1940 se había instalado en México. ${ }^{39}$

A Victoria Kent se le inició el proceso por el TERMC en 1941. Fue acusada de estar afiliada a la Liga de los Derechos del Hombre y pertenecer al "Claustro de Profesores de una Institución tan acusadamente influenciada por la masonería como el Instituto Escuela, filial de la Institución Libre de Enseñanza, perteneció a la masonería y llevó, a su conocida historia política, los postulados de la Secta a la que sirvió con fidelidad". Además, menciona el expediente, que al iniciarse el movimiento "alentó con sus propagandas el demagógico desenfreno que se implantó y posteriormente, desde su puesto de Secretaria de la Embajada Roja en París, cooperó eficientemente a la tendencia comunista que el Gobierno, al que representaba, adoptó en su política interior y exterior". La culparon también de ser vocal del Socorro Rojo Internacional. Estos hechos se declararon probados, por lo que la condenaron como autora de un delito consumado de masonería, con la concurrencia de circunstancias agravantes, a la pena de treinta años de reclusión mayor, así como a las demás penas establecidas en el artículo octavo de la LRMC. ${ }^{40}$

\section{LA MASONERÍA MEXICANA Y SU APOYO A LOS HERMANOS EN PELIGRO}

El grueso del exilio español llegó a México principalmente durante los años en los que Lázaro Cárdenas era presidente de la República. Para que esta

39 El 26 de julio de 1940 arribó a territorio mexicano por Coatzacoalcos, Veracruz, a bordo del vapor francés Santo Domingo.

40 CDMH, legajo 664, exp. 10. Expediente personal de Victoria Kent. 
recepción se concretara fue necesario que confluyeran diversas circunstancias, personas e intereses. En esta extensa red se puede ubicar a la masonería mexicana.

$\mathrm{Al}$ término de la Guerra Civil española, miles buscaron la seguridad que se les negaba en su país y las opciones para ser aceptados en otra nación eran reducidas. El gobierno francés ofreció su apoyo, pero pronto vio rebasadas sus expectativas con la avalancha de exiliados que se amontonaban en sus fronteras y la más conocida respuesta gubernamental francesa fue la creación de campos de concentración y la inserción en ellos de estos visitantes.

La Segunda Guerra Mundial y la ocupación francesa complicaron aún más la vida a estos inmigrantes en Francia. Era necesario buscar un nuevo destino. En este escenario se empezó a manejar la posibilidad de viajar a México. La noticia de que el presidente mexicano abría las puertas de su país a todo aquel republicano que deseara trasladarse a él, sin distinciones de sexo, edad, filiación política o religiosa, "con la simple formalidad de que expresen libremente su solicitud de acogerse al beneficio que les ofrece un país amigo en nombre de la más alta comprensión humana", ${ }^{41}$ resultó una luz de esperanza y las solicitudes a las representaciones mexicanas no se hicieron esperar.

En México no todos estuvieron de acuerdo con la oferta del Presidente, la oposición de la derecha se basaba en que consideraban un error político la llegada de estos exiliados. Argumentaron que podría alterarse la paz social, por el fortalecimiento que su presencia significaría para la izquierda del país, y que se inmiscuirían en la política mexicana, pretendiendo llevar a cabo una revolución similar a la que habían desarrollado en España. También consideraron la posibilidad de que los republicanos continuaran con su Guerra Civil en suelo mexicano, lo que colocaría a México ante una embarazosa situación internacional. Para calmar estas protestas, el gobierno aseguró que los republicanos firmarían documentos en los que se comprometían a no participar en la política mexicana. ${ }^{42}$

Otros grupos, como la masonería, se manifestaron en favor de la llegada de los españoles; no sólo de aquellos hermanos masones, a los que consideraban en peligro de muerte en Europa, sino que su apoyo se extendió a quienes tenían dificultades para encontrar un lugar para asentarse en América. Un ejemplo de lo antes dicho lo proporcionó la Gran Logia Valle de México, al dirigirse al presidente Cárdenas con el objetivo de solicitar su apoyo para

41 En Memoria de Relaciones Exteriores, 1940-1941, pp. 153-157. Citada en Matesanz, José Antonio, México y la república española. Antología de documentos, 1931-1977, México, Centro Republicano Español de México, 1978, p. 85.

42 Pérez Guerrero, Juan Carlos, La identidad del exilio republicano en México, Madrid, Fundación Universitaria Española, 2008, p. 126. 
que refugiados españoles llegaran a México, ya que Santo Domingo, en República Dominicana, no les había permitido la entrada. Agregaban que los masones ofrecían su ayuda para distribuirlos en el país. ${ }^{43}$

Son varios los documentos localizados que dan cuenta de las diversas solicitudes que enviaron las logias masónicas al presidente Cárdenas para pedir la entrada de masones españoles a México. Algunas de estas peticiones conservan anotaciones al margen con indicaciones de que se debían archivar en los documentos personales o confidenciales del entonces jefe del ejecutivo mexicano. Esta suerte corrió la petición efectuada por Generoso Canales, gran maestro de la Gran Logia Unida La Oriental Peninsular. Este documento tiene fecha de 20 de julio de 1940 y en él se solicita la intervención de Cárdenas para que permitiera la entrada al país de "800 refugiados españoles masones que se encuentran en París". ${ }^{44}$

A la petición de Generoso Canales se sumó la de la masonería de Nuevo León, representada por los profesores Juan F. Escamilla y Manuel Flores. Al parecer, la suerte de los ochocientos masones españoles en Francia fue un asunto que multiplicó las peticiones para su traslado, pues también el doctor Jaime N. Casanova, gran maestro de la logia del estado de Chiapas, el 4 de julio de 1940, solicitó al Presidente que se permitiera su entrada al país. Además, en su petición, Casanova apuntaba que la Junta de Auxilio a los Republicanos Españoles (JARE) estaba dispuesta a costear la inmigración y sostenimiento de dichos elementos en México. A esta solicitud también se añadió la del gran maestro de la logia Cosmos del estado de Chihuahua, Lázaro Villareal, fechada en junio de 1940. Esta logia secundaba las gestiones hechas por el H. Consejo Masónico y Masonería Regular de la República para la entrada al país de los masones en Francia, mencionando que sabían "que la agrupación española JARE está dispuesta a costear los gastos relativos a la emigración, así como al sostenimiento en México de dichos elementos". En favor de su petición, argumentaron que, debido a las condiciones que regían en Francia, "se encuentran en grave peligro los citados refugiados españoles, ya que de triunfar en dicho país el Gobierno Aleman [sic], quedarían en eminente peligro de ser entregados al gobierno actual español que rige el General Franco, quien indudablemente los mandaría fusilar o cuando menos los encarcelaría para toda la vida". ${ }^{45}$

43 Este documento fue enviado por Raúl Cordero Amador, Gran Maestro de la Logia Valle de México, al presidente de México el 8 de julio de 1940. En AGN, fondo Lázaro Cárdenas, C. 908, 546.6/2012-14, legajo 2.

44 AGN, fondo Lázaro Cárdenas, C. 908, 546.6/2012-14, legajo 2. Solicitud enviada a Lázaro Cárdenas para el traslado de masones españoles a México.

45 Idem. 
No le faltaba razón al gran maestro Lázaro Villareal, pues los juristas republicanos, como la mayoría de los exiliados, tuvieron que elegir entre la represión, la prisión, la muerte o el exilio. Las alternativas a éste no eran las mejores opciones, por lo que abandonar la patria resultó una necesidad más que una elección.

Así, la salida de España de los masones y las organizaciones masónicas es fácilmente explicable con las diversas iniciativas de Franco para perseguir a la masonería y las instituciones que fue creando y consolidando para su represión y exterminio. Después de la diáspora que siguió a la Guerra Civil, los hermanos masones buscaron la forma de reagruparse; una de las vías fue la reorganización del Grande Oriente Español en el exilio. En la Ciudad de México, fueron apoyados por la Gran Logia Valle de México. ${ }^{46}$ Por ejemplo, se establecieron trámites y plazos para regularizar su situación ante las autoridades masónicas, considerando las circunstancias de la Guerra Civil y la pérdida de documentación que ésta ocasionó. También se dio el caso de masones que se afiliaron a logias mexicanas, lo que las autoridades masónicas españolas consideraron aconsejable "para estrechar lazos fraternales con los hermanos mexicanos; lo que debió obedecer a que ya se realizaban iniciaciones y regularizaciones de españoles en talleres de la Gran Logia Valle de México". ${ }^{47}$

\section{EL MUNDO LABORAL MEXICANO}

Fueron varias instituciones mexicanas en las que prestaron sus servicios profesionales los juristas a los que se logró identificar como masones, o como pertenecientes a la masonería en algún momento de su vida. Por ejemplo, en el Instituto Juan Ruiz de Alarcón, colaboraron temporalmente Manuel

46 Los vínculos que tuvo la Logia Valle de México con la masonería española, con la Gran Logia Española y con el Grande Oriente Español son tratados por Carlos Francisco Martínez Moreno en "La gran logia «Valle de México» durante la Segunda República Española, 1931-1939”, Cultura Masónica, La historia tiene la palabra. II República española y masonería 75 años después, año 6, núm. 19, octubre de 2014, pp. 115-150. De este mismo autor, véase "Masonería española en el exilio de México. Masones españoles regularizados y afiliados en logias bajo la jurisdicción de la Gran Logia Valle de México, 1920-1959”, La masonería española, represión y exilios I, Zaragoza, Centro de Estudios Históricos de la Masonería Española, Departamento de Educación Cultura y Deporte del Gobierno de Aragón, 2010, pp. 211-230.

47 Martínez Moreno, Carlos Francisco, "Prensa masónica española en México. Grande Oriente Español en Exilio. Primera Época (1940-1947)”, Gibraltar, Cádiz, América y la Masonería. Constitucionalismo y libertad de prensa, 1812-2012, tomo I, Zaragoza, Centro de Estudios Históricos de la Masonería Español, Gobierno de Gibraltar, 2014, pp. 395-396. 
Martínez Pedroso y Gabriel Bonilla. Con el Fondo de Cultura Económica se dio una relación en diferentes estatus laborales: Julián Calvo colaboró como traductor y en labores administrativas, y Martínez Pedroso se desempeñó en el cuidado de la Colección de Historia y como traductor. ${ }^{48}$ La Casa de España en México-El Colegio de México contó entre sus filas a Pedroso y Ruiz-Funes. ${ }^{49}$

En la Escuela Nacional de Jurisprudencia - ahora Facultad de Derechoprestaron sus servicios Felipe Sánchez-Román, Ruiz-Funes, Martínez Pedroso, Demófilo de Buen y Victoria Kent, esta última fue directora de la Escuela de Capacitación para el Personal de Prisiones y Establecimientos Similares. También impartió las cátedras de Estudio del Medio Penitenciario y Sistemas e Instituciones Penitenciarias. La experiencia mexicana de Kent fue corta, pues fue invitada por la Organización de Naciones Unidas para colaborar con ella y, a raíz de esta invitación, se trasladó a Nueva York. ${ }^{50}$ Naciones Unidas también incorporó a sus filas a Julián Calvo Blanco, ${ }^{51}$ jurista que radicó largos años en México y que, debido a su colaboración con la ONU, cambió su residencia a Chile. Calvo fue un discípulo leal de Mariano Ruiz-Funes, cuya relación inició en España y continuó en el exilio. El mismo Calvo mencionó en una entrevista que acompañaba a Ruiz-Funes cuando impartía sus clases, debido a que su maestro era agorafóbico y no podía cruzar las calles solo. ${ }^{52}$ Ruiz-Funes colaboró, como ya se dijo, en El Colegio de México, institución que lo comisionó para auxiliar al procurador de justicia del Distrito Federal, Octavio Vejar Vázquez (1940). Posteriormente, trabajó para la Secretaría de Educación Pública (1941). En 1950 se le ubica como asesor técnico de la rec-

48 Aub, Max, "Los españoles del Fondo", Libro conmemorativo del 45 aniversario. Fondo de Cultura Económica, México, Fondo de Cultura Económica, 1980, p. 191.

49 Archivo Histórico de El Colegio de México (AHCM), sección archivos institucionales, sub-sección La Casa de España, años 1939-1983, caja 21, exp. 13, Mariano Ruiz-Funes García.

50 Archivo Histórico de la Universidad Nacional Autónoma de México (AHUNAM), Dirección General de Personal Académico y Administrativo (DGPAA), exp. 112/131/9501. Kent, Victoria.

51 Este jurista nació en 1909. Se licenció en derecho y a raíz de la Guerra Civil se exilió en México. Trabajó como traductor para el FCE. Fue secretario de la revista Litoral y colaborador de la revista Ultramar y Las Españas. Funcionario de la CEPAL y colaborador de la obra El exilio español de 1939. En Catálogo bibliográfico. Autores y traductores del exilio español en México, México, Fondo de Cultura Económica, 1999, pp. 10 y 11.

52 Instituto Nacional de Antropología e Historia (INAH), Archivo de la Palabra, Calvo Blanco, Julián, PHO/10/37. Entrevista a Julián Calvo, realizada en su domicilio particular de la ciudad de Madrid, por Concepción Ruiz-Funes, el día 5 de mayo de 1979. 
toría de la UNAM, y en 1952 formaba parte del Instituto de Investigaciones Sociales y de la Facultad de Derecho de esta misma universidad. ${ }^{53}$

También Gabriel Bonilla Marín colaboró para el gobierno mexicano; en su caso, se integró a la Comisión de Estudios de la Presidencia de la República y auxilió en actividades relacionadas con las leyes del seguro social. ${ }^{54}$ En la UNAM se incorporó a la Escuela Nacional de Economía. ${ }^{55}$

Demófilo de Buen fue otro jurista que engrosó las filas gubernamentales mexicanas. Fue asesor del procurador de justicia del Distrito Federal y colaboró en la Secretaría de Educación Pública. En la UNAM, se incorporó a la Escuela Nacional de Jurisprudencia. Posteriormente, fue contratado por la Universidad de Panamá y se trasladó a dicho país, aunque desgraciadamente fueron pocos años los que colaboró en esa institución, pues la muerte lo alcanzó en 1946.56

Era una época de intensa movilidad entre la comunidad de exiliados españoles, dinámica en la que también entraron los juristas masones que temporalmente asentaron su residencia en México. Así, tenemos que Victoria Kent se trasladó a Estados Unidos, Julián Calvo se mudó a Chile y Demófilo de Buen se instaló en Panamá. En los casos de Kent y Calvo el cambio se debió a la colaboración en Naciones Unidas.

Para ilustrar algunos de los senderos por los que transitaron los juristas masones en su búsqueda de trabajo en México, vamos a utilizar el caso de Manuel Martínez Pedroso, al que se puede considerar afortunado en comparación con otros compañeros estudiosos del derecho en similares circunstancias; lo anterior debido a que su incorporación se dio con el respaldo de importantes personalidades españolas y mexicanas.

La tarea de reconstruir las circunstancias que permitieron la inserción de Pedroso en dos de las más importantes instituciones educativas mexicanas -La Casa de España y la Escuela Nacional de Jurisprudencia- ofrece la posibilidad de conocer algunos de los mecanismos que se pusieron en marcha a la llegada de los republicanos españoles y que permitieron su incorporación en la sociedad que los recibió. En este caso, el catedrático español fue respaldado por influyentes mexicanos, entre ellos el presidente de La Casa de España, Alfonso Reyes, y el entonces embajador de México en Washington, D.C., Francisco Castillo Nájera.

53 AHUNAM, DGPAA, exp. 25/131/9686, Ruiz-Funes, Mariano.

54 Martínez Chávez, Eva Elizabeth y Conde Naranjo, Esteban, "Bonilla Marín, Gabriel (1888-1965)", op. cit.

55 AHUNAM, DGPAA, exp. 5822.

56 Martínez Chávez, Eva Elizabeth y Conde Naranjo, Esteban, "Buen y Lozano, Demófilo de (1890-1946)", op. cit. 
Al llegar a México, Pedroso se incorporó al Instituto Hispano-Mexicano Ruiz de Alarcón, uno de los primeros centros de enseñanza fundado por los exiliados en 1939, con fondos proporcionados por el presidente Lázaro Cárdenas. Este instituto cubría la enseñanza desde el jardín de niños hasta la preparatoria y contaba, además, con secciones de estudios mercantiles y jurídicos. ${ }^{57}$ Sin embargo, otro destino le esperaba a Martínez Pedroso. A pocos días de haberse instalado en la Ciudad de México -1o. de junio de 1939-, Alfonso Reyes recibió una misiva de Francisco Castillo Nájera, en la que le escribió que había tenido noticias de que se encontraba en México el profesor exiliado, a quien había conocido en Ginebra y en quien había apreciado sus altas cualidades y sus profundos conocimientos del Derecho Internacional. En la misma carta, Castillo Nájera expuso a Reyes: "mucho le agradecería que, si no encuentra inconveniente, se pusiera en contacto con el Prof. Pedroso y viera si es posible utilizar sus valiosos servicios en México". ${ }^{58}$ Después de esta recomendación, las gestiones para incorporar a Pedroso a La Casa de España se sucedieron rápidamente. Reyes contestó el 7 de junio de 1939 para indicarle que había visto varias veces a Pedroso en México "de quien soy camarada de trabajo de Madrid y hasta vecino de asiduas y constantes visitas en aquellos pasados tiempos, [por lo que] tendré el mayor gusto en atenderle en el sentido que usted me indica". El 29 del mismo mes, Reyes escribió a Martínez Pedroso para comunicarle: "La Casa de España en México se complace en invitar a usted para que se considere incorporado como Miembro de la misma, en calidad de honorario". ${ }^{59}$ El ingreso en La Casa de España implicaba la obligación de llevar a cabo ciertas actividades, como impartir un curso anual o dos semestrales en la UNAM, dictar cursos y lecciones en universidades estatales y, de ser posible, entregar alguna obra para su publicación. ${ }^{60}$

La relación que se fomentaba con la UNAM a través de los cursos en sus diferentes escuelas y facultades permitió que no pocos exiliados relacionados con La Casa de España terminaran colaborando de manera definitiva en esta institución. En el caso que nos ocupa, la inserción de Martínez Pedroso en la comunidad de la Universidad se dio gracias a la invitación de Mario de la

57 Lida, Clara E., Matesanz, José Antonio y Morán, Beatriz, "Las instituciones mexicanas y los intelectuales españoles refugiados: La Casa de España en México y los colegios del exilio", en Abellán José Luis y Monclús, Antonio (coord.), El Pensamiento Español Contemporáneo y la Idea de América II: El Pensamiento en el exilio, Barcelona, Anthropos, 1989, pp. 144 y 145.

58 AHCM, fondo La Casa de España, caja 19, exp. 2, 1939-1948. También se encuentra información sobre él en AHCM, fondo Alfonso Reyes, caja 10, exp. 27, 1943 y caja 13, exp. 33, 1944.

59 AHCM, fondo La Casa de España, caja 19, exp. 2, 1939-1948.

60 Idem. 
Cueva, entonces rector de dicha casa de estudios, para impartir un cursillo sobre "Hobbes y la filosofía política en los siglos XVI y XVII", actividad que inició en enero de 1940. Ese mismo año fue invitado para dirigir el Seminario de Derecho Público en la Escuela Nacional de Jurisprudencia y se encargó de la cátedra de Teoría del Estado y luego de la de Derecho Internacional Público. Posteriormente, fue nombrado profesor de carrera de ambas cátedras. ${ }^{61}$

Después de este breve recorrido por los entresijos laborales en los que se vieron involucrados los juristas españoles masones radicados en México, podemos decir que la principal institución en la que se emplearon fue la Universidad Nacional Autónoma de México, principalmente, por medio de sus diversas escuelas y facultades. Algunos llegaron comisionados por La Casa de España-Colegio de México y otros de forma directa. Lo que no se puede discutir es el valor profesional de estos exiliados, ya que independientemente de su pertenencia a la masonería, su inserción en las filas de la UNAM se respaldó por su experiencia y valía profesional.

\section{ARCHIVOS HISTÓRICOS}

Archivo General de la Nación (México).

Archivo Histórico de El Colegio de México (México).

Archivo Histórico de la Universidad Nacional Autónoma de México (México).

Centro Documental de la Memoria Histórica (España).

Instituto Nacional de Antropología e Historia (México).

\section{BIBLIOGRAFÍA}

Álvaro DueÑas, Manuel, "Por ministerio de ley y voluntad del caudillo". La jurisdicción especial de responsabilidades políticas (1939-1945), tesis doctoral, Departamento de Historia Contemporánea, Madrid, Universidad Autónoma de Madrid, 1997.

Aub, Max, "Los españoles del Fondo", Libro conmemorativo del 45 aniversario. Fondo de Cultura Económica, México, Fondo de Cultura Económica, 1980, pp. 189-193.

61 Pedroso, Manuel, "Curriculum vitae", en Serrano Migallón, Fernando, (coord.), Manuel Martínez del Pedroso. Homenaje, México, Cátedra México País de Asilo, Porrúa, Universidad Nacional Autónoma de México-Facultad de Derecho, 2008, p. XVIII. 
Esta obra forma parte del acervo de la Biblioteca Jurídica Virtual del Instituto de Investigaciones Jurídicas de la UNAM www.juridicas.unam.mx https://biblio.juridicas.unam.mx/bjv

Catálogo bibliográfico. Autores y traductores del exilio español en México, México, Fondo de Cultura Económica, 1999.

Coma ForT, José María, "González Oliveros, Wenceslao (1890-1965)", Diccionario de catedráticos españoles de derecho (1847-1943), Universidad Carlos III de Madrid, Instituto Figuerola de Historia y Ciencias Sociales, 2011, disponible en: http://wrere.uc3m.es/diccionariodecatedraticos.

Lida, Clara E., Matesanz, José Antonio y Morán, Beatriz, "Las instituciones mexicanas y los intelectuales españoles refugiados: La Casa de España en México y los colegios del exilio", en Abellán José Luis y Monclús, Antonio (coord.), El Pensamiento Español Contemporáneo y la Idea de América II: El Pensamiento en el exilio, Barcelona, Anthropos, 1989.

Martínez Chávez, Eva Elizabeth y Conde Naranjo, Esteban, "Bonilla Marín, Gabriel (1888-1965)", Diccionario de catedráticos españoles de derecho (1847-1943), Universidad Carlos III de Madrid, Instituto Figuerola de Historia y Ciencias Sociales, 2011, disponible en: http://wrwreuc3m.es/ diccionariodecatedraticos.

Martínez Chávez, Eva Elizabeth y COnde Naranjo, Esteban, "Buen y Lozano, Demófilo de (1890-1946)", Diccionario de catedráticos españoles de derecho (1847-1943), Universidad Carlos III de Madrid, Instituto Figuerola de Historia y Ciencias Sociales, 2011, disponible en: http://wrere.uc3m.es/ diccionariodecatedraticos.

Martínez Moreno, Carlos Francisco, "Masonería española en el exilio de México. Masones españoles regularizados y afiliados en logias bajo la jurisdicción de la Gran Logia Valle de México, 1920-1959", La masonería española, represión y exilios I, Zaragoza, Centro de Estudios Históricos de la Masonería Española, Departamento de Educación Cultura y Deporte del Gobierno de Aragón, 2010.

Martínez Moreno, Garlos Francisco, "La Gran Logia «Valle de México» durante la Segunda República Española, 1931-1939”, Cultura Masónica, La historia tiene la palabra. II República española y masonería 75 años después, año 6 , núm. 19, octubre de 2014.

Martínez Moreno, Carlos Francisco, "Prensa masónica española en México. Grande Oriente Español en Exilio. Primera Época (1940-1947)", Gibraltar, Cádiz, América y la Masonería. Constitucionalismo y libertad de prensa, 1812-2012, tomo I, Zaragoza, Centro de Estudios Históricos de la Masonería Español, Gobierno de Gibraltar, 2014.

Matesanz, José Antonio, México y la república española. Antología de documentos, 1931-1977, México, Centro Republicano Español de México, 1978. 
Esta obra forma parte del acervo de la Biblioteca Jurídica Virtual del Instituto de Investigaciones Jurídicas de la UNAM

Pedroso, Manuel, "Curriculum vitae", en Serrano Migallón, Fernando, (coord.), Manuel Martínez del Pedroso. Homenaje, México, Cátedra México País de Asilo, Porrúa, Universidad Nacional Autónoma de México, Facultad de Derecho, 2008.

Pérez Guerrero, Juan Carlos, La identidad del exilio republicano en México, Madrid, Fundación Universitaria Española, 2008.

PORTILLA, Guillermo, La consagración del derecho penal de autor durante el franquismo. El Tribunal Especial para la Represión de la Masonería y el Comunismo, Granada, Comares, 2009.

Turrión García, María José, "La biblioteca de la Sección Guerra Givil del Archivo Histórico Nacional (Salamanca)", Boletín ANABAD, vol. XLVII, núm. 2, 1997, pp. 89-113. 


\title{
LA EDUCACIÓN DESPUÉS DE LAS REFORMAS DE 1833
}

\author{
Anne STAPLES \\ Sumario: I. Después de la derrota. II. Retomando el pasado. III. Cam- \\ biar, pero no tan aprisa. IV. La discreta gestión de Manuel Baranda. V. La \\ misma meta por caminos distintos. VI. Nada puede contra la opinión pública.
}

A lo largo de los años, los términos de liberalismo, secularización y laicismo han caracterizado a distintas influencias dentro del pensamiento político mexicano. Es muy cuestionable que realmente sean las palabras que describan de manera adecuada los esfuerzos reformistas de las primeras décadas de independencia y las reacciones contrarias. Este artículo propone visualizar los proyectos educativos y la oposición a ellos como parte de una continuidad ilustrada racionalista, producto de la efervescencia cuyo efecto más conocido fueron las reformas borbónicas. Nadie en México en los años cercanos a las reformas de 1833 estaba en contra del progreso. Al contrario, los aliados a todas las corrientes ideológicas buscaban resolver los problemas que mantenían al país en el atraso económico e intelectual (según el criterio de la época) respecto a Europa. No había acuerdos en cuanto a cómo eliminarlo, sobre todo frente a intereses creados. En el fondo de la cuestión yacía el concepto del individuo frente al Estado. Una sociedad corporativista lograba cubrir con su manto protector las identidades individuales y atraer con primacía su fidelidad y lealtad. El Estado claramente deseaba fundar su poder en la apropiación de esas identidades y lealtades, dejando a cualquier otro grupo en segundo lugar, incluso a la familia. Desde luego que las corporaciones antiguas, sobre todo la Iglesia, eran los más fuertes competidores en esa lucha por dominar la voluntad y la obediencia del individuo. Cualquier acción percibida como un ataque a la preeminencia de la Iglesia era rechazada por parte de un sector de la sociedad, temeroso de un futuro sin el freno moral del catolicismo y la intolerancia religiosa. En esas tensiones entre el cambio

\footnotetext{
* El Colegio de México.
} 
Esta obra forma parte del acervo de la Biblioteca Jurídica Virtual del Instituto de Investigaciones Jurídicas de la UNAM www.juridicas.unam.mx

para utilizar racionalmente los recursos y el tiempo, y el miedo de destruir las instituciones cohesionadas durante el Virreinato, encontramos la explicación de reformas y contrarreformas. Hablar de la trinidad liberalismo-secularización-laicismo es un anacronismo que no ayuda a entender la lucha entre los grupos en el poder, el temor y las grandes esperanzas que despertaron el optimismo desbordante de la Ilustración y el independizarse de España. No podemos encapsular las marchas y contramarchas que sufrieron los planes de estudio o la vida de las instituciones educativas dentro de explicaciones de teoría política que no tomen en cuenta el deseo de resolver antiguos problemas y conservar a la vez la cultura católica que permeaba todo el ambiente social de la nueva República mexicana.

Si no hay tal dicotomía liberal/conservador durante estas primeras décadas de independencia, tenemos que buscar otros conceptos o intereses que expliquen cambios institucionales promulgados y rechazados. Desde luego que la convicción de las bondades de una sociedad corporativista, frente a individuos que buscan su propio bienestar en vez de procurar el bien común, divide ideológicamente a los actores políticos de la época. La defensa de los privilegios y de los ingresos desempeña un papel fundamental que no se ha tomado en cuenta de manera suficiente para explicar los años posteriores a los de Gómez Farías. La reacción tuvo ese sentido: proteger prerrogativas que supuestamente las autoridades atacaban debido a su programa reformista, opuesto a los intereses de los que habían detentado el poder. Los mestizos y criollos que se reunían en las logias yorkinas, por ejemplo, querían apropiarse de puestos gubernamentales y de influencias políticas disfrutados por viejos burócratas heredados del Virreinato o de hijos de familias que habían ostentado un gran peso social. La lucha se da entre estos individuos y no tanto por las tensiones entre los aspectos formales e institucionales de la educación.

Abolir la Universidad es el mejor ejemplo de ese conflicto, pues peligraron los intereses pecuniarios del claustro y el prestigio de los egresados, que se definían como pertenecientes a esa comunidad académica. El papel de la Universidad fue más bien simbólico y burocrático, no académico. Acabar con ella fue un proyecto destinado a retirar la influencia de una burocracia que estrangulaba los esfuerzos de reorganizar un ramo de la administración pública. Las otras interpretaciones que se han dado a las reformas de 1833 y su pronto rechazo por el Congreso permitían, sin duda, describir algunas de las tensiones presentes en la sociedad en ese momento, pero no recalcan con firmeza que lo secular no estaba en mente de nadie, que la sociedad y los individuos fueron profundamente creyentes y convencidos de la bondad de una religión (no necesariamente la Iglesia como institución) imprescindible en la vida cotidiana y de la nación. Gómez Farías y su grupo de seguidores 
no querían acabar con el catolicismo; sus reformas no iban en contra de la religión, pues no hay evidencias de esto. Querían reorganizar y eliminar la influencia política y social de los elementos contrincantes, reducir el papel de la Iglesia como institución en la vida pública, así como modificar los fueros que permitían un alto grado de impunidad y de indefensión del público en general. Había muchos problemas que resolver, nadie lo dudaba, pero los medios y los métodos para hacerlo variaban mucho, a tal grado que hasta la fecha seguimos teniendo una visión maniquea de grupos en conflicto acerca de los conceptos de modernidad, liberalismo, secularización y laicismo, cuando en el fondo enmascaraban reacomodos entre grupos en lucha por el poder. La Iglesia fue competidora, la religión no. Pero como las dos están imbricadas, tendemos hoy a entender la historia sin separar el anticlericalismo del profundo sentimiento religioso que permeaba toda la sociedad.

\section{DESPUÉS DE LA DERROTA}

En lo inmediato, casi todas las reformas de 1833 fueron un fracaso rotundo, por lo que el Congreso de la Unión prohibió que hubiera otras más el 23 de abril de 1834, antes del regreso al poder de Santa Anna. ${ }^{1}$ Sin duda, el contexto tuvo la culpa del rechazo a la legislación de Gómez Farías, pues no fue debido a lo radical de las medidas, ni a la violenta oposición de la sociedad, sino al timing. El vicepresidente no fue buen político. Con José María Luis Mora atrás y un congreso del mismo parecer, quiso aprovechar la oportunidad que le daban las facultades extraordinarias para promulgar, todas al mismo tiempo, las reformas que se habían buscado desde la época de los Borbones. Resultó ser una bomba. No quiso quitarle todo el fuero al clero ni al ejército sino reducir su alcance, pero se interpretó como un ataque frontal a ambos. Al instante, volvió en su contra a la Iglesia y al ejército. Enojó a los donadores al cambiar el destino de las herencias dejadas a las instituciones educativas, lo que se vio como un ataque a la propiedad privada porque se reunieron en una olla común, lo que contravenía los últimos deseos de quienes transfirieron dinero o bienes raíces a un colegio en particular. Hizo rabiar a los doctores de la Nacional y Pontificia Universidad al clausurarla, pues se quedaron sin las propinas que eran su medio de vida. Como si fuera una caja

1 "Cesan las facultades extraordinarias concedidas al ejecutivo en la ley publicada el 19 de octubre del año anterior", misma que Gómez Farías aprovechó inmediatamente para reorganizar la educación superior. Dublán, Manuel y María Lozano, José, Legislación mexicana o colección de las disposiciones legislativas expedidas desde la Independencia de la República, Imprenta del Comercio, a cargo de Dublán y Lozano, 1891, t. II, p. 691. 
de Pandora abierta de repente, el gobierno consolidó las estructuras educativas y las dotaciones económicas que las sostenían, se abrogó la facultad de otorgar grados académicos, liberó a las monjas del poder del brazo secular en caso de dejar la vida monástica y abolió la coacción civil del pago de los diezmos, entre otras medidas. (En este caso, no revocó Santa Anna la ley, pues no le convenía el cobro sobre la producción de algodón en sus extensas haciendas que iban desde el puerto de Veracruz hasta Xalapa. ${ }^{2}$ Sus aliados agricultores también estaban de acuerdo con cancelar esta exacción, aunque la Iglesia siguiera presionando para su pago.)

En respuesta a estas "intromisiones" en su jurisdicción, el clero empezó a predicar que las heladas, las inundaciones, la llegada del cólera y la aurora boreal eran signos clarísimos de la ira divina. Razón por la cual Santa Anna recibió cartas en su hacienda veracruzana, Manga de Clavo, en las cuales le suplicaban regresar a salvar a la patria. Los legisladores antirreformistas inscribieron su nombre con letras de oro tras la tribuna del congreso cuando abolió las leyes de su vicepresidente. Era demasiado para una sociedad misoneísta, que dudaba de la eficacia de los cambios y que prefería ser cuidadosa ante el peligro de empeorar la ya difícil vida de la república. Y, sin embargo, Santa Anna estaba consciente de la necesidad de extender la educación y de apoyarla en lo posible. Su donativo "de 2000 pesos anuales al fondo de educación pública creado en abril de 1833" es una prueba. ${ }^{3}$ Varios santanistas pertenecían a la Compañía Lancasteriana. De ninguna manera quiso obstaculizar el progreso de las instituciones educativas, pero objetaba el modo como el congreso radical de 1833 había implementado las reformas, sobre todo cuando atacaban los fueros del ejército. Su objeción se convirtió en acción y regresó a la capital para encabezar el gobierno, pues se enfrentaba a un ambiente cargado de resentimientos y tensiones que habían crecido de manera constante.

Como lo ha descrito Will Fowler, el dilema de Santa Anna "era aplicar la política liberal moderada de Victoria en una época de polarización. La violencia de la guerra civil de 1832 mostró la intensidad de dicha polarización. Seguían irresueltas antiguas disputas desde la guerra de independencia. [Y para colmo de males] los moderados encargados del gabinete, e incluyo aquí a Gómez Farías, eran incapaces de controlar al congreso". ${ }^{4}$

2 Fowler, Will, "Las propiedades veracruzanas de Santa Anna", Memorias de la Academia Mexicana de Historia Correspondiente de la Real de Madrid, 1999-2000, t. XLIII, pp. 63-92.

3 Fowler, Will, Santa Anna, Xalapa, Universidad Veracruzana, 201 1, p. 200.

4 Ibidem, p. 212. 
Esta obra forma parte del acervo de la Biblioteca Jurídica Virtual del Instituto de Investigaciones Jurídicas de la UNAM www.juridicas.unam.mx

\section{RETOMANDO EL PASADO}

Debe admitirse que no todas las reformas fueron una gran sorpresa. Muchas fueron producto de anteriores intentos de remediar rutinas obsoletas, volver más eficiente el manejo de los recursos y preparar a los jóvenes para actuar en un mundo más secular. Durante la década de 1820 no había un profundo desacuerdo en cuanto a este tema. Solamente cuando los cambios se identificaron con una ideología dizque revolucionaria o la de una logia masónica competidora fue cuando se estigmatizaron como si fueran maquinaciones dirigidas a destruir la religión y la república, envolviendo el conflicto en una agresiva retórica. Llama la atención el consenso que hubo entre los miembros de la Suprema Junta Gubernativa, por ejemplo, en cuanto a la necesidad de educar al pueblo y alejarlo de "groseras preocupaciones", ${ }^{5}$ o de parte de personas tan disímiles como José María Luis Mora y el medio hermano de Lucas Alamán, el vicario de monjas y miembro del cabildo de la catedral metropolitana Juan Bautista Arechederreta. Es fácil comprobar este consenso si comparamos los planes educativos propuestos entre 1822 y $1844 .{ }^{6}$

A partir de 1822 se estableció en México la Sociedad Lancasteriana, también conocida como la Compañía Lancasteriana. ${ }^{7}$ La composición de la membresía en esta sociedad benéfica que promovía la educación masiva popular reunía tanto a yorkinos como a escoceses. Muchos autores han comentado el hecho de que se trabajó conjuntamente para intentar sacar la educación de su atraso. Todas las facciones políticas y religiosas (anticlericales o no) apoyaban la noción de promover la enseñanza de primeras letras. Durante años, la Compañía siguió reuniendo iniciados de distintas logias, pero se perdió este consenso al enfrentarse en el campo de batalla por las Leyes de Reforma. La guerra puso fin a cualquier diálogo, consenso, negociación o acuerdo entre partes, como sucede con toda guerra civil. La radicalización de

5 Echeverría, Patricia, "Mexican Education in the Press and Spanish Cortes 18101821 ", tesis de maestría, Universidad de Texas en Austin, 1969, citada en Ramos Escandón, Carmen, Planear para progresar. Planes educativos en el México nuevo 1820-1833, México, Universidad Pedagógica Nacional, 1994, p. 19.

6 Los dos personajes pertenecían al México de buenas familias y educación esmerada, miembros de la "ciudad letrada" y hombres de bien. Ibidem, p. 19.

7 Fowler, Will, "The Compañía Lancasteriana and the élite in independent Mexico, 18221845", Tesserae. Fournal of Iberian and Latin American Studies, vol. 2, núm. 1, 1997, pp. 81-110; Tanck de Estrada, Dorothy, "Las escuelas lancasterianas en la Ciudad de México: 1822-1842", Independencia y educación. Cultura cívica, educación indígena y literatura infantil, México, El Colegio de México, 2013, pp. 335-352; Staples, Anne, Recuento de una batalla inconclusa. La educación mexicana de Iturbide a fuárez, México, El Colegio de México, 2005. 
las posiciones ideológicas llevó a una secularización acelerada, forzada por la ley, aun en contra de las tradiciones del pueblo, como una medida obligada para la supervivencia de la nación, según los vencedores de la guerra.

Desde los primeros años de independencia, José María Luis Mora propuso crear una cátedra de filosofía constitucional y de economía doméstica en el Colegio de San Ildefonso y, eventualmente, reunir en instituciones afines las materias que se daban de manera dispersa o que estuvieran duplicadas, como en el caso de San Ildefonso y San Gregorio. Hubo otros proyectos de reglamentos generales de instrucción pública en 1823, 1826 y 1832, así que los planes de 1833 incorporaron anhelos formulados con antelación. ${ }^{8}$ Donde se apartaron los criterios fue en el hecho de que Mora quería convertir al joven estudiante en "hombre de bien", "que privilegia el cumplimiento de sus deberes cívicos por encima de cualquier otro", de acuerdo con el ideario liberal, y Alamán buscaba convertir a los jóvenes en hombres virtuosos, buenos creyentes y respetuosos de la moral católica, la cual se consideraba la base del buen funcionamiento de la sociedad. Eran dos caminos para llegar a la misma meta de una sociedad armoniosa, capaz de lograr el progreso y la felicidad. ${ }^{9}$ Ambos compartían un elemento fundamental: asimilar la obediencia como guía rectora de la vida. ${ }^{10}$

En 1823, al estar al frente del Ministerio de lo Interior y del Exterior, Alamán reunió a cuarenta interesados en cuestiones educativas para proponer un plan que terminó por parecerse mucho al reglamento dictado por las cortes españolas en junio de 1821, pero que no fue promulgado en México, debido a la declaración de independencia. ${ }^{11}$ Este reglamento sería la base de gran parte de la legislación educativa mexicana durante las siguientes cuatro décadas. Es importante enfatizar este hecho, para que no parezca que el liberalismo entró por la puerta del despacho de Gómez Farías y de su colega Mora. Ya existía la inquietud, ya estaba diagnosticada la enfermedad -es decir, el analfabetismo del pueblo- y ya se conocía el remedio. No fueron las ideologías lo que impidió llevarlas a cabo, sino la falta de recursos; los cambios en el gobierno; los 1500 pronunciamientos que tuvieron lugar durante esas mismas décadas; ${ }^{12}$ la inestabilidad en todas sus formas, que impidió introducir las reformas y las

\footnotetext{
8 Ramos Escandón, Carmen, op. cit., pp. 90, 104-133 y 142-166.

9 O’Gorman, Edmundo, México, el trauma de su historia, México, Universidad Nacional Autónoma de México, 1977, p. 25.

10 Ramos Escandón, op. cit., p. 27.

11 Ibidem, p. 29.

12 Fowler, Will, "Introducción", en Fowler, Will (ed.), Malcontents, Rebels, \&̊ Pronunciados. The Politics of Insurrection in Nineteenth-Century Mexico, Lincoln y Londres, University of Nebraska Press, 2012, p. X.
} 
innovaciones que el tiempo y las nuevas circunstancias demandaban. Creo que es tiempo de darle menos importancia al grupo político o masónico al que pertenecían los actores en este drama nacional y darnos cuenta de que sus opciones y su libertad de movimiento se restringieron mucho por la falta de recursos. En suma, lo que deseaban los actores políticos era extender la educación primaria y hacerla universal (la misma para todo el mundo): doctrina cristiana, lectura y escritura, cuentas para los muchachos y labores de mano para las muchachas.

También falta recordar que las reformas de 1833 estuvieron lejos de ser antirreligiosas. Uno de los establecimientos creados por el gobierno de Gómez Farías fue el de los estudios eclesiásticos. La estrategia era reunir en una sola institución los cursos idénticos que se ofrecían en varios lugares, con el fin de ahorrar sueldos de maestros. Se llegaba al absurdo de tener clases de teología en varios colegios sin alumnos inscritos, pagando el sueldo de un catedrático que era de los más elevados. Otro ejemplo fue el de los cursos de derecho, ofrecidos en más de un colegio. Un caso, ya tardío, en la Puebla de 1843, es característico de esta situación. Los dos catedráticos mejor pagados del Colegio del Espíritu Santo de Puebla (350 pesos al año cada uno) fueron los de derecho natural y derecho canónico. En el primero, hubo 22 alumnos inscritos; en el segundo, seis. En cambio, quien impartía el curso de latín (mínimos) a los muchachos de primer ingreso tenía que lidiar con 62 de ellos por 200 pesos de sueldo anual. ${ }^{13}$

La educación superior fue causa de mayores conflictos. Como observó la investigadora Carmen Ramos Escandón: "la tendencia a modificar la educación superior científica y literaria no era compartida sino por una pequeña minoría". ${ }^{14}$ La tradición, el apego a las escuelas y las rivalidades fueron obstáculos a los cambios repentinos. Las opciones para los estudiantes eran, primera, someterse a una instrucción religiosa en un ambiente monacal, como el que reinaba dentro de los colegios y noviciados de las órdenes religiosas, en los seminarios diocesanos tridentinos o en la Nacional y Pontificia Universidad, en los cuales se ofrecía una educación clásica, tradicional, copiada de la Universidad de Salamanca, con hincapié en los autores católicos aprobados, o asistir a un colegio del Gobierno Federal, como el de San Ildefonso. La segunda opción fueron los nuevos institutos literarios científicos y de artes,

13 "Estado que manifiesta el número de cátedras de este colegio y el de sus cursantes respectivos", Seminario Conciliar de la Puebla de los Ángeles, 22 de septiembre de 1843, f. 334, en Ríos Zúñiga, Rosalina y Rosa Íñiguez, Cristian, La reforma educativa de Manuel Baranda, Documentos para su estudio (1842-1846), México, Instituto de Investigaciones sobre la Universidad y la Educación-Universidad Nacional Autónoma de México, 2011, pp. 216 y 217.

14 Ramos Escandón, Carmen, op. cit., p. 23. 
algunos con planes tan radicales como el de Jalisco, con una sección de puras matemáticas, o tan tradicionales como el de Oaxaca, donde el primer rector fue dominico (aunque pocos años después el secretario general fue Benito Juárez). Si podemos hablar de un conflicto, sería entre instituciones de nueva cuna frente a las supervivientes del Virreinato. Sin embargo, conservaban características comunes: en todas se estudiaba latín y se vivía intensamente la cultura católica. Laicización es un término que necesita esperar más de medio siglo para empezar a tener sentido. En los momentos que examinamos aquí, después de la abolición de las reformas de Gómez Farías, apenas nos acercamos a los inicios de la secularización. ${ }^{15}$

\section{CAMBIAR, PERO NO TAN APRISA}

En 1834, se hizo lo posible por devolver a las escuelas el estatus legal y organizativo que tuvieron antes de las reformas de Gómez Farías. ${ }^{16}$ Pero nada regresa a su estado anterior: el tiempo modifica todo. Así, aunque las leyes duraron apenas unos nueve meses, en este caso no nació una nueva criatura sino la frustración de no llevar a cabo las innovaciones largamente deseadas. En noviembre de 1834, el gobierno de Santa Anna tuvo listo un plan provisional de estudios, más practicable -según sus apologistas- que el de Gómez Farías. Sus bondades, según ellos, eran poner "a todos los establecimientos y a la juventud en aptitud de sucesivas y graduales reformas, sin retrogradar ni sofocar los adelantos de las ciencias". ${ }^{17}$ Una vez más, se reorganizaron las materias que se ofrecerían en cada establecimiento, tratando de respetar el orden que tuvieron antes de 1833. Prueba para algunos liberales radicales de que Santa Anna encabezaba un régimen retrógrado fue el hecho de que "[t] odos los colegiales reasumi[eran] su antiguo traje", contra el cual había luchado Mora. ${ }^{18}$ Pero es la misma discusión de hoy, de si los niños deben ir a la escuela uniformados o no.

15 Staples, Anne, "Secularización: Estado e Iglesia en tiempos de Gómez Farías", Estudios de Historia Moderna y Contemporánea de México, 1986, vol. 10, pp. 109-123.

16 "Hecho impracticable el plan de instrucción púbica que formó la dirección creada en virtud de facultades extraordinarias, dispuso suspenderlos S.E. el general presidente". Circular de la Secretaría de Relaciones, Plan provisional de arreglo de estudios, citado en Ramos Escandón, Carmen, op. cit., p. 185. Dublán, Manuel y María Lozano, José, op. cit., 1478, vol. 2, núm pp. 754-762.

17 Ramos Escandón, Carmen, op. cit, p. 185.

18 Artículo 22, Plan provisional, 12 de noviembre de 1834, en Ramos Escandón, Carmen, op. cit., p. 188. 
Se ha analizado poco la circular que la Secretaría de Relaciones, encabezada por Francisco María Lombardo, envió en noviembre de 1834. La primera preocupación parece haber sido la de devolver los fondos a sus destinos originales, como si, por antonomasia, el problema fuera de derechos, de respetar la voluntad de los testadores. El gobierno reconoció que hubo una falta importante de recursos, pero señaló que fueron intocables los otorgados por la sociedad civil. Aquí resalta la palabra gradual, pues espantó la rapidez con que se quisieron introducir las reformas del año anterior; de ahora en adelante, se harían las modificaciones necesarias, pero con tiempo, para determinar sus efectos a largo plazo y sin perjudicar los derechos de nadie. Dos colegios manejados por el Estado (o sea los internados), San Juan de Letrán y San Gregorio, impartirían desde primeras letras hasta la carrera de derecho. Si comparamos los planes de 1833 y 1834, San Juan de Letrán, que en la primera fecha se convirtió en un seminario de ciencias eclesiásticas, con cátedras de latín, náhuatl, otomí, historia de la biblia, autores eclesiásticos y moral cristiana, en la segunda conservó el latín, pero se ofrecieron los cursos de francés, retórica, filosofía, teología y los dos derechos. Es decir, perdió su carácter de seminario para la preparación del clero. En cierto sentido, bajo el régimen de Santa Anna, la educación superior se secularizó y se enfocó a la preparación de abogados y de clérigos con una formación en derecho, pero no para el sacerdocio como tal.

Otro ejemplo interesante es el de San Ildefonso. En 1833, se convirtió en el quinto establecimiento de jurisprudencia con cursos de latín, ética, retórica, y todos los campos del derecho. En 1834, se redujo mucho la gama de cursos de derecho, para quedarse con latín, retórica, filosofía, teología y derechos canónico y civil. Es decir, se empobreció su programa, posiblemente, en parte, por no haber tenido matriculados en la amplia gama ofrecida el año anterior. San Gregorio aceptaba, en 1834 y como antes, a jóvenes de primeras letras, pues había sido creado para niños indígenas, como también lo hacía San Juan de Letrán. Para cursar lo que hoy equivaldría a la secundaria, los jóvenes podían inscribirse en el Colegio de Minería. En todos ellos se repetían varios cursos, sobre todo los de humanidades, con lo que se echaba abajo el deseo de economizar esfuerzos y dedicar una institución a una sola carrera, salvo los colegios de Minería y de Medicina. De los dos, Minería conservaría el aspecto más científico, pues el ingreso no requería estudios previos de filosofía (y necesariamente de latín). Sin duda, hubo en otras instituciones un renovado hincapié en el estudio del latín y un mayor número de materias que se impartían en este idioma, muy en consonancia con el sentir de los educadores en muchos otros países del mundo occidental. Queda claro que nuevamente 
la Universidad ejercería el monopolio de otorgar los grados de bachiller, licenciado y doctor. No había maestrías, y ninguna institución, incluyendo la Universidad de Guadalajara, podía otorgar títulos a sus propios egresados, un evidente paso hacia atrás.

Con el deseo de desentrañar algunos aspectos de este plan provisional, que daba una cara más acorde con el México moderno de la cuarta década del siglo XIX -según sus promotores-, cabría apuntar que, por ejemplo, se remplazó la cátedra de prima de filosofía por una de zoología (artículo 79), y se redujeron los tiempos de estudio previo de filosofía para los estudiantes de medicina (artículo 81). ${ }^{19}$ Es difícil decir hasta qué punto este "retroceso" en la educación detuvo el proceso de secularización. Nos hemos acostumbrado a satanizar a Santa Anna -que seguramente no prestaba mucha atención a las minucias de las leyes educativas-, sin ver que, en el fondo, hubo más cambios de forma que de fondo. En unos puntos es obvio que sí, mientras que, en otros, parecen más bien acciones para amortiguar el disgusto de los sectores influyentes, sobre todo clericales, a los que poco les importaba si se enseñaba latín o no en el Colegio de Minería, pero que no querían perder sus prerrogativas económicas y sociales en la Nacional y Pontificia Universidad.

\section{LA DISGRETA GESTIÓN DE MANUEL BARANDA}

Existen aspectos seculares, acordes con el siglo XIX, que se introdujeron durante los regímenes que encabezó Santa Anna. Pienso, en particular, en los efectuados debido a la iniciativa del Ministerio de Justicia e Instrucción Pública encabezado por Manuel Baranda (17 de julio de 1843 al 6 de diciembre de 1844). ${ }^{20}$ Sin hacer mucho alarde de ello, puso en práctica una serie de medidas que cambiaron el quehacer educativo, sin levantar las nubes opositoras de diez años antes (1833-1834). Baranda sobresale como una figura ecuánime, comprometida y sobre todo eficaz, pues en año y medio logró más que lo ocurrido en las dos décadas anteriores. Se podría considerar que el momento, por fin, había sido el apropiado. Quizás así fue, pero no hay que restarle méritos a Baranda, quien logró, a partir de 1843, darles uniformidad y estructura a los estudios. El conocimiento se tenía que ir construyendo, en forma lógica, encadenando los temas de una misma materia, y las materias dentro de una misma carrera. El ministro y sus consejeros se sentaron a pensar qué

19 Ramos Escandón, Carmen, op. cit., pp. 185-198.

20 Baranda fue ministro durante las presidencias de Antonio López de Santa Anna, Valentín Canalizo, y José Joaquín Herrera. Ríos Zúñiga, Rosalina y Rosa Íniguez Cristian, op. cit. 
debía ir primero realmente y qué después para la adecuada preparación de cada profesionista, pues creían que el dominio de unos conocimientos facilitaba entender y retener los siguientes. Desde luego, eso era deseable para los estudios en todo el país, y como se trataba de una república central, nada más fácil que imponer el plan a todos, por lo menos en teoría. En cambio, las reformas de 1833 afectaban únicamente al Distrito Federal y a los territorios.

Otra contribución importante de Baranda, visto desde nuestra perspectiva, fue su aceptación de la idea del cambio: no se podían hacer planes permanentes, pues los descubrimientos abren nuevos campos, por lo que, si un país quería estar a la altura de las naciones más civilizadas del orbe, debía desterrar la perpetuidad de su vocabulario. El conocimiento, entendía el ministro, progresaba; había avances científicos todos los días y no se podía quedar eternamente con los escritos de Aristóteles para explicar la naturaleza. México necesitaba conocer lo que se estaba descubriendo en otros países, no para copiarlo servilmente, sino para estar en condiciones de hacer investigaciones propias, de entender la propia realidad: "Recogeremos las luces que ellas se procuran, pero también nos esforzaremos en procurárnoslas por nosotros". ${ }^{21}$ Su apertura hacia el mundo occidental se nota en la introducción de lenguas modernas, economía política y una amplia gama de ciencias modernas en el plan de estudios. No encuentro otro autor del periodo que maneje estos conceptos. Con valor se enfrentaba a lo nuevo y quería que los estudiantes y profesores mexicanos hicieran lo mismo. Estos últimos debían redactar sus propios libros de texto y escoger los mejores autores, en un intento de renovación continua. Baranda propuso la primera centralización de todos los niveles educativos, tarea facilitada por haber convertido el año anterior a la Compañía Lancasteriana en Dirección General de Instrucción Primaria, un paso importante hacia la formación de una burocracia educativa nacional. Un plan de estudios único, progresivo y uniforme para cada carrera en cada parte de la República era una verdadera primicia. También lo fue la uniformidad en cuanto a administración y financiamiento, así como la facilidad de introducir nuevas materias. Sin embargo, las voces regionales resintieron que poco podían decir en cuanto a la dirección que llevarían los estudios locales, lo que se nota en las quejas de los departamentos al ver que ya no se podía cursar tal o cual carrera, como los casos de Guanajuato y Zacatecas, donde se suprimieron las cátedras de medicina ${ }^{22}$ (se suponía que el alumno iría a México o a Guadalajara, por ejemplo, para terminar sus estudios). La facilidad y,

21 Ibidem, pp. 96 y 97

22 "Memoria del Ministerio de Justicia e Instrucción Pública de 1844”, p. 38, en Ríos Zúñiga, Rosalina y Rosa Íñiguez, Cristian, ibidem, p. 96. 
sobre todo, el ahorro que representaba poder vivir en casa era de gran ayuda para los futuros profesionistas, pero de un plumazo se clausuraron clases en lugares que no ofrecían la carrera completa.

Se han criticado mucho los proyectos que siguieron al de Gómez Farías, por ser producto de regímenes centralistas, pero hace falta reconocer una orientación liberal, moderna e incluso secular en el preámbulo del plan de 1843: "Que con el fin de dar impulso a la instrucción pública; de uniformarla y de que se haga cierta y efectiva su mejora presente, como progresivos y firmes sus adelantos futuros" es una declaración de fe ilustrada. Buscar la uniformidad fue un viejo sueño de los ilustrados y un punto de partida común; poder intercambiar los estudios de un lugar con los de otro, y revalidarlos en todas partes. Nada más importante para una república central que la coequivalencia de estudios: que un médico o un abogado pudiera ejercer en cualquier parte promovía la movilidad y la modernidad. Igual que en la reforma de Gómez Farías, Baranda incluyó una carrera eclesiástica costeada por el gobierno, así que ninguna de las dos reformas se apartaba de la reconocida necesidad de tener clérigos bien entrenados, lo que no quita la tendencia secular de muchas materias e incluso instituciones. Esta nueva reforma, elaborada bajo un régimen "tradicionalista", seguía de cerca los proyectos anteriores y buscaba avanzar con cautela hacia "lo nuevo" cuando las circunstancias permitieran intentar romper los moldes antiguos y vencer la resistencia de miembros de la comunidad académica y de las fuerzas vivas que consideraban peligrosas esas innovaciones que podían obstaculizar el mantener llenos sus bolsillos y boyante la salud espiritual del país.

\section{LA MISMA META POR CAMINOS DISTINTOS}

Para mediados del siglo, la comunidad de miras en cuanto a temas educativos se había perdido, al no haber consenso en cuanto a qué debía enseñarse en las escuelas, ni siquiera en las de primeras letras. Para mí, el mejor ejemplo es el hecho de que en 1853 se expidiera una circular que recordaba la obligación de enseñar el catecismo de Ripalda media hora cada mañana y media hora cada tarde. ${ }^{23} \mathrm{El}$ solo hecho de tener que enviar la circular indica que la costumbre no se llevaba a cabo en todas partes y que no todo el mundo estaba

23 Artículo 1. "En todas las escuelas se enseñará precisa e indispensablemente, sin que ninguno de los maestros pueda eximirse, bajo la pena de cerrarle el establecimiento, doctrina cristiana por el catecismo del padre Ripalda, rezándola los niños todos los días, cuando menos media hora por la mañana y media hora por la tarde", decreto del 31 de marzo de 1853, Dublán, Manuel y Lozano, José María, op. cit., vol. 6, p. 352. 
de acuerdo con hacerlo. Siete años faltaban para llegar a la separación de Estado e Iglesia y esta orden fue de las últimas en procurar el establecimiento, largamente soñado, de una sociedad perfecta dentro de una nación católica. Fue un buen ejemplo del vaivén de las orientaciones políticas, de los esfuerzos por mantener en todo su esplendor la religión del Estado o de constreñirlo a la esfera privada y separar las dos potestades.

Una sociedad que exige la enseñanza del catecismo en sus escuelas públicas y privadas está lejos de aceptar el laicismo, pero no necesariamente el liberalismo. Creo que no cabe la menor duda en cuanto al consenso dentro de la sociedad mexicana, hasta la guerra de Reforma, de la necesidad de que todo niño aprendiera la doctrina cristiana, así que la disputa por una educación secular no se cristalizó hasta el Congreso Constituyente de 1857. No se concebía a una sociedad sin esa base. La moral consistía, en primer lugar, en aprender a temer y a respetar a la autoridad: Dios, la corte celestial, las autoridades terrenales, los padres y los mayores. La esencia de la enseñanza fue la obediencia a las leyes divinas y civiles y a la autoridad, en la forma que adoptara. ${ }^{24}$ Una sociedad sin ciudadanos obedientes no podía existir, pues era el caos. Y dentro de la familia, su falta provocaba una vida doméstica desordenada, disfuncional, inaceptable. El hecho de que los niños obedecieran a los padres, y que la mujer obedeciera al jefe de la familia se tomaba por imprescindible. Todavía a finales del siglo XIX, en un escrito de Horacio Barreda -hermano de Gabino--, se describe el peligro que representaba para el futuro de la humanidad una mujer que saliera de su casa a trabajar, dejando abandonados a sus hijos, al marido; dando la espalda a la comodidad del hogar, en búsqueda de una (necesariamente egoísta) meta personal. La sociedad, se decía, necesitaba una jerarquía, y esa jerarquía funcionaba si los subordinados obedecían y desempeñaban los papeles asignados por el derecho natural.

La doctrina cristiana enseñaba que la única moral verdadera era la católica, pues era divina en su origen, y por necesidad era lo que guiaba la cultura católica en la cual estaba inmersa. Cuando hablamos de secularización, tenemos que pensar en la redefinición que se hicieron de los espacios públicos como lugares para llevar a cabo actividades cotidianas sin un contenido religioso específico, tales como la política y el comercio. El sentido que puede darse a la secularización, antes de la guerra de Reforma, es el de retirar los ritos católicos de la vida pública. Como he escrito en otras partes, esto significaba construir cementerios manejados por el poder público o normar el

24 Staples, Anne, "El temor a Dios y al poder del Estado: diez lecciones bien aprendidas de la niñez mexicana decimonónica”, en Mazin, Oscar (ed.), Las representaciones del poder en las sociedades hispánicas, México, El Colegio de México, 2012, pp. 461- 480. 
toque de las campanas o, como ha visto Andrés Lira, destruir monumentos religiosos, tales como las capillas, que se habían convertido en basureros, sin dueño, sin estar al cuidado de nadie o que obstruían el tránsito. ${ }^{25}$ Se retiraban las imágenes de los nichos de los edificios, si el dueño no quería que los comerciantes, sobre todo extranjeros, pasaran enfrente sin siquiera persignarse o rezar una jaculatoria. Se ordenó que el viático saliera de catedral o de una parroquia sin tanto aparato de carruaje de lujo, campanas y escolta militar. ${ }^{26}$ Nada de esto tenía que ver con la moral. Eran prácticas de disciplina eclesiástica que habían estado en la mira de los reformadores desde el Estado borbónico. Nuestro primer ateo oficial, Ignacio Ramírez, siendo ministro de Instrucción Pública en 1861, decretó que la moral católica -es decir, la enseñanza de la doctrina cristiana- se sustituyera por la moral a secas, la moral universal. ${ }^{27}$ Esto implicaba cambiar en 180 grados el decreto ya citado, de 1853, que obligaba la enseñanza de la doctrina. Desde luego, no tuvo gran efecto, pues eran los mismos textos y los mismos maestros, y la mayoría de ellos estaba en total desacuerdo con lo que consideraba un desatino, por no decir una herejía: dejar de enseñar la doctrina cristiana.

\section{NADA PUEDE CONTRA LA OPINIÓN PÚBLICA}

Se han mencionado las pervivencias incorporadas en las reformas de $1833 \mathrm{y}$ sus secuelas, secularizantes o no, pero otro factor a tomar en cuenta es el de la opinión pública. A los políticos les convenía aparentar una devoción religiosa tradicional, como un medio para asegurar, en alguna medida, la estabilidad de la sociedad. Para el clero, el tema de siempre era el de perder el control sobre las conciencias, tarea cada vez más difícil en el ambiente mundano del siglo XIX. Tanto políticos como clérigos encontraron aliados entre la población analfabeta, la cual visualizaba los cambios como amenazas a su existencia misma. Una caricatura de esta actitud aparece en un escrito de 1839, que culpa a los masones de promover cambios incomprensibles para los incautos, sobre todo para las mujeres. Se recrea, en este escrito, un diálogo entre Tecla, una

25 "Secularización de la vida", La ciudad federal. México, 1824-1827; 1874-1884, México, El Colegio de México, 2012.

26 Staples, Anne, op. cit.

27 Ramírez remite a una moral sin fundamento religioso, posiblemente parecida a la contemplada por Hume que la relacionaba con las percepciones, más que con las costumbres. "Our decisions concerning moral rectitud and depravity are evidently perceptiones", véase en Ordieres, Alejandro, "La teoría del juicio moral en David Hume: un movimiento en tres teimpos", Estudios. Filosofia, Historia, Letras, vol. XV, núm. 21, verano de 2017, p. 52. 
pobre maestra ignorante, amiga de un egresado de los cursos de filosofía, don Canuto. Por supuesto, la representación de los géneros es la acostumbrada en la época. Ella es temerosa, asustada por tanta novedad; él, desde su posición de sabio, capacitado para aconsejarle tener mucho cuidado en la educación de las niñas bajo su cuidado. Ella habla con desprecio de libros que jamás ha leído como los de Voltaire y Rousseau; él acepta que andan por el mundo estos autores y que es necesario conocerlos, pero sólo si se es varón (medio siglo después, Manuel Payno dirá lo mismo: que un hombre puede leer incluso las novelas francesas de moda, pero las mujeres deben preferir el costurero y no andar calentando el cerebro). ${ }^{28}$ La maestra ensalza las virtudes del catecismo de Ripalda; el filósofo lo encuentra más rancio que el jamón, pero reclama también contra los "nuevos filósofos, llámense libertinos masones o ilustrados", que para él son todos iguales. La buena mujer encuentra que tiene más público el escritor que "infama contra justicia, descubre secreto o miente", como apelando a una mayor censura de la prensa, y que la manera de mejorar la sociedad es huir de los que abominan los tres votos de la vida monacal: "pobreza voluntaria, estado de castidad y vida de obediencia". ${ }^{29}$ Este pequeño diálogo, que aprovecha la forma del catecismo, resume la actitud antiintelectual y misoneísta que reinaba en una parte importante de la opinión pública, la que apoyaba los movimientos militares como los de "Religión y fueros", los que veían cualquier tendencia hacia la secularización como un paso más apuntando a la destrucción de la sociedad mexicana. Desde luego, los masones no fueron más que un pretexto para hablar de los "modernos" que amenazaban los valores reconocidos como auténticos por las familias mexicanas.

La sociedad mexicana tiraba cada vez más en direcciones opuestas, perdiendo el poco consenso que en una época pudo haberle caracterizado: el México profundo - por usar el término moderno de Gonzalo Beltrán--, de las comunidades rurales, de las mujeres sin mayor instrucción, de los sectores populares, de la población en general, frente a un pequeño sector, en contacto con los libros modernos, los descubrimientos técnicos, la vida cosmopolita. El proceso de secularización de la educación mexicana a partir de las reformas de Gómez Farías, así como los avances y retrocesos en este campo ilustran que no fue un proceso lineal, ni llegó a cambiar actitudes o valores de toda la población. No todos deseaban la secularización, ni era un valor positivo para todo el mundo. Las hondas divisiones dentro de la sociedad mexicana

28 Staples, Anne, "La lectura y los lectores en los primeros años de vida independiente", Historia de la lectura en México, México, El Colegio de México-El Ermitaño, 1988, pp. 105 y 106.

29 Algo de mazones, o sea, diálogo entre u filósofo y una maestra de amiga. Dispuesto por el R.P.D. Juan Ignacio Villaseñor Cervantes, del Oratorio de San Felipe Neri de México, México, Imprenta de Luis Abadiano y Valdés, 1839, 8 pp. (Condumex, Fondo LXX1 1-2 G inventario 33892, 082.172, V.A.). 
actual no son más que un reflejo de estas grietas que empezaban a aparecer, primero con las reformas borbónicas (si no es que antes), luego con las de 1833, y, en forma modificada, en los regímenes políticos que han seguido desde aquel entonces.

¿Qué papel desempeñaron realmente los masones en todo esto? Creo que habrá que recordar que entre ellos había ilustrados e ignorantes, generosos e intolerantes, como en la población en general. En cuestiones educativas, me resisto a creer que su afiliación masónica influyera de una manera determinante en los esfuerzos generalizados por encontrar los medios económicos, intelectuales y políticamente viables para mejorar el nivel educativo del pueblo mexicano. Todos se enfrentaron a una cruda realidad: inestabilidad política y pobreza generalizada, producto de un desarrollo dispar de las distintas regiones del país. Los conflictos internacionales no ayudaron, como tampoco lo hicieron las mezquindades, egoísmos, cinismos y mentiras de los hombres públicos y de los ciudadanos privados. No es tan fácil señalar con el dedo a un solo culpable. Con todo, lucharon, en la medida de sus capacidades, para buscar un futuro mejor para sus familias o para sí mismos. Sin asignarle un tinte político de liberal o conservador, de federalista o centralista, de yorkino o escocés a los actores políticos de aquel entonces, creo más provechoso examinar los obstáculos que enfrentaron y tratar de entender por qué costó tanto trabajo y tanto tiempo introducir las novedades que todos buscaban, bajo una u otra etiqueta. 
Masonería y sociedades secretas en México, editado por el Instituto de Investigaciones Jurídicas de la UNAM, se terminó de imprimir el 4 de octubre de 2018 en los talleres de Arte Gráfico y Sonoro, Agys Alevin, S. C., Retorno de Amores 14-102, colonia Del Valle, delegación Benito Juárez, 03100 Ciudad de México, tel. 5523 1151. Se utilizó tipo Baskerville en 9, 10 y 11 puntos. En esta edición se empleó papel cream book 70 x 95 de 60 gramos para los interiores y cartulina couché de 250 gramos para los forros. Consta de 200 ejemplares (impresión digital). 
En esta obra se integran varias reflexiones académicas sobre la masonería y sus vínculos con las sociedades secretas, sus prohibiciones papal y real, los movimientos independentistas americanos y novohispanos. En ellas se presentan diversas revisiones y perspectivas de análisis acerca de los siglos decimonono y vigésimo mexicanos, desde los movimientos insurgentes, las luchas entre liberales y conservadores, el porfiriato, el Constituyente de 1917, la revolución y el movimiento cristero, la mirada de los masones y de la elite católica, hasta el exilio republicano español.

En Masonería y sociedades secretas en México se reflexiona en el contexto de los 300 años de la fundación de la Gran Logia de Londres (24 de junio de 1717), de los 200 años de las primeras logias regulares en la Nueva España y del centenario de la Constitución de 1917; ello desde distintos estudios críticos que permitirán al lector advertir los argumentos a favor y en contra de la masonería, los masones y las sociedades secretas; sus aciertos, contradicciones y excesos, y sus aportes en algunos procesos fundamentales de la historia de México.

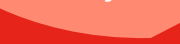

